\title{
Remedial Investigation for the Groundwater Operable Units at the Chemical Plant Area and the Ordnance Works Area, Weldon Spring, Missouri
}

July 1997

prepared by

MK-Ferguson Company and Jacobs Engineering Group, Inc., and

Environmental Assessment Division, Argonne National Laboratory

\section{prepared for}

U.S. Department of Energy, Weldon Spring Site Remedial Action Project, Weldon Spring, Missouri, under Contract W-31-109-Eng-38 and U.S. Department of the Army, Corps of Engineers, Kansas City District, Kansas City, Missouri 
This report is printed on recycled paper. 


\section{DISCLAIMER}

This report was prepared as an account of work sponsored by an agency of the United States Government. Neither the United States Government nor any agency thereof, nor any of their employees, make any warranty, express or implied, or assumes any legal liability or responsibility for the accuracy, completeness, or usefulness of any information, apparatus, product, or process disclosed, or represents that its use would not infringe privately owned rights. Reference herein to any specific commercial product, process, or service by trade name, trademark, manufacturer, or otherwise does not necessarily constitute or imply its endorsement, recommendation, or favoring by the United States Government or any agency thereof. The views and opinions of authors expressed herein do not necessarily state or reflect those of the United States Government or any agency thereof. 


\section{DISCLAIMER}

Portions of this document may be illegible in electronic image products. Images are produced from the best available original document. 


\section{CONTENTS}

NOTATION $\ldots \ldots \ldots \ldots \ldots \ldots \ldots \ldots \ldots \ldots \ldots \ldots \ldots \ldots \ldots \ldots \ldots \ldots \ldots \ldots \ldots \ldots$

ENGLISH/METRIC AND METRIC/ENGLISH EQUIVALENTS $\ldots \ldots \ldots \ldots \ldots \ldots$ xiv

1 INTRODUCTION $\ldots \ldots \ldots \ldots \ldots \ldots \ldots \ldots \ldots \ldots \ldots \ldots \ldots \ldots \ldots \ldots \ldots \ldots$

1.1 Purpose and Scope $\ldots \ldots \ldots \ldots \ldots \ldots \ldots \ldots \ldots \ldots \ldots \ldots \ldots \ldots \ldots \ldots \ldots$

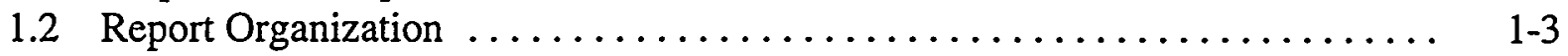

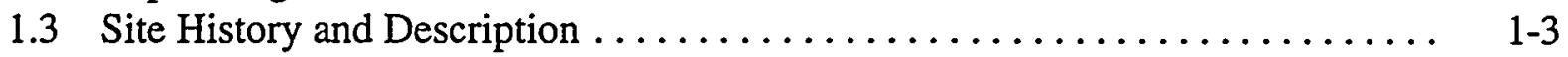

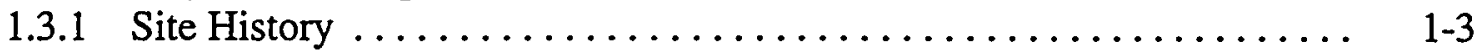

1.3.2 Site Descriptions . . . . . . . . . . . . . .

1.3.3 Environmental Setting $\ldots \ldots \ldots \ldots \ldots \ldots \ldots \ldots \ldots \ldots \ldots \ldots \ldots \ldots$

2 STUDY AREA INVESTIGATIONS $\ldots \ldots \ldots \ldots \ldots \ldots \ldots \ldots \ldots \ldots \ldots \ldots \ldots$

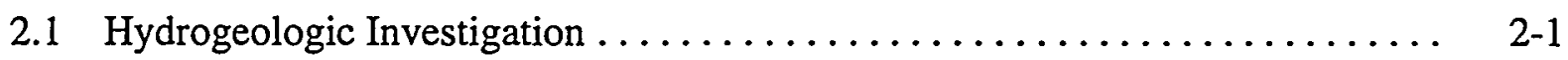

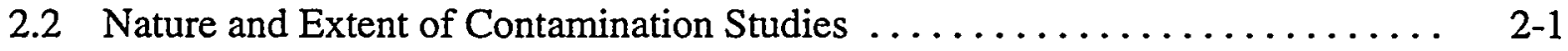

2.2.1 Background Water Quality ...................... 2-13

2.2.2 In Situ Sampling of Groundwater at the Southeast Drainage . . . . . . 2 2-14

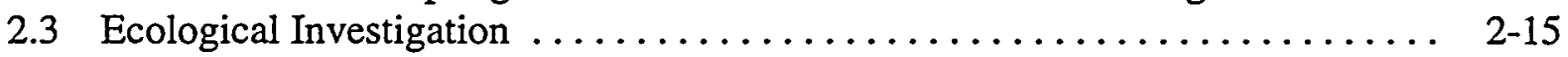

3 HYDROGEOLOGICAL INVESTIGATIONS OF THE STUDY AREA . . . . . . 3-1

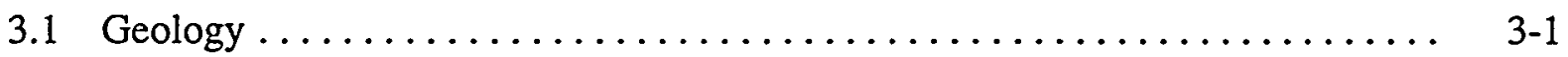

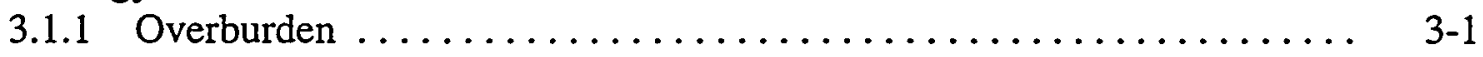

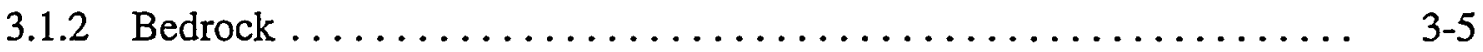

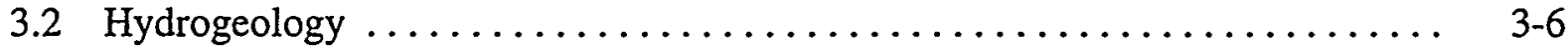

3.2.1 Hydrostratigraphic Unit Determination $\ldots \ldots \ldots \ldots \ldots \ldots \ldots \ldots \ldots$ 3-10

3.2.2 Aquifer Characteristics ........................... 3

3.2.3 Shallow Groundwater Surface $\ldots \ldots \ldots \ldots \ldots \ldots \ldots \ldots \ldots \ldots . \ldots \ldots$ 3-17

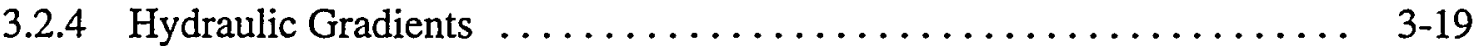

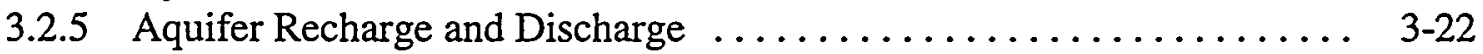

3.2.6 Groundwater and Surface Water Interaction ............. 3-24

3.3 Hydrogeologic Conceptual Model $\ldots \ldots \ldots \ldots \ldots \ldots \ldots \ldots \ldots \ldots \ldots \ldots \ldots$

4 NATURE AND EXTENT OF CONTAMINATION $\ldots \ldots \ldots \ldots \ldots \ldots \ldots \ldots \ldots$

4.1 Groundwater $\ldots \ldots \ldots \ldots \ldots \ldots \ldots \ldots \ldots \ldots \ldots \ldots \ldots \ldots \ldots \ldots \ldots .1$

4.1.1 Background Comparison for Naturally Occurring Constituents . . . . . . 4 4-8

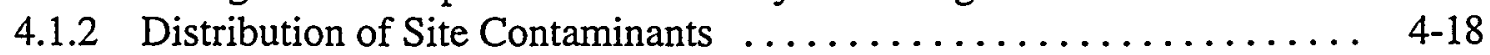

4.1.3 In Situ Sampling of Groundwater at the Southeast Drainage . . . . . . . 4-44 


\section{CONTENTS (Cont.)}

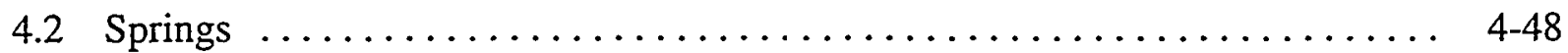

4.3 Summary of Contamination $\ldots \ldots \ldots \ldots \ldots \ldots \ldots \ldots \ldots \ldots \ldots \ldots, 4-51$

5 CONTAMINANT FATE AND MIGRATION $\ldots \ldots \ldots \ldots \ldots \ldots \ldots \ldots \ldots \ldots, 5-1$

5.1 Contaminant Sources and Routes of Migration $\ldots \ldots \ldots \ldots \ldots \ldots \ldots . \quad 5-2$

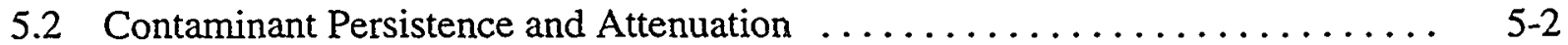

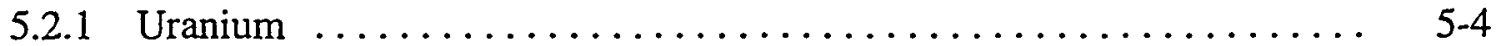

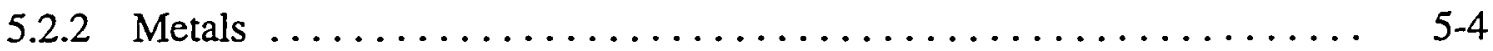

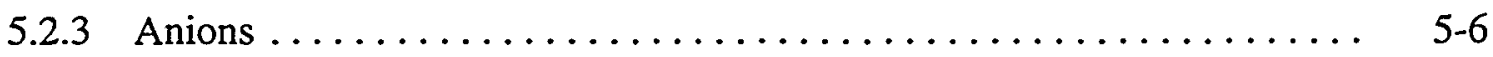

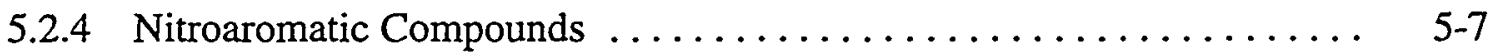

5.2 .5 Volatile Organic Compounds $\ldots \ldots \ldots \ldots \ldots \ldots \ldots \ldots \ldots \ldots, 5-10$

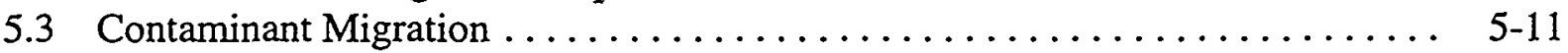

5.3.1 Migration within the Vadose Zone $\ldots \ldots \ldots \ldots \ldots \ldots \ldots \ldots \ldots, 5-12$

5.3.2 Migration of Contaminants within the Shallow Aquifer .......... 5-14

5.3.3 Migration of Contaminants by Surface and Subsurface Runoff ....... 5-18

6 SUMMARY OF THE BASELINE RISK ASSESSMENT $\ldots \ldots \ldots \ldots \ldots \ldots \ldots$ 6-1

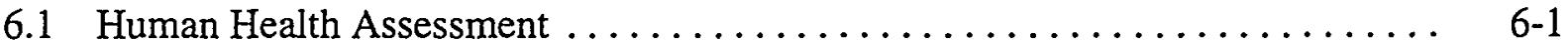

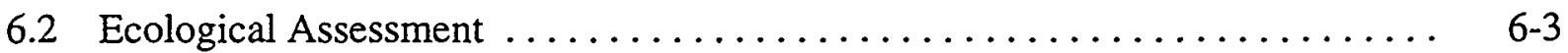

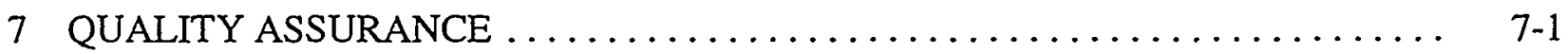

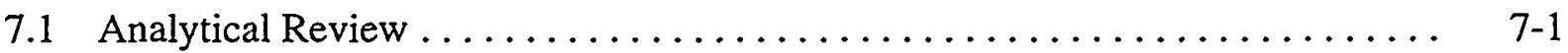

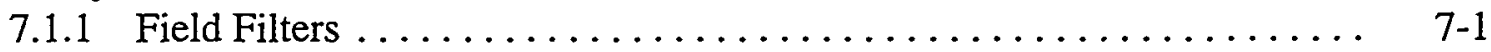

7.1 .2 Chain-of-Custody $\ldots \ldots \ldots \ldots \ldots \ldots \ldots \ldots \ldots \ldots \ldots \ldots \ldots \ldots \ldots \ldots \ldots, 2$

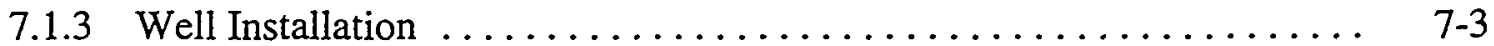

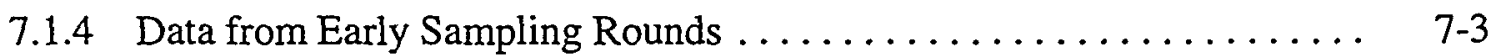

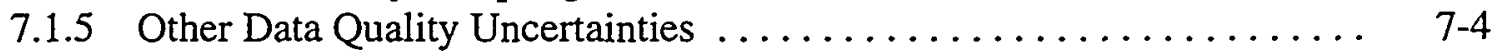

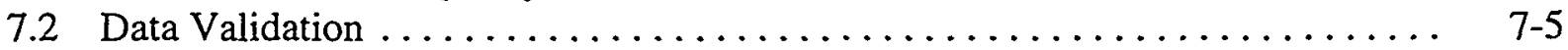

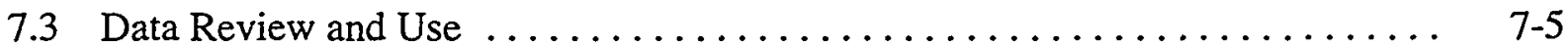

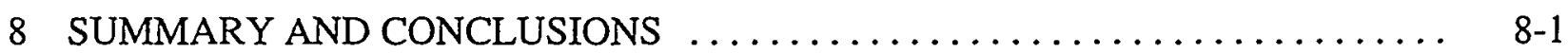

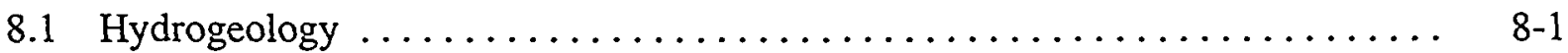

8.2 Nature and Extent of Potential Site-Related Contamination $\ldots \ldots \ldots \ldots \ldots$ 8-2

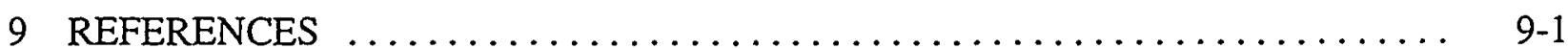




\section{CONTENTS (Cont.)}

APPENDIX A: Ecological Evaluations of the Burgermeister Spring Drainage $\ldots \ldots \ldots$ A-1

APPENDIX B: Hydrogeologic Investigations $\ldots \ldots \ldots \ldots \ldots \ldots \ldots \ldots \ldots \ldots \ldots \ldots \ldots \ldots$

APPENDIX C: Results of the 1995 Joint Groundwater Sampling for

Wells and Springs $\ldots \ldots \ldots \ldots \ldots \ldots \ldots \ldots \ldots \ldots \ldots \ldots \ldots \ldots \ldots \ldots, C-1$

APPENDIX D: Contaminant Fate and Transport Tables ................. D-1

\section{FIGURES}

1.1 Locations of the Chemical Plant Area and the Ordnance Works Area ........ 1-2

1.2 Current Disposition of the Properties Composing the Ordnance Works Area $\ldots \ldots \ldots \ldots \ldots \ldots \ldots \ldots \ldots \ldots \ldots \ldots \ldots \ldots \ldots \ldots \ldots, 1-5$

1.3 Locations of Waste Disposal Operations at the Ordnance Works Area ....... 1-6

1.4 Original Layout of the Chemical Plant Area $\ldots \ldots \ldots \ldots \ldots \ldots \ldots \ldots . \quad 1-8$

2.1 Location of Monitoring Wells and Springs at the Chemical Plant Area

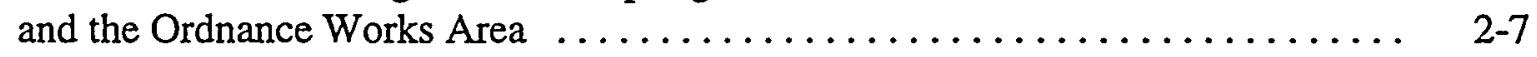

3.1 Stratigraphic Column of the Overburden and Shallow Bedrock Aquifer ....... 3-4

3.2 Surface Topography of the Chemical Plant Area and

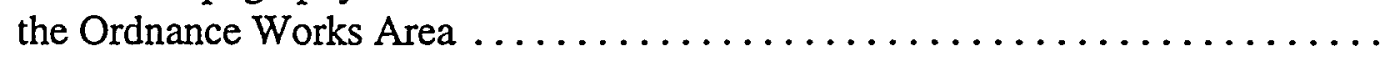

3.3 Bedrock Topography of the Chemical Plant Area and

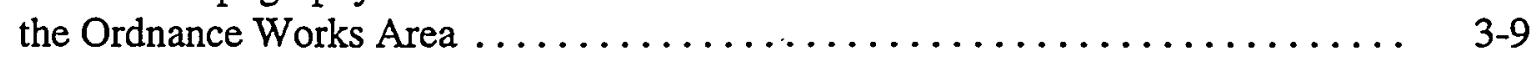

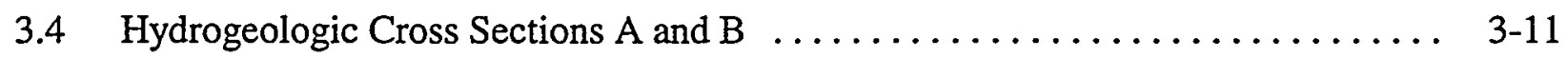

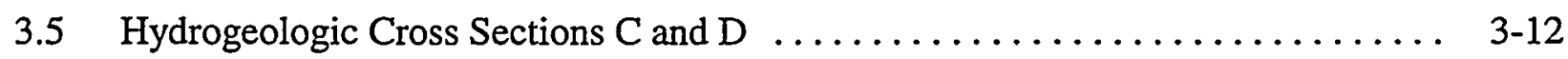

3.6 Comparison of Hydraulic Conductivity with Depth -

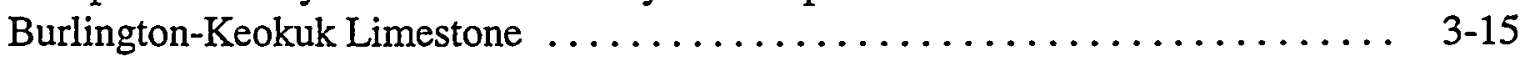

3.7 Hydraulic Head Distribution in the Shallow Groundwater $\ldots \ldots \ldots \ldots \ldots \ldots .3-18$ 


\section{FIGURES (Cont.)}

3.8 Gaining and Losing Stream Segments and Associated Springs

and Seeps in the Ordnance Works Area $\ldots \ldots \ldots \ldots \ldots \ldots \ldots \ldots \ldots . \ldots . . .23$

3.9 Water-Tracing Tests Performed at the Ordnance Works Area $\ldots \ldots \ldots \ldots \ldots$ 3-26

3.10 Flow Paths for Tracer Tests Performed at the Chemical Plant Area ........ 3-28

3.11 Tracer Test Results at Burgermeister Spring for the Dye Injection at AH-2004 ....................... $3-30$

3.12 Tracer Test Results at Burgermeister Spring for the Dye Injection at MW-2032 ............................. 3-31

3.13 Discharge and Storm Event Comparison at Burgermeister Spring .......... 3-32

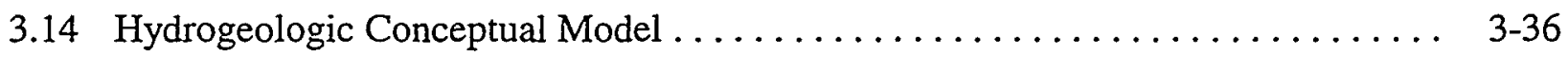

4.1 Distribution of Uranium Based on Data Collected Since 1987 at the Chemical Plant Area and the Ordnance Works Area

4.2 Distribution of Uranium at the Chemical Plant Area and the Ordnance Works Area

4.3 Distribution of Lithium at the Chemical Plant Area and

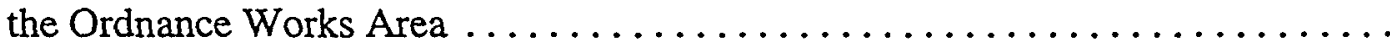

4.4 Distribution of Molybdenum at the Chemical Plant Area and the Ordnance Works Area

4.5 Distribution of Nitrate Based on Data Collected Since 1987 at the Chemical Plant Area and the Ordnance Works Area

4.6 Distribution of Nitrate at the Chemical Plant Area and the Ordnance Works Area

4.7 Distribution of Sulfate at the Chemical Plant Area and the Ordnance Works Area

4.8 Distribution of Chloride at the Chemical Plant Area and the Ordnance Works Area 


\section{FIGURES (Cont.)}

4.9 Distribution of 1,3,5-TNB at the Chemical Plant Area and

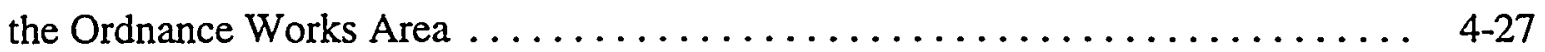

4.10 Distribution of 1,3-DNB at the Chemical Plant Area and

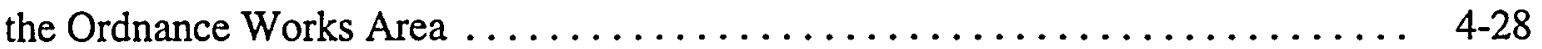

4.11 Distribution of 2,4,6-TNT at the Chemical Plant Area and

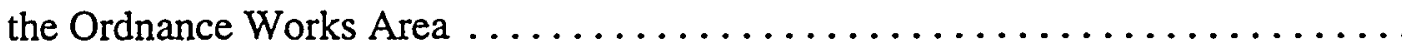

4.12 Distribution of 2,4-DNT at the Chemical Plant Area and the Ordnance Works Area

4.13 Distribution of 2,6-DNT at the Chemical Plant Area and the Ordnance Works Area

4.14 Distribution of 2-Amino-4,6-DNT at the Chemical Plant Area and the Ordnance Works Area

4.15 Distribution of 2-Nitrotoluene at the Chemical Plant Area and

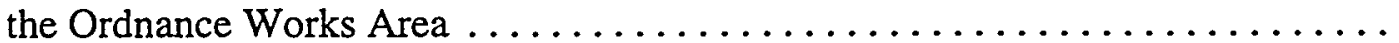

4.16 Distribution of 3-Nitrotoluene at the Chemical Plant Area and

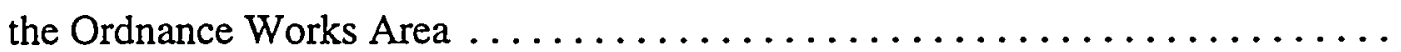

4.17 Distribution of 4-Amino-2,6-DNT at the Chemical Plant Area and

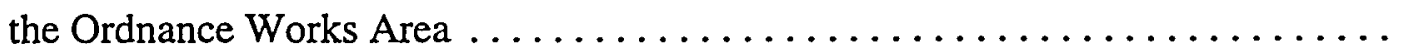

4.18 Distribution of 4-Nitrotoluene at the Chemical Plant Area and the Ordnance Works Area

4.19 Distribution of Nitrobenzene at the Chemical Plant Area and

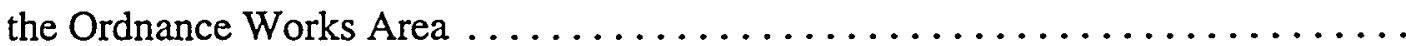

4.20 Distribution of TCE and 1,2-DCE at the Chemical Plant Area and

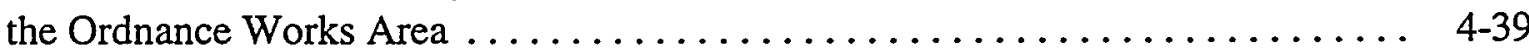

4.21 Location of In Situ Groundwater Sampling Sites

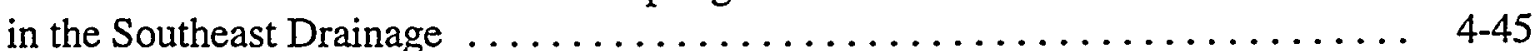

5.1 Fate and Transport Model for the Groundwater Operable Unit 


\section{FIGURES (Cont.)}

5.2 Microbial Transformation Productions of 2,4-DNT

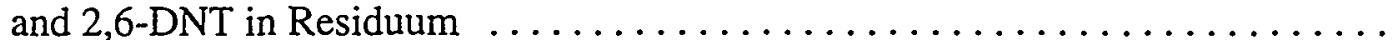

5.3 Frequency of Detection of Selected Nitroaromatic Compounds in Groundwater Samples from the Ordnance Works Area $\ldots \ldots \ldots \ldots \ldots \ldots .6 . \ldots .6$

5.4 Average Concentrations of Selected Nitroaromatic Compounds in Groundwater Samples from the Ordnance Works Area

5.5 Contaminant Flux versus Discharge of Burgermeister Spring 1987 to 1995

5.6 Uranium Flux versus Date Sampled, Burgermeister Spring $\ldots \ldots \ldots \ldots \ldots \ldots \quad 5-22$

A.1 Locations of the Chemical Plant Area and the Ordnance Works Area $\ldots . \ldots \ldots$ A-4

A.2 Sampling Locations from the Burgermeister Spring Drainage $\ldots \ldots \ldots \ldots \ldots$ A-7

B.1 Overburden Monitoring Locations - Chemical Plant Area ............. B-19

B.2 Cross Section through Raffinate Pits 3 and $4 \ldots \ldots \ldots \ldots \ldots \ldots \ldots \ldots \ldots \ldots \ldots$

B.3 Permeability Test Setup for Saturated and Unsaturated Bedrock $\ldots \ldots \ldots \ldots$ B-30

\section{TABLES}

2.1 Summary of Remedial Investigation Hydrogeologic Activities ........... 2-2

2.2 Monitoring Wells Associated with the Ordnance Works Area $\ldots \ldots \ldots \ldots \ldots .2-5$

2.3 Monitoring Wells at the Chemical Plant Area $\ldots \ldots \ldots \ldots \ldots \ldots \ldots .2-6$

2.4 Summary of Groundwater Sampling and Analysis at the Chemical Plant Area and the Ordnance Works Area $\ldots . \ldots \ldots \ldots \ldots . . .2-10$

2.5 Contaminants of Potential Concern Evaluated in the Joint Sampling Effort

3.1 Generalized Stratigraphy and Hydrostratigraphy for the Chemical Plant Area and the Ordnance Works Area.. 


\section{TABLES (Cont.)}

3.2 Vertical Gradients within the Shallow Aquifer at the Chemical

Plant Area and the Ordnance Works Area .................... 3-20

3.3 Vertical Gradients in the Shallow, Middle, and Deep Bedrock

Aquifers in the Weldon Spring Area $\ldots \ldots \ldots \ldots \ldots \ldots \ldots \ldots \ldots \ldots \ldots . .23-22$

3.4 Summary of Tracer Testing Results $\ldots \ldots \ldots \ldots \ldots \ldots \ldots \ldots \ldots \ldots \ldots . \quad 3-29$

4.1 Summary of 1995 Joint Sampling Data and Data Collected

from 1987-1994: Radionuclides and Metals .................... 4-2

4.2 Summary of 1995 Joint Sampling Data and Data Collected

from 1987-1994: Anions and Nitroaromatic Compounds $\ldots \ldots \ldots \ldots \ldots \ldots$ 4.6.

4.3 Background Groundwater Concentrations of Potential Contaminants ........ 4-10

4.4 Comparison of Site Data with Statistically Derived Background

Concentrations of Naturally Occurring Contaminants $\ldots \ldots \ldots \ldots \ldots \ldots \ldots, 4-11$

4.5 Quantile Test Results by Stratigraphic Unit of Metals Concentrations

in Groundwater at the Chemical Plant Area and the Ordnance Works Area ..... 4-14

4.6 Wilcoxon Rank-Sum Test Results by Stratigraphic Unit of Metals

Concentrations in Groundwater at the Chemical Plant Area and

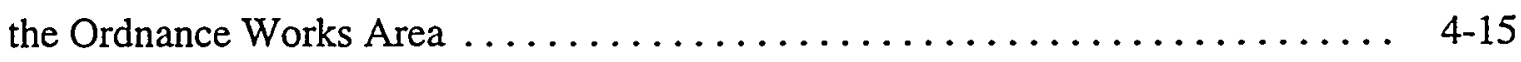

4.7 Statistical Evaluation by Stratigraphic Unit of Anion Concentrations

in Groundwater at the Chemical Plant Area and the Ordnance Works Area ..... 4-16

4.8 Radiological and Chemical Concentrations for In Situ Groundwater

Samples from the Southeast Drainage $\ldots \ldots \ldots \ldots \ldots \ldots \ldots \ldots \ldots \ldots .4 .46$

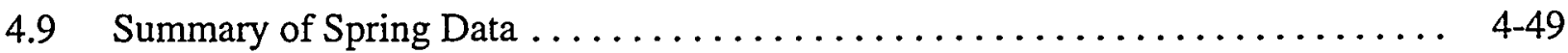

5.1 Summary of Environmental Processes Affecting Contaminant Fate

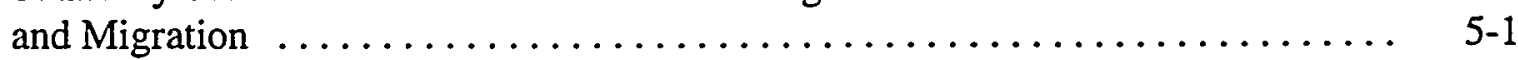

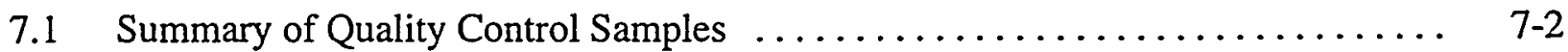

7.2 Data Points Identified as Outlier Values for the Groundwater

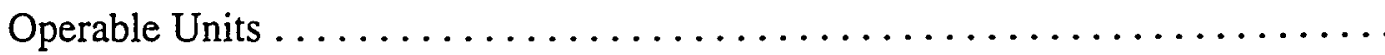




\section{TABLES (Cont.)}

A.1 Macroinvertebrates Collected from the Burgermeister Spring Drainage ....... A-9

A.2 Fish Species Collected from the Burgermeister Spring Drainage . . . . . . . . A-10

A.3 Reptiles and Amphibians Collected from the Burgermeister Spring Drainage . . . . . . . . . . . . . . . . . $\ldots \ldots$

A.4 Rare, Threatened, and Endangered Animals Reported from St. Charles County

A.5 Contaminant Tissue Concentrations and Estimated Bioconcentration Factors for Macroinvertebrate and Fish Tissue Samples Collected from Burgermeister Spring

A.6 Results of Acute and Chronic Toxicity Testing from the Burgermeister Spring Drainage

B.1 Monitoring Well Network Construction Summary - Chemical Plant Area .... . B-4

B.2 Monitoring Well Network Construction Summary - Ordnance Works Area .....

B.3 Physical Characteristics of the Overburden Units $\ldots \ldots \ldots \ldots \ldots \ldots \ldots \ldots$

B.4 Hydraulic Properties of the Overburden Units in the Vadose Zone as Determined from Laboratory Testing . . . . . . . . . . . . . . .

B.5 Soil-Moisture Characteristics of Overburden at the Chemical Plant Area .......

B.6 Summary of Single Well Hydraulic Conductivity Testing Results in the Overburden Units

B.7 Overburden Monitoring Well Construction and Water-Level Data at the Chemical Plant Area . . . . . . . . . . . . . . . . . . . . . . . . . .

B.8 Overburden Monitoring Well Construction and Water-Level Data at the Ordnance Works Area

B.9 Summary of Packer Test Results from the Overburden/Bedrock Interface $\ldots \ldots$.

B.10 Summary of Packer Test Results at the Chemical Plant Area . B-26

B.11 Summary of Packer Test Results at the Ordnance Works Area 


\section{TABLES (Cont.)}

B.12 Summary of Single Well Hydraulic Conductivity Slug Test Results at the Chemical Plant Area $\ldots \ldots \ldots \ldots \ldots \ldots \ldots \ldots \ldots \ldots \ldots \ldots \ldots \ldots \ldots \ldots \ldots \ldots$

B.13 Summary of Single Well Hydraulic Conductivity Slug Test Results at

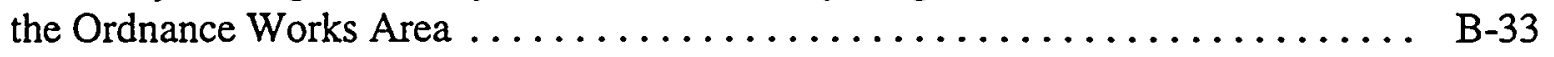

B.14 Summary of Water-Level Measurements — April and July $1995 \ldots \ldots \ldots \ldots$ B-35

B.15 Summary of Maximum and Minimum Static Water-Level Fluctuations of the Shallow Aquifer - the Chemical Plant Area and the Ordnance Works Area $\ldots \ldots \ldots \ldots \ldots \ldots \ldots \ldots \ldots \ldots \ldots \ldots \ldots \ldots \ldots$

C.1 Nitroaromatic Results from Joint Sampling, May $1995 \ldots \ldots \ldots \ldots \ldots \ldots$ C-4

C.2 Anion and Radiological Results from Groundwater Locations

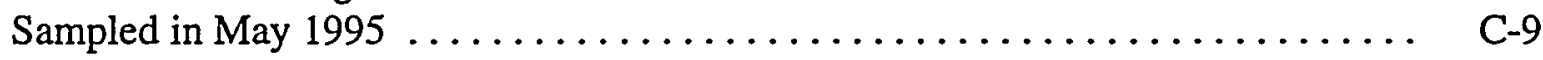

C.3 Metals Data from May 1995 Joint Sampling $\ldots \ldots \ldots \ldots \ldots \ldots \ldots \ldots$ C-13

C.4 Nitroaromatic Results from Joint Sampling, August $1995 \ldots \ldots \ldots \ldots \ldots \ldots$ C $\ldots \ldots$.35

C.5 Anion and Radiological Results for Groundwater

Samples from August $1995 \ldots \ldots \ldots \ldots \ldots \ldots \ldots \ldots \ldots \ldots \ldots \ldots \ldots \ldots \ldots$

C.6 Metals Results for August 1995 Joint Sampling .................. C-44

C.7 Results of 1995 Joint Spring Sampling $\ldots \ldots \ldots \ldots \ldots \ldots \ldots \ldots \ldots \ldots \ldots \ldots \ldots$

D.1 Estimated Distribution Coefficient Values for Contaminants in Site Soil ...... D-3

D.2 Results of Equilibrium-Speciation Calculations on Samples from Selected Contaminated Monitoring Wells at the Weldon Spring

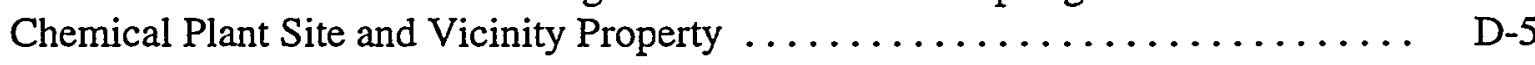

D.3 Selected Physical Properties and Environmental Parameters for

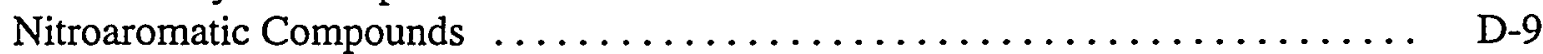




\section{NOTATION}

The following is a list of the acronyms, initialisms, and abbreviations (including units of measure) used in this document. Acronyms used only in tables are defined in the respective tables.

\section{ACRONYMS, INITIALISMS, AND ABBREVIATIONS}

$\begin{array}{ll}\text { AEC } & \text { U.S. Atomic Energy Commission } \\ \text { BRA } & \text { baseline risk assessment } \\ \text { CERCLA } & \text { Comprehensive Environmental Response, Compensation, and Liability Act } \\ \text { COPC } & \text { contaminants of potential concern } \\ \text { DCE } & \text { dichloroethene } \\ \text { DA } & \text { U.S. Department of the Army } \\ \text { DNA } & \text { dinitroaniline } \\ \text { DNAPL } & \text { dense, nonaqueous phase liquid } \\ \text { DNT } & \text { dinitrotoluene } \\ \text { DOE } & \text { U.S. Department of Energy } \\ \text { ECD } & \text { electron capture detector } \\ \text { EPA } & \text { U.S. Environmental Protection Agency } \\ \text { EQAPjP } & \text { Environmental Quality Assurance Project Plan } \\ \text { FS } & \text { feasibility study } \\ \text { GC } & \text { gas chromatography } \\ \text { GWOU } & \text { groundwater operable unit } \\ \text { HPCL } & \text { high-performance liquid chromatograph/chromotagraphy } \\ \text { IT } & \text { International Technology } \\ \text { K } & \text { distribution coefficient } \\ \text { Koc } & \text { organic fraction partition coeficient } \\ K_{\text {ow }} & \text { octanol-water partition coefficient } \\ \text { KPA } & \text { Kinetic Phosphorescence Analyzer } \\ \text { LCS } & \text { laboratory chemical spike } \\ \text { MCL } & \text { maximum contaminant level } \\ \text { MS } & \text { matrix spike } \\ \text { NB } & \text { nitrobenzene } \\ \text { NPL } & \text { National Priorities List } \\ \text { QA } & \text { quality assurance } \\ \text { QAPP } & \text { quality assurance program plan } \\ \text { QC } & \text { quality control } \\ \text { RI } & \text { remedial investigation } \\ \text { RBP } & \text { Rapid Bioassessment Protocol } \\ \text { RME } & \text { reasonable maximally exposed } \\ \text { RPD } & \text { relative percent difference } \\ \text { RQD } & \text { rock quality designation } \\ \text { SMCL } & \text { secondary maximum contaminant level } \\ \text { TCE } & \text { trichloroethylene } \\ & \end{array}$


TNB trinitrobenzene

TNT trinitrotoluene

UCL upper confidence limit

USGS U.S. Geological Survey

VOC volatile organic compound

\section{UNITS OF MEASURE}

$\begin{array}{ll}{ }^{\circ} \mathrm{C} & \text { degree(s) Celsius } \\ { }^{\circ} \mathrm{F} & \text { degree(s) Fahrenheit } \\ \mathrm{cm} & \text { centimeter(s) } \\ \mathrm{cm}^{2} & \text { square centimeter(s) } \\ \mathrm{cm}^{3} & \text { cubic centimeter(s) } \\ \mathrm{ft} & \text { foot (feet) } \\ \mathrm{ft}^{3} & \text { cubic foot (feet) } \\ \mathrm{g} & \text { gram(s) } \\ \mathrm{gal} & \text { gallon(s) } \\ \mathrm{h} & \text { hour(s) } \\ \mathrm{ha} & \text { hectare(s) } \\ \text { in. } & \text { inch(es) } \\ \mathrm{kg} & \text { kilogram(s) } \\ \mathrm{km} & \text { kilometer(s) } \\ \mathrm{km} & \text { square kilometer(s) } \\ \mathrm{L} & \text { liter(s) }\end{array}$

$\begin{array}{ll}\mathrm{m} & \text { meter(s) } \\ \mathrm{m}^{3} & \text { cubic meter(s) } \\ \mathrm{mg} & \text { milligram(s) } \\ \mathrm{mi} & \text { mile(s) } \\ \mathrm{mi}^{2} & \text { square mile(s) } \\ \mathrm{mL} & \text { milliliter(s) } \\ \mathrm{min} & \text { minute(s) } \\ \mathrm{pCi} & \text { picocurie(s) } \\ \mathrm{ppm} & \text { part(s) per million } \\ \mathrm{s} & \text { second(s) } \\ \mathrm{t} & \text { metric ton(s) } \\ \text { ton } & \text { short ton(s) } \\ \mu \mathrm{g} & \text { microgram(s) } \\ \mu \mathrm{L} & \text { microliter(s) } \\ \mu \mathrm{m} & \text { micrometer(s) } \\ \mu \mathrm{S} & \text { microsiemen(s) } \\ \mathrm{yd} & \text { cubic yard(s) }\end{array}$




\section{ENGLISH/METRIC AND METRIC/ENGLISH EQUIVALENTS}

In this document, units of measure are presented with the metric equivalent first, followed by the measured English unit in parentheses. In cases where the measurement was originally made in metric units, the values were not converted back to English units; in tables, the data are generally in English or metric units only. The following table lists the appropriate equivalents for English and metric units.

\begin{tabular}{|c|c|c|}
\hline Multiply & By & To Obtain \\
\hline \multicolumn{3}{|l|}{ English/Metric Equivalents } \\
\hline acres & 0.4047 & hectares (ha) \\
\hline cubic feet $\left(\mathrm{ft}^{3}\right)$ & 0.02832 & cubic meters $\left(\mathrm{m}^{3}\right)$ \\
\hline cubic yards $\left(\mathrm{yd}^{3}\right)$ & 0.7646 & cubic meters $\left(\mathrm{m}^{3}\right)$ \\
\hline degrees Fahrenheit $\left({ }^{\circ} \mathrm{F}\right)-32$ & 0.5555 & degrees Celsius $\left({ }^{\circ} \mathrm{C}\right)$ \\
\hline feet $(\mathrm{ft})$ & 0.3048 & meters $(\mathrm{m})$ \\
\hline gallons (gal) & 3.785 & liters $(L)$ \\
\hline gallons (gal) & 0.003785 & cubic meters $\left(\mathrm{m}^{3}\right)$ \\
\hline inches (in.) & 2.54 .0 & centimeters $(\mathrm{cm})$ \\
\hline miles (mi) & 1.609 & kilometers (km) \\
\hline pounds (lb) & 0.4536 & kilograms (kg) \\
\hline short tons (tons) & 907.2 & kilograms (kg) \\
\hline short tons (tons) & 0.9072 & metric tons $(t)$ \\
\hline square feet $\left(\mathrm{ft}^{2}\right)$ & 0.09290 & square meters $\left(\mathrm{m}^{2}\right)$ \\
\hline square yards $\left(\mathrm{yd}^{2}\right)$ & 0.8361 & square meters $\left(\mathrm{m}^{2}\right)$ \\
\hline square miles $\left(\mathrm{mi}^{2}\right)$ & 2.590 & square kilometers $\left(\mathrm{km}^{2}\right)$ \\
\hline yards $(y d)$ & 0.9144 & meters (m) \\
\hline \multicolumn{3}{|l|}{ Metric/English Equivalents } \\
\hline centimeters $(\mathrm{cm})$ & 0.3937 & inches (in.) \\
\hline cubic meters $\left(\mathrm{m}^{3}\right)$ & 35.31 . & cubic feet $\left(\mathrm{ft}^{3}\right)$ \\
\hline cubic meters $\left(\mathrm{m}^{3}\right)$ & 1.308 & cubic yards $\left(\mathrm{yd}^{3}\right)$ \\
\hline cubic meters $\left(\mathrm{m}^{3}\right)$ & 264.2 & gallons (gal) \\
\hline degrees Celsius $\left({ }^{\circ} \mathrm{C}\right)+17.78$ & 1.8 & degrees Fahrenheit $\left({ }^{\circ} \mathrm{F}\right)$ \\
\hline hectares (ha) & 2.471 & acres \\
\hline kilograms (kg) & 2.205 & pounds (lb) \\
\hline kilograms (kg) & 0.001102 & short tons (tons) \\
\hline kilometers (km) & 0.6214 & miles (mi) \\
\hline liters (L) & 0.2642 & gallons (gal) \\
\hline meters (m) & 3.281 & feet $(f t)$ \\
\hline meters (m) & 1.094 & yards $(y d)$ \\
\hline metric tons $(t)$ & 1.102 & short tons (tons) \\
\hline square kilometers $\left(\mathrm{km}^{2}\right)$ & 0.3861 & square miles $\left(\mathrm{mi}^{2}\right)$ \\
\hline square meters $\left(\mathrm{m}^{2}\right)$ & 10.76 & square feet $\left(\mathrm{ft}^{2}\right)$ \\
\hline square meters $\left(\mathrm{m}^{2}\right)$ & 1.196 & square yards $\left(y d^{2}\right)$ \\
\hline
\end{tabular}




\section{INTRODUCTION}

The U.S. Department of Energy (DOE) and the U.S. Department of the Army (DA) are conducting cleanup activities at two properties - the DOE chemical plant area and the DA ordnance works area (the latter includes the training area) - located in the Weldon Spring area in St. Charles County, Missouri (Figure 1.1). These areas are on the National Priorities List (NPL), and cleanup activities at both areas are conducted in accordance with the Comprehensive Environmental Response, Compensation, and Liability Act (CERCLA), as amended. DOE and DA are conducting a joint remedial investigation (RI) and baseline risk assessment (BRA) as part of the remedial investigation/feasibility study (RI/FS) for the groundwater operable units for the two areas. This joint effort will optimize further data collection and interpretation efforts and facilitate overall remedial decision making since the aquifer of concern is common to both areas. A Work Plan issued jointly in 1995 by DOE and the DA (DOE 1995b) discusses the results of investigations completed at the time of preparation of the report. The investigations were necessary to provide an understanding of the groundwater system beneath the chemical plant area and the ordnance works area. The Work Plan also identifies additional data requirements for verification of the evaluation presented.

\subsection{PURPOSE AND SCOPE}

The principal groundwater systems identified in the Weldon Spring region are an alluvial aquifer and three bedrock aquifers: shallow, middle, and deep (Kleeschulte and Imes 1994). The focus of this RI for the groundwater operable units is primarily the shallow bedrock aquifer, which is composed of the Burlington-Keokuk Limestone, the Fern Glen Formation, and associated saturated overburden materials. This focus is consistent with the understanding of the groundwater system, which is based on hydrogeologic investigations and groundwater sampling results discussed in the Work Plan (DOE 1995b)

This RI describes the nature and extent of contamination in the shallow aquifer system at the chemical plant area and the ordnance works area. Uranium, nitroaromatic compounds, metals, and anions have been identified as contaminants of potential concern (COPC) (DOE 1995b). Specifically, this RI presents the results of numerous investigations conducted to identify site-related contaminants, characterize the hydrogeology of the area, and identify environmental pathways for contaminant migration from known or suspected contaminant sources. In addition, this RI characterizes the ecological resources that may be affected by the discharge of contaminated groundwater to the surface waters of springs and streams in the area. A BRA was conducted as part of the RI to evaluate potential human health and ecological impacts due to contamination associated with the groundwater operable units (GWOUs) of the two areas. The shallow aquifer is a carbonate system characterized by the presence of a number of losing stream segments and sinkholes, conduits 


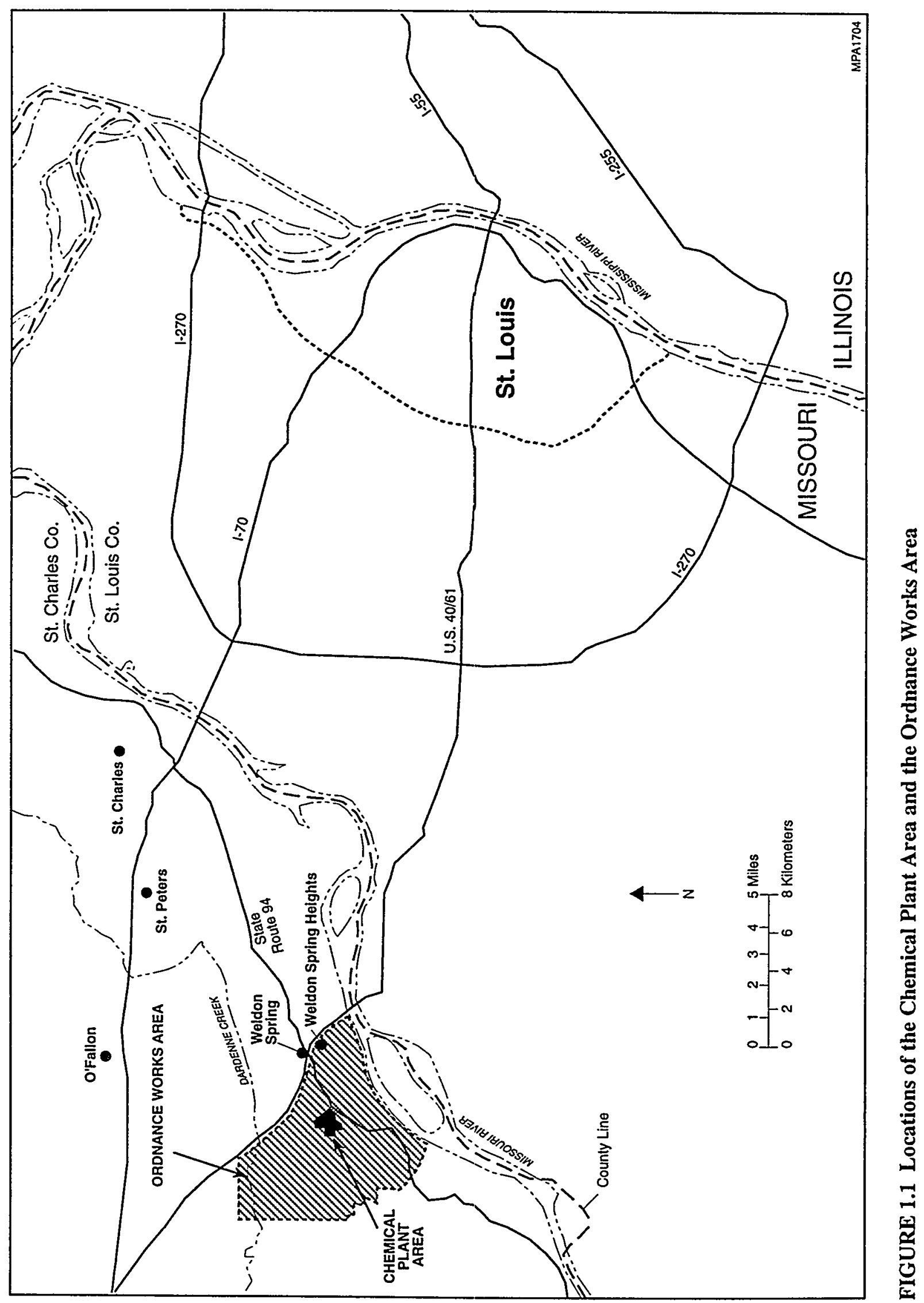


that discharge to springs, solution-broadened joints and fractures, and extensively weathered bedrock. Springs are included in this RI because they represent the hydrologic connection between the shallow groundwater and surface water. The alluvial aquifer located in the very southern portion of the ordnance works area is not being addressed in this RI. Because of its distant location, it does not have a strong connection with the hydrology of the chemical plant area and the ordnance works area to the north. The alluvial aquifer is included in DOE's Weldon Spring Quarry Residuals Operable Unit as discussed in the Work Plan (DOE 1995b).

\subsection{REPORT ORGANIZATION}

This RI is organized as follows. Chapter 1, this introduction, discusses the purpose and scope and includes a brief summary of the site history and environmental setting relevant to the GWOUs. Chapter 2 discusses the hydrogeological investigations and groundwater sampling and analysis activities conducted as part of this RI; a brief summary of the ecological investigations is also provided. Chapter 3 describes the hydrogeologic conceptual model developed from the investigations discussed in Chapter 2. Chapter 4 discusses the groundwater and spring data collected to support this RI; the nature and extent of site-related contamination are also discussed. Chapter 5 presents the contaminant migration process and contaminant persistence for each of the COPC. Chapter 6 summarizes the risk assessment performed for the GWOUs. Chapter 7 summarizes the quality control and quality assurance measures implemented to support the data collection activities, and Chapter 8 provides the summary and conclusions for this RI. All references cited in this RI are listed in Chapter 9. Appendixes A and B provide information on ecological and hydrological investigations, respectively, that were used to support this $\mathrm{RI}$. Appendix $\mathrm{C}$ presents the results of the joint sampling of groundwater and springs, and Appendix $\mathrm{D}$ presents chemical and physical property data used in determinations of contaminant fate and transport.

\subsection{SITE HISTORY AND DESCRIPTION}

\subsubsection{Site History}

During the early 1940s, the DA acquired 6,974 ha (17,232 acres) of private land in St. Charles County for construction of the Weldon Spring Ordnance Works trinitrotoluene (TNT) dinitrotoluene (DNT) production facility. The Weldon Spring Ordnance Works facility consisted of 18 nearly identical and independent TNT manufacturing lines and 2 DNT lines that were operated by the Atlas Powder Company from 1941 through 1945. In April 1946, the facility was declared surplus property, and by 1949 , the bulk of the property was distributed to state and local jurisdictions. The remaining 840 ha (2,063 acres) of the ordnance works, which contained all the TNT/DNT lines and most of the other facilities, was reinstated to the DA in 1954 as a National 
Industrial Plant Reserve Property (Daubel 1992). In May 1955, 83 ha (205 acres) of the U.S. Army National Industrial Plant Reserve was transferred to the U.S. Atomic Energy Commission (AEC) for construction of the Weldon Spring Uranium Feed Materials Plant. About 6 ha (15 acres) of additional land was later transferred from the DA to the AEC for expansion of waste storage capacity.

From 1958 until 1966, the feed materials plant processed uranium ore concentrates and some scrap metals to uranium trioxide, intermediate compounds, and uranium metal for shipment to other AEC facilities. A small amount of thorium was also processed. Operations at the plant ceased in 1966. Responsibility for the land and facilities of the feed materials plant was temporarily transferred back to the DA in 1966; plans by the DA included refitting the plant for chemical herbicide production. Contamination from previous uranium processing activities was found to be too extensive to proceed with the plant renovation. In 1971, a 21-ha (52-acre) tract containing four waste lagoons (raffinate pits) was transferred back to the AEC, while the remaining chemical plant area was retained by the DA. From 1971 to 1981 , no activities took place, and the site was placed in caretaker status from 1981 through 1985. Custody of most of the chemical plant building area (67 ha [165 acres]) was transferred from the DA to DOE in October 1985.

DOE established the Weldon Spring Site Remedial Action Project in July 1986. The DA began remedial investigation activities at the former Weldon Spring Ordnance Works area in 1987. The chemical plant and raffinate pit area were added to the NPL in March 1989. The former ordnance works area, including the Weldon Spring Training Area, was added to the NPL in February 1990.

\subsubsection{Site Descriptions}

The former Weldon Spring ordnance works once encompassed a total area of 6,974 ha $(17,232$ acres), which has since been divided into several contiguous areas under different ownership. The current disposition of the property is depicted in Figure 1.2 and discussed in Section 1.3.3. The DA currently retains ownership of the 670-ha (1,655-acre) Weldon Spring Training Area, which contained the majority of the production facilities. Public access to the training area is restricted. The 88-ha (217-acre) chemical plant area lies within the boundaries of the former ordnance works area.

The Weldon Spring ordnance works (Figure 1.3) originally included 1,038 structures and buildings. As part of the historical decontamination efforts at the former ordnance works area, abandoned production buildings were disassembled, salvaged, razed, or burned in place (IT Corporation 1993a). Approximately 30 structures remain at the training area (IT Corporation 1993a). 


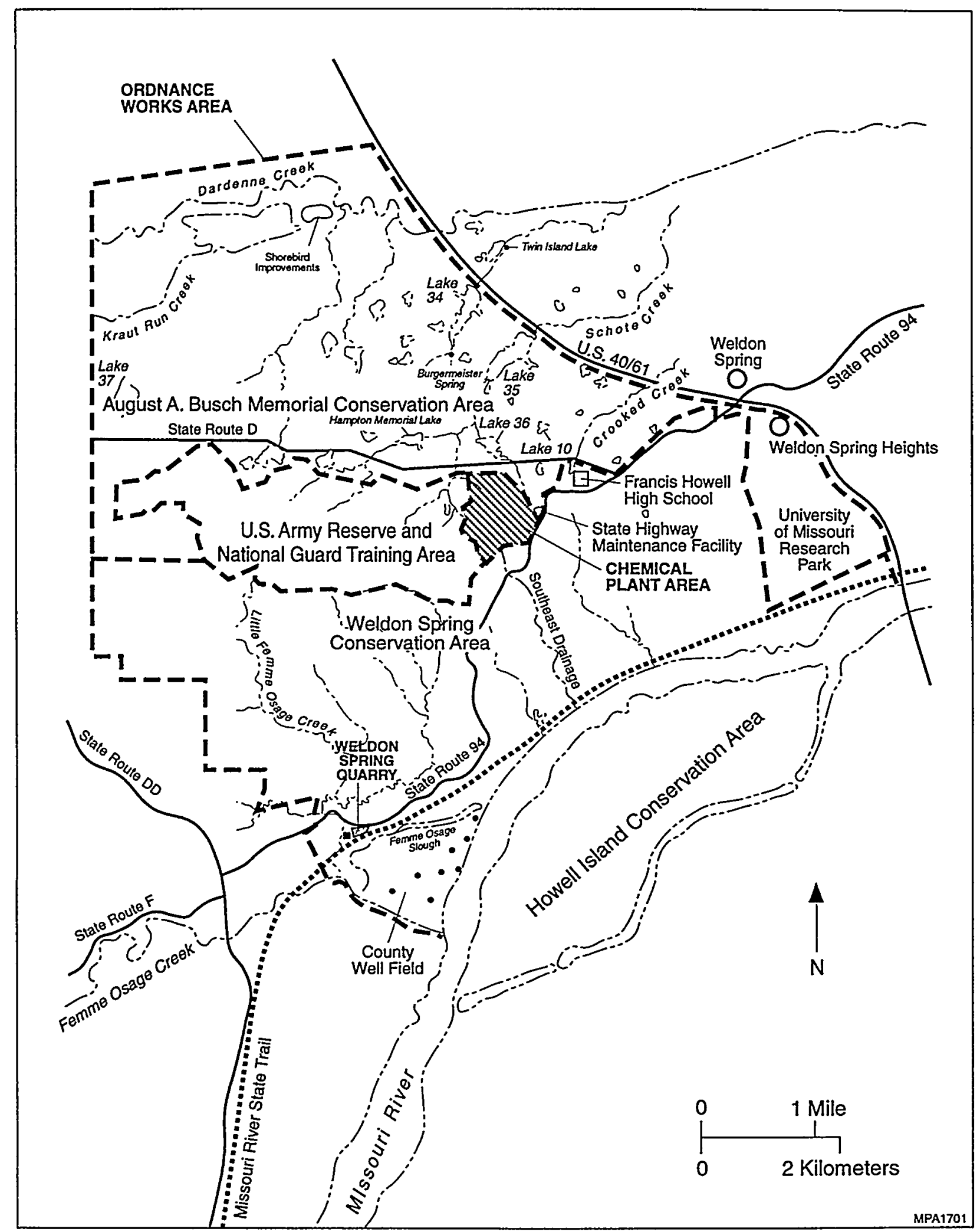

FIGURE 1.2 Current Disposition of the Properties Composing the Ordnance Works Area 


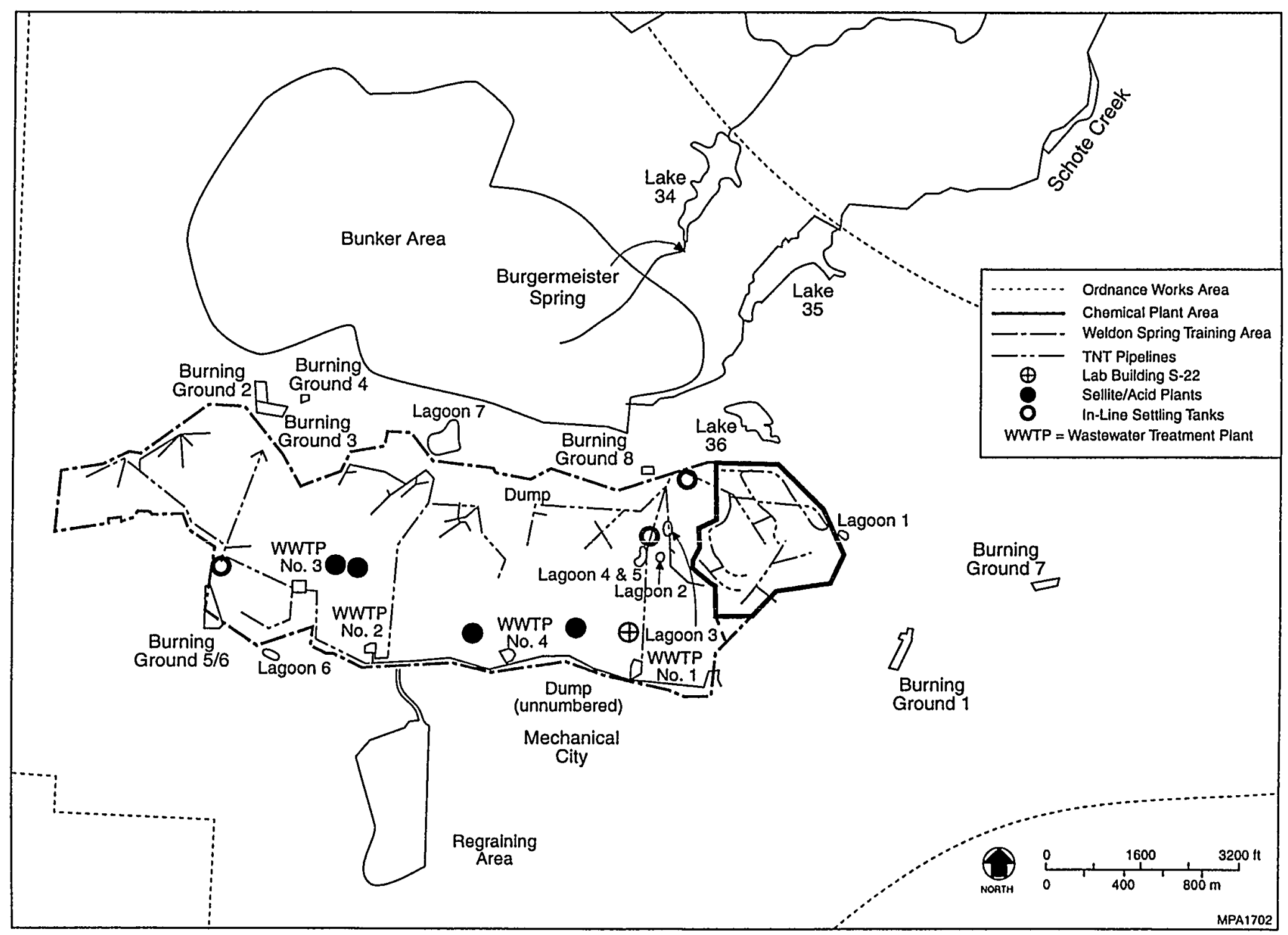

FIGURE 1.3 Locations of Waste Disposal Operations at the Ordnance Works Area 
Potential historical source areas at the former ordnance works for groundwater contamination beneath the site include the TNT and DNT production lines, three wastewater treatment plants, in-line settling tanks, eight burning grounds, sellite/acid plants, laboratory buildings, Mechanical City (facility maintenance area), regraining areas, underground toluene and wooden wastewater transport pipelines, three dump areas, and seven wastewater lagoons (Figure 1.3). The burning grounds were used for waste products, general refuse, and waste from decontamination activities during the production period and subsequent cleanup.

The seven wastewater storage lagoons were constructed at the production area to store wastewater prior to constructing the water treatment facilities (IT Corporation 1993a). These wastewater lagoons have been drained and/or partially earth-filled by past decontamination activities. Six of the seven remnant lagoons (2 through 7 ) are located within the central portion of the former ordnance works area; the seventh lagoon, Lagoon 1, is located east of the chemical plant area. Currently, all lagoons except Lagoon 2 (completely earth-filled) are partially filled with ponded water (IT Corporation 1993a).

After completion of planned remedial activities at the ordnance works area, the following potential sources for groundwater contamination will remain: sorbed contaminants on soil particles under unsaturated conditions, contaminants sorbed onto material under saturated conditions, and contaminated sediment within the conduit to Burgermeister Spring.

Features remaining at the chemical plant area include the foundations of 40 process and nonprocess buildings, four raffinate pits, two former pond areas (Ash Pond and Frog Pond), and two former dump areas (north and south) (Figure 1.4). Soils in the dump areas and at scattered locations throughout the chemical plant are radioactively contaminated, and discrete locations also contain elevated concentrations of certain metals and organic compounds (MK-Ferguson Company and Jacobs Engineering Group, Inc. 1992a).

Potential historical sources of groundwater contamination at the chemical plant area include process buildings, the raffinate pits, the Ash and Frog Pond areas, the former TNT processing lines, scattered pockets of contaminated soils, and subsurface materials surrounding the building foundations.

The four raffinate pits cover about 11 ha (26 acres) in the southwestern portion of the chemical plant area. They were used during the operational period of the chemical plant to receive waste slurry from processing operations. These pits constitute the most radiologically and chemically contaminated portion of the chemical plant area and at one time contained a maximum of about $152,911 \mathrm{~m}^{3}\left(200,000 \mathrm{yd}^{3}\right)$ of sludge and $215,768,476 \mathrm{~L}(57,000,000 \mathrm{gal})$ of water (MK-Ferguson Company and Jacobs Engineering Group, Inc. 1992a). In addition, drums and rubble from earlier decontamination activities at the chemical plant were disposed of in some of the pits (MK-Ferguson Company and Jacobs Engineering Group, Inc. 1992a). 


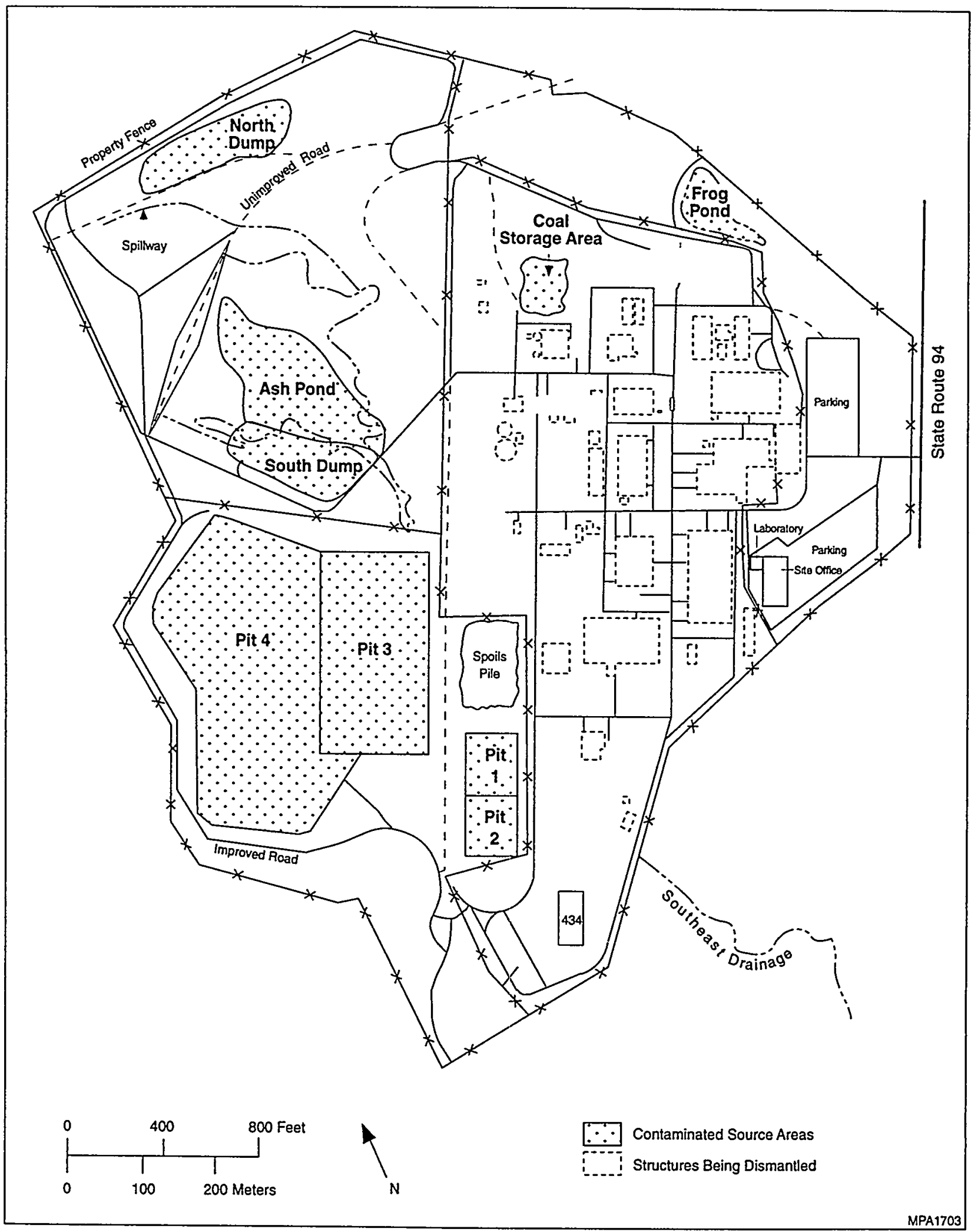

FIGURE 1.4 Original Layout of the Chemical Plant Area 
After completion of remedial activities associated with previous decisions for the chemical plant area, three sources of contamination will remain: contaminated subsurface material in the vadose zone (contaminants sorbed onto soil particles under unsaturated conditions), contaminated consolidated rock and unconsolidated residuum in the phreatic zone (contaminants sorbed onto material under saturated conditions), and contaminated sediment within the conduit to Burgermeister Spring.

\subsubsection{Environmental Setting}

\subsubsection{Land Use}

The original Weldon Spring Ordnance Works site covered approximately 6,974 ha $(17,233$ acres) in St. Charles County. Current land use of the former ordnance works area includes the Weldon Spring Training Area, the DOE Weldon Spring Site, Missouri Department of Conservation and Missouri Department of Natural Resources-Division of State Parks-managed lands, the Francis Howell High School, a Missouri Department of Transportation maintenance facility, the village of Weldon Spring Heights, and a University of Missouri research park.

The Weldon Spring Training Area is located in the center of the former ordnance works area. The training area occupies approximately 670 ha (1,655 acres) and shares its eastern boundary with the chemical plant area. The training area is used by the U.S. Army Reserve, Missouri Army National Guard, and occasionally other military units for training exercises (IT Corporation 1993a). An average of 300 troops participate in training activities on weekends throughout the year. The 89th Regional Support Command, U.S. Army Reserve, has developed plans to construct a training center at the Weldon Spring Training Area. This facility would contain headquarters for several reserve units with about 30 full-time personnel. The units headquartered at the facility would conduct drills on assigned weekends and evenings at the facility and the training area.

The DOE Weldon Spring site consists of two geographically distinct areas, an 88-ha (217-acre) chemical plant area and a 4-ha (9-acre) limestone quarry. The chemical plant area is located in the central portion of the ordnance works area, and the quarry is located about $6 \mathrm{~km}(4 \mathrm{mi})$ south-southwest of the chemical plant area. Characterization and remediation activities are currently ongoing at both areas.

Most of the land of the ordnance works area consists of two state conservation areas. The August A. Busch Memorial Conservation Area, located in the northern portion of the ordnance works area and immediately adjacent to the chemical plant area and the training area, includes about 2,828 ha $(6,987$ acres) of actively managed grassland and forest. The Weldon Spring Conservation Area comprises about 2,977 ha (7,356 acres) of primarily forested land and is located in the southern 
portion of the ordnance works area and south and east of the chemical plant and training areas. Both conservation areas are actively managed for fish and wildlife production and are used annually by more than 1,200,000 visitors for fishing, hunting, and hiking (Crigler 1992). The two conservation areas also annually host approximately 100,000 fishing trips. Although the conservation areas are used primarily for recreational activities, approximately $17 \%$ of the land area is leased to farmers for the production of domestic animal feed.

The Francis Howell High School occupies approximately 25 ha (61 acres) within the former Weldon Spring Ordnance Works site and is located about $1 \mathrm{~km}(0.6 \mathrm{mi})$ northeast of the chemical plant area (Figure 1.4). The school employs about 200 teachers and other staff and has a student enrollment of about 2,400. A State of Missouri Highway Department maintenance facility is located about $183 \mathrm{~m}$ (600 ft) northeast of the chemical plant area and employs nine full-time staff and one mechanic (Sizemore 1991). The former staff housing complex for the former Weldon Spring Ordnance Works site, located about $0.8 \mathrm{~km}(0.5 \mathrm{mi})$ southeast of the intersection of State Route 94 and U.S. Route 40/61, is currently a private housing development known as Weldon Spring Heights. This development occupies about 26 ha (63 acres) and has a population of about 80.

\subsubsection{Groundwater Use}

The aquifer as a whole beneath the boundaries of the chemical plant area and the ordnance works area is currently not used for drinking water or for irrigation. Drinking water is provided by the St. Charles County Water Department.

It is unlikely that the shallow aquifer beneath the ordnance works area and chemical plant area would be used by a future resident on the basis of the current and projected land use. The DA intends to continue using the training area for training activities in the future. The chemical plant area is currently being remediated, with all site waste being disposed of in an engineered disposal cell constructed on-site. The size of the cell is estimated to encompass approximately one-third of the chemical plant area.

In addition, a large portion of the former ordnance works area has been converted into conservation areas. The August A. Busch Memorial Conservation Area and the Weldon Spring Conservation Area are managed by the Missouri Department of Conservation and are open throughout the year for recreational use. These areas are extensively used, as indicated by the estimated 1,200,000 visits each year (Crigler 1992).

A total of 45 old wells were identified on or very near to the ordnance works area as a result of a review of archival records from state files and interviews with persons familiar with the site. Many of the private wells identified were open to the deeper bedrock aquifers (i.e., Kimmswick and St. Peter) in order to obtain sufficient well yields. Although some of these private wells were open 
to the shallow aquifer, in order to obtain sufficient yield most of these wells were open throughout the entire shallow aquifer (including all or part of the Fern Glen) rather than only the upper weathered part of the Burlington-Keokuk.

It is unlikely that a future resident would have a well open only to the upper part of the shallow aquifer because of the low transmissivity and low yield. A future resident would likely screen a private well in the deeper, more productive aquifers or, because of the $80-\mathrm{ft}$ casing requirement, the well would be open to a larger portion of the shallow aquifer (rather than only the upper weathered unit of the Burlington-Keokuk). Finally, a municipal water supplier rather than individual wells would likely be the source of water for a future subdivision with multiple single family housing units.

No known shallow aquifer wells within the ordnance works area or chemical plant area are being used as sources of water. The closest private well to the former ordnance works site is located at Twin Island Lakes campground, approximately $0.20 \mathrm{~km}(0.12 \mathrm{mi})$ north of the August A. Busch Conservation Area. This well is estimated to be 70 to $91 \mathrm{~m}$ ( 230 to $300 \mathrm{ft}$ ) below the ground surface and is located downgradient from the site.

\subsubsection{Ecological Resources}

The ordnance works area and the chemical plant area are located along the boundary of the Ozark Border and Glaciated Plains physiographic provinces (based on physiographic provinces described in Johnson (1987). Land in the area varies from rolling hills to sloped forests to floodplain areas. This province possesses a variety of habitats that support a diverse flora and fauna (Missouri Department of Conservation 1991). The chemical plant area and portions of the ordnance works area are characterized by grasslands, old field habitat, and sparse to moderate woodland growth, primarily along creeks and drainages. Much of the chemical plant area is now cleared as a result of remedial actions in the area.

Sixty percent of the ordnance works area is forested and includes upland, slope, palustrine, and riparian forest habitats. Other terrestrial habitats found in the former ordnance works area are open fields, pastures, and cultivated farmlands.

A total of 29 mammal species have been reported in St. Charles County (DOE 1992a). Deer, squirrel, opossum, and racoon are common mammals and have been observed feeding and resting within the boundaries of the chemical plant area and the training area. Approximately 277 avian species have been reported from the conservation areas (Missouri Department of Conservation 1991), including wild turkey, great horned owl, red-tailed hawk, and several waterfowl and wading species, including wood duck, Canada goose, mallard, and great blue heron. 
A total of 47 reptile species, 25 amphibian species, and 105 fish species have been reported in St. Charles County (DOE 1992a). Common herptofauna (reptiles and amphibians) found in this area include red-eared turtle, green frog, spring peeper, and central newt.

Surface water impoundments (lakes, reservoirs, and ponds) constitute the primary aquatic habitat present at the ordnance works area. Excluding the Missouri River, the principal stream habitat is Dardenne Creek, located in the Busch Conservation Area, and its larger tributaries. Numerous smaller streams and springs occur throughout the area, but the occurrence of surface water in many of these is ephemeral in nature and dependent on the precipitation regime and groundwater discharge. Many of the more than 105 species of fish reported in St. Charles County (Dickneite 1988) likely occur within suitable habitats in the conservation area. The reservoirs in the conservation areas are actively managed for recreational fishing and are stocked with such game species as bluegill, largemouth bass, black crappie, and channel catfish (Missouri Department of Conservation 1989). The larger stream habitats are known to support game and nongame fish species typically found in similar habitats throughout the Midwest and include a variety of centrarchids, minnows, shiners, and darters. Because of the ephemeral nature of flows, many of the small streams and springs provide limited year-round habitat for fish.

Five federal-listed threatened or endangered species, five federal candidate (C2) species, 13 state endangered species, and 19 state rare species have been reported from St. Charles County (DOE 1995b). Federal-listed species reported from or near the conservation areas or the ordnance works area include the bald eagle (Haliaeetus leucocephalus), peregrine falcon (Falco perigrinus), interior least tern (Sterna antillarum), pallid sturgeon (Scaphirhynchus albus), and decurrent false aster (Boltonia decurrens) (DOE 1995b). The peregrine falcon and interior least tern only occur in the area as season migrants, and the pallid sturgeon is restricted to the Missouri River. The decurrent false aster occurs in slough habitats along the Missouri River but has not been reported in the area of the ordnance works area. Wintering bald eagles roost at the Howell Island Conservation Area and may forage in the ordnance works area. The sicklefin chub and sturgeon chub, both federal C2 species, and the paddlefish are large river species and if present in the area would be restricted to the Missouri River. Many of the $\mathrm{C} 2$ species, as well as the state-listed species, have been reported from the Busch or Weldon Spring Conservation areas and may utilize habitats receiving groundwater discharge (springs and seeps). 


\section{STUDY AREA INVESTIGATIONS}

A number of investigations have been performed since 1987 to define the geological, hydrological, and contaminant profiles of the aquifer system at the chemical plant area and the ordnance works area. In addition, ecological surveys and sampling have also been performed to support the determination of environmental impacts from site-related contamination. Section 2.1 is a brief summary of the hydrological investigations relevant to the GWOUs. A description of the monitoring networks and data collected from these networks to delineate type and levels of site-related contamination is presented in Section 2.2. Section 2.3 describes activities performed as part of the ecological investigations.

\subsection{HYDROGEOLOGIC INVESTIGATION}

Numerous hydrogeological investigations have been conducted at the chemical plant area and the ordnance works area to develop a hydrogeological conceptual model for the GWOUs. The investigations that focused on characterizing the shallow aquifer system and identifying potential flow paths for contaminant migration included installation of a monitoring well, logging of bedrock and overburden core, measuring of static water levels, aquifer and tracer testing, and physical and chemical analyses of subsurface soils. Table 2.1 summarizes all relevant hydrogeological investigations.

Additional hydrogeological investigations were recently completed to further understand the groundwater flow system in the shallow aquifer. The studies performed in 1995 included installation of several additional monitoring wells and angled boreholes and aquifer testing in these wells. Aquifer testing was also performed for wells that had not been previously tested. More recent tracer tests were also performed (see Table 2.1). A detailed description of the hydrogeologic investigations listed in Table 2.1 is presented in Chapter 3.

\subsection{NATURE AND EXTENT OF CONTAMINATION STUDIES}

As discussed above, monitoring wells have been installed at the chemical plant area and the ordnance works area to provide geological, hydrological, and contaminant characterization data. Tables 2.2 and 2.3 list the groundwater monitoring wells and the completion intervals; the locations of the wells are shown in Figure 2.1.

Groundwater sampling and analysis have been ongoing at the chemical plant area since 1987. From 1987 to 1990 , groundwater monitoring generally consisted of quarterly sampling of the wells composing the chemical plant monitoring network. In 1990, the monitoring frequency was 
TABLE 2.1 Summary of Remedial Investigation Hlydrogeologic Activities

\begin{tabular}{ll}
\multicolumn{1}{c|}{ Activity } & \multicolumn{1}{c}{ Purpose } \\
\hline $\begin{array}{l}\text { Water-level measurements; sampling and } \\
\text { analyses of groundwater and surface water } \\
\text { samples. }\end{array}$ & $\begin{array}{l}\text { To deternine the extent and magnitude of } \\
\text { groundwater and surface water } \\
\text { contamination from chemical plant } \\
\text { operation and the disposal of waste in the } \\
\text { raffinate pits. }\end{array}$
\end{tabular}

Description of monitoring equipment and methodology used, results summary, and discussion of significance of the results.

Geophysical surveys, trenching, borehole drilling and sampling, installation of groundwater monitoring wells, laboratory soil property analyses, and groundwater sampling and analyses.

Water-level measurements; streamflow measurements; dye tracing; and sampling and analyses of groundwater, springs, and the raffinate pits.

Water samples from 27 springs and seeps within a $3-\mathrm{km}(2-\mathrm{mi})$ radius of the chemical plant area were collected and analyzed for nitroaromatic compounds, uranium, metals, and inorganic anions. Groundwater was also sampled at the chemical plant area.

Three types of aquifer tests were performed: slug tesis, pumping tests, and tracer tests.

Chemical analyses of groundwater and surface water samples, mineralogic and chemical analyses of overburden samples, laboratory sorption experiments, chemical and mineralogic characterization of sludge and interstitial samples from Raffinate Pit 3, and geochemical computer simulations.

Literature search, classification of stream segments as gaining or losing, identification of spring locations, water tracing tests, continuous gauging of selected springs, and continuous waterlevel monitoring in selected monitoring wells.

Classification of surface drainages into losing and gaining stream segments. locations of karst features (e.g., springs, caves, and sinkholes), water tracing tests, and continuous water-level monitoring of selected wells.
To consolidate documents prepared by Shell Engineering and Associates, Inc., on a water balance study conducted at the chemical plant area raffinate pits and to summarize the results.

To determine if contaminants from site activities have impacted the groundwater and to evaluate the geology and hydrogeology, a hydrogeological characterization study was conducted at the chemical plant area.

To determine the extent and magnitude of surface and groundwater contamination at the chemical plant area.

To determine the extent of contamination in surface water and groundwater near the chemical plant area.

To characterize the hydraulic properties of the shallow aquifer (i.e., BurlingtonKeokuk Limestone) beneath the chemical plant area.

To determine the geochemistry of the shailow aquifer and geochemical controls on the migration of uranium and other constituents from the raffinate pits.

To define the relationships between precipitation, surface runoff, groundwater recharge, and shallow groundwater discharge. The study area included most of the original ordnance works area and a small area to the northeast between U.S. Highway 40/61 and Dardenne Creek.

To identify the shallow groundwater discharge points that might be affected by nunoff from the training area. The study area included the ordnance works area and the adjoining land to the west of it.
Organization/Report

Kleeschulte and Emmett 1986. Compilation and Preliminary Interpretation of Hydrologic Data for the Weldon Spring Radioactive Waste-Disposal Sites, St. Charles Counry, Missouri-A Progress Report.

Bechtel National, Inc. 1986, Report on Water Balance Studies from 1983 to 1985, Weldon Spring Raffinate Pits, Weldon Spring, Missouri.

Bechtel National, Inc. 1987, Hydrogeological Characterization Repon for Weldon Spring Chemical Plant, Weldon Spring, Missouri.

Kleeschulte and Emmen 1987, Hydrology and Water Quality at the Weldon Spring Radioactive Waste-Disposal Sites, St. Charles County, Missouri.

MK-Ferguson Company and Jacobs Engineering Group, Inc. 1989c, Phase I Spring and Seep Report: Weldon Spring Site Remedial Action Project, Weldon Spring, Missouri.

MK-Ferguson Company and Jacobs Engineering Group. Inc. 1990b, Aquifer Characteristics Data Report for the Weldon Spring Chemical Plant/Raffinate Pits and Vicinity Properties.

Schumacher 1990, Geochemical Data for the Weldon Spring Chemical Plant Site and Vicinity Property, St. Charles County, Missouri - 1989-90; Schumacher 1993, Geochemistry and Migration of Contaminants at the Weldon Spring Chemical Plant Site, St. Charles, Missouri - 1989-91.

Missouri Department of Natural Resources 1991, Shallow Groundwater Investigations at Weldon Spring, Missouri, Final Report for Fiscal Years 1988-1990.

Price 1991, Shallow Groundwater Investigations at the Weldon Spring Training Area, St. Charles County. Missouri. 
TABLE 2.1 (Cont.)

\begin{tabular}{l} 
Activity \\
\hline Laboratory batch experiments and \\
geochemical modeling.
\end{tabular}

Installation of monitoring wells and measurement of static water levels.

Exploratory trenching and soil borings to characterize the surficial material units, laboratory testing to determine engineering properties of each surficial material unit, and detailed mapping and cross-section development of the surficial material units.

Installation of monitoring wells, logging of bedrock core, aquifer testing (i.e., slug tests), measurement of static water levels, and groundwater sampling and analysis.

Water was collected and analyzed for nitroaromatic compounds from lysimeters installed in the unsaturated zone at locations along former TNT production lines and groundwater. Surface water, surficial soil samples, and subsurface soil core samples were also analyzed for nitroaromatic compounds. Soils samples were collected from various overburden units at the training area for physical, chemical, and mineralogic

characterization.

Water-level measurements, sampling and analyses of groundwater and springs, and simulation of the groundwater flow system with a three-dimensional flow model.

Incorporation and interpretation of selected data collected by the DA, DOE, U.S. Geological Survey (USGS), and Missouri Deparment of Natural Resources. Relogging of bedrock and overburden core samples from DA wells and bedrock core samples from some of the DOE monitoring wells was a component of this investigation.

Physical and chemical analyses of soil and water samples from lysimeters installed in the unsaturated zone, ground water and spring water quality data, discharge and water quality data collected during stormwater runoff events at two continuous record stream gauging stations and six ancillary stormwater runoff monitoring sites, and water-level data.
Purpose

Organization/Report
To determine the potential for migmtion of molybdenum, uranium, and other constituents from the raffinate pits, investigations were conducted at the chemical plant area.

To characterize the shallow aquifer system.

To characterize and map the surficial units, define the types of soils, and determine their origins. The study area included the training area.

To characterize the shallow aquifer system beneath the ordnance works area.

To investigate the environmental fate of TNT at the training area.

To improve understanding of the geohydrology, to better define the extent of groundwater contamination, and to quantitatively assess the ground water flow system in St. Charles County.

To present a geohydrologic description of the ordnance works area and chemical plant area that consists of descriptions of the geology and groundwater hydrology.

To collect hydrologic and water quality data at the ordnance works area.
Schumacher and Stollenwerk 1991 , Geochemical Controls on Migration of Molybdenum, Uranium, and Other Constituents at the Weldon Spring Chemical Plant Site.

MK-Ferguson Company and Jacobs Engineering Group, Inc. 1992a, Remedial Investigation for the Chemical Plant Area of the Weldon Spring Site.

Rueff 1992, Surficial Materials Investigation at the Weldon Spring Training Area, St. Charles County, Missouri.

IT Corporation 1993a, Final Remedial Investigation Report, Weldon Spring Training Area. Weldon Spring. Missouri.

Schumacher et al. 1993, Geochemical Data for the Weldon Spring Training Area and Vicinity Property. St. Charles County, Missouri-1990-92.
Kleeschulte and Imes 1994, Geohydrology, Water Quality, and Simulation of GroundWater Flow at the Weldon Spring Chemical Plant and Vicinity, St. Charles County, Missouri.

Mugel 1997, Geohydrology of the Weldon Spring Ordnance Works, St. Charles County, Missouri.
Schumacher et al. 1996, Hydrologic and Water-Quality Data for the Weldon Spring Ordnance Works, St. Charles County. Missouri - 1992-95. 
TABLE 2.1 (Cont.)

Activity

Installation of eight monitoring wells (six at the ordnance works area and two at the chemical plant area).

Retrofit of one existing monitoring well at the ordnance works.

Core drilling of three angled borings at the chemical plant.

Packer testing of the bedrock during coring of monitoring wells and angled borings.

Injection of dye tracers in two angled borings and one monitoring well and monitoring for resurgence at nearby springs.

Single well hydraulic conductivity testing (slug testing) on several existing monitoring wells at both the ordnance works area and the chemical plant area.

Water-level monitoring of complete groundwater monitoring network.

Precipitation measurements.

Purpose

Organization/Report

To provide information on groundwater elevation and flow direction and water quality in both the weathered and unweathered Burlington-Keokuk Limestone in areas where data were not available.

To provide data on the weathered Burlington-Keokuk Limestone, monitoring well USGS-7 was retrofitted from an open hole construction to that of a discrete monitoring interval and renamed MWD-112.

To further evaluate the areas of suspected highly conductive paleochannels on the basis of geological data and prior aquifer testing, three angled borings were drilled $30^{\circ}$ from vertical to increase the likelihood of intersecting verical fracture zones.

To evaluate the vertical variation of hydraulic conductivity in the weathered and unweathered Burlington-Keokuk Limestone and to identify any highly transmissive zones, packer (water pressure) tests were performed in the bedrock portion of each monitoring well and angled boring.

To determine if a subsurface hydraulic connection exists between the northern and western portions of the chemical plant area to Burgermeister Spring (Drainage 6300), tracer testing was performed.

To provide a comprehensive data set for evaluation of the areal distribution of hydraulic conductivity in the weathered and unweathered Burlington-Keokuk Limestone, slug tests were performed on locations not previously tested.

To provide a regional picture of the potentiometric surface of the shallow aquifer, static water level measurements were obtained from the active monitoring well networks at both the ordnance works area and the chemical plant area.

To evaluate the response of the shallow aquifer system to precipitation events, daily precipitation measurements were obtained and compared to static groundwater levels in monitoring wells and discharge rates in springs.
Additional activity performed by IT Corporation and MK-Ferguson Company and Jacobs Engineering Group, Inc., as part of this RI.

Additional activity performed by IT Corporation as part of this RI.

Additional activity performed by MK-Ferguson Company and Jacobs Engineering Group, Inc., as part of this RI.

Additional activity performed by MK-Ferguson Company and Jacobs Engineering Group, Inc., as part of this R1.

Additional activity performed by MK-Ferguson Company and Jacobs Engineering Group, Inc., as part of this RI.

Additional activity performed by MK-Ferguson Company and Jacobs Engineering Group, Inc., as part of this RI.

Additional activity performed by MK-Ferguson Company and Jacobs Engineering Group, Inc., as part of this RI.

Additional activity performed by MK-Ferguson Company and Jacobs Engineering Group, Inc., as part of this RI. 
TABLE 2.2 Monitoring Wells Associated with the Ordnance Works Area

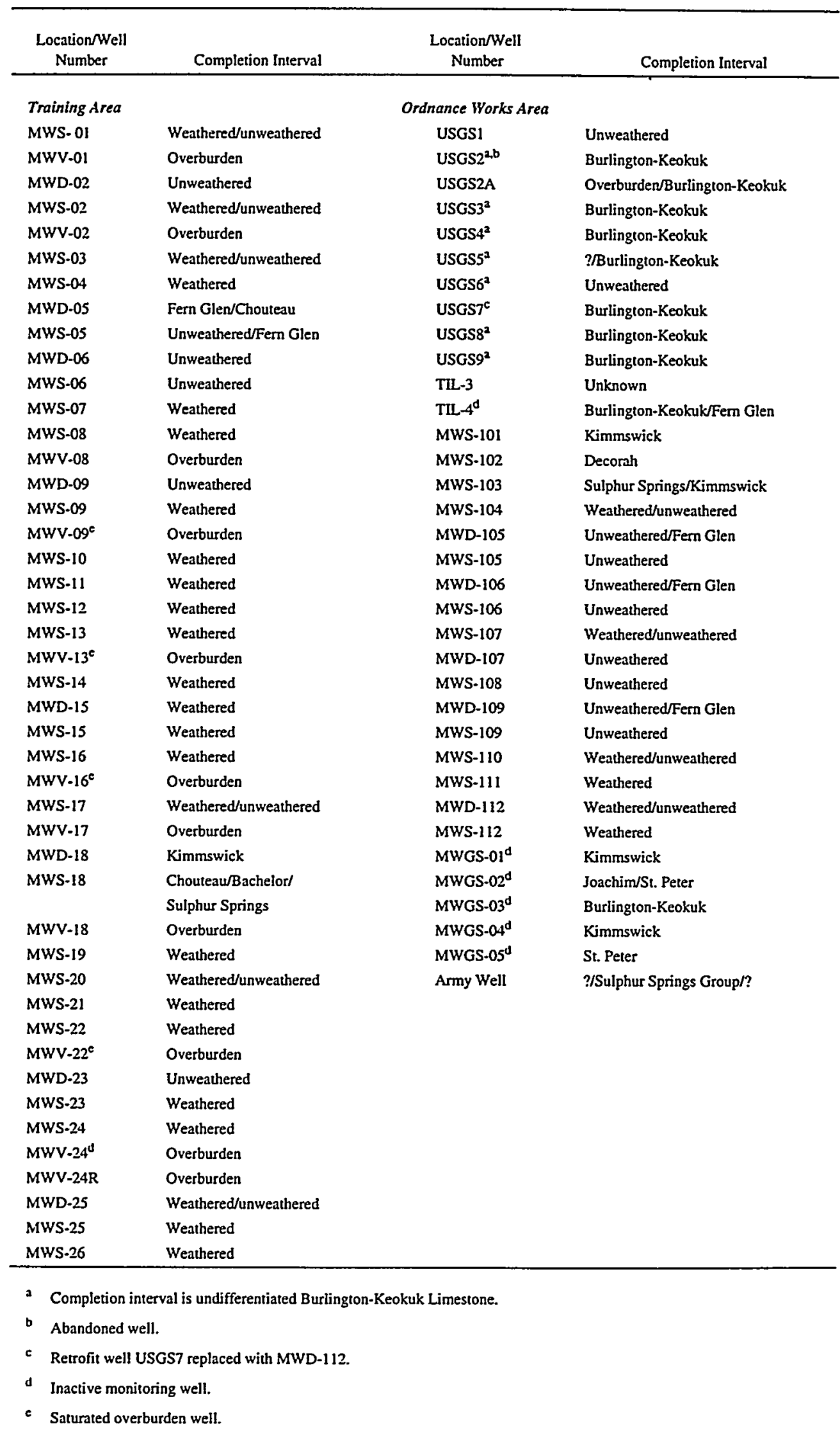


TABLE 2.3 Monitoring Wells at the Chemical Plant Area

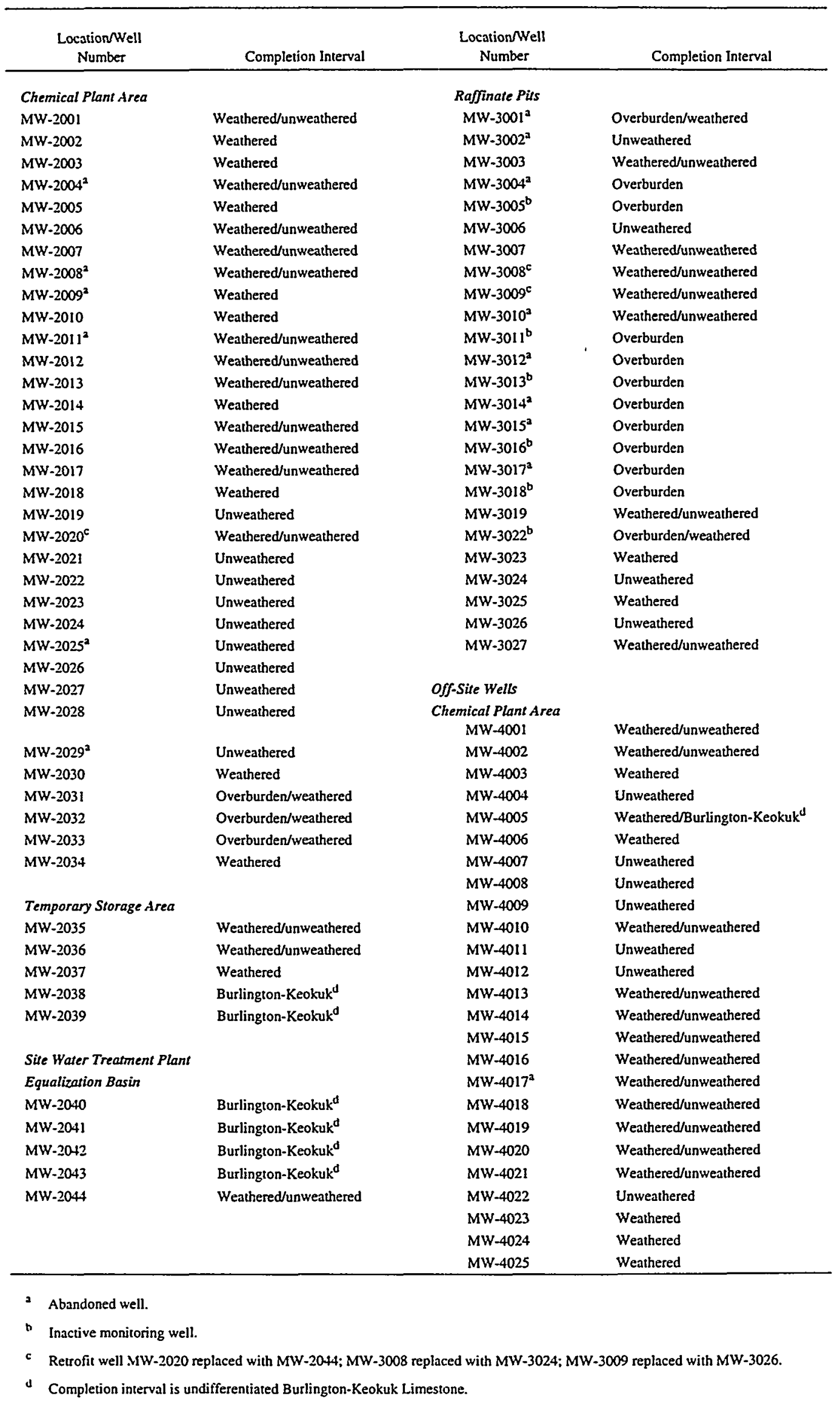




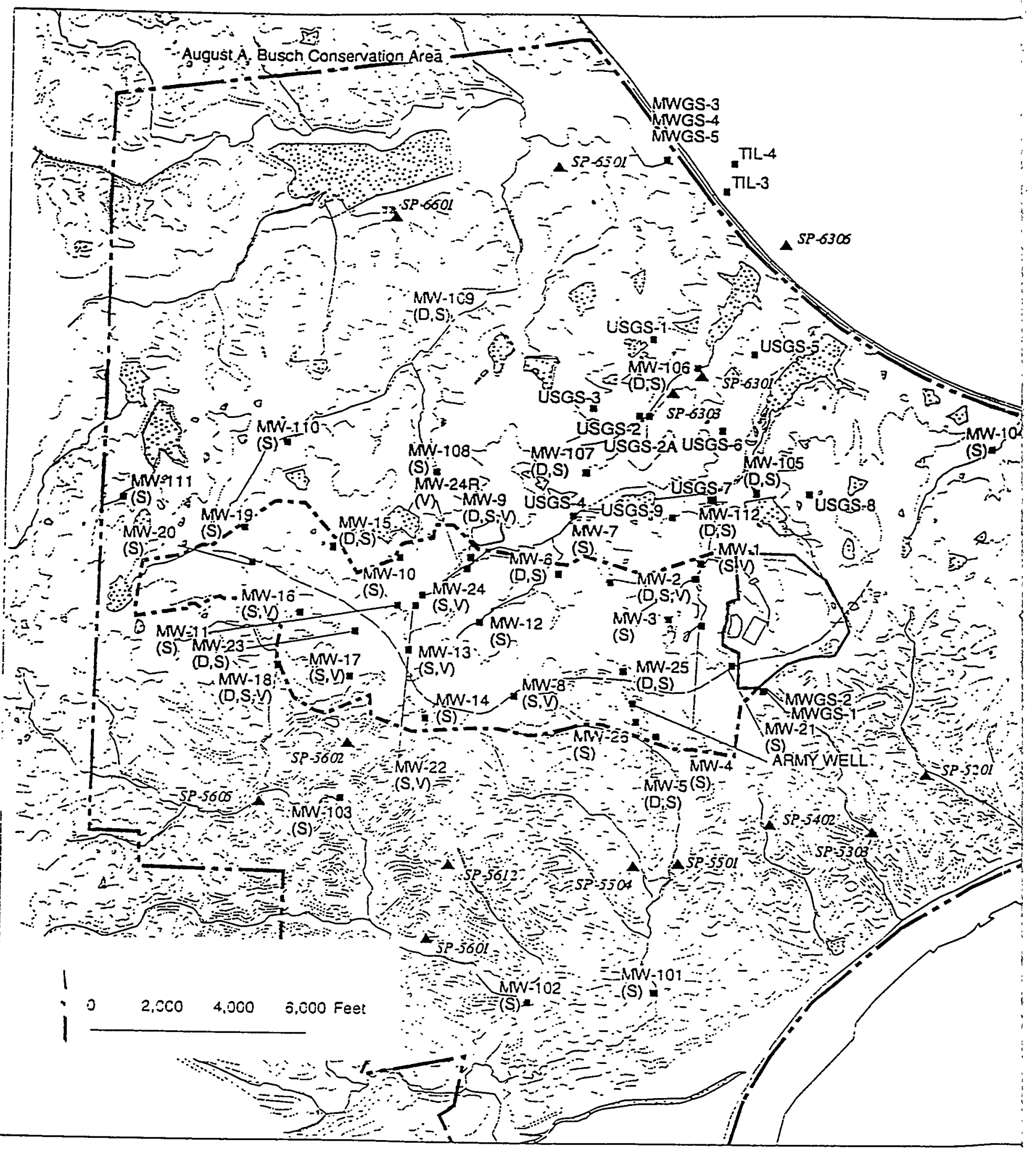

FIGURE 2.1 Location of Monitoring Wells and Springs at the Chemical Plant Area and the Ordnance Work 
reduced to semiannually at monitoring locations where contaminants exceeded water quality criteria and to annually at remaining locations (DOE 1995b). Data collected prior to 1995 have been compiled and presented in various reports listed in Table 2.4 .

Groundwater sampling was begun in the ordnance works area in 1989. Two sampling rounds in March and October of 1989 were conducted on the central portion of the ordnance works area (training area) wells. One sampling round was conducted in January 1990 on wells outside the training area; a round was conducted in May and June 1991 for all training area and ordnance works wells (IT Corporation 1995a). Quarterly sampling for analyses of nitroaromatics, metals, and inorganic anions was initiated in 1992. Since February 1993, quarterly samples have been analyzed only for nitroaromatics; metals and inorganic anions analyses are conducted annually (IT Corporation 1995a). Most of the wells completed in the overburden monitor perched water, except for five wells (MWV-09, MWV-13, MWV-16, MWV-22, and MWV-24R) that monitor the saturated overburden. Table 2.4 lists the reports in which groundwater data collected at the ordnance works area previous to 1995 have been compiled.

Several additional sampling activities were conducted in 1995 to provide further data to define the nature and extent of contamination in the shallow groundwater aquifer. Two wells completed in the weathered zone of the Burlington-Keokuk Limestone, MW-4024 and MW-4025, were installed southeast of the chemical plant area to delineate the extent of uranium contamination. Because of difficulties encountered during installation, MW-4024 was not completed until July 1995. The well was sampled at the time of well completion and was also sampled in August. Seven wells and one retrofit well installed on the ordnance works area for the hydrogeological investigation were sampled during both 1995 sampling events. MWS-24 is routinely not sampled because of previous well installation problems with an adjacent well. Samples for metals and anions analyses were not obtained from MWS- 26 for the August round because the wells went dry prior to obtaining an adequate volume of water for analysis. Also, May and August samples were not obtained from MWV-8 and MWV-18 (located on the training area) because the wells were dry.

A joint sampling effort was conducted by DOE and the DA during May and August 1995; this sampling involved all currently monitored wells. In addition, in order to collect more recent data to determine groundwater discharge at the area springs, 15 springs were included for the joint sampling effort (Figure 2.1). Parameters evaluated under the joint sampling effort were those identified as COPC in the Work Plan (DOE 1995b) and are shown in Table 2.5. The list includes parameters that were not routinely analyzed at the ordnance works area (e.g., concentrations of uranium, lithium, molybdenum, and nitrate) and chemical plant area (e.g., degradation products of DNT and TNT). Because sampling methods, target analytes, and analytical procedures varied in the past, the joint sampling effort provided a unified sampling method, and target analyte list and specific analytical procedures to produce a set of comparable data between both areas. 
TABLE 2.4 Summary of Groundwater Sampling and Analysis at the Chemical Plant Area and the Ordnance Works Area

Activity

Groundwater monitoring 1987 — chemical plant area

Groundwater monitoring 1988 - chemical plant area

Groundwater monitoring 1989 - chemical plant area

Groundwater monitoring 1990 — chemical plant area

Groundwater monitoring 1991 - chemical plant area

Groundwater monitoring 1992 - chemical plant area

Groundwater monitoring 1993 - chemical plant area

Groundwater monitoring 1994 — chemical plant area

Groundwater monitoring, Rounds 1-3, March and

October 1989 and June 1991 — ordnance works area

Groundwater monitoring, Round 4, February 1992 ordnance works area

Groundwater monitoring, Round 5, May/June 1992 ordnance works area
Water Quality Phase I Assessment Report, MK-Ferguson and Jacobs Engineering Group, Inc. 1987

Phase II Groundwater Quality Assessment for the Weldon Spring Site, Chemical Plant, Raffinate Pits, and Surrounding Vicinity Properties, MK-Ferguson

Company and Jacobs Engineering Group, Inc. 1989d

Annual Site Environmental Report 1989, MK-Ferguson Company and Jacobs Engineering Group, Inc. 1990a

Annual Site Environmental Report for Calendar Year 1990, MK-Ferguson Company and Jacobs Engineering Group, Inc. 1991

Weldon Spring Site Environmental Report for Calendar Year 1991, MK-Ferguson Company and Jacobs Engineering Group, Inc. 1992b

Weldon Spring Site Environmental Report for Calendar Year 1992, MK-Ferguson Company and Jacobs Engineering Group, Inc. 1993b

Weldon Spring Site Environmental Report for Calendar Year 1993, MK-Ferguson Company and Jacobs Engineering Group, Inc. 1994

Weldon Spring Site Environmental Report for Calendar Year 1994, MK-Ferguson Company and Jacobs Engineering Group, Inc. 1995

Final Remedial Investigation Report, Weldon Spring Training Area, Weldon Spring, Missouri, IT Corporation 1993a

Quarterly Groundwater Monitoring, First Report (Revision No. 2, New Data), IT Corporation 1992b

Quarterly Groundwater Monitoring, Second Report, IT Corporation 1992c 
TABLE 2.4 (Cont.)

Activity

Report

Groundwater monitoring, Round 6, August 1992 ordnance works area

Groundwater monitoring, Round 7, December 1992 - ordnance works area

Groundwater monitoring, Round 8, February 1993 ordnance works area

Groundwater monitoring, Round 9, May 1993 ordnance works area

Groundwater monitoring, Round 10, August 1993 ordnance works area

Groundwater monitoring, Round 11, November 1993 — ordnance works area

Groundwater monitoring, Round 12, February 1994 - ordnance works area

Groundwater monitoring, Round 13, May 1994 ordnance works area

Groundwater monitoring, Round 14, August 1994 ordnance works area

Groundwater monitoring, Round 15, November 1994

- ordnance works area

Groundwater monitoring, Round 16, February 1995

— ordnance works area
Quarterly Groundwater Monitoring, Third Report, IT Corporation 1992d

Quarterly Groundwater Monitoring, Fourth Report, IT Corporation 1993e

1993: Groundwater Monitoring Report First Yearly Sampling Round, Weldon Spring Ordnance Works, IT Corporation 1993b

1993: Second Quarterly Groundwater Monitoring Report, Weldon Spring Ordnance Works, IT Corporation 1993c

1993: Third Quarterly Groundwater Monitoring Report, Weldon Spring Ordnance Works, IT Corporation 1993d

1993: Fourth Quarterly Groundwater Monitoring Report, Weldon Spring Ordnance Works, IT Corporation 1994d

1994: Second Yearly Groundwater Monitoring Report, Weldon Spring Ordnance Works, IT Corporation 1994c

1994: Second Quarterly Groundwater Monitoring Report, Weldon Spring Ordnance Works, IT Corporation 1994b

1994: Third Quarterly Groundwater Monitoring Report, Weldon Spring Ordnance Works, IT Corporation 1994e

1994: Fourth Quarterly Groundwater Monitoring Report, Weldon Spring Ordnance Works, IT Corporation 1995a

1995: Third Yearly Groundwater Monitoring Report, Weldon Spring Ordnance Works, IT Corporation $1995 \mathrm{c}$ 
TABLE 2.4 (Cont.)

\begin{tabular}{ll}
\hline \multicolumn{1}{c}{ Activity } & \multicolumn{1}{c}{ Report } \\
\hline $\begin{array}{l}\text { Groundwater monitoring, Joint Sampling Round } 1 \\
\text { (Round 17) - chemical plant area and ordnance } \\
\text { works area }\end{array}$ & $\begin{array}{l}\text { 1995: Second Quarterly Groundwater Monitoring } \\
\text { Report, Weldon Spring Ordnance Works, IT } \\
\text { Corporation 1995b }\end{array}$ \\
$\begin{array}{l}\text { Groundwater monitoring, Joint Sampling Round 2 } \\
\text { (Round 18) - chemical plant area and ordnance } \\
\text { works area }\end{array}$ & $\begin{array}{l}\text { 1995: Third Quarterly Groundwater Monitoring } \\
\text { Report, IT Corporation 1995c }\end{array}$ \\
\hline
\end{tabular}

TABLE 2.5 Contaminants of Potential Concern Evaluated in the Joint Sampling Effort

\begin{tabular}{ll}
\hline Human & \\
Health COPC & Ecological COPC \\
\hline Uranium & Uranium $^{\mathrm{a}}$ \\
Aluminum & Arsenic \\
Antimony & Chromium \\
Arsenic & Lead \\
Barium & Manganese \\
Cadmium & Mercury \\
Chromium & Molybdenum \\
Copper & Nickel \\
Iron & Selenium \\
Lead & Silver \\
Lithium & Thallium \\
Chloride & Nitrate \\
Fluoride & Nitroaromatic compounds \\
Nitrate & \\
Sulfate & \\
Nitroaromatic & \\
compounds & \\
\hline & \\
a Retained on the basis of chemotoxicity only. \\
b Nitroaromatics include the following 11 compounds: \\
1,3 -dinitrobenzene, 2,4-dinitrotoluene, 2,6-dinitrotoluene, \\
1,3,5-trinitrobenzene, 2,4,6-trinitrotoluene, nitrobenzene, \\
2-amino-4,6-dinitrotoluene, 4-amino-2,6-dinitrotoluene, \\
2-nitrotoluene, 3-nitrotoluene, and 4-nitrotoluene. \\
& \\
\hline
\end{tabular}


Three springs - 5101, 5605, and 5612 - were not accessible during the May sampling event. The access to Spring 5101 was flooded, the discharge point for Spring 5605 could not be located because of high levels of water in the stream, and Spring 5612 was not flowing at the time of sampling. Samples were obtained from all locations during the August sampling event.

Toluene and carbon disulfide were also analyzed in samples from two ordnance works wells, MWS-5 and MWS-104. Toluene was detected in MWS-5 in a sample collected in 1989, and carbon disulfide was detected in MWS-104 in a 1990 sample. These detects were suspected to be due to laboratory contamination, and no detected concentrations of these compounds were found in the 1995 joint samples. Recent (1996 and 1997) data, collected from monitoring wells as part of a volatile organic compound (VOC) monitoring program at the chemical plant area, indicate the presence of very low levels of toluene in groundwater from some wells. These recent data are discussed in detail in Chapter 4.

\subsubsection{Background Water Quality}

Both the chemical plant area and the training area are located on a local surface water high and straddle a regional groundwater divide, and, therefore, it was not feasible to conduct upgradient/ downgradient water quality comparisons to determine the extent of site-related contamination in the groundwater system. It was necessary to use existing on-site wells to estimate background levels of naturally occurring constituents (i.e., metals and anions). Organic compounds (primarily nitroaromatics compounds) are anthropogenic, and any detected concentration of these was assumed to be site related. Several wells open to the Burlington-Keokuk were identified in the Work Plan (DOE 1995b) as potential background locations since these areas had not shown detectable nitroaromatic compounds (a key contaminant at the training area) and were not believed to have been impacted from historical source areas. Monitoring well locations - MWS-13, MWS-23, and MWS-111 - were selected to represent background for the weathered zone of the Burlington Keokuk; MWD-105, MWD-106, MWS-108, and MWD-109 were selected to represent background for the unweathered zone. Monitoring wells MWD-105, MWS-108, and MWD-109 are located in the Busch Conservation Area north of the training area and the chemical plant area; MWS-13 and MWS-23 are located in the western portion of the training area; and MWS-111 is located northwest of the training area.

The background monitoring wells for this RI were selected on the basis of (1) completion in similar hydrostratigraphic units (e.g., weathered unit of the Burlington-Keokuk); (2) location outside of areas directly affected by contamination from the chemical plant area; and (3) location upgradient or at a distance from explosive production areas. Other factors evaluated for identifying background monitoring wells included groundwater sampling data (e.g., no impacts from past production operations indicated on the basis of no detectable concentrations of nitroaromatic compounds) and recognition, on the basis of dye tracing studies, of the potential for contaminant 
migration from known or suspected source areas at the chemical plant area and the ordnance works area. Background well MWS- 13 was eliminated from use because sulfate values were consistently higher than in other locations. Background well MWD-106 was also eliminated from use because it is located in the 6300 drainage basin near Burgermeister Spring. Because springs represent locations of groundwater discharge to the surface, the groundwater data collected from the background monitoring wells completed in the weathered zone of the Burlington-Keokuk were selected to represent background spring data. These data were compared with data collected from springs from across the ordnance works area and surrounding vicinity.

\subsubsection{In Situ Sampling of Groundwater at the Southeast Drainage}

Data requirements identified in the Work Plan (DOE 1995b) also include the need to collect preliminary information regarding contaminant levels in groundwater beneath the lower portion of the Southeast Drainage. Groundwater samples were obtained from six locations in August 1995. Boreholes were drilled using a hollow stem auger rather than the hydropunch technique specified in the Sampling Plan (DOE 1995a). This method was chosen because subsurface materials were believed to be too rocky for hydropunch methods. For each location, drilling was completed upon first encounter with groundwater; depths ranged from 1 to $3 \mathrm{~m}$ ( 3 to $10 \mathrm{ft}$ ). A water sample from an open borehole was then obtained with disposable bailers. The groundwater samples collected were very turbid because of the drilling methods used. These unfiltered groundwater samples were analyzed for metals, uranium, nitroaromatic compounds, nitrate, and sulfate.

These locations were resampled in April 1996 utilizing a hydropunch method. The hydropunch method was used because the push point could be advanced through the subsurface soils and because the method decreases the possibility of sediment disturbance such as that noted in the August 1995 sampling. Samples were obtained from boreholes with temporary casings and filtered using a $0.45-\mu \mathrm{m}$ filter. The samples were obtained at depths where water was first encountered and deeper, where possible. Because depth to bedrock was unknown, deeper samples were collected by sampling at the depth where the push point was advanced to refusal (refusal at bedrock noted only for sample IS-4003) or to a depth of 9 to $12 \mathrm{~m}$ (30 to $40 \mathrm{ft}$ ). Temporary casings and $1-\mathrm{m}$ ( $2-\mathrm{ft}$ ) screens were then installed at each point to allow an adequate sample to be gathered. The interval for two sampling locations (i.e., IS-4005 and IS-4006) did not yield enough water for laboratory analysis; therefore, samples obtained were analyzed for uranium only by using a Kinetic Phosphorescence Analyzer (KPA) method.

To better delineate contamination in the Southeast Drainage Area, a monitoring well was installed in May 1997. Data collected from this well will be evaluated and included in the FS. 


\subsection{ECOLOGICAL INVESTIGATION}

A number of ecological investigations have been conducted to support the baseline ecological risk assessment for the groundwater operable units. Additional ecological investigations have been completed to evaluate potential or actual impacts of other site-related contamination and media. The investigations supporting the groundwater BRA focused on surface water habitats (springs) that receive direct groundwater discharge. The ecological investigations included biotic surveys, habitat assessments of selected surface waters, and toxicity testing of surface water and sediment from selected surface water habitats.

Groundwater from the chemical plant area and within the former Weldon Spring Ordnance Works site discharges to the surface at a number of springs and seeps. However, because of natural variations in groundwater discharge and precipitation, many of the springs and seeps do not provide suitable year-round habitat capable of supporting a diverse biota. Thus, the ecological investigations targeted Burgermeister Spring and downstream waters. Burgermeister Spring (SP-6301) is located within the 6300 drainage of the ordnance works area and receives groundwater discharge from the chemical plant area. Burgermeister Spring is within the Dardenne Creek watershed and represents the headwaters of Lake 34 in the Busch Conservation Area. Except for a small portion of the drainage immediately below the spring, Burgermeister Spring and the downstream waters provide year-round habitat for aquatic biota.

Surface water and sediment were collected from Burgermeister Spring and analyzed for nitroaromatic compounds, metals, and inorganic ions. Surface water and sediment were also collected for toxicity testing. Sampling locations and methods, analytical methods, and toxicity test methods are described in the Sampling Plan (DOE 1995a) and the Work Plan (DOE 1995b).

Macroinvertebrates and fish were collected from Burgermeister Spring and analyzed for contaminant levels. Biotic surveys of aquatic invertebrates, fish, and amphibians from Burgermeister Spring and downstream habitats were conducted to identify potential receptor species for the ecological risk assessment and to characterize the condition of the biotic communities currently inhabiting the spring and downstream habitats. The ecological investigations also included evaluations of habitat quality. These evaluations, employing EPA Rapid Bioassessment Protocol methods (EPA 1989b), characterize aquatic habitats and biotic communities on the basis of physical characteristics, such as water depth, current velocity, and siltation, independent of potential contamination.

The results of the ecological investigations (see Appendix A) were incorporated into the ecological risk portion of the baseline risk assessment (DOE and DA 1997), which is summarized in Section 6.2 of this RI. The Sampling Plan (DOE 1995a) and the Work Plan (DOE 1995b) identify similar ecological investigations for two springs within the 5300 drainage (Southeast Drainage); the results of these investigations are presented in a separate report (DOE 1996). 


\section{HYDROGEOLOGICAL INVESTIGATIONS OF THE STUDY AREA}

This chapter summarizes the hydrogeological investigations performed at the ordnance works area and the chemical plant area to characterize the shallow aquifer and define potential pathways for contaminant migration. In addition to these investigations, those performed as part of this RI to refine the hydrogeologic conceptual model described in the Work Plan (DOE 1995b) are also discussed. Appendix B includes a discussion of the overburden and bedrock, as well as data summary tables, testing methods, figures, and geologic logs and well diagrams for the monitoring wells installed to complete the monitoring network to support this RI.

\subsection{GEOLOGY}

The geology of the Weldon Spring area can generally be divided into unconsolidated surficial material (overburden) and bedrock formations. Table 3.1 summarizes the generalized stratigraphy and hydrostratigraphy for the area. Additional information regarding the overburden and bedrock geology is provided in Section B.1 of Appendix B.

\subsubsection{Overburden}

The thickness of unconsolidated material or overburden ranges from 0 to $21 \mathrm{~m}(0$ to $70 \mathrm{ft}$ ) in the vicinity of the chemical plant area and the ordnance works area on the basis of new and reinterpreted top of bedrock data (Mugel 1997). The actual thickness depends on topography and/or previous construction at each of the sites. Some of the thickest overburden occurs in the northern part of the training area and north of the training area (Mugel 1997). The overburden is thinnest along the topographic high on the southern edge of the training area and the chemical plant area because of erosion. South of the training area and the chemical plant area, many of the stream beds are in bedrock, thus the overburden is not present.

The seven principal overburden units found at the chemical plant area and the ordnance works area are (1) fill/topsoil, (2) Peoria Loess, (3) Roxana Silt, (4) Ferrelview Formation, (5) clay till, (6) basal till, and (7) residuum (see Figure 3.1). Section B.1.1 of Appendix B gives a more complete description of each overburden unit and a summary of physical characteristics on the basis of laboratory tests performed on soils from the chemical plant area and training area.

The Ferrelview Formation, the till units (basal and clay), and the residuum allow recharge to the shallow aquifer system because of the presence of hairline fractures and permeable zones (MK-Ferguson Company and Jacobs Engineering Group, Inc. 1992a; Rueff 1992; Mugel 1997). The residuum and till units are saturated in localized portions of the ordnance works area and chemical 
TABLE 3.1 Generalized Stratigraphy and Hydrostratigraphy for the Chemical Plant Area and the Ordnance Works Area

\begin{tabular}{|c|c|c|c|c|c|}
\hline System & Series & Stratigraphic Unit & Thickness (ft) & Physical Characteristics & Hydrostratigraphic Unit" \\
\hline \multirow[t]{5}{*}{ Quaternary } & Holocene & Alluvium & $0-120$ & Silt, sand, gravel & Alluvial aquifer \\
\hline & Pleistocene & Loess and glacial drift & $0-11$ & Silty clay to silt & Not classifted ${ }^{b}$ \\
\hline & & Ferrelview Formation & $0-22$ & Clay to silty clay & Glacial draft confining unit \\
\hline & & Glacial till unit & $0-47$ & $\begin{array}{l}\text { Sandy and silty clay to clayey silt, with scuttered rock } \\
\text { fragments }\end{array}$ & Shaliow aquifer \\
\hline & & Basal till unit & $0-10$ & Sandy, clayey, silty gravel or gravelly silt & \\
\hline \multirow[t]{5}{*}{ Mississippian } & Osagean & Residuum unit & $0-38$ & Clay, chert, silt; locally contains limestone fragments & \\
\hline & & Burlington-Keokuk Limestone & $0-185$ & $\begin{array}{l}\text { Limestone; silty, argillaceous, thickly bedded, cherty, } \\
\text { fractured }\end{array}$ & Shallow aquifer \\
\hline & & Fern Glen Formation & $0-67$ & $\begin{array}{l}\text { Limestone; fine-grained, medium to thickly bedded, } \\
\text { cherty }\end{array}$ & \\
\hline & Kinderhookian & Chouteau Group & $0-45(+)$ & $\begin{array}{l}\text { Dolomitic limestone; fine-grained, thinly to medium } \\
\text { bedded }\end{array}$ & Upper confining \\
\hline & & Bachelor Formation & $0-2$ & Sandstonc; calcareous cement & \\
\hline \multirow[t]{3}{*}{ Devonian } & Upper & Sulphur Springs Group & & & \\
\hline & & $\begin{array}{l}\text { Bushberg } \\
\text { Sandstone }\end{array}$ & $0-20$ & Quartz sandstone; fine to medium-grained, friable & \\
\hline & & $\begin{array}{l}\text { Glen Park } \\
\text { Limestone }\end{array}$ & $0-25$ & $\begin{array}{l}\text { Calcarcous siltstone, sandstone, uletic limestone, and } \\
\text { hard carbonaceous shale }\end{array}$ & \\
\hline \multirow[t]{3}{*}{ Ordovician } & Cincinnatian & Maquoketa Shalet & $0-11$ & $\begin{array}{l}\text { Calcareous or dolomitic shale; typically thinly } \\
\text { laminated, silty with shaley limestone lenses }\end{array}$ & \\
\hline & Champlainian & Kimtnswick Limestone & $41-104$ & $\begin{array}{l}\text { Limestone; coarsely crystalline, medium to thick } \\
\text { bedded, cheny near base }\end{array}$ & Middle aquifer \\
\hline & & Decorah Group & $25-36$ & $\begin{array}{l}\text { Shale with thin interbeds of very finely crystalline } \\
\text { limestone }\end{array}$ & Confining unit \\
\hline
\end{tabular}


TABLE 3.1 (Cont.)

\begin{tabular}{|c|c|c|c|c|c|}
\hline System & Series & Stratigraphic Unit & Thickness (ft) & Physical Characteristics & Hydrostratigraphic Unit \\
\hline \multirow[t]{8}{*}{$\begin{array}{l}\text { Ordovician } \\
\text { (Cont.) }\end{array}$} & $\begin{array}{l}\text { Chanplainian } \\
\text { (Cont.) }\end{array}$ & Plattin Limestone & $70-125$ & Limestone; finely crystalline, thinly bedded & Lower confining unit (cont.) \\
\hline & & Joachim Dolomite & $80-10.5$ & $\begin{array}{l}\text { Dolostone; thin to thickly bedded, grades into } \\
\text { siltstone, shales cormmon }\end{array}$ & \\
\hline & & St. Peter Sandstone & $120-150$ & $\begin{array}{l}\text { Quanz sandstone; fine- to medium-grained, massively } \\
\text { bedded }\end{array}$ & Deep aquifer \\
\hline & Canadian & Powell Dolomite & $50-60$ & $\begin{array}{l}\text { Dolostone; fine to medium crystalline, minor cher } \\
\text { and shale }\end{array}$ & \\
\hline & & Cotter Dolomite & $200-250$ & $\begin{array}{l}\text { Argillaceous, cherty dolomite; fine to medium } \\
\text { crystalline; interbedded with shale }\end{array}$ & \\
\hline & & Jefferson City Dolomite & $160-180$ & Dolomite; fine to medium crystalline & \\
\hline & & Roubidoux Fonnation & $150-170$ & Dolomitic sandstone & \\
\hline & & Gasconade Dolomile & r & Cherty dolomite & \\
\hline \multirow[t]{2}{*}{ Cumbrian } & Upper & Eminence Dolomite & $\mathbf{r}$ & $\begin{array}{l}\text { Dolomite; mediun to coarsely crystalline, medium- } \\
\text { bedded to massive }\end{array}$ & \\
\hline & & Potosi Dolomite & r & $\begin{array}{l}\text { Dolomite; fine to medium crystalline, thick bedded to } \\
\text { massive; drusy quartz common }\end{array}$ & \\
\hline
\end{tabular}

a When no hydrostratigraphic unit is listed, the unit is the same as for the preceding entry.

b These units are saturated in some places at the chemical plant area and the ordnance works area.

- A confining unit only where the base of the unit is below the potentiometric of the shallow aquifer, mainly in the August A. Busch Memorial Conservation Area.

4 Residuum consists of the residual material from the weathering of the uppermost bedrock formation and possibly younger rocks. The uppernost bedrock formation in most places is the Burlington-Keokuk Limestone.

c Identified in monitoring well MWGS-2.

r Insurficient data to estimate thickness.

Sources: Data from Whitfield et al. (1989); DOE (1992a); Kleeschulte and lines (1994); and Mugel (1997). 


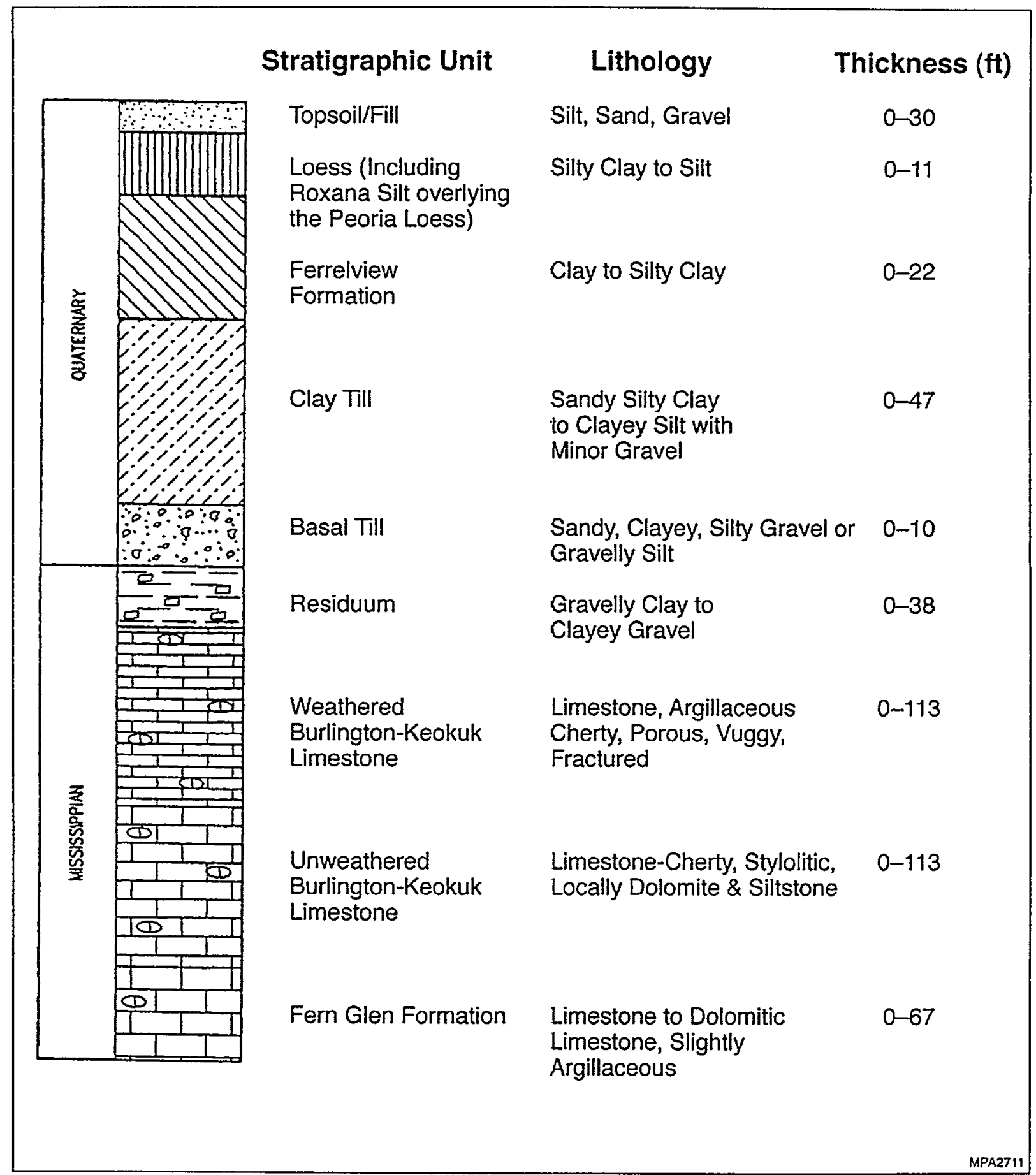

FIGURE 3.1 Stratigraphic Column of the Overburden and Shallow Bedrock Aquifer 
plant area. In the northern portion of the ordnance works area, saturation of these units becomes more predominant, and the units act as a leaky confining unit to the shallow aquifer (Mugel 1997). The glacially derived till units are not present south of the training area.

\subsubsection{Bedrock}

The uppermost bedrock unit beneath most of the ordnance works area and the chemical plant area is the Burlington-Keokuk Limestone. A detailed discussion of the bedrock units composing the regional shallow bedrock aquifer is provided in Section B.1.2 of Appendix B. Detailed and site-specific descriptions of each unit and subunit are provided in documents produced for each of the two areas (MK-Ferguson Company and Jacobs Engineering Group, Inc. 1992a; IT Corporation, 1992a, 1993a; Mugel 1997).

The Burlington-Keokuk Limestone is a fine to coarse-grained, thinly to massively bedded limestone containing $60 \%$ chert as nodules and interbeds. The approximate thickness of this limestone ranges from 0 to $56 \mathrm{~m}$ ( 0 to $185 \mathrm{ft}$ ) in the ordnance works area (Mugel 1997), and from 12 to $56 \mathrm{~m} \mathrm{(40} \mathrm{to} 185 \mathrm{ft}$ ) at the chemical plant area (Whitfield et al. 1989). In the southern portion of the ordnance works area, the Burlington-Keokuk Limestone is no longer present (because of erosion).

On the basis of stratigraphy and the degree of weathering, the Burlington-Keokuk Limestone has been characterized as having two different units. The weathered unit is the uppermost portion of the limestone formation and is characterized as generally having a higher hydraulic conductivity because of increased weathering. The lower unweathered unit is characterized as generally having a lower hydraulic conductivity because of a decrease in weathering. Most of the hydrologic discussion in Section 3.2 emphasizes the overburden units and the Burlington-Keokuk Limestone (Figure 3.1).

The present day topography (Figure 3.2) of the two areas reflects the subsurface topography (Figure 3.3) of the bedrock except in the northern portion of the ordnance works area where glacially derived materials were deposited over the existing topography. A bedrock high is present near the southern boundary of the training area and the chemical plant area and coincides with a topographic high.

Subsurface data indicate the presence of linear bedrock lows that are likely preglacial drainages in the top of the weathered Burlington-Keokuk Limestone near the northern and western boundaries of the chemical plant area (Figure 3.3). Geologic investigations have not identified any linear bedrock lows at the training area, but on the basis of the current understanding of the geology and groundwater flow, it is possible that such features exist. Large-scale closed depressions are not 
exhibited on the bedrock surface, although swallow holes have been identified in several drainages in the nearby conservation areas (Missouri Department of Natural Resources 1991).

Beneath the Burlington-Keokuk Limestone is the Fern Glen Formation, a medium to thickly bedded, fine-grained dolomite and limestone with some layers of chert. On the basis of the rock core from the ordnance works area, the formation is estimated to range from 0 to $20 \mathrm{~m}(0$ to $67 \mathrm{ft})$ thick. Erosion has eliminated this unit in the southern portion of the ordnance works area.

\subsection{HYDROGEOLOGY}

The principal aquifer systems identified in the Weldon Spring area are the alluvial aquifer and the three bedrock aquifers: shallow, middle, and deep (Kleeschulte and Emmett 1987). The relationship between the regional hydrostratigraphy and geologic units is presented in Table 3.1. The three regional bedrock aquifers are separated by thick sequences of bedrock that form confining units. The shallow aquifer is composed of saturated overburden, the Burlington-Keokuk Limestone and the Fern Glen Formation. The shallow bedrock aquifer is separated from the middle bedrock aquifer (Kimmswick Limestone) by 21 to $41 \mathrm{~m}$ (70 to $135 \mathrm{ft}$ ) of fine-textured limestone, shalely sandstone, and shale, which form a leaky confining unit over the middle bedrock aquifer. Beneath the middle aquifer is 64 to $90 \mathrm{~m}$ ( 210 to $295 \mathrm{ft}$ ) of shales and fine-grained limestones that form a confining unit over the deep aquifer (St. Peter Sandstone to Potosi Dolomite).

As discussed in Chapter 1, the focus of this RI is the shallow groundwater system, which includes the overburden units (i.e., residuum and till) in areas where these units are saturated, and the Burlington-Keokuk Limestone and the Fern Glen Formation (Mugel 1997). The overburden units and the weathered portion of the Burlington-Keokuk Limestone constitute the more permeable section of this aquifer where the groundwater flow can be characterized by Darcian diffuse flow with superimposed conduit flow. Although the Burlington-Keokuk Limestone is fractured, both horizontally and vertically, and has undergone dissolution that has enlarged the fractures, groundwater flow through the shallow aquifer can be described by the hydraulic head distribution in the aquifer; that is, groundwater will flow from areas of higher head toward areas of lower head (in accordance with Darcy's Law). The assumption is that if the bedrock has sufficiently high density of interconnected fractures, the bedrock unit will behave as a porous media, and Darcy's law may apply on a large scale. This assumption can be applied to portions of the chemical plant area and the ordnance works area, although discrete flow in large fractures or solution features must be taken into account in those areas that show evidence of preferential flow.

In the chemical plant area and in most of the ordnance works area, the shallow aquifer is an unconfined or water table aquifer. However, in the northern portion of the ordnance works area, it behaves as a confined aquifer because the potentiometric surface is above the base of the confining layer, which consists of glacial drift composed of clays and silts (Mugel 1997). The confining units 


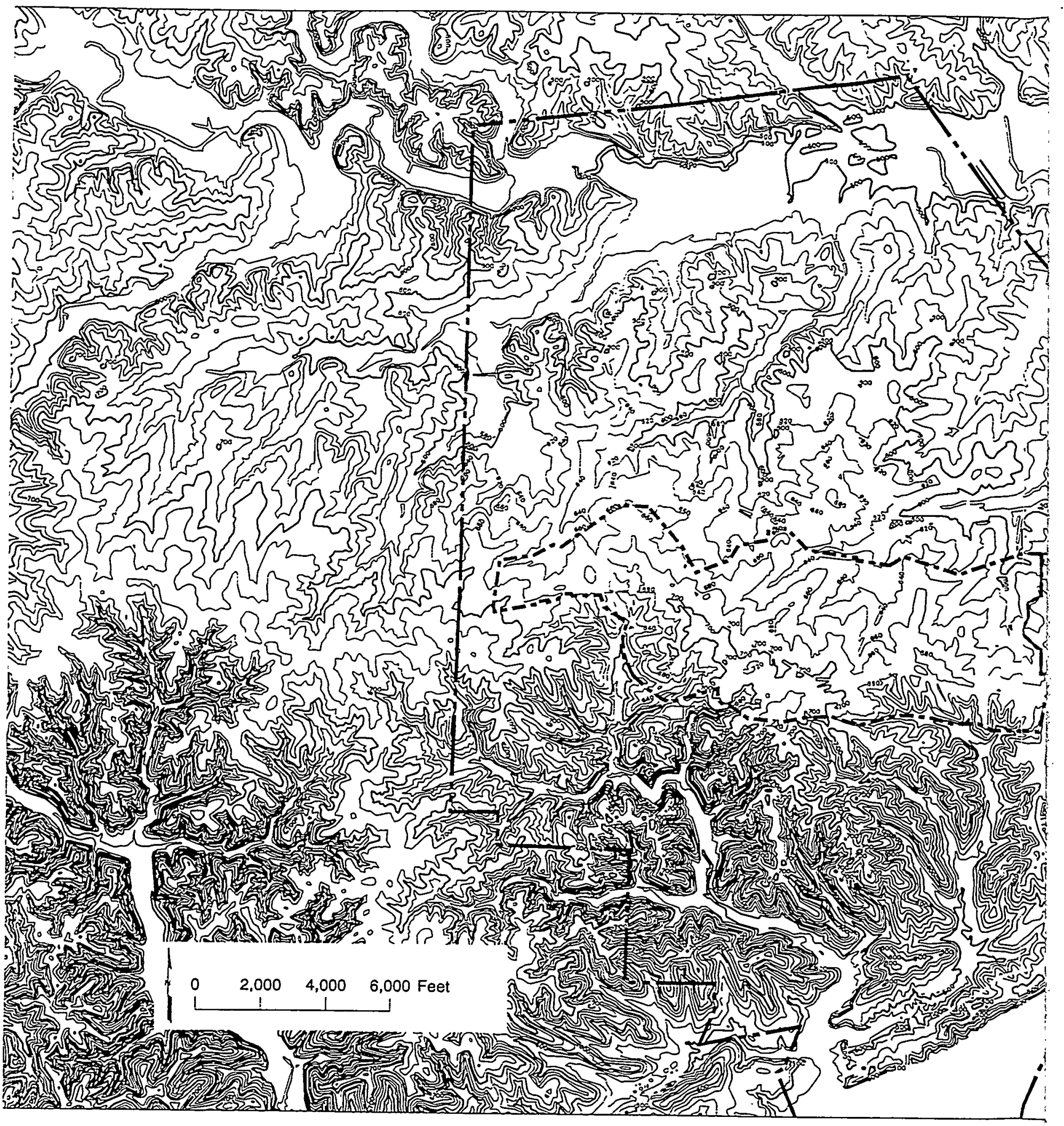

FIGURE 3.2 Surface Topography of the Chemical Plant Area and the Ordnance Works Area 


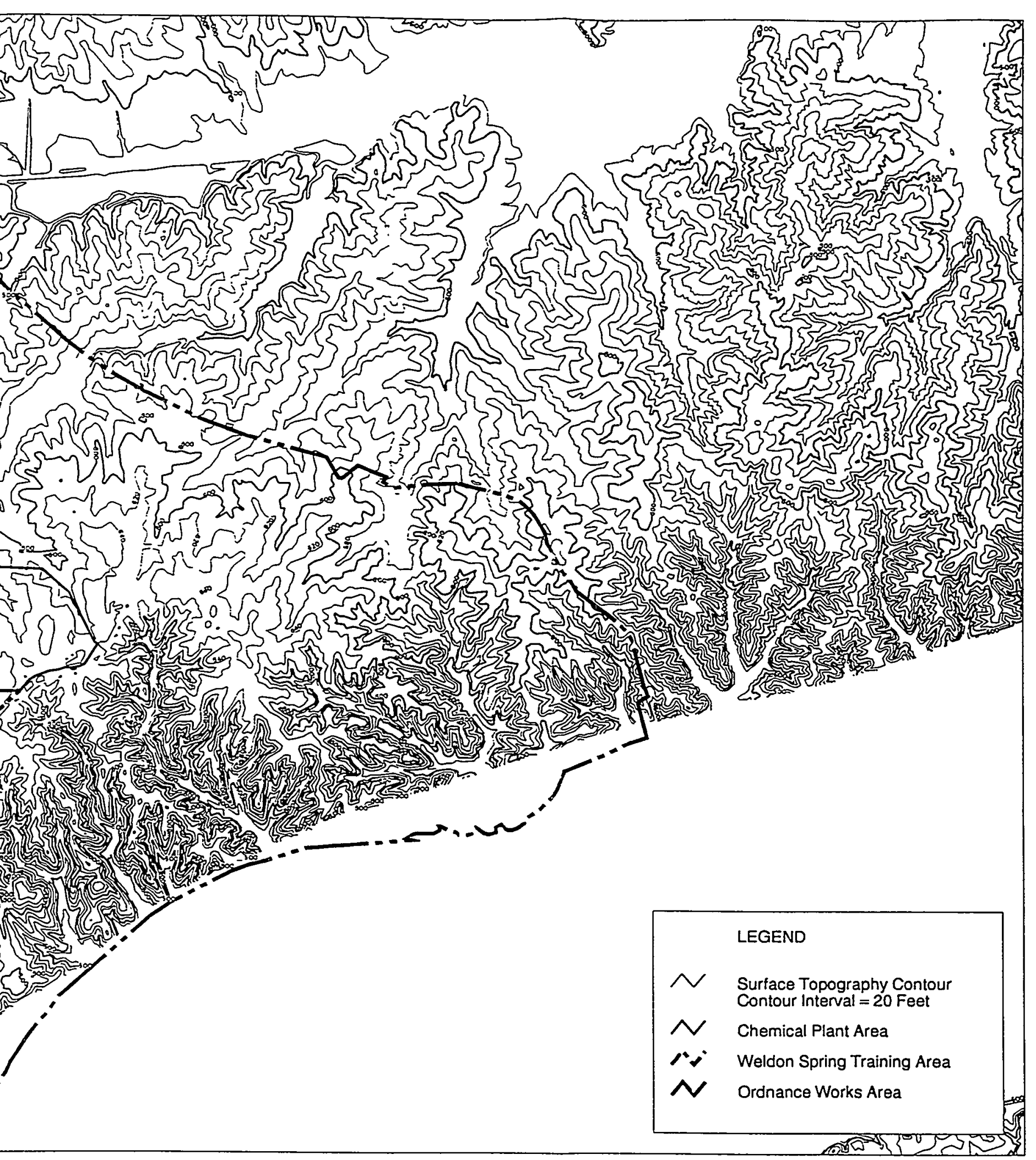




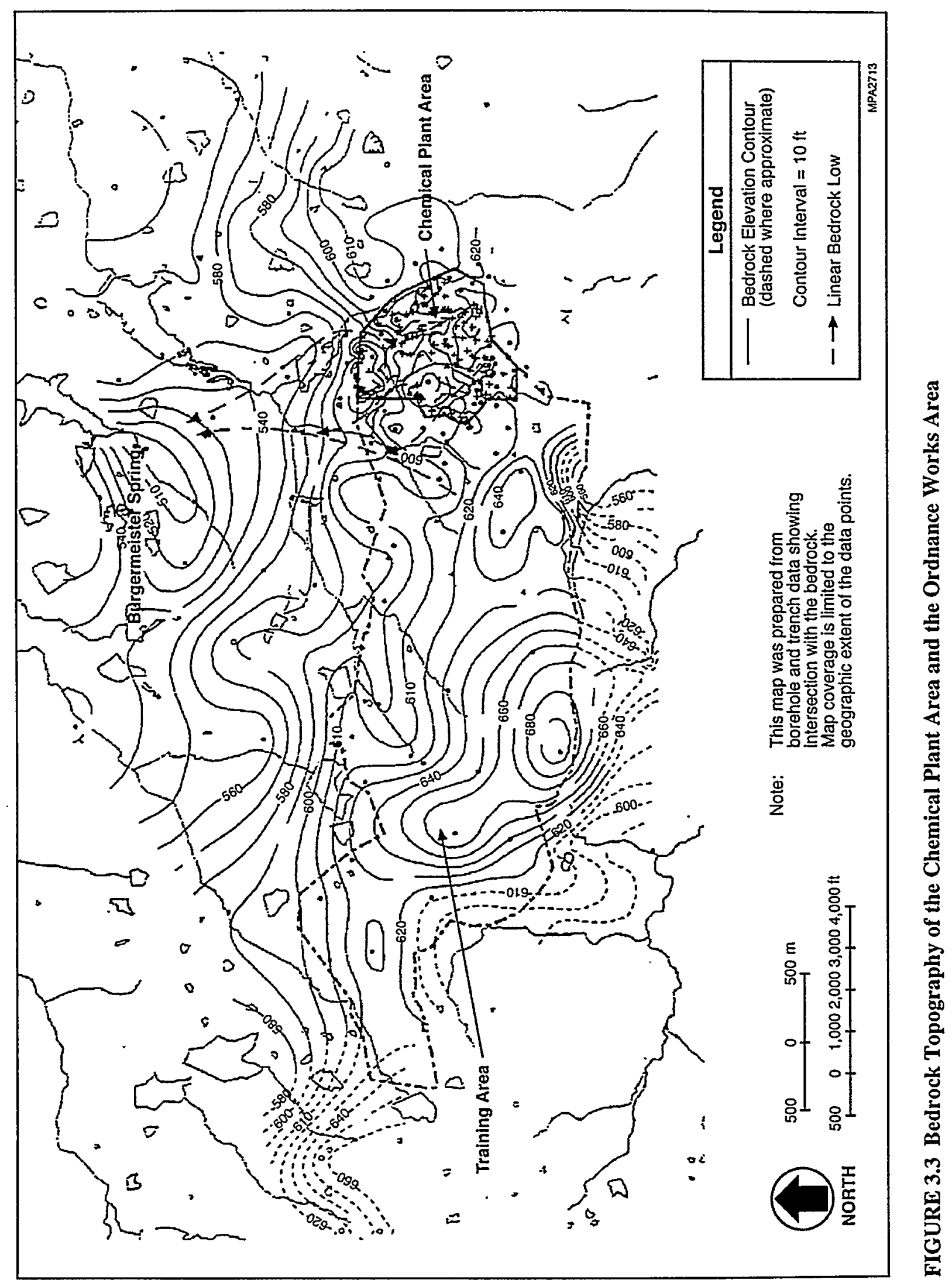


with a low hydraulic conductivity retard groundwater movement through the unit as compared with the more permeable limestone and saturated residuum units. The glacial till unit does not confine groundwater at the chemical plant area, in the central and southern parts of the ordnance works area, or where the potentiometric surface occurs below the base of the unit (Mugel 1997).

\subsubsection{Hydrostratigraphic Unit Determination}

As discussed in Section 3.1, the Burlington-Keokuk Limestone has been divided into two units, an upper weathered zone that generally overlies a lower unweathered zone. The contact between these two units is gradational. The major observations made from previous hydrogeologic studies (Table 2.1) are as follows:

- In general, higher hydraulic conductivities have been measured in the weathered limestone unit than in the unweathered portion of the limestone;

- The weathered limestone unit exhibits relatively thin, highly conductive zones, consisting of fracture zones and solution features;

- The degree of weathering and intensity of fractures generally decrease with depth in the Burlington-Keokuk Limestone;

- Intervals of water loss during drilling activities diminish with depth; and

- The number and size of solution vugs and voids diminish with depth.

The upper hydrostratigraphic unit of the shallow aquifer is the saturated overburden and weathered unit of the Burlington-Keokuk Limestone; the lower unit is the unweathered unit and the Fern Glen Formation. Cross sections indicate that the weathered Burlington-Keokuk Limestone is typically saturated across most of the training area and the ordnance works area where the formation is present (Figures 3.4 and 3.5). Unsaturated weathered Burlington-Keokuk Limestone is present in some areas at the chemical plant area. As shown in these two figures, the thickness of the weathered unit varies across the site; the thickness generally is greater in areas where the bedrock topography is highest. In the northern portion of the ordnance works area, the weathered unit thins and/or disappears.

The depth to water varies from less than 3 to $18 \mathrm{~m}$ (10 to $60 \mathrm{ft}$ ) across the chemical plant area and the ordnance works area. The depth varies with difference in surface topography and/or bedrock topography. The vadose zone (unsaturated zone) generally occurs in the overburden, although in some areas it also includes parts of the weathered limestone. The vadose zone is generally thinner in stream segments where the surface topography is lowest. The thicker portions 


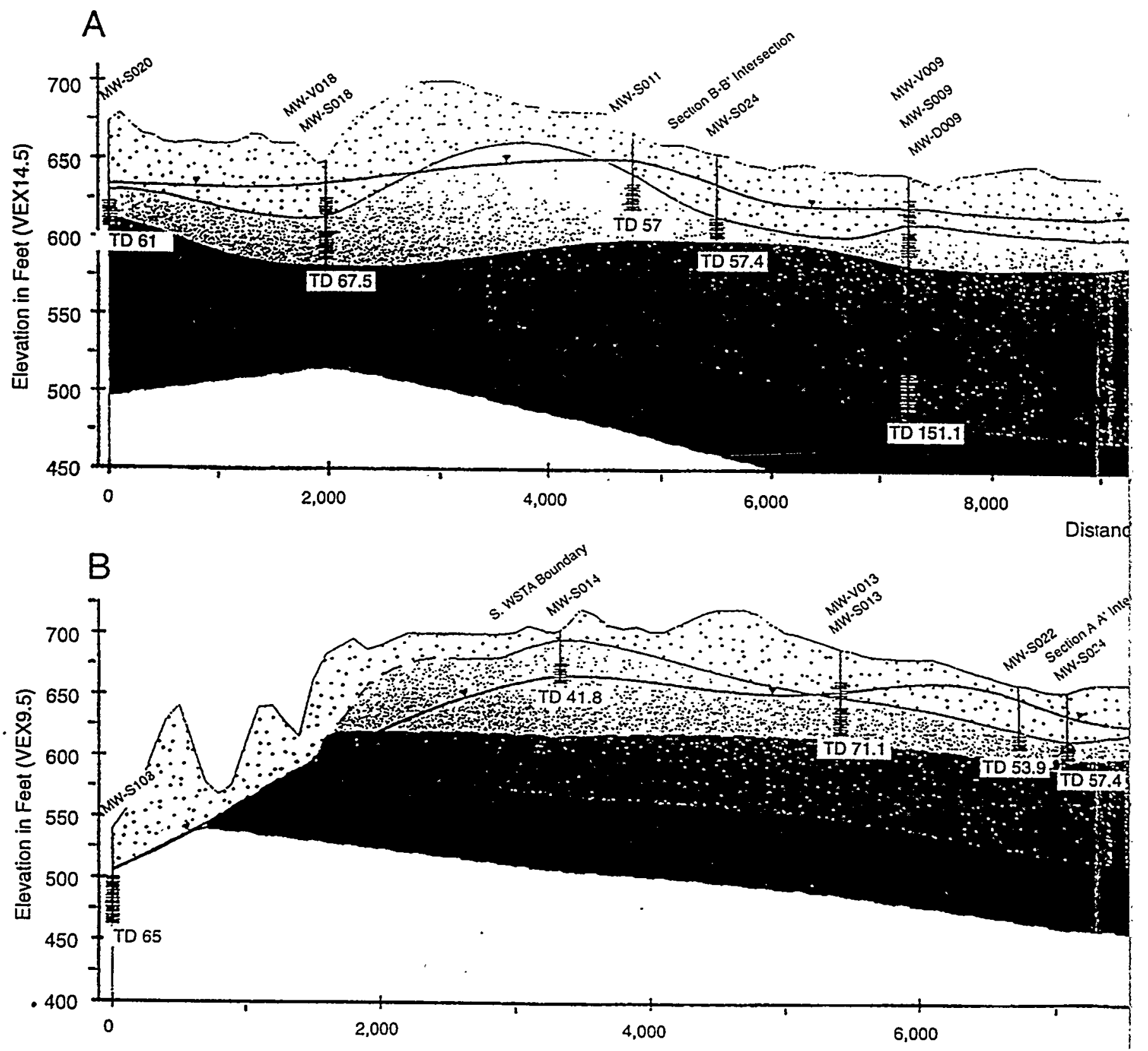

Distance

Legend

\begin{tabular}{|c|c|}
\hline$\because \because \because$ & Overburden \\
\hline$\because \because 3$ & Weathered Burtington-Keokuk Limstone \\
\hline 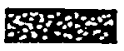 & Unweathered Burlington-Keokuk Limestone \\
\hline & Fem Glen Formation \\
\hline & Formations Older Than Fern Glen \\
\hline - & Inferred Contact \\
\hline
\end{tabular}



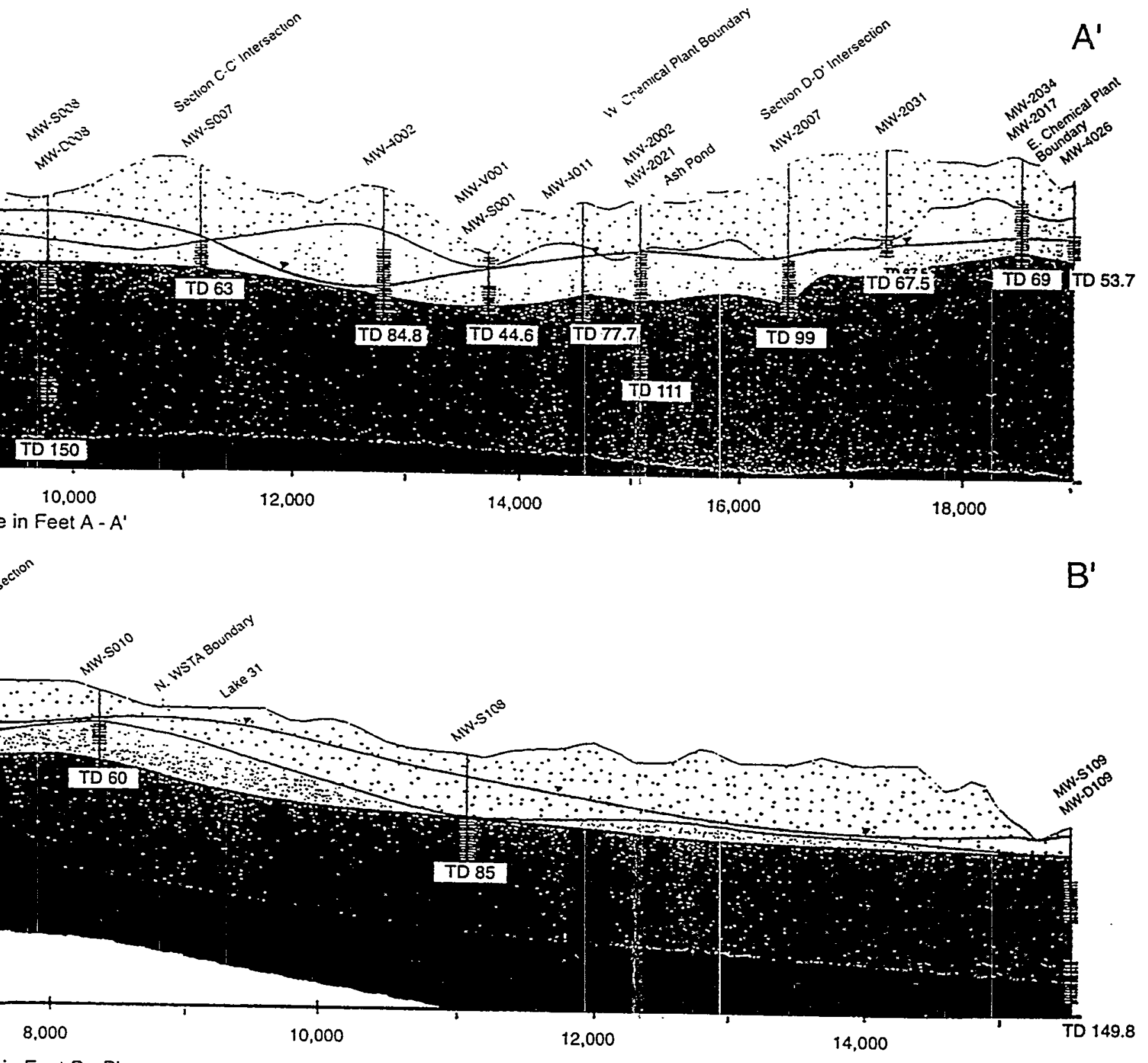

in Feet $B-B^{\prime}$

Location Map

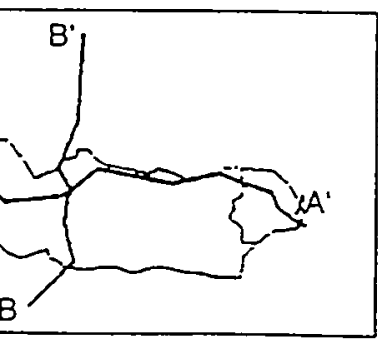




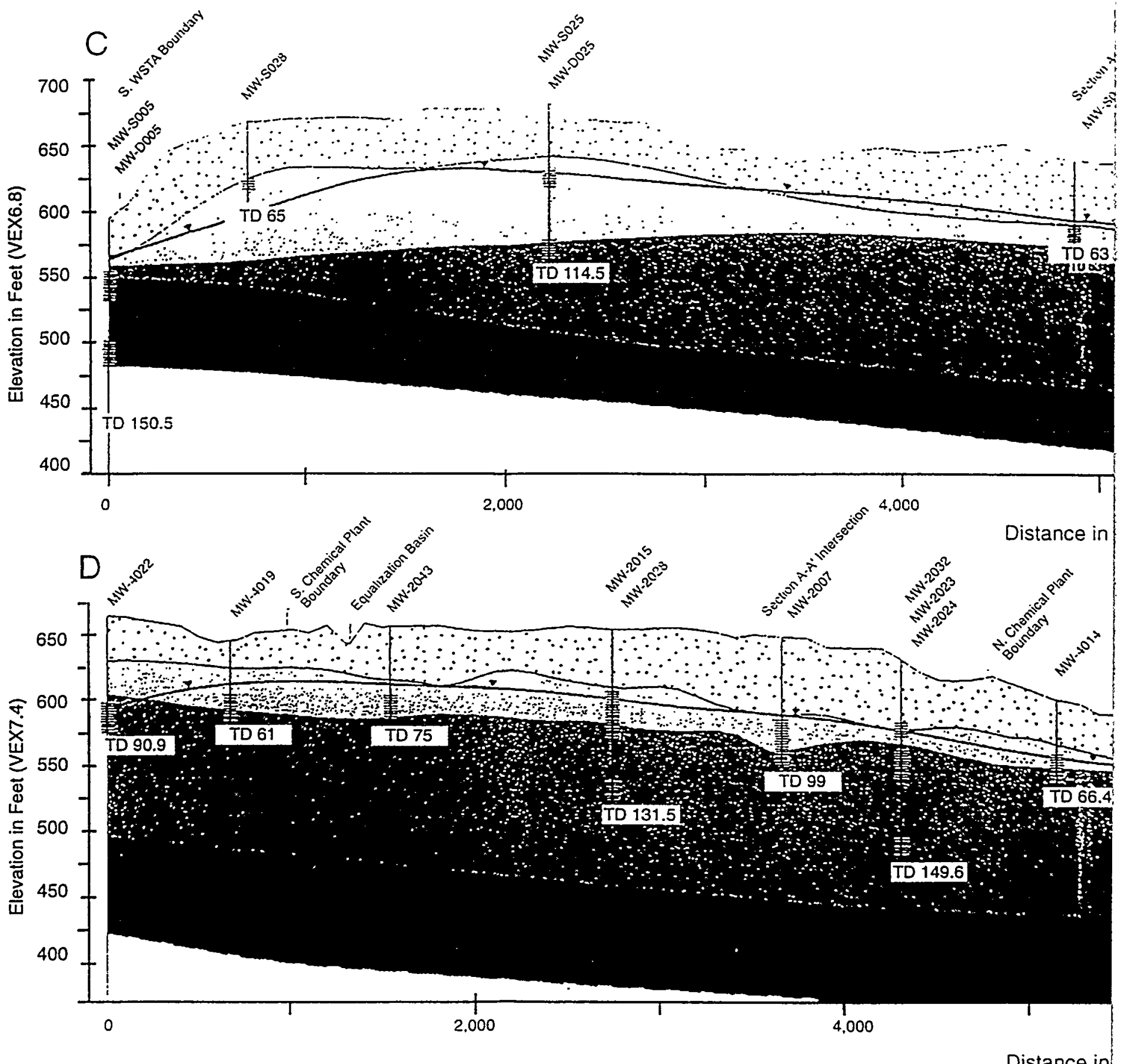

Legend

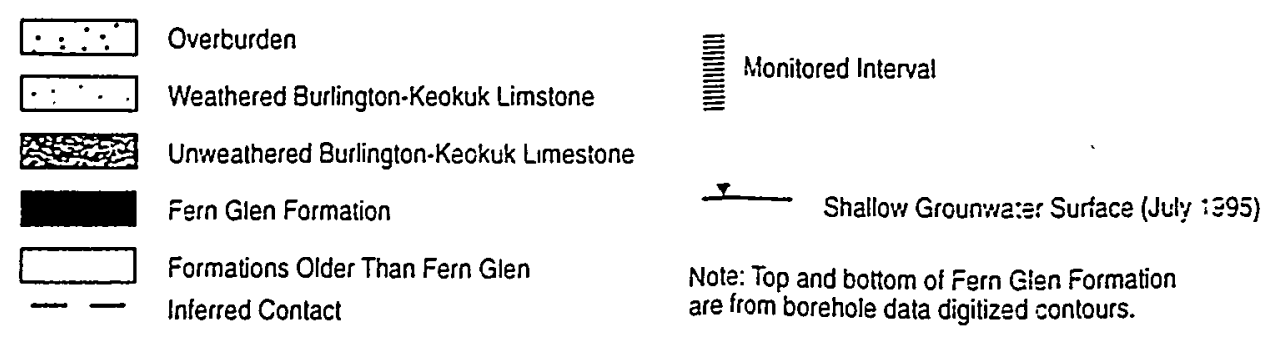

Distance in

FIGURE 3.5 Hydrogeologic Cross Sections C and D 


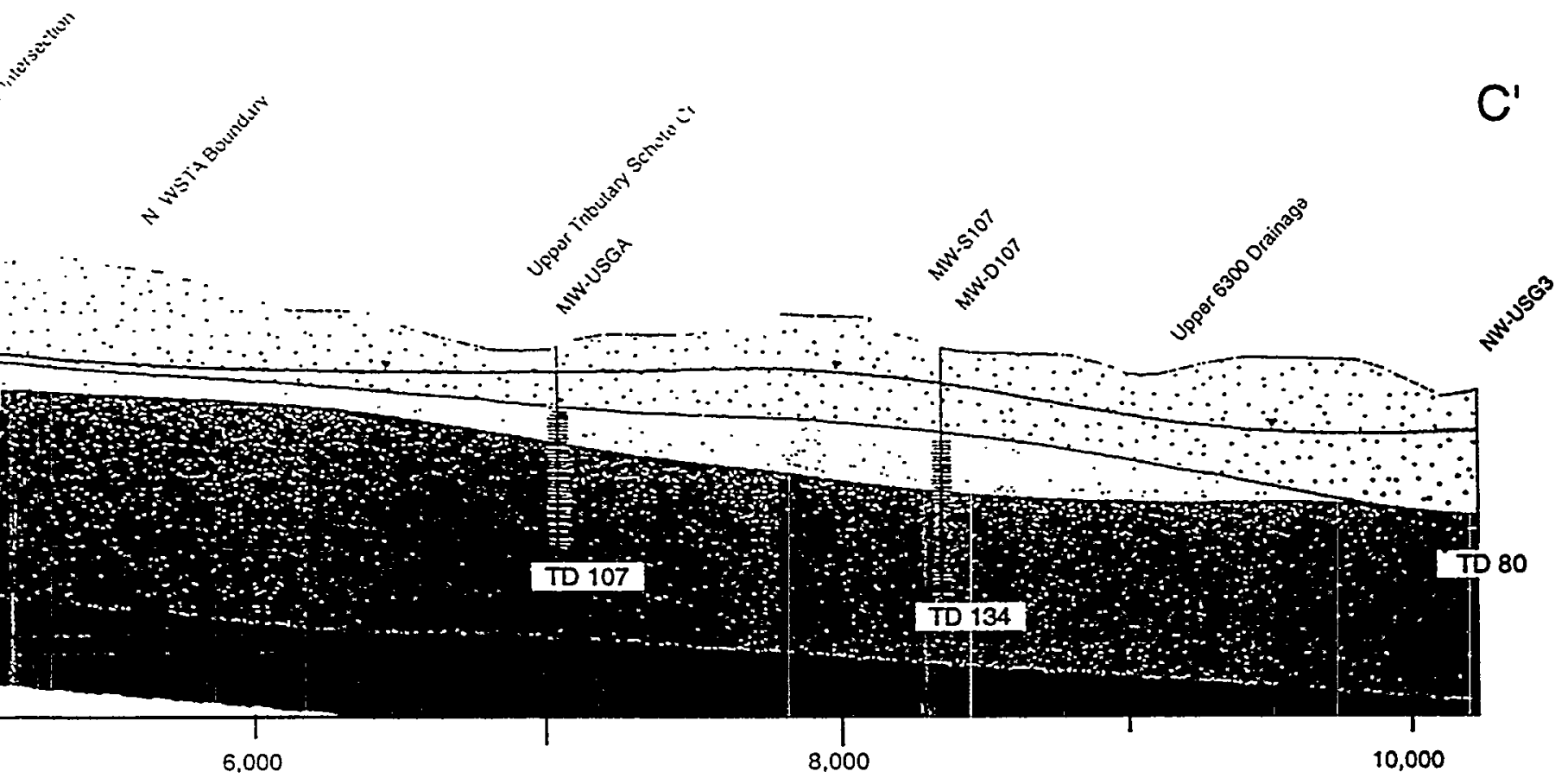

$=e$ et $C-C^{\prime}$

$D^{\prime}$

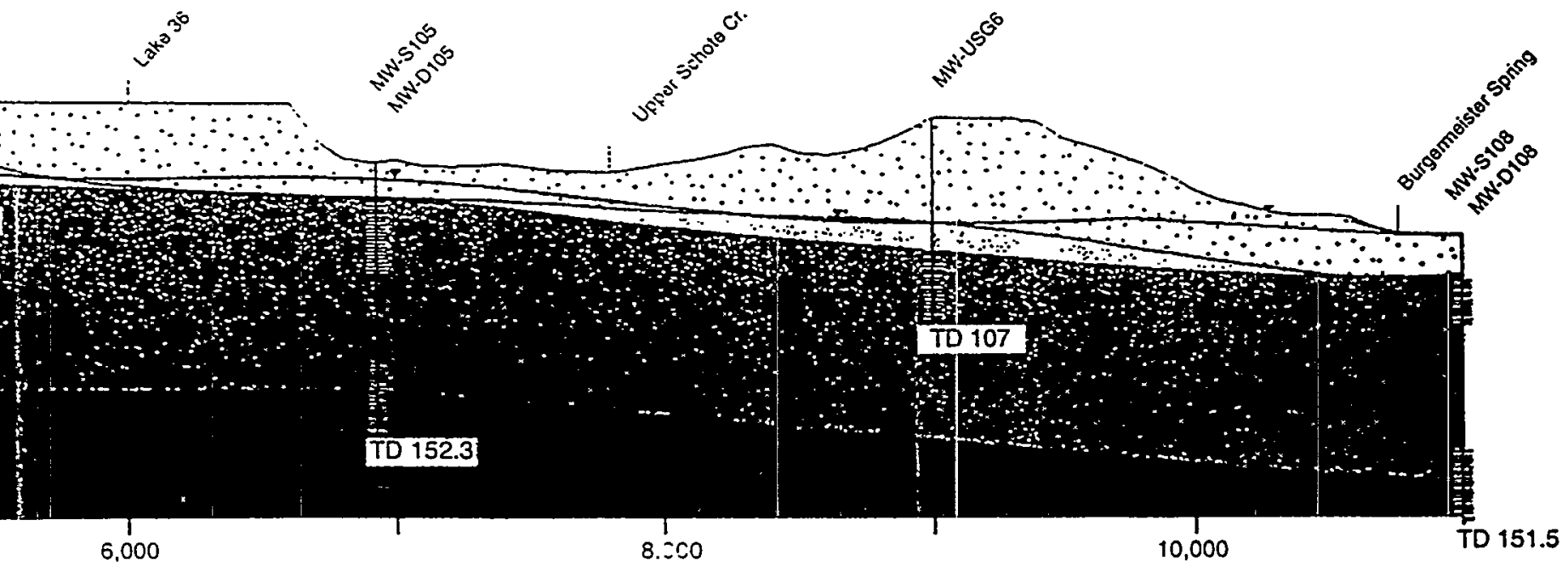

Feet D - D'

ocation Map

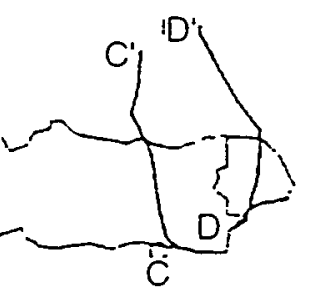


of the vadose zone occur along the topographic high along the southern edge of the training area and chemical plant area. The vadose zone is also thicker in bedrock lows and extends north from the chemical plant area where the static water level is generally lower.

Saturated overburden occurs in the northern and western portions of the ordnance works area and in several small, isolated locations within the chemical plant area. These areas coincide with the location of paleochannels or paleovalleys on the bedrock surface that have been identified from geologic investigations. Geologic logs from both sites indicate that saturation in the overburden is typically limited to the residuum at the chemical plant area and the training area where the static water level is above the top of bedrock. To the north, the till units become saturated where the static water level is above the top of bedrock.

\subsubsection{Aquifer Characteristics}

\subsubsection{Hydraulic Conductivity}

Hydraulic conductivity describes the rate at which groundwater can move through an aquifer. The hydraulic conductivity of the saturated overburden and Burlington-Keokuk Limestone has been estimated by in situ pressure (packer) tests and single-well hydraulic conductivity (slug) tests. The procedures for determining hydraulic conductivity by these methods are described in Sections B.2.3 and B.2.4 of Appendix B.

Slug tests were performed in 1987 in three of the overburden monitoring wells (MW-3004, MW-3005, and MW-3011) screened in the clay till unit around the perimeter of the raffinate pits (Table B.6). These tests indicated an average saturated hydraulic conductivity of $1.2 \times 10^{-8} \mathrm{~cm} / \mathrm{s}$ $\left(3.9 \times 10^{-10} \mathrm{ft} / \mathrm{s}\right)$ for the clay till unit, which is in general agreement with laboratory estimates (MK-Ferguson Company and Jacobs Engineering Group, Inc. 1992a).

Slug testing was performed at the training area on four overburden monitoring wells that typically show saturated conditions (Table B.6). The remaining overburden wells were not tested because little water was present. The screened interval for three of these wells is in the saturated residuum near the top of bedrock; one well is screened in the till and residuum (IT Corporation 1993a). The hydraulic conductivities ranged from $1.05 \times 10^{-7}$ to $4.17 \times 10^{-4} \mathrm{~cm} / \mathrm{s}\left(3.4 \times 10^{-9}\right.$ to $\left.1.4 \times 10^{-5} \mathrm{ft} / \mathrm{s}\right)$, indicating that the residuum is very heterogeneous. Locally in areas where the residuum is cohesive and clay rich, the hydraulic conductivity values are lower than in areas where the residuum is composed of noncohesive gravels. The higher hydraulic conductivity values in the overburden were at or near the bedrock interface (i.e., base of the residuum). Hydraulic conductivities near the overburden/bedrock interface are generally higher than those of the overlying overburden materials (clay, till). 
Packer tests performed at both the chemical plant area and the training area provide further evidence that the hydraulic conductivity near the residuum/bedrock interface is generally much higher than in other overburden units. The average saturated hydraulic conductivity at the residuum/bedrock interface is $3.7 \times 10^{-2} \mathrm{~cm} / \mathrm{s}\left(1.2 \times 10^{-3} \mathrm{ft} / \mathrm{s}\right)$ (Table B.9) (Bechtel National, Inc. 1987; MK-Ferguson Company and Jacobs Engineering Group, Inc. 1992a). Results of slug testing of wells screened at this interval indicate average hydraulic conductivities of $1.5 \times 10^{-2} \mathrm{~cm} / \mathrm{s}$ $\left(4.9 \times 10^{-4} \mathrm{ft} / \mathrm{s}\right)$ (Tables B.12 and B.13). This relatively high conductivity may indicate a preferential lateral flow zone where the interface is saturated. In saturated conditions, water entering this zone is likely to be diverted laterally rather than continuing to migrate vertically. Water will continue to migrate laterally until encountering a more permeable zone that allows vertical movement or until the preferential flow zone terminates.

Packer tests were performed during previous hydrogeologic investigations at the chemical plant area (Bechtel National, Inc. 1987; MK-Ferguson Company and Jacobs Engineering Group, Inc. 1992a) and were also performed to support this RI. These tests were conducted to obtain hydraulic conductivity estimates for intervals of the weathered and unweathered units of the BurlingtonKeokuk Limestone. The results of the packer tests are summarized in Tables B.10 and B.11.

Single-well hydraulic conductivity tests (slug tests) were performed to obtain information on the areal distribution of hydraulic conductivity values in the shallow aquifer. The slug testing results for the chemical plant area and the ordnance works area are summarized in Tables B.12 and B.13, respectively. Results of the slug testing indicate that although the hydraulic conductivity of the weathered and unweathered portions of the Burlington-Keokuk Limestone is highly variable, the hydraulic conductivity in the unweathered portion of the bedrock is generally higher than that in the unweathered unit. The variability of the conductivity values depends on the portion of the aquifer tested that corresponds to the screened depth of the well. The highest conductivity values in the weathered unit appear to correlate with areas of known preferential flow (e.g., in the northern parts of the chemical plant area and north of the training area).

Characteristics of the Burlington-Keokuk Limestone that influence groundwater flow include the primary porosity of the limestone, the distribution and interconnection of fractures, the presence of solution features, and the degree of clay filling within fractures and solution features. Although the hydraulic conductivity of the Burlington-Keokuk Limestone is highly variable on the basis of location and depth, the values become less variable with depth. In the weathered unit, the hydraulic conductivity ranges from $10^{-7}$ to $10^{-2} \mathrm{~cm} / \mathrm{s}\left(10^{-9}\right.$ to $\left.10^{-4} \mathrm{ft} / \mathrm{s}\right)$. The upper part of the weathered unit shows a greater variation in hydraulic conductivity than does the lower part (see Figure 3.6). For example, within the top $5 \mathrm{~m}$ (15 ft), the range of hydraulic conductivity values is

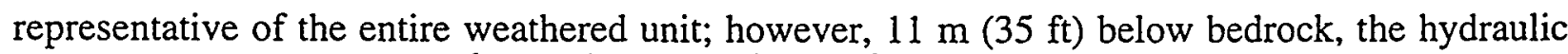
conductivity ranges from $10^{-6}$ to $10^{-4} \mathrm{~cm} / \mathrm{s}\left(10^{-8}\right.$ to $\left.10^{-6} \mathrm{ft} / \mathrm{s}\right)$. In the unweathered unit, the hydraulic 


\section{$3-15$}
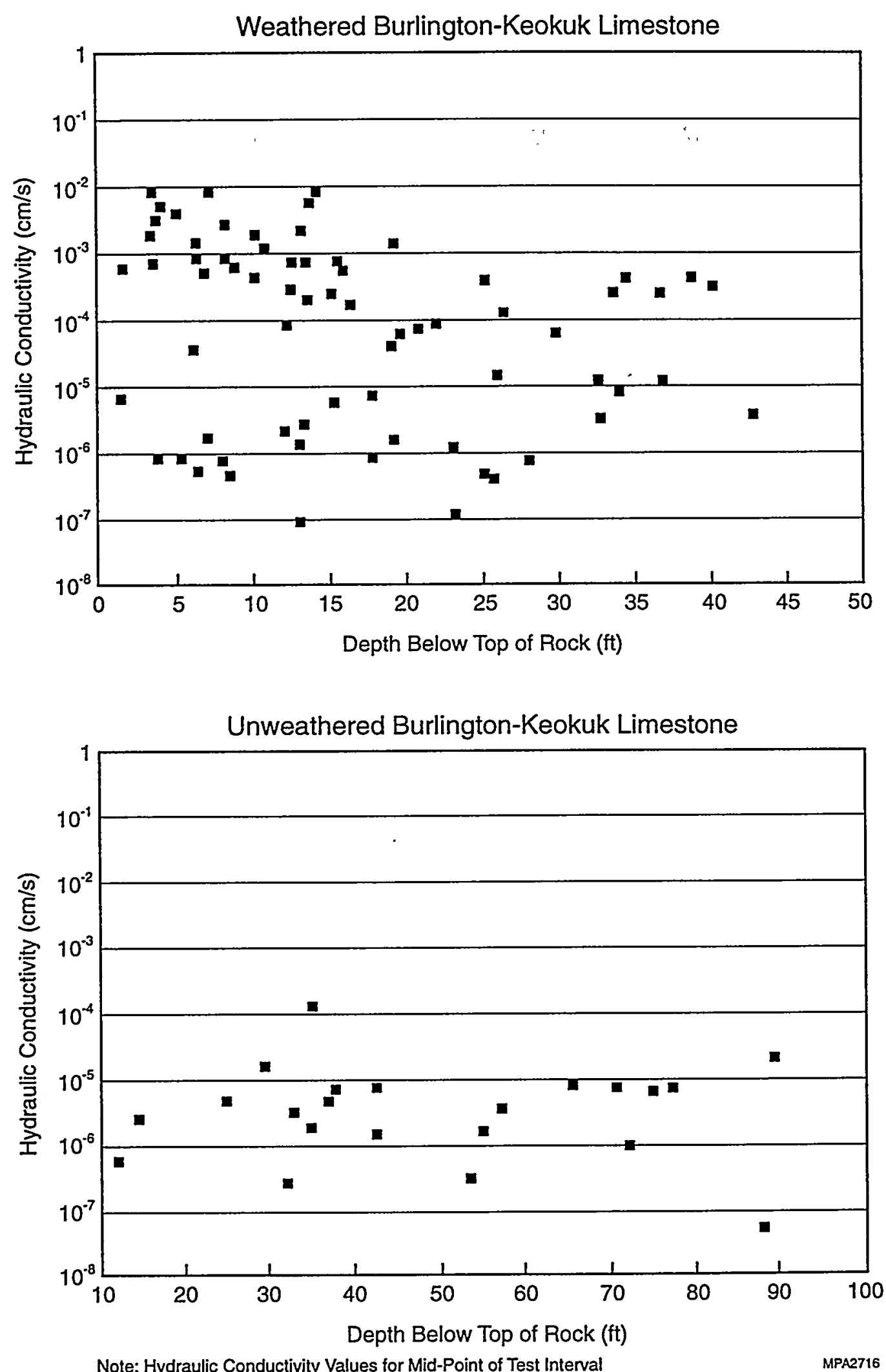

FIGURE 3.6 Comparison of Hydraulic Conductivity with Depth - BurlingtonKeokuk Limestone 
conductivity typically ranges from $10^{-7}$ to $10^{-5} \mathrm{~cm} / \mathrm{s}\left(10^{-9}\right.$ to $\left.10^{-7} \mathrm{ft} / \mathrm{s}\right)$, with few exceptions through the entire thickness (Figure 3.6). Exceptions to these trends occur when a zone of greater fracture frequency or localized weathering is encountered at depth or when fracture zones in the upper portion of the bedrock are filled with clay. This condition was recently observed during testing on angled boring AH-2003 in the unweathered unit of the Burlington-Keokuk Limestone and in AH-2004, MWS-26, and MWD-107 in the weathered unit.

Comparison of packer test results and slug test results from locations where both tests methods were used indicates that the slug test values can be at least an order of magnitude lower than packer test values for a given location (MK-Ferguson Company and Jacobs Engineering Group, Inc. 1992a). This difference is probably the result of the length of the testing interval and the presence of discontinuities in the bedrock.

\subsubsection{Primary and Secondary Porosity}

The saturated Burlington-Keokuk Limestone in the shallow aquifer exhibits both primary porosity resulting from the presence of intergranular voids within the rock matrix and secondary porosity due to fracturing and solution activity within the rock. The secondary porosity component is a predominant factor in the weathered unit at the chemical plant area and the ordnance works area because of the extensive fracturing and weathering of the bedrock.

Packer testing in the weathered unit indicates thin zones of high conductivity encompassed in a less-conductive matrix (MK-Ferguson Company and Jacobs Engineering Group, Inc. 1992a). The higher hydraulic conductivity in this portion of the Burlington-Keokuk is influenced by the fracturing. Angled borings indicate that horizontal fractures along the bedding planes dominate vertical fracturing by approximately 20:1 within the weathered limestone. The unit is moderately to highly fractured, and $73 \%$ of the rock quality designation (RQD) values are in the poor to very poor category (MK-Ferguson Company and Jacobs Engineering Group, Inc. 1992a).

The unweathered limestone unit is characterized by its lack of significant weathering or fracturing. An estimated 79\% of the RQD values for this unit are in the fair to excellent category (MK-Ferguson Company and Jacobs Engineering Group, Inc. 1992a). Rock core logs indicate that large solution features are uncommon in this unit.

\subsubsection{Anisotropy and Heterogeneity}

The shallow bedrock aquifer is both anisotropic and heterogeneous. The weathered Burlington-Keokuk Limestone is characterized by significant secondary porosity and permeability derived from joints, fractures, and bedding planes that can control vertical and horizontal 
groundwater flow. Data from rock core from the angled borings indicate that horizontal fractures are more predominant than vertical fractures, and thus contribute to preferential horizontal flow.

A general decrease in the degree of weathering, fracturing, and solution activity in the Burlington-Keokuk Limestone has established a heterogeneous trend in the vertical direction. Less weathering and solution activity with depth correlates to lower hydraulic conductivities and slower groundwater movement deeper in the Burlington-Keokuk Limestone.

\subsubsection{Shallow Groundwater Surface}

Groundwater levels fluctuate in elevation but generally remain within the weathered bedrock or overburden. Water-level elevations were measured from all active chemical plant area and ordnance works area monitoring wells in April and July 1995 to provide a regional perspective of the groundwater system. At each well, the measured water levels for both months were within the range of water-level elevations measured between 1987 and 1994. Table B.14 summarizes the static water-level measurements for April and July.

A potentiometric map (Figure 3.7) of the shallow aquifer was prepared on the basis of water-level elevations collected in July during the joint sampling effort. The potentiometric surface was derived with data from wells completed in the same hydrostratigraphic unit. Wells in the weathered unit were used preferentially over wells completed in the unweathered unit, and in the northern portion of the ordnance works area (where the weathered unit is absent), the depth of initial water was used. In areas where water-level measurements were available for two or more monitoring wells in a cluster, the measurement in the uppermost unit (e.g., typically the weathered unit) was used. Water-level measurements of known, existing perched water were not used to construct the map.

Evidence is present of a groundwater divide along the southern part of the training area and extending through the southern portion of the chemical plant area. In general, the shallow groundwater surface mimics the topography at the training area, chemical plant area, and the southern and eastern portions of the ordnance works area. The general flow direction is toward the Burgermeister Spring (6300 drainage) through a series of trough-like features that extend northward from both the eastern and central part of the training area and the chemical plant area. On the western part of the training area, groundwater flow is to the north. Groundwater flow in the southern portions

of the chemical plant area and the training area exhibits steep gradients into the drainages to the south and southeast (drainages 5300-5600). 


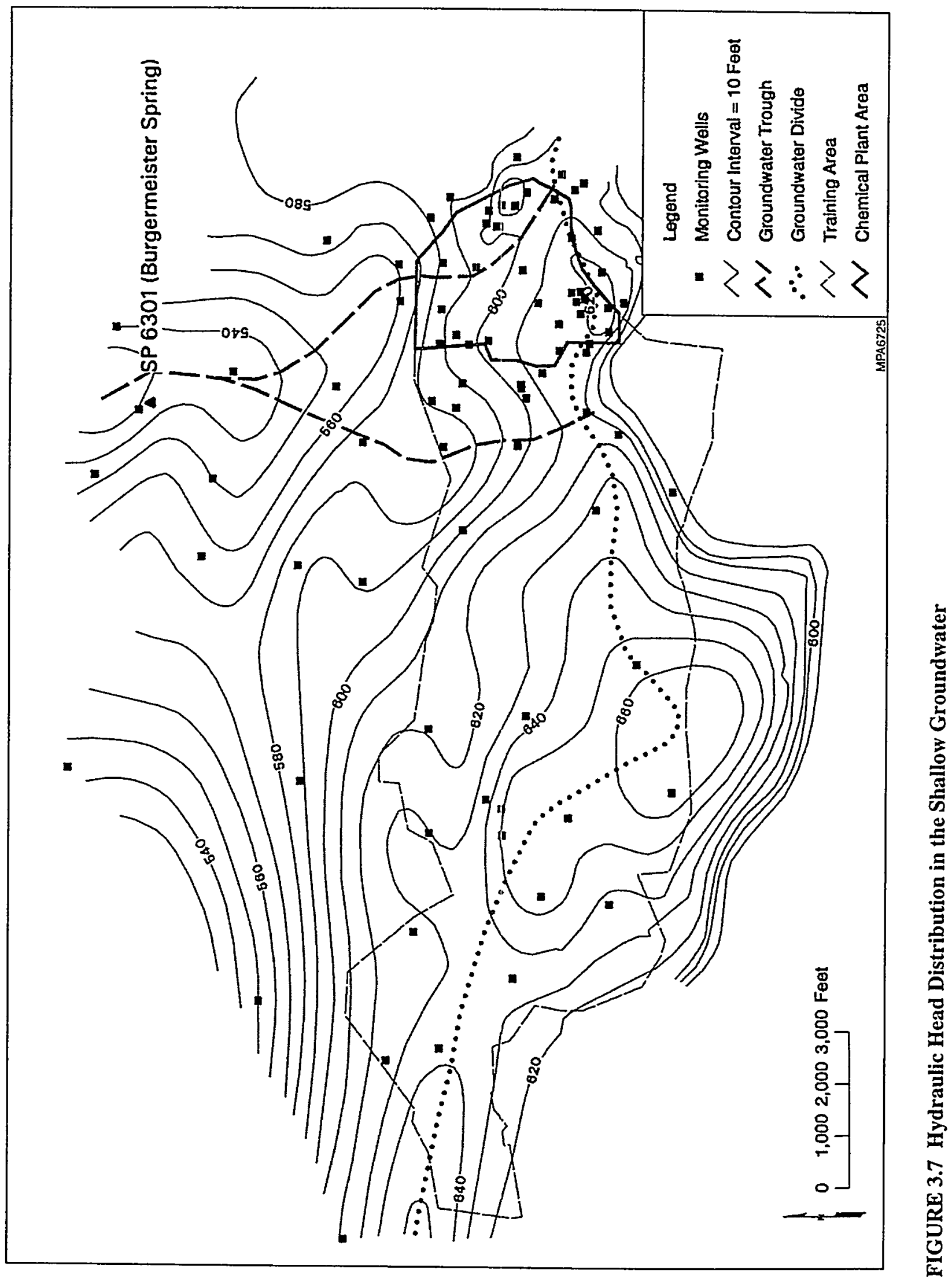


Groundwater levels fluctuate with time. Table B.15 summarizes the maximum static waterlevel fluctuations for each location. The smaller groundwater fluctuations were observed in several wells located at the southern and north-central portions of the chemical plant area. The larger fluctuations were observed at wells located on the western part of the training area, north of the training area, and in a few scattered locations within the chemical plant area. In general, small fluctuations typically occur in areas of larger hydraulic conductivities; for example MW-2032 and MW-4013 in the north part of the chemical plant area and MW-2037 and MW-2038 near Raffinate Pits 3 and 4 have hydraulic conductivities of $10^{-3} \mathrm{~cm} / \mathrm{s}\left(10^{-5} \mathrm{ft} / \mathrm{s}\right)$ or greater and fluctuations less than $0.3 \mathrm{~m}(1 \mathrm{ft})$. The location-dependence of the water-level fluctuations may be attributed to the properties and the thickness of the vadose zone and the topographic surface. In general, the locations with greater fluctuation are in areas of thin overburden with potentially higher unsaturated hydraulic conductivities and also in areas such as stream valleys. In these locations, the greatest fluctuations are likely the result of quick movement of infiltration from precipitation and/or runoff into the groundwater system and the slow movement of water out of the well into the aquifer. Conversely, the locations with smaller groundwater fluctuation are in areas of thicker overburden and potentially lower unsaturated hydraulic conductivities.

Perched groundwater has been observed at several locations and is probably due to the presence of overburden materials with low hydraulic conductivity (see Section 1.1.2 of Appendix B). Perched conditions have consistently been encountered in the vicinity of the raffinate pits, as indicated by static water levels in MW-3004, MW-3005, MW-3011, MW-3013, and MW-3015 at the chemical plant area. These wells are completed in the overburden, and their water levels are at least $3 \mathrm{~m}(10 \mathrm{ft})$ above the elevation of the water table as determined from wells completed in the shallow aquifer. At the training area, perched water was detected in MWV-8, MWV-17, and MWV-18 (Figure 2.1). These three wells are completed in the overburden unit, and they are either dry or their water levels are consistently higher than the water table of the shallow aquifer.

\subsubsection{Hydraulic Gradients}

The direction of groundwater flow depends on the hydraulic head distribution, and the rate of flow depends on the hydraulic gradient. Horizontal hydraulic gradients were determined from the potentiometric surface of the shallow groundwater aquifer.

Except in the southern portion of the ordnance works area, the horizontal hydraulic gradients range from 0.001 to 0.04 across the chemical plant area and the ordnance works area in the shallow aquifer. The steeper gradients in the southern portion of the training area are likely a result of topographic controls on the groundwater system.

Vertical gradients within the shallow groundwater system have been evaluated in well clusters at both the chemical plant area and the ordnance works area (Table 3.2). These vertical 
TABLE 3.2 Vertical Gradients within the Shallow Aquifer at the Chemical Plant Area and the Ordnance Works Area

\begin{tabular}{|c|c|c|c|c|c|}
\hline \multicolumn{2}{|c|}{ Well Pair } & $\begin{array}{c}\text { Vertical } \\
\text { Gradient }^{\mathrm{a}} \\
\end{array}$ & \multicolumn{2}{|c|}{ Well Pair } & $\begin{array}{c}\text { Vertical } \\
\text { Gradient }^{\mathrm{a}}\end{array}$ \\
\hline \multicolumn{6}{|c|}{ Weathered and Unweathered Burlington-Keokuk Limestone } \\
\hline MW-2002 & MW-2021 & 1 & MW-3025 & $\mathrm{MW}-3024^{\mathrm{b}}$ & 1 \\
\hline MW-2004 & MW-2029 & $\downarrow$ & MW-3027 & MW-3026 & 1 \\
\hline MW-2005 & MW-2022 & 1 & MW-4006 & MW-4007 & 1 \\
\hline MW-2006 & MW-2026 & 1 & MWS-2 & MWD-2 & $i$ \\
\hline MW-2008 & MW-2025 & 1 & MWS-23 & MWD-23 & 1 \\
\hline MW-2015 & MW-2028 & 1 & MWS-107 & MWD-107 & 1 \\
\hline MW-2018 & MW-2019 & $\downarrow$ & MWS-9 & MWD-9 & $!$ \\
\hline MW-2033 & MW-2027 & 1 & MWS-25 & MWD-25 & $!$ \\
\hline MW-3001 & MW-3002 & $\downarrow$ & MWS-112 & MWD-112 & 1 \\
\hline MW-3023 & MW-3006 & $\downarrow$ & & & \\
\hline \multicolumn{6}{|c|}{ Burlington-Keokuk Limestone and Fern Glen Formation } \\
\hline MWS-5 & MWD-5 & t & MWS-106 & MWD-106 & 1 \\
\hline MWS-105 & MWD-105 & $i$ & MWS-109 & MWD-109 & it \\
\hline \multicolumn{6}{|c|}{ Overburden and Burlington-Keokuk Limestone } \\
\hline MWV-1 & MWS-1 & 11 & MWV-13 & MWS-13 & 11 \\
\hline MWV-2 & MWS-2 & $!$ & MWV-16 & MWS-16 & 1 \\
\hline MWV-9 & MWS-9 & 1 & MWV-22 & MWS-22 & 11 \\
\hline
\end{tabular}

gradient directions were evaluated by examining the static water-level elevations measured from 1987 to 1996 for each well cluster. The majority of the well pairs exhibit downward vertical gradients, which suggests recharge within the Burlington-Keokuk Limestone.

Well pairs open to both the weathered and unweathered units of the Burlington-Keokuk Limestone at the chemical plant area and the ordnance works area exhibit downward gradients (Table 3.2). However, one well pair (MWS-02 and MWD-02) at the ordnance works area exhibits an upward gradient. This location is adjacent to a deeply eroded stream segment and shows evidence of discharge from the shallow groundwater in the northern portion of the training area. It is likely that this condition occurs elsewhere in the northern and southern portions of the ordnance works area where deeply incised valleys are present. 
Vertical gradients between the Burlington-Keokuk Limestone and the underlying Fern Glen Formation were determined for well clusters in the northern and southern portions of the ordnance works area (Table 3.2). An upward gradient was determined for well pair MWS-05 and MWD-05, located adjacent to a steeply incised valley. This vertical gradient is the result of discharge of the shallow aquifer to this valley. Upward gradients were also determined for two well pairs (MWS-106 and MWD-106 and MWD-109 and MWS-109) located in drainage areas north of the training area. These upward gradients are the result of discharge of the shallow aquifer to Dardenne Creek, a regional groundwater drain for the shallow aquifer. Monitoring well MWD-106 has consistently exhibited artesian conditions since installation. Well pair MWS-109 and MWD-109 occasionally has shown both upward and downward gradients that are likely the result of seasonal groundwater fluctuations.

The vertical gradients between the saturated overburden and Burlington-Keokuk Limestone were evaluated on the basis of well clusters at the training area (Table 3.2). Downward gradients were observed in most of the well pairs, indicating recharge from the overburden to the underlying bedrock. Upward gradients were observed at well pair location MWV-09 and MWS-09, and occasionally at well pairs MWV-01 and MWS-01 and MWV-13 and MWS-13. The upward hydraulic gradients are probably a result of the topographic surface and the location of well pairs adjacent to streams. Groundwater discharges to gaining reaches of streams. In areas where the potentiometric surface is below the stream bed, groundwater can flow from the bedrock to the overburden where the overburden is permeable (Mugel 1997). In addition to well pairs MWV-01 and MWS-01, pairs MWV-13 and MWS-13 and MWV-22 and MWS-22 have shown both upward and downward gradients (IT Corporation 1995a). The difference in water levels between the overburden and weathered wells is less than $0.3 \mathrm{~m}(1 \mathrm{ft})$ and most likely is the result of seasonal fluctuations in groundwater levels and the lower hydraulic conductivity of the overburden.

Vertical gradients between the shallow, middle, and deep bedrock aquifers were evaluated with static water-level data from wells MW-4019, MWS-101, and MWGS-1 through MWGS-5 (Table 3.3) obtained in 1989 through 1995 (Kleeschulte 1995). Several of these wells are set in clusters, which allows evaluation of discharge/recharge conditions in different areas of the ordnance works (Figure 2.1). The cluster comprising wells MW-4019, MWGS-1, and MWGS-2 is located south of the chemical plant area near the groundwater divide. The vertical gradients between the three aquifers are downward and indicate recharge through the bedrock units.

The cluster consisting of wells MWGS-3, MWGS-4, and MWGS-5 is adjacent to Dardenne Creek in the northern portion of the ordnance works area. The vertical gradients indicate that the shallow and middle bedrock aquifers discharge to Dardenne Creek in this area because of upward gradients and artesian conditions exhibited in these wells. The potentiometric surface of the deep bedrock aquifer is significantly lower than that of the shallow and middle aquifers, which indicates a limited hydrogeologic connection between the deep and upper aquifers. 
TABLE 3.3 Vertical Gradients in the Shallow, Middle, and Deep Bedrock Aquifers in the Weldon Spring Area

\begin{tabular}{|c|c|c|c|}
\hline \multicolumn{2}{|c|}{ Well Pair } & Location & Vertical Gradient ${ }^{\mathrm{a}}$ \\
\hline \multicolumn{4}{|c|}{ Shallow and Middle Bedrock Aquifers } \\
\hline MW-4019 & MWGS-1 & Groundwater Divide & $\downarrow$ \\
\hline MWGS-3 & MWGS-4 & Dardenne Creek & $\uparrow$ \\
\hline \multicolumn{4}{|c|}{ Middle and Deep Aquifers } \\
\hline MWGS-1 & MWGS-2 & Groundwater Divide & $!$ \\
\hline MWGS-4 & MWGS-5 & Dardenne Creek & No communication \\
\hline
\end{tabular}

Well MWS-101, open to the Kimmswick Limestone, is located adjacent to the Little Femme Osage Creek in the southern portion of the ordnance works area. Artesian conditions observed in this well since installation indicate upward gradients from the middle aquifer. The artesian conditions are likely the result of regional discharge to the Little Femme Osage Creek. The shallow aquifer is not present in this portion of the area because of erosion of these units.

\subsubsection{Aquifer Recharge and Discharge}

Regionally, the principal source of recharge to the shallow aquifer is infiltration of precipitation in areas where glacial drift is not present or the shallow bedrock formations are near the surface (MK-Ferguson Company and Jacobs Engineering Group, Inc. 1992a). In the vicinity of the chemical plant area and the ordnance works area, recharge occurs by infiltration through the soil matrix and hairline fractures in some of the overburden materials and from water entering the aquifer through losing stream reaches and segments or where erosion has removed the less permeable overburden units. Results of lysimeter studies in the training area indicate recharge through the unsaturated overburden as evidenced by affected water quality of samples from beneath known surficial soil contamination. Recharge from the raffinate pits through the overburden is also indicated by the results from lysimeter studies (MK-Ferguson Company and Jacobs Engineering Group, Inc. 1992a).

Groundwater discharges from the shallow aquifer can be observed as springs and seeps (Figure 3.8) in or near gullies both north and south of the groundwater divide. The final discharge points for groundwater flow are tributaries of the Mississippi River north of the divide (such as Dardenne Creek) and the Missouri River south of the divide. 


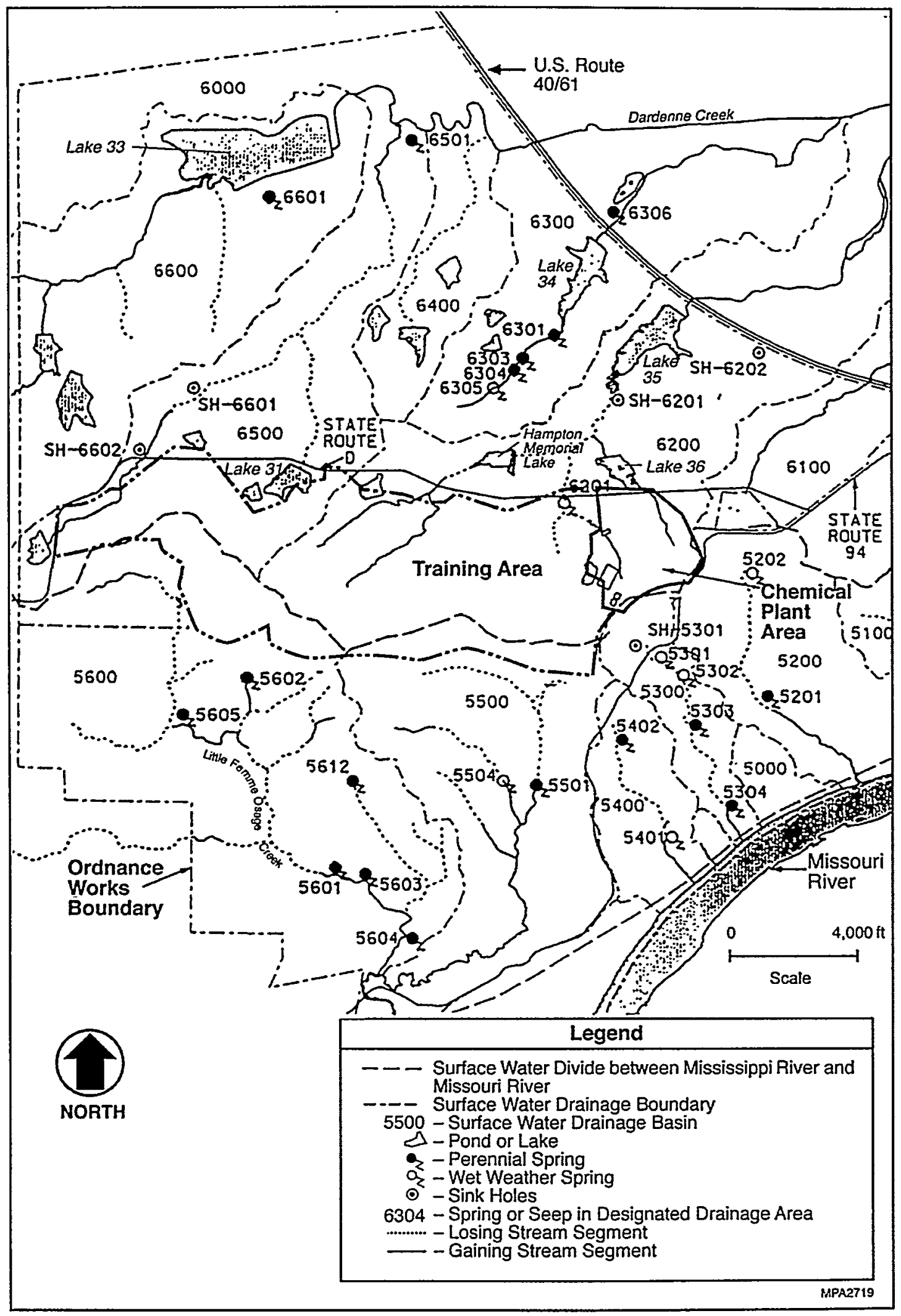

FIGURE 3.8 Gaining and Losing Stream Segments and Associated Springs and Seeps in the Ordnance Works Area 
To address the concern about the potential for contaminated water to enter the deep aquifer from directly beneath the chemical plant area, the U.S. Geological Survey (USGS) completed a modeling study to quantitatively assess the groundwater flow system in St. Charles County. A regional three-dimensional groundwater flow model was developed to describe groundwater flow between the shallow, middle, and deep aquifers in the county. The study encompassed $725 \mathrm{~km}^{2}$ $\left(280 \mathrm{mi}^{2}\right)$, which included most of St. Charles County. The results of the steady-state model simulations indicate that $21 \%$ of the groundwater flow out of the shallow aquifer beneath the chemical plant area has the potential to enter the middle aquifer. Approximately $80 \%$ of the groundwater flow out of the middle aquifer in the same area has the potential to infiltrate into the deep aquifer (Kleeschulte and Imes 1994). The quantity of water infiltrating from the shallow aquifer to the deep aquifer is small, and the time required for water to travel this distance is measured in hundreds of years (Kleeschulte 1991).

\subsubsection{Groundwater and Surface Water Interaction}

The Missouri Department of Natural Resources, Division of Geology and Land Survey, conducted a three-year investigation of the shallow groundwater in the Weldon Spring area (Missouri Department of National Resources 1991; Price 1991; IT Corporation 1992a). The investigation was conducted to inventory karst features (e.g., springs and sinkholes), identify the shallow groundwater discharge points for the chemical plant area and the training area, classify losing and gaining stream segments, perform stream run tracer tests, and monitor groundwater levels using continuous recorders. As part of the shallow groundwater investigations, a survey was performed in 1987 to locate springs and seeps that might be affected by groundwater or surface water discharges from the chemical plant area, the training area, and the ordnance works area. A total of 75 springs and seeps were located in the ordnance works area (Missouri Department of Natural Resources 1991). Three of these springs and seeps are perennial, and the larger wet-weather springs (considered the most significant hydrologically) and small intermittent springs and seeps only become active immediately following precipitation; these findings suggest very local recharge areas.

Within the ordnance works area, five sinkholes were identified (Figure 3.8). As with the springs, these sinkholes are small. Only one sinkhole, which periodically drains a portion of Lake 35, has exhibited any significant effect on the local hydrology. All others have a very limited internal drainage area and are not considered important hydrologic features. All of these sinkholes are located outside the chemical plant area and the training area (Price 1991).

Losing stream segments in the Missouri River watershed have been identified by visual observations (Missouri Department of Natural Resources 1991). Seepage runs on the drainages in the Mississippi River watershed were conducted to determine losing stream segments in that area. Swallow holes were also identified in both watersheds in the Weldon Spring area (Kleeschulte and Emmett 1987). 
Twelve stream tracer injections were made during the final two years of the study, and 11 of these indicated at least one subsurface hydrologic connection (Figure 3.9). The dye tests showed two general patterns of subsurface drainage:

- Groundwater in drainages of the Missouri River watershed (south of the groundwater divide) does not cross into other drainages, and

- Groundwater in drainages of the Mississippi River watershed (north of the groundwater divide) can cross surface water divides and emerge in other drainages.

Examples of these differing hydrologic flow patterns are demonstrated by the dye traces south of Lake 35 and the Southeast Drainage (5200). Tracer was injected in a swallow hole near Lake 35 (Figures 3.8 and 3.9). Within six days of the injection, dye was detected in six locations at or downstream of Lake 34, which is in adjoining drainage 6300 . The dye had traveled about $1.6 \mathrm{~km}$ ( $1 \mathrm{mi}$ ) in a northerly direction before surfacing in several seeps and springs in and downstream of Lake 34. Dye was not recovered further downstream in Schote Creek or in Burgermeister Spring, which are located a short distance northwest of the swallow hole.

A dye and water trace performed in the Southeast Drainage revealed a hydrologic connection between the head of the drainage and several springs within the drainage (Figure 3.9). Also, four losing sequences were identified within the drainage. A swallow hole was observed near the head of the drainage where all water was lost. Water was then observed to alternately seep into and surface from the streambed at four different points along the streambed. The short stretches of surface flow were separated by larger segments of dry streambed. Each losing stream segment in the valley appeared to be part of the recharge area for the next spring located farther downstream, until the reach at the end of the drainage became a gaining stream segment.

The results of the Missouri Department of Natural Resources investigations (Missouri Department of National Resources 1991; Price 1991) indicate that the shallow aquifer beneath the chemical plant area and the ordnance works area has characteristics typical of a carbonate groundwater system (e.g., weathered bedrock and solution-broadened joints and fractures). Studies performed by the Missouri Department of Natural Resources (1991) during 1989 found no effects of solution features such as subsurface conduits beneath the chemical plant area. Despite the lack of identified subsurface conduits at the time, overland flow from the northwestern portion of the chemical plant was lost in a losing reach of an unnamed tributary of Schote Creek about $305 \mathrm{~m}$ (1,000 ft) northwest of Ash Pond (Missouri Department of National Resources 1991; MK-Ferguson Company and Jacobs Engineering Group, Inc. 1992a). The results of the Missouri Department of Natural Resources water-tracing studies indicate that a subsurface conduit is present between the unnamed tributary of Schote Creek and Burgermeister Spring. The travel time for the 1,981-m 


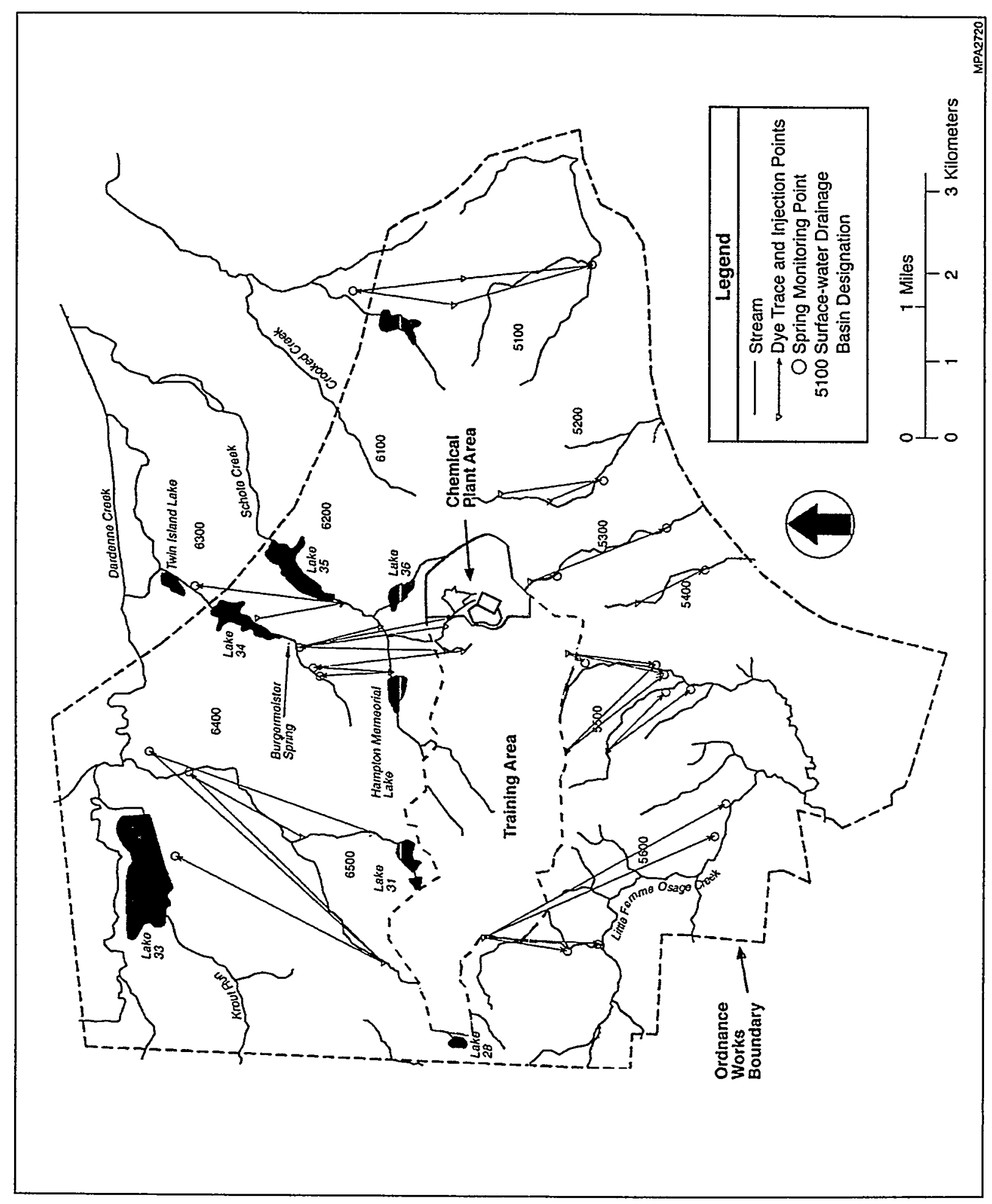

尊 
(6,500-ft) straight-line distance was estimated to be 48 to 72 hours, depending on previous rainfall (Missouri Department of Natural Resources 1991).

As part of the angled borehole drilling performed under this RI, dye tracing was conducted to determine whether a subsurface hydraulic connection could be detected between Burgermeister Spring and the northern and western portions of the chemical plant area. On the basis of data from previous aquifer testing (high values of hydraulic conductivity) and the presence of specific contaminants detected at Burgermeister Spring, it was suspected that these sections of the chemical plant area are directly connected with the conduit system that discharges to Burgermeister Spring. Two angled borings and one monitoring well that had recently been slug tested were selected for injection of dye. Three springs in the 6300 drainage were monitored for resurgence of the dye; however, the dye was only detected in Burgermeister Spring (Figure 3.10). The time required for the tracer to travel from the injection point to the recovery point (i.e., Burgermeister Spring) was used to calculate estimated groundwater velocities. These velocities were specific to the prevailing flow conditions during each dye trace. The results of this tracer testing are summarized in Table 3.4.

The data at the springs were collected at close time intervals, along with precipitation data, in an effort to gain further insight into the flow characteristics of the aquifer. Plots of the average relative dye intensity at the springs with respect to time for two successful tracer tests are shown in Figures 3.11 and 3.12. These plots illustrate the fluctuation of the dye intensity throughout the monitoring period. Also indicated in these figures are precipitation events that occurred during the testing period. Review of these plots indicates that the increases in dye intensity typically coincided with precipitation events. This quick response of Burgermeister Spring to precipitation is illustrated in Figure 3.13 in a plot of discharge from the spring compared with precipitation.

Complex conduit systems typically showed multiple dye intensity peaks representative of the dye traveling different distances to the resurgence point (Jones 1984). The multiple peaks in the recovery curves for the tracer tests correlated with storm events. This correlation suggests remobilization and flushing of the stored tracer (i.e., dye) in the conduits as a result of the conduits' receiving infiltration from losing streams during recharge events. The results of the hydraulic conductivity testing of the overburden indicate that recharge from infiltration of precipitation through the overburden matrix is slow. However, in areas where surface water runoff from precipitation enters losing stream segments (and thinner overburden exists) residence time is shorter, resulting in faster response to precipitation events compared with infiltration from precipitation through the overburden.

The results of two water balance studies are presented below. The first is for the Southeast Drainage, and the second is for the 6200 and 6300 drainages at the chemical plant area and the ordnance works area. For the Southeast Drainage, the results of seepage runs performed for the drainage were analyzed as an alternative approach to a water balance (Missouri Department of 


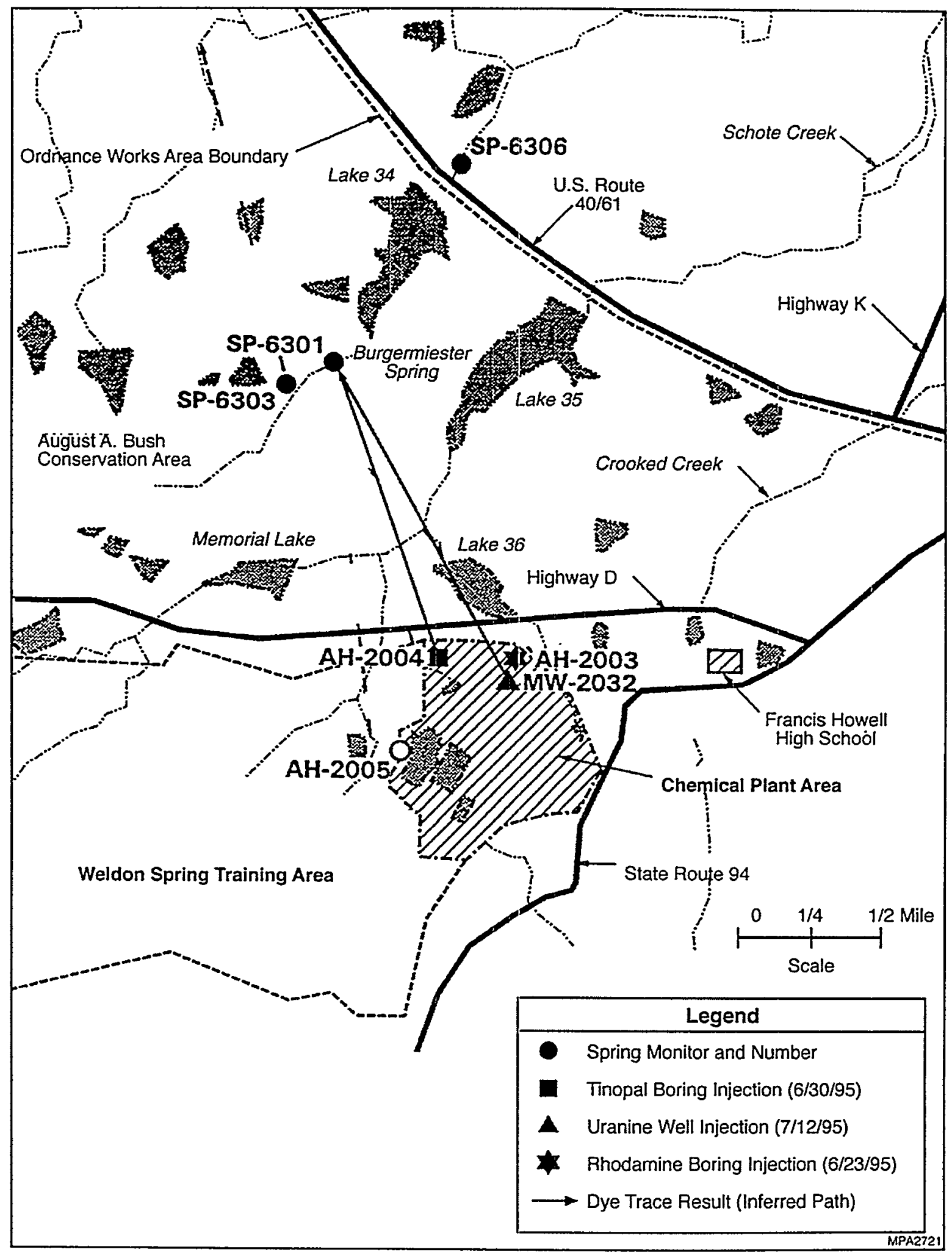

FIGURE 3.10 Flow Paths for Tracer Tests Performed at the Chemical Plant Area 
TABLE 3.4 Summary of Tracer Testing Results

\begin{tabular}{|c|c|c|c|c|c|c|c|}
\hline Location & $\begin{array}{l}\text { Injection } \\
\text { Interval }^{\mathrm{a}} \\
\text { (ft) }\end{array}$ & $\begin{array}{l}\text { Bedrock } \\
\text { Interval }^{\mathrm{b}}\end{array}$ & $\begin{array}{l}\text { Injection } \\
\text { Date }\end{array}$ & Dye & $\begin{array}{l}\text { Initial } \\
\text { Detection } \\
\text { Date }\end{array}$ & $\begin{array}{l}\text { Minimum } \\
\text { Distance } \\
\text { (ft) }\end{array}$ & $\begin{array}{l}\text { Calculated } \\
\text { Groundwater } \\
\text { Velocities } \\
\text { (ft/min) }\end{array}$ \\
\hline AH-2003 & $66.7-75.9$ & $\begin{array}{l}\text { Weathered/ } \\
\text { unweathered }\end{array}$ & $6 / 23 / 95$ & $\begin{array}{l}\text { Rhodamine } \\
\text { WT }\end{array}$ & $N A^{c}$ & 6,100 & NA \\
\hline AH-2004 & $26.8-44.4$ & Weathered & $6 / 30 / 95$ & Tinopal & $\begin{array}{l}\text { 7/2/95 - } \\
7 / 3 / 95\end{array}$ & 5,900 & $1.36-2.05$ \\
\hline MW-2032 & $48.0-58.6$ & $\begin{array}{l}\text { Residuum/ } \\
\text { weathered }\end{array}$ & $7 / 12 / 95$ & Uranine & $\begin{array}{c}7 / 19 / 95- \\
7 / 21 / 95\end{array}$ & 6,500 & $0.50-0.64$ \\
\hline
\end{tabular}

a Injection intervals were measured as feet below ground surface (vertical).

b Bedrock intervals are within the Burlington-Keokuk Limestone.

c NA $=$ data not available.

Natural Resources 1991). This method was used because there is no detailed information on the local precipitation or evapotranspiration. In addition to the seepage runs, on two occasions (October 29, 1987 , and in September 1990), water was released at a rate of $379 \mathrm{~L} / \mathrm{m}$ (100 gpm) from a hydrant located near the DOE fence at the head of the Southeast Drainage to determine the adequacy of the drainage to receive water from the proposed water treatment plant. Observations made in the drainage revealed results very similar to those previously obtained. That is, at each spring further downstream, the same flow resurfaced and stayed at the surface for a short distance before sinking again into the stream bed. Pyranine dye was also injected into the surface flow near the hydrant. For three weeks after the injection, dye was detected at the downstream springs; however, no dye was detected outside of the drainage.

On the basis of the results of the above seepage runs and dye tracer studies, the Southeast Drainage appears to be a closed system that has little observable loss to adjacent drainages or the underlying groundwater system. Because detailed information apparently was not collected on the actual flows at the downstream locations, it is not possible to quantify the losses of the surficial stream to the groundwater system. Recharge is, however, anticipated to be small (large values of recharge to groundwater would have produced observable changes in the downstream flows).

The topography of the Southeast Drainage also provides some insights into its hydrogeological behavior. Because the stream in the Southeast Drainage is surrounded by fairly steep wall, the bottom of the drainage is a likely place for groundwater discharge from the surrounding uplands. That is, the groundwater gradient in the vicinity of the stream bed is likely to be vertically up (Toth 1963). This groundwater discharge can provide the sustained base flow 


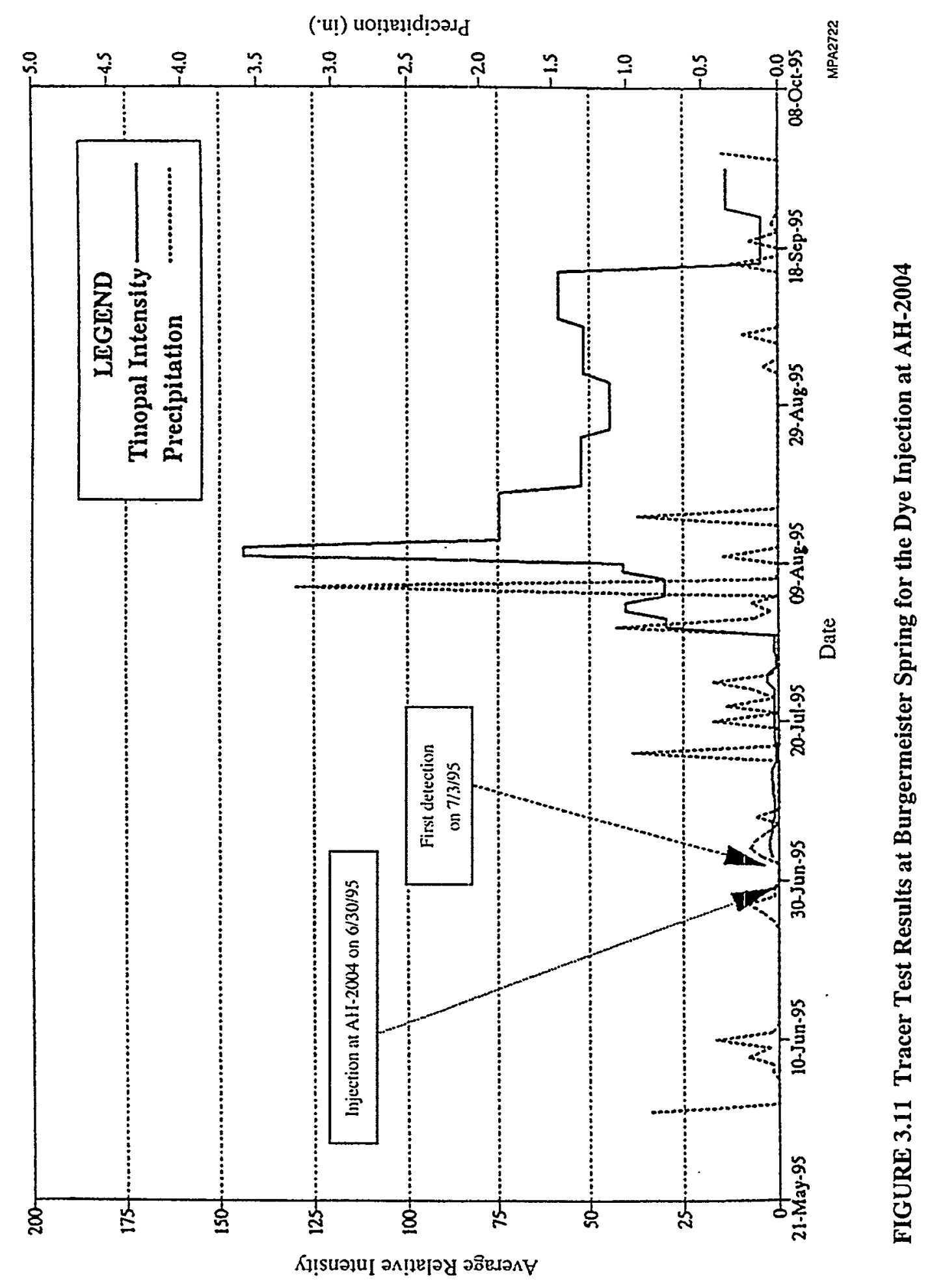




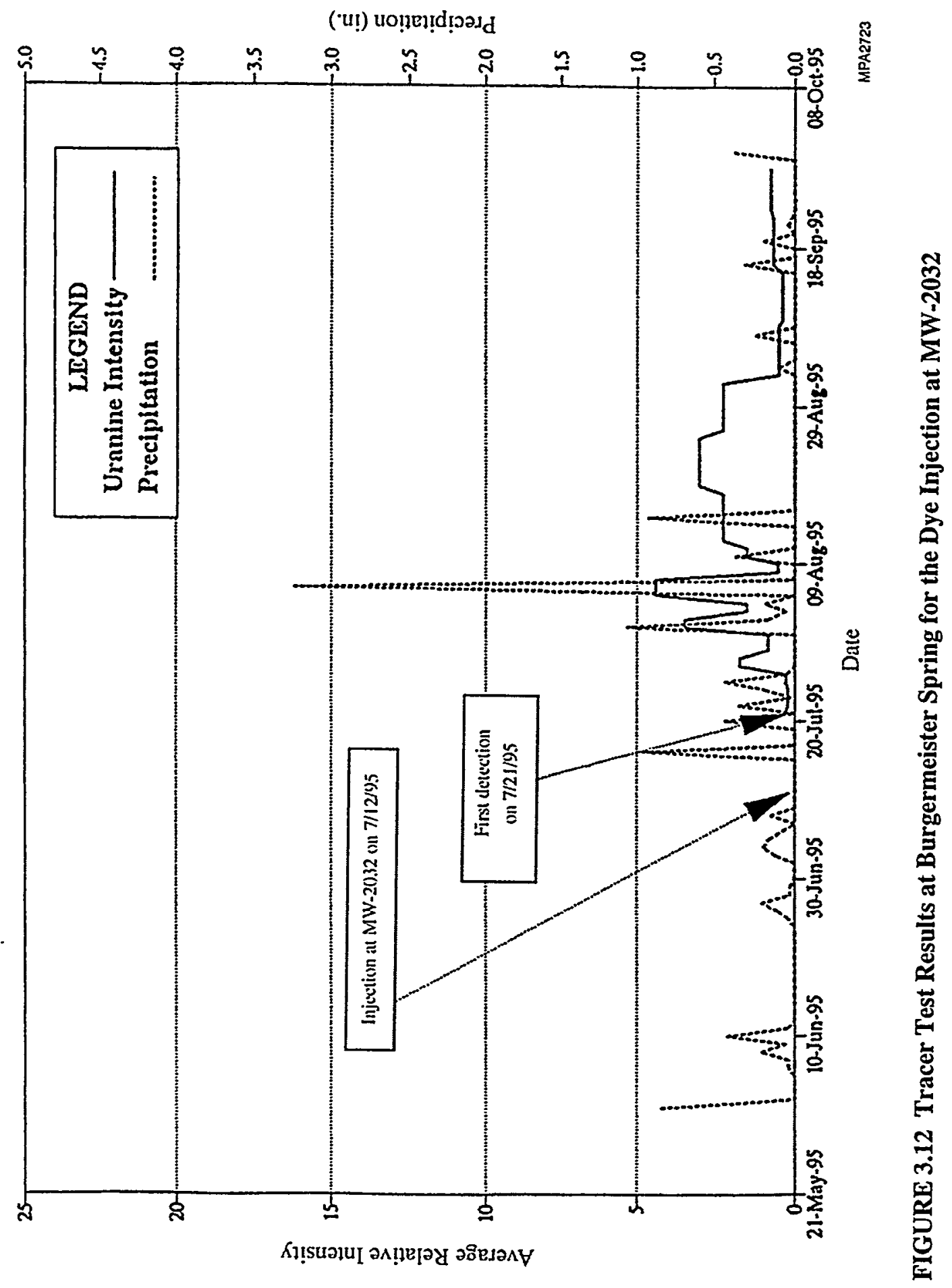




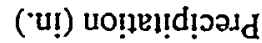

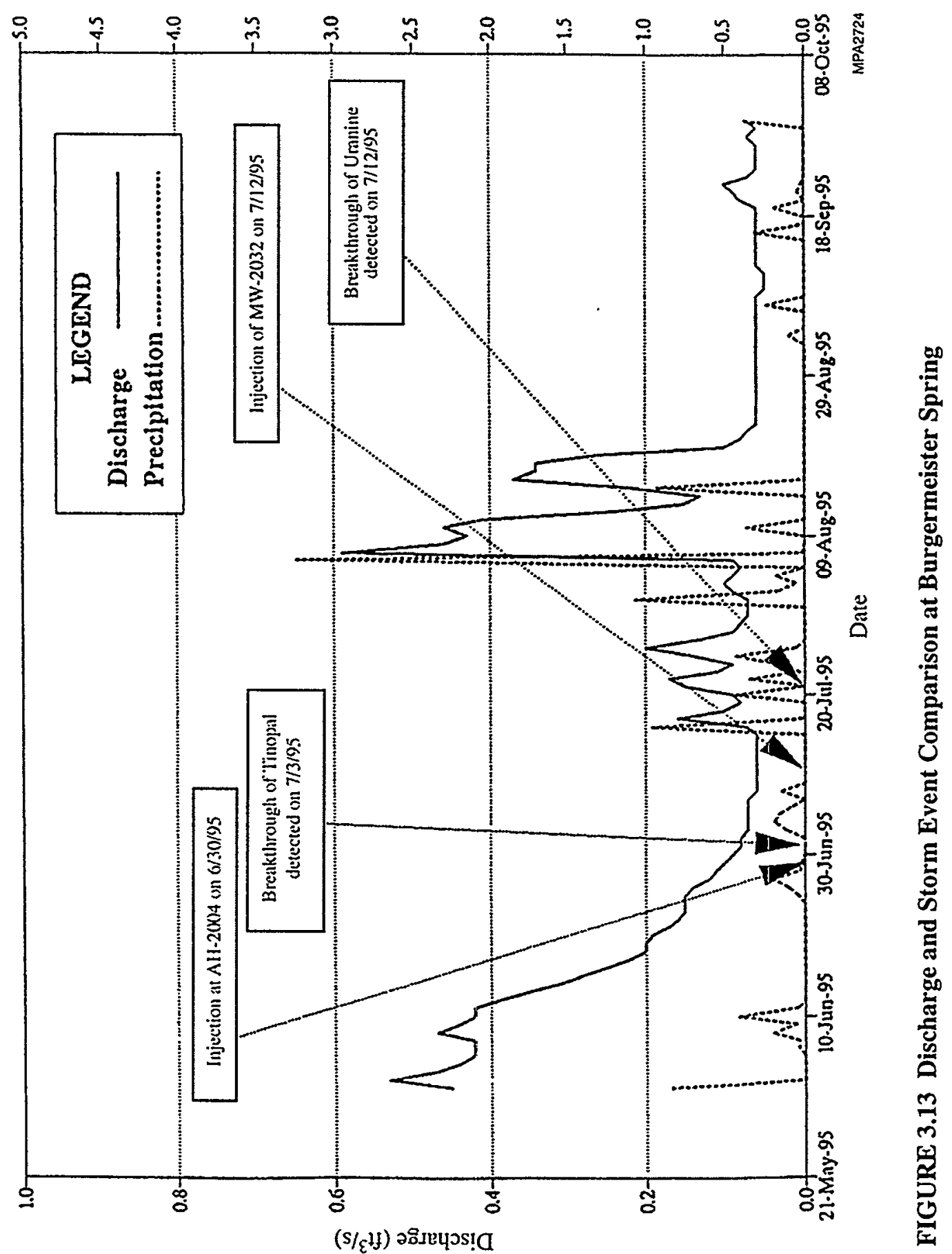


observed in the lower reach of the stream and can also limit the amount of groundwater recharge from the surface.

In June 1987,19 total-catch rain gages were installed over a $11.9-\mathrm{km}^{2}\left(4.6-\mathrm{mi}^{2}\right)$ area that included the drainage basins of the unnamed tributary of which Burgermeister Spring is located and Schote Creek (Kleeschulte and Cross 1990); these streams are parts of the 6300 drainage and 6200 drainage, respectively. For the two-year USGS study that began in 1987, the drainages were combined because the northern portion of the chemical plant area (north of the surface water divide) is located in the Schote Creek drainage (6200), but interbasin transfer of water occurs from Schote Creek to the unnamed tributary containing Burgermeister Spring in the 6300 drainage (Kleeschulte and Emmet 1987). Daily total precipitation for the study area was calculated by the isohyetal method. In addition to the precipitation data, discharge data were also collected daily at Burgermeister Spring, the unnamed tributary at Twin Island Lake, and Schote Creek at U.S. Highway 40 and 61.

On the basis of the above information collected from August 1987 through September 1989, the USGS completed a water-balance study indicating that about $25 \%$ of the total precipitation to the study area leaves as surface water runoff via Schote Creek and the unnamed tributary (Kleeschulte and Imes 1994). For an average annual precipitation of $94 \mathrm{~cm} / \mathrm{yr}$ (37 in./yr) (DOE $1992 \mathrm{~b}$ ), about $23 \mathrm{~cm} / \mathrm{yr}$ (9 in./yr) would leave as surface runoff and $71 \mathrm{~cm} / \mathrm{yr}$ ( $28 \mathrm{in} . / \mathrm{yr}$ ) would go to evapotranspiration and infiltration to the groundwater. Because the estimated potential evapotranspiration for the Weldon Spring area is about equal to the average annual precipitation (DOE 1992b), the estimated evapotranspiration and recharge values are within the range of the potential evapotranspiration.

Without additional information on recharge or evapotranspiration, the estimated sum of evapotranspiration and recharge cannot be further separated. However, in the modeling study performed by the USGS (Kleeschulte and Imes 1994), the maximum recharge to the shallow groundwater aquifer was $6.4 \mathrm{~cm} / \mathrm{yr}(2.5 \mathrm{in} . / \mathrm{yr})$. For this value of recharge, the estimated average evapotranspiration would be $65 \mathrm{~cm} / \mathrm{yr}$ (25.5 in./yr). This value is less than the potential evapotranspiration reported (DOE 1992b), and physically realistic.

Within the groundwater system, a second water balance can be performed. Under steadystate conditions (no net change in groundwater storage), inflow is equal to outflow. On the basis of the three-dimensional groundwater model developed by Kleeschulte and Imes (1994), 75\% of the inflow to the upper, shallow aquifer (Burlington/Keokuk Limestones and the Fern Glenn Formation) in the immediate vicinity of the chemical plant area is derived from precipitation. The remaining $25 \%$ is derived from lateral inflow into the layer. For $6.4 \mathrm{~cm} / \mathrm{yr}(2.5 \mathrm{in} . / \mathrm{yr})$ of infiltration from precipitation, the average total recharge to the shallow aquifer in the vicinity of the chemical plant area is, therefore, about $8.4 \mathrm{~cm} / \mathrm{yr}$ ( $3.3 \mathrm{in} . / \mathrm{yr}$ ). About $21 \%$ of this recharge, that is, about $1.8 \mathrm{~cm} / \mathrm{yr}$ (0.7 in./yr), leaks downward into the middle aquifer (Kimmswick Limestone) (Kleeschulte and Imes 1994). 
About $94 \%$ of the total recharge to the middle aquifer in the immediate vicinity of the chemical plant area is derived from vertical leakage (Kleeschulte and Imes 1994). The remaining 6\% is derived from lateral inflow. The average total recharge to the middle aquifer is, therefore, about $1.9 \mathrm{~cm} / \mathrm{yr}(0.75 \mathrm{in} . / \mathrm{yr})$. Approximately $80 \%$ of this water recharges the deep aquifer (top of the St. Peter Sandstone to the base of the Potosi Dolomite); the other $20 \%$ is lateral outflow. On the basis of the above calculations, the vertical recharge to the deep aquifer is about $1.5 \mathrm{~cm} / \mathrm{yr}$ (0.6 in./yr).

The above groundwater balance probably overestimates the amount of deep infiltration derived from precipitation, because the Kleeschulte and Imes model (1994) does not incorporate groundwater losses from the shallow aquifer to the conduit that discharges at Burgermeister Spring. During the two-year mini-water balance study (Kleeschulte and Cross 1990), about $430,000 \mathrm{~m}^{3}$ (350 acre-ft) of water was discharged from Burgermeister Spring. This volume represents about $2 \%$ of the total precipitation on the combined 6200 and 6300 drainages. Most groundwater discharging at Burgermeister Spring, however, is likely to be derived from precipitation at the chemical plant area and adjacent training area.

In calendar year 1996, the total flow from Burgermeister Spring was about $210,000 \mathrm{~m}^{3}$ (168 acre-ft) (Kleeschulte 1997). If this flow was derived primarily from precipitation on the chemical plant area and immediate vicinity north of the groundwater divide (approximately 405 ha [1,000 acres]), the discharge at Burgermeister Springs would represent about $80 \%$ of the surface infiltration of $6.4 \mathrm{~cm} / \mathrm{yr}$ ( $2.5 \mathrm{in} . / \mathrm{yr}$ ) (the maximum value of USGS recharge used in the above calculations). If the drainage area of the conduit is less, the percentage of infiltration would increase correspondingly.

If $80 \%$ of the infiltration from rainfall is lost to Burgermeister Spring, the net recharge to the shallow aquifer would be $1.3 \mathrm{~cm} / \mathrm{yr}(0.5 \mathrm{in} . / \mathrm{yr})$. If we then assume that the remainder (middle and deep aquifers) of the USGS model (Kleeschulte and Imes 1994) behaves as before, the amount of recharge to the middle aquifer would be $21 \%$ of the effective infiltration, or about $0.25 \mathrm{~cm} / \mathrm{yr}$ ( $0.1 \mathrm{in} . / \mathrm{yr}$ ). If this recharge is still $94 \%$ of the total recharge to the middle aquifer, recharge to the middle aquifer would be about $0.28 \mathrm{~cm} / \mathrm{yr}(0.11 \mathrm{in} . / \mathrm{yr})$. Approximately $80 \%$ of this water $(0.25 \mathrm{~cm} / \mathrm{yr}$ [0.1 in./yr]) would then go on to recharge the deep aquifer. This value is about a factor of six less than the value calculated above under the assumption that no groundwater is lost to Burgermeister Spring and represents about $0.3 \%$ of the total precipitation on the Burgermeister Spring catchment.

Because of uncertainties in the various input parameters and modeling assumptions, the effective average recharge to the deep aquifer is not known precisely, and may differ from the above estimated values by a factor of two. However, the amount of recharge to the deep aquifer is likely to be small (on the order of less than $1 \%$ ) because of the small amount of effective surface infiltration, lateral losses to Burgermeister Spring, and presence of material of low hydraulic conductivity in the vertical soil column. Additional site-specific field work aimed at providing 
specific evapotranspiration values, improved surface flow estimates, improved delineation of the Burgermeister Spring catchment, and estimates of total precipitation would improve these calculations. More detailed groundwater flow simulations would also reduce uncertainties in the estimates for lateral and vertical flows in the vicinity of the chemical plant area.

\subsection{HYDROGEOLOGIC CONCEPTUAL MODEL}

The hydrogeologic conceptual model (Figure 3.14) consists of several complex components: thinly bedded limestone, losing and gaining stream segments and sinkholes, preferential flow zones that discharge to springs, pronounced groundwater troughs in the shallow groundwater surface, solution-enlarged joints and fractures, and extensively weathered limestone bedrock. The shallow bedrock aquifer is unconfined and has locally semiconfining conditions as the result of the presence of a leaking confining glacial unit in the northern and central portions of the ordnance works area. The shallow aquifer is conceptualized to be a diffuse flow system with superimposed conduit flow. The matrix in which diffuse flow occurs is a storage reservoir with a low hydraulic conductivity that slows transfer to the conduit system. The superimposed conduit system allows for quick movement of water when it is released from the diffuse flow area to the system or is introduced from other sources (losing streams) directly into the conduit system.

Groundwater recharge occurs as infiltration from precipitation through the overburden, from surface water runoff, and from surface water impoundments. Infiltration through the overburden occurs through the soil matrix and hairline fractures observed in some of the overburden units, which have abundant near-vertical hairline fractures. Some of those fractures extend for more than $3 \mathrm{~m}$ (10 ft) (Rueff 1992). Many fractures in the loess are open and contain small roots and iron and magnesium oxides that indicate the movement of water. Hydraulic conductivity testing of these materials, lysimeter studies, and the presence of the groundwater mound beneath the chemical plant area and the training area all indicate that recharge through the overburden is slow. These lower hydraulic conductivities likely allow storage of water in the overburden. This stored water may provide a slow, constant recharge to the shallow groundwater system.

Recharge occurs as surface water runoff enters losing stream segments where thinner overburden areas exist at both the chemical plant area and the ordnance works area. This form of recharge has a shorter residence time in the system, as evidenced by the quick discharge response of Burgermeister Spring to precipitation events. It can be assumed that other large springs in the area (i.e., springs in drainages $5300,5600,6500$, and 6600 ) behave similarly. This recharge is more rapid relative to infiltration through the overburden. Finally, recharge also occurs as infiltration from surface water bodies (impoundments), such as the raffinate pits, lakes, and lagoons.

Groundwater movement in the underlying limestone is controlled principally by horizontal fractures, bedding planes, and solution features. The lower section of the residuum near the bedrock contact has been identified as more permeable because of the presence of relic chert beds, gravels, 


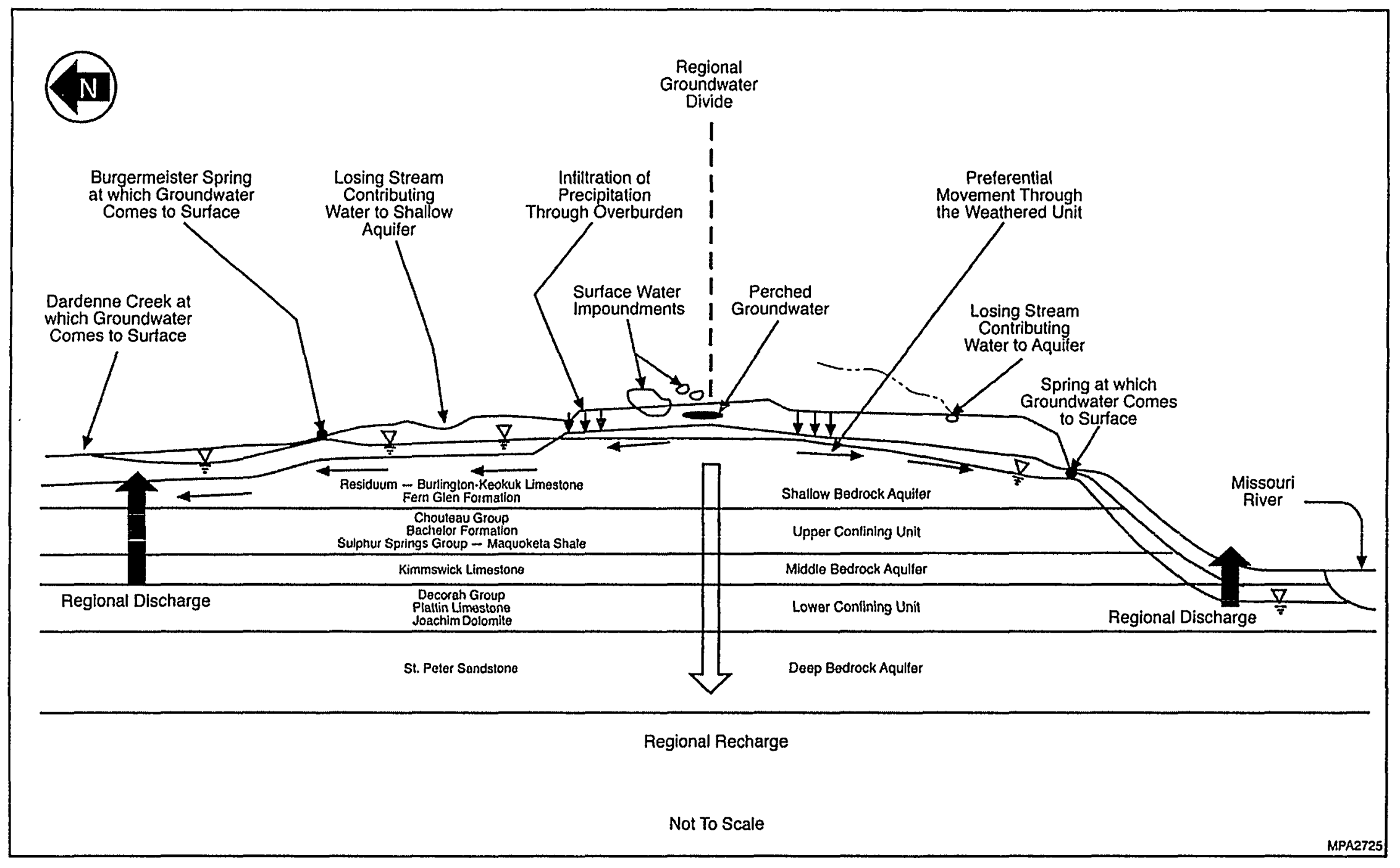

FIGURE 3.14 Hydrogeologic Conceptual Model 
and weathered limestone. Preferential horizontal groundwater flow occurs along the contact of the saturated residuum with the underlying weathered limestone. Vertical movement occurs and is likely limited to areas that exhibit greater vertical weathering or fracturing. The downward vertical gradient within the overburden, Burlington-Keokuk Limestone, and Fern Glen Formation over most of the chemical plant area and the ordnance works area indicates recharge to the shallow aquifer system. The upward gradients that occur between these units represent groundwater discharge primarily along deeply eroded stream segments. Upward gradients are prevalent near Burgermeister Spring between the Burlington-Keokuk Limestone and the Fern Glen Formation and indicate discharge of the shallow aquifer to Dardenne Creek, a tributary to the Mississippi River.

Groundwater discharge also occurs at springs and seeps at the ordnance works area. Results of tracer tests indicate that groundwater flow is contained within surface water drainages south of the groundwater divide; north of the divide, groundwater crosses into other drainages. A primary point of resurgence for the chemical plant area north of the groundwater divide is Burgermeister Spring (SP-6301). Burgermeister Spring is also a primary point of resurgence for the ordnance works area north of the groundwater divide. South of the groundwater divide, resurgence occurs at numerous springs within smaller individual watersheds. 


\section{3-38}




\section{NATURE AND EXTENT OF CONTAMINATION}

This chapter evaluates the nature and extent of contamination within the groundwater system for the chemical plant area and the ordnance works area. This evaluation is based on data collected under DOE and DA environmental monitoring programs from 1987 through 1995. In addition, a joint sampling effort was also conducted in May and August of 1995 to produce a comparable data set for both areas. The joint sampling involved all active monitoring wells and 15 springs. Groundwater and spring data for the joint sampling are presented in detail in Appendix C. These data, together with previously collected data for the evaluation of groundwater contamination, are evaluated in Section 4.1; data for contamination in groundwater discharge to area springs are evaluated in Section 4.2.

\subsection{GROUNDWATER}

For this RI, the groundwater contamination discussions are summarized on the basis of the well completions as in the Work Plan (DOE 1995b) for the GWOUs. The groundwater data were grouped into four stratigraphic units: the overburden, weathered Burlington-Keokuk Limestone, unweathered Burlington-Keokuk, and deeper units. The data from wells that monitor formations deeper than the Burlington-Keokuk were grouped together (there are no deep wells on the chemical plant area). Completion intervals for individual wells on the chemical plant area and the ordnance works area are provided in Chapter 2 (Tables 2.2 and 2.3) and in Appendix B. These groupings facilitate evaluation of the vertical distribution of contaminants.

Data for the chemical plant area and the ordnance works area were combined and evaluated together because the groundwater system is continuous beneath both areas. A summary of the data collected for the joint sampling and data collected prior to 1995 for metals and anions and nitroaromatic compounds is presented in Tables 4.1 and 4.2, respectively. Sampling for nitrite was not conducted as part of the joint sampling effort. Because early data indicated that nitrate levels are very low and nitrite readily oxidizes to nitrates, nitrite sampling was discontinued. For evaluation of the nature and extent of contamination, filtered and unfiltered metals data were combined on the basis of results from a study conducted by DOE on the effects of filtering water samples on contaminant concentrations (MK-Ferguson Company and Jacobs Engineering Group Inc. 1995). The results of this study indicated that sample filtering does not have a large impact on the results; the only metals that exhibited significantly higher concentrations (i.e., a relative percent difference of $20 \%$ or higher) in the unfiltered samples were aluminum, iron, lead, chromium, and manganese. Concentrations of antimony have been consistently higher for dissolved samples than in the unfiltered samples in wells associated with the ordnance works area and those wells sampled during the joint sampling effort. This problem has been attributed to antimony leaching from the filter used during groundwater sampling. Hence, dissolved antimony data from both the ordnance works area 


\section{TABLE 4.1 Summary of 1995 Joint Sampling Data and Data Collected from 1987-1994: Radionuclides and Metals}

\begin{tabular}{|c|c|c|c|c|c|c|c|c|c|c|c|c|}
\hline & \multicolumn{12}{|c|}{ Weathered Unit } \\
\hline & \multicolumn{6}{|c|}{1995 Joint Sampling Data } & \multicolumn{6}{|c|}{ 1987-1994 Dnta } \\
\hline & \multicolumn{3}{|c|}{ Filtered } & \multicolumn{3}{|c|}{ Unfiltered } & \multicolumn{3}{|c|}{ Filtered } & \multicolumn{3}{|c|}{ Unfilicred } \\
\hline & $\begin{array}{l}\text { Delection } \\
\text { Frequency }\end{array}$ & Range & Mean" & $\begin{array}{l}\text { Detection } \\
\text { Frequency }\end{array}$ & Range & $\operatorname{Mean}^{\mathrm{a}}$ & $\begin{array}{l}\text { Delection } \\
\text { Frequency }\end{array}$ & Range & Mean $^{2}$ & $\begin{array}{l}\text { Detection } \\
\text { Frequency }\end{array}$ & Range & Mcan \\
\hline \multicolumn{13}{|c|}{ Radionuclides (pCi/L) } \\
\hline Uranium, total & NS & NS & NS & $151 / 156$ & $0.0010-60$ & 2.6 & $3 / 3$ & $1.0-8.0$ & 4.4 & $699 / 867$ & $0.20-870$ & 5.6 \\
\hline \multicolumn{13}{|l|}{ Metals ( $\mu \mathrm{g} / \mathrm{L})$} \\
\hline Aluminum & $57 / 158$ & $2.5-280$ & 24 & $111 / 158$ & $3.8-27000$ & 670 & $118 / 570$ & $3-12,000$ & 84 & $168 / 212$ & $21-58,000$ & 2,800 \\
\hline Antimonyb & NS & NS & $N S^{\mathfrak{c}}$ & $26 / 164$ & $0.0050-5.6$ & 0.74 & NS & NS & NS & $2.3 / 204$ & $1.7-24$ & 7 \\
\hline Arsenic & $32 / 165$ & $0.066-15$ & 1.5 & $24 / 167$ & $0.12-15$ & 1.6 & $72 / 645$ & $0.60-17$ & 1.8 & $75 / 215$ & $0.60-4.30$ & 5.1 \\
\hline Barium & $161 / 161$ & $19-8.30$ & 180 & $163 / 163$ & $26-900$ & 190 & $598 / 677$ & $13-2.200$ & 210 & $188 / 215$ & $22-840$ & 180 \\
\hline Cadmium & $8 / 165$ & $0.056-0.53$ & 0.49 & $8 / 167$ & $0.009-0.74$ & 0.51 & $37 / 513$ & $0.20-11$ & 1.7 & $54 / 208$ & $0.20-5$ & 1.1 \\
\hline Chromium & $118 / 164$ & $0.91-23$ & 2.8 & $127 / 167$ & $1.1-120$ & 5.1 & $90 / 664$ & $0.90-250$ & 7.0 & $56 / 216$ & $2.0-90$ & 6.8 \\
\hline Copper & $45 / 165$ & $0.69-42$ & 2.8 & $81 / 165$ & $1.1-85$ & 5.6 & $84 / 488$ & $0.40-75$ & 6.2 & $105 / 204$ & $1.0-150$ & 11 \\
\hline Iron & $96 / 138$ & $7.6-610$ & 84 & $118 / 139$ & $16-32,000$ & 850 & $302 / 617$ & $1.7-22,000$ & 190 & $195 / 212$ & $9.0-42,000$ & 3,800 \\
\hline Lead & $23 / 163$ & $0.026-2.3$ & 1.1 & $93 / 164$ & $0.009-46$ & 3.4 & $141 / 603$ & $0.70-65$ & 2.6 & $103 / 216$ & $0.80-200$ & 7.6 \\
\hline Lithium & $140 / 161$ & $1.2-680$ & 50 & $142 / 160$ & $1.2-650$ & 50 & $153 / 406$ & $1.3-1,500$ & 110 & $5 / 14$ & $340-910$ & 240 \\
\hline Manganese & $95 / 163$ & $0.088-240$ & 15 & $131 / 161$ & $1.2-1000$ & 44 & $312 / 627$ & $0.60-740$ & 27 & $181 / 212$ & $1.3-2,100$ & 190 \\
\hline Mercury & $5 / 162$ & $0.29-3.8$ & 0.14 & $9 / 164$ & $0.20-4.5$ & 0.16 & $54 / 513$ & $0.05-44$ & 0.26 & $16 / 208$ & $0.2-1.0$ & 0.11 \\
\hline Molybdenum & $67 / 164$ & $0.17-260$ & 4.9 & $69 / 164$ & $0.13-250$ & 4.9 & $55 / 272$ & $5.7-250$ & 19 & $2 / 6$ & $10-220$ & 44 \\
\hline Nickel & $148 / 161$ & $0.10-95$ & 8.4 & $156 / 161$ & $0.010-170$ & 12 & $97 / 622$ & $0.70-3.30$ & 17 & $64 / 212$ & $6.0-260$ & 22 \\
\hline Selenium & $38 / 165$ & $0.045-13$ & 2.4 & $36 / 167$ & $0.27-1.3$ & 2.3 & $134 / 509$ & $0.40-65$ & 2.9 & $31 / 208$ & $1.0-16$ & 1.4 \\
\hline Silver & $7 / 165$ & $0.0050-3.2$ & 0.5 & $1.5 / 167$ & $0.0050-14$ & 0.69 & $17 / 596$ & $2.0-3.38$ & 5.3 & $3 / 216$ & $3.7-4.50$ & 5.0 \\
\hline Thallium & $5 / 165$ & $0.020-2.2$ & 0.67 & $5 / 165$ & $0.069-1.9$ & 0.67 & $29 / 447$ & $0.10-5.8$ & 2.3 & $22 / 204$ & $1.0-4$ & 1.9 \\
\hline Uranium, rotal & NS & NS & NS & $151 / 156$ & $0.0015-90$ & 4.0 & $3 / 3$ & $1.5-12$ & 6.5 & $699 / 867$ & $0.30-1,300$ & 8.3 \\
\hline
\end{tabular}


TABLE 4.1 (Cont.)

\begin{tabular}{|c|c|c|c|c|c|c|c|c|c|c|c|c|}
\hline & \multicolumn{12}{|c|}{ Unweathered Unit } \\
\hline & \multicolumn{6}{|c|}{1995 Joint Sampling Data } & \multicolumn{6}{|c|}{ 1987-1994 Data } \\
\hline & \multicolumn{3}{|c|}{ Filtered } & \multicolumn{3}{|c|}{ Unfiltered } & \multicolumn{3}{|c|}{ Filtered } & \multicolumn{3}{|c|}{ Unfiltered } \\
\hline & $\begin{array}{l}\text { Detection } \\
\text { Frequency }\end{array}$ & Range & $\operatorname{Mcan}^{2}$ & $\begin{array}{l}\text { Detection } \\
\text { Frequency }\end{array}$ & Range & $\operatorname{Mcan}^{2}$ & $\begin{array}{l}\text { Detection } \\
\text { Frequency }\end{array}$ & Range & $\operatorname{Mean}^{2}$ & $\begin{array}{l}\text { Detection } \\
\text { Frequency }\end{array}$ & Range & $\operatorname{Mcan}^{a}$ \\
\hline \multicolumn{13}{|c|}{ Radionuclides (pCi/L) } \\
\hline Uranium, total & NS & NS & NS & $54 / 56$ & $0.11-5.2$ & 1.7 & NS & NS & NS & $262 / 314$ & $0.20-17$ & 2.4 \\
\hline \multicolumn{13}{|l|}{ Metals ( $\mu g / L)$} \\
\hline Aluminum & $28 / 59$ & $13-570$ & 31 & $42 / 59$ & $15-62,000$ & 2,800 & $39 / 218$ & $0.3-1.900$ & 70 & $68 / 83$ & $20-73,000$ & 2,800 \\
\hline Antimony ${ }^{b}$ & NS & NS & NS & $10 / 60$ & $0.23-4.4$ & 0.70 & NS & NS & NS & $8 / 78$ & $2.3-80$ & 7.5 \\
\hline Arsenic & $7 / 60$ & $2.3-9.2$ & 1.5 & $10 / 60$ & $2.2-18$ & 2.1 & $50 / 227$ & $0.030-.34$ & 2.0 & $29 / 83$ & $0.70-68$ & 3.0 \\
\hline Barium & $60 / 60$ & $18-1.400$ & 190 & $60 / 60$ & $20-2,600$ & 250 & $203 / 228$ & $10-2,000$ & 170 & $75 / 83$ & $76-14,000$ & 350 \\
\hline Cadmium & $0 / 60$ & $N D^{4}$ & ND & $4 / 60$ & $0.028-3.0$ & 0.58 & $12 / 193$ & $0.20-18$ & 1.7 & $23 / 78$ & $0.20-6$ & 1.0 \\
\hline Chromium & $51 / 60$ & $1.2-95$ & 5.7 & $52 / 60$ & $1.0-180$ & 13 & $35 / 227$ & $3.2-140$ & 6.9 & $10 / 83$ & $2.0-88$ & 6.3 \\
\hline Copper & $13 / 60$ & $2.1-6.1$ & 1.7 & $28 / 60$ & $2.0-220$ & 8.9 & $32 / 191$ & $0.80-2.3$ & 4.8 & $34 / 78$ & $1.0-120$ & 10 \\
\hline Iron & $28 / 48$ & $18-1,500$ & 94 & $37 / 48$ & $18-57.000$ & 3,300 & $133 / 226$ & $7.0-7,500$ & 110 & $76 / 83$ & $50-96,000$ & 3.300 \\
\hline Lead & $4 / 60$ & $1.0-2.7$ & 0.57 & $29 / 60$ & $1.0-370$ & 15 & $50 / 217$ & $0.80-37$ & 2.3 & $32 / 83$ & $2.0-400$ & 13 \\
\hline Lithium & $57 / 60$ & $0.30-210$ & 19 & $58 / 60$ & $0.90-200$ & 20 & $41 / 150$ & $3.7-280$ & 29 & $2 / 6$ & $33-78$ & 39 \\
\hline Manganese & $49 / 60$ & $1.1-4.30$ & 72 & $56 / 60$ & $1.0-4,900$ & 230 & $173 / 228$ & $1.0-530$ & 63 & $73 / 83$ & $4,0-3,700$ & 180 \\
\hline Mercury & $2 / 59$ & $0.93-0.94$ & 0.13 & $3 / 59$ & $0.21-1.5$ & 0.15 & $10 / 189$ & $0.030-2.5$ & 0.12 & $5 / 78$ & $0.10-1.1$ & 0.10 \\
\hline Molybdenum & $44 / 60$ & $1.0-37$ & 5.6 & $41 / 60$ & $1.1-37$ & 5.5 & $33 / 113$ & $3.7-1.100$ & 24 & $0 / 1$ & ND & ND \\
\hline Nickel & $57 / 60$ & $1.0-90$ & 7.0 & $59 / 60$ & $1.2-290$ & 18 & $13 / 227$ & $0.40-27$ & 8.9 & $20 / 83$ & $6.4-580$ & 19 \\
\hline Selenium & $6 / 60$ & $3.4-1.3$ & 2.0 & $6 / 60$ & $4.2-14$ & 2.1 & $31 / 191$ & $1.0-39$ & 2.0 & $3 / 78$ & $1.0-7.4$ & 1.2 \\
\hline Silver & $0 / 60$ & ND & ND & $4 / 60$ & $0.0070-22$ & 1.2 & $9 / 215$ & $2.0-10$ & 3.3 & $1 / 83$ & 9.1 & 2.9 \\
\hline Thallium & $0 / 60$ & ND & ND & $1 / 60$ & 1.1 & 0.53 & $12 / 183$ & $0.10-15$ & 2.1 & $4 / 78$ & $1.3-3.0$ & 1.5 \\
\hline Uranium, rota! & NS & NS & NS & $54 / 56$ & $0.17-7.7$ & 2.6 & NS & NS & NS & $262 / 314$ & $0.30-25$ & 3.6 \\
\hline
\end{tabular}


TABLE 4.1 (Cont.)

\begin{tabular}{|c|c|c|c|c|c|c|c|c|c|c|c|c|}
\hline & \multicolumn{12}{|c|}{ Overburden Unit } \\
\hline & \multicolumn{6}{|c|}{1995 Joint Sampling Data } & \multicolumn{6}{|c|}{ 1987-1994 Data } \\
\hline & & Fillered & & & Unfillered & & & [iiltered & & & Unfillered & \\
\hline & $\begin{array}{l}\text { Detection } \\
\text { Frequency }\end{array}$ & Range & $\operatorname{Mean}^{A}$ & $\begin{array}{l}\text { Detection } \\
\text { Frequency }\end{array}$ & Range & Mean $^{\mathrm{a}}$ & $\begin{array}{l}\text { Detection } \\
\text { Frequency }\end{array}$ & Range & Mean $^{2}$ & $\begin{array}{l}\text { Detection } \\
\text { Frequency }\end{array}$ & Range & $\operatorname{Mean}^{2}$ \\
\hline \multicolumn{13}{|c|}{ Radionuclides ( $\mathrm{pCi} / \mathrm{L}$ ) } \\
\hline Uranium, total & NS & NS & NS & $17 / 18$ & $0.061-4.2$ & 1.5 & $4 / 4$ & $2.0-3.4$ & 2.5 & $45 / 53$ & $0.50-33$ & 3.4 \\
\hline \multicolumn{13}{|l|}{ Mctals $(\mu \mathrm{g} / \mathrm{L})$} \\
\hline Aluminum & $13 / 20$ & $0.25-570$ & 55 & $18 / 20$ & $23-2,200$ & 470 & $16 / 65$ & $3.0-1.300$ & 73 & $40 / 50$ & $90-57,000$ & 6.400 \\
\hline Antimony ${ }^{b}$ & NS & NS & NS & $1 / 20$ & 1.7 & 0.56 & NS & NS & NS & $3 / 46$ & $6.0-17$ & 11 \\
\hline Arsenic & $1 / 20$ & 4.5 & 1.2 & $5 / 20$ & $0.26-7.6$ & 1.5 & $14 / 65$ & $0.70-4.0$ & 2.1 & $22 / 50$ & $0.60-16$ & 3.8 \\
\hline Barium & $20 / 20$ & $26-310$ & 110 & $20 / 20$ & $37-340$ & 120 & $53 / 66$ & $23-660$ & 140 & $40 / 50$ & $35-960$ & 200 \\
\hline Cadmium & $3 / 20$ & $0.043-0.15$ & 0.44 & $4 / 20$ & $0.071-1.2$ & 0.47 & $9 / 60$ & $0.26-4.0$ & 1.6 & $18 / 46$ & $0.20-10$ & 1.7 \\
\hline Chromium & $11 / 20$ & $1.0-6.6$ & 1.7 & $13 / 20$ & $1.2-11$ & 3.2 & $2 / 66$ & $4.1-79$ & 4.8 & $17 / 50$ & $4.0-150$ & 15 \\
\hline Copper & $13 / 20$ & $0.48-6.8$ & 2.3 & $14 / 20$ & $0.91-16$ & 5.2 & $9 / 60$ & $1.8-21$ & 5.5 & $27 / 46$ & $2.0-9.3$ & 16 \\
\hline Iron & $14 / 18$ & $0.91-380$ & 88 & $16 / 18$ & $41-3.200$ & 580 & $31 / 65$ & $10-1.800$ & 98 & $48 / 50$ & $20-100,000$ & 12,000 \\
\hline Lead & $2 / 20$ & $0.55-1.5$ & 0.55 & $10 / 20$ & $0.074-19$ & 3.0 & $18 / 66$ & $1.2-37$ & 2.4 & $27 / 50$ & $3.5-96$ & 13 \\
\hline Lithium & $17 / 20$ & $0.25-13$ & 4.0 & $17 / 20$ & $0.26-14$ & 4.3 & $3 / 22$ & $7.1-64$ & 17 & $1 / 8$ & 35 & 29 \\
\hline Manganese & $18 / 20$ & $0.42-5.3$ & 6.7 & $20 / 20$ & $2.4-190$ & 46 & $34 / 65$ & $1.0-300$ & 28 & $42 / 50$ & $2.2-4,300$ & 460 \\
\hline Mercury & $0 / 20$ & ND & ND & $1 / 20$ & 0.35 & 0.11 & $5 / 60$ & $0.11-1.8$ & 0.14 & $3 / 46$ & $0.20-0.30$ & 0.11 \\
\hline Molybdenum & $5 / 20$ & $0.34-1.4$ & 0.61 & $5 / 20$ & $0.49-1.8$ & 0.69 & $2 / 17$ & $22-58$ & 14 & $0 / 4$ & ND & ND \\
\hline Nickel & $20 / 20$ & $0.64-55$ & 6.8 & $20 / 20$ & $0.94-51$ & 8.5 & $4 / 65$ & $9.0-60$ & 11 & $23 / 50$ & $8.0-170$ & 26 \\
\hline Selenium & $3 / 20$ & $0.14-4.6$ & 1.7 & $3 / 20$ & $0.39-4.8$ & 1.7 & $12 / 60$ & $1.0-20$ & 2.1 & $1 / 46$ & 2.0 & 1.3 \\
\hline Silver & $0 / 20$ & ND & ND & $1 / 20$ & 2.9 & 0.62 & $1 / 65$ & 17 & 3.5 & $0 / 49$ & NI) & NI \\
\hline Thallium & $0 / 20$ & ND & ND & $0 / 20$ & ND & ND & $4 / 60$ & $1.1-6.0$ & 2.3 & $3 / 46$ & $2.0-9.0$ & 2.3 \\
\hline Uranium, Iotal & NS & NS & NS & $17 / 18$ & $0.091-6.3$ & 2.3 & $4 / 4$ & $3.0-5.1$ & 3.8 & $45 / 53$ & $0.75-49$ & 5.1 \\
\hline
\end{tabular}


TABLE 4.1 (Cont.)

\begin{tabular}{|c|c|c|c|c|c|c|c|c|c|c|c|c|}
\hline & \multicolumn{12}{|c|}{ Decp Unit } \\
\hline & \multicolumn{6}{|c|}{1995 Joint Sampling Data } & \multicolumn{6}{|c|}{ 1987-1994 Data } \\
\hline & & Filiered & & & Unfiltered & & & Filicred & & & Unfiltered & \\
\hline & $\begin{array}{l}\text { Detection } \\
\text { Frequency }\end{array}$ & Ringe & $\operatorname{Men}^{2}$ & $\begin{array}{l}\text { Detection } \\
\text { Frequency }\end{array}$ & Range & $\mathrm{Mean}^{2}$ & $\begin{array}{c}\text { Detection } \\
\text { Frequency }\end{array}$ & Range & $\operatorname{Mcan}^{2}$ & $\begin{array}{l}\text { Delection } \\
\text { Frequency }\end{array}$ & Rangc & Mcan" \\
\hline \multicolumn{13}{|c|}{ Radionuclides (pCi/L) } \\
\hline Uranium, total & NS & NS & NS & $12 / 14$ & $0.068-2.6$ & 0.79 & NS & NS & NS & NS & NS & NS \\
\hline \multicolumn{13}{|l|}{ Mctals $(\mu g / L)$} \\
\hline Aluminum & $7 / 14$ & $16-890$ & 85 & $13 / 14$ & $19-8,200$ & 1,100 & $14 / 47$ & $20-3,300$ & 160 & $38 / 47$ & $30-16,000$ & 3.000 \\
\hline Antimony ${ }^{\mathrm{h}}$ & NS & NS & NS & $3 / 14$ & $1.1-1.7$ & 0.71 & NS & NS & NS & $7 / 46$ & $2.7-6.6$ & 7.1 \\
\hline Arsenic & $6 / 14$ & $2.9-14$ & 4.1 & $9 / 14$ & $2.4-56$ & 12 & $20 / 46$ & $1.0-12$ & 3.5 & $26 / 46$ & $0.60-230$ & 16 \\
\hline Barium & $14 / 14$ & $50-460$ & 190 & $14 / 14$ & $60-450$ & 200 & $41 / 47$ & $23-470$ & 180 & $41 / 47$ & $38-480$ & 220 \\
\hline Cadmium & $0 / 14$ & ND & ND & $1 / 14$ & 1.6 & 0.58 & $6 / 46$ & $0.3-2.0$ & 1.1 & $26 / 47$ & $0.20-8.7$ & 1.4 \\
\hline Chromium & $8 / 14$ & $1.0-4.9$ & 1.5 & $10 / 14$ & $1.2-5.9$ & 2.4 & $5 / 47$ & $2.0-18$ & 4.1 & $9 / 46$ & $3.0-40$ & 5.1 \\
\hline Copper & $4 / 14$ & $2.3-7.3$ & 1.9 & $11 / 14$ & $2.0-33$ & 8.8 & $9 / 46$ & $1.0-18$ & 4.1 & $28 / 46$ & $2.0-50$ & 12 \\
\hline Iron & $11 / 14$ & $34-6,300$ & 1800 & $14 / 14$ & $34-18,000$ & 5,900 & $25 / 47$ & $15-8,900$ & 1,200 & $46 / 47$ & $130-51,000$ & 7,200 \\
\hline Lead & $1 / 14$ & 1.9 & 0.6 & $8 / 14$ & $1.5-180$ & 22 & $9 / 46$ & $1.1-19$ & 2.5 & $27 / 46$ & $2.0-270$ & 18 \\
\hline Lithium & $11 / 14$ & $1.0-20$ & 6.2 & $13 / 14$ & $1.1-20$ & 6.8 & NS & NS & NS & NS & NS & NS \\
\hline Manganese & $13 / 14$ & $1.4-880$ & 210 & $14 / 14$ & $6.1-880$ & 270 & $41 / 47$ & $4.1-870$ & 220 & $44 / 47$ & $6.2-1,800$ & 380 \\
\hline Mercury & $0 / 14$ & ND & ND & $0 / 14$ & ND & ND & $1 / 47$ & 5.5 & 0.20 & $3 / 46$ & $0.20-7.7$ & 0.26 \\
\hline Molybdenum & $7 / 14$ & $1.1-7.2$ & 2.3 & $7 / 14$ & $1.3-7.6$ & 2.3 & NS & NS & NS & NS & NS & NS \\
\hline Nickel & $12 / 14$ & $1.1-5.1$ & 2.5 & $12 / 14$ & $1.6-1.3$ & 4.9 & $5 / 46$ & $10-37$ & 8.8 & $11 / 46$ & $8.0-1.30$ & 15 \\
\hline Sclenium & $0 / 14$ & ND & ND & $0 / 14$ & ND & ND & $4 / 46$ & $0.8-2.0$ & 1.1 & $2 / 46$ & $1.0-1.4$ & 1.1 \\
\hline Silver & $0 / 14$ & ND & ND & $0 / 14$ & ND & ND & $2 / 46$ & $2.0-2.0$ & 2.9 & $0 / 46$ & ND & ND \\
\hline Thallium & $0 / 14$ & ND & ND & $0 / 14$ & ND & ND & $1 / 46$ & 2.0 & 2.4 & $3 / 46$ & $1.2-2.0$ & 1.7 \\
\hline Uranium, sotal & NS & NS & NS & $12 / 14$ & $0.10-3.9$ & 1.2 & NS & NS & NS & NS & NS & NS \\
\hline
\end{tabular}

2 The mean concentrations were calculated by substituting half the detection limit for values reported as nondetects.

h Filtered antimony data for the ordnance works area and joint data were excluded from data summaries because of possible contamination from field filters.

c NS = not sampled.

d $\mathrm{ND}=$ not detected. 
TABLE 4.2 Summary of 1995 Joint Sampling Data and Data Collected from 1987-1994: Anions and Nitroaromatic Compounds

\begin{tabular}{|c|c|c|c|c|c|c|c|c|c|c|c|c|}
\hline & \multicolumn{6}{|c|}{ Weathered Unit } & \multicolumn{6}{|c|}{ Unweathered Unit } \\
\hline & \multicolumn{3}{|c|}{1995 Joint Sampling Data } & \multicolumn{3}{|c|}{ 1987-1994 Data } & \multicolumn{3}{|c|}{1995 Joint Sampling Data } & \multicolumn{3}{|c|}{ 1987-1994 Data } \\
\hline & $\begin{array}{c}\text { Detection } \\
\text { Frequency }\end{array}$ & Range & $\operatorname{Mean}^{2}$ & $\begin{array}{l}\text { Detection } \\
\text { Frequency }\end{array}$ & Range & $\operatorname{Mean}^{2}$ & $\begin{array}{l}\text { Detection } \\
\text { Frequency }\end{array}$ & Range & $M \operatorname{can}^{2}$ & $\begin{array}{l}\text { Detection } \\
\text { Frequency }\end{array}$ & Range & $\operatorname{Mean}^{2}$ \\
\hline \multicolumn{13}{|l|}{ Anions $(\mathrm{mg} / \mathrm{L})$} \\
\hline Chloride & $79 / 85$ & $0.81-49$ & 7.6 & $896 / 927$ & $0.4-1.700$ & 18 & $26 / 30$ & $1-12$ & 2.3 & $328 / 346$ & $0.49-29$ & 2.6 \\
\hline Fluoride & $65 / 86$ & $0.055-0.34$ & 0.15 & $326 / 559$ & $0.050-54$ & 0.58 & $29 / 30$ & $0.066-0.99$ & 0.23 & $121 / 208$ & $0.050-2.1$ & 0.28 \\
\hline Nitrate & $136 / 162$ & $0.040-900$ & 41 & $790 / 863$ & $0.020-310,000$ & 620 & $18 / 59$ & $0.0050-370$ & 25 & $144 / 307$ & $0.020-1.200$ & 21 \\
\hline Nitrite-N & NS & NS & NS & $33 / 255$ & $0.010-97^{\circ}$ & 1.5 & NS & NS & NS & NS & NS & NS \\
\hline Sulfate & $80 / 90$ & $1.9-1,100$ & 65 & $1037 / 1073$ & $0.70-1,800$ & 78 & $32 / 32$ & $5.3-1.30$ & 28 & $387 / 398$ & $0.80-9,100$ & 53 \\
\hline \multicolumn{13}{|l|}{ Nitroaromatics ( $\mu \mathrm{g} / \mathrm{L}$ ) } \\
\hline 1,3,5-TNB & $57 / 165$ & $0.035-39$ & 1.7 & $450 / 1232$ & $0.016-89$ & 2.8 & $6 / 59$ & $0.044-0.14$ & 0.021 & $31 / 426$ & $0.020-17$ & 0.38 \\
\hline 1,3-DNB & $3 / 168$ & $0.17-0.86$ & 0.052 & $69 / 1232$ & $0.047-35$ & 0.3 & $2 / 59$ & $0.12-0.14$ & 0.048 & $2 / 426$ & $0.40-1.1$ & 0.35 \\
\hline $2,4,6 \cdot \mathrm{TNT}$ & $29 / 167$ & $0.028-29$ & 0.49 & $241 / 1230$ & $0.016-65$ & 0.85 & $0 / 60$ & $N D^{h}$ & ND & $3 / 426$ & $1.5-7.8$ & 0.37 \\
\hline 2,4-DNT & $78 / 167$ & $0.020-8.8$ & 0.25 & $399 / 1226$ & $0.014-940$ & 2.5 & $8 / 57$ & $0.036-0.13$ & 0.023 & $13 / 425$ & $0.022-0.59$ & 0.3 .3 \\
\hline 2,6-DNT & $80 / 162$ & $0.0071-15$ & 0.73 & $498 / 1222$ & $0.0052-950$ & 3.8 & $10 / 60$ & $0.021-0.45$ & 0.028 & $17 / 426$ & $0.012-2.9$ & 0.36 \\
\hline 2-Amino-4,6-DNT & $74 / 158$ & $0.016-16$ & 0.99 & $111 / 329$ & $0.025-24$ & 1.6 & $9 / 58$ & $0.031-0.77$ & 0.046 & $0 / 129$ & ND & ND \\
\hline 4-Amino-2,6-DNT & $80 / 158$ & $0.020-22$ & 1.5 & $131 / 329$ & $0.056-71$ & 3.0 & $10 / 58$ & $0.017-1.8$ & 0.099 & $4 / 129$ & $0.30-0.56$ & 0.15 \\
\hline 2-Nitrotoluene & $30 / 161$ & $0.083-100$ & 1.3 & $15 / 371$ & $0.30-900$ & 3.0 & $3 / 58$ & $0.054-0.3$ & 0.028 & $0 / 147$ & ND & ND \\
\hline 3-Nitrotoluene & $14 / 166$ & $0.032-7.7$ & 0.13 & $18 / 388$ & $0.08-480$ & 3.5 & $1 / 59$ & 0.041 & 0.016 & $0 / 152$ & ND & ND \\
\hline 4-Nitrotoluene & $8 / 166$ & $0.15-30$ & 0.27 & $29 / 388$ & $0.13-2,600$ & 7.9 & $0 / 60$ & ND & ND & $1 / 152$ & 1.1 & 0.14 \\
\hline Nitrobenzene & $4 / 168$ & $0.042-0.062$ & 0.021 & $78 / 1231$ & $0.017-22$ & 0.3 & $0 / 60$ & ND & ND & $8 / 425$ & $0.030-6.0$ & 0.39 \\
\hline \multicolumn{13}{|c|}{ Volatile Organic Compounds $(\mu g / L)^{c}$} \\
\hline Trichioroethylene & - & - & - & $29 / 8.3$ & $1.0-9.000$ & 270 & - & - & - & $2 / 17^{4}$ & $48-60$ & 6.7 \\
\hline 1,2-Dichloroethene & - & - & - & $17 / 83$ & $1.0-39$ & 3.2 & - & - & - & $1 / 16^{\prime \prime}$ & 0.97 & 0.065 \\
\hline
\end{tabular}


TABLE 4.2 (Cont.)

\begin{tabular}{|c|c|c|c|c|c|c|c|c|c|c|c|c|}
\hline & \multicolumn{6}{|c|}{ Overburden Unit } & \multicolumn{6}{|c|}{ Decp Unit } \\
\hline & \multicolumn{3}{|c|}{1995 Joint Sampling Data } & \multicolumn{3}{|c|}{ 1987-1994 Data } & \multicolumn{3}{|c|}{1995 Joint Sampling Data } & \multicolumn{3}{|c|}{ 1987-1994 Data } \\
\hline & $\begin{array}{c}\text { Detection } \\
\text { Frequency }\end{array}$ & Range & $\operatorname{Mean}^{2}$ & $\begin{array}{c}\text { Decection } \\
\text { Frequency }\end{array}$ & Range & Mean $^{2}$ & $\begin{array}{l}\text { Detection } \\
\text { Frequency }\end{array}$ & Range & Mean $^{2}$ & $\begin{array}{c}\text { Detection } \\
\text { Frequency }\end{array}$ & Range & $\operatorname{Mean}^{\mathrm{a}}$ \\
\hline \multicolumn{13}{|l|}{ Anions $(\mathrm{mg} / \mathrm{L})$} \\
\hline Chloride & $8 / 10$ & $1.1-17$ & 4.2 & $83 / 86$ & $0.5-43$ & 6.8 & $7 \pi$ & $1.8-9.1$ & 3.6 & $44 / 46$ & $0.50-1.3$ & 3.2 \\
\hline Fluoride & $8 / 10$ & $0.090-0.26$ & 0.14 & $50 / 67$ & $0.12-1.7$ & 0.39 & $7 \pi$ & $0.090-1.5$ & 0.66 & $42 / 45$ & $0.12-13$ & 0.94 \\
\hline Nitralc & $19 / 20$ & $0.18-56$ & 5.4 & $52 / 52$ & $0.38-2,200$ & 250 & $4 / 14$ & $0.12-0.33$ & 0.099 & $1 / 1$ & 1.2 & 1.2 \\
\hline Nitrite-N & NS & NS & NS & $3 / 16$ & $0.010-0.12$ & 0.047 & NS & NS & NS & NS & NS & NS \\
\hline Sulfate & $10 / 10$ & $14-360$ & 64 & $88 / 94$ & $1.2-920$ & 130 & $7 n$ & $8.4-100$ & 32 & $41 / 46$ & $3.2-100$ & 29 \\
\hline \multicolumn{13}{|l|}{ Nitronromatics $(\mu g / L)$} \\
\hline 1,3,5-TNB & $11 / 20$ & $0.038-14$ & 2.4 & $64 / 147$ & $0.036-29$ & 3.3 & $0 / 14$ & ND & ND & $2 / 97$ & $0.9-\mathrm{I} .6$ & 0.16 \\
\hline 1,3-DNB & $2 / 20$ & $0.32-0.40$ & 0.077 & $10 / 147$ & $0.25-2.2$ & 0.21 & $0 / 14$ & ND & ND & $1 / 97$ & 0.35 & 0.14 \\
\hline $2,4,6-\mathrm{TNT}$ & $13 / 20$ & $0.035-30$ & 4.3 & $70 / 147$ & $0.082-57$ & 5.3 & $0 / 14$ & ND & ND & $3 / 97$ & $0.46-6.8$ & 0.22 \\
\hline 2,4-DNT & $10 / 20$ & $0.059-20$ & 1.9 & $54 / 147$ & $0.033-84$ & 3.2 & $0 / 14$ & ND & ND & $1 / 97$ & 0.35 & 0.14 \\
\hline 2,6-DNT & $16 / 20$ & $0.018-4.9$ & 1.3 & $63 / 146$ & $0.03-1,200$ & 17 & $0 / 14$ & ND & ND & i/97 & 0.36 & 0.14 \\
\hline 2-Amino-4,6-DNT & $16 / 20$ & $0.04-35$ & 4.3 & $31 / 80$ & $0.40-44$ & 4.8 & $0 / 14$ & ND & ND & $0 / 81$ & ND & ND \\
\hline 4-Amino-2,6-DNT & $16 / 20$ & $0.18-26$ & 3.8 & $36 / 80$ & $0.30-53$ & 5.0 & $0 / 14$ & ND & ND & $1 / 81$ & 0.42 & 0.15 \\
\hline 2-Nitrotoluene & $7 / 17$ & $0.13-0.65$ & 0.13 & $2 / 92$ & $0.30-0.76$ & 0.16 & $0 / 14$ & ND & ND & $0 / 94$ & ND & ND \\
\hline 3-Nitrotoluene & $5 / 19$ & $0.032-0.1 .3$ & 0.029 & $6 / 96$ & $0.05-1.7$ & 0.18 & $0 / 14$ & ND & ND & $3 / 97$ & $0.060-0.63$ & 0.15 \\
\hline 4-Nitrotoluene & $5 / 20$ & $0.063-0.22$ & 0.041 & $5 / 96$ & $0.30-1.4$ & 0.17 & $0 / 14$ & ND & ND & $1 / 97$ & 1.2 & 0.15 \\
\hline Nitrobenzene & $0 / 20$ & ND & $\mathrm{ND}$ & $17 / 148$ & $0.40-31$ & 1.2 & $0 / 14$ & ND & ND & $0 / 97$ & NIS & ND \\
\hline \multicolumn{13}{|c|}{ Volatilc Organic Compounds $(\mu \mathrm{g} / \mathrm{L})^{c}$} \\
\hline Trichloroethylene & - & - & - & 1/9 & 1.0 & 0.11 & - & - & - & - & - & - \\
\hline 1,2-dichloroethene & - & - & - & $3 / 9$ & $1.0-5.0$ & 1.0 & - & - & - & - & - & - \\
\hline
\end{tabular}

2 The mean concentrations for anions were calculated by substituting half the detection limit for values reported as nondelects. For nitroaromatics, concentrations were calculated by substituting a zero for nundetects. No mean concentrations were calculated for nitroaromatics, which had a $0 \%$ detection frequency.

h $\mathrm{ND}=$ not detected.

c Data for volatile organic compounds collected from 1996-1997.

d Detections reported for only one were (MW-3024); this well was retrofit at the of 1996; there were no detcetions in the retrofitted well.

c Suspected outlier values for nitrite were reported for two wells: $97 \mathrm{mg} / \mathrm{L}$ for $\mathrm{MW}-2003$ and $61 \mathrm{mg} / \mathrm{L}$ for $\mathrm{MW}-3009$. The next highest level of nitrite reported was $1.4 \mathrm{mg} / \mathrm{L}$. 
and the joint sampling were excluded from evaluation for this RI because of potential contamination from filters.

The results of the joint data are generally consistent with the data collected prior to 1995 . For most of the constituents, the range and means for the joint data are lower. This observation is most pronounced for nitrates and uranium detected in the weathered unit. Some of this variability can be attributed to suspected outliers in the pre-1990 data: More recent data are believed to be representative of current conditions in the groundwater system. Overall, the highest contaminant concentrations for nitroaromatic compounds, anions, and some metals (such as uranium) are found in the shallow portions of the aquifer (weathered unit and overburden).

Recent (1996 and 1997) sampling of monitoring wells and springs at the chemical plant area and vicinity was conducted as part of a VOC monitoring program. Results indicated the presence of trichloroethylene (TCE) and 1,2-dichloroethene (1,2-DCE) in a few wells located near the raffinate pits. Results also indicated the presence of very low levels of toluene. Estimated values were reported for nine wells, with concentrations ranging from $0.33-2.0 \mu \mathrm{g} / \mathrm{L}$. This finding is consistent with earlier data collected for toluene when wells were first installed; toluene was detected in five wells at levels ranging from 1.0 to $2.3 \mu \mathrm{g} / \mathrm{L}$. Soil characterization activities done in support of the RI for the chemical plant area resulted in a few (i.e., 9 out of 252) low-level detections of toluene in soils adjacent to the process buildings. Levels ranged from 11 to $160 \mathrm{ppb}$. These low concentrations in soil are attributed to decontamination activities that involved use of toluene to decontaminate sampling equipment. No other VOCs were detected in groundwater or springs.

Section 4.1.2 discusses the nature and extent of contamination in groundwater. For the naturally occurring constituents (metals and anions), a background comparison was conducted to determine the list of contaminants that are present at levels above background. The discussion on the nature and extent of contamination of naturally occurring constituents focuses on the list of COPC identified by the background comparison presented in Section 4.1.1.

\subsubsection{Background Comparison for Naturally Occurring Constituents}

A background comparison was performed for all naturally occurring constituents to determine whether site concentrations of potential contaminants differ from naturally occurring background concentrations. As discussed in Chapter 2, five wells were identified as representative of background groundwater quality: MWS-23 and MWS-111 for the weathered Burlington-Keokuk Limestone; MWS-105, MWS-108, and MWS-109 for the unweathered Burlington-Keokuk. It was not possible to identify background wells representative of the overburden and deeper formations. Therefore, contaminant concentrations in the overburden unit were compared with the statistically derived background for the weathered unit, while contaminant concentrations in the deeper formations were compared with the statistically derived background levels for the unweathered unit. 
Since most of the stratigraphically deeper formations are predominantly limestone and all the wells are relatively shallow, it was expected that the groundwater quality of individual formations would be similar. A summary of the statistically derived background groundwater concentrations for potential contaminants is presented in Table 4.3. Because uranium, lithium, and molybdenum are not associated with materials that were processed at the ordnance works, these parameters were not included in the DA monitoring program.

For background comparison, data for the chemical plant area and the ordnance works area were combined within each hydrostratigraphic unit and compared to the appropriate background data set. A 95\% upper confidence limit of the arithmetic average (UCL) was calculated for each parameter in the background and site groundwater data sets, and these UCL values were then compared with one another. The results of this comparison are presented in Table 4.4 and discussed below. Table 4.4 also provides available regulatory limits for groundwater quality (maximum contaminant levels [MCLs] and secondary maximum contaminant levels [SMCLs]) for use as points of reference in the discussion.

The UCLs for many of the metals and anions detected in the unweathered BurlingtonKeokuk and deep formations exceeded the statistically derived background levels for the unweathered unit (Table 4.4), although many of these exceedances were less than a factor of 2. Metals present in the unweathered unit with UCL concentrations at or below background levels were antimony, arsenic, cadmium, silver, and thallium; fluoride was the only anion present below background levels. In the deep unit, antimony, cadmium, selenium, and silver exhibited UCL concentrations at or below background levels.

Within the weathered hydrostratigraphic unit, only lithium, molybdenum, uranium, chloride, nitrate, and sulfate had UCL concentrations that exceeded statistically derived background levels by more than a factor of about 2 (Table 4.4). Among these contaminants and for which MCL or SMCL values are available, only the nitrate UCL concentration exceeded an MCL or SMCL value. Among the metals and anions in the overburden unit, only molybdenum, uranium, chloride, nitrate, and sulfate exhibited UCL concentrations that exceeded the background levels by more than a factor of about 2 (Table 4.4). Among these contaminants and for which MCL or SMCL values are available, only nitrate exceeded an MCL or SMCL concentration.

Within the unweathered unit, UCL concentrations exceeding the statistically derived background levels by more than a factor of about 2 were calculated for aluminum, chromium, iron, lead, lithium, molybdenum, uranium, nitrate, and sulfate (Table 4.4). Among these, only the aluminum, iron, and nitrate UCL concentrations exceeded available MCL or SMCL levels. Within the deep hydrostratigraphic unit, aluminum, arsenic, iron, lead, manganese, molybdenum, chloride, fluoride, and nitrate exhibited UCL concentrations that exceeded background levels by more than a factor of about 2 (Table 4.4). The UCL values for aluminum, iron, lead, and manganese exceeded MCL or SMCL levels. 
TABLE 4.3 Background Groundwater Concentrations of Potential Contaminants

\begin{tabular}{|c|c|c|c|c|c|c|c|c|c|c|}
\hline & \multicolumn{5}{|c|}{ Weathered Unit } & \multicolumn{5}{|c|}{ Unweathered Unit } \\
\hline & $\begin{array}{l}\text { Delection } \\
\text { Frequency }\end{array}$ & Range & Mean $^{\mathrm{a}}$ & $\begin{array}{c}\text { Standard } \\
\text { Deviation }\end{array}$ & $\begin{array}{c}95 \% \\
\text { UCL }^{\mathrm{a}}\end{array}$ & $\begin{array}{l}\text { Detcction } \\
\text { Frequency }\end{array}$ & Range & $\operatorname{Mcan}^{\mathrm{a}}$ & $\begin{array}{l}\text { Standard } \\
\text { Deviation }\end{array}$ & $\begin{array}{l}95 \% \\
\mathrm{UCL}^{\mathrm{a}}\end{array}$ \\
\hline \multicolumn{11}{|c|}{ Radionuclides (pCi/L) } \\
\hline Uranium, total & $4 / 4$ & $0.41-0.94$ & 0.64 & 0.25 & 0.93 & $4 / 6$ & $0.28-0.56$ & 0.34 & 0.18 & 0.48 \\
\hline \multicolumn{11}{|l|}{ Metals $(\mu \mathrm{g} / \mathrm{L})$} \\
\hline Aluminum & $20 / 34$ & $45-16,000$ & 2,000 & 3,900 & 3,100 & $29 / 54$ & $16-2,600$ & 220 & 490 & 330 \\
\hline Antimony & $7 / 34$ & $1.1-6.3$ & 5.1 & 9.4 & 6.3 & $10 / 54$ & $1-20$ & 5.3 & 9.3 & 7.5 \\
\hline Arsenic & $7 / 34$ & $0.9-13$ & 2.5 & 2.9 & 3.4 & $14 / 54$ & $0.6-9.7$ & 2.0 & 1.9 & 2.5 \\
\hline Barium & $32 / 34$ & $89-490$ & 270 & 140 & 310 & $48 / 54$ & $81-310$ & 130 & 32 & 140 \\
\hline Cadmium & $8 / 34$ & $0.20-0.70$ & 0.67 & 0.73 & 0.70 & $8 / 54$ & $0.28-1.8$ & 0.96 & 1.4 & 1.3 \\
\hline Chromium & $10 / 34$ & $1.6-22$ & 4.8 & 5.1 & 6.2 & $12 / 54$ & $1.0-3.1$ & 2.9 & 2.8 & 3.1 \\
\hline Copper & $17 / 34$ & $1.0-58$ & 10 & 14 & 14 & $17 / 54$ & $1.0-62$ & 4.5 & 8.8 & 6.5 \\
\hline Iron & $26 / 34$ & $10-21,000$ & 3,000 & 5,200 & 4,500 & $39 / 53$ & $22-3,000$ & 250 & 480 & 360 \\
\hline Lead & $19 / 34$ & $0.70-15$ & 4.1 & 4.1 & 5.2 & $10 / 54$ & $1.1-16$ & 2.4 & 3.4 & 3.2 \\
\hline Lithium & $5 / 8$ & $2.0-11$ & 3.9 & 4.1 & 6.6 & $12 / 12$ & $3.3-4.7$ & 3.9 & 0.48 & 4.1 \\
\hline Manganese & $24 / 33$ & $3.9-900$ & 200 & 280 & 290 & $53 / 54$ & $1.7-290$ & 78 & 73 & 95 \\
\hline Mercury & $2 / 34$ & $0.1-2.0$ & 0.15 & 0.33 & 0.25 & $3 / 54$ & $0.10-0.50$ & 0.098 & 0.059 & 0.11 \\
\hline Molybdenum & $0 / 8$ & - & 0.5 & 0 & 0.50 & $4 / 12$ & $1.3-2.4$ & 0.91 & 0.66 & 1.3 \\
\hline Nickel & $17 / 34$ & $1.8-920$ & 39 & 160 & 84 & $15 / 54$ & $1.3-20$ & 6.6 & 5.7 & 7.9 \\
\hline Selenium & $2 / 34$ & $1.0-1.1$ & 1.2 & 0.98 & 1.1 & $4 / 54$ & $1.0-2.0$ & 1.3 & 1 & 1.5 \\
\hline Silver & $0 / 34$ & - & 2.3 & 1.8 & 2.9 & $1 / 54$ & 3.0 & 2.4 & 1.7 & 2.7 \\
\hline Thalliuin & $0 / 34$ & - & 1.3 & 1.5 & 1.8 & $3 / 54$ & $3.0-7.0$ & 1.5 & 1.6 & 1.9 \\
\hline Uranium, total & $4 / 4$ & $0.61-1.4$ & 0.95 & 0.38 & 1.4 & $4 / 6$ & $0.41-0.83$ & 0.5 & 0.26 & 0.72 \\
\hline \multicolumn{11}{|l|}{ Anions (mg/L) } \\
\hline Chloride & $12 / 15$ & $0.98-3.0$ & 1.2 & 0.72 & 1.6 & $22 / 24$ & $0.4-2.6$ & 1.1 & 0.62 & 1.4 \\
\hline Fluoride & $10 / 15$ & $0.15-1.1$ & 0.31 & 0.28 & 0.44 & $21 / 24$ & $0.19-0.84$ & 0.4 & 0.21 & 0.48 \\
\hline Nitrate & $3 / 4$ & $0.20-0.25$ & 0.19 & 0.093 & 0.25 & $0 / 6$ & - & 0.050 & 0 & 0.050 \\
\hline Sulfatc & $10 / 15$ & $0.42-22$ & 8.5 & 7.7 & 12 & $24 / 24$ & $9.5-61$ & 22 & 11 & 26 \\
\hline
\end{tabular}

a The mean concentration and $95 \%$ UCL values were calculated by using half the sample detection limits for values reported as nondetect. For contaminants where the UCL is greater than the maximum reported concentration, the maximum was reported as the UCL. 
TABLE 4.4 Comparison of Site Data with Statistically Derived Background Concentrations of Naturally Occurring Contaminants ${ }^{\mathrm{a}}$

\begin{tabular}{|c|c|c|c|c|c|c|c|}
\hline & $\begin{array}{l}\text { Weathered } \\
\text { Background } \\
\text { UCL }\end{array}$ & $\begin{array}{l}\text { Weathered } \\
\text { Site } \\
\text { UCL }\end{array}$ & $\begin{array}{l}\text { Overburden } \\
\text { Site } \\
\text { UCL }\end{array}$ & $\begin{array}{l}\text { Unweathered } \\
\text { Background } \\
\text { UCL }\end{array}$ & $\begin{array}{c}\text { Unweathered } \\
\text { Site } \\
\text { UCL }\end{array}$ & $\begin{array}{l}\text { Deep } \\
\text { Site } \\
\text { UCL }\end{array}$ & $\mathrm{MCL}$ \\
\hline \multicolumn{8}{|c|}{ Radionuclides (pCi/L) } \\
\hline Uranium, total & 0.93 & 6.5 & 3.7 & 0.48 & 2.5 & 1.2 & 14 \\
\hline \multicolumn{8}{|l|}{ Metals $(\mu \mathrm{g} / \mathrm{L})$} \\
\hline Aluminum & 3,100 & 870 & 3,100 & 330 & 1,500 & 1,800 & $50-200^{b}$ \\
\hline Antimony & 6.3 & 5.1 & 10 & 7.5 & 6.2 & 6.6 & 6 \\
\hline Arsenic & 3.4 & 2.1 & 2.8 & 2.5 & 2.4 & 13 & 50 \\
\hline Barium & 310 & 210 & 170 & 140 & 280 & 220 & 2,000 \\
\hline Cadmium & 0.70 & 1.3 & 1.5 & 1.3 & 1.3 & 1.3 & 5 \\
\hline Chromium & 6.2 & 6.8 & 9.7 & 3.1 & 8.8 & 4.7 & 100 \\
\hline Copper & 14 & 6.9 & 9.9 & 6.5 & 7.2 & 9.0 & $1,000^{b}$ \\
\hline Iron & 4,500 & 1,200 & 5,800 & 360 & 1,700 & 5,100 & $300^{b}$ \\
\hline Lead & 5.2 & 3.8 & 7.3 & 3.2 & 8.3 & 16 & $15^{\mathrm{c}}$ \\
\hline Lithium & 6.6 & 100 & 14 & 4.1 & 31 & 8.3 & _- \\
\hline Manganese & 290 & 65 & 230 & 95 & 140 & 340 & $50^{b}$ \\
\hline Mercury & 0.25 & 0.29 & 0.14 & 0.11 & 0.15 & 0.33 & 2 \\
\hline Molybdenum & 0.50 & 14 & 6.8 & 1.3 & 22 & 3.2 & - \\
\hline Nickel & 84 & 17 & 18 & 7.9 & 15 & 12 & 100 \\
\hline Selenium & 1.1 & 2.8 & 2.0 & 1.5 & 2.1 & 1.3 & 50 \\
\hline Silver & 2.9 & 5.3 & 3.0 & 2.7 & 2.7 & 2.0 & $100^{\mathrm{b}}$ \\
\hline Thallium & 1.8 & 1.8 & 2.0 & 1.9 & 1.6 & 2.0 & $2^{b}$ \\
\hline Uranium, total & 1.4 & 9.7 & 5.5 & 0.72 & 3.7 & 1.7 & $20^{d}$ \\
\hline \multicolumn{8}{|l|}{ Anions (mg/L) } \\
\hline Chloride & 1.6 & 21 & 7.6 & 1.4 & 2.8 & 3.8 & $250^{b}$ \\
\hline Fluoride & 0.44 & 0.67 & 0.42 & 0.48 & 0.30 & 1.3 & 2 \\
\hline Nitrate & 0.25 & 1,000 & 270 & 0.050 & 34 & 0.31 & 10 \\
\hline Sulfate & 12 & 84 & 160 & 26 & 85 & 37 & $250^{\mathrm{b}}$ \\
\hline
\end{tabular}

a Background comparisons performed by comparing the UCL for the weathered background wells with the UCL for the weathered and overburden site wells, and the UCL for the unweathered background wells with the UCL for the unweathered and deeper unit site wells.

b $\mathrm{SMCL}$

c Action level.

d The proposed MCL for uranium is $20 \mu \mathrm{g} /$, which corresponds to $14 \mathrm{pCi} / \mathrm{L}$ on the basis of the ratio of uranium isotopes in site soil. 
Although statistically derived background concentrations were exceeded for a number of contaminants, most exceedances were within a factor of about 2 or less and the differences were generally less than $5 \mu \mathrm{g} / \mathrm{L}$ in magnitude. Within the weathered unit, contaminants for which the UCL exceeded the weathered background UCL by a factor of 5 or more included lithium, molybdenum, uranium, chloride, nitrate, and sulfate. Within the overburden unit, only the UCL' values for molybdenum, chloride, nitrate, and sulfate exceeded background levels by a factor of 5 or more. Within the deeper units, the background UCL levels were exceeded by a factor of 5 or more only by aluminum, iron, lithium, molybdenum, uranium, and nitrate in the unweathered unit, and by aluminum, arsenic, iron, lead, and nitrate in the deep unit. Contaminants for which the UCL exceeded the appropriate background UCL by a factor of 10 or more included lithium, molybdenum, chloride, and nitrate in the weathered unit; molybdenum, nitrate, and sulfate in the overburden unit; molybdenum and nitrate in the unweathered unit; and iron in the deep unit.

The comparison of background and site groundwater data indicates that most of the COPC in groundwater are present at concentrations that differ little from background levels. In contrast, only a few of the COPC are present at levels moderately or greatly exceeding background levels. Contaminants indicated to moderately exceed background (UCL exceeds background UCL by a factor of 5 to 10) include aluminum, arsenic, lead, and uranium, while contaminants greatly exceeding background (exceeding the background UCL by a factor of 10 or more) include iron, lithium, molybdenum, chloride, nitrate, and sulfate.

None of the UCL values for these COPC exceeded the background UCL levels by the same magnitude among all the stratigraphic units, and no apparent regular trend exists for contaminant concentrations among the stratigraphic units. For example, the UCL value for iron is about equal to background for the overburden unit, below the background UCL level in the weathered unit, about 5 times greater for the unweathered unit, and about 14 times greater for the deep unit. For arsenic, the UCL values were below the background UCL value for the weathered, overburden, and unweathered units, but about 5 times above background for the deep unit. In contrast to these contaminants, the UCL value for nitrate differed the most from background in the weathered unit and the least in the deep unit.

Two additional statistical evaluations (the Gehan rank-sum test and the Quantile test) were conducted on the site and background data sets in order to identify metals and anions that are present at the site at concentrations that differ significantly from background.

The Gehan (Wilcoxon) rank-sum test was used to compare the distribution of the site and background data sets. The null (default) hypothesis for this test is that the site data set distribution is equal to the background data set distribution. The alternative hypothesis is that the distributions differ. 
The Gehan test first ranks the data by concentration value, then uses this ranking to determine the probability of the site distributions exceeding the background distribution. The two data sets are combined and ordered from smallest to largest on the basis of concentration; the smallest observation gets rank 1; the second smallest, rank 2; and so on. The two data sets are then separated by origin (site or background), and a test statistic is calculated on the basis of the sum of the ranks associated with each data set. If the site sum is greater than the background sum, higher concentrations are present at the site than in the background.

The significance level and $p$-value determine how different the two sums are; the significance level is a value between 0 and 1 that is chosen before sampling for statistical testing begins; $p$-values originate from the statistical test using actual data. A $p$-value that is smaller than the significance level indicates that at the site, the sum is significantly greater than the background sum.

The Quantile test determines whether the tails of the data set distributions are different. As in the Gehan test, the two data sets are combined and ranked; however, they are not separated. Rather, the 80th percentile of the combined data set is determined, and the number of site and background values greater than this value are counted separately. The 80th percentile is the value that exceeds $80 \%$ of the data values. The $p$-value is a comparison of the counts; if the number of the site values sufficiently exceeds the number of background concentrations, the $p$-values will be less than the significance level, and it can be concluded that the concentration at the site significantly exceeds the background concentration.

The results of the Quantile and Gehan tests indicated that concentrations of barium, chloride, lead, lithium, and nickel differed significantly from background only in the unweathered and deep units at both the chemical plant area and the ordnance works area (Tables 4.5 and 4.6). In contrast, aluminum, arsenic, cadmium, copper, iron, manganese, and fluoride concentrations are significantly different from background levels only in the deep unit and only beneath the ordnance works area. Chromium concentrations differ significantly from background levels at both the chemical plant area and ordnance works area only in the weathered unit.

Within the weathered and overburden units, chloride, sulfate, molybdenum, and uranium concentrations differed significantly from background levels at both the chemical plant area and the ordnance works area; selenium concentrations differed from background levels only at the chemical plant area. Chloride and sulfate concentrations differed from background only at the chemical plant area. Chloride and sulfate concentrations in the unweathered unit beneath the ordnance works area did not significantly differ from background levels (Table 4.7). The Quantile test indicated that nitrate did not exceed background levels within any of the stratigraphic units beneath the chemical plant area and the ordnance works area. Nitrate concentrations were indicated by the Gehan test to significantly exceed background at the chemical plant area and the ordnance works area in all stratigraphic units except the unweathered unit beneath the ordnance works area. 
TABLE 4.5 Quantile Test Results by Stratigraphic Unit (Overburden, Weathered, Unweathered, and Deep) of Metals Concentrations in Groundwater at the Chemical Plant Area (Chemical) and the Ordnance Works Area (Army) ${ }^{a}$

Quantile Test

\begin{tabular}{|l|c|c|c|c|c|c|c|c|c|}
\hline Well & Al & Sb & As & Ba & Cd & Cr & Cu & Fe & Pb \\
\hline C/W & 0.9982 & 0.4772 & NVT $^{\mathrm{b}}$ & 0.7255 & NVT & 0.3442 & 0.6733 & 1.00 & 0.8431 \\
\hline C/U & 0.9977 & 0.4559 & 0.9163 & $0.0^{c}$ & NVT & $0.0^{c}$ & 0.1846 & 0.9973 & $0.0175^{c}$ \\
\hline C/O & 0.9917 & NVT & NVT & 0.9823 & NVT & 0.4122 & 0.8393 & 0.9413 & 0.6390 \\
\hline A/W & 0.9992 & 0.2978 & 0.1574 & 1.00 & NVT & 0.9839 & 0.9773 & 0.9998 & 0.9992 \\
\hline A/U & 0.4659 & 0.3222 & 0.6114 & $0.0^{c}$ & NVT & $0.0490^{c}$ & 0.3183 & $0.0490^{c}$ & 0.3183 \\
\hline A/O & 0.9035 & NVT & 0.2690 & 1.00 & 0.4527 & 0.7988 & 0.9035 & 0.9865 & 0.9608 \\
\hline A/D & $0.0129^{c}$ & NVT & $0.0^{c}$ & $0.0^{c}$ & $0.0859^{c}$ & 0.1739 & $0.0030^{c}$ & 0.0 & $0.0001^{c}$ \\
\hline
\end{tabular}

\begin{tabular}{|c|c|c|c|c|c|c|c|c|c|}
\hline Well & $\mathbf{L i}$ & Mn & $\mathrm{Hg}$ & $\mathrm{Mb}$ & $\mathrm{Ni}$ & Se & Ag & $\mathrm{Tl}$ & $\mathbf{U}$ \\
\hline $\mathrm{C} / \mathrm{W}$ & 0.7599 & 1.00 & NVT & 0.2920 & 0.8720 & NVT & NVT & NVT & 0.4612 \\
\hline $\mathrm{C} / \mathrm{U}$ & $0.0665^{c}$ & 0.8496 & NVT & $0.0^{\mathrm{c}}$ & $0.0469^{c}$ & NVT & NVT & NVT & 0.2594 \\
\hline $\mathrm{C} / \mathrm{O}$ & 0.8238 & 0.9844 & NVT & 0.9767 & 0.9626 & $0.0002^{c}$ & NVT & NVT & 0.3999 \\
\hline $\mathrm{A} / \mathrm{W}$ & 0.8081 & 1.00 & NVT & $0.0002^{c}$ & 0.9916 & NVT & NVT & NVT & 0.4065 \\
\hline $\mathbf{A} / \mathbf{U}$ & $0.0545^{c}$ & 0.9100 & NVT & $0.0^{c}$ & $0.0490^{c}$ & NVT & NVT & NVT & 0.2361 \\
\hline $\mathrm{A} / \mathrm{O}$ & 0.8168 & 0.9865 & NVT & $0.0864^{c}$ & 0.9608 & NVT & NVT & NVT & 0.3756 \\
\hline $\mathbf{A} / \mathbf{D}$ & $0.0404^{c}$ & $0.0^{c}$ & NVT & $0.0^{c}$ & $0.0820^{c}$ & NVT & NVT & NVT & 0.2066 \\
\hline
\end{tabular}

a $\mathrm{C} / \mathrm{W}=$ chemical weathered $\mathrm{C} / \mathrm{U}=$ chemical/unweathered $\mathrm{C} / \mathrm{O}=$ chemical/overburden $; \mathrm{AW}=\mathrm{Army} /$ weathered; $\mathrm{A} / \mathrm{U}=$ Army/unweathered; $\mathrm{H} / \mathrm{O}=$ Army overburden; and $\mathrm{A} / \mathrm{D}=$ Army Deep.

b $\mathrm{NVT}=$ not a valid test; $80 \%$ of the combined data are below the detection limit.

c Significantly different from background. 
TABLE 4.6 Wilcoxon (Gehan) Rank-Sum Test Results by Stratigraphic Unit (Overburden, Weathered, Unweathered, and Deep) of Metals Concentrations in Groundwater at the Chemical Plant Area (Chemical) and the Ordnance Works Area (Army) ${ }^{\mathbf{a}}$

Wilcoxon (Gehan) Rank-Sum Test

\begin{tabular}{|l|c|c|c|c|c|c|c|c|c|}
\hline Well & Al & Sb & As & Ba & Cd & $\mathbf{C r}$ & $\mathbf{C u}$ & $\mathbf{F e}$ & Pb \\
\hline C/W & 0.9777 & 0.2908 & 0.9824 & 0.7255 & 0.4484 & 0.3130 & 0.6733 & 0.9999 & 0.9389 \\
\hline C/U & 0.9571 & 0.2777 & 0.7348 & 0.3044 & 0.3964 & $0.0002^{\mathrm{b}}$ & 0.2361 & 0.9987 & 0.1087 \\
\hline C/O & 0.8239 & 0.3686 & 0.5431 & 0.9195 & 0.4188 & 0.2825 & 0.5647 & 0.7923 & 0.5841 \\
\hline A/W & 0.9811 & 0.2849 & 0.3740 & 1.00 & 0.6053 & 0.6198 & 0.9491 & 0.9735 & 0.9892 \\
\hline A/U & 0.5243 & 0.3014 & 0.5223 & $0.0029^{\mathrm{b}}$ & 0.5748 & 0.2298 & 0.4207 & 0.8042 & 0.2607 \\
\hline A/O & 0.8465 & 0.7887 & 0.5198 & 1.00 & 0.5216 & 0.7837 & 0.9231 & 0.8364 & 0.9805 \\
\hline A/D & $0.0662^{\mathrm{b}}$ & 0.5252 & $0.0016^{\mathrm{b}}$ & $0.0002^{\mathrm{b}}$ & 0.2798 & 0.3862 & $0.0607^{\mathrm{b}}$ & $0.0^{\mathrm{b}}$ & $0.0167^{\mathrm{b}}$ \\
\hline
\end{tabular}

\begin{tabular}{|c|c|c|c|c|c|c|c|c|c|}
\hline Well & $\mathrm{Li}$ & $\mathrm{Mn}$ & $\mathrm{Hg}$ & $\mathrm{Mb}$ & $\mathrm{Ni}$ & $\mathrm{Se}$ & $\mathbf{A g}$ & $\mathbf{T I}$ & $\mathbf{U}$ \\
\hline $\mathrm{C} / \mathrm{W}$ & 0.2121 & 1.00 & 0.4191 & $0.0899^{\mathrm{b}}$ & 0.5396 & 0.3154 & 0.5262 & 0.5121 & $0.0190^{\mathrm{b}}$ \\
\hline C/U & $0.0447^{\mathrm{b}}$ & 0.9862 & 0.3227 & $0.0^{\mathrm{b}}$ & 0.1280 & $0.0408^{\mathrm{b}}$ & 0.4276 & 0.5521 & $0.0004^{\mathrm{b}}$ \\
\hline C/O & 0.1747 & 0.9808 & 0.2893 & 0.2509 & 0.6326 & $0.0119^{\mathrm{b}}$ & 0.3715 & 0.4056 & $0.0028^{\mathrm{b}}$ \\
\hline A/W & 0.2812 & 0.9986 & 0.3778 & $0.0^{\mathrm{b}}$ & 0.9136 & 0.2573 & 0.4756 & 0.3342 & $0.0925^{\mathrm{b}}$ \\
\hline A/U & 0.8081 & 0.9966 & 0.3662 & $0.0^{\mathrm{b}}$ & 0.1109 & 0.4239 & 0.7810 & 0.5969 & $0.0009^{\mathrm{b}}$ \\
\hline A/O & 0.4528 & 0.9882 & 0.6137 & $0.0113^{\mathrm{b}}$ & 0.9553 & 0.5734 & 0.5078 & 0.3390 & $0.0490^{\mathrm{b}}$ \\
\hline A/D & 0.1672 & $0.0023^{\mathrm{b}}$ & 0.5812 & $0.0^{\mathrm{b}}$ & 0.3209 & 0.6744 & 0.5505 & 0.6661 & 0.3550 \\
\hline
\end{tabular}

a $\mathrm{C} / \mathrm{W}=$ chemical weathered; $\mathrm{C} / \mathrm{U}=$ chemical/unweathered $\mathrm{C} / \mathrm{O}=$ chemical/overburden; $\mathrm{AW}=\mathrm{Army} /$ weathered; $\mathrm{A} / \mathrm{U}=\mathrm{Army} /$ unweathered; $\mathrm{H} / \mathrm{O}=$ Army overburden; and $\mathrm{A} / \mathrm{D}=$ Army Deep.

b Significantly different from background. 
TABLE 4.7 Statistical Evaluation by Stratigraphic Unit (Overburden, Weathered, Unweathered, and Deep) of Anion Concentrations in Groundwater at the Chemical Plant Area (Chemical) and the Ordnance Works Area (Army) ${ }^{\text {a }}$

Quantile Test

\begin{tabular}{|l|c|c|c|c|}
\hline \multicolumn{1}{|c|}{ Well } & $\mathrm{Cl}^{-}$ & $\mathrm{F}^{-}$ & $\mathrm{NO}_{3}^{-}$ & $\mathrm{SO}_{4}^{-}$ \\
\hline $\mathrm{C} / \mathrm{W}$ & $0.0341^{\mathrm{b}}$ & 0.6541 & 0.4098 & $0.0346^{\mathrm{b}}$ \\
\hline $\mathrm{C} / \mathrm{U}$ & $0.0040^{\mathrm{b}}$ & 1.00 & 0.2616 & $0.0287^{\mathrm{b}}$ \\
\hline $\mathrm{C} / \mathrm{O}$ & $0.0223^{\mathrm{b}}$ & 0.1317 & 0.3990 & $0.0210^{\mathrm{b}}$ \\
\hline $\mathrm{A} / \mathrm{W}$ & $0.0320^{\mathrm{b}}$ & 0.3948 & 0.4065 & $0.0325^{\mathrm{b}}$ \\
\hline $\mathrm{A} / \mathrm{U}$ & 0.4742 & 0.2548 & $\mathrm{NVT}$ & 0.9836 \\
\hline $\mathrm{A} / \mathrm{O}$ & $0.0216^{\mathrm{b}}$ & 0.3714 & 0.3756 & $0.0216^{\mathrm{b}}$ \\
\hline $\mathrm{A} / \mathrm{D}$ & $0.0016^{\mathrm{b}}$ & $0.0016^{\mathrm{b}}$ & 0.2066 & $0.0198^{\mathrm{b}}$ \\
\hline
\end{tabular}

Wilcoxon (Gehan) Rank-Sum Test

\begin{tabular}{|l|c|c|c|c|}
\hline \multicolumn{1}{|c|}{ Well } & $\mathrm{Cl}^{-}$ & $\mathbf{F}^{-}$ & $\mathrm{NO}_{3}^{-}$ & $\mathrm{SO}_{4}^{-}$ \\
\hline $\mathrm{C} / \mathrm{W}$ & $0.0^{\mathrm{b}}$ & 0.8854 & $0.0028^{\mathrm{b}}$ & $0.0^{\mathrm{b}}$ \\
\hline $\mathrm{C} / \mathrm{U}$ & $0.0^{\mathrm{b}}$ & 1.00 & $0.0237^{\mathrm{b}}$ & 0.2068 \\
\hline $\mathrm{C} / \mathrm{O}$ & $0.0^{\mathrm{b}}$ & 0.3959 & $0.0005^{\mathrm{b}}$ & $0.0^{\mathrm{a}}$ \\
\hline $\mathrm{A} / \mathrm{W}$ & $0.0012^{\mathrm{b}}$ & 0.4352 & $0.0729^{\mathrm{b}}$ & $0.0001^{\mathrm{b}}$ \\
\hline $\mathrm{A} / \mathrm{U}$ & 0.4096 & 0.8441 & 0.1335 & 0.9987 \\
\hline $\mathrm{A} / \mathrm{O}$ & $0.0006^{\mathrm{b}}$ & 0.3570 & $0.0148^{\mathrm{b}}$ & $0.0^{\mathrm{b}}$ \\
\hline $\mathrm{A} / \mathrm{D}$ & $0.0^{\mathrm{b}}$ & $0.0148^{\mathrm{b}}$ & $0.0979^{\mathrm{b}}$ & 0.3053 \\
\hline
\end{tabular}

a $\mathrm{C} / \mathrm{W}=$ chemical weathered $\mathrm{C} / \mathrm{U}=$ chemical/unweathered; $\mathrm{C} / \mathrm{O}=$ chemical overburden; $\mathrm{AW}=$ Army/weathered; $\mathrm{A} / \mathrm{U}=$ Army/unweathered;

$\mathrm{H} / \mathrm{O}=$ Army overburden; and $\mathrm{A} / \mathrm{D}=$ Army Deep; $\mathrm{NVT}=$ not a valid test.

b Significantly different from background. 
The results of the comparisons using UCL values were comparable to the results obtained from the Quantile and Gehan tests; for most of the metals, minimal differences occurred between the background and site data. The Quantile and Gehan tests indicated differences for aluminum, arsenic, barium, cadmium, copper, iron, lead, lithium, manganese, molybdenum, nickel, and uranium. In contrast, the comparison of site and background UCL concentrations indicated that barium, cadmium, copper, manganese, and nickel differed only slightly between site and background data.

Arsenic is associated with the ores that were processed at the chemical plant and is a contaminant in the raffinate pits. However, arsenic was only detected at levels below background concentrations from those wells downgradient of the raffinate pits. In addition, arsenic was detected to the southwest of the training area. The high UCL value calculated for arsenic for the deep unit was the result of a very high concentration detected from well MWS-103 from this area. It is hydrologically not possible that the wells in this area could have been impacted by contaminants from the chemical plant area, and arsenic is not associated with past activities at the ordnance works. In addition, the Burlington-Keokuk Limestone is absent from the southwestern portion of the former ordnance works area due to erosion. The uppermost bedrock in this area consists of the Kimmswick and Decorah formations; MWS-103 is open to these formations. Thus, it is likely that the reported arsenic concentrations are indicative of background levels for this area.

Similarly, the site concentrations of aluminum, iron, and lead may actually reflect local background levels. The data indicate a very heterogeneous distribution of these metals among the stratigraphic units at the chemical plant area and the ordnance works area. The UCL values for aluminum, iron, and lead exceeded background UCL values by more than a factor of 2 only in the unweathered and/or deep units (Table 4.4). However, the unweathered background UCL values of these metals were less than the background UCL values for the weathered unit. In addition, the UCL values for aluminum and iron for the unweathered and deep units were less than or about equal to their respective background UCL values for the weathered unit.

In contrast to the aforementioned metals, lithium, molybdenum, and uranium were detected at levels above background in a large percentage of wells on both the chemical plant area and the ordnance works area, and especially at the chemical plant area. The higher frequency of detection for uranium was expected, since this metal is a known contaminant at the raffinate pits and in soils at the chemical plant area. Lithium and molybdenum are associated with uranium ores, and both of these metals were contaminants in the raffinate pit sludges and surface water.

The differences between the site and background concentrations indicated for lithium, molybdenum, and uranium could be a function of the smaller background sample size compared to the site sample size. The background wells were sampled less frequently for these metals. Elevated nitrate, chloride, and sulfate were indicated from the Quantile and Gehan tests and the UCL comparisons. 


\subsubsection{Distribution of Site Contaminants}

On the basis of a review of groundwater quality data and the background comparison, lithium, molybdenum, uranium, nitrate, chloride, sulfate, nitroaromatic compounds, TCE and 1,2-DCE were identified as site contaminants. The distribution of site contaminants is illustrated in Figures 4.1 through 4.4 for metals (including uranium), Figures 4.5 through 4.8 for the anions; Figures 4.9 through 4.19 for the nitroaromatic compounds, and Figure 4.20 for TCE and 1,2-DCE. The UCL values for each well, calculated on the basis of all data collected from 1987 to 1995 , are shown in the figures. Additional figures for nitrate and uranium are also provided for which UCL values for each well are calculated on the basis of more recent data only (1995-1997). Data from quarterly sampling were averaged to calculate the UCL for each well. This procedure is appropriate because no time trending has been observed. UCLs are posted for each well rather than drawing isopleths because no plume has been identified. For metals and anions, only those wells that exceeded the statistically derived background are shown. The distribution maps for nitroaromatic compounds show all the locations where these compounds were detected. Contaminants for which an MCL or SMCL is available include chloride $(250 \mathrm{mg} / \mathrm{L})$, nitrate $(10 \mathrm{mg} / \mathrm{L})$, and sulfate (250 $\mathrm{mg} / \mathrm{L}$ ). Wells that had UCL values above the MCL or SMCL values are designated in the figures.

\subsubsection{Metals}

Contaminant distributions for uranium are shown in Figures 4.1 and 4.2. Figure 4.1 illustrates the UCLs for each well based on data collected since 1987. An additional map is also presented using more recent data (Figure 4.2) that provide a more current indication of contaminant levels for each well. Wells that are considered to be impacted by uranium processing activities are designated in the distribution maps; these wells were determined on the basis of data evaluation, existing or previous source areas, and groundwater flow. Concentrations are also compared with the proposed MCL of $20 \mu \mathrm{g} / \mathrm{L}$, which corresponds to an activity concentration of $14 \mathrm{pCi} / \mathrm{L}$ on the basis of the ratio of uranium isotopes measured in soil at the chemical plant area (i.e., an activity ratio of 1 to 1 between $\mathrm{U}-234$ and U-238).

In general, the areas with uranium contamination include the area around the raffinate pits and Ash Pond, the Frog Pond area, south and southeast portions of the chemical plant area and adjacent boundary, and west of the chemical plant area boundary extending north to Burgermeister Spring. Uranium contamination is primarily limited to the overburden and weathered units of the aquifer. Uranium levels are much lower in the unweathered and deeper units $(0.028$ to $6.6 \mathrm{pCi} / \mathrm{L}$ in the unweathered, and less than $3.0 \mathrm{pCi} / \mathrm{L}$ in the deeper unit).

The highest UCLs for uranium (as shown on Figure 4.1) are indicated for wells MW-3009, MW-3008, MW-4010, and MW-4024. The well with the highest UCL is MW-4010 (130 pCi/L), 


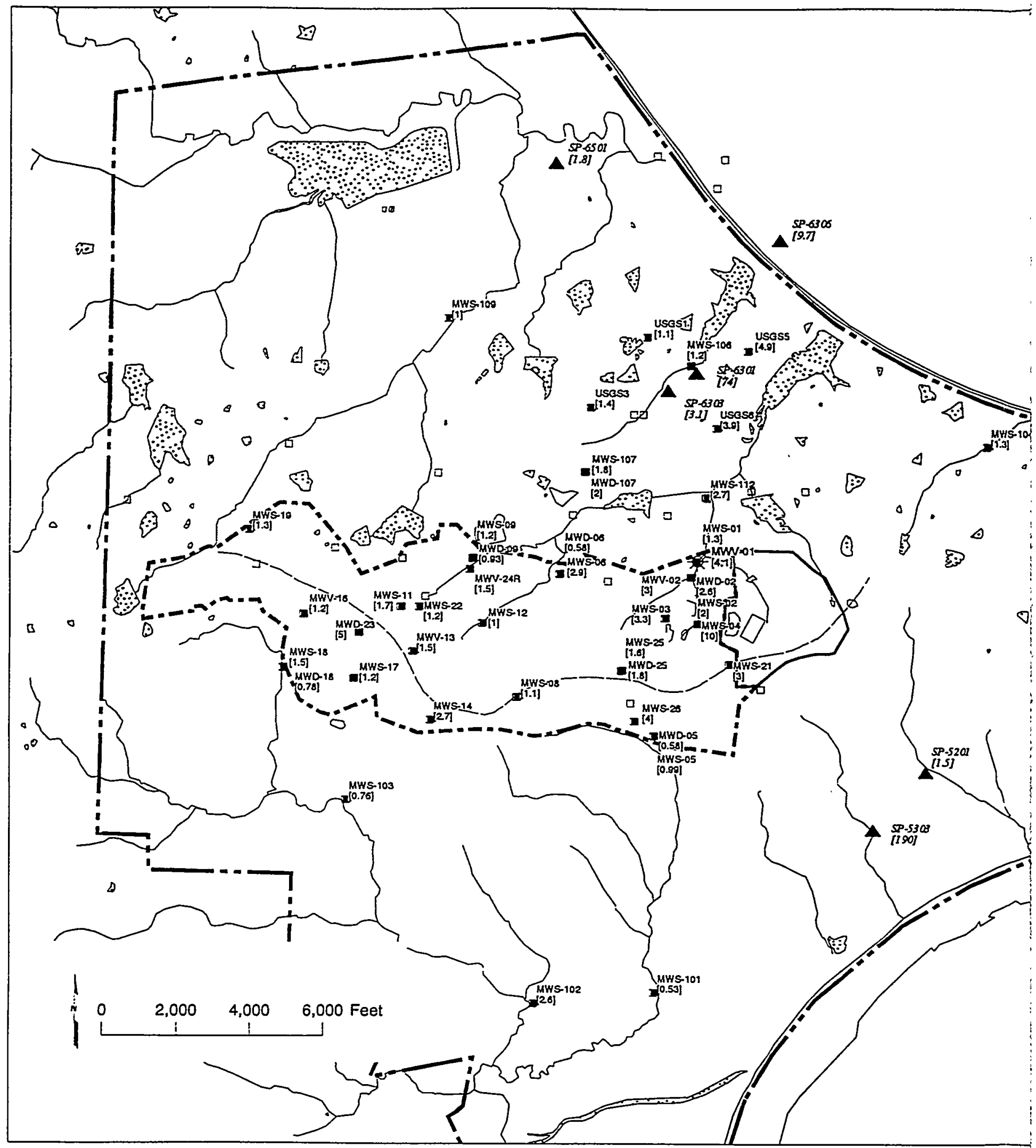

FIGURE 4.1 Distribution of Uranium Based on Data Collected Since 1987 at the Chemical Plant Area and 


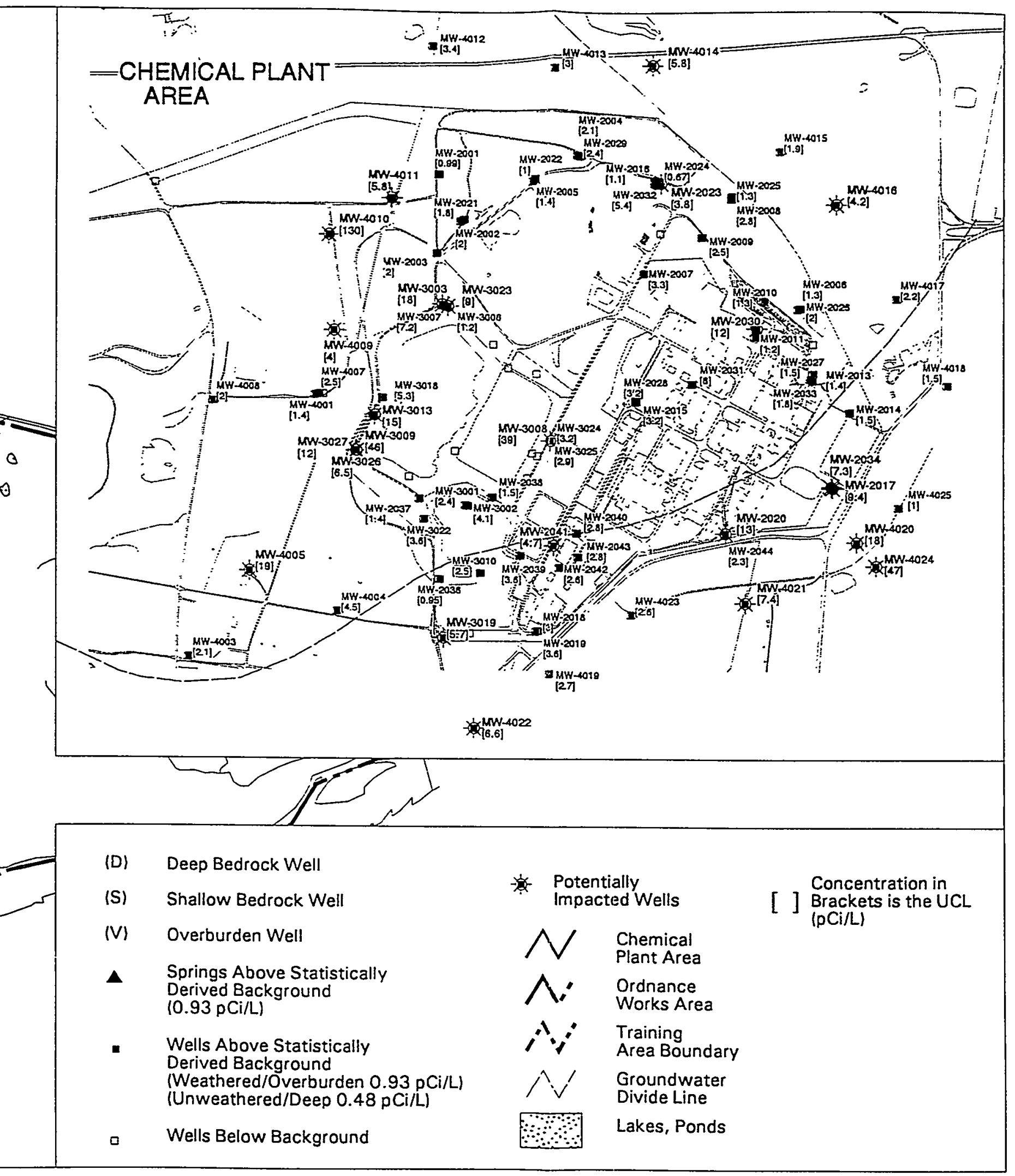

the Ordnance Works Area 


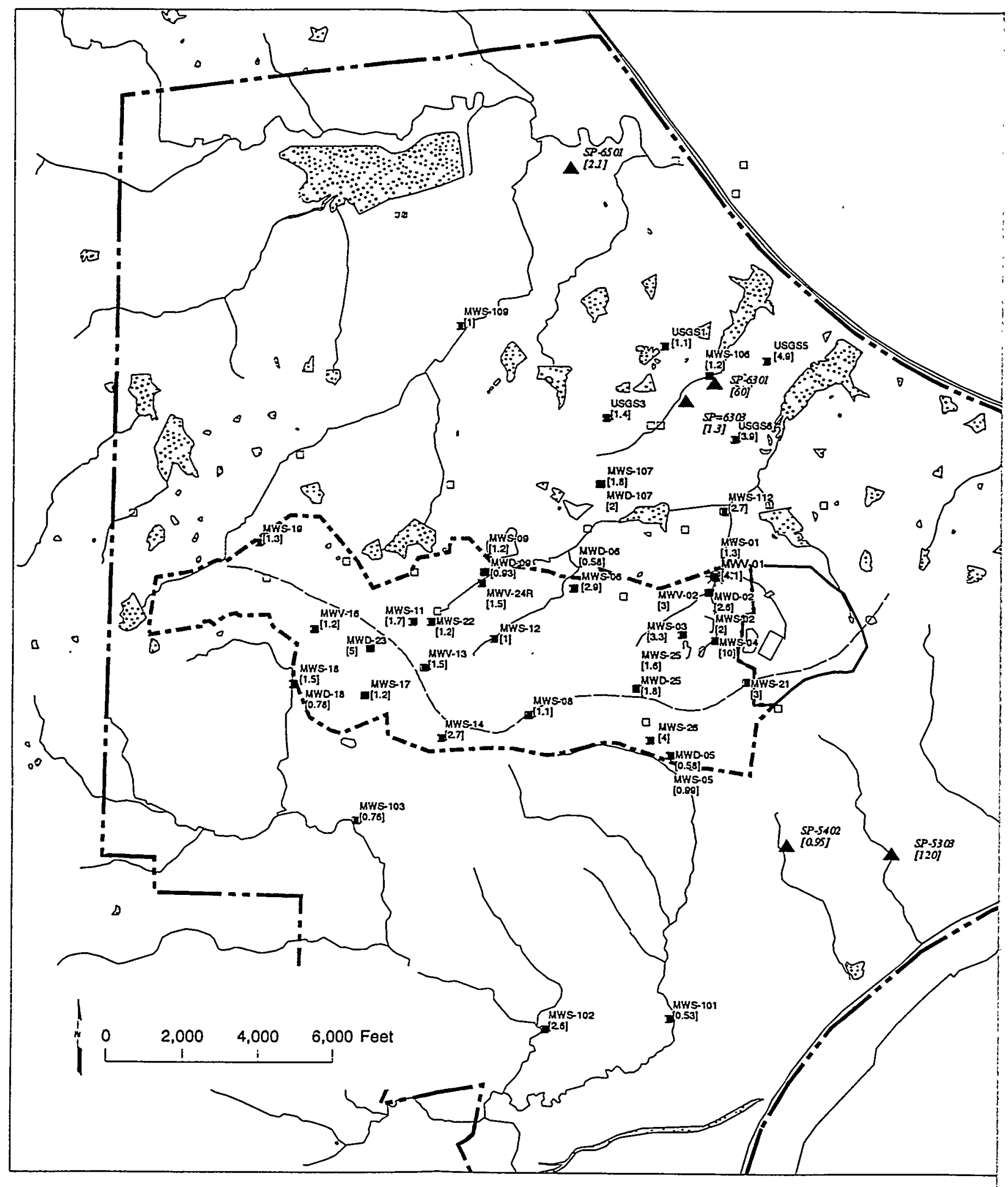

FIGURE 4.2 Distribution of Uranium Based on Data Collected Since 1995 at the Chemical Plant Ar. 


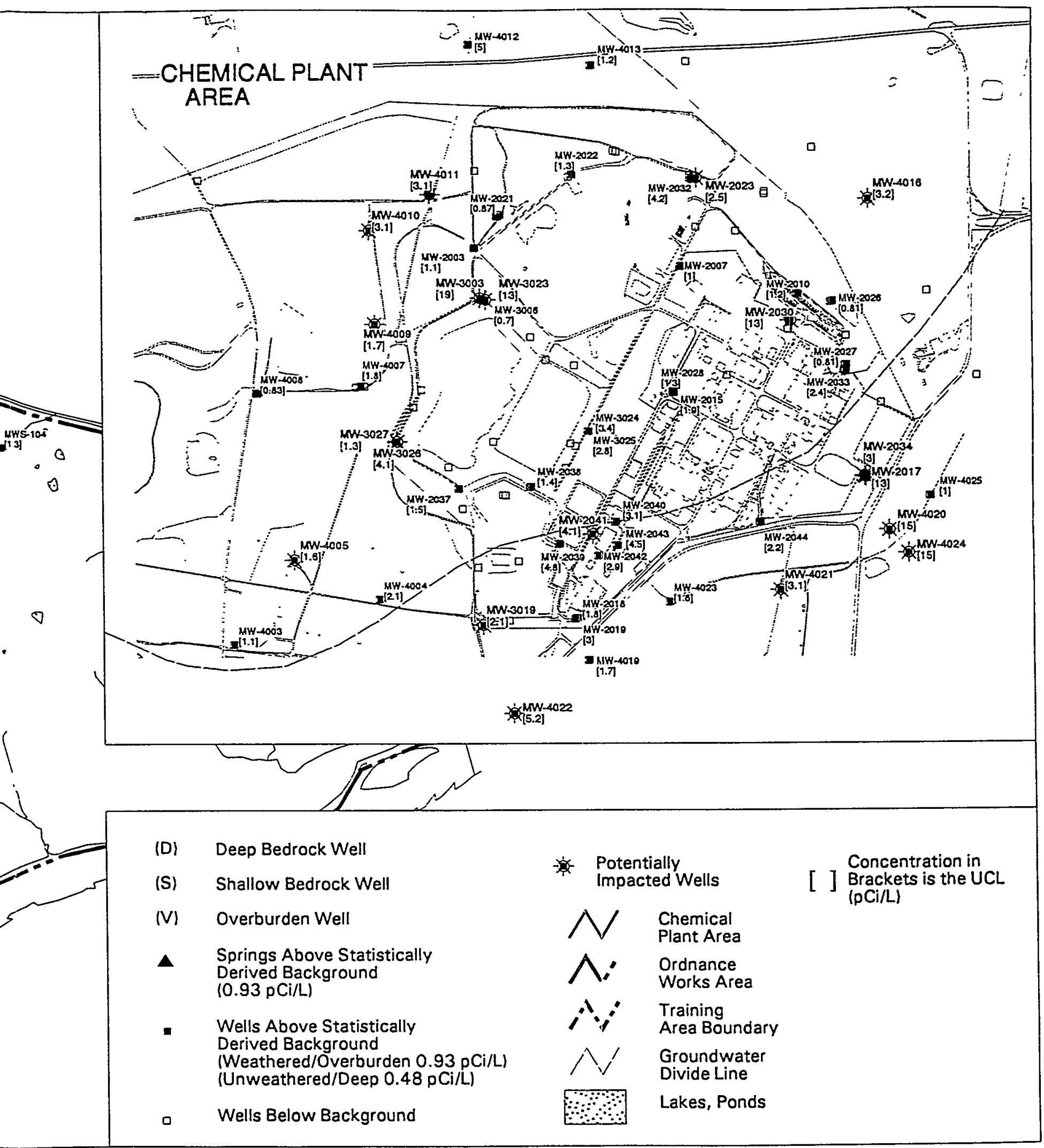

ea and the Ordnance Works Area 


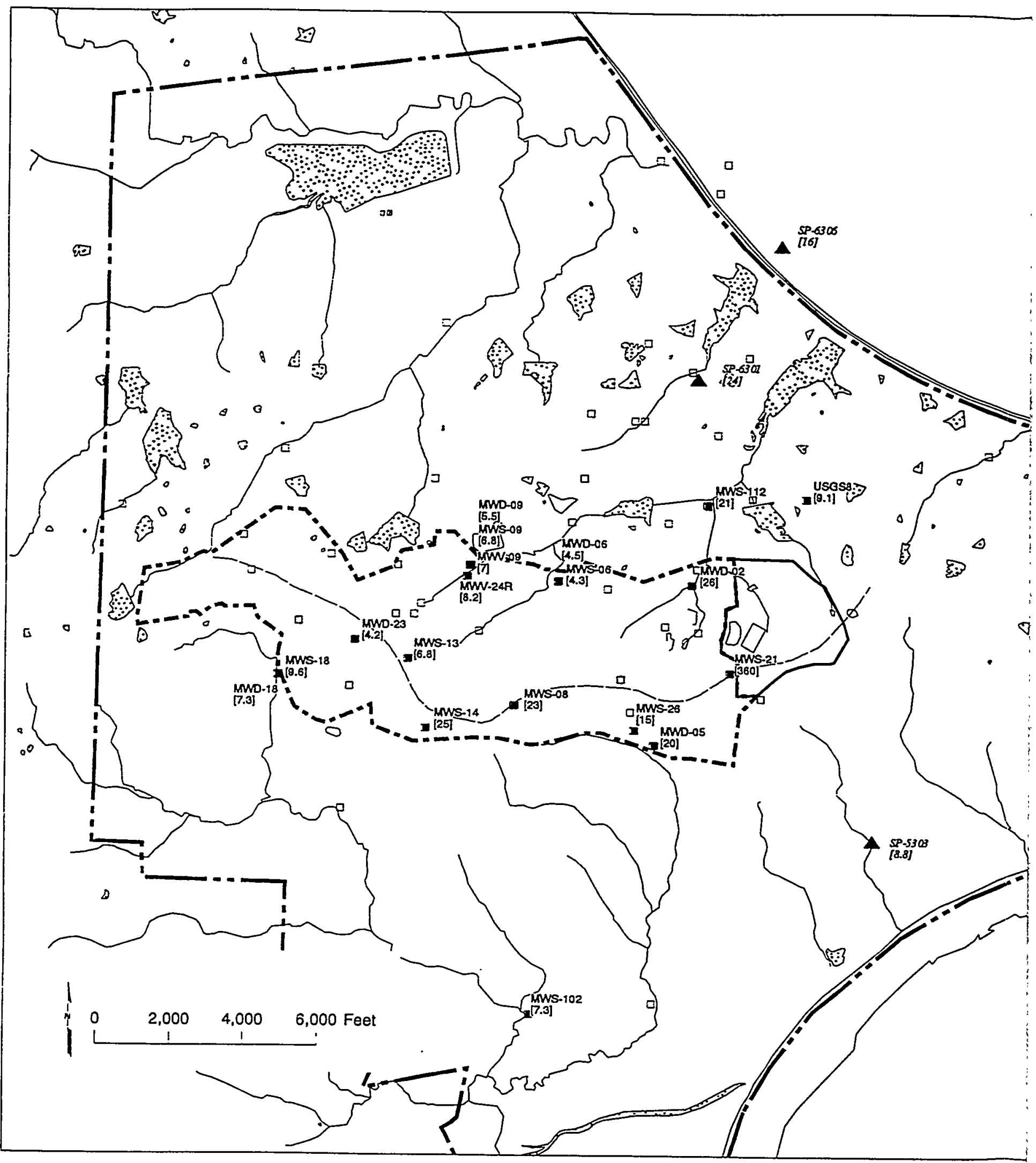

FIGURE 4.3 Distribution of Lithium at the Chemical Plant Area and the Ordnance Works Area 


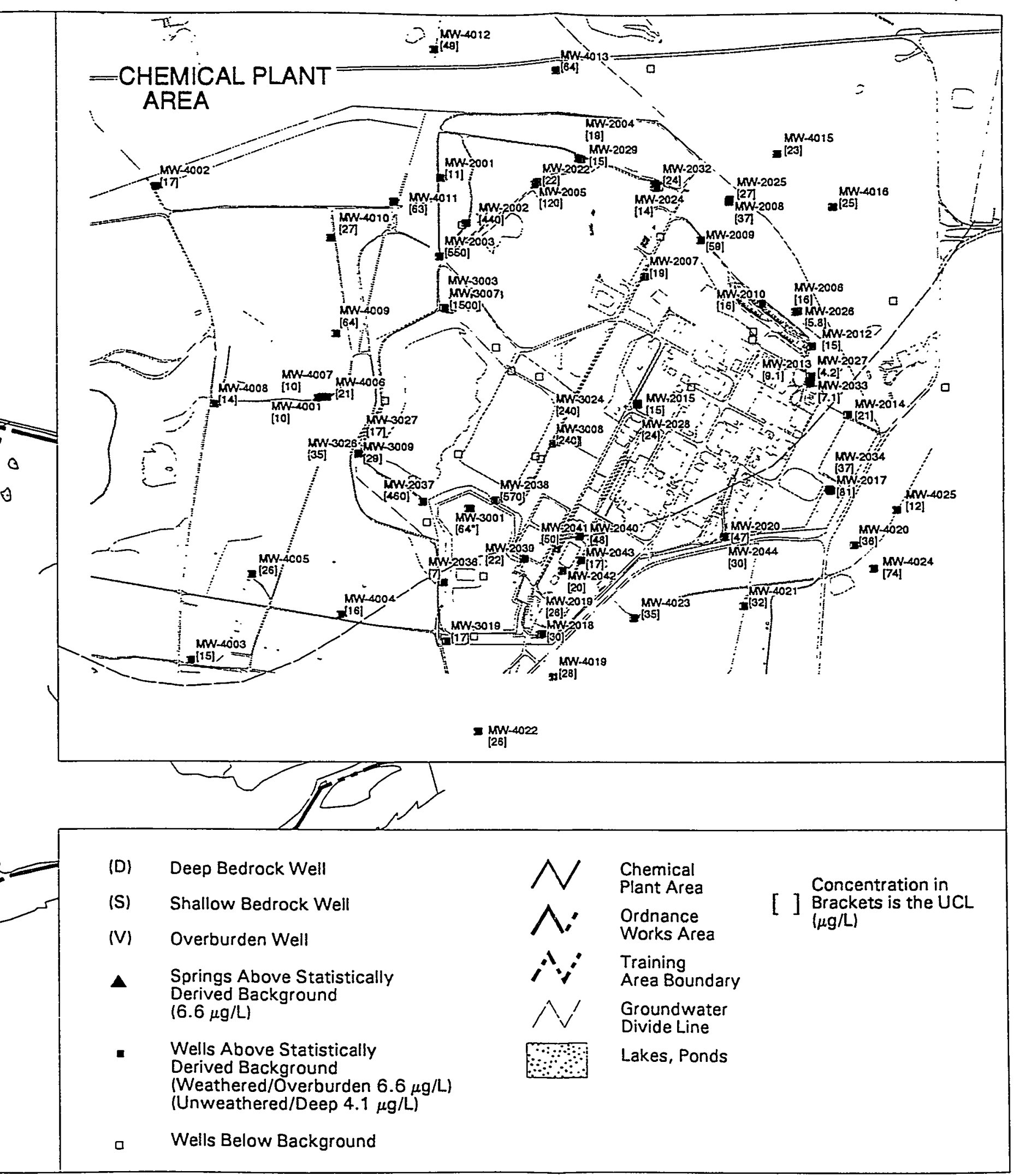




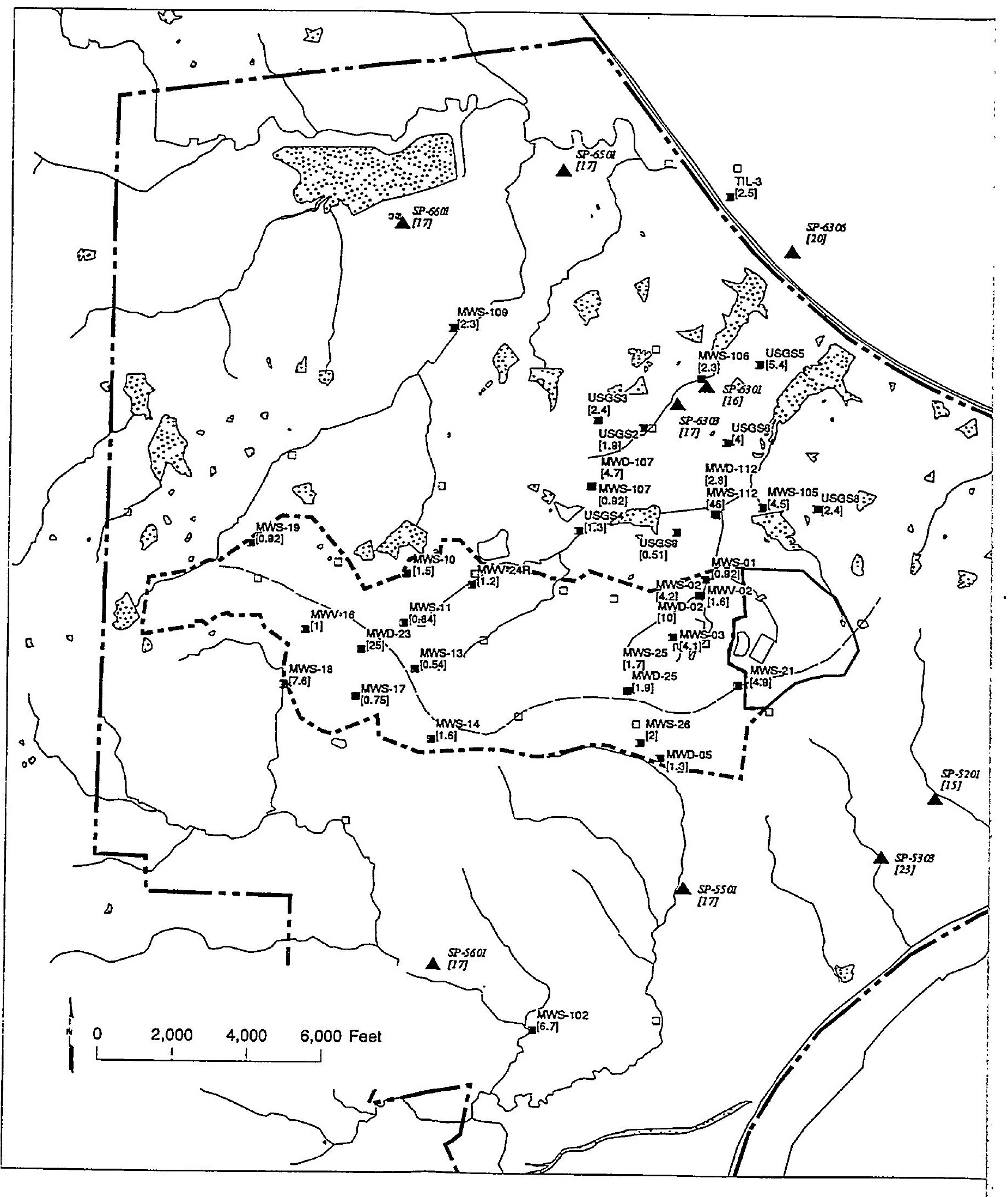

FIGURE 4.4 Distribution of Molybdenum at the at the Chemical Plant Area and the Ordnance Woi 


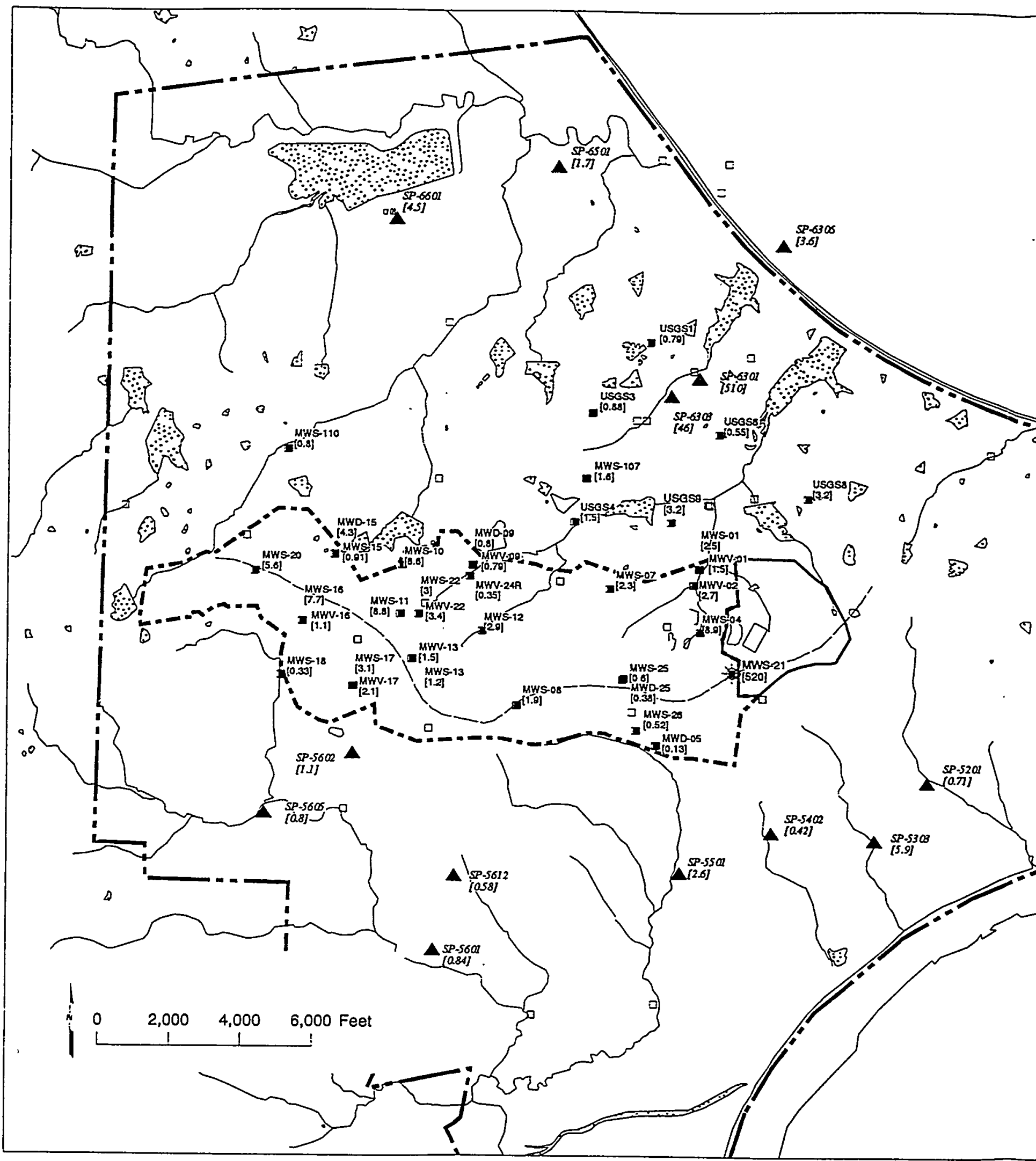

FIGURE 4.5 Distribution of Nitrate Based on Data Collected Since 1987 at the Chemical Plant Area and $t$ 


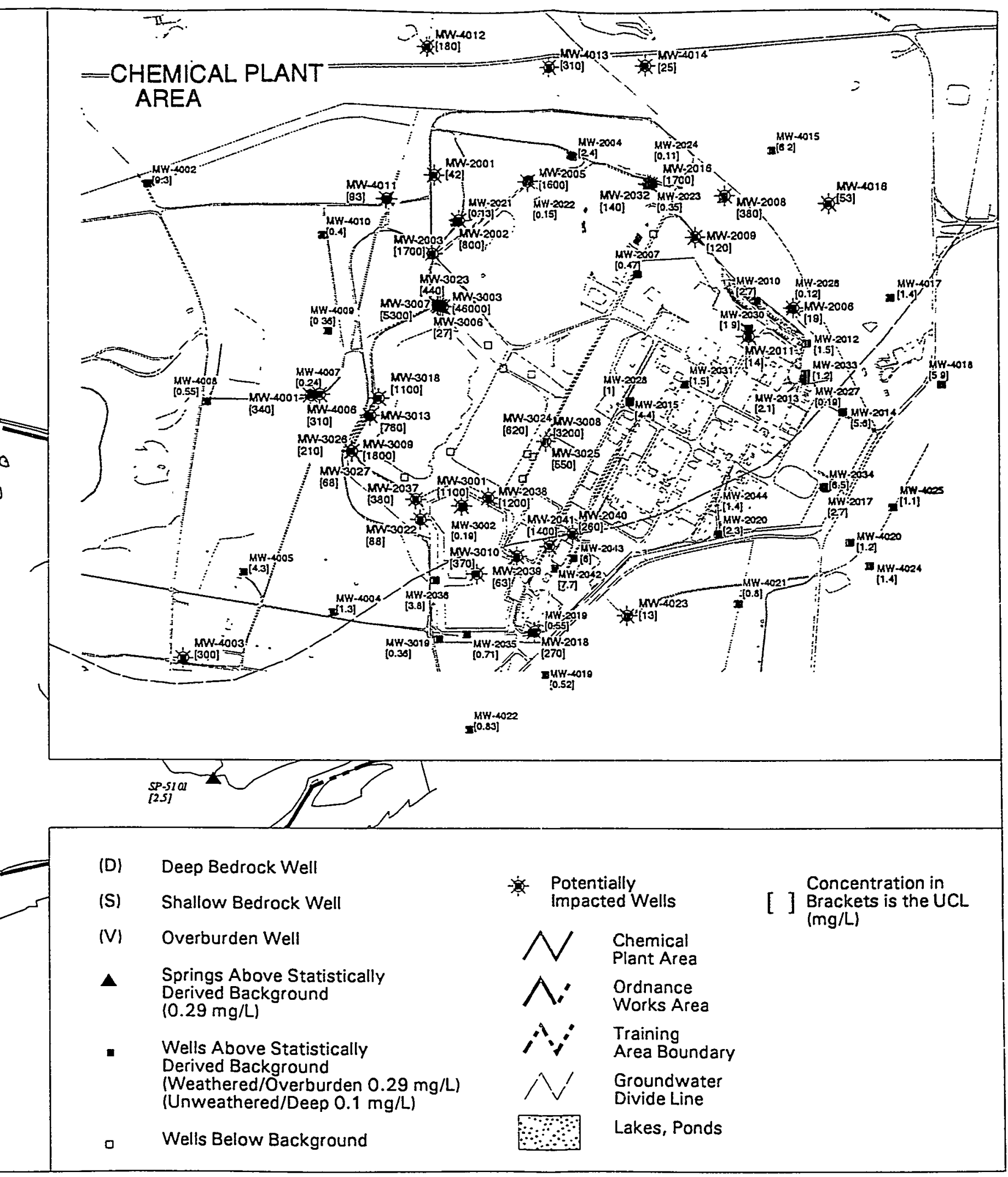

he Ordnance Works Area 


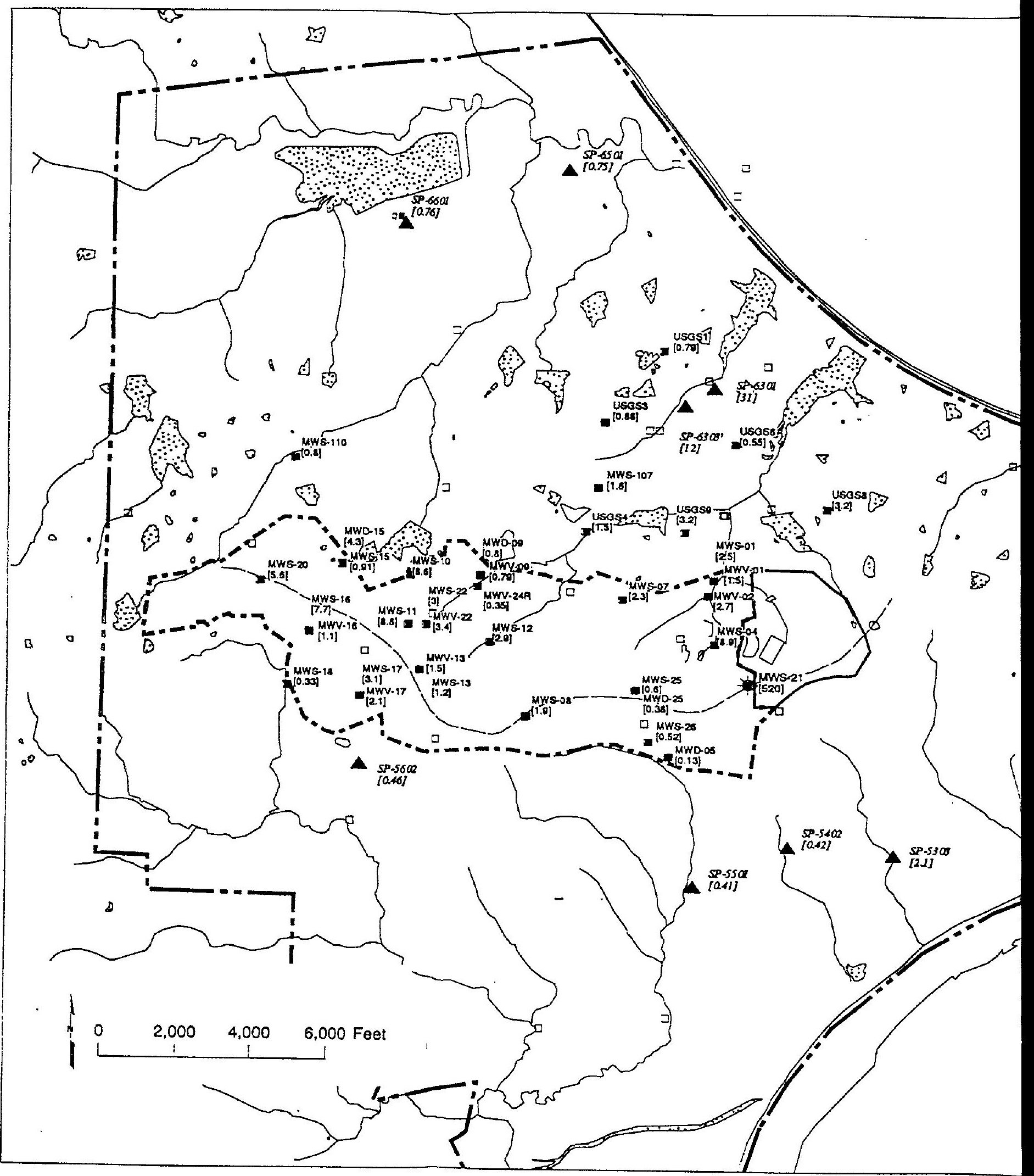

FIGURE 4.6 Distribution of Nitrate Based on Data Collected Since 1995 at the Chemical Plant Area an 


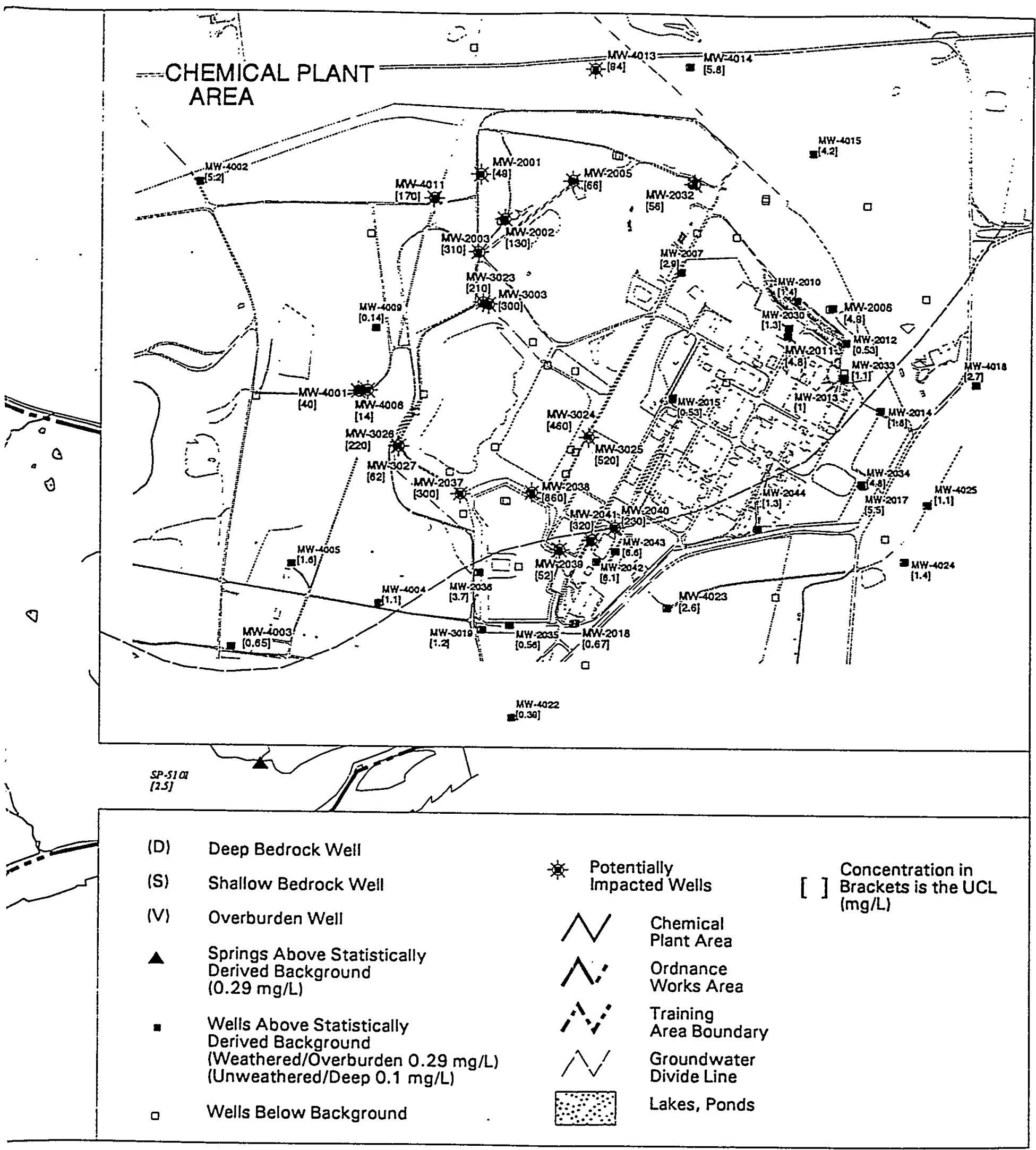

Id the Ordnance Works Area 


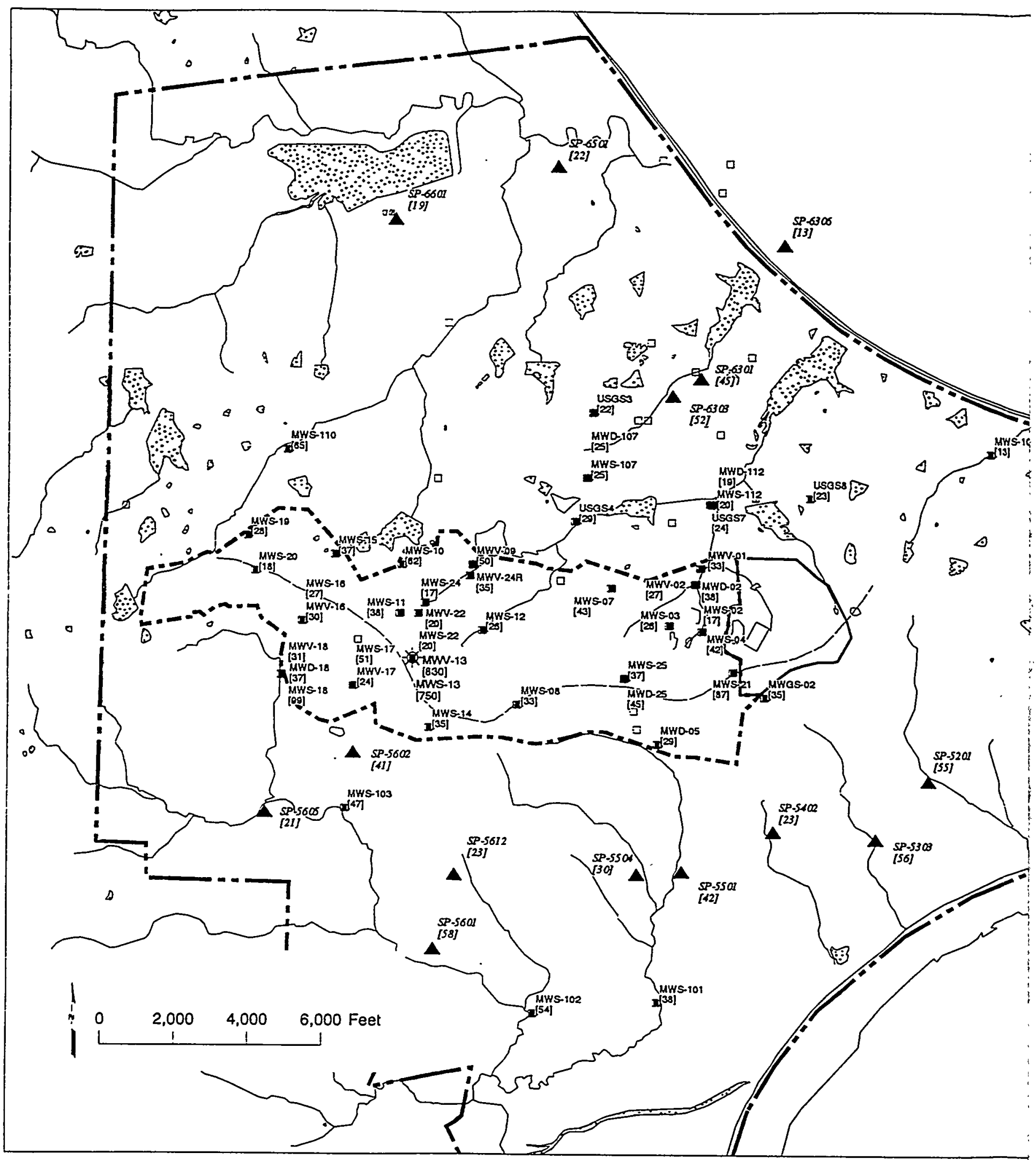

FIGURE 4.7 Distribution of Sulfate at the Chemical Plant Area and the Ordnance Works Area 


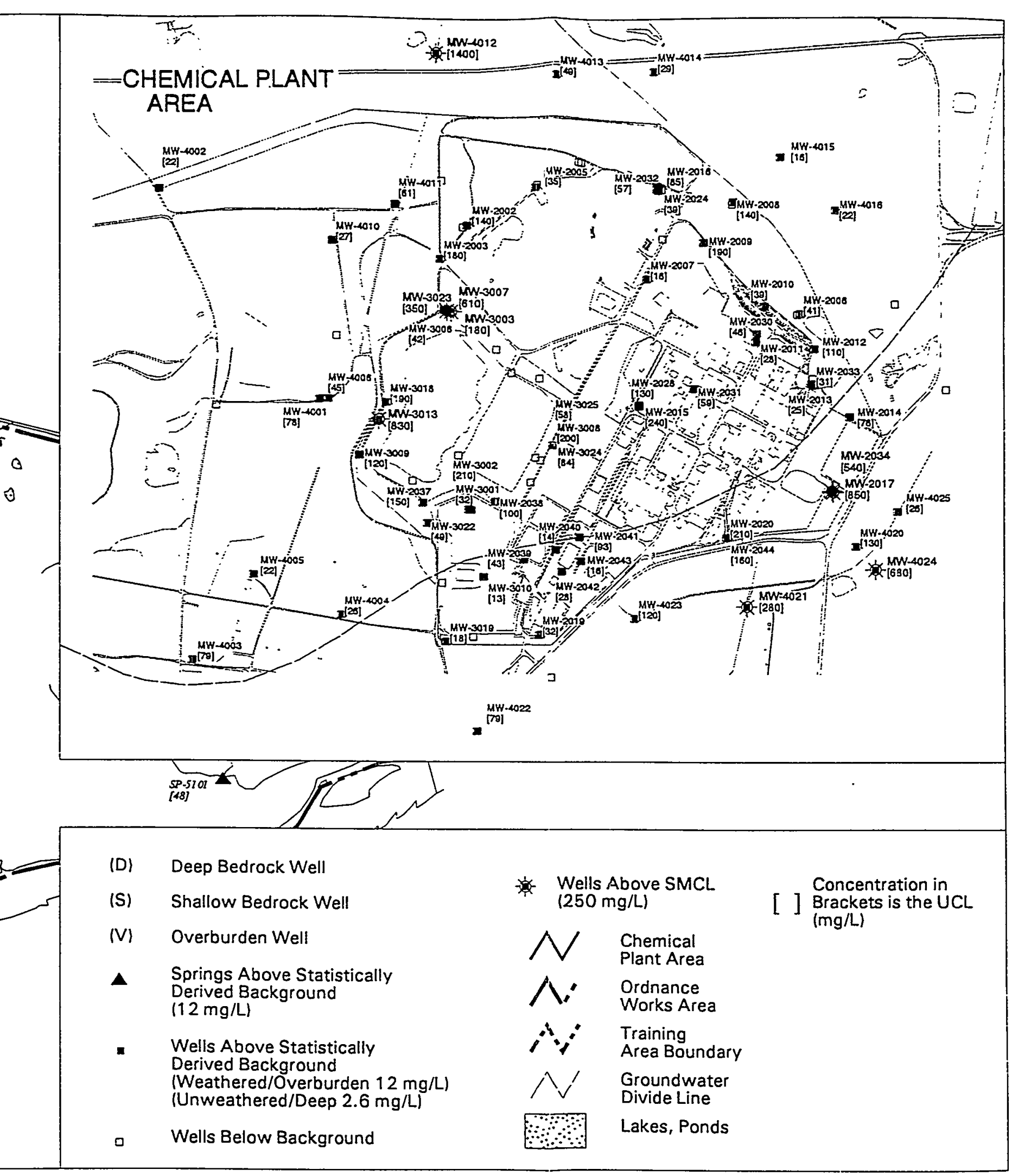




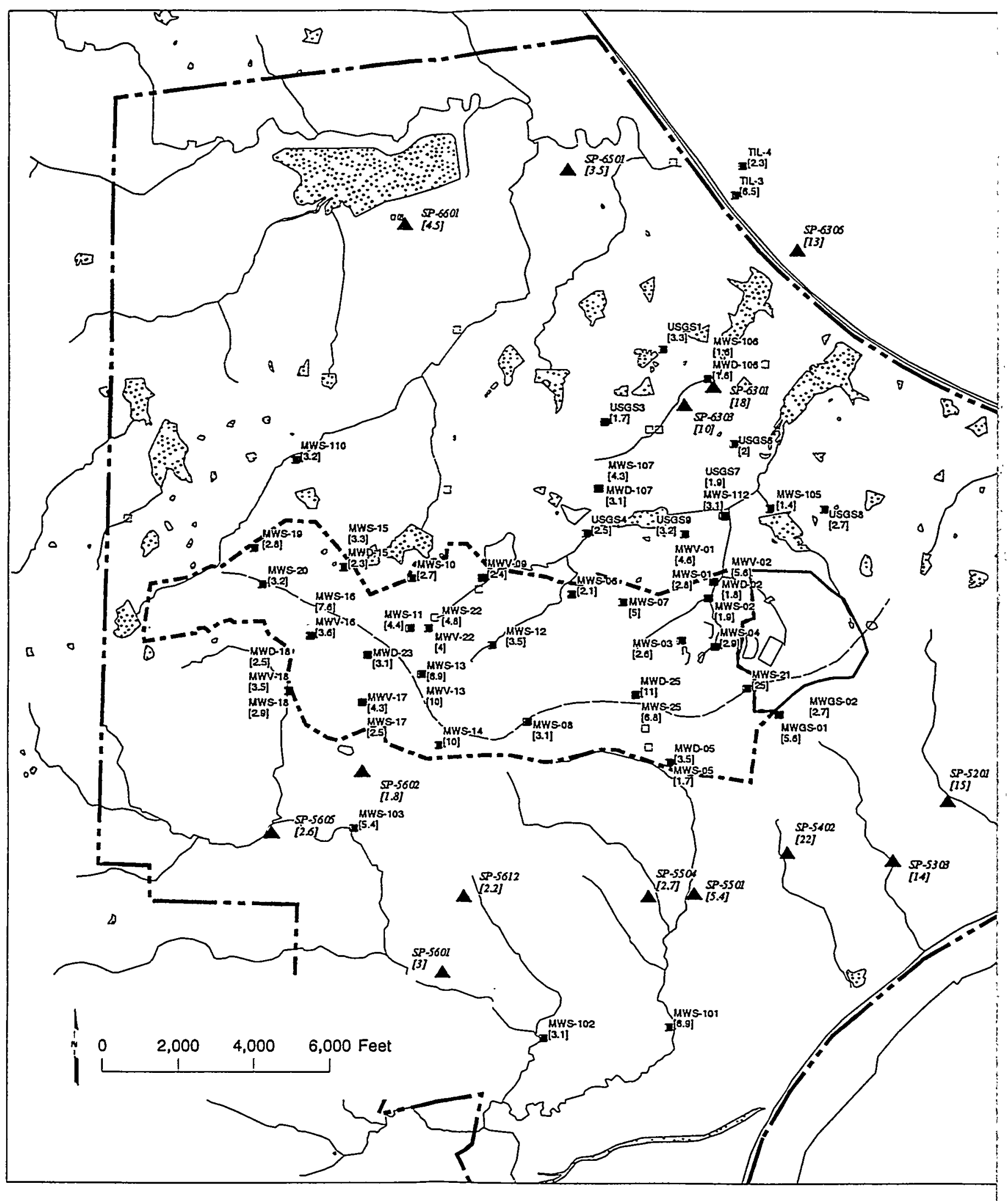

FIGURE 4.8 Distribution of Chloride at the Chemical Plant Area and the Ordnance Works Area 


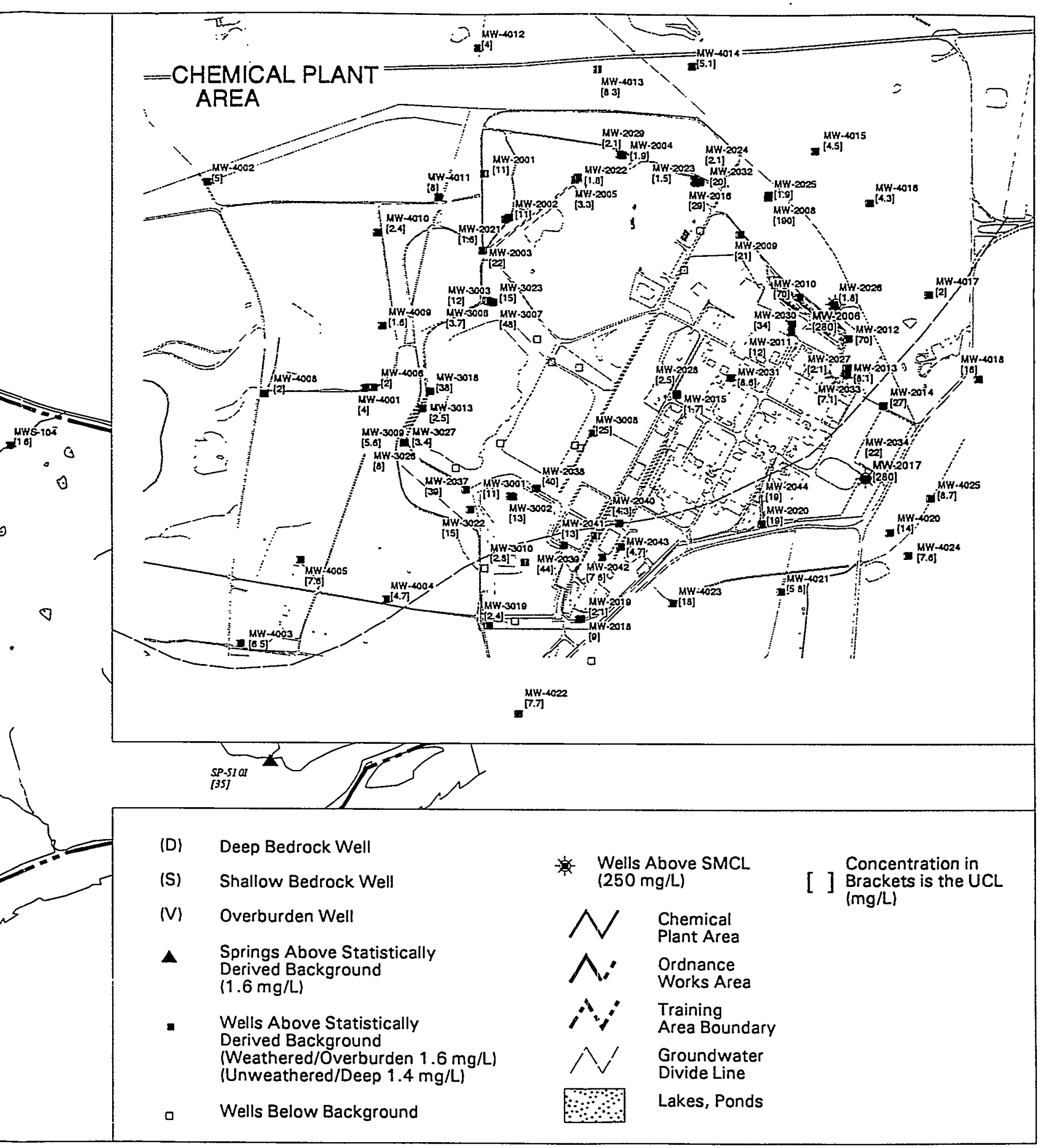




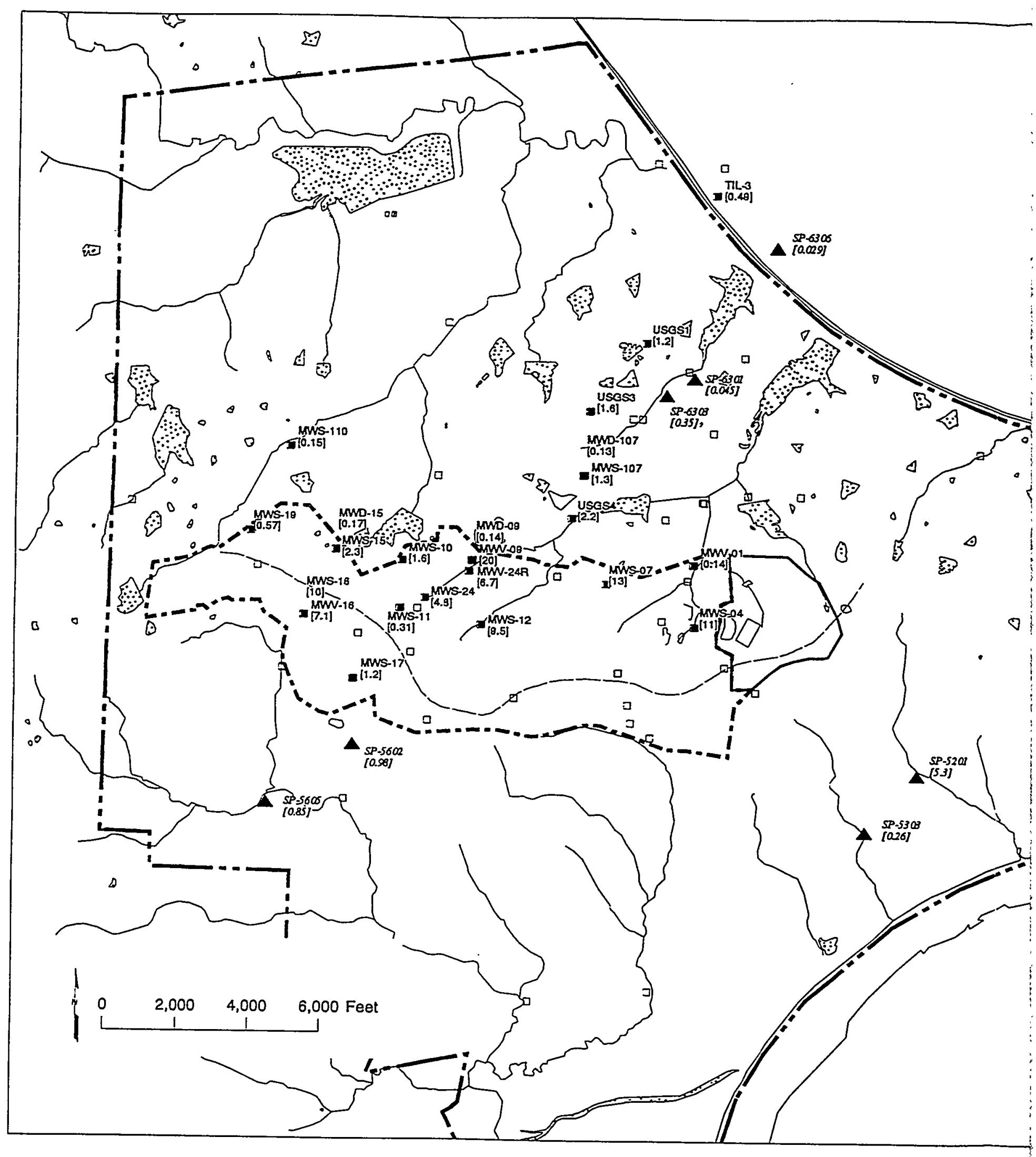

FIGURE 4.9 Distribution of 1,3,5-TNB at the Chemical Plant Area and the Ordnance Works Area 


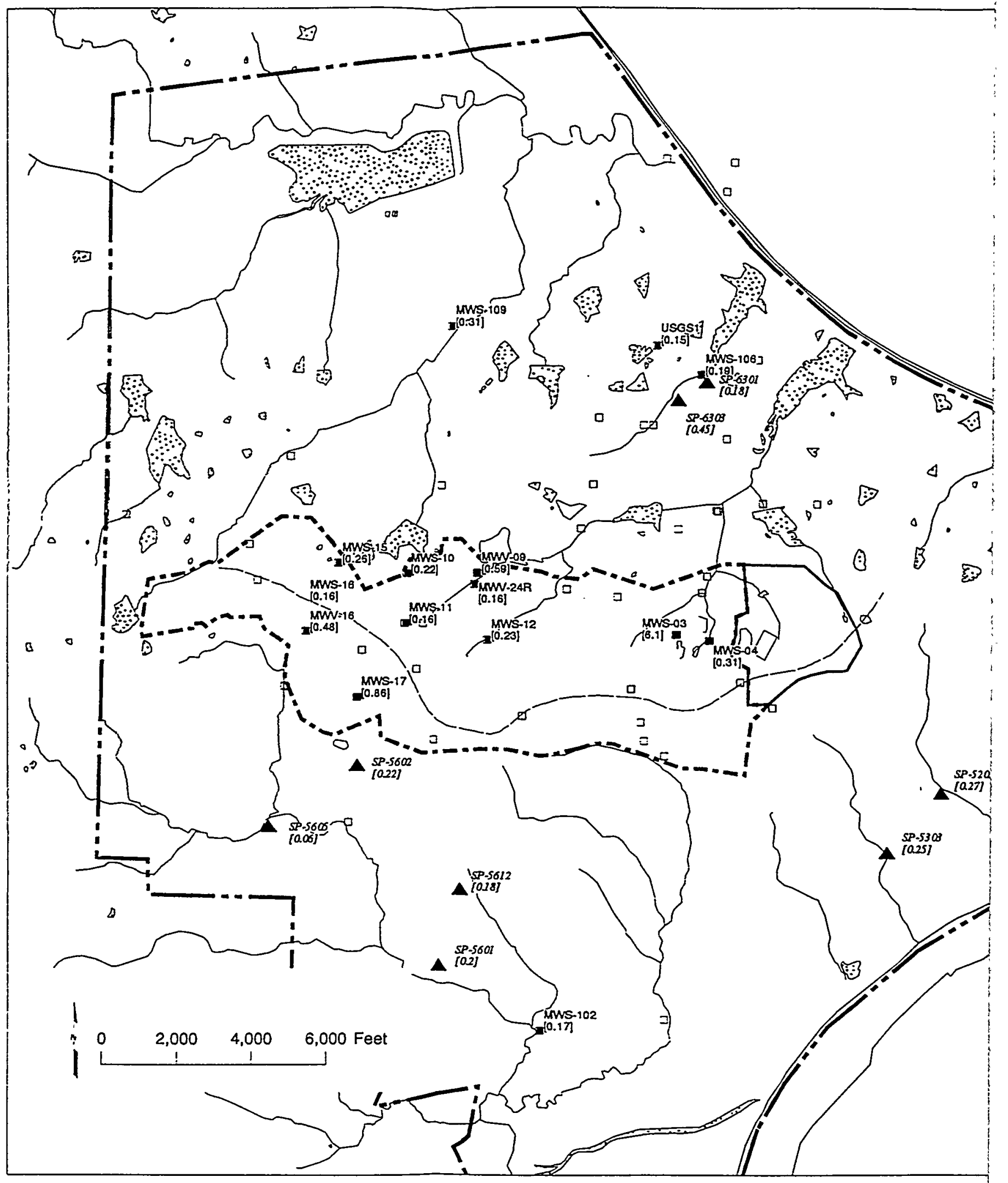

FIGURE 4.10 Distribution of 1,3-DNB at the Chemical Plant Area and the Ordnance Works Area 


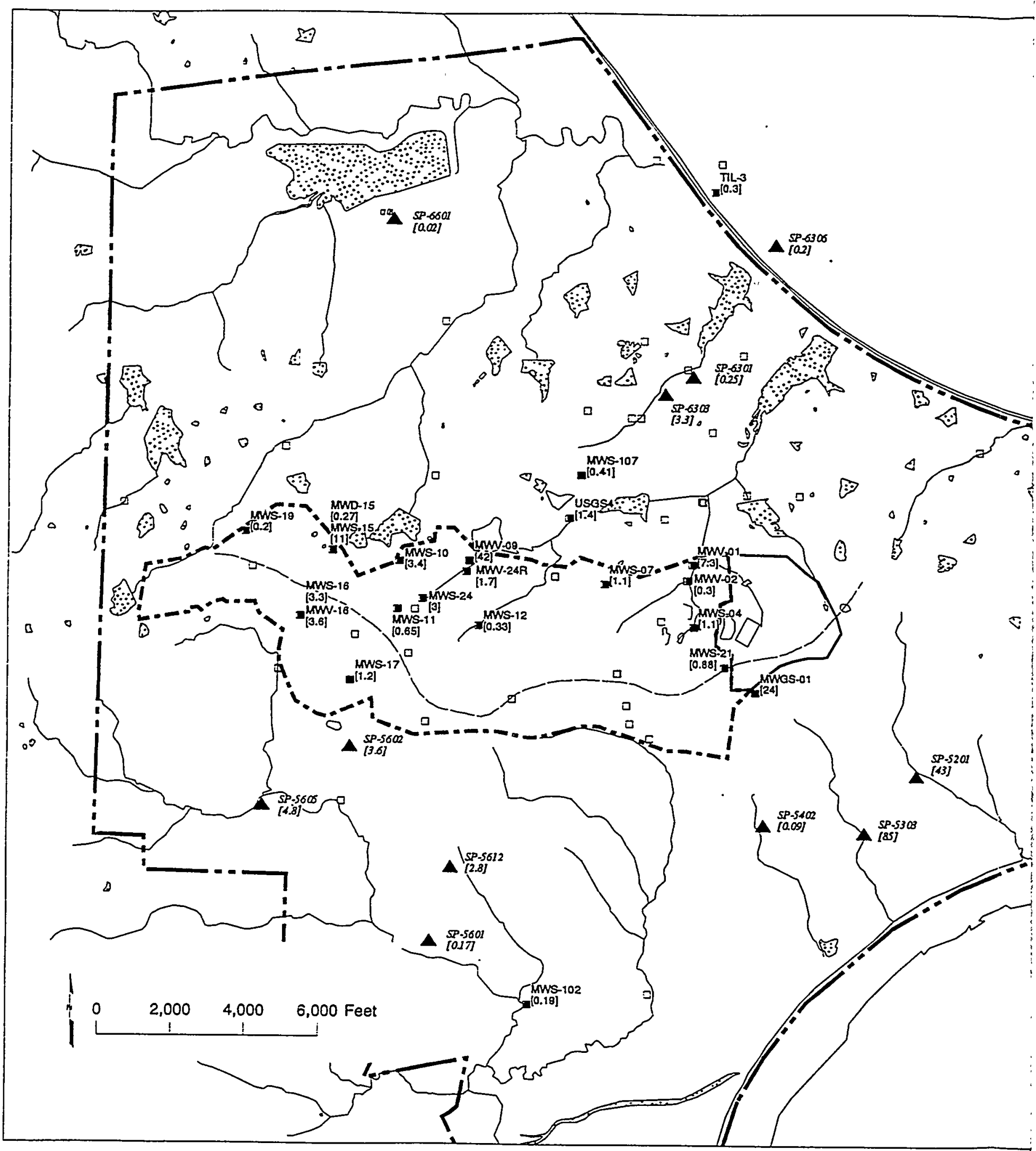

FIGURE 4.11 Distribution of 2,4,6-TNT at the Chemical Plant Area and the Ordnance Works Area 


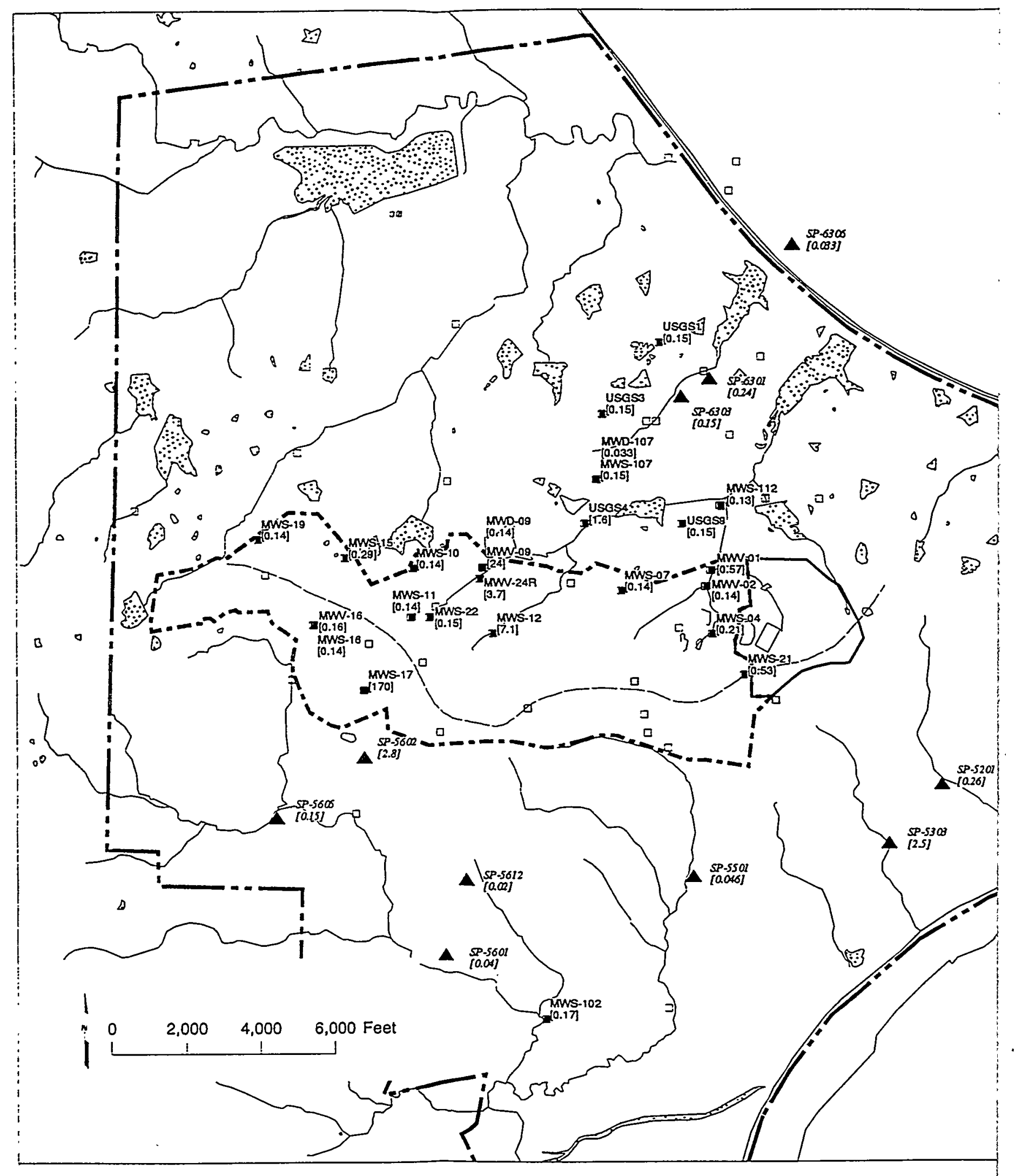

FIGURE 4.12 Distribution of 2,4-DNT at the Chemical Plant Area and the Ordnance Works Area 


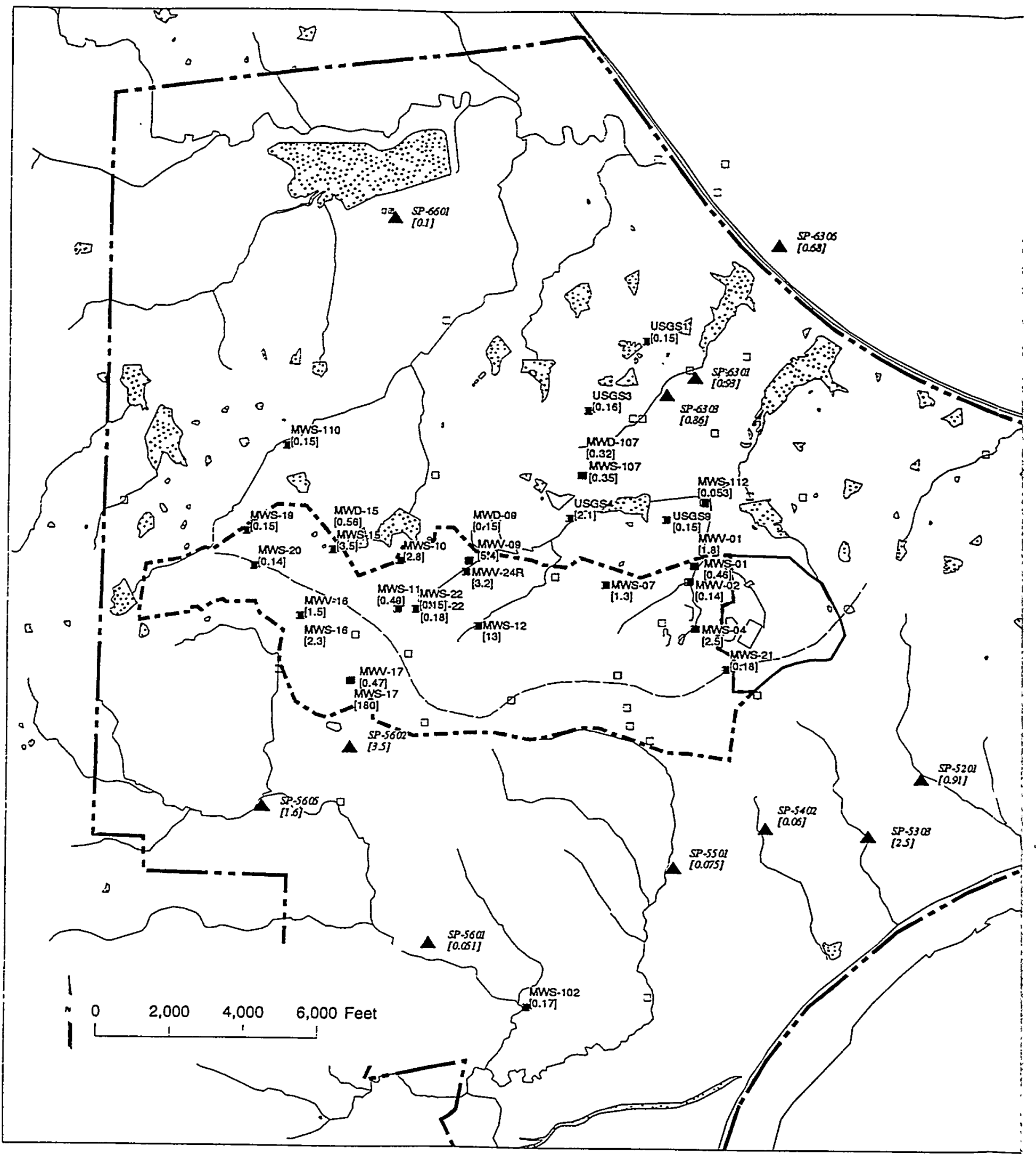

FIGURE 4.13 Distribution of 2,6-DNT at the Chemical Plant Area and the Ordnance Works Area 


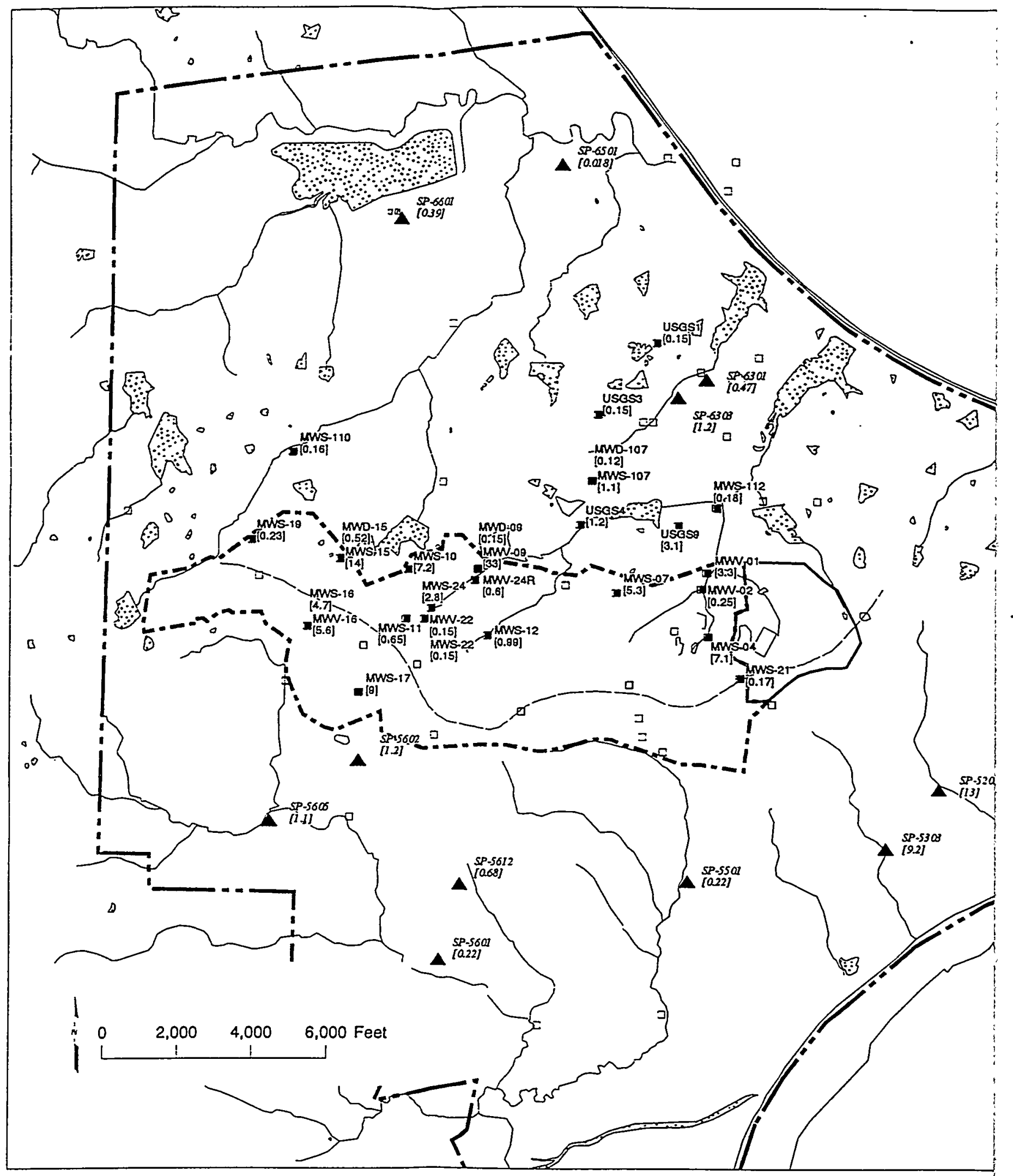

FIGURE 4.14 Distribution of 2-Amino-4,6-DNT at the Chemical Plant Area and the Ordnance Worl 


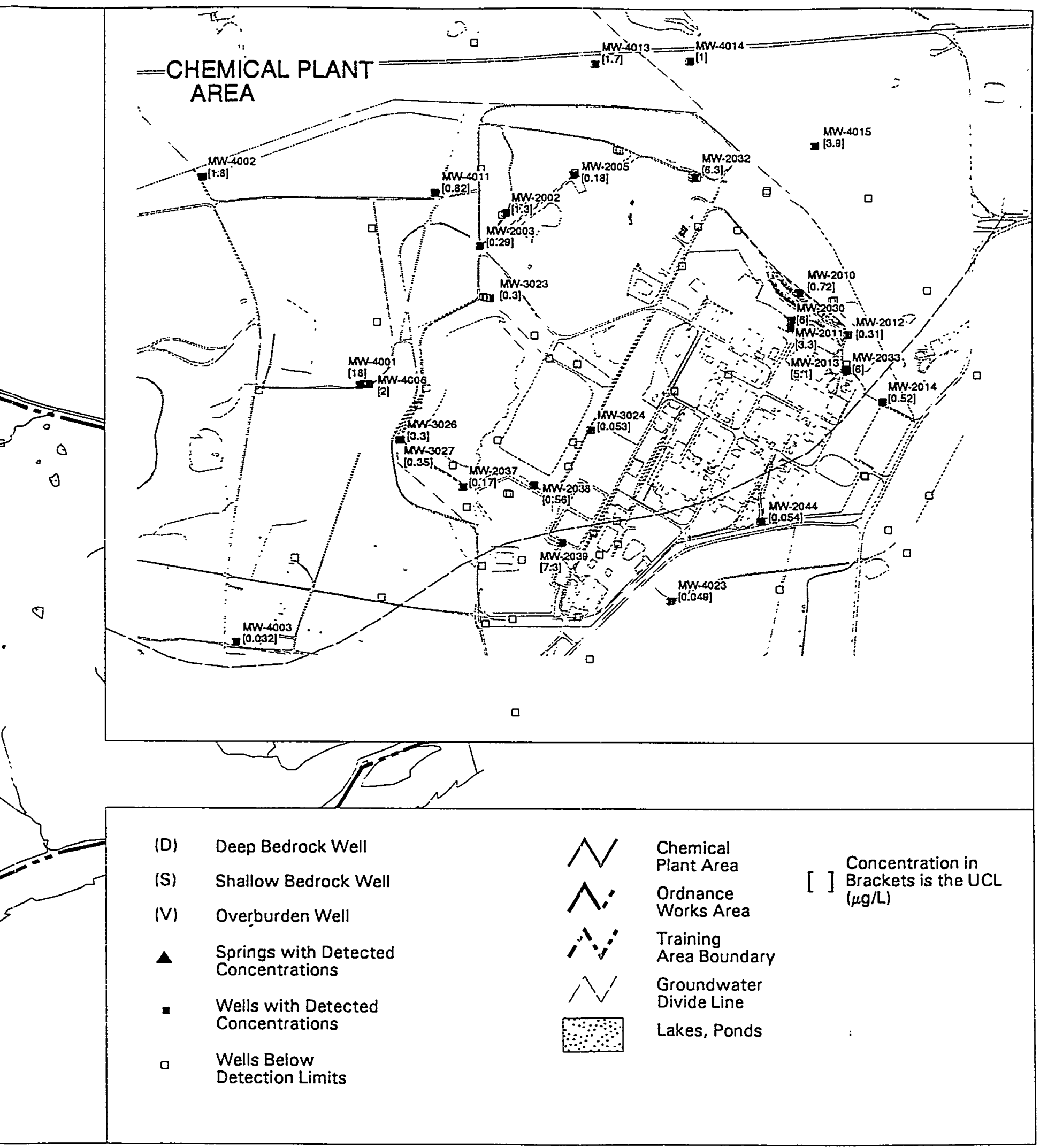




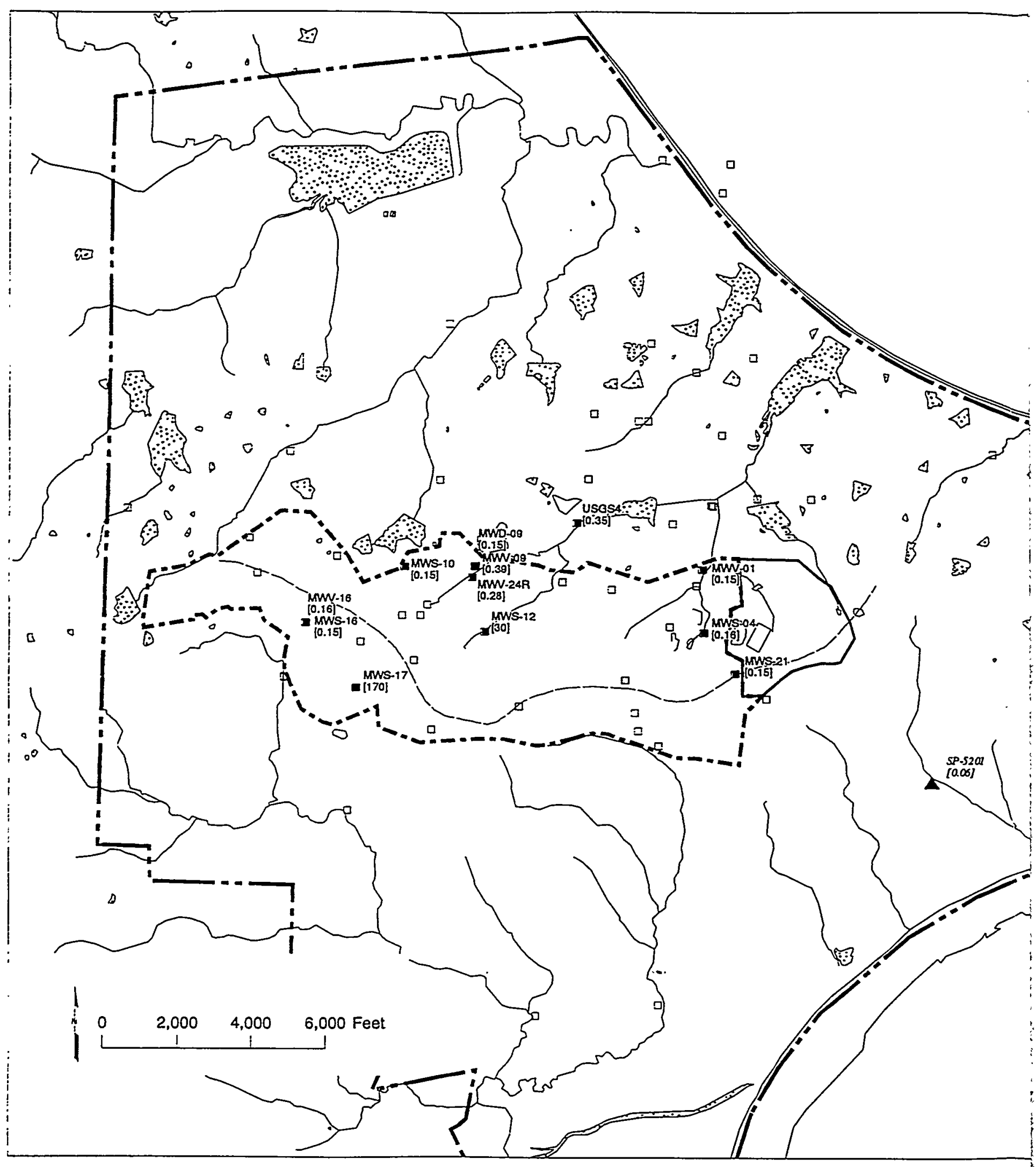

FIGURE 4.15 Distribution of 2-Nitrotoluene at the Chemical Plant Area and the Ordnance Works Area 


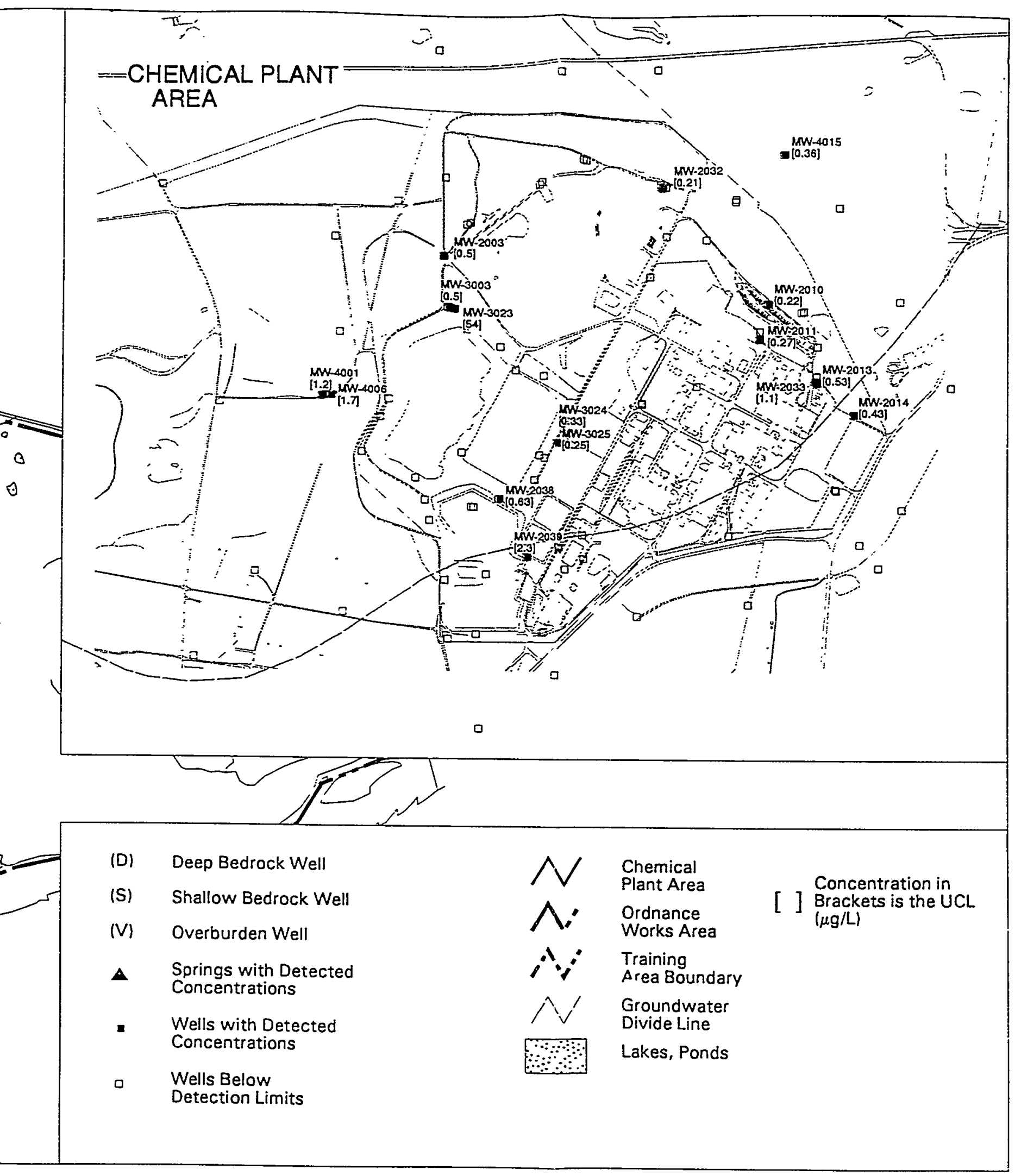




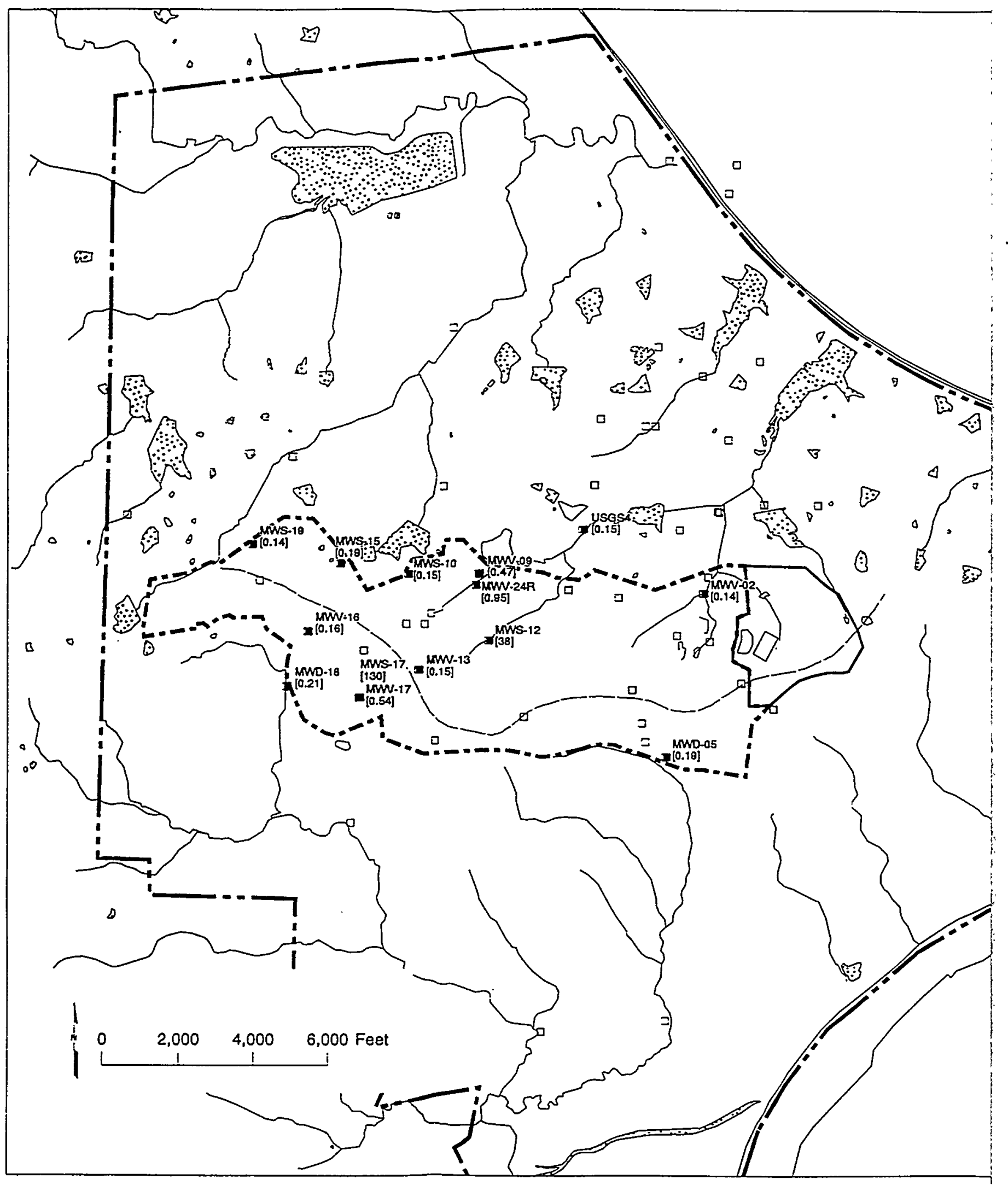

FIGURE 4.16 Distribution of 3-Nitrotoluene at the Chemical Plant Area and the Ordnance Works A 


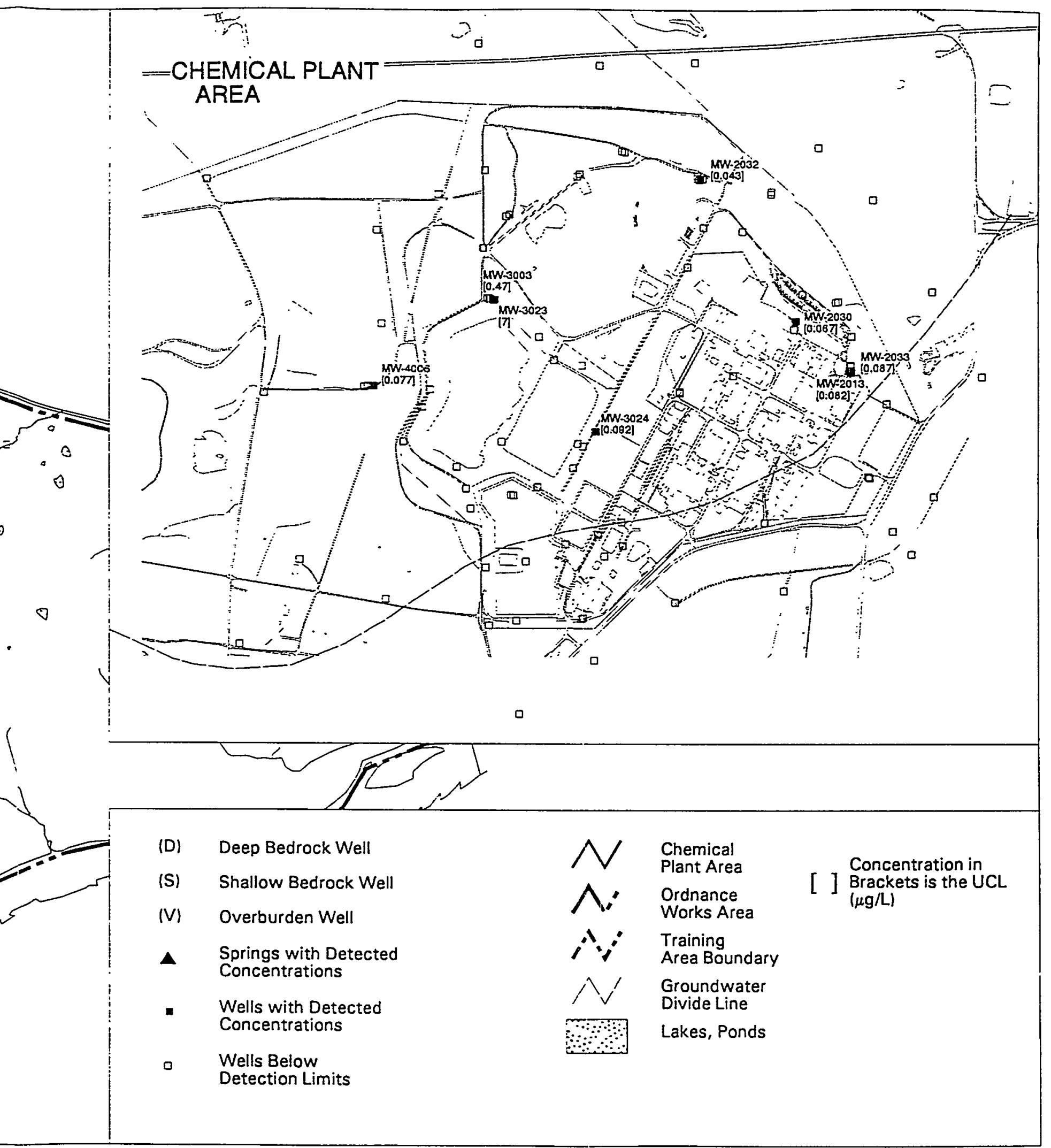




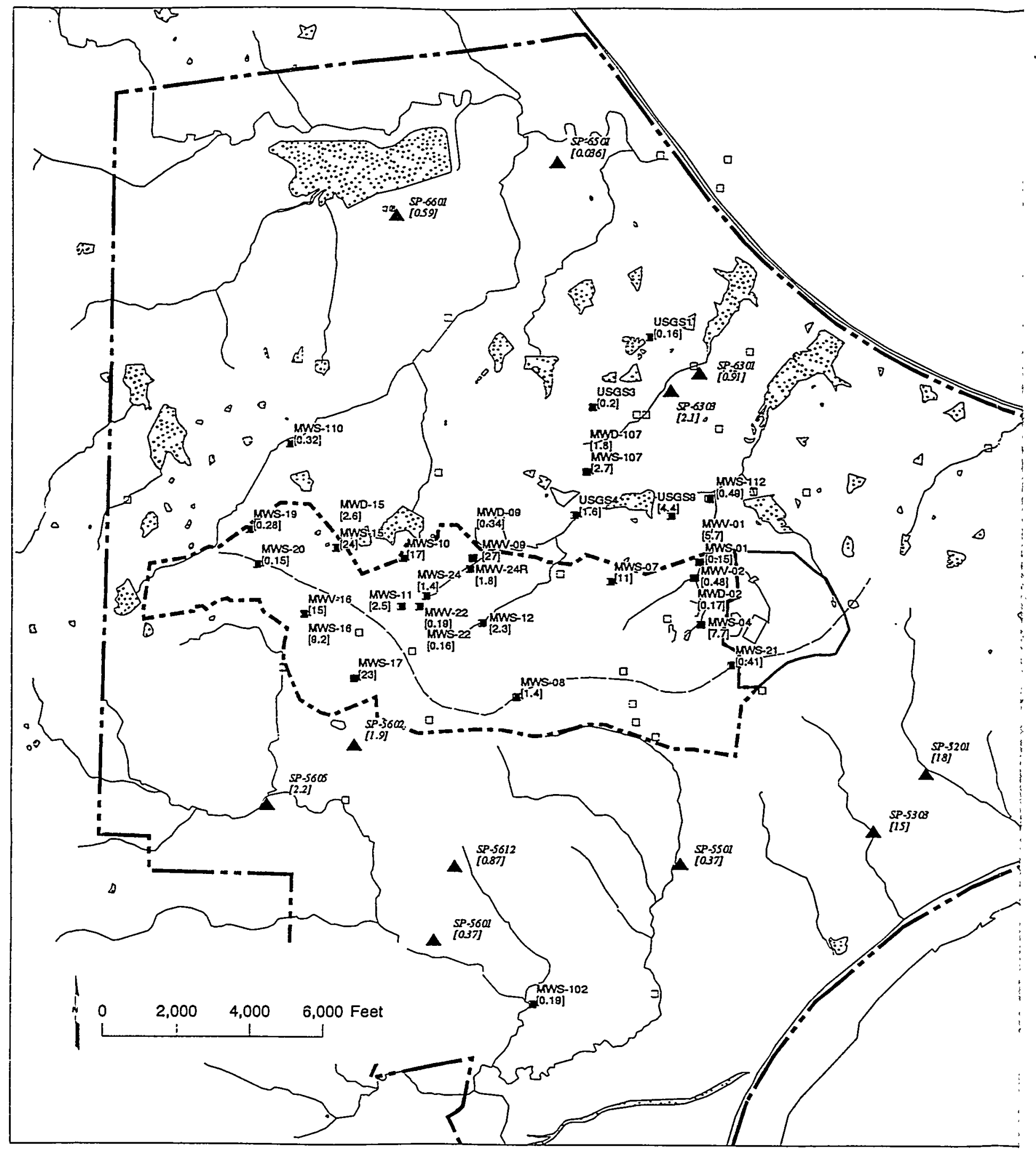

FIGURE 4.17 Distribution of 4-Amino-2,6-DNT at the Chemical Plant Area and the Ordnance Works A 


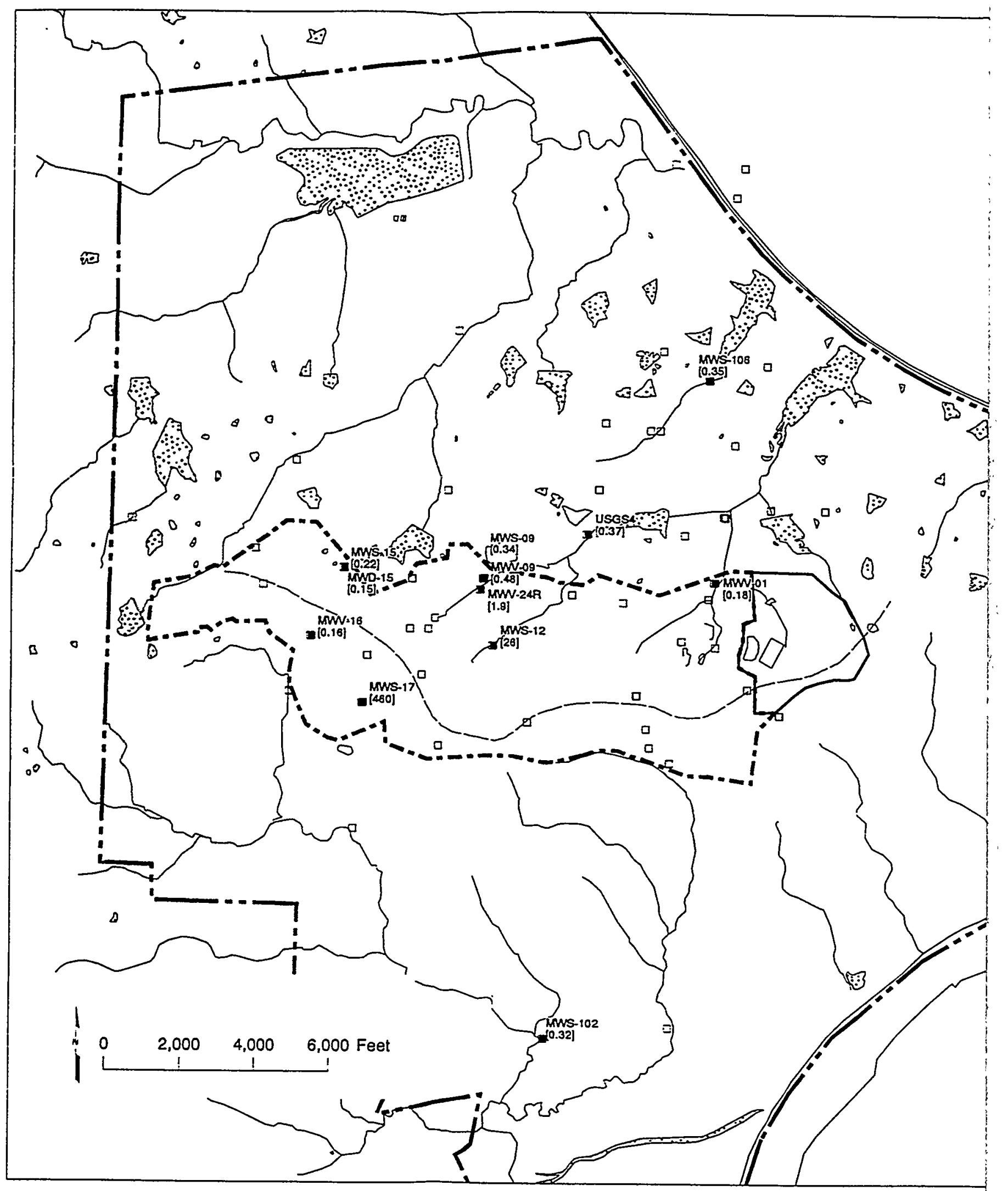

FIGURE 4.18 Distribution of 4-Nitrotoluene at the Chemical Plant Area and the Ordnance Work 


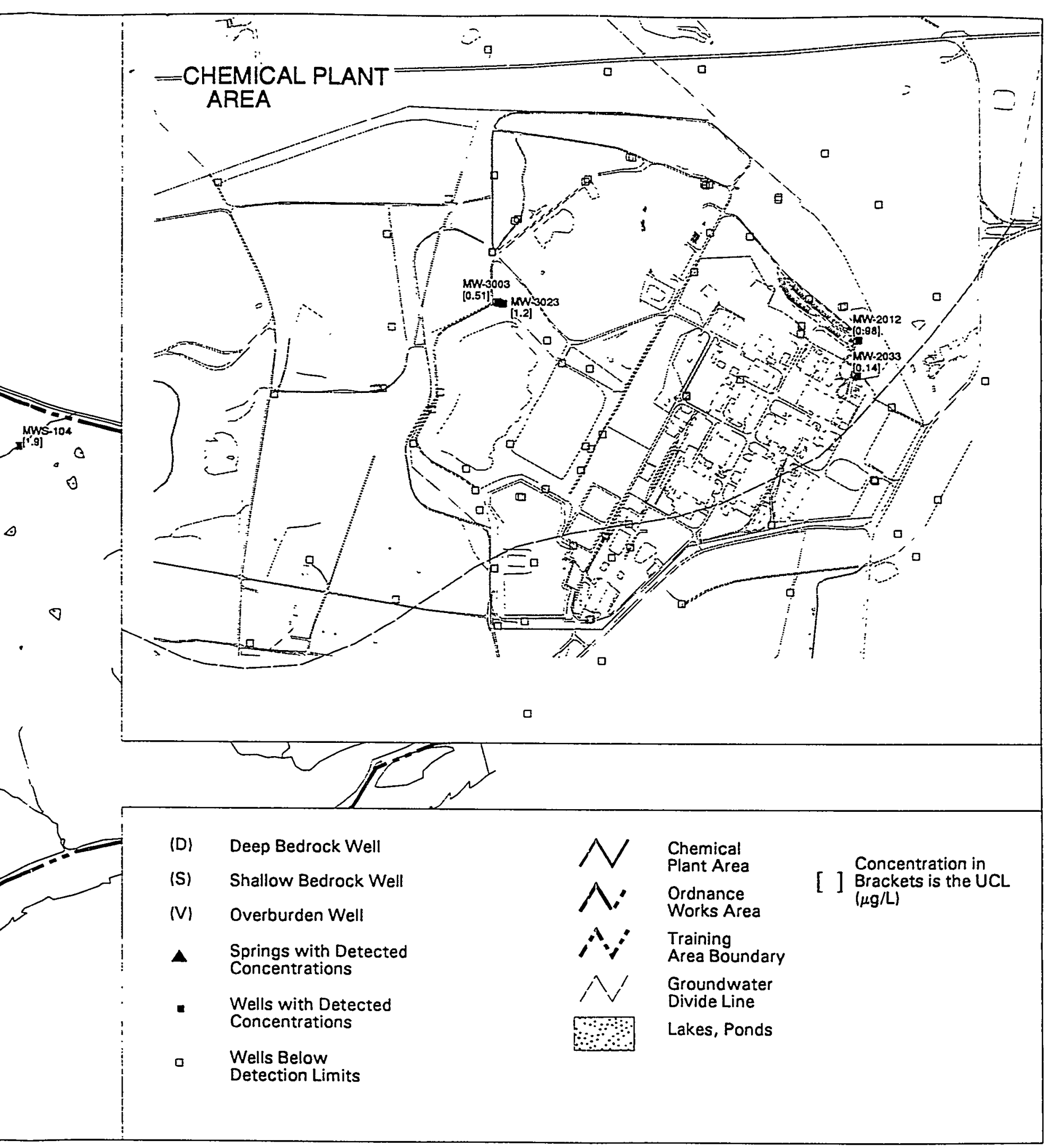




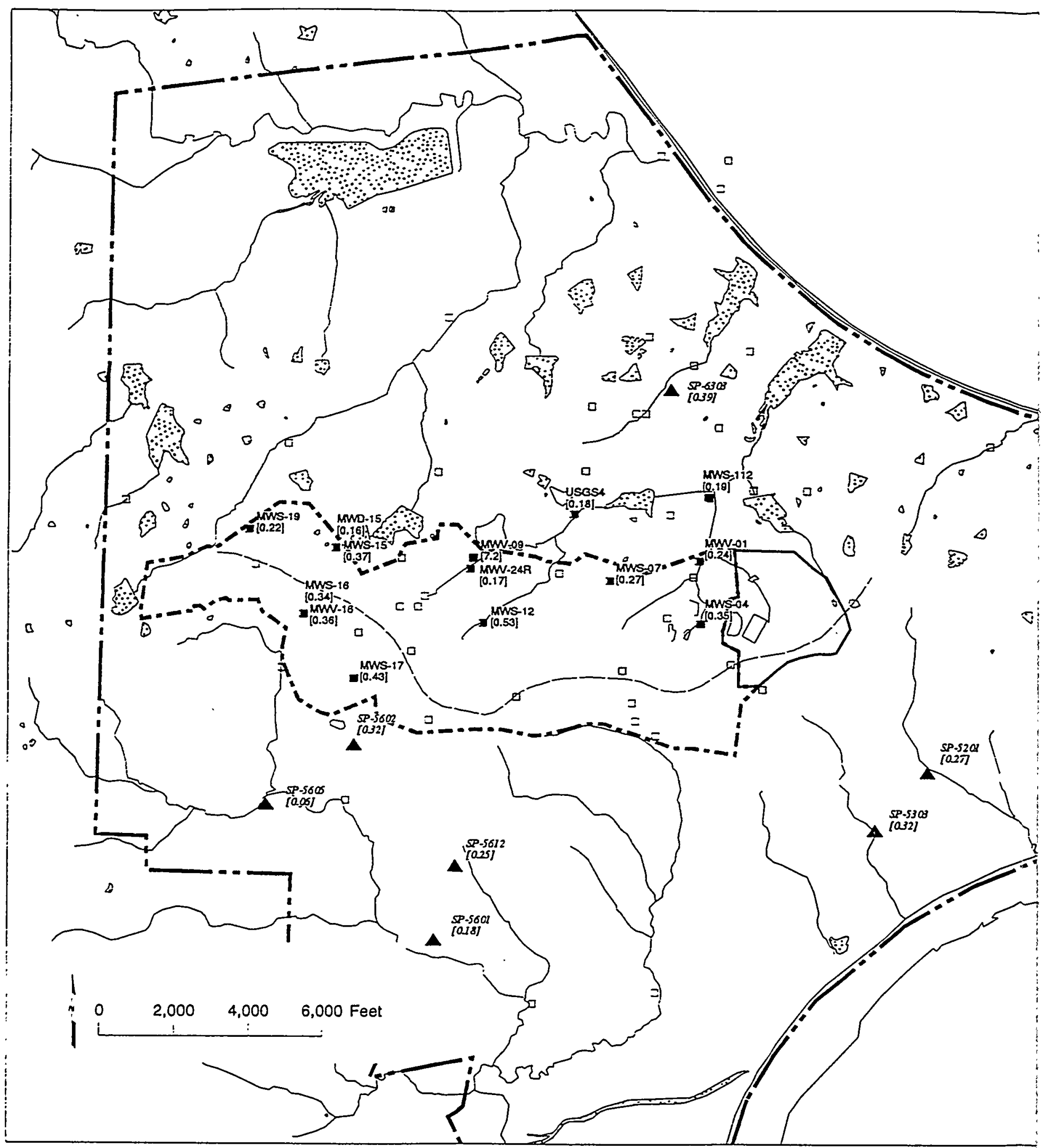

FIGURE 4.19 Distribution of Nitrobenzene at the Chemical Plant Area and the Ordnance Works Area 


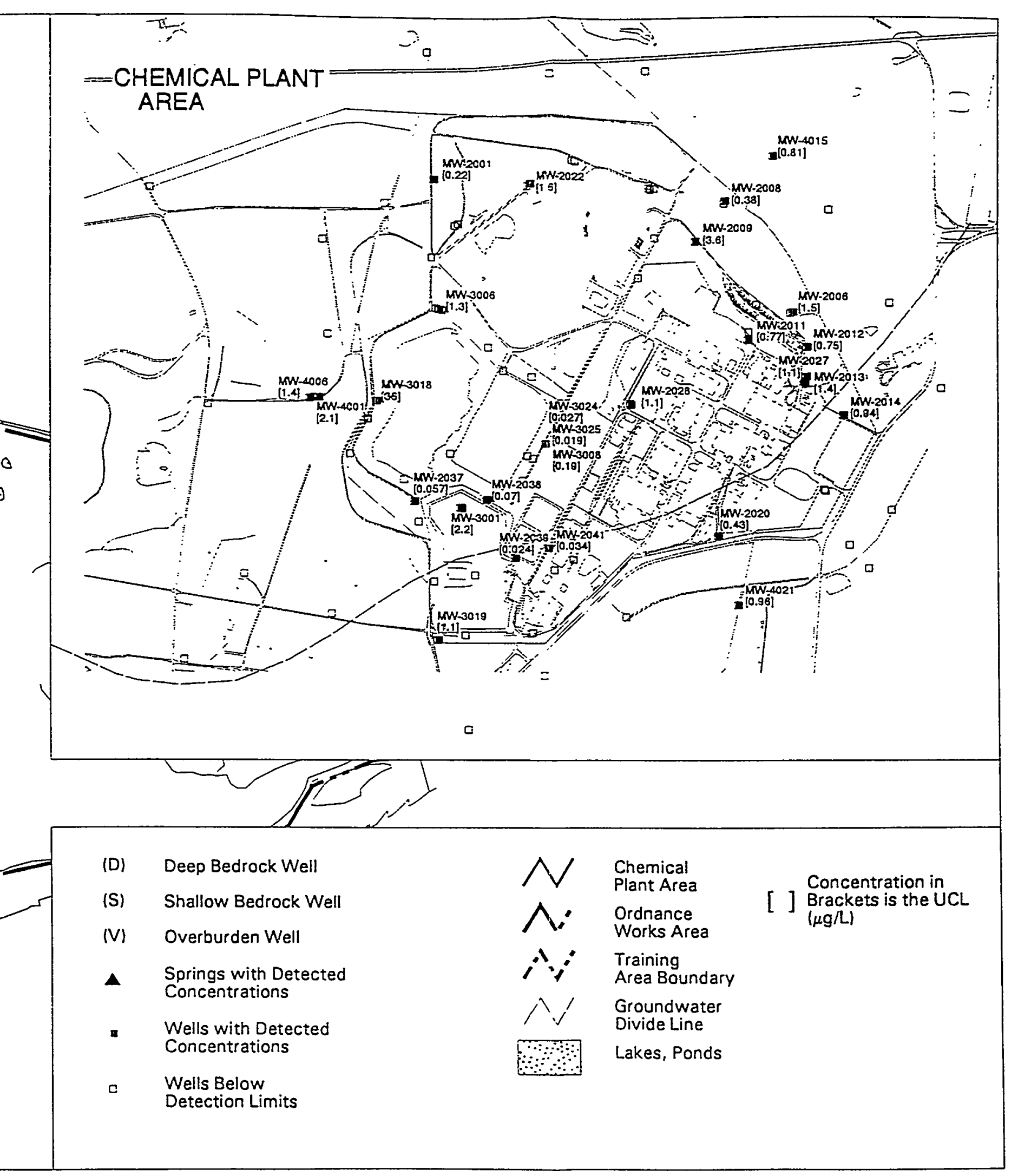




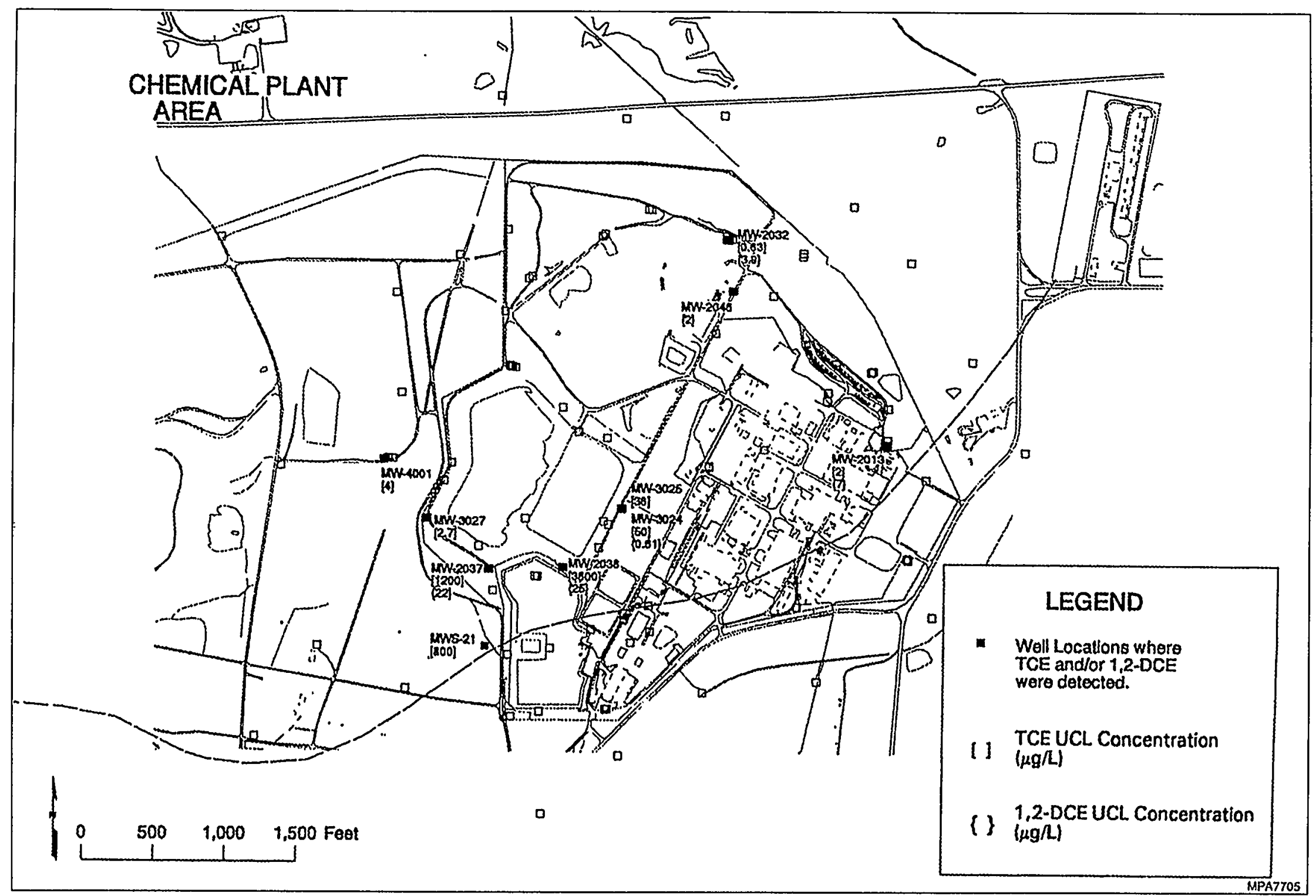

FIGURE 4.20 Distribution of TCE and 1,2-DCE at the Chemical Plant Area and the Ordnance Works Area 
located just west of the chemical plant area downgradient of the raffinate pits. However, the UCL for this well is biased high due to an anomalous uranium concentration detected during the early stages of the monitoring program. A similar outlier was also detected for MW-4005. Recent data collected for these wells are similar to background levels. Monitoring wells MW-3009 and MW-3008, located adjacent to the raffinate pits, were originally constructed as open hole wells and open to both the weathered and unweathered units. In 1994, these wells were both retrofitted. Monitoring well MW-3008 was retrofitted with MW-3024, which is only open to the unweathered unit. In addition, a new well, MW-3025, was installed adjacent to MW-3024 and is open only to the weathered unit. Similarly, MW-3009 was retrofitted with MW-3026, which is open only to the unweathered unit. A new well, MW-3027, was installed adjacent to MW-3026 and is open primarily to the unweathered unit. Concentrations in these retrofit wells have been much lower (maximum concentration of $12 \mathrm{pCi} / \mathrm{L}$ in the weathered wells and $6.5 \mathrm{pCi} / \mathrm{L}$ in the unweathered) than before the wells were retrofitted. Monitoring well MW-4024, located on the southeastern boundary of the chemical plant, is a new well installed to delineate the boundary of contamination flowing south from MW-4020. The maximum uranium level detected in this well was $60 \mathrm{pCi} / \mathrm{L}$, which may be a result of contamination from the bentonite grout used in the well installation (see Chapter 7). Concentrations in this well have declined since installation; the most recent data collected indicated low levels (i.e., 4.1 and $7.1 \mathrm{pCi} / \mathrm{L}$ ).

Recent data indicate the highest levels of uranium located in MW-3003, located downgradient of the raffinate pits. Only three wells (including MW-4024) have UCLs which are greater than the proposed MCL for uranium of $14 \mathrm{pCi} / \mathrm{L}$.

The contaminant distribution for lithium is shown in Figure 4.3. Lithium was detected throughout the groundwater system; higher concentrations were detected in the vicinity of, or downgradient from, the raffinate pits and the Ash Pond area. Monitoring wells with UCL lithium concentrations greater than $100 \mu \mathrm{g} / \mathrm{L}$ include MW-3003, MW-3007, MW-3008, MW-3023, MW-2002, MW-2003, MW-2005, MW-2037, MW-2038, and MWS-12 (Figure 4.3). All of these wells are open to the weathered unit, and the maximum lithium concentration detected from these wells was $1,500 \mu \mathrm{g} / \mathrm{L}$ in MW-3007. The UCL lithium concentrations on the training area (with the exception of MWS-21 and MWD-02) ranged from 1.2 to $21 \mu \mathrm{g} / \mathrm{L}$ in the weathered unit, from 2.2 to $26 \mu \mathrm{g} / \mathrm{L}$ in the unweathered unit, and from 1.1 to $20 \mu \mathrm{g} / \mathrm{L}$ in the deeper unit. Because lithium is associated with the ores that were processed at the chemical plant, it is reasonable that elevated levels of lithium would be detected downgradient of the raffinate pits where elevated levels of lithium have been found in the sludges and surface water. Lithium detected in other areas of the groundwater system may be representative of background levels. Although some wells contain high levels of lithium, these levels must be viewed in the context of the limited background data collected for lithium.

The contaminant distribution for molybdenum is shown in Figure 4.4. Molybdenum concentrations are also widespread in the groundwater system but unlike lithium and uranium, 
molybdenum was not detected in a large percentage of wells (only in about $30 \%$ of the wells). At the chemical plant area, the highest molybdenum concentrations were detected from MW-3023 (UCL concentration of $230 \mu \mathrm{g} / \mathrm{L}$ ), MW-3006 (UCL concentration of $390 \mu \mathrm{g} / \mathrm{L}$ ), and MW-3007 (maximum concentration of $120 \mu \mathrm{g} / \mathrm{L}$ ). Among the other wells on the chemical plant area, the UCL molybdenum concentrations ranged from 1.4 to $58 \mu \mathrm{g} / \mathrm{L}$. On the ordnance works area, the UCL molybdenum concentrations ranged from 0.50 to $25 \mu \mathrm{g} / \mathrm{L}$; the highest UCL concentration was from well MWS-112 (47 $\mu \mathrm{g} / \mathrm{L})$, which is located downgradient of the raffinate pits.

\subsubsection{Inorganic Anions}

Contaminant distributions for nitrate are depicted in Figures 4.5 and 4.6. As was done for uranium, a separate map is presented based on recent data (Figure 4.6). The recent data are believed to represent a more accurate presentation of current contamination levels. Wells that are considered to be impacted are designated in the distribution maps; these wells were determined on the basis of data evaluation, source areas, the MCL for nitrate $(10 \mathrm{mg} / \mathrm{L})$, and groundwater flow.

Very high levels of nitrate are present in areas near the raffinate pits and Ash Pond; the highest nitrate levels were detected from wells MW-3003 (UCL of 46,000 mg/L) and MW-3007 (UCL of 5,300 mg/L). The UCL for MW-3003 is exceptionally high because of an anomalous, high concentration detected prior to 1990. In areas where nitrate is elevated, concentrations tend to decrease with depth. At the chemical plant area, nitrate levels in wells open to the unweathered unit were all below the nitrate MCL concentration of $10 \mu \mathrm{g} / \mathrm{L}$, with the exception of four wells; MW-3024, MW-3026, MW-3006, and MW-4012 (Figure 4.5). Recent data indicate background levels of nitrate in MW-4012. The extent of nitrate contamination is primarily limited to the chemical plant area; contamination also extends beyond the site boundaries to the north and west. Wells on the middle and western portions of the training area have very low levels of nitrate, and are not considered to be impacted.

The contaminant distribution for sulfate is shown in Figure 4.7. Sulfate contamination is widespread throughout the groundwater system. Ten wells had UCL sulfate concentrations greater than the sulfate SMCL of $250 \mathrm{mg} / \mathrm{L}$. Two of these wells, MWV-13 (830 mg/L) and MWS-13 (750 mg/L), are located on the ordnance works area about 50 yards downgradient of Sellite Plant 2. Wells on the chemical plant area and the adjacent area for which the UCL for sulfate exceeded the sulfate SMCL concentration included MW-3013 (830 mg/L), MW-4012 (1,400 mg/L), MW-2017 (850 mg/L), MW-2034 (540 mg/L), MW-3007 (610 mg/L), MW-3023 (350 m/L), MW-4021 (280 mg/L), and MW-4024 (680 mg/L) (Figure 4.7).

The contaminant distribution for chloride is shown in Figure 4.8. Chloride contamination in groundwater is generally low; higher concentrations were found predominately in wells open to the weathered unit near the eastern boundary of the chemical plant area. The highest levels were 
found in MW-2006 (280 mg/L), MW-2008 (190 mg/L), MW-2012 (70 mg/L) and MW-2017 $(280 \mathrm{mg} / \mathrm{L})$. Chloride levels on the ordnance works area are low.

\subsubsection{Nitroaromatic Compounds}

The distribution of nitroaromatic compounds in groundwater beneath the chemical plant and ordnance works areas is shown in Figures 4.9 to 4.19. Nitroaromatics do not appear to be distributed throughout the groundwater system but rather occur sporadically at low levels across the system; higher levels generally occur in the overburden and weathered units. Within the overburden unit, the highest levels of nitroaromatic contamination were found primarily in MW-3018 and MWV-09. The highest UCL concentrations of the primary nitroaromatic compounds were estimated for well MW-3018, which is located on the chemical plant area $(80 \mu \mathrm{g} / \mathrm{L} 2,4-\mathrm{DNT} ; 1,100 \mu \mathrm{g} / \mathrm{L}$ 2,6-DNT; and $31 \mu \mathrm{g} / \mathrm{L}$ nitrobenzene). Lower UCL concentrations were detected in MWV-09 ( $24 \mu \mathrm{g} / \mathrm{L}$ 2,4-DNT; $5.4 \mu \mathrm{g} / \mathrm{L}$ 2,6-DNT; and $7.2 \mu \mathrm{g} / \mathrm{L}$ nitrobenzene). Well MWV-09 also had the highest UCL concentrations of 2-amino-4,6-DNT $(33 \mu \mathrm{g} / \mathrm{L})$ and 4-amino-2,6-DNT $(27 \mu \mathrm{g} / \mathrm{L})$.

Within the weathered unit, the most frequently detected nitroaromatic compounds were 2,4-DNT; 2,6-DNT; 1,3,5-TNB; 2,4,6-TNT; and the amino-DNT degradation compounds. The distribution patterns are relatively similar among the DNT compounds (Figures 4.9 to 4.19 ). The highest concentrations of these compounds were found at the chemical plant in the Frog Pond area and in the central portion of the training area. The highest UCL concentrations were found in MWS-17 (170 $\mu \mathrm{g} / \mathrm{L}$ 2,4-DNT and $180 \mu \mathrm{g} / \mathrm{L} 2,6-\mathrm{DNT})$. At the chemical plant area, the highest concentrations were detected in the Frog Pond area in MW-2013 (96 $\mu \mathrm{g} / \mathrm{L} 2,4-\mathrm{DNT})$ and MW-2009 $(130 \mu \mathrm{g} / \mathrm{L}$ 2,6-DNT). These wells are located where both wash and grainer houses previously existed. On the training area, the highest UCL concentrations of the amino-DNT degradation compounds were found in MWS-15 (14 $\mu \mathrm{g} / \mathrm{L}$ 2-amino-4,6-DNT and $24 \mu \mathrm{g} / \mathrm{L}$ 4-amino-2,6-DNT) and MW-4001 (18 $\mu \mathrm{g} / \mathrm{L}$ 2-amino-4,6-DNT and $23 \mu \mathrm{g} / \mathrm{L}$ 4-amino-2,6-DNT).

The highest concentrations of 1,3,5-TNB (Figure 4.9) and 2,4,6,-TNT (Figure 4.11) were found in wells at the training area and at the chemical plant area in the vicinity of Frog Pond. The highest UCL for 1,3,5,-TNB was estimated for MW-4001 (57 $\mu \mathrm{g} / \mathrm{L})$; the highest UCL for 2,4,6,-TNT was estimated for MW-2030 (19 $\mathrm{gg} / \mathrm{L})$.

Highest concentrations of the remaining nitroaromatic degradation products were detected primarily in wells MWS-12 and MWS-17, which are located on the central portion of the training area. The UCL concentrations of 2-NT, 3-NT, and 4-NT were $170 \mu \mathrm{g} / \mathrm{L}, 130 \mu \mathrm{g} / \mathrm{L}$, and $460 \mu \mathrm{g} / \mathrm{L}$, respectively, at MWS-17, and $30 \mu \mathrm{g} / \mathrm{L}, 38 \mu \mathrm{g} / \mathrm{L}$, and $26 \mu \mathrm{g} / \mathrm{L}$, respectively, at MWS- 12 .

In the unweathered and deeper units of the aquifer, nitroaromatic compounds were detected at much lower frequencies and concentrations than in the more shallow units. 


\subsubsection{Volatile Organic Compounds}

Sampling of VOCs in groundwater was initiated in response to detection of hexane during workplace monitoring in the headspace of sludge tanks at the Chemical StabilizationlSolidification Pilot Plant, to determine whether contamination in sludge may have migrated into groundwater. Two monitoring wells near the raffinate pits (i.e., MW-3025 and MW-2038) were sampled. Results indicated the presence of trichloroethylene (TCE) and 1,2-dichloroethene (1,2-DCE); no other VOCs were detected. A sitewide sampling was conducted starting in mid-1996 for VOCs in monitoring wells and three springs (i.e., Burgermeister Spring, and SP-5303 and SP-5304 in the Southeast Drainage) at the chemical plant area. TCE was detected in four of the 45 wells monitored. A maximum concentration of $9,000 \mu \mathrm{g} / \mathrm{L}$ was detected in MW-2038. Estimated values below the detection limit were also indicated for three other wells. Concentrations of 1,2-DCE were detected in two wells in the vicinity of the raffinate pits; a maximum concentration of $39 \mu \mathrm{g} / \mathrm{L}$ was detected in MW-2038. Samples from MW-2013, located near Frog Pond, also contained 1,2-DCE at levels ranging from 7 to $16 \mu \mathrm{g} / \mathrm{L}$. Estimated values ranging from 1 to $5 \mu \mathrm{g} / \mathrm{L}$ were reported for two additional wells. Four newly installed compliance wells for the disposal cell were also monitored for VOCs as part of the baseline sampling program for the disposal cell. An estimated 1,2-DCE value of $2 \mu \mathrm{g} / \mathrm{L}$ was reported for one of the wells (MW-2046).

In 1997, six wells located southwest of the chemical plant area were added to the monitoring program. TCE was detected in MWS-21, located on the training area adjacent to the southwestern boundary of the chemical plant area. No other VOCs were detected in groundwater. In addition, no VOCs were detected in the springs. The presence of TCE and DCE is believed to be a recent occurrence; sampling for VOCs before 1990 indicated only one low-level detection of TCE in MW-2030 (7 $\mu \mathrm{g} / \mathrm{L})$.

The distribution of contamination in groundwater is illustrated in Figure 4.20 for TCE and 1,2-DCE. In general, detections were limited to the area south and southeast of Raffinate Pits 3 and 4. The contamination is contained in the saturated overburden and weathered portion of the aquifer and appears to be migrating to the southwest. On the basis of the monitoring data, it appears that additional releases are not now occurring. Monthly sampling of groundwater wells in the vicinity of the raffinate pits (including wells on the southwestern portion of the training area) is planned through the end of 1997 to monitor the migration of these compounds. The springs (e.g., Burgermeister Spring, SP-6303, SP-5303, and SP-5304) will also continue to be monitored.

Possible sources of groundwater contamination include waste drums recently removed from the southeastern corner of Raffinate Pit 4 and contaminated soils and sludges in Raffinate Pits 3 and 4. Oil residues from some of the drums contained TCE at levels up to $280,000 \mu \mathrm{g} / \mathrm{kg}$. Sampling of soil and sludge in the pits has not indicated the presence of any significant source of VOC contamination; two samples from Raffinate Pit 3 indicated low levels of TCE, ranging from 12 to $23 \mu \mathrm{g} / \mathrm{L}$. It is suspected that TCE occurs in isolated pockets, and it is possible that the source may 
already have been depleted. Additional sampling with a soil gas technology was done to investigate the presence of remaining sources (MK-Ferguson Company and Jacobs Engineering Group 1997b). Soil gas within the overburden material was analyzed to determine if the soils or underlying groundwater is contaminated with TCE. The results of the soil gas sampling did not identify the presence of remaining sources that would have contributed to the groundwater contamination. A few low-level concentrations of TCE were detected at five locations on the training area, west and south of the raffinate pits. Concentrations ranged from 1.2 to $2.9 \mathrm{ppb}$. Soil samples were also collected in these locations for analysis in the laboratory. Volatiles were not detected in any of the samples. The soil gas technology was also employed to sample groundwater in areas where saturated overburden is present. Groundwater was obtained at only one location west of Raffinate Pit 4, and volatiles were not detected above the detection limit (i.e., 1 ppb).

\subsubsection{In Situ Sampling of Groundwater at the Southeast Drainage}

Groundwater contamination in the Southeast Drainage (5300 drainage) was evaluated using in situ data collected from six locations in the lower portion of the drainage. The locations of the in situ samples are depicted in Figure 4.22, and the results of the in situ groundwater sampling are presented in Table 4.8. Samples were collected at the depth where water was first encountered and at depth; concentrations detected in the samples were compared with levels detected at the nearest discharge points, Springs 5303 and 5304 (Figures 3.9 and 4.21).

Uranium concentrations detected in the shallow groundwater samples (at the depth where groundwater was first encountered) ranged from 24 to $160 \mathrm{pCi} / \mathrm{L}$. In deeper samples, lower levels of uranium were detected and ranged from 2.1 to $80 \mathrm{pCi} / \mathrm{L}$. These concentrations were lower than the maximum concentrations but within the ranges detected in both Spring 5303 (67 to $370 \mathrm{pCi} / \mathrm{L}$ ) and Spring 5304 (40 to $310 \mathrm{pCi} / \mathrm{L}$ ). Sulfate was also detected in all samples; concentrations ranged between 30 and $220 \mathrm{mg} / \mathrm{L}$. Sulfate levels were higher than concentrations detected in Springs 5303 and 5304 (i.e., a maximum of $67 \mathrm{mg} / \mathrm{L}$ ), but were similar to levels detected further upstream in the drainage at Spring 5302.

Nitroaromatic compounds were only sampled at depths where groundwater was first encountered (Table 4.8). The nitroaromatic compounds 2,4-DNT, 2,6-DNT, and the amino-DNT compounds were detected in all samples at low levels ranging from 0.0080 to $3.3 \mu \mathrm{g} / \mathrm{L}$. The compounds 1,3,5-TNB, 1,3-DNB, and 2,4,6-TNT were detected in three samples at levels ranging from $0.024 \mu \mathrm{g} / \mathrm{L}$ for $2,4,6-\mathrm{TNT}$ to $0.12 \mu \mathrm{g} / \mathrm{L}$ for $1,3,5-\mathrm{TNB}$ and $1,3-\mathrm{DNB}$. The concentrations were within or lower than the range of concentrations measured in Springs 5303 and 5304. For these springs, the highest concentrations were detected in Spring 5303; the maximum concentration for 2,4,6-TNT was $280 \mu \mathrm{g} / \mathrm{L}$, and for both 2,4-DNT and 2,6-DNT it was $11 \mu \mathrm{g} / \mathrm{L}$. Nitrobenzene and the nitrotoluene compounds were not detected in any of the in situ samples. 


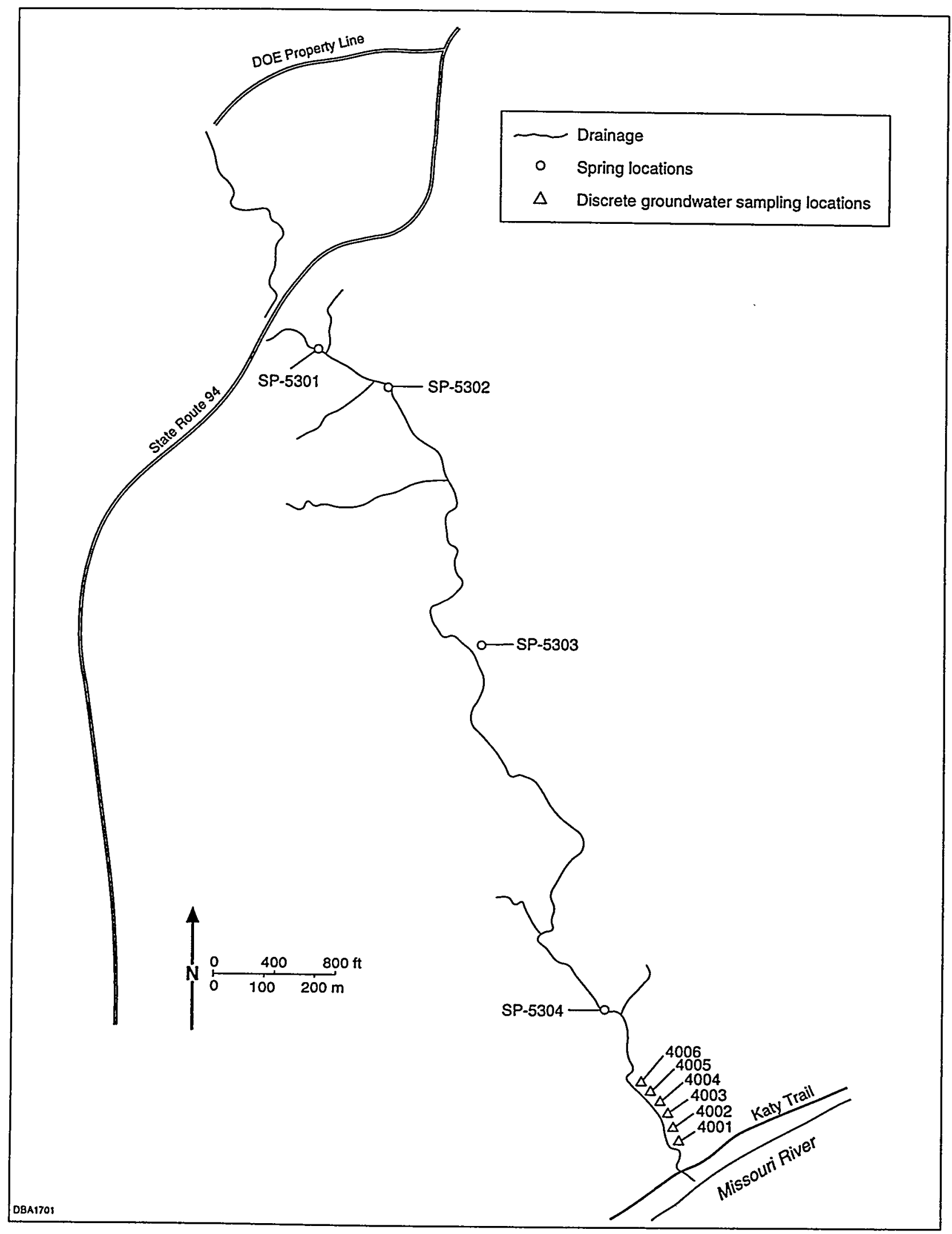

FIGURE 4.21 Location of In Situ Groundwater Sampling Sites in the Southeast Drainage 
TABLE 4.8 Radiological and Chemical Concentrations for In Situ Groundwater Samples from the Southeast Drainage

\begin{tabular}{|c|c|c|c|c|c|c|}
\hline Parameter & $\begin{array}{l}\text { IS }-4001^{a} \\
(15.0 \mathrm{ft})\end{array}$ & $\begin{array}{l}\text { IS }-4001 \mathrm{~B}^{\mathrm{b}} \\
(34-38 \mathrm{ft})\end{array}$ & $\begin{array}{c}\text { IS- } 4002^{\mathrm{a}} \\
(9.0 \mathrm{ft})\end{array}$ & $\begin{array}{l}\text { IS- } 4002 \mathrm{~B}^{\mathrm{b}} \\
(28-31.5 \mathrm{ft})\end{array}$ & $\begin{array}{c}\text { IS }-4003^{\mathrm{a}} \\
(5.0 \mathrm{ft})\end{array}$ & $\begin{array}{l}\text { IS }-4003 \mathrm{~B}^{\mathrm{b}} \\
(7.5-9.0 \mathrm{ft})\end{array}$ \\
\hline \multicolumn{7}{|l|}{ Radiological (pCi/L) } \\
\hline Uranium & 87 & 2.1 & 140 & 6.1 & 160 & 71 \\
\hline \multicolumn{7}{|l|}{ Metals $(\mu \mathrm{g} / \mathrm{L})$} \\
\hline Antimony & $\mathrm{ND}^{\mathrm{c}}$ & 3.2 & ND & ND & 6.2 & ND \\
\hline Arsenic & ND & ND & ND & ND & ND & 3.4 \\
\hline Cadmium & ND & ND & ND & ND & ND & ND \\
\hline Lithium & 14 & 11 & 18 & 8.0 & 6.9 & 6.4 \\
\hline Lead & ND & ND & ND & ND & ND & ND \\
\hline Nickel & ND & ND & ND & ND & ND & ND \\
\hline Molybdenum & 30 & 67 & 38 & 47 & 30 & 75 \\
\hline Thallium & ND & ND & ND & ND & $\mathrm{ND}$ & ND \\
\hline \multicolumn{7}{|l|}{ Anions (mg/L) } \\
\hline Nitrate & ND & $-d$ & ND & - & 0.16 & - \\
\hline Sulfate & 53 & 79 & 53 & 66 & 40 & 55 \\
\hline \multicolumn{7}{|l|}{ Nitroaromatics $(\mu \mathrm{g} / \mathrm{L})$} \\
\hline 1,3,5-TNB & ND & - & 0.04 & - & ND & - \\
\hline 1,3-DNB & ND & - & 0.12 & - & ND & - \\
\hline $2,4,6-\mathrm{TNT}$ & ND & - & 0.098 & - & 0.024 & - \\
\hline $2,4-\mathrm{DNT}$ & 0.11 & - & 3.3 & - & 0.11 & - \\
\hline 2,6-DNT & 0.0080 & - & 0.53 & - & 0.019 & - \\
\hline 2-Amino-4,6-DNT & 0.19 & - & 0.50 & - & 0.49 & - \\
\hline 4-Amino-2,6-DNT & 0.32 & - & 0.95 & - & 0.87 & - \\
\hline 2-Nitrotoluene & ND & - & ND & - & ND & - \\
\hline 3-Nitrotoluene & ND & - & ND & - & ND & - \\
\hline 4-Nitrotoluene & ND & - & ND & - & ND & - \\
\hline Nitrobenzene & ND & - & ND & - & ND & - \\
\hline
\end{tabular}


TABLE 4.8 (Cont.)

\begin{tabular}{|c|c|c|c|c|c|c|}
\hline Parameter & $\begin{array}{c}\text { IS }-4004^{a} \\
(6.0 \mathrm{ft})\end{array}$ & $\begin{array}{c}\text { IS }-4004 \mathrm{~B}^{\mathrm{b}} \\
(20.5 \mathrm{ft})\end{array}$ & $\begin{array}{c}\text { IS }-4005^{\mathrm{a}} \\
(8.0 \mathrm{ft}) \\
\end{array}$ & $\begin{array}{l}\text { IS }-4005 B^{b} \\
(34-37 f t)\end{array}$ & $\begin{array}{l}\text { IS-4006 } \\
(15.0 \mathrm{ft})\end{array}$ & $\begin{array}{l}\text { IS-4006B b } \\
(28-30 \mathrm{ft})\end{array}$ \\
\hline \multicolumn{7}{|l|}{ Radiological (pCi/L) } \\
\hline Uranium & 137 & 9.1 & 32 & 80 & 24 & 27 \\
\hline \multicolumn{7}{|l|}{ Metals ( $\mu g / L)$} \\
\hline Antimony & 3.1 & 12 & 4.4 & - & ND & - \\
\hline Arsenic & ND & 4.7 & ND & - & 6.1 & - \\
\hline Cadmium & ND & ND & ND & - & ND & - \\
\hline Lithium & 5.0 & ND & 7.5 & - & 8.0 & - \\
\hline Lead & ND & ND & ND & - & 6.2 & - \\
\hline Nickel & ND & ND & ND & - & ND & - \\
\hline Molybdenum & ND & 20 & 14 & - & 38 & - \\
\hline Thallium & ND & ND & ND & - & ND & - \\
\hline \multicolumn{7}{|l|}{ Anions (mg/L) } \\
\hline Nitrate & ND & - & 0.46 & - & ND & - \\
\hline Sulfate & 42 & 30 & 40 & - & 220 & - \\
\hline \multicolumn{7}{|l|}{ Nitroaromatics $(\mu \mathrm{g} / \mathrm{L})$} \\
\hline 1,3,5-TNB & ND & - & 0.12 & - & ND & - \\
\hline 1,3-DNB & ND & - & ND & - & ND & - \\
\hline $2,4,6-\mathrm{TNT}$ & ND & - & 0.053 & - & ND & - \\
\hline 2,4-DNT & 0.32 & - & 0.25 & - & 0.16 & - \\
\hline 2,6-DNT & 0.12 & - & 0.31 & - & 0.0070 & - \\
\hline 2-Amino-4,6-DNT & 0.52 & - & 0.36 & - & 0.036 & - \\
\hline 4-Amino-2,6-DNT & 0.91 & - & 0.52 & - & 0.055 & - \\
\hline 2-Nitrotoluene & ND & - & ND & - & ND & - \\
\hline 3-Nitrotoluene & ND & - & ND & - & ND & - \\
\hline 4-Nitrotoluene & ND & - & $\mathrm{ND}$ & - & ND & - \\
\hline Nitrobenzene & ND & - & ND & - & ND & - \\
\hline
\end{tabular}

a The sample was collected at the depth where the groundwater was first encountered; the sample depth is in parentheses.

b The sample was collected at a depth greater than where the groundwater was first encountered; the sample depth is in parentheses.

c $\mathrm{ND}=$ not detected.

d A hyphen indicates that the parameter was not analyzed. 
The concentrations of the metals in the groundwater are consistent with levels that are discharging from the springs within the drainage. Thallium, nickel, and cadmium were not detected in the in situ samples; antimony, arsenic, and lead were detected in less than $40 \%$ of the samples and at only very low concentrations. Only two metals were detected at concentrations higher than levels detected in the springs. Within the groundwater, lithium and molybdenum were detected at maximum concentrations of $18 \mu \mathrm{g} / \mathrm{L}$ and $76 \mu \mathrm{g} / \mathrm{L}$, respectively, which are a factor of 2 higher than the maximum concentrations detected in the springs. The detected concentrations of lithium and molybdenum are within the range of detected concentrations in site groundwater.

The results of the in situ groundwater sampling indicate that, in general, groundwater concentrations are similar to or less than concentrations discharging from the lower springs in the Southeast Drainage. The major contaminant in groundwater is uranium, with low levels of nitroaromatic compounds, lithium, molybdenum, and sulfate. The probable sources of groundwater contamination are the contaminated sediments along the length of the drainage.

To better delineate the extent of uranium contamination in the area, a monitoring well was installed in the lower portion of the Southeast Drainage in May 1997 (MK-Ferguson Company and Jacobs Engineering Group 1997a). Quarterly sampling and analysis for site contaminants are planned over the next year. Sampling will also include thallium, at a detection limit of $1.0 \mu \mathrm{g} / \mathrm{L}$, to resolve issues with the in situ sampling that used a detection limit of $5.0 \mu \mathrm{g} / \mathrm{L}$. The first quarter sampling was conducted on May 12,1997 . Results indicated very low levels of nitrate $(0.12 \mathrm{mg} / \mathrm{L})$. Thallium, uranium, nitroaromatic compounds, TCE, and 1,2-DCE were not detected. Subsequent sampling for this monitoring well will be reported in the annual site monitoring report and/or the FS, as appropriate.

\subsection{SPRINGS}

Fifteen springs were sampled as part of the joint sampling for the groundwater remedial investigation and included 5101, 5201, 5303, 5402, 5501, 5504, 5601, 5602, 5605, 5612, 6301, $6303,6306,6501$, and 6601. The results of the 1995 joint sampling are presented in Appendix C. Table 4.9 summarizes these data, together with previous data collected since 1987 for the fifteen springs.

For naturally occurring contaminants, the UCL and range of concentrations were compared with the statistically derived background concentrations calculated for the weathered unit of the Burlington-Keokuk Limestone. This comparison indicated concentrations above background for chloride, nitrate, sulfate, antimony, cadmium, iron, lithium, manganese, mercury, molybdenum, silver, and uranium.

Antimony was detected infrequently, although values ranged up to $95 \mu \mathrm{g} / \mathrm{L}$ at Spring 5601 . several of these samples were filtered prior to analysis and, therefore, are currently being evaluated to determine if data should be rejected because of filter contamination as discussed in Section 4.1. 
TABLE 4.9 Summary of Spring Data ${ }^{a}$

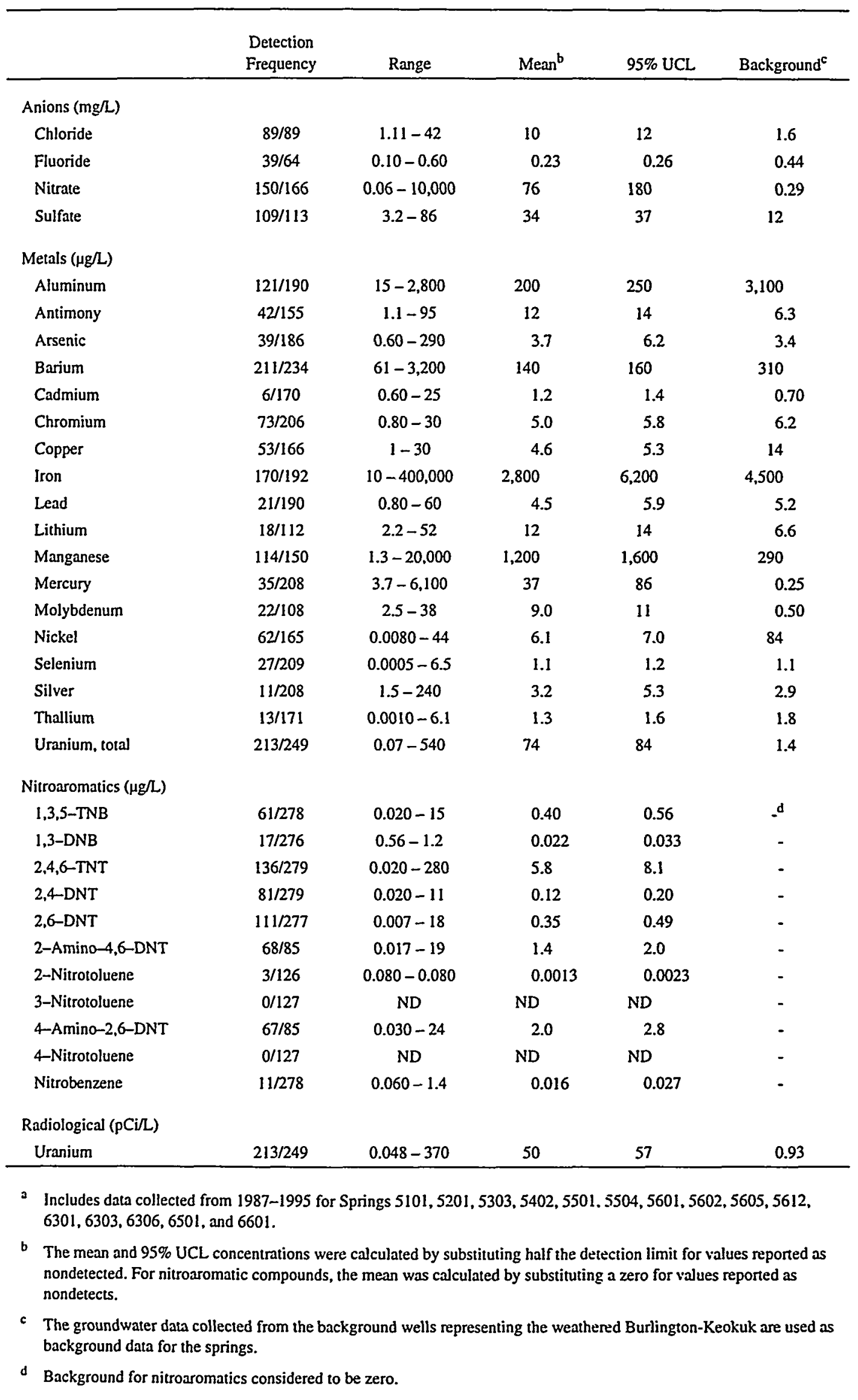


Arsenic was detected in about $20 \%$ of the samples but was found in $62 \%$ of the samples taken at Spring 6306; values ranged from 0.6 to $290 \mu \mathrm{g} / \mathrm{L}$. With the exception of the maximum arsenic concentration of $290 \mu \mathrm{g} / \mathrm{L}$ detected from Well 6306 in 1996, arsenic concentrations were all less than $16 \mu \mathrm{g} / \mathrm{L}$. This suggests that the single, maximum reported concentration is an outlier. Excluding this maximum concentration from the estimation of the UCL concentration, arsenic was below the background $95 \%$ UCL concentration.

Cadmium was detected once at Springs 5201, 5602, and 6301 and three times at Spring 6306; concentrations ranged from 0.60 to $25 \mu \mathrm{g} / \mathrm{L}$. Iron was detected in $88 \%$ of the samples. Although the UCL iron concentrations exceeded the background 95\% UCL level, this was due to a single high concentration $(400,000 \mu \mathrm{g} / \mathrm{L})$ detected at Spring 6306 in 1991. Including this data point, the iron UCL slightly exceeded the background level (by a factor of about 1.3). Excluding this single data point results in the UCL iron value being less than the background $95 \%$ UCL concentration by a factor of about 5 ( $860 \mu \mathrm{g} / \mathrm{L}$ for the springs and $4,500 \mu \mathrm{g} / \mathrm{L}$ for background).

Lithium was detected infrequently (only 16\% of all samples) at Springs 5303 and 5501 and primarily from the springs in the 6300 drainage: the highest concentration was reported from Burgermeister Spring (6301) at $52 \mu \mathrm{g} / \mathrm{L}$. Manganese was detected frequently ( $76 \%$ of all samples) in all springs sampled; the highest concentrations $(20,000 \mu \mathrm{g} / \mathrm{L})$ were reported from Spring 6306. Mercury was detected in $17 \%$ of the samples, primarily only at Springs 5602, 6301, 6303, 6306, 6501 , and 6601 . The highest concentrations were reported from springs located in the 5600 and 6300 drainages. Mercury concentrations ranged from $0.37 \mu \mathrm{g} / \mathrm{L}$ to $6,100 \mu \mathrm{g} / \mathrm{L}$; the UCL concentration exceeded the background level by a factor of about 340 . This magnitude of exceedance, however, is misleading and is due to a single high mercury concentration of $6,100 \mu \mathrm{g} / \mathrm{L}$ detected in Spring 6306. Excluding this value, the maximum reported mercury concentration was $340 \mu \mathrm{g} / \mathrm{L}$, with a mean value of $8 \mu \mathrm{g} / \mathrm{L}$. The UCL concentration $(12 \mu \mathrm{g} / \mathrm{L})$ exceeded background $(0.25 \mu \mathrm{g} / \mathrm{L})$ by a factor of 48. Molybdenum was detected in a few springs from the 5300 and 6300 drainages at concentrations up to $38 \mu \mathrm{g} / \mathrm{L}$. Selenium and silver were detected in only $5 \%$ and $8 \%$, respectively, of the spring samples and were absent from most springs. The UCL concentrations of these metals only slightly exceeded background levels $(1.2 \mu \mathrm{g} / \mathrm{L}$ versus $1.1 \mu \mathrm{g} / \mathrm{L})$ for selenium and $(5.3 \mu \mathrm{g} / \mathrm{L}$ versus $2.9 \mu \mathrm{g} / \mathrm{L}$ ) for silver. Elevated levels of iron were detected in many of the springs. Levels of iron exceeded the SMCL of $300 \mu \mathrm{g} / \mathrm{L}$ at 10 springs. Levels of manganese exceeded the SMCL of $50 \mu \mathrm{g} / \mathrm{L}$ at six springs. For comparison, the statistically derived background levels for iron and manganese also exceed the SMCL

Uranium was detected in all springs at low concentrations except in the springs in the 5300 and 6300 drainages. Uranium concentrations ranged from 0.048 to $370 \mathrm{pCi} / \mathrm{L}$; the maximum uranium concentration was reported from Spring 5303 in the Southeast Drainage.

Nitrate was detected at levels ranging from 0.06 to $10,000 \mathrm{mg} / \mathrm{L}$. Springs with the highest average nitrate concentrations were 6301 (Burgermeister Spring) $(210 \mathrm{mg} / \mathrm{L})$ and $6303(21 \mathrm{mg} / \mathrm{L})$. 
Average concentrations at other springs ranged from 0.26 to $3.6 \mathrm{mg} / \mathrm{L}$. The high $95 \% \mathrm{UCL}$ $(180 \mathrm{mg} / \mathrm{L})$ estimated for nitrate was the result of a single high nitrate concentration of $10,000 \mathrm{mg} / \mathrm{L}$ reported from Spring 6301 in 1988. This value may be an outlier, since the next highest reported nitrate concentration is only $210 \mathrm{mg} / \mathrm{L}$, reported in 1991 from Spring 6301. This concentration is approximately 50 times less than the 1988 concentration. Excluding the 1988 concentration, the UCL concentration was $18 \mathrm{mg} / \mathrm{L}$, which is an order of magnitude less than the UCL estimated using the 1988 value. Sulfate was detected in all springs and in $96 \%$ of all samples; the highest concentrations were found in Springs 5101, 5201, 5303, 6301, and 6303. Chloride was detected in $100 \%$ of the spring samples; concentrations ranged from 1.1 to $42 \mathrm{mg} / \mathrm{L}$ (Table 4.9).

The highest nitroaromatic concentrations were detected at four locations: Spring 5201 (downstream of Burning Ground 1), Spring 5303 (Southeast Drainage), Spring 6301 (Burgermeister Spring), and Spring 5602 (south of the training area). Springs 5201 and 5303 had the highest nitroaromatic concentrations, with concentrations of 120 and $280 \mu \mathrm{g} / \mathrm{L}$, respectively, for 2,4,6-TNT. Concentrations of other nitroaromatics detected in these four springs ranged from $3 \mu \mathrm{g} / \mathrm{L}$ to $17 \mu \mathrm{g} / \mathrm{L}$. Six nitroaromatic compounds (1,3,5-TNB; 2,4,6-TNT; 2,4-DNB; 2,6-DNB; and the two amino-DNT compounds) were detected frequently at 11 spring locations. All six of these nitroaromatic compounds were also detected at Springs 5201, 5303, 5602, 5605, 6301 and 6303. At Springs 5501, 5601,5612 , and 6601, all nitroaromatics except 1,3-TNB were detected in collected samples.

Nitrobenzene, 2-nitrotoluene, 3-nitrotoluene, and 4-nitrotoluene were not detected in any of the springs sampled and were detected in fewer than $6 \%$ of all samples. Nitroaromatics were not detected in two of the 15 springs sampled (Springs 5101 and 5504), and only 2-amino-4,6-DNT and 4-amino-2,6-DNT have been detected at Spring 6501. Concentrations of 2,4,6-TNT and 2,6-DNT have been detected only twice in Spring 5402 at low levels $(0.09 \mu \mathrm{g} / \mathrm{L})$.

Three springs were also sampled for VOCs in August and October of 1996. The springs included Burgermeister Spring and two springs in the Southeast Drainage (5303 and 5304). No VOCs were detected in these springs. These springs (including 6303) will continue to be monitored monthly for VOCs through the end of 1997.

\subsection{SUMMARY OF CONTAMINATION}

In summary, the site contaminants identified for groundwater include uranium, lithium, molybdenum, chloride, nitrate, sulfate, nitroaromatic compounds, trichloroethylene, and 1,2-dichloroethylene. For groundwater beneath the chemical plant area and the ordnance works area, the greatest extent and highest concentrations of contaminants are in the overburden and weathered units. Groundwater in the vicinity of the raffinate pits and Ash Pond exhibits the highest concentrations of lithium, molybdenum, nitrate, and uranium. In the Frog Pond area, groundwater has been impacted primarily by sulfate and nitroaromatic compounds. Nitroaromatic compounds are 
also present in groundwater in scattered locations across the chemical plant area and central portion of the training area. Some contamination from nitroaromatic compounds is also evident in groundwater beneath the former bunker area on the northern ordnance works area. Nitroaromatic compounds were detected at much lower frequencies and at lower levels in wells screened in the unweathered and deeper units of the aquifer.

The site contaminants identified for springs include uranium, antimony, cadmium, iron, lithium, manganese, mercury, molybdenum, silver, chloride, nitrate, sulfate, and nitroaromatic compounds. Uranium and nitrate were routinely detected above background levels in spring samples from two drainages, 5300 and 6300 . Elevated sulfate levels were found in springs in the 5100, 5200, 5300 , and 6300 drainages. Nitroaromatics were detected in springs from most of the drainages in the former ordnance works area, except for the 5100 drainage, and infrequently (twice) in the 5400 drainage. 


\section{CONTAMINANT FATE AND MIGRATION}

Analysis of the fate and migration of contaminants in an aquifer involves determining the behavior of a chemical released into the environment. This behavior can be described by three environmental processes: transformation, transfer, and transport (Mackay et al. 1985). Table 5.1 summarizes and gives examples of each process.

Migration is the combination of transfer and transport processes and governs the spatial and temporal distribution of a chemical in groundwater. The migration of contaminated water in the aquifer is controlled by a combination of hydrologic, geochemical, and biological factors. Principal among the hydrologic factors affecting migration at the chemical plant area and the ordnance works area are heterogeneity of the aquifer, preferential flow in fracture systems, locations of saturated and unsaturated zones with reference to historic and current sources, and interaction between surface water and the shallow groundwater aquifer.

TABLE 5.1 Summary of Environmental Processes Affecting Contaminant Fate and Migration Process $\quad$ Process Description with Example

Transformation Alteration of the form of a chemical through physical, chemical, and/or biological reactions. This process reduces the concentration of a chemical (attenuation) but does not necessarily slow its rate of transport (retardation). While the transport rate of the original chemical species is unlikely to change, the daughter products of the transformational processes are likely to exhibit their own transport rates. Examples of transformation processes potentially affecting the fate of COPC include hydrolysis, photolysis, oxidation/reduction, chemical precipitation, radioactive decay, and biodegradation.

Transfer Redistribution of a chemical between media. Examples of transfer are adsorption/desorption and dissolution in soil/water systems. Dissolution is a process by which a material changes from the solid to aqueous phase. Adsorption is the reversible adhesion of a solute to the aquifer matrix. Desorption is the release of a solute from the aquifer matrix into the soil/water system.

Transport Redistribution of a chemical within a single medium. Solute transport in groundwater occurs in response to hydraulic and chemical gradients and can be described with the advection/dispersion model. Advection is the process by which a solute is transported by the bulk motion of flowing groundwater; dispersion is produced by unequal velocities in the porous medium and causes spreading of the solute. The spreading of dissolved contaminants by dispersion produces dilution and attenuation. 
The discussion in this chapter of fate and migration integrates information from a number of sources, the primary ones being Baseline Assessment for the Chemical Plant Area of the Weldon Spring Site (DOE 1992a), Remedial Investigation of the Chemical Plant Area (MK-Ferguson Company and Jacobs Engineering Group, Inc. 1992a), Work Plan for the Remedial Investigation/Feasibility Study for the Groundwater Operable Unit at the Chemical Plant Area and the Ordnance Works Area (DOE 1995b), and Final Remedial Investigation, Weldon Spring Training Area (IT Corporation 1993a). The discussion of persistence and attenuation relies on site-specific research performed by the USGS (Schumacher and Stollenwerk 1991; Schumacher 1993). Information published by the USGS (Schumacher et al. 1996) also was used in the discussion of the fate and transport of nitroaromatic compounds.

\subsection{CONTAMINANT SOURCES AND ROUTES OF MIGRATION}

Figure 5.1 illustrates the fate and transport conceptual model that identifies historical and current source areas, release and transport mechanisms, migration pathways, and environmental media at the chemical plant area and the ordnance works area.

Contaminant migration to groundwater in the chemical plant area and the ordnance works area can be attributed to:

- Migration of contaminants from surface or near-surface sources through the overburden to the shallow aquifer,

- Seepage from surface water impoundments,

- Surface water runoff carrying contaminants from the historic surface source areas that entered the shallow groundwater system through losing stream segments, and

- Mobilization of contaminants within the groundwater system.

\subsection{CONTAMINANT PERSISTENCE AND ATTENUATION}

Uranium, metals (lithium and molybdenum), inorganic anions, nitroaromatic compounds, and volatile organic compounds (TCE) are the COPC for the GWOUs at the chemical plant area and the ordnance works area. Except for nitroaromatic and volatile organic compounds, these constituents also occur naturally. The fate and migration of these substances through the groundwater system depend in part on their mobility and persistence. The following sections briefly discuss the mobility and persistence of each contaminant on the basis of theoretical considerations, 


$\begin{array}{cccccc} & \text { Historical } & & \text { Contaminant } & \text { Contaminant } & \text { Impacted } \\ \text { Historical } & \text { Release } & \text { Source } & \text { Release } & \text { Migration } & \text { Media } \\ \text { Sources } & \text { Events } & \text { Media } & \text { Mechanism } & \text { Pathway } & \text {. }\end{array}$

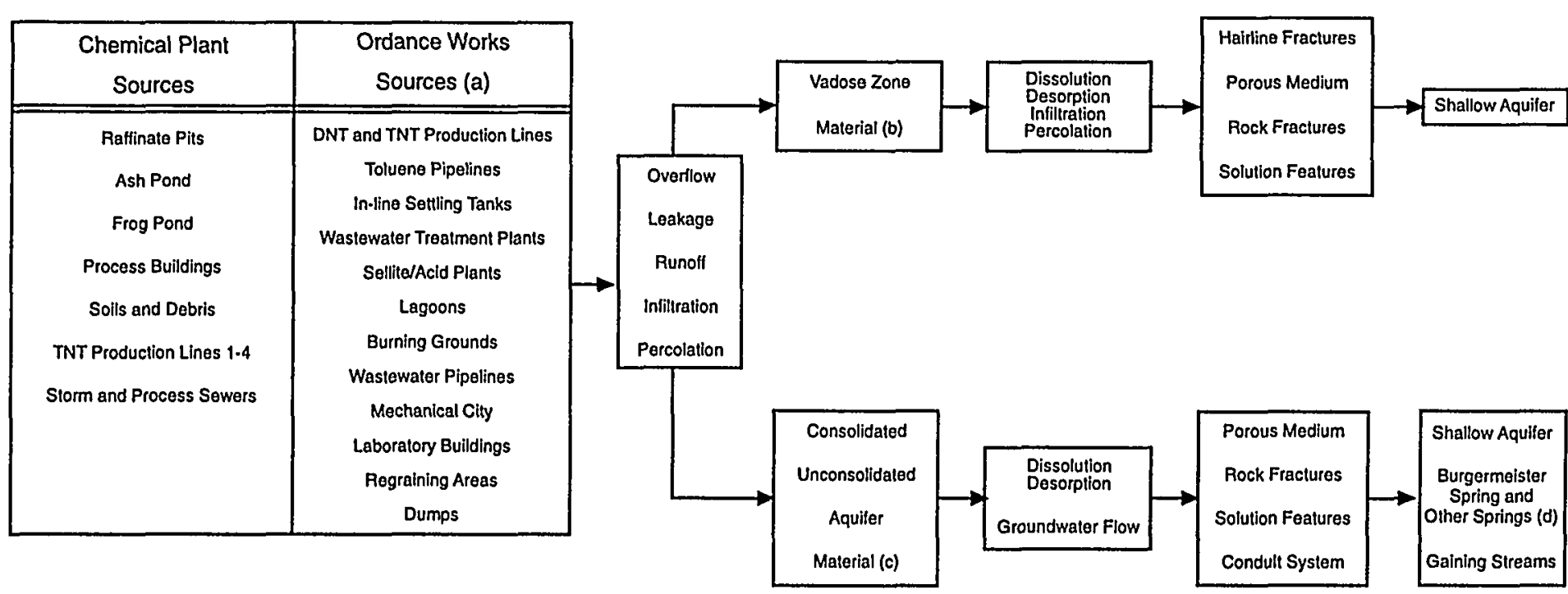

\section{NOTES}

(a) Other minor sources are laboratory building, storage bunkers, and dumps.

(b) Includes adsorbed contaminants and pore water in the vadose zone.

(c) Includes the adsorbed contaminants within the shallow unconfined aquifer.

(d) Includes sodiments.

MPA2701

FIGURE 5.1 Fate and Transport Model for the Groundwater Operable Unit 
the results of laboratory experiments to identify geochemical controls of the migration of contaminants (Schumacher and Stollenwerk 1991; Schumacher 1993), and the evaluation of groundwater quality data. These factors provide the basis for the information on the nature and distribution of contamination reported for the shallow aquifer.

\subsubsection{Uranium}

Dissolved uranium has three valence states: $+4,+5$, and +6 . In the presence of reduced iron or sulfur, $U(6+)$ is removed from solution by reduction to $U(4+)$ and precipitation of $U(4+)$ minerals such as uraninite $\left(\mathrm{UO}_{2}\right)$, which is relatively insoluble (Fetter 1993). Uraninite was not identified in the soils and pit sludges in the chemical plant area. $U(6+)$ has a tendency to form soluble complexes with a wide variety of inorganic anions, including carbonate, hydroxide, fluoride, phosphate, and sulfate (Fetter 1993). Most of the uranium within the sludges was present as U(6+) and in minerals such as carnotite or associated with phosphate minerals such as apatite (Schumacher 1993). Schumacher and Stollenwerk (1991) concluded that reduction to U(4+) and precipitation of U(4+) minerals probably do not occur within the raffinate pit sludges, and, as a result, uranium presumably exists mainly in the dissolved phase in infiltrating waters.

The results of geochemical modeling and laboratory experiments (Schumacher 1993) indicate significant adsorption of uranium within the overburden (Ferrelview Formation and clay till) beneath the raffinate pits. Adsorption of uranium was found to be dependent on the $\mathrm{pH}$ of the groundwater; adsorption generally decreased with an increase in $\mathrm{pH}$.

The adsorption experiments (Schumacher 1993) indicate that uranium can be effectively removed from raffinate pit seepage during infiltration through the overburden. Although uranium concentrations are elevated (four to five times) above background in wells adjacent to the raffinate pits, they are much lower than uranium concentrations in the raffinate pits. This decrease has been attributed to saturation of available adsorption sites, the formation of weakly sorbed uranium carbonate complexes, the existence of preferential flow paths through the overburden, or a combination of these possibilities (Schumacher and Stollenwerk 1991). Once in the groundwater, equilibrium-speciation calculations indicate that $\mathrm{U}(6+)$, in the form of uranium carbonate complexes, is very stable and mobile.

\subsubsection{Metals}

Metals have fairly limited mobility in soil and groundwater because of their tendency to undergo cation exchange or sorbtion to the surfaces of negatively charged clay particles. A distribution coefficient $\left(\mathrm{K}_{\mathrm{d}}\right)$ is a measure of the partitioning of solutes between liquid and solid phases in a porous medium. The $\mathrm{K}_{\mathrm{d}}$ depends on the solute species, the nature of the porous medium, 
and other conditions of the system such as $\mathrm{pH}$ and temperature. A compound having a large $\mathrm{K}_{\mathrm{d}}$ is strongly adsorbed by aquifer materials and, consequently, moves slower than the groundwater velocity.

Metals speciation, the form in which a molecule or ion is present in solution, is controlled by redox conditions. Speciation values indicating oxidation state and stable complex for the metals at the chemical plant area and the ordnance works area are presented in Table D.1 of Appendix D. The speciation, and thus the mobility of metals, can be changed significantly by relatively small quantities of iron and manganese oxides that often form amorphous coatings on the aquifer matrix. In some media, these hydrous-oxides help increase the adsorption capacity more than either clay particles or organic matter. Hydrous-oxides are thought to increase the adsorption of molybdenum and uranium in the overburden soils at the chemical plant area (Schumacher 1993).

Lithium is commonly present in trace amounts with aluminosilicate and hydroxide minerals and manganese oxides in soil; water-soluble lithium is correspondingly low. Lithium readily forms the stable monovalent ion, and although many lithium salts can be soluble in water, they are generally less soluble than the corresponding salts of other alkali metals such as sodium or potassium. Lithium does not substitute in carbonate rocks, and the carbonate is insoluble in water. Although transport would be expected to be similar to that for the other alkali metals as a result of the valence state, exchangeable lithium is usually found in much lower concentrations than sodium or potassium. Site-specific data were used to determine a $\mathrm{K}_{\mathrm{d}}$ of between 0.6 and $1.5 \mathrm{~mL} / \mathrm{g}$ for a solution in equilibrium with the clay till at neutral $\mathrm{pH}$ and values between 1.4 and $1.8 \mathrm{~mL} / \mathrm{g}$ for the Ferrelview Formation at neutral pH (Schumacher and Stollenwerk 1991). As part of the baseline assessment for the chemical plant area, a $\mathrm{K}_{\mathrm{d}}$ of $9 \mathrm{~mL} / \mathrm{g}$ was used on the basis of the calculated values and the results of a screening level leaching calculation using data for soil and groundwater near the site (DOE 1992a). Lithium is, therefore, expected to be fairly mobile at the chemical plant area.

The presence and concentrations of lithium in Burgermeister Spring are consistent with the low calculated distribution coefficients $(<2 \mathrm{~mL} / \mathrm{g}$ at neutral $\mathrm{pH})$ on the basis of laboratory sorption experiments (Schumacher 1993). Calculated distribution coefficient values for sorption of the siterelated contaminants are given in Table D.1 of Appendix D. Site-specific distribution coefficients at various $\mathrm{pH}$ values for the Ferrelview Formation and the clay till are given in Table D.2 of Appendix D.

Molybdenum commonly occurs as the oxide in uranium ore, as molybdate in solution, and can exist over a range of oxidation states. The molybdenate ion can complex with calcium, and adding lime to soil to increase the $\mathrm{pH}$ can increase molybdenum solubility. Adsorption of molybdate by iron and aluminum oxides decreases as soil $\mathrm{pH}$ increases above 4 . Hydrous iron oxides are the major influence on molybdenum adsorption in soil and in combination with organic matter may provide additional absorption in acid soil. Molybdenum is expected to be mobile in the neutral to 
alkaline $\mathrm{pH}$ conditions found in groundwater in the area, although the mobility will be partially restricted by the presence of iron oxides.

\subsubsection{Anions}

Nitrate is a highly soluble anion that is mobile in the subsurface because it is repelled by negatively charged clay particles. Nitrate may be removed from groundwater by plant uptake to a limited extent, but this process is generally considered insignificant. The most significant removal process for nitrate is denitrification, the biological or chemical reduction of nitrate to gaseous nitrogen compounds such as nitrous oxide and nitrogen gas. Environmental conditions favorable to denitrification include high organic carbon content, high $\mathrm{pH}$, and a restricted oxygen supply. Nitrate reducing organisms are inhibited by the presence of dissolved oxygen; therefore, the potential for nitrate accumulation is greater under aerobic conditions. If nitrate concentrations exceed the available carbon supply, nitrate accumulations could occur. Samples of groundwater from shallow monitoring wells completed in the weathered Burlington-Keokuk Limestone contain measurable quantities of dissolved oxygen $(>1 \mathrm{mg} / \mathrm{L})$, which is indicative of a moderately oxidizing environment (Schumacher 1993). Therefore, denitrification generally will be inhibited within the weathered limestone, and nitrate will persist.

The raffinate pits constitute the greatest source of nitrate contamination to the shallow aquifer. Nitrate concentrations exceed the EPA MCL of $10 \mathrm{mg} / \mathrm{L}$ in 22 wells at the chemical plant area and in 7 wells on the eastern part of the training area. These seven wells are completed in the weathered unit of the Burlington-Keokuk Limestone. Two wells completed in the unweathered unit at the chemical plant area had concentrations greater than $10 \mathrm{mg} / \mathrm{L}$ (Figures 4.5 and 4.6). The highest nitrate concentrations were found in wells near the raffinate pits and Ash Pond. Concentrations of nitrate in groundwater decrease outside these areas (except for nitrates at Burgermeister Spring) and are found infrequently at low levels.

Nitrate concentrations from monitoring well samples within the training area are generally low. Wells just northeast and west of the chemical plant boundary (MWS-21, MW-4001, MW-4003, MW-4006, MW-4011, MW-4012, MW-4013, MW-4014, and MW-4016) show elevated nitrate concentrations above the MCL. The elevated concentrations in these wells can probably be attributed to the raffinate pits, Ash Pond, and the production lines.

Sulfate $\left(\mathrm{SO}_{4}{ }^{-2}\right)$ and chloride $\left(\mathrm{Cl}^{-}\right)$are the most common forms of sulfur and chlorine present in groundwater systems. The chemical behavior of sulfur is strongly related to the redox properties of the groundwater environment. In the moderately oxidizing weathered bedrock, sulfur will be present as sulfate. The primary removal mechanism for sulfate in groundwater is reduction to sulfide and the subsequent formation of hydrogen sulfide $\left(\mathrm{H}_{2} \mathrm{~S}\right)$ or the precipitation of sulfide minerals such as pyrite ( $\mathrm{FeS}$ ). Increased concentrations of sulfate have been detected in monitoring 
wells downgradient of the former sellite plants and near the raffinate pits. Sulfate reduction is favored in anaerobic environments generally having a high organic carbon content. Anaerobic conditions have not been found within the shallow aquifer at the chemical plant area or the training area, but may exist in isolated areas within deeper parts of the unweathered rock near discharge areas along Dardenne Creek. Therefore, sulfate is expected to persist in the aquifer.

Because chloride does not enter into any significant microbiologic reactions or geochemical reactions (e.g., ion exchange, precipitation-dissolution), its migration in the environment will be attenuated only slightly, if at all. Thus, its behavior is conservative; that is, it will migrate at about the same velocity as the groundwater.

\subsubsection{Nitroaromatic Compounds}

More than 30 nitroaromatic compounds have been identified in wastewater from TNT manufacturing at ordnance works sites (Spanggord and Suta 1982). The major compounds identified were 2,4-DNT, 2,6-DNT, and 1,3,5-TNB. Munitions compounds produced at the ordnance works included 2,4,6-trinitrotoluene (2,4,6-TNT), 2,4-dinitrotoluene (2,4-DNT), and 2,6-dinitrotoluene (2,6-DNT). The predominant DNT isomer produced during the dinitration process was 2,4-DNT. The compound 2,4-DNT also composes about $2 \%$ by weight of crude TNT. During nitration, a small amount of TNT is oxidized to trinitrobenzoic acid, which appears in the finished product and waste streams as 1,3,5-trinitrobenzene (1,3,5-TNB) (Davis 1943).

Two important factors affecting the persistence and environmental fate of most nitroaromatic compounds are the presence of the benzene ring and the presence of the nitro- $\left(\mathrm{NO}_{2}{ }^{-}\right)$ group. The benzene ring imparts a certain amount of stability to the compounds and, in addition, the electronegativity of the nitro-( $\left.\mathrm{NO}_{2}^{-}\right)$group makes nitroaromatics reactive and susceptible to reduction (McGrath 1995). Selected physical and chemical properties of several nitroaromatic compounds are summarized in Table D.2 of Appendix D.

Photolysis is one of the major processes affecting the transformation of nitroaromatic compounds in waste streams and surface water bodies exposed to sunlight (Spanggord et al. 1980; Rosenblatt et al. 1989). Photolysis modifies the composition of the nitroaromatic waste material present in lagoons, surface water ponds, or spilled material at the soil surface. Photolysis of nitroaromatic compounds such as TNT and DNT involves the absorbance of light energy and the reduction to nitrobenzenes (such as TNB) and other compounds (McGrath 1995). Photolysis can occur relatively rapidly; half-lives are measured in hours to days (Table D.3).

Biotransformation is another process affecting the transportation of nitroaromatic compounds beneath the ground surface. The biochemistry of TNT is complicated by the fact that it contains toluene. Toluene is an organic compound that generally serves as an electron donor, along 
with the nitroaromatic compounds with the relatively oxidized nitro- $\left(\mathrm{NO}_{2}{ }^{-}\right)$groups that generally function as electron acceptors. In effect, TNT may act as both an electron donor and electron acceptor, while also being a carbon and nitrogen source. These various properties make TNT susceptible to a wide variety of transformations.

The microbial degradation of TNT and other nitroaromatic compounds has been reported in the literature. Studies have focused on degradation by artificially selected microbial communities (Parrish 1977; Carpenter et al. 1978; Kaplan and Kaplan 1982; Boopathy and Kupla 1992; Boopathy et al. 1993; Funk et al. 1993). Field investigations by the USGS at the ordnance works area have demonstrated that microorganisms indigenous to the soils and, more importantly, to the shallow aquifer have the ability to transform and degrade TNT, 2,4-DNT, and 2,6-DNT (Jones 1984; Missouri Department of Conservation 1991; DOE 1992a; MK-Environmental Services 1992a; Chapelle and Bradley 1993; Ecological Specialists 1996). Laboratory microcosm experiments conducted on core samples from saturated residuum and bedrock and uniformly radiolabeled (carbon-14) TNT and DNT showed that a variety of TNT and DNT degradation products were formed.

TNT mineralization (complete degradation to carbon dioxide $\left[\mathrm{CO}_{2}\right]$ ) studies using two different types of Weldon Spring topsoils showed approximately $11 \%$ and $6.5 \%$ TNT conversions to $\mathrm{CO}_{2}$. Similar TNT mineralization studies using shallow aquifer material showed a TNT to $\mathrm{CO}_{2}$ conversion of approximately $1 \%$ (Bradley et al. 1994). In DNT mineralization experiments using shallow aquifer material, approximately $28 \%$ and $8 \%$ of the 2,4-DNT and 2,6-DNT, respectively, were transformed to $\mathrm{CO}_{2}$ (Bradley et al. 1997).

The USGS also performed experiments using Weldon Spring topsoil to study the effects of moisture content, TNT concentration, oxygen condition, and supplemental carbon on the mineralization of TNT (Bradley and Chapelle 1995). Those studies concluded that the mineralization of TNT was inhibited by the addition of carbon substrate and by elevated TNT soil concentrations. Also, experiments using different soil-moisture levels (oversaturation to moisture levels representative of summer dry periods) showed that soil drying significantly inhibited TNT mineralization under both aerobic and anaerobic conditions. In addition, the experiments performed to study the effects of oxygen condition on TNT mineralization showed the highest mineralization rates using air head spaces in the incubation tubes, with lower rates for head spaces with oxygen amended air, and the lowest rates for helium (no oxygen) head spaces.

USGS laboratory experiments also indicated that 2,4-DNT and 2,4,6-TNT are more readily metabolized in the shallow aquifer than 2,6-DNT. More than 95\% of 2,4-DNT and 2,4,6-TNT was metabolized within 68 days in microcosms using material from the shallow aquifer, compared with $55 \%$ to $80 \%$ for $2,6-\mathrm{DNT}$. In all cases, the decrease in TNT or DNT was coupled with the appearance of 4-amino-2,6-dinitrotoluene (4-Am) and 2-amino-4,6-dinitrotoluene (2-Am) or amino 
nitrotoluenes (Bradley et al. 1994). Transformation of TNT to 4-Am and 2-Am appears to be the initial step in the degradation of TNT.

Mass balance experiments using radiolabeled DNT indicated that a significant mass of 2,4-DNT was transformed into highly polar intermediates hypothesized to be acid-derivatives of nitroaromatic compounds (Figure 5.2). Similar studies were not performed with TNT; however, chemical analysis of lysimeter samples from the unsaturated zone detected polar acid intermediates. The presence of these acid derivatives is important because these compounds generally are readily metabolized by a variety of microorganisms (Cartwright and Cain 1959; Nadiau and Spain 1995).

Processes other than transformation can significantly affect the fate and transport of nitroaromatics, including reversible and irreversible reactions of nitroaromatics with the soil. These processes, along with photolysis and biodegradation, are expected to be important attenuation mechanisms for nitroaromatics in the soil and groundwater.

The reversible reactions include nitroaromatic adsorption and desorption to soil. Experiments by USGS indicate that TNT and DNT adsorb to the glacial drift in moderate quantities, with distribution coefficients ranging from 0.53 to $3.5 \mathrm{~mL} / \mathrm{g}$ (Table D.3). Distribution coefficients from additional USGS studies for the aquifer materials were less than $1 \mathrm{~mL} / \mathrm{g}$ (Table D.3).

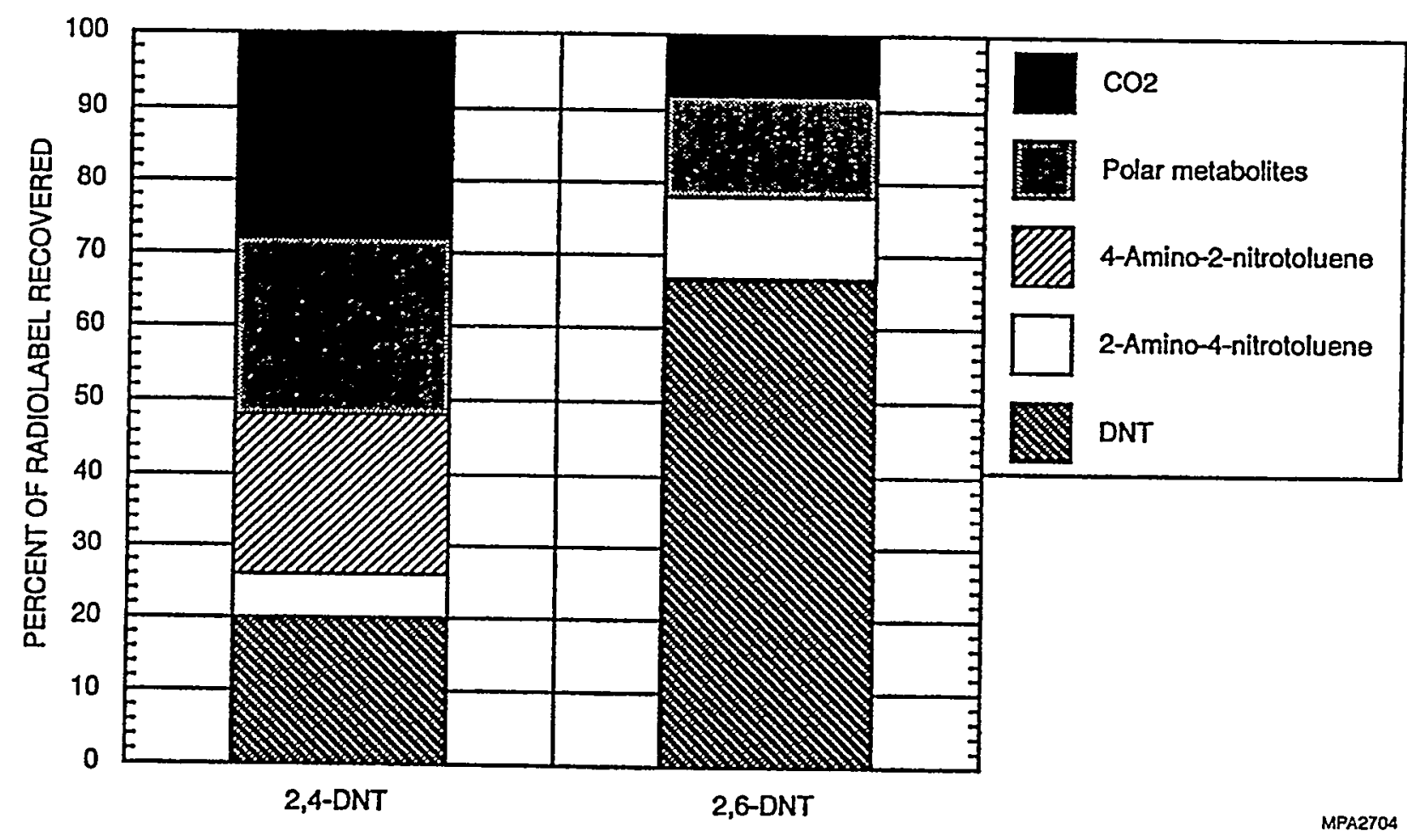

FIGURE 5.2 Microbial Transformation Productions of 2,4-DNT and 2,6-DNT in Residuum 
A phenomenon that potentially affects the prediction of the adsorption and desorption of nitroaromatics to soil is the time that the nitroaromatic has resided in the soil and/or aquifer. For example, Grant et al. (1995) have found significant differences in the recoveries of nitroaromatics in field-contaminated soils as compared with soils freshly spiked with nitroaromatics. In addition, they found significant differences between the stability of the nitroaromatics in field and freshly spiked samples. Since lab samples are normally prepared under relatively short time frames compared with the residence times of nitroaromatics in the soil and groundwater at Weldon Spring, use of the lab sorption and biodegradation results in predicting nitroaromatic behavior at Weldon Spring needs to take into account the potential differences between lab and field behavior.

In addition to reversible reactions, irreversible nitroaromatic-soil reactions can potentially affect nitroaromatic fate and transport. Price et al. (1995) discuss the apparent irreversible binding of TNT degradation products, 2-Amino and 4-Amino, to the soil. This process is potentially an important attenuation mechanism in determining the amount of nitroaromatics migrating to groundwater.

\subsubsection{Volatile Organic Compounds}

Recent sampling of groundwater in the chemical plant area indicates the presence of volatile organic compounds (TCE and 1,2-DCE). In general, detection of TCE has been limited to the area south and southeast of Raffinate Pits 3 and 4. The maximum concentrations of TCE observed (Section 4) exceed the EPA guideline value of $0.005 \mathrm{mg} / \mathrm{L}$; the maximum concentrations for 1,2-DCE are below the EPA guideline of $0.07 \mathrm{mg} / \mathrm{L}$ for cis-1,2-DCE, and $0.1 \mathrm{mg} / \mathrm{L}$ for trans-1,2DCE.

As implied by their designation (volatile organic compounds), TCE and 1,2-DCE readily volatilize from aquatic systems. In surface water, the half-life for TCE is about 3.5 hours (Thomas 1981). On the other hand, degradation by photolysis (Callahan et al. 1979) or hydrolysis (Dilling et al. 1975) is expected to be negligible.

Once in the groundwater system, TCE and 1,2-DCE would not be readily adsorbed onto soil or rock particles. Using the reported partition coefficients with respect to the organic fraction $\left(\mathrm{K}_{\mathrm{oc}}\right)$ for TCE and trans-1,2-DCE of about $65 \mathrm{~mL} / \mathrm{g}$ (Montgomery and Welkom 1991), the distribution coefficient, $\mathrm{K}_{\mathrm{d}}$, for the volatile organic compounds in a soil having an organic content of about $0.05 \%$ (consistent with site values measured by the USGS for depths greater than $0.3 \mathrm{~m}$ [1 ft]) (Schumacher et al. 1996) would be $0.3 \mathrm{~mL} / \mathrm{g}$. Because the distribution coefficient is small, adsorption would not be a significant process.

Under anoxic (anaerobic) conditions, reductive dehalogenation of TCE forms cis- and trans1,2-DCE (Montgomery and Welkom 1991). These compounds further biodegrade to vinyl chloride. 
Because conditions at the chemical plant area are mostly aerobic, these biodegradation processes are unlikely to occur, and the volatile organics would not significantly biodegrade.

Because TCE is fairly soluble in water $(1,100 \mathrm{mg} / \mathrm{L})$ (Montgomery and Welkom 1991) and is more dense (specific gravity of approximately 1.46), it would leach from the soil into the groundwater, dissolve until it reaches an equilibrium value, and tend to sink in the aquifer. When TCE exceeds its solubility limit, it forms globules that sink to the bottom of the aquifer and form a pool of dense, nonaqueous phase liquid (DNAPL). This DNAPL pool would then slowly dissolve into the passing groundwater and provide a continuous source of contamination for a potentially long period (Mackay and Cherry 1989).

\subsection{CONTAMINANT MIGRATION}

Several routes of migration have been identified that transport contaminants to the shallow aquifer and springs. Shallow aquifers in weathered limestone are vulnerable to contamination by percolation through the unsaturated overburden and bedrock and by surface runoff through losing stream segments. In the Weldon Spring area, the shallow aquifer is recharged by surface water from leaking surface impoundments, losing stream segments, and infiltration through overburden. The presence of contaminants in the aquifer results from contaminant loading from historic sources by infiltration through the overburden and contaminants that entered the groundwater through losing streams.

Elevated concentrations of nitrate, metals, uranium, and nitroaromatics have been detected in soils at the training area, the chemical plant area, and the ordnance works area (MK-Ferguson Company and Jacobs Engineering Group, Inc. 1989b). Nitrate, uranium, lithium, and molybdenum are the only constituents that persist with depth in soils, a condition that indicates that specific processes reduce substantial contaminant loading to the shallow aquifer via infiltration (MK-Ferguson Company and Jacobs Engineering Group, Inc. 1989a). Although nitroaromatic compounds do not persist in soil samples with depth, significant concentrations of nitroaromatic compounds have been detected by the USGS in pore water within the unsaturated zone beneath contaminated surficial soils. The presence of significant concentrations of nitroaromatic compounds in pore water samples suggests that infiltration from contaminated surficial soils is a significant source of nitroaromatic compounds to the groundwater.

Contaminant migration can also be tracked by analyzing the presence of tritium in groundwater (Schumacher 1990; Schumacher et al. 1993). Groundwater samples from the weathered and unweathered units of the Burlington-Keokuk Limestone were analyzed for tritium. The occurrence of tritium in groundwater arises from both natural and man-made sources. Tritium is produced naturally in the earth's atmosphere by the interaction of cosmic-ray-produced neutrons with nitrogen in a manner similar to carbon-14 production (Freeze and Cherry 1979). Large 
quantities of man-made tritium were introduced to the hydrological system as a result of atmospheric testing of thermonuclear devices. Groundwater that was recharged prior to 1953 is expected to have tritium concentrations below $5.7 \mathrm{pCi} / \mathrm{L}$. Because groundwater contains tritium at concentration levels above $5.7 \mathrm{pCi} / \mathrm{L}$, it is evident that the water, or at least a large fraction of the water, entered the aquifer sometime after 1953.

Contaminant fate and transport are further discussed by presenting the physical controls and migration processes that occur within the vadose zone, the shallow aquifer system, and from surface and subsurface runoff.

\subsubsection{Migration within the Vadose Zone}

\subsubsection{Physical Controls}

The movement of recharge water physically controls contaminant migration in the vadose zone. The primary mechanism of recharge for the underlying shallow aquifer at the chemical plant area and the training area is infiltration of precipitation through the overburden material. Substantial recharge also enters the unsaturated zone through losing stream segments. Most of this recharge is quickly lost, however, by rapid discharge to springs. In the vicinity of the raffinate pits, recharge from surface water impoundments may also be significant. The overburden below these features contains hairline fractures and macropores that act as preferential flow paths for the seepage and downward movement of water to the shallow aquifer.

Seepage from surface water impoundments at the chemical plant area also results in perched water above the Ferrelview Formation and mounding effects on the water table. The perched water indicates a zone of higher hydraulic conductivity over a zone of lower conductivity within the unsaturated zone. The mounded water table is a result of higher aquifer recharge at seepage points. The occurrence of contamination near the groundwater divide at the chemical plant area suggests seepage as the only possible source. Hydrologic factors contributing to the development of perched or mounded water in the overburden include the generally low vertical hydraulic conductivity, high soil moisture retention characteristics (MK-Environmental Services 1993), and the driving force for flow (hydraulic head) provided by impounded surface water.

At the ordnance works area, the primary physical controls on contaminant migration are infiltration of precipitation through the overburden, recharge from losing stream segments, and the hydrogeological and geochemical properties of the shallow aquifer. 


\subsubsection{Migration Process}

The migration pathways from potential source areas at the chemical plant area and the training area include infiltration through the overburden, which may require decades, and preferential flow through macropores. Macropores are large aperture pore spaces such as fractures and root holes in surficial soils and glacial drift. The probable migration route from the raffinate pits is downward seepage through unconsolidated surficial materials (Kleeschulte and Imes 1994). The widespread occurrence of tritium in groundwater beneath the low-permeability till portion of the overburden at the chemical plant area and the training area suggests that these fractures allow recharge and potential contaminants of concern to enter the aquifer quickly. Preferential flow through macropores is suspected on the basis of TCE migration from the raffinate pits and incomplete retardation of uranium and molybdenum in the overburden beneath the raffinate pits (Schumacher 1993). The overburden thickness beneath Raffinate Pits 3 and 4 is estimated to range from 3 to $7.6 \mathrm{~m}$ (10 to $25 \mathrm{ft}$ ); the minimum thickness occurs beneath Raffinate Pit 4 (MK-Engineering Company and Jacobs Engineering Group, Inc. 1992a).

Preferential flow through macropores may also account for the nitrate and nitroaromatic contamination observed beneath other surface impoundments on the chemical plant and ordnance works properties, particularly in areas where the overburden is thin, such as beneath Ash Pond, Burning Ground 1, and Lagoon 6 (Figure 3.2). The Ash Pond area has relatively high levels of contamination and is near a subsurface preferential flow path that is in hydraulic communication with Burgermeister Spring. Infiltration from Lagoon 6 is probably a source of nitroaromatics detected in Spring 5602 (IT Corporation 1992a; Schumacher et al. 1996), and Burning Ground 1 is the likely source of nitroaromatics detected in Spring 5201 (IT Corporation 1993a).

At the training area, water quality data obtained from lysimeters installed beneath a former wastewater settling tank indicate that nitroaromatic compounds, especially TNT and TNB, are migrating through the overburden (Schumacher et al. 1996). The lysimeters are located at various

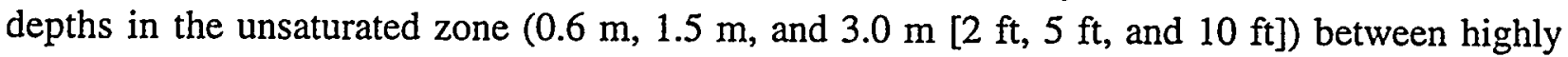
contaminated surficial soils (more than $100,000 \mathrm{mg} / \mathrm{kg}$ TNT) and the water table (about $4 \mathrm{~m} \mathrm{[12 \textrm {ft } ]}$ deep). In general, concentrations of nitroaromatic compounds in the deep lysimeter (completed in the residuum) were larger than concentrations detected in most monitoring well samples from the ordnance works area. Concentrations of nitroaromatic compounds in monitoring well MWS-24 downgradient of the lysimeters were greater than those in upgradient wells MWV-22 and MWS-22. This condition indicates that surficial soils are a source for groundwater contamination.

Data from the lysimeter clusters indicate substantial degradation of TNT and TNB, because these compounds migrate downward through the unsaturated zone. Large concentrations (up to several milligrams per liter) of the microbial transformation products 2-Am and 4-Am were detected in samples from the shallow unsaturated zone. Moderately large concentrations of 3,5-dinitroaniline 
(3,5-DNA) were also detected, which suggests microbial degradation of TNB (Schumacher et al. 1996).

Data from the lysimeters indicate that the flux of nitroaromatic compounds through the unsaturated zone is seasonal and depends on the availability of moisture within the soil. Nitroaromatic concentrations generally increase in the fall and winter and peak in the spring. Infiltration increases during this period because of the sustained decreased evapotranspiration in the fall and winter months (Schumacher et al. 1992). The lysimeter data, combined with the presence of detectable tritium concentrations in the shallow aquifer at the training area, indicate that soils constitute a potential source of nitroaromatic compounds in groundwater.

\subsubsection{Migration of Contaminants within the Shallow Aquifer}

\subsubsection{Physical Controls}

Because of the topographic influence on the potentiometric surface, the east-west groundwater divide that transects the chemical plant area and the training area is coincident with the surface water divide that separates the Missouri and Mississippi river drainages (Figure 3.18). Seasonal water-level fluctuations are generally less than $1 \mathrm{~m}(4 \mathrm{ft})$, and the locations of the divide and the groundwater flow pattern are nearly constant throughout the year (Kleeschulte and Imes 1994). Exceptions have been observed in several ordnance works and chemical plant monitoring wells that respond dramatically to precipitation events and that have had historical water-level fluctuations exceeding $3 \mathrm{~m}$ (10 ft). The locations of these wells coincide with the general locations of preferential flow paths identified by the Missouri Department of Natural Resources (1991).

Typically, the shallow aquifer becomes less permeable with depth because of the decrease in rock weathering and fracture intensity of the Burlington-Keokuk Limestone. The greatest variability in hydraulic conductivity typically occurs in the upper $6 \mathrm{~m}(20 \mathrm{ft})$ of the weathered limestone. The highest values were observed at saturated areas of the residuum/bedrock interface. The locations of highest hydraulic conductivity generally correspond to linear depressions in the bedrock topography that are speculated to be conduits consisting of highly weathered limestone.

At the training area, nitroaromatics have migrated into the groundwater despite the presence of fairly thick, impermeable overburden on the site. Fractures in the clay or root holes may act as preferred pathways leading to the underlying bedrock. The limestone bedrock underlying the site is close to the surface in the natural drainageways of the site. The migration of COPC into the shallow bedrock aquifer has been enhanced by this relationship. Fractures and secondary porosity due to solution features, such as those that formed the springs, also allow for relatively easy lateral transport (IT Corporation 1993a). 
Analysis of rock core from angle borings indicates that fracturing in the shallow bedrock aquifer is predominantly horizontal and typically occurs along bedding planes. Fracture densities are significantly higher in the weathered bedrock unit than in the unweathered unit (DOE 1996). Dissolution features are also present in the weathered unit and are generally oriented parallel to bedding planes.

Loss of circulation and core were common during drilling in the northern part of the chemical plant area. The aquifer is highly anisotropic where preferential flow occurs along horizontal features; the horizontal hydraulic conductivity is much greater than the vertical hydraulic conductivity. In the weathered limestone, high hydraulic conductivity estimates and high nitrate concentrations relative to concentrations in the unweathered unit indicate that the shallow aquifer is stratified, with most of the recharge water moving laterally within the weathered limestone. Deep percolation through the unweathered limestone is low. The presence of tritium and larger calcium/magnesium ratios in water samples from shallow uncontaminated monitoring wells can be explained by the shorter residence time of water in the weathered upper part of the shallow aquifer (Schumacher 1993).

In the chemical plant area, the horizontal migration of groundwater contaminants in the shallow aquifer appears to be controlled by preferential flow pathways linked to paleochannels in the weathered Burlington-Keokuk Limestone, as discussed in Chapter 3. Dye tracer tests indicate that the preferential flow system in the chemical plant area north of the groundwater divide is convergent to Burgermeister Spring. Dye tracer studies at the chemical plant area and the ordnance works have identified several subsurface conduit flow systems (Chapter 3). These tests indicate that the limestone conduit system has storage capacity as illustrated by the persistence of the tracer in Burgermeister Spring several months after injection. These tests also indicate that intermittently active conduits are present. The dispersion of the tracer and the varying peaks in tracer concentration in relation to precipitation events suggest that the tracer resides in portions of the system. Hydraulic connection was also demonstrated between losing stream segments and downstream gaining segments and springs in drainages south of the chemical plant area and the training area.

\subsubsection{Migration Processes}

Solute migration within the shallow aquifer is affected by the processes of advection, dispersion, sorption, irreversible binding, and degradation. The rate of solute migration by advection is a function of the concentration gradient and the volumetric flow rate. Dispersion of the solute front occurs as a result of mechanical mixing, nonuniform flow velocities, and molecular diffusion in response to chemical gradients (Freeze and Cherry 1979).

Adsorption occurs along the flow path as dissolved material interacts with the porous medium and is removed from solution. Degradation removes material from solution by changing its 
physical or chemical properties. General patterns in the distribution of COPC are consistent with operations at the ordnance works area, site hydrology, and microbial processes in the aquifer.

Overall, nitroaromatic compounds were detected less frequently and in smaller average concentrations in downgradient wells on the Busch Conservation Area to the north than in wells at the chemical plant area and the training area (Figures 5.3 and 5.4). Although TNT and 2,4-DNT were the predominant nitroaromatic compounds produced at the ordnance works area, 2-Am and 4-Am are frequently detected in the groundwater and spring samples (Figure 5.3) and represent a substantial quantity of the total concentration of nitroaromatics detected in the shallow aquifer (Figure 5.4).

The greater persistence of 2,6-DNT compared with that of 2,4-DNT in the laboratory results is consistent with higher relative concentrations of 2,6-DNT in the shallow aquifer. 2,6-DNT is generally detected at a slightly higher frequency (Figure 5.3) and has larger average concentrations compared with 2,4-DNT (Figure 5.4).
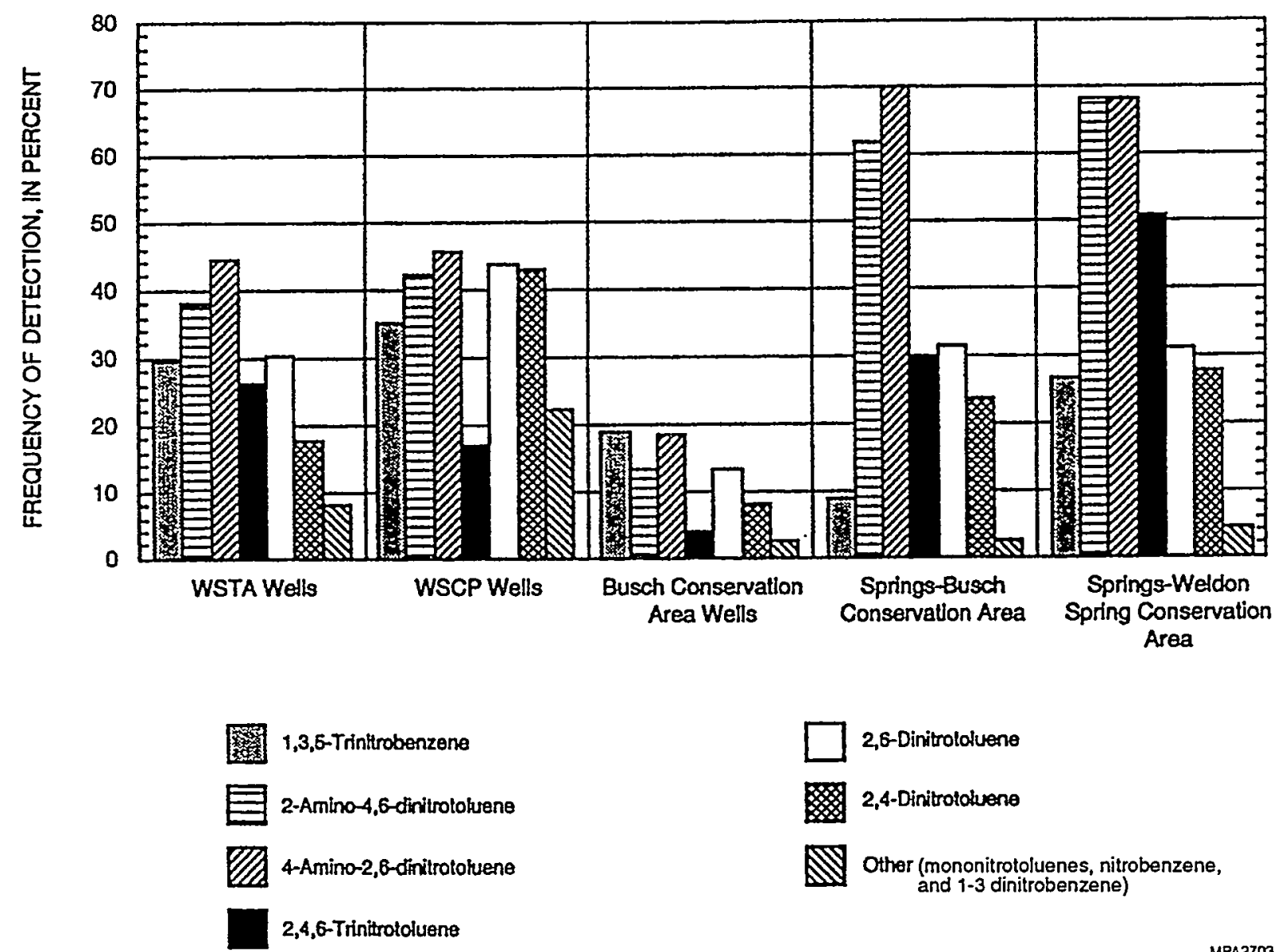

2,6-Dinitrololuene

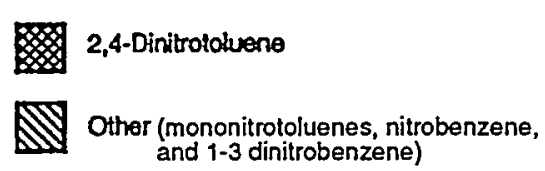

MPA2703

FIGURE 5.3 Frequency of Detection of Selected Nitroaromatic Compounds in Groundwater Samples from the Ordnance Works Area 


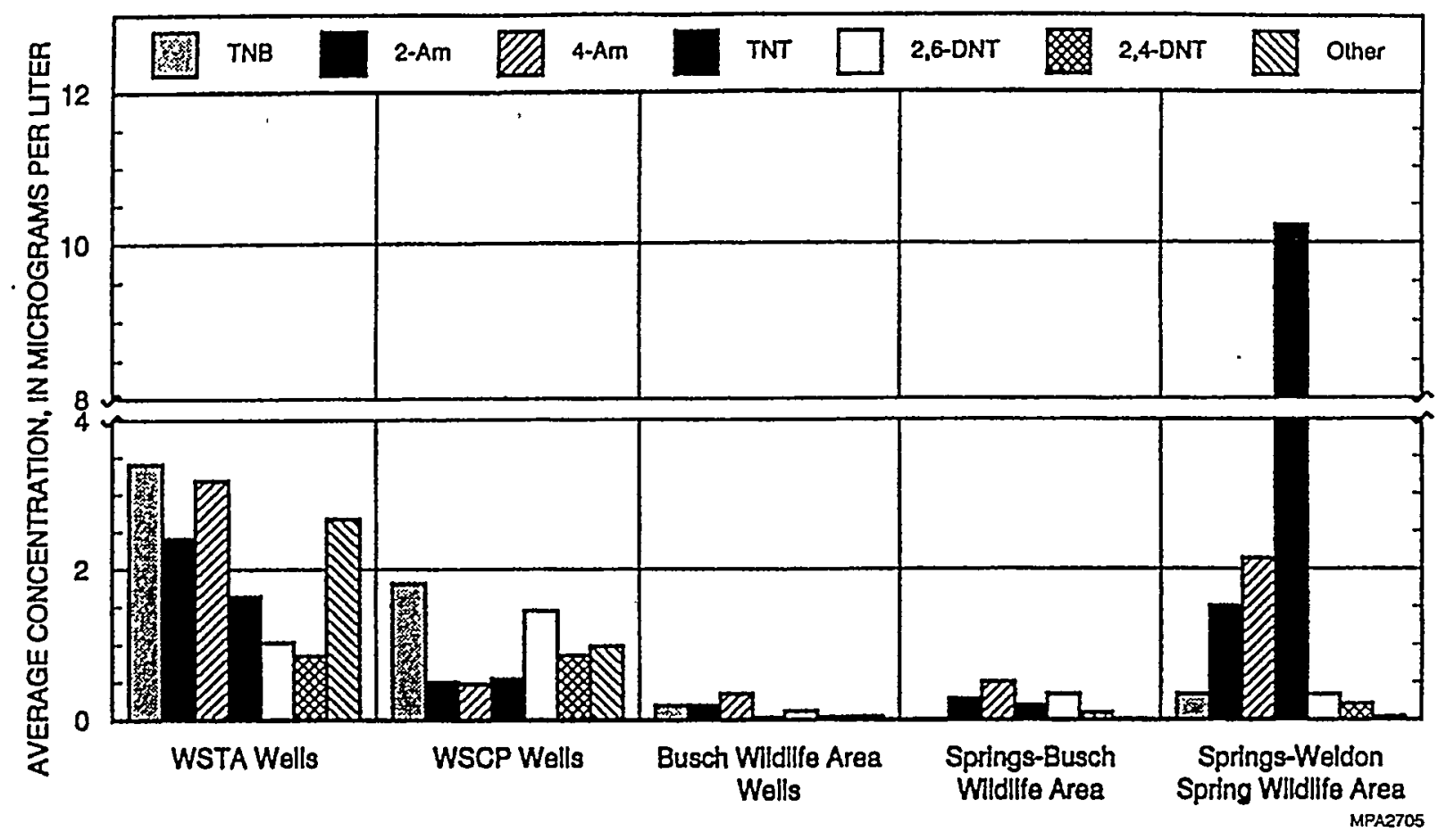

FIGURE 5.4 Average Concentrations of Selected Nitroaromatic Compounds in Groundwater Samples from the Ordnance Works Area

The distribution of nitrotoluenes is also consistent with site hydrology and microbial processes in the aquifer. Small concentrations (less than $1 \mu \mathrm{g} / \mathrm{L}$ ) of nitrotoluenes are widely scattered across the ordnance works; however, nitrotoluenes are generally absent in samples from springs and surface water (Schumacher et al. 1996). Average concentrations of nitrotoluenes larger than a few micrograms per liter were found only in samples from monitoring wells MW-3023, MWS-12, and MWS-17. Concentrations of the DNT degradation product 2-nitrotoluene in samples from MWS-12 and MWS-17 are highly correlated to concentrations of 2,4-DNT and 2,6-DNT and have correlation coefficients of linear regression of 0.72 and 0.87 at a $99 \%$ significance level. Only two samples from well MW-3023 were analyzed for nitrotoluenes, thus precluding the use of regression analysis. The strong relationship between 2-nitrotoluene and DNT and the transient appearance of nitrotoluene as a microbial transformation product of DNT in microcosm experiments suggest that DNT is being transformed to nitrotoluene in the aquifer. Nitrotoluenes are generally metabolized rapidly, which may explain why appreciable concentrations were detected in only a few wells.

Contamination originating at either the chemical plant area or the training area can migrate toward the Twin Island Lakes area to the north of the ordnance works area by a combination of diffuse flow in a direction consistent with the existing hydraulic gradient and losing stream segments 
that carried red water in the past. Because streams in the immediate vicinity of Twin Island Lakes are weak losers, the dominant flow path would be diffuse flow through the shallow groundwater aquifer.

\subsubsection{Migration of Contaminants by Surface and Subsurface Runoff}

\subsubsection{Physical Controls}

The chemical plant area and the ordnance works area are located on the east-west drainage divide between the Missouri and Mississippi watersheds. Surface water runoff in the western part of the ordnance works area and south of the divide flows to the Little Femme Osage Creek and its tributaries, which ultimately discharge into the Missouri River. Surface water runoff in the eastern part of the ordnance works area and south of the drainage divide also discharges to the Missouri River. However, surface drainage to the north of the divide converges at Dardenne Creek and its tributaries. Schote Creek, the largest of the tributaries, drains a major portion of the chemical plant area and the training area. Dardenne Creek flows easterly to the Mississippi River.

Most of the tributaries in these areas have losing reaches and springs and, therefore, surface water and shallow groundwater interactions are significant within the chemical plant areas and the ordnance works area. Surface water entering the shallow groundwater system along losing reaches is a potential pathway for groundwater contamination. At the training and chemical plant areas, some shallow groundwater north of the divide flows to the north, crosses drainage boundaries, and emerges in other drainages. This groundwater eventually discharges to tributaries of the Mississippi River. South of the divide, groundwater typically remains within drainage basins and discharges to both perennial and wet weather springs located in the same drainage and flows to tributaries of the Missouri River. This discharge includes water that enters the drainage basin from overland flow and precipitation and is lost in losing stream reaches to the shallow aquifer.

In the northeastern portion of the training area and the northwestern portion of the chemical plant area, a subsurface conduit system transports water rapidly to Burgermeister Spring and an associated wet weather spring. Historical data indicate relatively low flow rates under baseflow conditions $\left(\sim 2 \mathrm{~L} / \mathrm{s}\left[\sim 0.07 \mathrm{ft}^{3} / \mathrm{s}\right]\right)$ and much higher rates during and following precipitation events. A total combined discharge exceeding $113 \mathrm{~L} / \mathrm{s}\left(4 \mathrm{ft}^{3} / \mathrm{s}\right)$ was measured for these springs.

\subsubsection{Migration Processes}

Historical documentation of contaminants entering losing streams and affecting groundwater, as evidenced by red water contamination emerging in vicinity springs, was 
documented by the USGS during operation of the ordnance works (Fishel and Williams 1944). In addition, groundwater contamination from leakage of lagoons was also noted. In general, contaminants entering the groundwater system through losing stream reaches will likely move in the shallow, more active flow system that is dominated by conduit flow and will discharge rapidly to springs.

Surface drainages receiving part of their flow from the chemical plant area and the training area are the Southeast Drainage (5300), Schote Creek (6200), and the 6300 drainage via interconnection with Schote Creek through the conduit flow system (Figures 3.9 and 3.10). Waterlevel, dye-trace, and water-quality data indicate groundwater contamination by interception of surface runoff in the Southeast Drainage and the Burgermeister Spring conduit system. Elevated concentrations of sodium and chloride in the discharge at Burgermeister Spring indicate the contribution of surface runoff from a highway department facility on the east tributary of Schote Creek through a losing stream reach upstream from Lake 35. Dye injected into a losing stream segment ' of Schote Creek north of the chemical plant area emerged at Burgermeister Spring (approximately $1,981 \mathrm{~m}$ [6,500 ft] away) two to three days later (Missouri Department of Natural Resources 1991).

The ability of streams to maintain flow and transport sediment is significant in determining the potential for surface water to act as a source of contamination. The flow-duration curve for Schote Creek has a steep slope, indicating that this stream derives much of its flow from direct runoff, as does the hydrograph for Burgermeister Spring. Recharge to the shallow groundwater aquifer in the immediate vicinity of losing stream segments is primarily derived from the losing stream. Contamination in the stream can, therefore, directly contaminate the groundwater. Once lost from a surface stream, water can enter the existing conduit system and be transported rapidly to emergent springs. Residual contamination in the conduit system can be mobilized by dissolution, desorption, and sediment transport during precipitation events.

Comparison of mass flux patterns for uranium and nitrate at Burgermeister Spring reveals potentially different trends in the transport mechanisms for these contaminants (Figure 5.5). The mass flux of nitrate is about constant or slightly decreased with increasing discharge, whereas the mass flux of uranium increases with increasing discharge. The direct relationship for uranium suggests that the major sources of uranium are recharge by surface runoff lost to the subsurface (Johnson et al. 1989) and mobilization from storage in the conduit. Raffinate pit seepage is suspected as a source of low uranium levels during baseflow. The lower nitrate flux at high discharge is a result of groundwater dilution by surface water.

The historical tendency for uranium concentrations in Burgermeister Spring discharge to decrease during low-flow periods appears to be related to the absence of flow in the losing segment of Schote Creek downstream from Ash Pond (Schumacher 1993). In contrast, values of specific conductance, anions, nitrate, and lithium increase during low-flow conditions, which indicates a base 
flow source (raffinate pits) for these constituents (Figure 5.5). To date, no volatile organic compounds have been detected at the springs. A plot of uranium concentration versus time (Figure 5.6) shows an upward trend prior to 1989 and then suggests a decrease in uranium concentration from 1990 to 1995 since completion of the Ash Pond diversion in 1989.

Dye tracer studies performed at the chemical plant area indicate that the limestone has storage capacity because of the temporary entrapment in dead-end conduits, which results in a ratelimited storage-release mechanism. The higher uranium values observed at Burgermeister Spring during high flow may be partially attributable to this storage in the conduit system. The lowpermeability limestone beneath the preferential pathways provides contaminant storage and supplies the baseflow discharge at Burgermeister Spring. Raffinate pit seepage has been shown to contribute uranium measured at low concentrations during baseflow (Schumacher 1993).

In areas such as in the vicinity of USGS-3, the concentration of nitroaromatic compounds (TNB) is high, whereas the concentration of tritium is low. Losing stream segments containing red water in the early 1940s acted as a source for groundwater contamination. It is possible that nitroaromatic. concentrations in runoff entering losing streams were large enough that molecular diffusion into the surrounding rock matrix or precipitation of crystalline material within the deeper unsaturated zone or the shallow aquifer occurred. The reversal of this process would occur much more slowly and would act as a source for nitroaromatic contamination for many years. The present absence of tritium at these locations indicates that either the geometry of the losing stream segments has changed since the 1940s or that tritium has not had sufficient time to be transported by diffuse flow to the vicinity of the wells.

In the vicinity of the training area and Burning Ground 1 (5200 drainage), an area that on average has a relatively high nitroaromatic concentration in runoff water, it is unlikely that losing stream segments would contribute significantly to nitroaromatic groundwater contamination for the following reasons: the concentrations of nitroaromatic compounds in stormwater runoff are small (generally less than a few $\mu \mathrm{g} / \mathrm{L}$ ) (Schumacher et al. 1996); groundwater concentrations, on average, are larger than those measured in surface water runoff; and groundwater sampling indicates a detectable quantity of nitrotoluene that is generally absent in surface water runoff. Comparison of filtered and unfiltered samples indicates that the nitroaromatic compounds detected are being transported primarily in the dissolved phase (particle sizes less than $0.45 \mu \mathrm{m}$ ). 

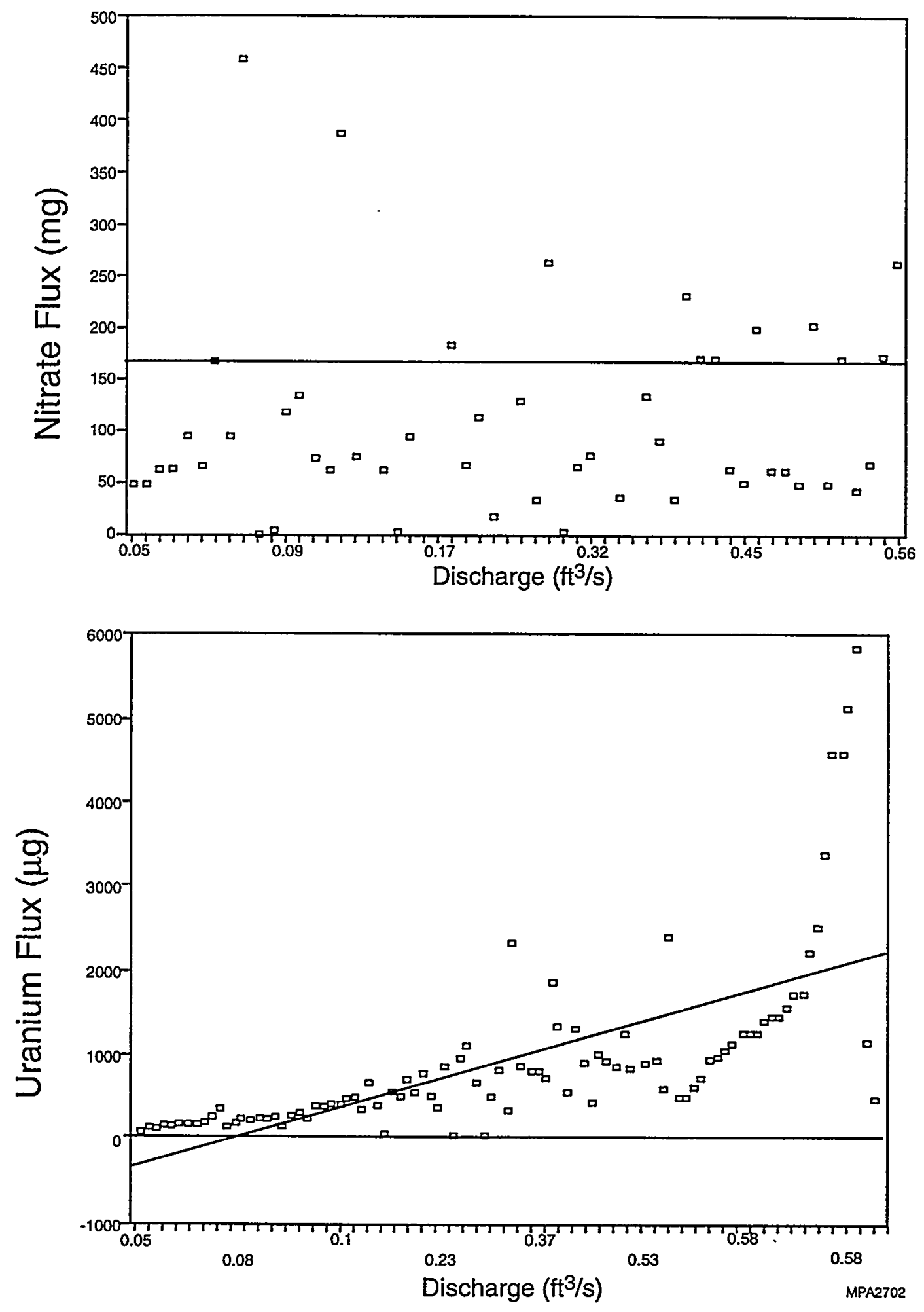

FIGURE 5.5 Contaminant Flux versus Discharge of Burgermeister Spring 1987 to 1995 
1987 to 1990
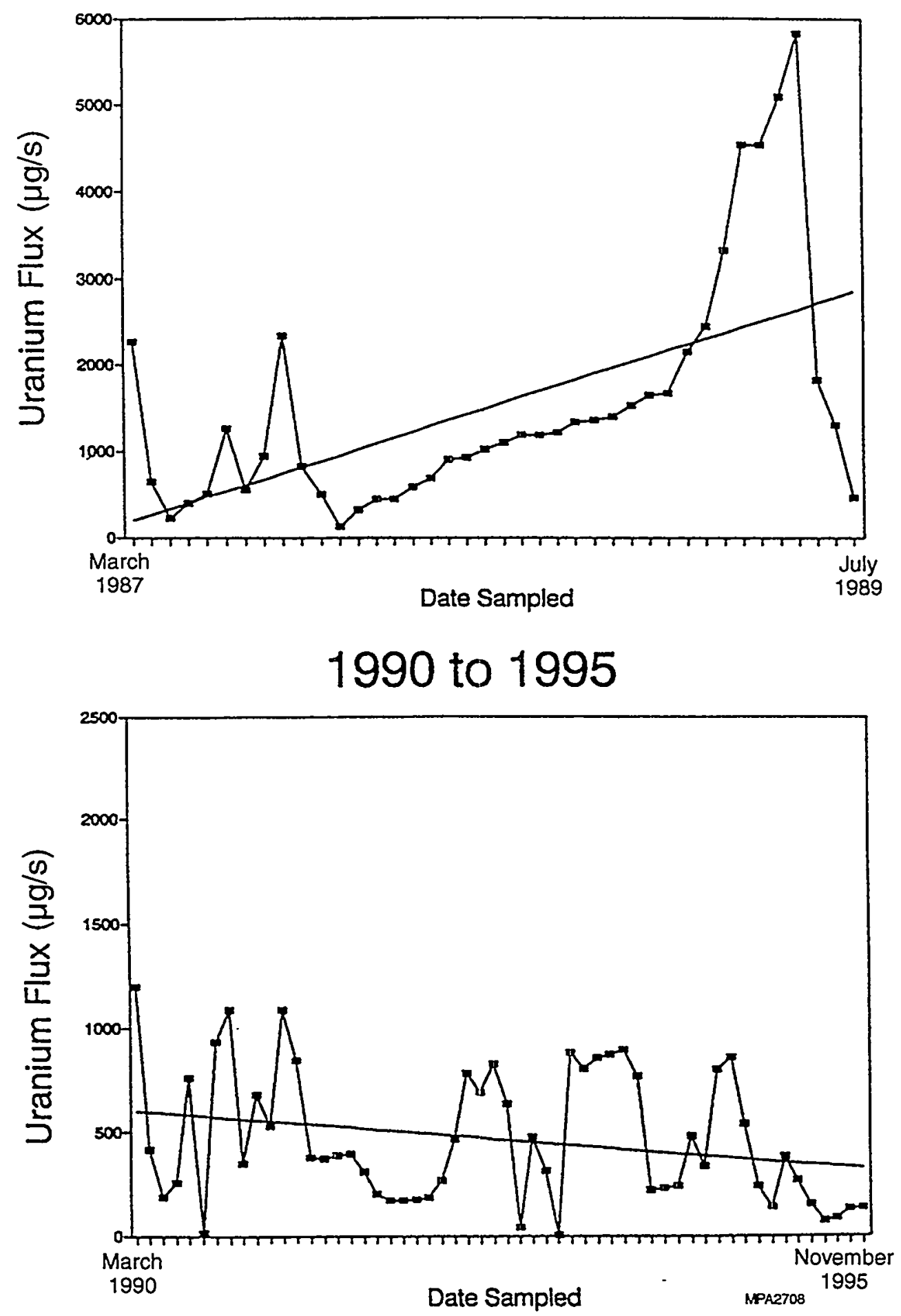

FIGURE 5.6 Uranium Flux versus Date Sampled, Burgermeister Spring 


\section{SUMMARY OF THE BASELINE RISK ASSESSMENT}

A combined assessment addressing both human health and ecological impacts was performed as part of this RI. A separate report has been prepared to present details of the risk assessment (DOE and DA 1997); this section summarizes that assessment. The human health component of the baseline risk assessment included an evaluation of the radiological and chemical risks from contamination in the shallow aquifer system that are common to both the chemical plant area and ordnance works area. Springwater data were also used to calculate potential human health impacts at the springs. The ecological risk assessment focused on Burgermeister Spring because the aquatic habitats associated with this spring are more permanent than the habitats at other springs in the area and, thus, may be used by a greater variety and number of biota than habitats at other springs.

\subsection{HUMAN HEALTH ASSESSMENT}

Site-related COPC were identified from the list of contaminants presented in Table 2.4. For groundwater, the COPC are lithium, molybdenum, uranium, nitrate, chloride, sulfate, nitroaromatic compounds, TCE, and 1,2-DCE.

Under current land use, the most likely receptor was assumed to be a recreational visitor who might be exposed to contaminated discharge water at one of the springs. No current access and use of the groundwater was assumed on the basis of current land use information. Foreseeable future land use is expected to be similar to current land use. Exposure of Army reservists that visit the training area for drills was not evaluated separately because there are no active springs within the boundaries of the training area. Also, calculations presented for the recreational visitor are representative of those for Army reservists because the exposure parameters (e.g., duration and frequency) would be similar.

Calculations for a residential scenario were also included to provide upper-bound information regarding human health risk from groundwater. Maximum concentrations in groundwater for COPC from the 1995 joint DOE/DA sampling rounds were used as exposure point concentrations. This approach was taken because the 1995 joint data were consistent with the data obtained since 1987 and are, therefore, representative of the nature and extent of contamination. The use of more recent data also provides risk estimates that are representative of current conditions at the site. In addition, a well-by-well calculation was performed because results of the RI have shown contaminant concentrations to be heterogeneous.

Both a hazard index and carcinogenic risk were calculated by using the UCL or maximum value for each COPC in springwater for each of the 15 springs sampled in 1995 to evaluate potential 
exposure of the recreational visitor. Similar calculations were performed for each well to determine potential exposure of a future resident. Pathways evaluated for the recreational scenario were ingestion and dermal contact. The primary pathway of concern for groundwater is ingestion; however, the dermal pathway was also assessed. In addition, the inhalation pathway was evaluated for TCE. Standard exposure parameters recommended by the EPA were used in the calculations. Current contaminant concentrations were also assumed for future scenarios. This approach is considered conservative since contaminant concentrations are expected to decrease with time as a result of source removal activities currently in progress at both the chemical plant area and the ordnance works area.

Neither carcinogenic risk nor systemic toxicity is indicated for the recreational visitor incidentally ingesting and dermally exposed to springwater in the area covered by the GWOUs. The radiological risk estimates range from $4 \times 10^{-9}$ to $2 \times 10^{-6}$. These values are low and well within the target risk range of $1 \times 10^{-6}$ to $1 \times 10^{-4}$ recommended by the EPA (EPA 1990). The chemical risk estimates are similarly low, ranging from $2 \times 10^{-10}$ to $3 \times 10^{-7}$. The EPA has provided a quantitative measure for adverse health effects other than cancer; a hazard index greater than 1 indicates potential adverse health effects. The hazard indexes estimated for the recreational visitor at the springs range from less than 0.001 to 0.2 .

The well-by-well calculations of radiological and chemical carcinogenic risks to determine potential exposure of a hypothetical future resident indicate that the majority of the 155 wells evaluated do not contain contaminants at levels that contribute to a risk higher than $10^{-4}$. Excluding contributions from TCE, chemical risk estimates for only 4 of the 155 wells are higher than $10^{-4}$ (e.g., MWV-09, MWS-12, MW-2030, MWS-17). The chemical risk estimates for the 155 wells range from $1 \times 10^{-7}$ to $2 \times 10^{-4}$. The primary contributors to the risks are 2,4-dinitrotoluene and 2,6-dinitrotoluene. The radiological risk estimates for all wells are within the target risk range. The range of estimates for radiological risks from uranium is $7 \times 10^{-8}$ to $7 \times 10^{-5}$.

Concentrations of TCE were detected in nine wells at or in the vicinity of the chemical plant area. The total carcinogenic risks at these wells, incorporating risk from TCE, are as follows: $2 \times 10^{-5}$ (MW-3024), $4 \times 10^{-4}$ (MW-2037), $1 \times 10^{-3}$ (MW-2038), $1 \times 10^{-5}$ (MW-3025), $1 \times 10^{-6}$ (MW-4001), $2 \times 10^{-7}$ (MW-2032), $3 \times 10^{-4}$ (MWS-21), $9 \times 10^{-7}$ (MW-3027), and $6 \times 10^{-7}$ (MW-2013).

The hazard indexes for the 155 wells evaluated range from less than 0.01 to 40 . Forty-three of 155 hazard indexes are greater than 1. Twenty-seven of the estimates that are greater than 1 are attributable primarily to nitroaromatic compounds; 15 estimates are attributable to nitrates, and 1 to uranium. Elevated nitroaromatic compounds have been identified for wells in various locations at the two areas. Elevated nitrates occur mostly in chemical plant area wells. 


\subsection{ECOLOGICAL ASSESSMENT}

The ecological risk assessment evaluated risks to ecological resources by using data on springs in the chemical plant area and the ordnance works area. Although direct exposure to groundwater is unlikely for aquatic and terrestrial biota, fish and wildlife may be exposed at locations where the groundwater discharges to surface water habitats, namely springs. Risks to aquatic biota were evaluated by using biotic surveys and media toxicity and by comparing media concentrations to ecological benchmark ("safe") media concentrations. Risks to terrestrial biota were evaluated by melding contaminant uptake via ingestion of water and comparing the predicted doses to species-specific benchmark doses. Maximum concentrations of the potential site-related contaminants were used for all benchmark comparisons and uptake modeling. The data used for the ecological risk assessment included the same data on springs used in the human health risk assessment, as well as sediment data collected specifically for the ecological risk assessment at the Burgermeister Spring and selected downstream locations. Burgermeister Spring was selected as the exposure area for all uptake modeling scenarios, biotic surveys, and toxicity testing because the spring and downstream habitats represent the largest and most permanent spring-related aquatic habitat in the area.

Surveys of macroinvertebrates, fish, and amphibians inhabiting the Burgermeister Spring drainage found no evidence of adverse effects to these aquatic biota. The spring was determined to contain generally good aquatic habitat comparable to the habitat evaluated at a reference spring location, and the species present are typical of those found in similar habitats throughout the Midwest. Although the fish community was limited in diversity and the macroinvertebrate community was categorized as slightly impaired, the communities are likely affected by the physical nature of the spring and its drainage rather than by contaminant levels. Flow in the uppermost portion of Burgermeister Spring is maintained by groundwater discharge at the spring. Under low flow conditions, as commonly occur in the summer, the spring becomes intermittent, and portions of the habitat become dry. Surveys found the amphibian community to be similar in species composition to the community identified at the reference spring and to typical communities in similar habitats in the Midwest.

The results of toxicity testing indicate the potential for some toxicity to fish and invertebrates from surface water and sediment in Burgermeister Spring proper. Surface water and sediment toxicity were also measured at some locations downstream of the spring, but no clear toxicity gradient is evident extending downstream from the spring. The presence of apparently unaffected macroinvertebrate, fish, and amphibian communities in the drainage at locations where media toxicity was detected suggests that local populations are tolerant of (or have adapted to) the contaminant levels present in surface water and sediment in the Burgermeister Spring drainage.

Modeling of contaminant uptake by the white-tailed deer and the American robin drinking from Burgermeister Spring (but using maximum contaminant concentrations reported from all 
springs) predicted very low levels of contaminant uptake by these species. Risk estimation based on the modeled contaminant doses indicates no risk to terrestrial biota drinking from the spring. Risk estimates for aquatic biota on the basis of media concentrations indicate that surface water concentrations of arsenic, cadmium, copper, lead, manganese, 1,3,5-trinitrobenzene, 2,4,6-trinitrotoluene, and sediment concentrations of arsenic, lead, and silver may pose low to moderate risks to aquatic biota in the drainage.

Although the risk estimates for iron and mercury indicated extreme risks to aquatic biota, the risk estimates were derived on the basis of maximum reported concentrations that may represent outliers. Risk estimates derived without using these maximum values indicated low or no risks for mercury and iron, respectively. Even though some risks to aquatic biota are indicated, the aquatic community in Burgermeister Spring is typical of similar habitats elsewhere in the Midwest and does not appear to be adversely affected by contaminant concentrations at this time. Few of the remaining springs in the area provide suitable habitat and, at best, naturally support only very limited aquatic communities.

These evaluations indicate that current contaminant levels in surface water in area springs pose little or no risk to terrestrial biota of the chemical plant and ordnance works areas. Risk calculations for aquatic biota indicate that concentrations of some contaminants in surface water and sediment from springs may pose low risks to aquatic biota. However, most of the risk estimates only slightly exceeded the target risk range. In addition, most springs do not naturally provide permanent habitat to support aquatic biota, and, thus, the potential risks are not expected to be ecologically significant. Although some toxicity has been indicated for surface water and sediment from Burgermeister Spring, the results of the biotic surveys show no evidence that the aquatic biota are being adversely affected by present contaminant levels. Thus, the ecological significance of the toxicity is small, and aquatic ecological resources of the area should not be expected to be adversely affected. 


\section{QUALITY ASSURANCE}

Remedial investigation activities for the GWOUs were conducted in accordance with the respective quality assurance program plans (QAPPs) developed for each site. The QAPP used for GWOU activities at the ordnance works area is entitled the Chemical Data Acquisition Plan, Weldon Spring Ordnance Works Remedial Design, Weldon Spring, Missouri (IT Corporation 1994a). For the chemical plant area, the QAPP is entitled Environmental Quality Assurance Project Plan (EQAPjP) (MK-Ferguson and Jacobs Engineering Group, Inc. 1993a). These documents provide guidelines to ensure that all environmental activities conducted for the groundwater remedial investigation were performed in a manner resulting in the collection of quality data.

Extensive quality control (QC) measures and quality assurance (QA) evaluations were performed on data collected for the groundwater operable unit. This section summarizes these measures. Table 7.1 defines the types of QC samples that were collected, frequency of collection, and the purpose for sample collection.

\subsection{ANALYTICAL REVIEW}

The data quality objectives developed for the GWOUs provide for the collection of the right type, quality, and quantity of data to support remedial decisions. This process ensures that the samples collected were analyzed at appropriate detection limits and by adequate methods to support the risk assessment. All laboratories (including those used for the 1995 sampling) are required to conform to approved analytical methods and $\mathrm{QA} / \mathrm{QC}$ procedures.

All data quality requirements for the GWOUs were met as required in the Sampling Plan (DOE 1995a), with the following exceptions: two chain-of-custody incidents, a sample filter problem, and analytical problems resulting from the grout used during well installation. These exceptions are discussed in Sections 7.1.1.1 to 7.1.1.3. Reasons for the rejection of certain data are discussed in Sections 7.1.1.4 and 7.1.1.5. Section 7.1.1.6 discusses other data quality uncertainties.

\subsubsection{Field Filters}

Beginning with the fifth sampling round in April 1992 for training area and ordnance works wells and all chemical plant area samples from 1987 to 1995, filters manufactured by QED Groundwater Specialists were used for filtering groundwater prior to metals analysis. IT Corporation reported in the July 1992 Groundwater Monitoring Report (IT Corporation 1992c) that antimony appeared in the dissolved metals results. This was inconsistent with past sampling results, and IT Corporation suspected that antimony was being leached from the filter paper. In a subsequent 
TABLE 7.1 Summary of Quality Control Samples

\begin{tabular}{|c|c|c|}
\hline Quality Control Sample Type & Frequency ${ }^{\mathrm{a}}$ & Purpose \\
\hline Matrix spikes & $\begin{array}{l}1 \text { per } 20(5 \%) \\
\text { samples or } 1 \text { per } \\
14 \text { days }\end{array}$ & $\begin{array}{l}\text { Monitors the effect of matrix interferences on the } \\
\text { detection of an analyte. }\end{array}$ \\
\hline External QA sample & 1 per 10 samples & $\begin{array}{l}\text { Compares the primary laboratory with the secondary } \\
\text { laboratory and provides an additional check on the } \\
\text { performance of the primary laboratory. }\end{array}$ \\
\hline Field duplicate & 1 per month & $\begin{array}{l}\text { Monitors field conditions that may affect the } \\
\text { reproducibility of samples collected from a given } \\
\text { location. }\end{array}$ \\
\hline $\begin{array}{l}\text { Equipment blank (nondedicated } \\
\text { equipment only) }\end{array}$ & $\begin{array}{l}1 \text { per } 20(5 \%) \\
\text { samples }\end{array}$ & $\begin{array}{l}\text { Monitors the effectiveness of decontamination } \\
\text { procedures used on nondedicated sampling } \\
\text { equipment. }\end{array}$ \\
\hline Deionized water blank & 1 per month & $\begin{array}{l}\text { Monitors the purity of distilled water used for field } \\
\text { blanks and decontamination of sampling equipment. }\end{array}$ \\
\hline Trip blank & 1 per month & $\begin{array}{l}\text { Monitors VOCs that may be introduced during } \\
\text { sampling, transportation, or handling at the } \\
\text { laboratory. }\end{array}$ \\
\hline
\end{tabular}

a As stipulated in Weldon Spring Site Remedial Action Project Environmental Safety and Health Procedure 4.1.4s, Rev. 3.

November 1992 report, a sample of the filter paper was analyzed, and antimony was indeed found to be present (IT Corporation 1993b). In addition, it was reported by the manufacturer of the filters that up to $50 \mu \mathrm{g} / \mathrm{L}$ of antimony can be leached from the filter papers (Kaminski 1995). According to EPA guidance, if filtered samples showed detected antimony at a concentration of less than $250 \mu \mathrm{g} / \mathrm{L}(5 \times 50 \mu \mathrm{g} / \mathrm{L})$, the data point would be rejected. Because no samples exceeded this concentration, all filtered samples that had detections for antimony were rejected and not used. A large number of filtered samples were affected by this situation, and, therefore, only antimony data from unfiltered samples were used for the RI and BRA.

\subsubsection{Chain-of-Custody}

Chain-of-custody was maintained on all sample collection and shipment activities with the exception of one request for eight samples. In the cases where chain-of-custody was not maintained, the data were rejected. 
One shipping incident was also reported during the August sampling event; two coolers were inadvertently shipped to the wrong laboratory. One cooler of nitroaromatic samples was shipped to the analytical laboratory that performed metals analysis, while the other cooler went to the nitroaromatics lab. The chain-of-custody was maintained on the coolers, and the shipments were reshipped to the appropriate laboratories.

\subsubsection{Well Installation}

Monitoring Well 4024 was installed in early July 1995, and on July 5, 1995, the well was sampled. The total uranium value for the first sample for this well was much higher than expected on the basis of values reported for nearby wells. After observing this, an informal study was performed on the bentonite grout used in well construction. In this study, $500 \mathrm{~g}$ of dry bentonite supplied by the well subcontractor was analyzed by gamma spectroscopy and found to have $2.84 \mathrm{pCi} / \mathrm{g}$ of uranium-238. This grout comes from natural sources, which means that about half of the total uranium activity in the grout comes from uranium-238 and about half comes from uranium-234. Therefore, the activity of the total uranium in the bentonite should be roughly two times the activity of uranium-238. In an effort to determine if leaching occurs, about $500 \mathrm{~g}$ of the bentonite was placed in a 1-L nalgene container. Approximately $150 \mathrm{~mL}$ of tap water was added to the container, which resulted in saturation of the bentonite. The tap water, as well as the following aliquots, were analyzed by KPA. The uranium activity level in the tap water was below the detection limit at $0.0032 \mathrm{pCi} / \mathrm{L}$. Aliquots of the water sitting above the grout were collected after one day, two days, and seven days. The analysis results after one, two, and seven days were $1.65 \mathrm{pCi} / \mathrm{L}$, $2.49 \mathrm{pCi} / \mathrm{L}$, and $38.9 \mathrm{pCi} / \mathrm{L}$ of total uranium, respectively. These results demonstrate that some of the uranium from the bentonite may have leached into the water in the wells. Furthermore, the values of total uranium for subsequent samples in this well dropped considerably. The value for the sample taken on August 11, 1995, was $16.6 \mathrm{pCi} / \mathrm{L}$. The values for the samples taken in May and September 1996 were 8.67 and $4.07 \mathrm{pCi} / \mathrm{L}$, respectively. This analysis will help to assess previous and future elevated uranium concentrations reported in existing and newly developed wells at the chemical plant area and the ordnance works area.

\subsubsection{Data from Early Sampling Rounds}

Because of discrepancies in analytical methods and QA procedures that occurred during the first and third rounds of DA sampling in March and October 1989 and May and June 1991, data from the ordnance works area and training area sampling Rounds 1 and 3 were not used for the RI and BRA. The data were excluded because of QA/QC problems, such as missed holding times, poor matrix spike (MS) recoveries, and poor laboratory chemical spike (LCS) recoveries. 
Nitroaromatics data generated from samples taken at the ordnance works and the training area in November 1992 (Round 7) were rejected because of sporadic blank contamination. Metals data were acceptable. Nitroaromatic data were retaken in December 1992 (Round 7A) and were found to be acceptable.

In Round 15, November 1994, nitroaromatic data from Well USGS2A were rejected because the holding time was exceeded.

\subsubsection{Other Data Quality Uncertainties}

Issues that could affect data used in the RI and BRA include changes in sampling techniques and analytical methodologies and modified laboratory procedures, for example:

- Changes in Sampling Techniques. In May 1994, wells at the training and ordnance works areas were switched from bailers to bladder pumps. This sampling methodology is known to affect analytical results. The actual magnitude of this effect is uncertain.

- Changes in Analytical Methodology. Theoretically, all valid analytical methods should arrive at the same result for the same sample. In practice, however, because each method requires slightly different analytical expertise, changes in analytical methods can produce different analytical results from the same sample. This, however, appears to be a minor problem for the groundwater data since split samples taken and analyzed by subcontracted laboratories have generally agreed with QA laboratory split samples by the DA. This is true even though the QA laboratory of the DA has been using Method 8330 (a high-performance chromatograph/ chromatography [HPLC] method), the USGS has been using a variation of Method 8330, and other subcontractor laboratories were using other versions of a gas chromatograph (GC) method. Before Method 8330 was used, the Weldon Spring Ordnance Works wells were analyzed by a U.S. Army Toxic and Hazardous Materials Agency HPLC method for Rounds 1 and 2 for training area wells and by EPA Method 609 for Round 1 for other ordnance works wells. Method 8330 was used for all ordnance works wells in Rounds 3 to 12, and variations of the Army Environmental Hygiene Agency GC/electron capture detector (ECD) method were used for all subsequent rounds. Results from all of these methods have been generally comparable. Therefore, the changes in methodology over the years are not considered a significant factor in data quality. 


\subsection{DATA VALIDATION}

The DOE and DA QA program for environmental data includes validation or assessment of quality sufficiency of the analytical data that are used to make remedial decisions under CERCLA. Data validation is defined as the review of analytical data documentation used to qualify the quality and usability of data. Factors considered in this determination include sample integrity, laboratory performance, and compliance with procedural QC criteria and data quality requirements. Data validation also provides an assessment of the accuracy, precision, and completeness of the reported analytical data.

Accuracy is defined as how close an analyzed value is to the true value. It is usually associated with LCS recoveries and MS recoveries. A value of $100 \%$ is the best accuracy. Precision is defined as how close two analyzed values match each other. Precision is normally expressed as the relative percent difference (RPD). An RPD of $0 \%$ is the best precision. The data acceptance criterion is defined as the ratio of accepted data points to the validated data points (accepted plus rejected) in a data set. The EPA uses an acceptance limit of $85 \%$ for its Contract Laboratory Program work with individual laboratories. The Weldon Spring Site Remedial Action Project uses this value as well.

Validation was conducted on at least $10 \%$ of the chemical plant data collected before 1995 , as required by standard operating procedures. For the ordnance works data, quality sufficiency evaluations were conducted for $100 \%$ of the groundwater data collected before the joint sampling quarters. The objectives of the DA quality sufficiency evaluations are similar to those of DOE's validation activities performed at the Weldon Spring Site Remedial Action Project. All data collected from the 1995 joint sampling events from both areas were validated or evaluated. Similar evaluation and validation procedures and frequencies were applied to data collected from springs.

\subsection{DATA REVIEW AND USE}

In the preparation of the RI report, data from the 1995 joint sampling quarters were compared with previously collected data for the sample location. Data were reported as nondetected (but with the detection limit identified), as detected values, or as uncensored data. Uncensored values were defined as data reported at a concentration measured at less then the required detection limit of the analytical methods or instrumentation. For the chemical plant groundwater data, $1.37 \%$ of the data were reported as uncensored; for the ordnance works groundwater data, $1.83 \%$ of the data were uncensored; the percent of uncensored data in the sediments database was $0.93 \%$; the percentage of uncensored data in the springs database was $0.54 \%$. In all statistical summaries provided in this RI report, one-half the detection limit was used for calculating averages in nondetect data. The EPA recommends the use of this value for statistical manipulation of data when the percentage of nondetects in the data set is small and uncensored data are not available (EPA 1989a). 
Data for the GWOUs were also evaluated with a statistical method whereby data for the same location for each parameter are reviewed to examine potential outliers within the data set. The summary is based on trimmed data sets and Gaussian statistics. The data are ranked relative to the tolerance intervals, which are defined by the trimmed mean $(\mu) \pm 3$ standard deviations $(\sigma)$. Although some data sets may not follow a Gaussian (normal) distribution, this approach provides a conservative means for identifying extreme values (potential outliers) and is simple to use. This value also approximates the 98th percentile of the data set for the location and the parameter. For the RI, these data were included in summary tables but were not used in statistical summary or average calculations. Table 7.2 lists the data points that were identified as outliers as a result of calculation of the mean from historic data, existing conditions at the sites, and potential contaminant source areas.

TABLE 7.2 Data Points Identified as Outlier Values for the Groundwater Operable Units

\begin{tabular}{lccc}
\hline \multicolumn{1}{c}{ Parameter } & Location & Outlier Value & $\begin{array}{c}\text { Next Value in } \\
\text { Data Set }\end{array}$ \\
\hline Manganese & MWS-111 & $27,000 \mu \mathrm{g} / \mathrm{L}$ (Round 8) & $904 \mu \mathrm{g} / \mathrm{L}$ \\
Aluminum & MWD-106 & $2,000 \mu \mathrm{g} / \mathrm{L}$ (Round 7) & $29 \mu \mathrm{g} / \mathrm{L}$ \\
Iron & MWD-106 & $1,400 \mu \mathrm{g} / \mathrm{L}$ (Round 7) & $76.8 \mu \mathrm{g} / \mathrm{L}$ \\
Iron & MWD-109 & $4,100 \mu \mathrm{g} / \mathrm{L}$ (Round 4) & $270 \mu \mathrm{g} / \mathrm{L}$ \\
\hline
\end{tabular}




\section{SUMMARY AND CONCLUSIONS}

An RI was conducted to evaluate the nature and extent of potential contamination in the shallow aquifer system at the DOE chemical plant area and the DA ordnance works area. The remedial investigation evaluated geological, groundwater, and spring data collected from 1987 to 1995, including data from a 1995 joint sampling effort conducted at the chemical plant area and the ordnance works area. These data were used to characterize the hydrogeology of the chemical plant area and the ordnance works area and to describe the nature and extent of contamination in the groundwater system of the area. These data were also used to prepare a BRA that evaluates the potential effects of exposure to contaminated groundwater and springwater to human health and the environment.

\subsection{HYDROGEOLOGY}

The focus of the groundwater remedial investigation was the shallow aquifer system, which consists of the first encountered groundwater at the chemical plant area and the ordnance works area. The shallow aquifer system includes the saturated overburden, the Burlington-Keokuk Limestone, and the Fern Glen Formation. In general, the flow in this aquifer can be characterized as Darcian diffuse flow through the saturated overburden and limestone bedrock matrix, with superimposed conduit flow through the larger joints and solution features in the limestone bedrock. Interaction between the surface water and groundwater occurs through losing and gaining stream segments in the ordnance works area and through groundwater discharge to springs. Losing stream segments allow surface water runoff to enter into the subsurface and act as localized recharge to the shallow groundwater system. Gaining stream segments and springs reflect discharge of the aquifer to the surface water system. This type of groundwater flow is typical of carbonate aquifer systems.

The Burlington-Keokuk Limestone can be divided into weathered and unweathered hydrostratigraphic units on the basis of stratigraphic characteristics, degree of weathering, and fracture density. This division is pertinent to the ability of groundwater to move through the bedrock. The hydraulic conductivity of the Burlington-Keokuk Limestone decreases with depth, and the greatest variation in hydraulic conductivity occurs in the upper 3 to $6 \mathrm{~m}(10$ to $20 \mathrm{ft}$ ) of the weathered unit. The Fern Glen Formation is included in the lower hydrostratigraphic unit because of its similarity to the unweathered Burlington-Keokuk unit, thick bedding, fine-grained texture, and its position directly below the unweathered unit.

Recharge to the shallow aquifer occurs as infiltration of precipitation and impounded surface water through the overburden materials. The hydraulic conductivity of the overburden units is low due to the predominance of clay in the till and residuum units, which contain permeable zones and hairline fractures that allow infiltration by gravity drainage. Recharge also occurs as surface 
water runoff entering the aquifer system through numerous losing stream segments; however, the residence time of this water in the system is short. Discharge of the shallow aquifer occurs at springs and seeps in the area. The larger flow rates from these springs are due, in part, to precipitation events.

Paleochannels or paleovalleys (preglacial drainages) have been identified in the top of the bedrock surface in the northern portion of the chemical plant area and the training area. These paleochannels, which in some cases coincide with troughs in the shallow groundwater surface, are more transmissive than other areas. Higher hydraulic conductivities are associated with the paleochannels in these areas, primarily at the residuum/bedrock contact. These higher conductivity values are likely due to increased weathering along the contact, which results in high fracture intensity and gravel content. These paleochannels allow for a greater horizontal movement of groundwater.

Tracer tests indicate that the paleochannel or paleovalley areas are connected to a subsurface conduit system in the northern portion of the chemical plant area and the training area. The conduit system allows for rapid movement of groundwater through the bedrock; travel times are on the order of several feet per minute. The conduit system is complex and consists of branching and converging conduit flow routes. Tracer tests indicate a relationship between precipitation events and groundwater discharge in the conduit system.

Vertical gradients between the overburden and Burlington-Keokuk Limestone and within the Burlington-Keokuk Limestone indicate recharge (downward movement) conditions. Upward gradients between and within these units in the northern portion of the training area likely represent localized discharge of the shallower groundwater to stream segments in this area. Vertical gradients between the Burlington-Keokuk Limestone and the Fern Glen Formation indicate upward gradients, generally in the northern portion of the ordnance works area, and reflect the discharge of the shallow aquifer to Dardenne Creek.

\subsection{NATURE AND EXTENT OF POTENTIAL SITE-RELATED CONTAMINATION}

The site-related contaminants of potential concern include uranium, nitroaromatic compounds, nitrate, sulfate, chloride, lithium, molybdenum, TCE, and 1,2-DCE. Contamination in the groundwater is generally confined to the shallow, weathered portion of the Burlington-Keokuk, which discharges to springs in the ordnance works area.

Historical sources of groundwater contamination at the chemical plant and ordnance works areas include surface water impoundments, buildings, TNT and DNT production lines, wastewater pipelines, soils and debris from the ordnance production and uranium processing activities, and waste disposal areas, including burning grounds and dumps. Contaminant sources of the 
groundwater also include sorbed contaminants in the overburden material and contaminated sediment within the shallow aquifer system.

The current sources of uranium in the groundwater and springs are the absorbed uranium and contaminated sediment in the shallow aquifer system (including the conduits) and the adsorbed material in the vadose zone. Uranium-contaminated groundwater is detected north of the raffinate pits, near Frog Pond, south of the chemical plant area, and on the eastern part of the training area near the raffinate pits. Previous sludge and surface water analyses indicate that the raffinate pits probably are the primary historical source of uranium groundwater contamination (MK-Ferguson Company and Jacobs Engineering Group, Inc. 1992a). Uranium entered the shallow aquifer from the pits via infiltration through fractures in the overburden. Geochemical investigations previously conducted by the USGS indicate that uranium and other metals readily sorb to overburden materials, thus limiting their transport to the underlying shallow groundwater system (Schumacher et al. 1993). The results of these investigations suggest that the uranium infiltrating from the pits has reduced mobility because of precipitation and adsorption to materials in the saturated overburden, which supports the limited extent of uranium contamination detected in the groundwater.

In contrast, the historical data on concentrations of uranium in the nearby surface water (i.e., Burgermeister Spring) suggest that during storm events, surface water runoff increased and transported uranium from contaminated soils in the areas of Ash Pond and Frog Pond. The uranium was probably transported in both the dissolved and particulate forms. In the drainages downstream from Ash Pond and Frog Pond, surface water is lost to the subsurface. In the subsurface, a portion of the dissolved uranium was probably transferred to solid phases by chemical precipitation and adsorption, while the remainder of the uranium was transported through conduits and discharged to Burgermeister Spring. In addition to carrying the dissolved uranium, surface runoff also transported sediment contaminated with uranium to the subsurface.

The results of the in situ groundwater sampling, in the Southeast Drainage reveal concentrations of uranium to be relatively elevated (as high as $164 \mathrm{pCi} / \mathrm{L}$ ). To provide better delineation of the extent of uranium contamination in this area, DOE has installed a monitoring well in the Southeast Drainage area. Data collection began in May 1997. Uranium was not detected in the initial round of sampling. Analyses for other site contaminants indicated low levels and nondetections. Further data collected for this well will be summarized in the annual site monitoring report and/or the FS, as appropriate.

Higher concentrations of lithium and molybdenum were detected in the shallow aquifer near the raffinate pits. As is the case for uranium, the raffinate pits constitute the historical source of these two metals. Adsorption and precipitation play a role in attenuating metal concentrations in the saturated overburden. However, lithium, because of its fairly low estimated distribution coefficient, is one of the more mobile metals (DOE 1992a). Lithium potentially seeps from the raffinate pits into the shallow aquifer and is transported by diffuse flow until it enters the conduit 
system and discharges to springs. Molybdenum behaves in a similar manner except that its mobility is inhibited by a larger distribution coefficient (DOE 1992a).

The contamination of groundwater with nitrate and sulfate is detected near the raffinate pits and Ash Pond area, which are the historic sources of these contaminants. Nitrate and sulfate probably infiltrate from the raffinate pits and Ash Pond into the shallow groundwater, enter the conduit system, and are discharged to springs. Unlike metals, nitrate and sulfate are highly mobile in the shallow groundwater system. In addition, conditions for denitrification, a naturally occurring process that converts nitrate to nitrogen, are not present at the chemical plant area, thus allowing nitrate to persist in the groundwater. Similarly, sulfate-reducing conditions have not been identified within the shallow aquifer, thus sulfate is also persistent in the groundwater.

Groundwater contamination with nitroaromatic compounds occurs sporadically at low levels across the groundwater system. Presence of nitroaromatic compounds in the groundwater is suspected to be a result of leakage from former TNT process lines, discharge from wastewater lines, and leaching of TNT-contaminated soils. The nitroaromatic compounds and their degradation products infiltrate into the shallow groundwater system and are discharged to springs by diffuse and discrete flow mechanisms. Nitroaromatics have low persistence and relatively low solubilities, but their mobilities are high as a result of low distribution coefficients. Biotransformation in the overburden material and shallow aquifer is the primary process affecting their distribution in the groundwater system. Microorganisms have been shown to transform and degrade TNT and DNT (Schumacher et al. 1993). The groundwater characterization results suggest that biotransformation is affecting nitroaromatic contamination in groundwater at the chemical plant area and the ordnance works area. In general, TNT and DNT concentrations decrease with distance from the historic source areas, while concentrations of degradation products increase. The decrease in TNT and DNT has been shown to be correlated at the ordnance works area with the increase in 2-amino4,6-dinitrotoluene and 4-amino-2,6-dinitrotoluene (Schumacher et al. 1993).

Recent groundwater contamination with TCE and 1,2-DCE is localized primarily in the vicinity of Raffinate Pits 3 and 4 . Contamination extends to the southwestern boundary within the training area and is contained in the weathered portion of the aquifer. Volatiles have not been detected in the springs. Possible sources of contamination include waste drums that were recently removed from Pit 4 and contaminated soils and sludges in Raffinate Pits 3 and 4. Further sampling of possible remaining sources is planned using a soil gas technology and soil sampling. Any contamination found will be scheduled for removal as part of the raffinate pit remediation.

Carcinogenic (radiological and chemical) risk and systemic toxicity are not indicated for current or future recreational visitors from incidental ingestion and dermal exposure to springwater. Potential chemical carcinogenic risks above the acceptable risk range of $1 \times 10^{-6}$ to $1 \times 10^{-4}$ for a hypothetical future resident are indicated for only a few wells. Risks are due primarily to nitroaromatic compounds and TCE. No radiological carcinogenic risks above a risk level of $1 \times 10^{-4}$ 
are indicated for any of the wells. Systemic toxicity is indicated for about $25 \%$ of the wells evaluated, due primarily to the presence of nitroaromatic compounds in well water from various locations at the chemical plant area and the ordnance works area, and the presence of nitrates mostly in chemical plant area wells.

Little evidence exists to indicate that aquatic biota are being adversely affected by contaminants in groundwater that is discharging to area springs. Some surface water and sediment toxicity were identified for Burgermeister Spring, and calculations based on maximum contaminant concentrations reported from all area springs indicate a potential for low or moderate risks to aquatic biota. However, the ecological significance of the observed toxicity and estimated risks is very minor. Biotic surveys at Burgermeister Spring identified the presence of an aquatic community typical of similar habitats in the Midwest. That community exhibited no indications of being affected by contaminants. Furthermore, most springs in the area do not provide permanent habitat capable of supporting more than a very limited aquatic biota. No risks were identified for terrestrial biota drinking from area springs; risk levels were two or more orders of magnitude below the target risk level. On the basis of these results, there is no evidence that ecological resources are being adversely affected by groundwater contamination discharging to springs in the area, and current levels of groundwater contamination pose little or no risk to aquatic or terrestrial biota. 


\section{REFERENCES}

Bechtel National, Inc., 1986, Report on Water Balance Studies from 1983 to 1985, Weldon Spring Raffinate Pits, Weldon Spring, Missouri, DOE/OR/20722-94, prepared for U.S. Department of Energy, Oak Ridge Operations Office, Oak Ridge, Tenn., March.

Bechtel National, Inc, 1987, Hydrogeological Characterization Report for Weldon Spring Chemical Plant, Weldon Spring, Missouri, DOE/OR/20722-137, prepared for U.S. Department of Energy, Oak Ridge Operations Office, Oak Ridge, Tenn., July.

Boopathy, R.C., and C.F. Kupla, 1992, "Trinitrotoluene (TNT) as a Sole Nitrogen Source for Sulfate-Reducing Bacterium Desulfovibro sp. (B strain) Isolated from an Anaerobic Digester," Current Microbiology 25:235-241.

Boopathy, R.C., et al., 1993, "Metabolism of 2,4,6-trinitrotoluene (TNT) by Desulfovibro sp. (B strain)," Applied Environmental Microbiology 39:270.

Bradley, P.M., et al., 1994, "Microbial Degradation of Nitroaromatic Contaminants in Aquifers and Surface Soils," Proceedings of the 18th Annual Army Environmental Research and Development Symposium, Williamsburg, Va.

Bradley, P.M., and Chapelle, F.H., 1995, "Factors Affecting Microbial 2,4,6-Trinitrotoluene Mineralization in Contaminated Soil," Environmental Science and Technology 29(3):802-806.

Bradley, P.M., et al., 1997, "Potential for Intrinsic Bioremediation of a DNT-Contaminated Aquifer," Ground Water 35(1):12-17.

Callahan, M.A., et al., 1979, Water-Related Environmental Fate of 129 Priority Pollutants, Volume II: Halogenated Aliphatic Hydrocarbons, Halogenated Ethers, Cyclic Aromatics, Phthalate Esters, Polycylic Aromatic Hydrocarbons, Nitrosamines, and Miscellaneous Compounds, EPA-440/4-79-029b, U.S. Environmental Protection Agency, Office of Water and Waste Management, Washington, D.C., Dec.

Carpenter D.F., et al., 1978, "Microbial Transformation of ${ }^{14} \mathrm{C}$-Labeled 2,4,6-Trinitrotoluene in an Activated-Sludge System," Applied Environmental Microbiology 35:949-954.

Cartwright, N.J., and R.B. Cain, 1959, "Bacterial Degradation of the Nitrobenzoic Acid," Biochemistry Journal 71:248-261. 
Chapelle F.H., and P.M. Bradley, 1993, "Microbial Degradation of Nitrotoluenes in Surface Soils and Aquifer Sediments, Weldon Spring, Missouri," in Proceedings of the U.S. Geological Survey Toxic Substances Hydrology Program, Technical Meeting, U.S. Geological Survey Water-Resources Investigation Report 94-4015G, D.W. Morganwalp and D.A. Arsonson (editors), Colorado Springs, Co., Sept. 20-24, 1993.

Crigler, D., 1992, personal communication from Crigler (Wildlife Management Biologist, August A. Busch Memorial Wildlife Area, St. Charles, Mo.) to G. Valett (Project Management Contractor, Weldon Spring Site Remedial Action Project, St. Charles, Mo.), as documented in memorandum from G. Valett to R. Ferguson (Jacobs Engineering Group, Inc., Weldon Spring Site Remedial Action Project, St. Charles, Mo.), May 21.

Davis, T.L., 1943, The Chemistry of Powder and Explosives, Angriff Press, Hollywood, Calif.

Daubel, K., 1992, personal communication from Daubel (U.S. Department of Army) to M. Sizemore (MK-Ferguson Company, Weldon Spring Site Remedial Action Project, St. Charles, Mo.), as documented in memorandum from M. Sizemore to M. MacDonell (Environmental Assessment and Information Sciences Division, Argonne National Laboratory, Argonne, Ill.), March 17.

Dickneite, D.F., 1988, letter with enclosure from Dickneite (Environmental Administrator, Missouri Department of Conservation, Jefferson City, Mo.) to I. Hlohowskyj (Environmental Assessment and Information Sciences Division, Argonne National Laboratory, Argonne, Ill.), Aug. 24.

Dilling, W.L., et al., 1975, "Evaporation Rates of Methylene Chloride, Chloroform, 1,1,1Trichloroethane, Trichloroethylene, Tetrachloroethylene, and Other Chlorinated Compounds in Dilute Aqueous Solutions," Environmental Science and Technology 9:833-838.

DOE: see U.S. Department of Energy.

Ecological Specialists, Inc, 1996, Ecological Characterization for the Weldon Spring Site Remedial Action Project, ESI Project No. 95-015, prepared for MK-Ferguson, St. Charles, Mo., March.

EPA: see U.S. Environmental Protection Agency.

Fetter, C.W, 1993, Contaminant Hydrogeology, prepared for Department of Geology, University of Wisconsin-Oshkosh, Macmillan, New York, N.Y.

Fishel, V.C., and C. C. Williams, 1944, The Contamination of Ground and Surface Waters by Liquid Waste from the Weldon Spring Ordnance Works, Missouri, U.S. Geological Survey, Lawrence, Kan.

Freeze, R.A., and J.A. Cherry, 1979, Groundwater, Prentice-Hall, Inc., Englewood Cliffs, N.J. 
Funk, S.B., et al., 1993, "Initial Phase Optimization for Bioremediation of Munitions-Contaminated Soils," Applied Environmental Microbiology 59:2,171-2,177.

Grant, C.G., et al., 1995, "Holding-Time Estimates for Soils Containing Explosives Residues: Comparison of Fortification vs. Field Contamination," Environmental Toxicology and Chemistry 14(11):1865-1874.

International Technology Corporation, 1992a, Final Remedial Investigation Report, Weldon Spring Ordnance Works, Weldon Spring, Missouri, Project No. 312071, prepared by International Technology Corporation, Itasca, Ill., for U.S. Department of the Army, Corps of Engineers, Kansas City District, Nov.

International Technology Corporation, 1992b, Quarterly Groundwater Monitoring, First Report (Revision No. 2, New Data), Project No. 312188, prepared by International Technology Corporation, Itasca, Ill., for U.S. Department of the Army, Corps of Engineers, Kansas City District, May (Round 4 analytical data; Feb. 1992).

International Technology Corporation, 1992c, Quarterly Groundwater Monitoring, Second Report, Project No. 312188, prepared by International Technology Corporation, Itasca, Ill., for U.S. Department of the Army, Corps of Engineers, Kansas City District, July (Round 5 analytical data; May/June 1992).

International Technology Corporation, 1992d, Quarterly Groundwater Monitoring, Third Report, Weldon Spring Ordnance Works, Project No. 312188, prepared by International Technology Corporation, Itasca, Ill., for U.S. Department of the Army, Corps of Engineers, Kansas City District, Oct. (Round 6 analytical data; Aug. 1992).

International Technology Corporation, 1993a, Final Remedial Investigation Report, Weldon Spring Training Area, Weldon Spring, Missouri, Project No. 312188, prepared by International Technology Corporation, Itasca, Ill., for U.S. Department of the Army, Corps of Engineers, Kansas City District, March (Rounds 1-3 analytical data; March and Oct. 1989; June 1991).

International Technology Corporation, 1993b, 1993: Groundwater Monitoring Report First Yearly Sampling Round, Weldon Spring Ordnance Works, Project No. 312071, prepared by International Technology Corporation, Itasca, Ill., for U.S. Department of the Army, Corps of Engineers, Kansas City District, April (Round 8 analytical data; Feb. 1993).

International Technology Corporation, 1993c, 1993: Second Quarterly Groundwater Monitoring Report, Weldon Spring Ordnance Works, Project No. 312071, prepared by International Technology Corporation, Itasca, Ill., for U.S. Department of the Army, Corps of Engineers, Kansas City District, July (Round 9 analytical data; May 1993). 
International Technology Corporation, 1993d, 1993: Third Quarterly Groundwater Monitoring Report, Weldon Spring Ordnance Works, Project No. 312071, prepared by International Technology Corporation, Itasca, Ill., for U.S. Department of the Army, Corps of Engineers, Kansas City District, Sept. (Round 10 analytical data; Aug. 1993).

International Technology Corporation, 1993e, Quarterly Groundwater Monitoring, Fourth Report, Project No. 312071, prepared by International Technology Corporation, Itasca, Ill., for U.S. Department of the Army, Corps of Engineers, Kansas City District, Jan. (Round 7 analytical data; Dec. 1992).

International Technology Corporation, 1994a, Chemical Data Acquisition Plan, Weldon Spring Ordnance Works Remedial Design, Weldon Spring, Missouri, Project No. 312428, prepared by International Technology Corporation, Itasca, Ill., for U.S. Department of the Army, Corps of Engineers, Kansas City District, June.

International Technology Corporation, 1994b, 1994: Second Quarterly Groundwater Monitoring Report, Weldon Spring Ordnance Works, Project No. 312430, prepared by International Technology Corporation, Itasca, Ill., for U.S. Department of the Army, Corps of Engineers, Kansas City District, Aug. (Round 13 analytical data; May 1994).

International Technology Corporation, 1994c, 1994: Second Yearly Groundwater Monitoring Report, Weldon Springs Ordnance Works, Project No. 312071, prepared by International Technology Corporation, Itasca, Ill., for U.S. Department of the Army, Corps of Engineers, Kansas City District, April (Round 12 analytical data; Feb. 1994).

International Technology Corporation, 1994d, 1993: Fourth Quarterly Groundwater Monitoring Report, Weldon Spring Ordnance Works, Project No. 312071, prepared by International Technology Corporation, Itasca, Ill., for U.S. Department of the Army, Corps of Engineers, Kansas City District, Jan. (Round 11 analytical data; Nov. 1993).

International Technology Corporation, 1994e, 1994: Third Quarterly Groundwater Monitoring Report, Weldon Spring Ordnance Works, Project No. 312430, prepared by International Technology Corporation, Itasca, Ill., for U.S. Department of the Army, Corps of Engineers, Kansas City District, Oct. (Round 14 analytical data; Aug. 1994).

International Technology Corporation, 1995a, 1994: Fourth Quarterly Groundwater Monitoring Report Weldon Spring Ordnance Works, Project No. 312430, prepared by International Technology Corporation, Itasca, Ill., for U.S. Department of the Army, Corps of Engineers, Kansas City District, Jan. (Round 15 analytical data; Nov. 1994). 
International Technology Corporation, 1995b, 1995: Third Yearly Groundwater Monitoring Report, Weldon Spring Ordnance Works, Project No. 312071, prepared by International Technology Corporation, Itasca, Ill., for U.S. Department of the Army, Corps of Engineers, Kansas City District, April (Round 16 analytical data; Feb. 1995).

IT: see International Technology Corporation.

Johnson, T.R., 1987, The Amphibians and Reptiles of Missouri, Missouri Department of Conservation, Jefferson City, Mo.

Johnson, K., et al., 1989, Hydrological and Geochemical Controls Limiting Transport in Groundwater at Weldon Spring, Missouri, prepared for Morrison-Knudsen Environmental Services, Boise, Idaho.

Jones, W.K., 1984, “Analysis and Interpretation of Data from Tracer Tests in Karst Areas," The NSS Bulletin 46(Oct.):41-47.

Kaminski, D.B., 1995, letter from Kaminski (Vice President, Sales, QED Groundwater Specialists, Walnut Creek, Calif.) to M. Jank (International Technology Corporation, Itasca, Ill.), July 18.

Kaplan, D.L., and A.M. Kaplan, 1982, "Thermophilic Biotransformations of 2,4,6-trinitrotoluene under Simulated Composting Conditions," Applied and Environmental Microbiology 44:3,200-3,205.

Kleeschulte, M.J., 1991, "Geohydrology of Bedrock Aquifers and Public Supply and Domestic Water Use, 1962-85, in St. Charles County, Missouri," Proceedings of the Geosciences Workshop, Feb. 21, O'Fallon, Mo., Weldon Spring Site Remedial Action Project, U.S. Department of Energy.

Kleeschulte, M.J., 1995, Hydrologic Data for the Weldon Spring Chemical Plant Site and Vicinity Property, St. Charles County, Missouri, 1989-95, U.S. Geological Survey Open-File Report 95-463, Rolla, Mo.

Kleeschulte, M.J., 1997, Letter from Kleeschulte (U.S. Geological Survey) to Bruce Ballew (U.S. Department of Energy) "Second Quarter-1997 Discharge Data for Burgermeister Spring," April 17.

Kleeschulte, M.J., and L.F. Emmett, 1986, Compilation and Preliminary Interpretation of Hydrologic Data for the Weldon Spring Radioactive Waste-Disposal Sites, St. Charles County, Missouri-A Progress Report, U.S. Geological Survey Water Resources Investigations Report 85-4272, Rolla, Mo. 
Kleeschulte, M.J., and L.F. Emmett, 1987, Hydrology and Water Quality at the Weldon Spring Radioactive Waste - Disposal Sites, St. Charles County, Missouri, U.S. Geological Survey Water Resources Investigations Report 87-4169, Rolla, Mo.

Kleeschulte, M.J., and P.W. Cross, 1990, Hydrologic Data for the Weldon Spring Chemical Plant Site and Vicinity Property, St. Charles County, Missouri -- 1986-89, U.S. Geological Survey OpenFile Report 90-552, Rolla, Mo.

Kleeschulte, M.J., and J.L. Imes, 1994, Geohydrology, Water Quality, and Simulation of GroundWater Flow at the Weldon Spring Chemical Plant and Vicinity, St. Charles County, Missouri, 1987-90, U.S. Geological Survey Open-File Report 93-648, prepared in cooperation with the U.S. Department of Energy, Rolla, Mo.

Mackay, D., et al., 1985, "Transport of Organic Contaminants in Groundwater," Environmental Science and Technology 19(5).

Mackay, D.M., and J.A. Cherry, 1989, "Groundwater Contamination: Pump-and-Treat Remediation," Environmental Science and Technology 23(6):630-636.

McGrath, C., 1995, Review of Formulations for Processes Affecting the Subsurface Transport of Explosives, U.S. Army Corps of Engineers Waterways Experiment Station Technical Report IRRP-95-2.

Missouri Department of Conservation, 1989, Area Management Plan for the August A. Busch Complex, Jefferson City, Mo.

Missouri Department of Conservation, 1991, A Checklist of Birds of the August A. Busch Memorial Wildlife Area, St. Charles, Missouri, Jefferson City, Mo.

Missouri Department of Natural Resources, 1991, Shallow Groundwater Investigations at Weldon Spring, Missouri, Final Report for Fiscal Years 1988-1990, prepared for Weldon Spring Site Remedial Action Project by the Division of Geology and Land Survey, Rolla, Mo., June.

MK-Environmental Services, 1992, WSSRAP Disposal Facility Dust Control Methods and Criteria Study, Report 384OR-799-00, rev. 0, prepared for MK-Ferguson Group, Boise, Idaho, Jan.

MK-Environmental Services, 1993, WSSRAP Disposal Facility Supporting Study 3A: Hydraulic Properties of Undisturbed Soils, Report 3840R-7137-A, rev. B, prepared for MK-Ferguson Group, Boise, Idaho, Nov. 
MK-Ferguson Company and Jacobs Engineering Group, Inc., 1987, Water Quality Phase I Assessment Report, DOE/OR/21548-003, prepared for U.S. Department of Energy, Oak Ridge Operations Office, Weldon Spring Site Remedial Action Project, St. Charles, Mo.

MK-Ferguson Company and Jacobs Engineering Group, Inc., 1989a, Chemical Soil Data Report to Support Interim Response Actions, Construction Staging Area, and Administration Building, DOE/OR/21548-051, rev. 0, prepared for U.S. Department of Energy, Oak Ridge Operations Office, Weldon Spring Site Remedial Action Project, St. Charles, Mo., Feb.

MK-Ferguson Company and Jacobs Engineering Group, Inc., 1989b, Chemical Soil Investigation Report for the Weldon Spring Chemical Plant/Raffinate Pits, Phase II, DOE/OR/21548-061, rev. 0, prepared for U.S. Department of Energy, Oak Ridge Operations Office, Weldon Spring Site Remedial Action Project, St. Charles, Mo., Aug.

MK-Ferguson Company and Jacobs Engineering Group, Inc., 1989c, Phase I Spring and Seep Report: Weldon Spring Site Remedial Action Project, Weldon Spring, Missouri, DOE/OR/21548045, rev. 0, prepared for U.S. Department of Energy, Oak Ridge Operations Office, Weldon Spring Site Remedial Action Project, St. Charles, Mo., Aug.

MK-Ferguson Company and Jacobs Engineering Group, Inc., 1989d, Phase II Groundwater Quality Assessment for the Weldon Spring Site, Chemical Plant, Raffinate Pits, and Surrounding Vicinity Properties, DOE/OR/21548-078, prepared for U.S. Department of Energy, Oak Ridge Operations Office, Weldon Spring Site Remedial Action Project, St. Charles, Mo.

MK-Ferguson Company and Jacobs Engineering Group, Inc., 1990a, Annual Site Environmental Report 1989, DOE/OR/21548-129, prepared for U.S. Department of Energy, Oak Ridge Operations Office, Weldon Spring Site Remedial Action Project, St. Charles, Mo.

MK-Ferguson Company and Jacobs Engineering Group, Inc., 1990b, Aquifer Characteristics Data Report for the Weldon Spring Site Chemical Plant/Raffinate Pits and Vicinity Properties, DOE/OR/21548-122, rev. 0, prepared for U.S. Department of Energy, Oak Ridge Operations Office, Weldon Spring Site Remedial Action Project, St. Charles, Mo., Nov.

MK-Ferguson Company and Jacobs Engineering Group, Inc., 1991, Annual Site Environmental Report for Calendar Year 1990, DOE/OR/21548-193, prepared for U.S. Department of Energy, Oak Ridge Operations Office, Weldon Spring Site Remedial Action Project, St. Charles, Mo.

MK-Ferguson Company and Jacobs Engineering Group, Inc., 1992a, Remedial Investigation for the Chemical Plant Area of the Weldon Spring Site, DOE/OR/21548-074, rev. 0, 2 vols., prepared for U.S. Department of Energy, Oak Ridge Operations Office, Weldon Spring Site Remedial Action Project, St. Charles, Mo., Nov. 
MK-Ferguson Company and Jacobs Engineering Group, Inc., 1992b, Weldon Spring Site Environmental Report for Calendar Year 1991, DOE/OR/21548-283, rev. 1, prepared for U.S. Department of Energy, Oak Ridge Operations Office, Weldon Spring Site Remedial Action Project, St. Charles, Mo., July.

MK-Ferguson Company and Jacobs Engineering Group; Inc., 1993a, Environmental Quality Assurance Project Plan, DOE/OR/21548-352, rev. 1, prepared for U.S. Department of Energy, Oak Ridge Operations Office, Weldon Spring Site Remedial Action Project, St. Charles, Mo., July.

MK-Ferguson Company and Jacobs Engineering Group, Inc., 1993b, Weldon Spring Site Environmental Report for Calendar Year 1992, DOE/OR/21548-372, rev. 0, prepared for U.S. Department of Energy, Oak Ridge Operations Office, Weldon Spring Site Remedial Action Project, St. Charles, Mo., June.

MK-Ferguson Company and Jacobs Engineering Group, Inc., 1994, Weldon Spring Site Environmental Report for Calendar Year 1993, DOE/OR/21548-436, rev. 0, prepared for U.S. Department of Energy, Oak Ridge Operations Office, Weldon Spring Site Remedial Action Project, St. Charles, Mo., May.

MK-Ferguson Company and Jacobs Engineering Group, Inc., 1995, Weldon Spring Site Environmental Report for Calendar Year 1994, DOE/OR/21548-436, prepared for U.S. Department of Energy, Oak Ridge Operations Office, Weldon Spring Site Remedial Action Project, St. Charles, Mo.

MK-Ferguson Company and Jacobs Engineering Group, 1997a, Sampling Plan for the Remedial Investigation/Feasibility Study for the Groundwater Operable Units at the Chemical Plant Area and Ordnance Works Area, Weldon Spring, Missouri (Appendix to the Work Plan); Addendum 2: Installation and Sampling of New Monitoring Well in the Lower Southeast Drainage, DOE/OR/21548-445, prepared for U.S. Department of Energy, Oak Ridge Operations Office, Weldon Spring Site Remedial Action Project, Weldon Spring Mo., April.

MK-Ferguson Company and Jacobs Engineering Group, 1997b, Sampling Plan for the RI/FS for the Groundwater Operable Units at the Chemical Plant Area and Ordnance Works Area, Weldon Spring, Missouri, Addendum 3: Soil Gas Sampling and Analysis for TCE at the Chemical Plant Area, DOE/OR/21548-445, prepared for U.S. Department of Energy, Oak Ridge Operations Office, Weldon Spring Site Remedial Action Project, Weldon Spring, Mo., June.

Montgomery, J.H. and L.M. Welkom, 1991, Groundwater Chemicals Desk Reference, Lewis Publishers, Inc., Chelsea, Mich. 
Mugel, D.N., 1997, Geohydrology of the Weldon Spring Ordnance Works, St. Charles County, Missouri, USGS Water-Resources Investigations Report 96-4171, in press, prepared in cooperation with the U.S. Army Corps of Engineers, Rolla, Mo.

Nadiau, L.J., and J.C. Spain, 1995, "Bacterial Degradation of m-Nitrobenzoic Acid," Applied Environmental Microbiology 61:840-843.

Parrish, F.W., 1977, "Fungal Transformation of 2,4-Dinitrotoluene and 2,4,6-Trinitrotoluene," Applied Environmental Microbiology 34:232-233.

Price, C.B., et al., 1995, Transformation of 2,4,6-Trinitrotoluene under Controlled Eh, pH Conditions, WES Technical Report IRRP-95-5, Sept.

Price, P., 1991, Shallow Groundwater Investigations at the Weldon Spring Training Area, St. Charles County, Missouri, prepared by Missouri Department of Natural Resources for U.S. Department of the Army, Corps of Engineers, Kansas City District.

Rosenblatt, D.H., et al., 1989, “Organic Explosives and Related Compounds," in The Handbook of Environmental Chemistry, O. Hutzinger (editor), Springer-Verlag, New York, N.Y.

Rueff, M., 1992, Surficial Materials Investigation at the Weldon Spring Training Area, St. Charles County, Missouri, prepared for U.S. Department of the Army, Corps of Engineers, Kansas City District, by the Missouri Department of Natural Resources, Sept.

Schumacher, J.G., 1990, Geochemical Data for the Weldon Spring Chemical Plant Site and Vicinity Property, St. Charles County, Missouri - 1989-90, USGS Open File Report 90-351, revised in 1991, prepared in cooperation with U.S. Department of Energy, Rolla, Mo.

Schumacher, J.G., 1993, Geochemistry and Migration of Contaminants at the Weldon Spring Chemical Plant Site, St. Charles County, Missouri-1989-91, U.S. Geological Survey, Open-File Report 93-433, prepared in cooperation with U.S. Department of Energy, Rolla, Mo.

Schumacher, J.G., and K.G. Stollenwerk, 1991, "Geochemical Controls on Migration of Molybdenum, Uranium, and Other Constituents at the Weldon Spring Chemical Plant Site," Proceedings of the Geosciences Workshop, Feb. 21, O'Fallon, Mo., Weldon Spring Site Remedial Action Project, U.S. Department of Energy.

Schumacher, J.G., et al., 1992, "Migration of Nitroaromatic Compounds in Unsaturated Soil at the Abandoned Weldon Spring Ordnance Works, St. Charles County, Missouri," Proceedings of the 16th Annual Army Environmental Research and Development Symposium, Williamsburg, Va. 
Schumacher, J.G., et al., 1993, Geochemical Data for the Weldon Spring Training Area and Vicinity Property, St. Charles County, Missouri - 1900-1992, U.S. Geological Survey, Open-File Report 93-153, prepared in cooperation with U.S. Army, Corps of Engineers, Kansas City District.

Schumacher, J.G., et al., 1996, Hydrologic and Water-Quality Data for the Weldon Spring Ordnance Works, St. Charles County, Missouri - 1992-95, USGS Open File Report 96-218, prepared in cooperation with U.S. Army, Corps of Engineers, Kansas City District.

Sizemore, M., 1991, memorandum from Sizemore (MK-Ferguson Company, Weldon Spring Site Remedial Action Project, St. Charles, Mo.) to M. MacDonell (Argonne National Laboratory, Argonne, Ill.), Nov. 18.

Spanggord, R.J., et al., 1980, Environmental Fate Studies on Certain Munition Waste-Water Components, Final Report, Part II - Laboratory Study, SRI Report L5U-7934, SRI International, Menlo Park, Calif.

Spanggord R.J., and B.E. Suta, 1982, "Effluent Analysis of Wastewater Generated in the Manufacture of 2,4,6-Trinitrotoluene; 2: Determination of a Representative Discharge of EtheyExtractable Compounds," Environmental Science and Technology 16:233-256.

Thomas, R.G., 1981, "Volatilization from Soil," in Handbook of Chemical Property Estimation Methods, W.J. Lyman et al. (editors), McGraw-Hill Book Company, Inc., New York, N.Y.

Toth, J., 1963, "A Theoretical Analysis of Groundwater Flow in Small Drainage Basins," Journal of Geophysical Research 68:4795-4812.

U.S. Department of Energy, 1992a, Baseline Assessment for the Chemical Plant Area of the Weldon Spring Site, DOE/OR/21548-091, prepared by U.S. Department of Energy, Weldon Spring Remedial Action Project, St. Charles, Mo., with technical assistance from the Environmental Assessment and Information Sciences Division, Argonne National Laboratory, Argonne, Ill., Nov.

U.S. Department of Energy, 1992b, Remedial Investigation for the Chemical Plant Area of the Weldon Spring Site, Vol. 1, RI/FS-EIS Document DOE/EIS-0185D, Nov.

U.S. Department of Energy, 1995a, Sampling Plan for the Remedial Investigation/Feasibility Study for the Groundwater Operable Units at the Chemical Plant Area and at the Ordnance Works Area, Weldon Spring, Missouri (Appendix to the Work Plan), DOE/OR/21548-445, rev. 1, U.S. Department of Energy, Oak Ridge Operations Office, St. Charles, Mo., July. 
U.S. Department of Energy, 1995b, Work Plan for the Remedial Investigation/Feasibility Study for the Groundwater Operable Unit at the Chemical Plant Area and the Ordnance Works Area, Weldon Spring, Mo., DOE/OR/21548-567, prepared for the Weldon Spring Site Remedial Action Project, Weldon Spring, Mo., by the Environmental Assessment Division, Argonne National Laboratory, Argonne, Ill., Aug.

U.S. Department of Energy, 1996, Engineering Evaluation/Cost Analysis for the Proposed Removal Action at the Southeast Drainage near the Weldon Spring Site, Weldon Spring, Missouri, DOE/OR/21548-584, prepared for U.S. Department of Energy, Weldon Spring Site Remedial Action Project, Weldon Spring, Mo., Oct.

U.S. Department of Energy and U.S. Department of the Army, 1997, Baseline Risk Assessment for the Groundwater Operable Units at the Chemical Plant Area and Ordnance Works Area, Weldon Spring, Missouri, DOE/OR/21548-568, prepared for U.S. Department of Energy, Weldon Spring Site Remedial Action Project, by the Environmental Assessment Division, Argonne National Laboratory, Argonne, Ill., July.

U.S. Environmental Protection Agency, 1989a. Statistical Analysis of Ground-Water Monitoring Data at RCRA Facilities Interim Final Guidance, EPA/530-SW-89-026, Office of Solid Waste, Waste Management Division, Washington, D.C., April.

U.S. Environmental Protection Agency, 1898b, Rapid Bioassessment Protocols for Use in Streams and Rivers: Benthic Macroinvertebrates and Fish, EPA/444/4-89, Assessment and Watershed Protection Division, Washington, D.C., May.

U.S. Environmental Protection Agency, 1990, "National Oil and Hazardous Substances Pollution Contingency Plan; Final Rule (40 CFR Part 300)," Federal Register 55(46):8666-8865, March 8.

Whitfield, J.W., et al., 1989, Geologic Map of the Weldon Spring 7.5 Minute Quadrangle, St. Charles County, Mo., OFM-89-252-GI, Missouri Department of Natural Resources, Division of Geology and Land Survey, Rolla, Mo. 
APPENDIX A:

ECOLOGICAL EVALUATIONS OF THE BURGERMEISTER SPRING DRAINAGE 
A-2 


\section{APPENDIX A:}

\section{ECOLOGICAL EVALUATIONS OF THE BURGERMEISTER SPRING DRAINAGE}

\section{A.1 STUDY AREA}

The U.S. Department of Energy (DOE) and the U.S. Department of the Army (DA) are conducting cleanup activities at two properties - the chemical plant area and the ordnance works area (the latter includes the training area) - located adjacent to one another in St. Charles County, Missouri. The chemical plant area and the ordnance works area are located about $48 \mathrm{~km}$ (30 mi) west of St. Louis and $22 \mathrm{~km}(14 \mathrm{mi})$ southwest of the city of St. Charles (Figure A.1). The ordnance works area was a former explosives production facility that manufactured trinitrotoluene (TNT) and dinitrotoluene (DNT) and covered 7,000 ha (17,232 acres). The 88-ha (217-acre) chemical plant area is located within the boundaries of the ordnance works area. This area is chemically and radioactively contaminated as a result of uranium processing activities conducted during the $1950 \mathrm{~s}$ and 1960s, as well as explosives work conducted during the 1940s (DOE 1995).

The ordnance works area and the chemical plant area are located within the Ozark Border physiographic province. Land in the area varies from rolling hills to sloped forests to floodplains. This province possesses a variety of habitats that support a diverse flora and fauna (Missouri Department of Conservation 1991). The chemical plant area and portions of the ordnance works area are characterized by grasslands, old field habitat, and sparse to moderate woodland growth, primarily along creeks and drainages. Much of the chemical plant area is now cleared as a result of remedial actions.

About $60 \%$ of the ordnance works area is forested and includes upland, slope, riparian, and wetland forests. Open field, pasture, and cultivated farmland habitats also occur in the upland areas. The upland forests consist of oak and oak-hickory forests dominated by northern red oak, white oak, and shagbark hickory; understory species include flowering dogwood and redbud. Coniferous species that occur in upland and slope areas include eastern red cedar and short-leaved pine. The riparian and wetland forests are dominated by silver maple, American elm, eastern sycamore, and eastern cottonwood. Upland forest trees include oaks and shagbark hickory. Slopes of streams typically include oak and hickory, as well as species common to mesic sites, such as sugar maple, American elm, and black walnut. Floodplains, creek bottoms, and banks of lakes support willow, cottonwood, silver maple, elm, hackberry, and boxelder. Other prominent habitat types of the ordnance works area include old fields and pastures. Typical plants of old fields include grasses, goldenrod, asters, mustards, and ragweed (IT Corporation 1993). 


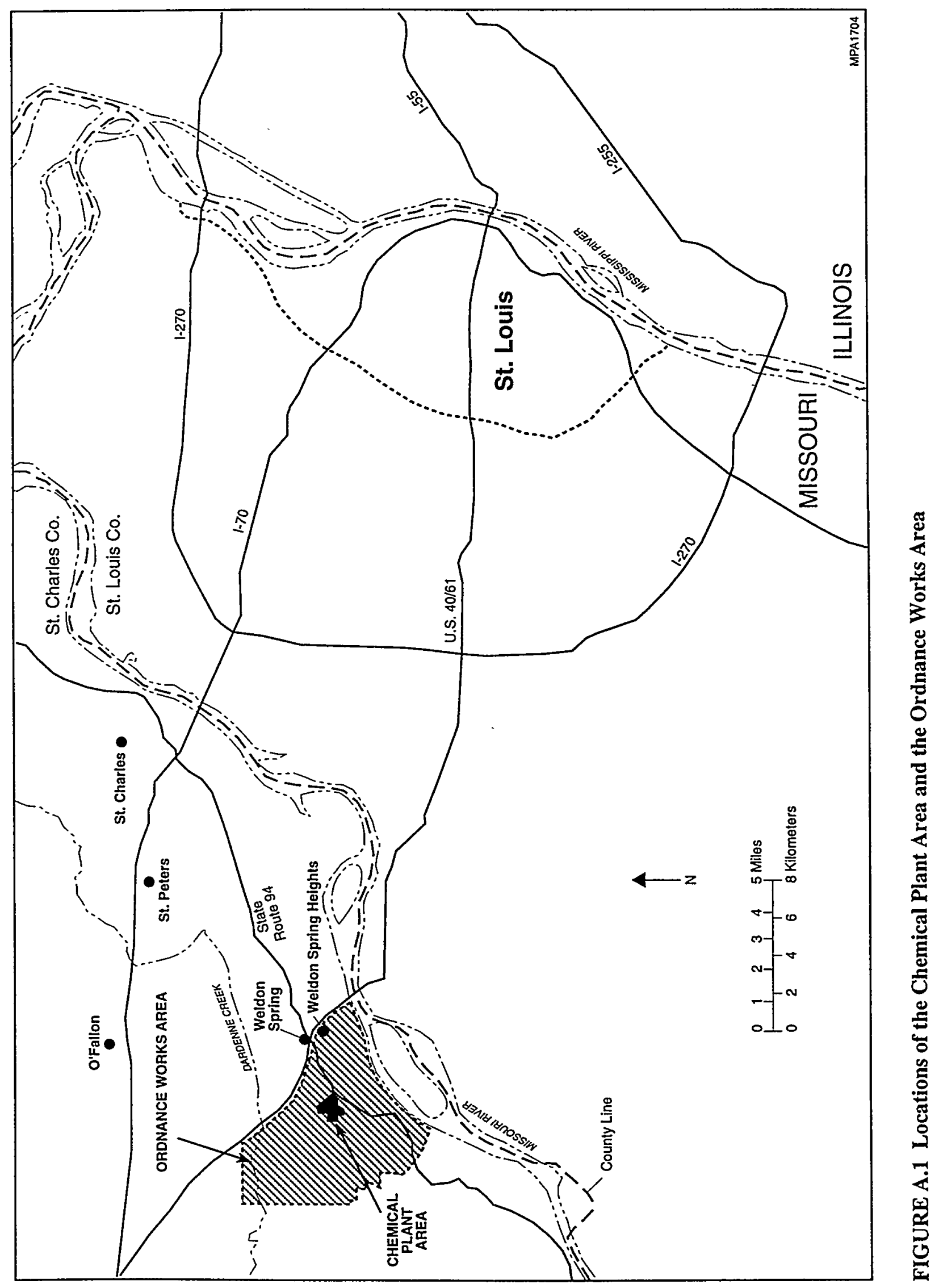


The original Weldon Spring Ordnance Works has been divided into several contiguous areas with different ownership (Figure 1.2). These areas now include the chemical plant area and the quarry, the Weldon Spring Training Area, the August A. Busch Memorial Conservation Area, the Weldon Spring Conservation Area, the Francis Howell High School and Francis Howell Administration Annex, the community of Weldon Spring Heights, the University of Missouri Research Park, the St. Charles County well field, and the maintenance facility of the Missouri Highway Department (DOE 1995). The Busch Conservation Complex, which consists of the August A. Busch Memorial Conservation Area (2,828 ha [6,987 acres] of grassland and forest) and the Weldon Spring Conservation Area (2,977 ha [7,356 acres] of primarily forest land), is actively managed for wildlife by the Missouri Department of Conservation (DOE 1995).

The Busch Conservation Complex contains a wide variety of terrestrial and aquatic habitats and supports a diverse biota. More than 277 species of birds, 29 species of mammals, 47 species of reptiles, 25 species of amphibians, and 100 species of fish have been reported in St. Charles County; many of which occur at the Busch Conservation Complex (Missouri Department of Conservation 1989, 1991; Dickneite 1988). A detailed description of the vegetation, fish and wildlife, and habitats of the Busch Conservation Complex is presented in the baseline assessment of the chemical plant area (DOE 1992).

Burgermeister Spring has been routinely monitored by both the DA and DOE because it appears to be a major groundwater discharge area for drainage from the eastern and central portions of the training area and the northern.portion of the chemical plant area (DOE 1995). Concentrations of some contaminants in Burgermeister Spring are as high or higher than concentrations from most other springs in the area. In addition, Burgermeister Spring and downstream areas provide more permanent habitat for aquatic biota than most of the other springs in the area and thus likely support a more diverse and abundant aquatic biota than the other springs. Therefore, maximum environmental impacts could be associated with contaminants in the Burgermeister Spring system.

\section{A.2 BURGERMEISTER SPRING - AFFECTED ENVIRONMENT}

\section{A.2.1 Habitat Description}

At Burgermeister Spring, groundwater discharges into a square concrete enclosure about $1.5 \mathrm{~m}(4.9 \mathrm{ft})$ on each side and about $0.5 \mathrm{~m}(1.6 \mathrm{ft})$ high. The floor of the enclosure is clean sand and gravel, through which groundwater discharge is evident. Springwater within the enclosure flows through a crack in the concrete wall into a small natural stream channel (DOE 1995). This drainage occurs within a small corridor of riparian forest surrounded by agricultural fields and some upland forest areas. Soils along Burgermeister Spring are characterized as Dockery silt loam, a poorly drained soil located on nearly level lands (MK-Environmental Services 1992). Portions of the 
Burgermeister Spring drainage have been identified as palustrine emergent wetlands (U.S. Fish and Wildlife Service 1989). However, no wetland surveys have been conducted as part of the remediation investigation to confirm whether these areas meet the criteria for jurisdictional wetlands (i.e., hydrological conditions, wetland soils, and predominance of wetland plant species). The Burgermeister Spring drainage is located within the 100-year floodplain of Dardenne Creek (Federal Insurance Administration 1978). This drainage in turn flows into a main reach of an unnamed tributary of Dardenne Creek about $1.0 \mathrm{~km}(0.6 \mathrm{mi})$ downstream of the spring. This stream flows into Lake 34 and eventually discharges into Dardenne Creek (Figure 1.2). Because riffle areas below the weir were not flowing from late August to November of 1995, isolated pool areas were created within the length of the drainage to Lake 34 (Ecological Specialists, Inc. 1996a).

Four sites were sampled from the Burgermeister Spring drainage (Figure A.2). The sites were located along an approximately 300-m (984-ft) reach of stream between the spring (Site 6301) and its receiving stream that drains toward Lake 34. Location 1 encompassed the area from the spring to the weir, which is located about $30 \mathrm{~m}$ (98 ft) downstream of the spring. This area is primarily shallow riffle, but is pooled by the weir. The small pool created by the weir is about $2 \mathrm{~m}$ $(7 \mathrm{ft})$ by $3 \mathrm{~m}(9 \mathrm{ft})$ and about $0.3 \mathrm{~m}(1 \mathrm{ft})$ deep with a sand/silt bottom (DOE 1995). Stream width

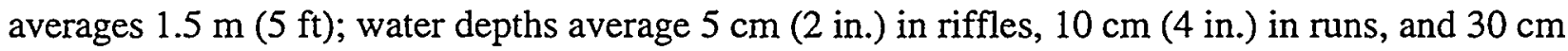
(12 in.) in the pooled area near the weir. Substrates at Location 1 consisted of gravel (50\%), cobble (10\%), sand (25\%), and silt (15\%) (Ecological Specialists, Inc. 1996b).

Location 2 extended from the weir $15 \mathrm{~m}$ ( $49 \mathrm{ft}$ ) downstream to the confluence with a larger

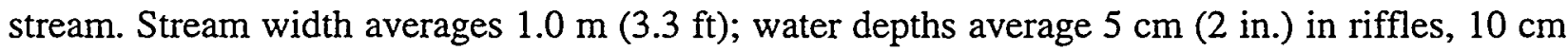
(4 in.) in runs, and $15 \mathrm{~cm}(6 \mathrm{in}$.$) in the pooled area in the middle of the location. The substrate$ throughout Location 2 consisted of gravel (60\%), cobble (30\%), and sand (10\%) (Ecological Specialists, Inc. 1996b).

Location 3 was in the larger stream, starting at the downstream end of Location 2 and extending $30 \mathrm{~m}$ ( $98 \mathrm{ft}$ ) downstream from Location 2: Habitat within Location 3 consists of two small pools and a shallow riffle/run. Stream width averages $2.5 \mathrm{~m}(8.0 \mathrm{ft})$; water depths average $5 \mathrm{~cm}$ ( 2 in.) in riffles, $15 \mathrm{~cm}(6 \mathrm{in.})$ in runs, and $30 \mathrm{~cm}(12 \mathrm{in}$.$) in the pooled areas. The substrate$ throughout Location 3 consisted of gravel $(50 \%)$, cobble (10\%), sand (25\%), and silt (15\%) (Ecological Specialists, Inc. 1996b).

Location 4 started $100 \mathrm{~m}$ ( $305 \mathrm{ft}$ ) downstream from Location 3 and was $30 \mathrm{~m}(98 \mathrm{ft})$ long. This site consists of one small pool and one larger pool connected by a shallow riffle/run. Stream

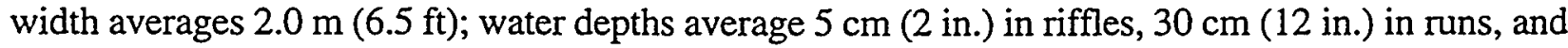
$75 \mathrm{~cm}$ (30 in.) in the pooled areas. The substrate throughout Location 4 consisted of boulders (5\%), gravel (40\%), cobble (50\%), and sand (5\%) (Ecological Specialists, Inc. 1996b). 


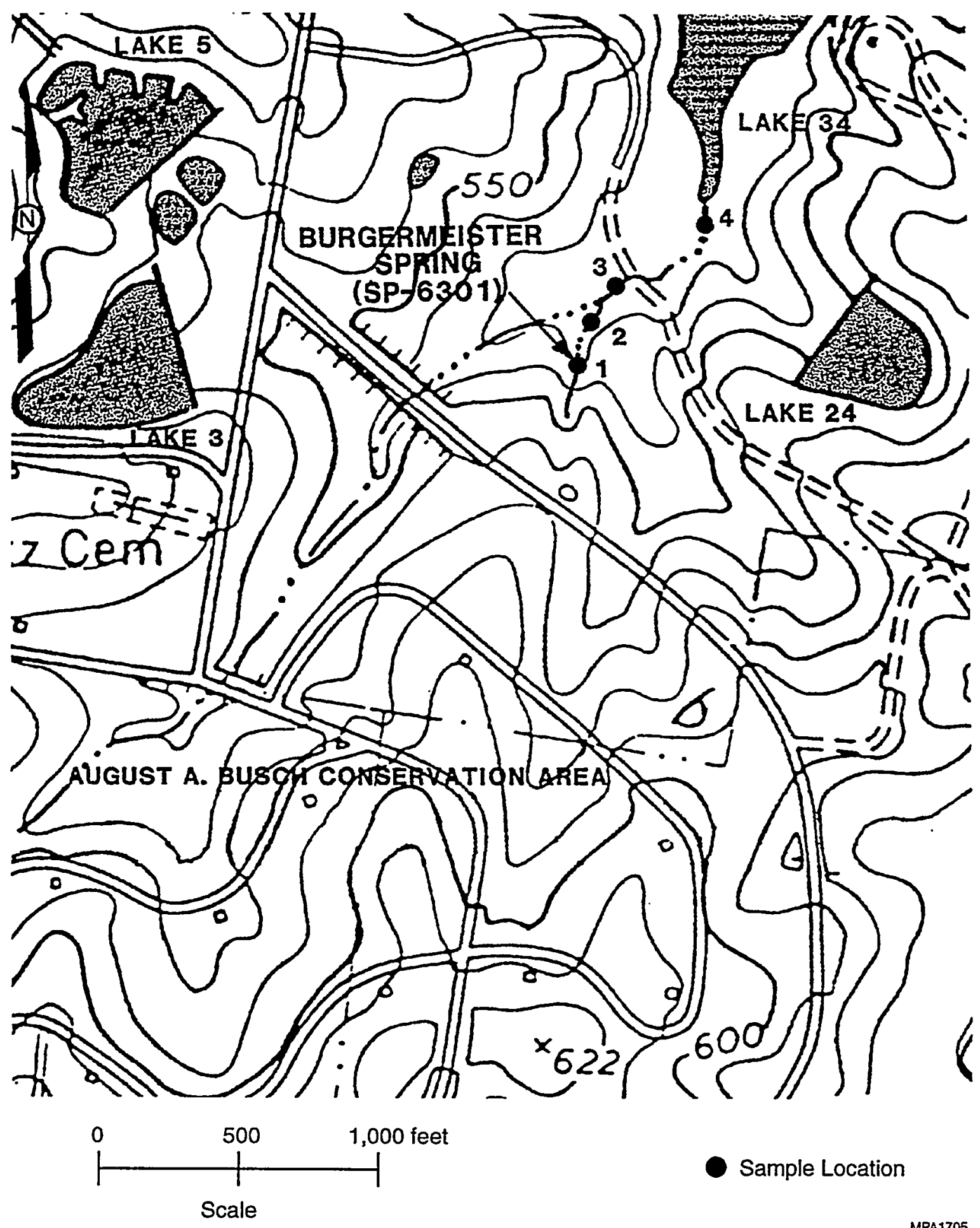

FIGURE A.2 Sampling Locations from the Burgermeister Spring Drainage 
Flow throughout the drainage averages $<0.008 \mathrm{~m}^{3} / \mathrm{s}\left(<0.3 \mathrm{ft}^{3} / \mathrm{s}\right)$. However, Burgermeister Spring discharge responds rapidly to precipitation. Although normally clear running, the drainage becomes turbid during storms. Daily mean groundwater discharge values have ranged from a low of $0.001 \mathrm{~m}^{3} / \mathrm{s}\left(0.05 \mathrm{ft}^{3} / \mathrm{s}\right)$ in September to a maximum of $0.025 \mathrm{~m}^{3} / \mathrm{s}\left(0.89 \mathrm{ft}^{3} / \mathrm{s}\right)$ in May. Sediment odor is normal and deposits of oils are absent. The bottoms of stones are not blackened by microbes common in low oxygen environments; dissolved oxygen concentrations have averaged 9.2 to $9.3 \mathrm{mg} / \mathrm{L}$. Water temperatures during the spring of 1996 averaged 13.6 to $14.3^{\circ} \mathrm{C}\left(56.5-57.7^{\circ} \mathrm{F}\right)$. Yearly water temperatures range from 11.4 to $28.4^{\circ} \mathrm{C}\left(52.5-83.1^{\circ} \mathrm{F}\right)$. The $\mathrm{pH}$ averaged from 6.7 to 7.0 , while conductivity averages 344 to $391 \mu \mathrm{S} / \mathrm{s}$. The high water mark estimated at the top of the

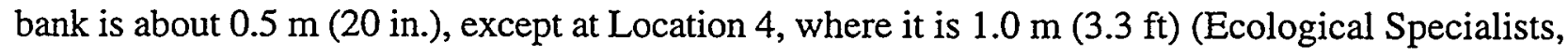
Inc. 1996b). Water clarity is rated as clear, and the stream type is rated cold on the basis of its temperature and subsurface source (Ecological Specialists, Inc. 1996a).

\section{A.2.2 Biota}

Burgermeister Spring is located in the former ordnance works area north of the chemical plant in an area of upland forest with relatively dense understory. Tree species present in this area include red oak, persimmon, Kentucky coffee tree, and cottonwood. Vegetation along the bank of the drainage has greater than $80 \%$ coverage and consists predominantly of shrubs and small deciduous trees. The dominant tree species found along the Burgermeister Spring drainage include northern red oak and eastern cottonwood; understory species consist of American elm and persimmon. Ground cover immediately around the spring is dominated by periwinkle, whereas the shrubby understory is predominantly honeysuckle (DOE 1995).

The Burgermeister Spring drainage is of sufficient size and habitat diversity to support a variety of aquatic species. Water quality is adequate to support pollution-intolerant fish and invertebrates (Ecological Specialists, Inc. 1996a). However, the weir located about $75 \mathrm{~m}$ (246 ft) downstream of the spring outflow area creates a man-made barrier for fish habitation of the upper portion of the drainage. Surveys of aquatic macroinvertebrates and fish in Burgermeister Spring drainage were conducted to identify biota most at risk of exposure to contaminants and to identify any realized adverse ecological effects.

Macroinvertebrates were collected from Burgermeister Spring drainage following the U.S. Environmental Protection Agency's (EPA's) Rapid Bioassessment Protocol (RBP) Method III Protocol (EPA 1989). A fairly diverse assemblage of macroinvertebrates was collected from the drainage (Table A.1). The most abundant macroinvertebrates collected were amphipods (Gammarus sp.), isopods, and chironomids (Microspectra sp.). 
TABLE A.1 Macroinvertebrates Collected from the Burgermeister Spring Drainage

\begin{tabular}{|c|c|}
\hline Turbellaria (flatworms) & Insecta \\
\hline Tricladida & Plecoptera (stoneflies) \\
\hline Planariidae & Nemouridae \\
\hline Dugesia sp. & Trichoptera (caddisflies) \\
\hline Oligochaeta (worms) & Trichoptera pupae \\
\hline $\begin{array}{l}\text { Plesiopora } \\
\text { Plios }\end{array}$ & Glossosomatidae \\
\hline Naididae & Glossosoma sp. \\
\hline Dero digitata & Lepidostomatidae \\
\hline Tubificidae & Lepidostoma sp. \\
\hline Limnodrilus hoffmeisteri & $\begin{array}{l}\text { Bracnycentriaae } \\
\text { Polycentropodidae }\end{array}$ \\
\hline Tubifex tubifex & Coleoptera (beetles) \\
\hline Immature tubiticids & $\begin{array}{l}\text { Noteridae } \\
\text { Dytiscidae }\end{array}$ \\
\hline Hirudinea (leeches) & Diptera (flies) \\
\hline & Ceratopogonidae \\
\hline Crustacea & Chironomidae \\
\hline Amphipoda (scuds) & Orthocladius sp. \\
\hline Gammaridae & Eukiefferiella sp. \\
\hline Gammarus sp. & Paratendipes sp. \\
\hline Isopoda (sow bugs) & Polypedilum sp. \\
\hline Asellidae & Polypedilum illinoense \\
\hline Caecidotea sp. & Microspectra \\
\hline Lirceus sp. & Muscidae \\
\hline & Tipulidae \\
\hline \multicolumn{2}{|l|}{ Mollusca } \\
\hline \multicolumn{2}{|l|}{ Gastropoda (snails) } \\
\hline \multicolumn{2}{|l|}{ Physidae } \\
\hline \multicolumn{2}{|l|}{ Pelecypoda (clams) } \\
\hline \multicolumn{2}{|l|}{ Sphaeriidae } \\
\hline Sphaerium sp. & \\
\hline
\end{tabular}

Fish surveys were conducted in the Burgermeister Spring drainage in 1991, 1994, and 1995 by seining and electrofishing. Eight species and one hybrid were collected (Table A.2). Most of the individuals collected were juveniles of species that inhabit Lake 34 (e.g., sunfish, largemouth bass, and black crappie). The orangethroat darter and brook silverside are creek species. No fish were collected in the upper reach of the drainage because of the barrier created by the weir. A debris dam located just downstream of the weir also acted as a partial barrier and likely limited the occurrence of fish between the debris dam and weir. Another fish reported from the drainage below the weir is the redfin shiner; other fish species in the larger stream that flows into Lake 34 are white crappie, carp, and black bullhead (DOE 1995). Other species known to occur in Lake 34 (e.g., channel catfish 
TABLE A.2 Fish Species Collected from the Burgermeister Spring Drainage

\begin{tabular}{ll}
\hline \multicolumn{1}{c}{ Common Name } & \multicolumn{1}{c}{ Scientific Name } \\
\hline & \\
Brook silverside & Labidesthes sicculus \\
Bluegill & Lepomis macrochirus \\
Longear sunfish & Lepomis megalotis \\
Green sunfish & Lepomis cyanellus \\
Orangespotted sunfish & Lepomis humilis \\
Longear x green sunfish hybrid & Lepomis megalotis x cyanellus \\
Largemouth bass & Micropterus salmoides \\
Black crappie & Pomoxis nigromaculatus \\
Orangethroat darter & Etheostoma spectabile \\
\hline
\end{tabular}

and flathead catfish) may use the Burgermeister Spring drainage as a spawning area, although it is unlikely that they would enter the spring and its immediate downstream reach (i.e., Locations 1 and 2).

Amphibian and reptile surveys were conducted in the Burgermeister Spring drainage during March and April and September and October, 1995; auditory and transect surveys and bucket traps were used. Six amphibian and one reptile species were identified (Table A.3). All species encountered were common species ubiquitous to the Midwest.

Table A.4 lists the rare, threatened, and endangered species that have been known to occur in St. Charles County. The list includes four state endangered species, 12 state rare species, and two state watch list species. Two of these species (sturgeon and sicklefin chubs) are also federal candidate species (species being considered for inclusion as threatened or endangered on the federal listing), while the bald eagle is a federal threatened species.

The chub species are not expected to occur in the Burgermeister Spring drainage because they are known to prefer large river habitat such as the Missouri River (Pflieger 1975). A night roost for overwintering bald eagles is located at Howell Island Wildlife Area in the Missouri River southeast of the site. This roost site has been declared critical habitat by the State of Missouri. A critical habitat is a specific area of the state that is occupied by a threatened or endangered species and is essential to the conservation of the species. Areas identified as critical habitat are granted special management considerations for protection. However, the Howell Island Wildlife Area is not classified as a federally designated critical habitat. No state or federal critical habitat has been identified at Burgermeister Spring or in the Busch Conservation Complex. 
TABLE A.3 Reptiles and Amphibians Collected from the Burgermeister Spring Drainage

\begin{tabular}{ll}
\hline Common Name & Scientific Name \\
\hline $\begin{array}{l}\text { Reptiles } \\
\text { Northern water snake }\end{array}$ & Nerodia sipedon sipedon \\
Amphibians & \\
Eastern American toad & $\begin{array}{l}\text { Bufo americanus americanus } \\
\text { Blanchard's cricket frog }\end{array}$ \\
Spring peeper & $\begin{array}{l}\text { Pseudacris crucifer } \\
\text { Green frog }\end{array}$ \\
Southern leopard frog & $\begin{array}{l}\text { Rana clamitans } \\
\text { Eastern gray treefrog }\end{array}$ \\
Central newt & $\begin{array}{l}\text { Hyla versicolor } \\
\text { Notophthalmus viridescens louisianensis }\end{array}$ \\
\hline
\end{tabular}

Four of the state-listed species are known to occur in the Weldon Spring area: Cooper's hawk, pied-billed grebe, Blanding's turtle, and wood frog. The Cooper's hawk nests in pine plantations in the Weldon Spring Conservation Area. It was not sighted during surveys conducted at Burgermeister Spring in 1992 (MK-Ferguson and Jacobs Engineering Group, Inc. 1993). The pied-billed grebe is commonly found during spring and fall at the Busch Conservation Area, but it primarily uses the open waters of the lakes. The Blanding's turtle inhabits marshes, bogs, lakes, and small streams. Although it has been reported from the Busch Conservation Area, it has not been reported from Lake 34 or at the Burgermeister Spring drainage. The wood frog is generally associated with wooded hillsides, and it usually breeds in small, fishless woodland ponds and pools. It has been reported from the Weldon Spring Conservation Area but not from the Burgermeister Spring drainage during amphibian surveys.

The king rail and the common moorhen are listed as state endangered and rare species, respectively. They are reported as occurring casually in the Busch Conservation Area, but not every year. The long-tailed weasel, a state rare species, occurs in the Weldon Spring Conservation Area and could potentially use the terrestrial habitats in the vicinity of Burgermeister Spring (DOE 1995). The remaining species listed in Table A.4 are not expected to be found at the Busch Conservation Area or to use the Burgermeister Spring drainage.

\section{A.3 ENVIRONMENTAL EVALUATION}

As previously mentioned, groundwater from portions of the chemical plant area and the DA training area discharges into Burgermeister Spring. As a result, surface water and sediments in the 
TABLE A.4 Rare, Threatened, and Endangered Animals Reported from St. Charles County

\begin{tabular}{|c|c|c|c|}
\hline \multicolumn{2}{|c|}{ Species } & \multicolumn{2}{|c|}{ Status } \\
\hline Common Name & Scientific Name & Federal $^{\mathrm{a}}$ & State $^{b}$ \\
\hline \multicolumn{4}{|l|}{ Fish } \\
\hline Brown bullhead & Ameiurus nebulosus & - & $\mathrm{R}$ \\
\hline Highfin carpsucker & Carpiodes velifer & - & $\mathrm{R}$ \\
\hline Blue sucker & Cycleptus elongatus & - & WL \\
\hline Mooneye & Hiodon tergisus & - & $\mathrm{R}$ \\
\hline Alligator gar & Atractosteus spatula & - & $\mathrm{R}$ \\
\hline Sturgeon chub & Macrhybopsis gelida & $\mathrm{C}$ & $\mathrm{R}$ \\
\hline Sicklefin chub & Macrhybopsis meeki & $\mathrm{C}$ & $\mathrm{R}$ \\
\hline River darter & Percina shumardi & - & WL \\
\hline \multicolumn{4}{|c|}{ Amphibians and Reptiles } \\
\hline Wood frog & Rana sylvatica & - & $\mathrm{R}$ \\
\hline Western fox snake & Elaphe vulpina vulpina & - & $\mathrm{E}$ \\
\hline Blanding's turtle & Emydoidea blandingi & - & $E$ \\
\hline \multicolumn{4}{|l|}{ Birds } \\
\hline Bald eagle & Haliaeetus leucocephalus & $\mathrm{T}$ & $\mathrm{E}$ \\
\hline Cooper's hawk & Accipiter cooperii & - & $\mathrm{R}$ \\
\hline Common moorhen & Gallinula chloropus & - & $\mathrm{R}$ \\
\hline Pied-billed grebe & Podilymbus podiceps & - & $\mathrm{R}$ \\
\hline King rail & Rallus elegans & - & $\mathrm{E}$ \\
\hline Barn owl & Tyto alba & - & $\mathrm{R}$ \\
\hline \multicolumn{4}{|l|}{ Mammals } \\
\hline Long-tailed weasel & Mustela frenata & - & $\mathrm{R}$ \\
\hline
\end{tabular}

a A hyphen indicates that no federal status has been established; $C=$ candidate; $\mathrm{T}=$ threatened.

b $\mathrm{E}=$ endangered; $\mathrm{R}=$ rare; $\mathrm{WL}=$ watch list. 
Burgermeister Spring drainage can contain site-related contaminants at levels that may affect ecological receptors that inhabit or utilize the drainage. The EPA has developed the Rapid Bioassessment Protocol (RBP) Method (EPA 1989) that provides guidance regarding information needed to establish a relationship between environmental contaminants and observed ecological effects. This information includes (1) characterization of the nature, extent, and magnitude of contamination; (2) ecological surveys to identify biota potentially at risk of exposure and to establish whether adverse ecological effects have occurred; and (3) toxicity tests to identify potential ecological impacts and to establish a link between the toxicity of the hazardous waste or contaminants and any realized adverse ecological effects. These data were obtained to determine whether measurable contaminant levels occur in Burgermeister Spring drainage and whether the contaminants pose an unacceptable risk to ecological resources in the area.

\section{A.3.1 Rapid Bioassessment Protocol}

The EPA's RBP Method (EPA 1989) was conducted at four locations in the Burgermeister Spring drainage (Figure A.2). The habitat assessment portion of the RBP evaluated physical conditions of the spring (Section 2.1), as well as its potential to support a biological community. The habitat assessment of the Burgermeister Spring drainage revealed a generally undisturbed, silt free, variable streambed habitat. Low flow, low pool to riffle ratios, and presence of channel obstructions (e.g., wood debris and weirs) are important factors that limit overall habitat quality (Ecological Specialists, Inc. 1996a). Deeper pools located in areas downstream of the spring provide better habitat than the shallow water levels near the mouth of the spring. No local watershed erosion or non-point-source pollution was evident. However, the lowermost sampling location (Location 4) near Lake 34 did show some evidence of channel alteration, scouring, and less embeddedness compared with the other sampling locations.

Various biotic matrices were calculated as part of the RBP macroinvertebrate assessment. The macroinvertebrate community was found to be slightly impaired in May 1995; in November 1995, it was classified as not impaired (Environmental Science and Engineering, Inc. 1995).

Fish surveys (May and November 1995) were used to assess community structure and impairment of the Burgermeister Spring drainage in accordance with the RBP Method V (EPA 1989). The results of those surveys showed a community integrity rating of fair to poor. The low community integrity rating is the result of low flow and physical habitat constraints for many fish species, rather than water quality conditions. 


\section{A.3.2 Tissue Analysis}

The potential contaminants of ecological concern in Burgermeister Spring include arsenic, chromium, lead, mercury, selenium, silver, uranium, nitrate, and nitroaromatics (DOE 1995); macroinvertebrates and fishes were collected and prepared for whole body tissue analysis for these contaminants. Amphipods and chironomids constituted the dominant taxa used for the macroinvertebrate tissue samples; various sunfish species were used for the fish samples. The concentrations of uranium and metals in macroinvertebrates and fish collected from the Burgermeister Spring drainage are presented in Table A.5. No nitroaromatics were detected in fish samples. Macroinvertebrates were not sampled for nitroaromatics, and neither macroinvertebrates nor fish were sampled for nitrates because of low sample mass. Uranium concentrations in macroinvertebrates ranged from $0.048 \mathrm{pCi} / \mathrm{g}$ to $294 \mathrm{pCi} / \mathrm{g}$; concentrations in fish ranged from $0.045 \mathrm{pCi} / \mathrm{g}$ to $0.073 \mathrm{pCi} / \mathrm{g}$.

Mercury and silver were not detected in macroinvertebrate tissue samples; arsenic, chromium, and selenium were detected infrequently. Lead was detected more frequently in macroinvertebrates but at low levels ranging from 1.1 to $2.7 \mu \mathrm{g} / \mathrm{g}$. Silver and selenium were not detected in fish samples, while arsenic was detected infrequently. Chromium, lead, and mercury were detected in fish samples but at low concentrations.

\section{A.3.3 Toxicity Testing}

Toxicity testing data were generated from surface water and sediment samples collected from the four sampling locations in the Burgermeister Spring drainage. The toxicity tests were performed with four test organisms: cladocera (Daphnia magna), amphipod (Hyallela azteca), fathead minnow (Pimephales promelas), and African clawed frog (Xenopus laevis). Acute and chronic tests were performed, as needed. Abbreviated acute toxicity tests were performed first. If the results indicated significant mortality at the 5\% level, then additional samples were collected and submitted for acute serial dilution (definitive) tests. If mortality was not found to be significant at the 5\% level, then samples were recollected and chronic toxicity tests were performed. Table A.6 gives the results of the toxicity tests.

While a few positive responses were reported from toxicity testing among species, media, and location, toxicity was not consistently found for any location in the Burgermeister Spring drainage.

\section{A.4 CONCLUSIONS}

Results of surveys for macroinvertebrates, fish, and herpetofauna at the Burgermeister Spring drainage indicated no evidence of adverse effects to these biota resulting from site-related 
TABLE A.5 Contaminant Tissue Concentrations and Estimated Bioconcentration Factors for Macroinvertebrate and Fish Tissue Samples Collected from Burgermeister Spring

\begin{tabular}{lccc}
\hline \multicolumn{1}{c}{ Contaminant } & Detects/Total & $\begin{array}{c}\text { Mean Tissue } \\
\text { Concentration }(\mu \mathrm{g} / \mathrm{g}, \\
\text { except as noted })\end{array}$ & $\begin{array}{c}\text { Bioconcentration } \\
\text { Factor }^{\mathrm{a}}\end{array}$ \\
\hline Macroinvertebrate Tissue & & & \\
Arsenic & $1 / 4$ & 3.89 & 0.23 \\
Chromium & $1 / 4$ & 3.61 & 0.14 \\
Lead & $3 / 4$ & 2.18 & 0.06 \\
Mercury & $0 / 4$ & $\mathrm{ND}$ & $\mathrm{NA}$ \\
Selenium & $1 / 4$ & 3.98 & 11.05 \\
Silver & $0 / 4$ & $\mathrm{ND}$ & $\mathrm{NA}$ \\
Uranium & $16 / 16$ & $31.1 \mathrm{pCi} / \mathrm{g}$ & 13.2 \\
& & & \\
Fish Tissue & & & 20.0 \\
Arsenic & $1 / 4$ & 0.04 & 103.3 \\
Chromium & $4 / 4$ & 0.62 & 30 \\
Lead & $3 / 4$ & 0.03 & $1,100^{\mathrm{d}}$ \\
Mercury & $4 / 4$ & 0.11 & $\mathrm{NA}$ \\
Selenium & $0 / 4$ & $\mathrm{ND}$ & $\mathrm{NA}$ \\
Silver & $0 / 4$ & $\mathrm{ND}$ & 0.98 \\
Uranium & $4 / 4$ & $0.049 \mathrm{pCi} / \mathrm{g}$ & \\
\hline & & & \\
\hline
\end{tabular}

a Bioconcentration factor calculated as the mean tissue concentration divided by the mean sediment concentration (for macroinvertebrates) or the mean surface water concentration (for fish). Mean sediment and surface water concentrations were calculated by using only data collected concurrently with fish samples from Burgermeister Spring.

${ }^{b} \mathrm{ND}=$ not detected.

c $\mathrm{NA}=$ not applicable.

d Mercury was not detected in surface water samples collected concurrently with fish samples from Burgermeister Spring. Bioconcentration factor estimated using $1 / 2$ the detection limit. 
TABLE A.6 Results of Acute and Chronic Toxicity Testing from the Burgermeister Spring Drainage

\begin{tabular}{lcccc}
\hline & \multicolumn{4}{c}{ Toxicity at Sampling Location } \\
\cline { 2 - 5 } Organism, Toxicity Test & Location 1 & Location 2 & Location 3 & Location 4 \\
\hline Surface Water & & & & \\
Daphnia, 96-hour acute survival & $-\mathrm{a}$ & - & - & - \\
Hyallela, 96-hour acute survival & - & - & - & - \\
Pimephales, 96-hour acute survival & $37.5 \% \mathrm{~b}$ & $37.5 \%$ & - & - \\
Xenopus, 96-hour acute survival & - & - & - & - \\
Daphnia, 7-day chronic & - & - & - & - \\
Hyallela, 7-day chronic & - & - & - & - \\
Pimephales, 7-day chronic & NC & NC & - & - \\
Xenopus, 7-day chronic & - & - & $70 \%$ & - \\
Sediment & & & & - \\
Daphnia, 96-hour acute survival & - & - & - & - \\
Hyallela, 96-hour acute survival & - & - & - & - \\
Pimephales, 96-hour acute survival & - & $75 \%$ & - & - \\
Xenopus, 96-hour acute survival & - & - & - & - \\
Daphnia, 7-day chronic & - & - & - & - \\
Hyallela, 7-day chronic & $82 \%$ & - & - & - \\
Pimephales, 7-day chronic & - & - & - & $50 \%$ \\
Xenopus, 7-day chronic & - & $73 \%$ & - & - \\
\hline
\end{tabular}

a A hyphen indicates no significant media toxicity ( $p>0.05$ ).

b Values are percent survival for significant media toxicity ( $\mathrm{p} \leq 0.05)$.

c $\mathrm{NC}=$ chronic toxicity testing not conducted because media toxicity at this sampling location indicated by the results of the corresponding acute toxicity test.

contaminants. The drainage was determined to have generally good aquatic habitat, and the species present are typical of those found in comparable habitats throughout the Midwest. Although the fish community was limited in diversity and the macroinvertebrate community was categorized as slightly impaired, the communities are likely affected by the physical nature of the drainage system rather than by contaminant levels. In particular, the aquatic community is strongly influenced by low flow in late summer and fall. The habitat found at the spring is adequate to support a variety of aquatic fauna, but is limited by the availability of permanent surface water.

The results of toxicity testing indicate the potential for some toxicity to biota from water and sediments in Burgermeister Spring and its drainage, although no clear toxicity gradient is evident extending downstream from the spring. The presence of apparently unaffected macro- 
invertebrates, fish, and amphibians in the drainage suggests that local biota are tolerant of (or have adapted to) the contaminant levels present in surface waters and sediments in the Burgermeister Spring drainage.

\section{A.5 APPENDIX A REFERENCES}

Dickneite, D.F., 1988, letter, with enclosure, from Dickneite (Environmental Administrator, Missouri Department of Conservation, Jefferson City, Mo.) to I. Hlohowskyj (Argonne National Laboratory, Argonne, Ill.), Aug. 24.

DOE: see U.S. Department of Energy.

Ecological Specialists, Inc., 1996a, Ecological Characterization for the Weldon Spring Site Remedial Action Project, ESI Project \#95-015, prepared for MK-Ferguson, St. Charles, Mo., March.

Ecological Specialists, Inc., 1996b, Ecological Characterization for the Weldon Spring Site Remedial Action Project, Option Period, Spring 1996, ESI Project \#96-012, prepared for MK-Ferguson, St. Charles, Mo., July.

Environmental Science and Engineering, Inc., 1995, 1994 Aquatic Surveillance Monitoring Program WP-402, ESE No. 593-1109-060, prepared for MK-Ferguson Company, St. Charles, Mo., June 21.

EPA: see U.S. Environmental Protection Agency.

Federal Insurance Administration, 1978, Flood Insurance Rate Map, St. Charles County, Missouri (Unincorporated Area), Community-Panel Number 2903150250 A, p. 250 of 350, U.S. Department of Housing and Urban Development, National Flood Insurance Program, Washington, D.C.

International Technology Corporation, 1993, Final Remedial Investigation Report, Weldon Spring Training Area, Weldon Spring, Missouri, Project No. 312188, prepared by International Technology Corporation, Itasca, Ill., for U.S. Department of the Army, Corps of Engineers, Kansas City District, March.

Missouri Department of Conservation, 1989, Area Management Plan for the August A. Busch Complex, Jefferson City, Mo.

Missouri Department of Conservation, 1991, A Checklist of Birds of the August A. Busch Memorial Wildlife Area, St. Charles, Missouri, Jefferson City, Mo. 
MK-Environmental Services, 1992, WSSRAP Disposal Facility Dust Control Methods and Criteria Study, Report No. 384OR-799-00, Rev. 0, prepared for MK-Ferguson Group, Boise, Idaho, Jan.

MK-Ferguson Company and Jacobs Engineering Group, Inc., 1993, Weldon Spring Site Environmental Report for Calendar Year 1992, Weldon Spring Site Remedial Action Project; DOE/OR/21548-372, Rev. 0, prepared for the U.S. Department of Energy, Oak Ridge Operations Office, St. Charles, Mo. June.

Pflieger, W.L., 1975, The Fishes of Missouri, Missouri Department of Conservation, Jefferson City, Mo.

U.S. Department of Energy, 1992, Baseline Assessment for the Chemical Plant Area of the Weldon Spring Site, DOE/EIS-0185D (DOE/OR/21548-091), prepared by U.S. Department of Energy, Oak Ridge Field Office, Weldon Spring Site Remedial Action Project, St. Charles, Mo., with technical assistance from Argonne National Laboratory, Environmental Assessment and Information Sciences Division, Argonne, Ill., Nov.

U.S. Department of Energy, 1995, Work Plan for the Remedial Investigation/Feasibility Study for the Groundwater Operable Unit at the Chemical Plant Area and the Ordnance Works Area, Weldon Spring, Mo., DOE/OR/21548-567, prepared for Weldon Spring Site Remedial Action Project, Weldon Spring, Mo., by the Environmental Assessment Division, Argonne National Laboratory, Argonne Ill., Aug.

U.S. Environmental Protection Agency, 1989, Rapid Bioassessment Protocols for Use in Streams and Rivers: Benthic Macroinvertebrates and Fish, EPA/444/4-89-001, Assessment and Watershed Protection Division, Washington, D.C., May.

U.S. Fish and Wildlife Service, 1989, National Wetlands Inventory Map, Weldon Spring Quadrangle, U.S. Department of the Interior, National Wetlands Inventory, St. Petersburg, Fla., June. 
$B-1$

APPENDIX B:

HYDROGEOLOGIC INVESTIGATIONS

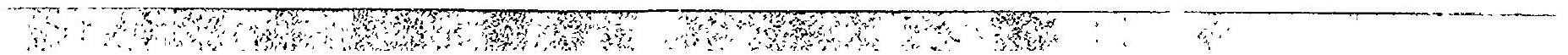


B-2 


\section{APPENDIX B:}

\section{HYDROGEOLOGIC INVESTIGATIONS}

\section{B.1 BACKGROUND INFORMATION ON GEOLOGY AND HYDROGEOLOGY OF THE WELDON SPRING AREA}

Numerous investigations have been performed at the chemical plant area, the training area, and the ordnance works area to characterize the overburden materials and bedrock units and to quantify the hydraulic properties of these materials. As part of these investigations, monitoring wells were installed in the chemical plant area and the ordnance works area to provide geologic and hydrologic characterization data. Tables B.1 and B.2 list the groundwater monitoring wells and give the construction summaries for these two respective areas. The information in this section is provided to support the discussion in Chapter 3.

\section{B.1.1 Overburden}

The thickness of unconsolidated material or overburden ranges from 0 to $21 \mathrm{~m}(0$ to $70 \mathrm{ft}$ ) in the vicinity of the chemical plant area and the ordnance works area (Mugel 1997). The seven principal overburden units include (1) fill/topsoil, (2) Peoria Loess, (3) Roxana Silt, (4) Ferrelview Formation, (5) clay till, (6) basal till, and (7) residuum. Table B.3 gives the physical characteristics of each of these overburden units.

\section{B.1.1.1 Unsaturated Overburden}

Laboratory testing for determination of in situ moisture content, porosity, and saturated hydraulic conductivity of the overburden materials has been performed in support of the design of the disposal cell at the chemical plant area. The results of these tests can generally be applied to the same units in both the training area and ordnance works area sites. A summary of these properties is provided in Table B.4.

Each of these hydraulic parameters plays a part in recharge to the shallow aquifer. The results of the in situ moisture testing indicate that with the exception of the residuum, the upper overburden units are generally near moisture saturation (MK-Environmental Services 1993). This finding is consistent with the low permeability and small particle size of the overburden units. These near-saturation moisture contents are likely the result of infiltration from precipitation, capillary rise from groundwater, and low hydraulic conductivities. The moisture content of the residuum is below 


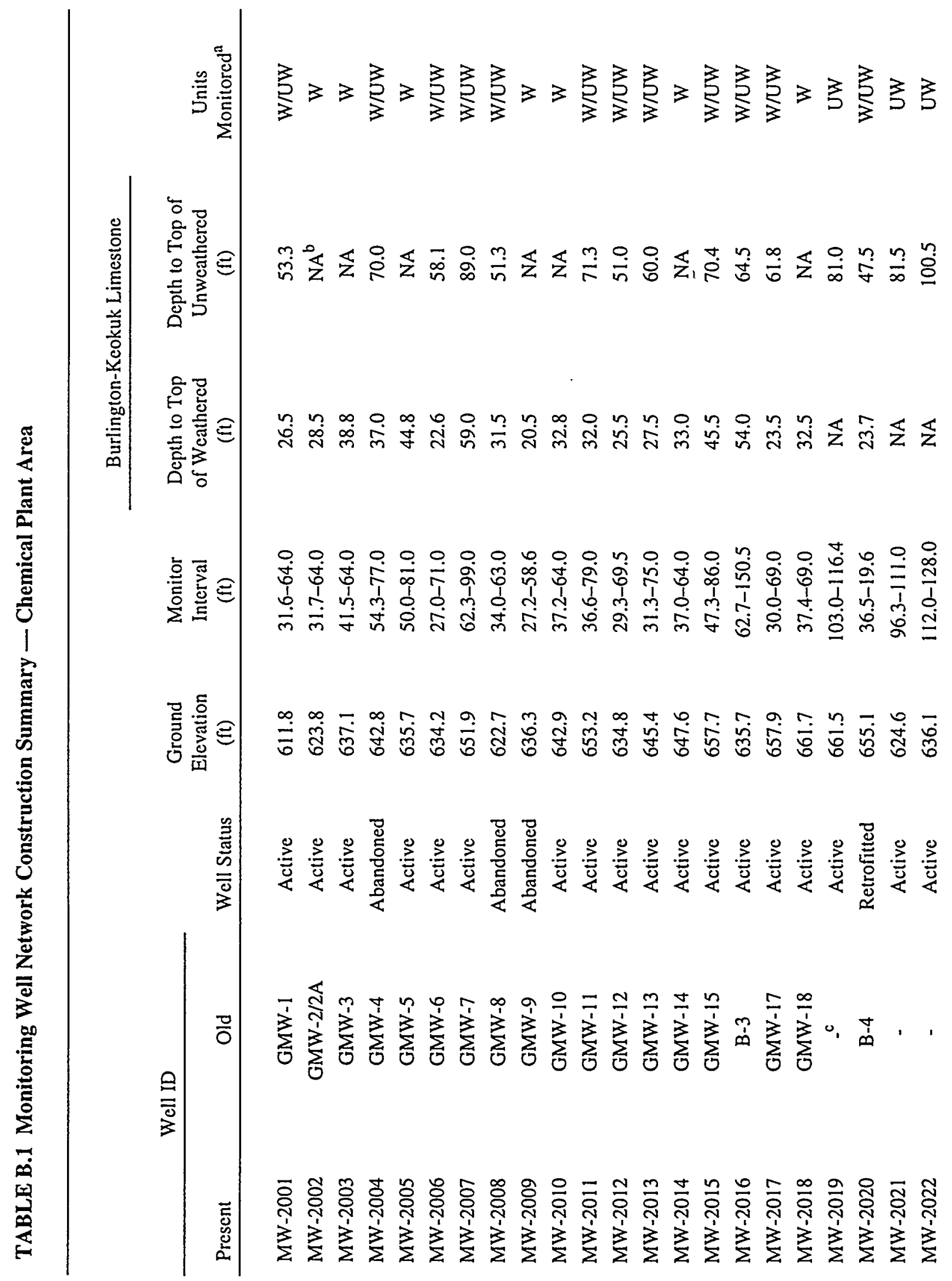


TABLE B.1 (Cont.)

\begin{tabular}{|c|c|c|c|c|c|c|c|}
\hline \multirow{2}{*}{\multicolumn{2}{|c|}{ Well ID }} & \multirow[b]{3}{*}{ Well Status } & \multirow{3}{*}{$\begin{array}{l}\text { Ground } \\
\text { Elevation } \\
(\mathrm{ft})\end{array}$} & \multirow{3}{*}{$\begin{array}{l}\text { Monitor } \\
\text { Interval } \\
(\mathrm{ft})\end{array}$} & \multicolumn{2}{|c|}{ Burlington-Keokuk Limestone } & \multirow[b]{3}{*}{$\begin{array}{c}\text { Units } \\
\text { Monitored }^{\mathrm{a}} \\
\end{array}$} \\
\hline & & & & & \multirow{2}{*}{$\begin{array}{l}\text { Depth to Top } \\
\text { of Weathered } \\
(\mathrm{ft})\end{array}$} & \multirow{2}{*}{$\begin{array}{c}\text { Depth to Top of } \\
\text { Unweathered } \\
\text { (ft) }\end{array}$} & \\
\hline Present & Old & & & & & & \\
\hline MW-2023 & - & Active & 635.8 & $68.5-91.5$ & NA & NA & $U W^{d}$ \\
\hline MW-2024 & - & Active & 634.9 & $135.0-149.6$ & ND & NA & $U W^{d}$ \\
\hline MW-2025 & - & Abandoned & 622.2 & $94.0-108.6$ & ND & 70.5 & uW \\
\hline MW-2026 & - & Active & 634.8 & $105.5-118.0$ & ND & 81.0 & UW \\
\hline MW-2027 & - & Active & 646.3 & $107.0-122.0$ & ND & 80.2 & UW \\
\hline MW-2028 & - & Active & 657.8 & $116.0-131.5$ & ND & 91.6 & UW \\
\hline MW-2029 & - & Abandoned & 643.1 & $89.0-101.3$ & ND & NA & $U W^{\mathfrak{e}}$ \\
\hline MW-2030 & - & Active & 652.9 & $30.5-59.0$ & 29.5 & $\mathrm{NA}$ & W \\
\hline MW-2031 & - & Abandoned & 660.6 & $55.0-67.5$ & 58.0 & NA & $\mathrm{OB} / \mathrm{W}$ \\
\hline MW-2032 & - & Active & 635.8 & $48.0-58.6$ & 53.2 & $\mathrm{NA}$ & $\mathrm{OB} / \mathrm{W}$ \\
\hline MW-2033 & - & Active & 644.8 & $23.1-46.3$ & 23.2 & NA & $\mathrm{OB} / \mathrm{W}$ \\
\hline MW-2034 & - & Active & 658.2 & $34.5-60.0$ & 34.5 & $\mathrm{NA}$ & W \\
\hline MW-2035 & - & Active & 667.0 & $62.8-77.5$ & 35.0 & 73.1 & W/UW \\
\hline MW-2036 & - & Active & 655.9 & $52.5-8.0$ & 46.0 & 64.6 & W/UW \\
\hline MW-2037 & - & Active & 656.7 & $45.5-63.5$ & 40.0 & $\mathrm{NA}$ & W \\
\hline MW-2038 & - & Active & 665.0 & $55.0-71.5$ & 52.5 & $\mathrm{NA}$ & UD \\
\hline MW-2039 & - & Active & 663.4 & $53.3-69.0$ & 44.5 & NA & UD \\
\hline MW-2040 & - & Active & 662.4 & $54.5-74.0$ & 44.5 & NA & UD \\
\hline MW-2041 & - & Active & 661.6 & $61.5-82.0$ & 43.0 & NA & UD \\
\hline MW-2042 & - & Active & 662.7 & $56.0-77.5$ & 43.5 & NA & UD \\
\hline MW-2043 & - & Active & 662.6 & $56.5-75.0$ & 45.0 & $\mathrm{NA}$ & UD \\
\hline MW-2044 & - & Retrofitted & 655.1 & $37.1-64.1$ & 23.7 & 47.5 & W/UW \\
\hline MW-3001 & - & Abandoned & 664.3 & $52.8-78.0$ & 53.5 & 85.0 & $\mathrm{OB} / \mathrm{W}$ \\
\hline
\end{tabular}




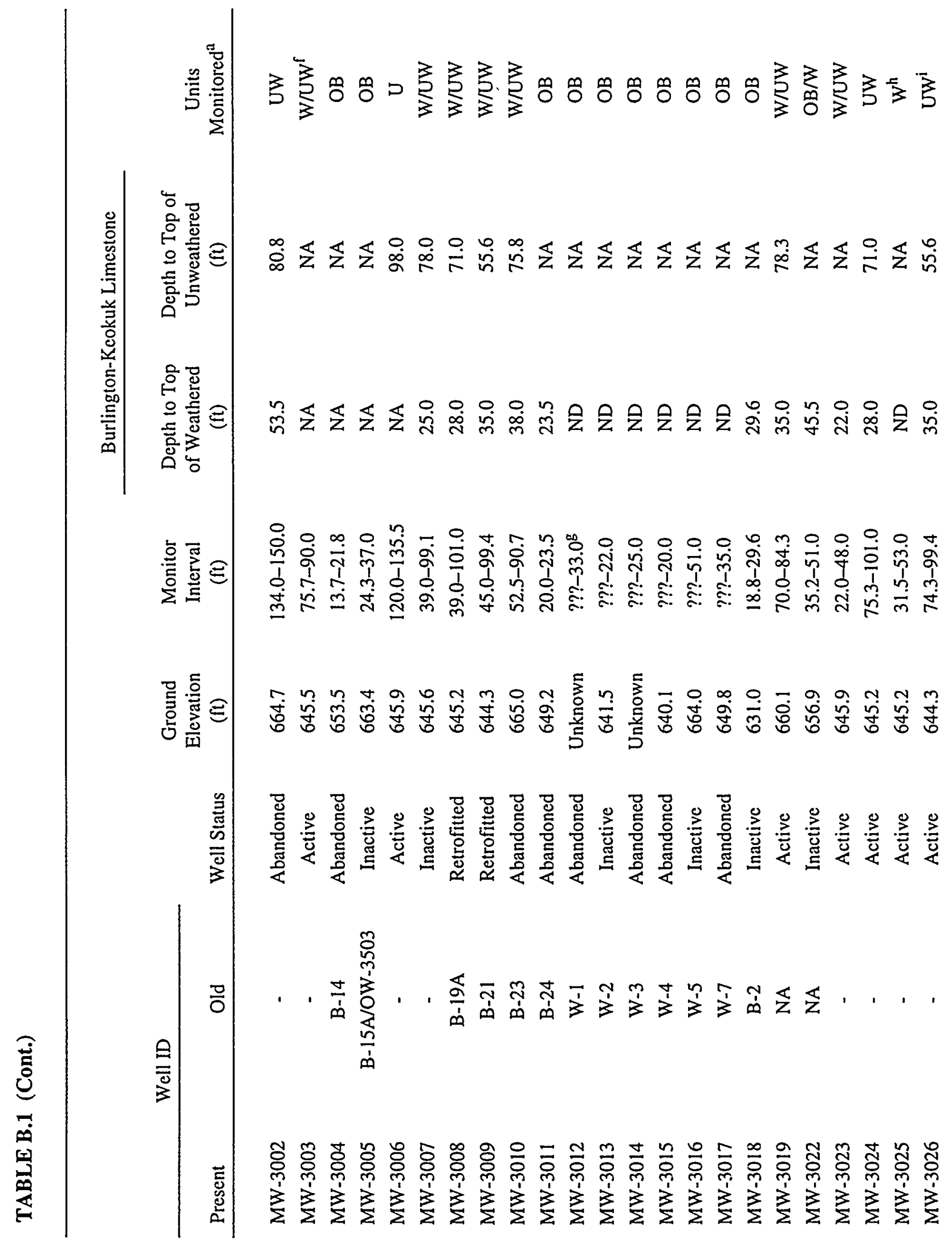


TABLE B.1 (Cont.)

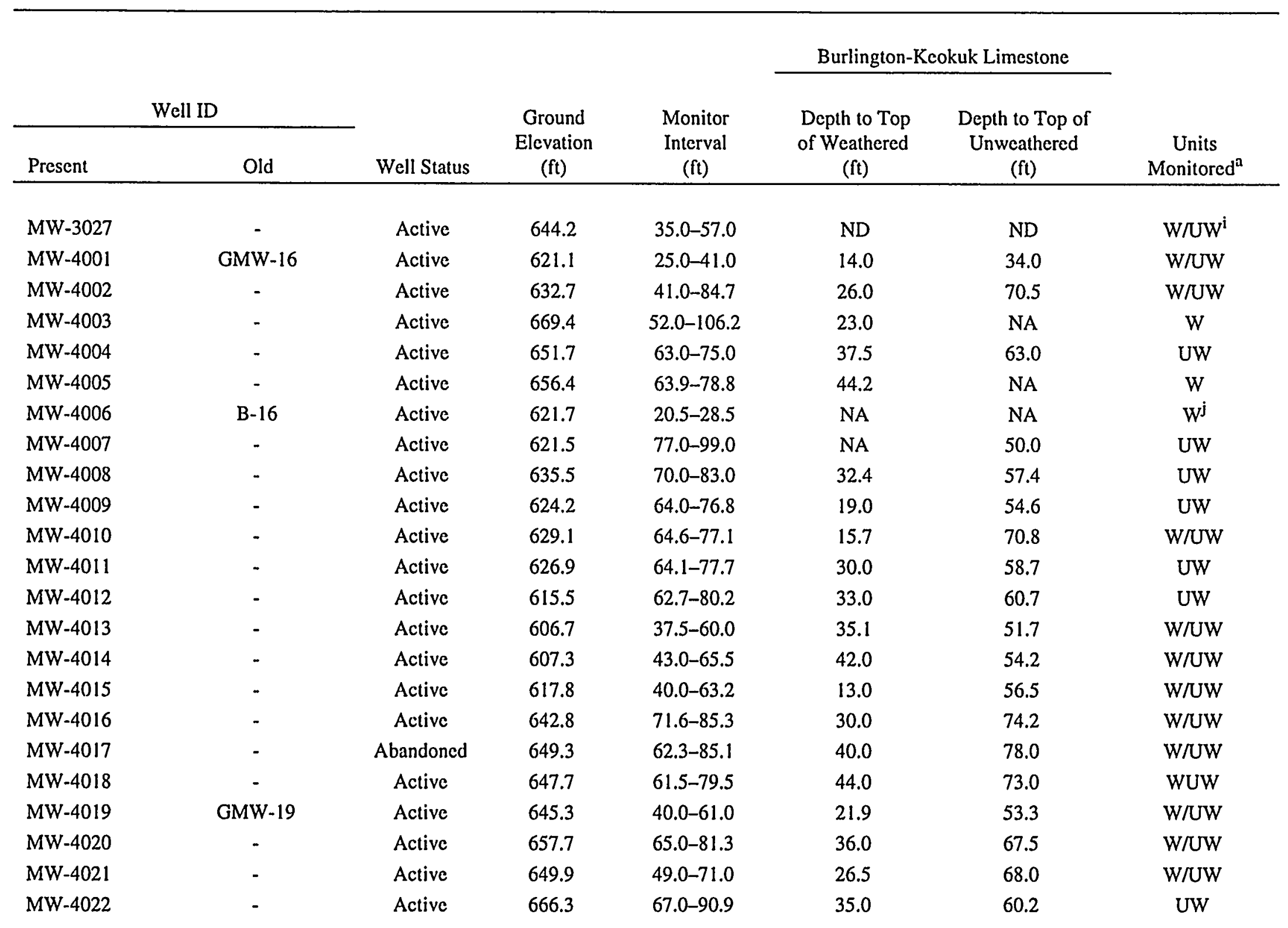


TABLE B.1 (Cont.)

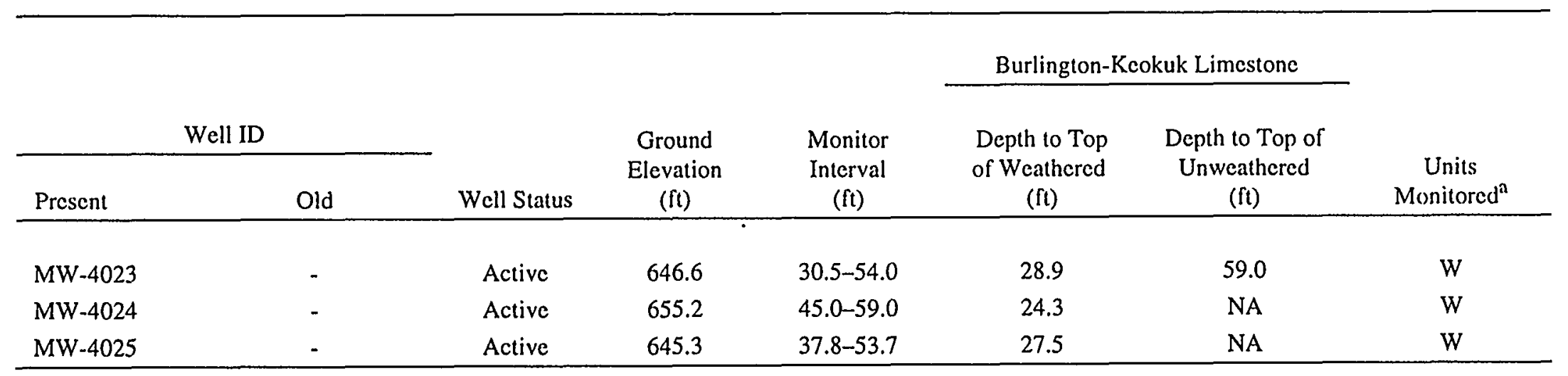

a $\mathrm{OB}=$ overburdened; $\mathrm{UD}=$ undifferentiated; rock not cored, no samples or $\log ; \mathrm{UW}=$ unweathered; $\mathrm{W}=$ weathered.

b $\mathrm{NA}=$ data not available.

c A hyphen indicates no prior identification system.

d No log; unit open to well based on stratigraphy in MW-2016.

c No log; unit open to well based on stratigraphy in MW-2004.

$f$ No log; units open to well based on stratigraphy in MW-3007.

g ??? = questionable data.

h No log; unit open to well based on stratigraphy in MW-3024 (retrofit of MW-3008).

i No log; units open to well based on stratigraphy in MW-3026.

j No core; unit open to well based on MW-4001 and MW-4007.

Source: Mugel (1997). 


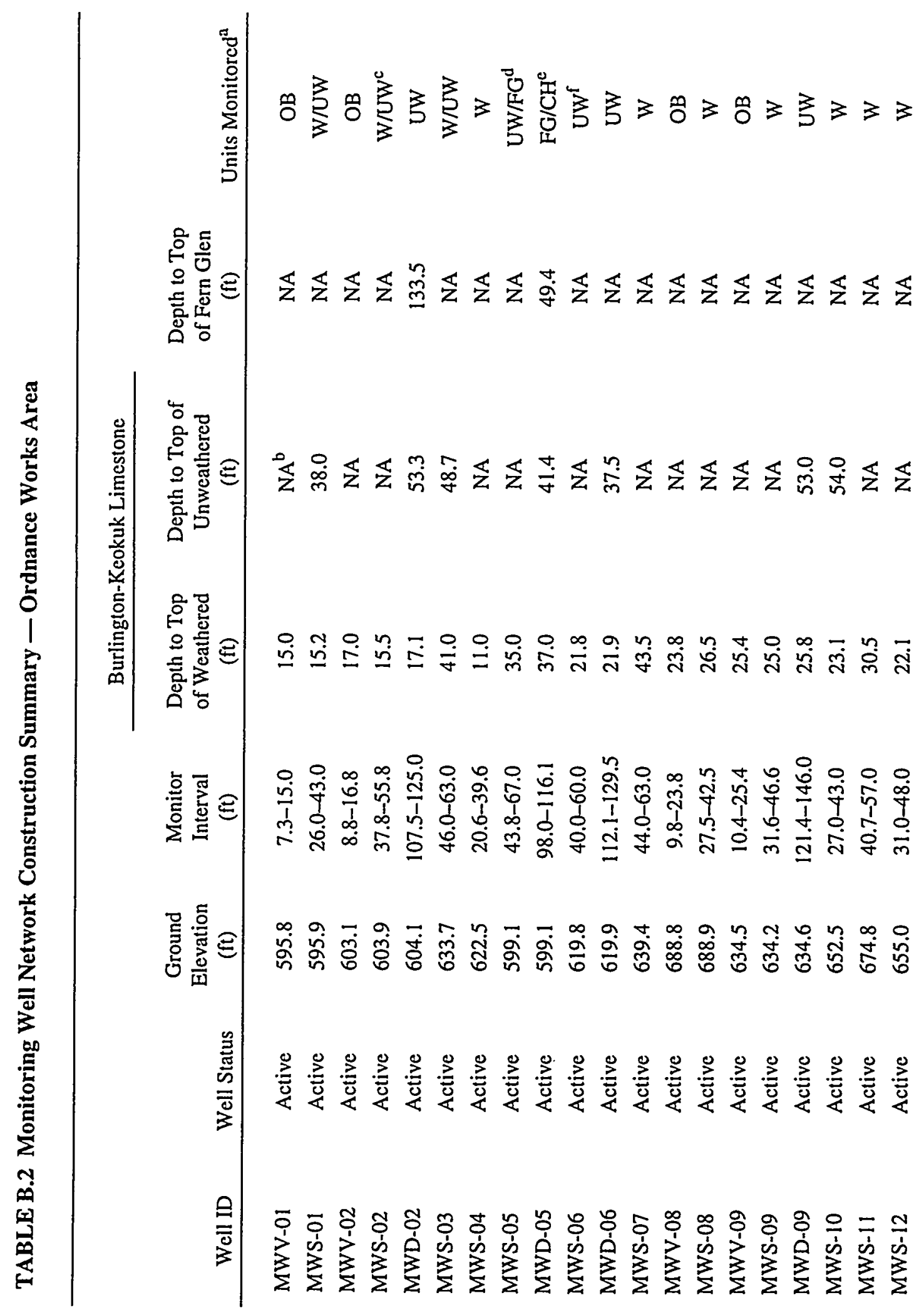




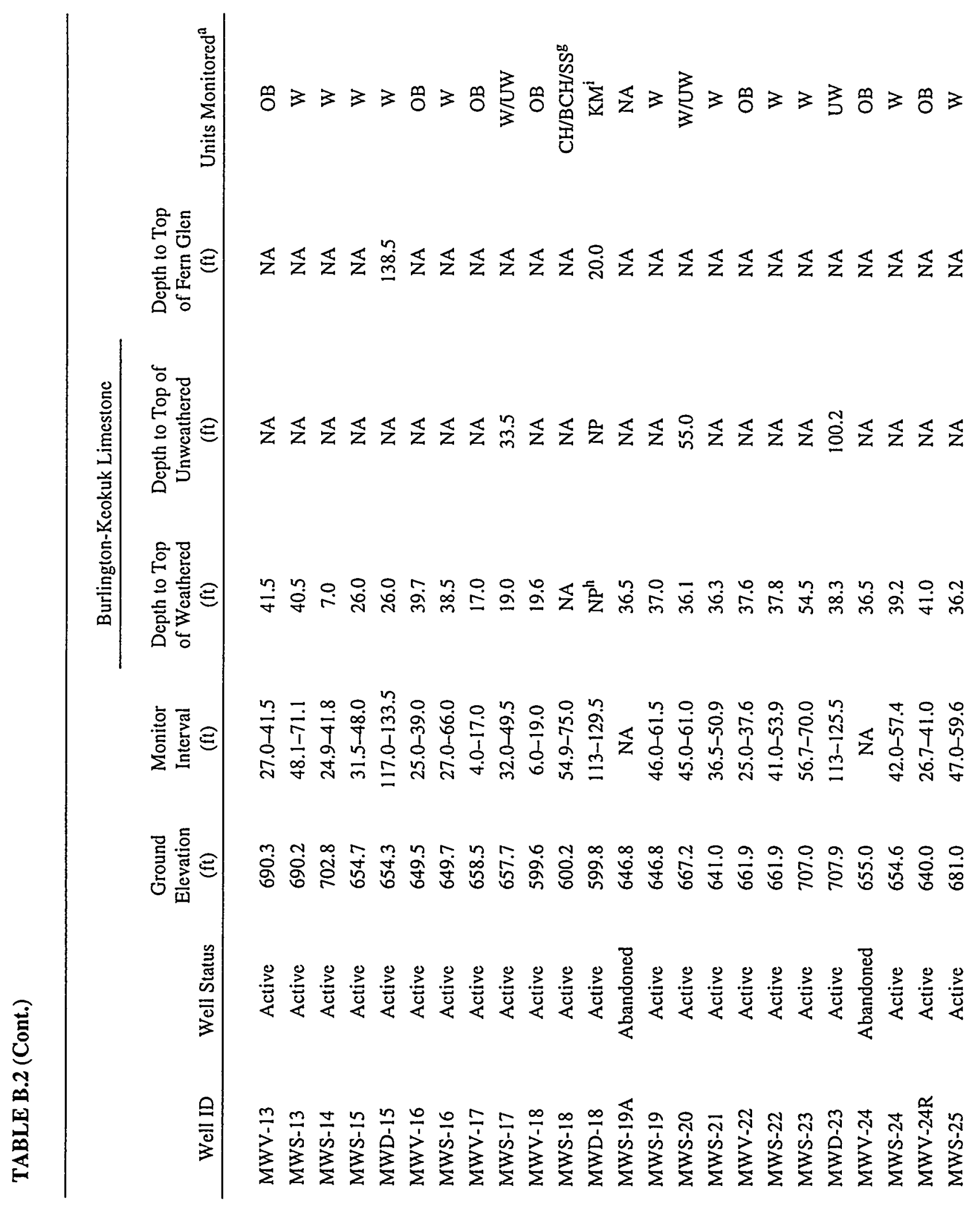


TABLE B.2 (Cont.)

\begin{tabular}{|c|c|c|c|c|c|c|c|}
\hline \multirow[b]{2}{*}{ Well ID } & \multirow[b]{2}{*}{ Well Status } & \multirow[b]{2}{*}{$\begin{array}{c}\text { Ground } \\
\text { Elevation } \\
\text { (ft) }\end{array}$} & \multirow[b]{2}{*}{$\begin{array}{l}\text { Monitor } \\
\text { Interval } \\
\text { (ft) }\end{array}$} & \multicolumn{2}{|c|}{ Burlington-Keokuk Limestone } & \multirow[b]{2}{*}{$\begin{array}{l}\text { Depth to Top } \\
\text { of Fern Glen } \\
\text { (ft) }\end{array}$} & \multirow[b]{2}{*}{ Units Monitored $^{\mathrm{a}}$} \\
\hline & & & & $\begin{array}{c}\text { Depth to Top } \\
\text { of Weathered } \\
\text { (ft) }\end{array}$ & $\begin{array}{l}\text { Depth to Top of } \\
\text { Unweathered } \\
\text { (ft) }\end{array}$ & & \\
\hline MWD-25 & Active & 681.0 & $102.5-114.5$ & 36.5 & 103.0 & NA & W/UW \\
\hline MWS-26 & Active & 672.4 & $41.5-54.5$ & 40.6 & NA & NA & W \\
\hline MWD-26 & Retrofitted & 607.2 & $121.5-134.0$ & 46.0 & 79.0 & NA & UW \\
\hline MWS-101 & Active & 489.5 & $50.0-85.0$ & NP & $\mathrm{NP}$ & $\mathrm{NP}$ & $\mathrm{KM}^{\mathrm{j}}$ \\
\hline MWS-102 & Active & 479.2 & $57.5-90.0$ & NP & NP & $\mathrm{NP}$ & $\mathrm{DC}$ \\
\hline MWS-103 & Active & 527.7 & $28.0-65.0$ & $\mathrm{NP}$ & $\mathrm{NP}$ & NP & SS/KM \\
\hline MWS-104 & Active & 564.7 & $22.9-56.0$ & 15.5 & 43.8 & NA & W/UW \\
\hline MWS-105 & Active & 573.7 & $30.2-69.2$ & 28.7 & NA & NA & $U W^{k}$ \\
\hline MWD-105 & Active & 573.7 & $115.3-152.3$ & NA & 28.9 & 130.4 & UW/FG \\
\hline MWS-106 & Active & 530.7 & $25.0-48.0$ & $\mathrm{NA}$ & $\mathrm{NA}$ & NA & UW' \\
\hline MWD-106 & Active & 531.0 & $114.7-148.2$ & NA & 23.5 & 132.8 & UW/FG \\
\hline MWS-107 & Active & 607.2 & $52.0-85.5$ & 49.0 & 78.5 & NA & W/UW \\
\hline MWD-107 & Active & 607.2 & $121.5-134.0$ & 46.0 & 79.0 & NA & UW \\
\hline MWS-108 & Active & 604.4 & $52.0-85.0$ & $N P$ & 50.3 & NA & UW \\
\hline MWS-109 & Active & 550.3 & $41.2-75.5$ & 22.0 & $\mathrm{NA}$ & $\mathrm{NA}$ & $\mathrm{UW}^{\mathrm{m}}$ \\
\hline MWD-109 & Active & 550.4 & $105.1-139.3$ & NP & 21.8 & 124.9 & UW/FG \\
\hline MWS- 110 & Active & 604.8 & $55.0-89.5$ & 15.5 & 79.0 & $\mathrm{NA}$ & W/UW \\
\hline MWS-111 & Active & 620.8 & $42.0-75.2$ & 35.5 & $\mathrm{NA}$ & NA & W \\
\hline MWS- 112 & Active & 572.6 & $23.7-38.7$ & 18.0 & 28.5 & $\mathrm{NA}$ & W/UW \\
\hline MWD- 112 & Active & 572.6 & $94.2-106.8$ & 18.0 & ND & NA & UW \\
\hline USGS-1 & Active & 589.0 & $57-107$ & 38.0 & 48.0 & NA & UW \\
\hline USGS-2 & Abandoned & 554 & at 50 & 50 & $\mathrm{NA}$ & NA & UD B-K \\
\hline USGS-2A & Active & 559 & $26-107$ & 50 & $\mathrm{NA}$ & $\mathrm{NA}$ & OB/UD B-K \\
\hline
\end{tabular}


TABLE B.2 (Cont.)

\begin{tabular}{|c|c|c|c|c|c|c|c|}
\hline \multirow[b]{2}{*}{ Well ID } & \multirow[b]{2}{*}{ Well Status } & \multirow[b]{2}{*}{$\begin{array}{l}\text { Ground } \\
\text { Elevation } \\
(\mathrm{ft})\end{array}$} & \multirow[b]{2}{*}{$\begin{array}{l}\text { Monitor } \\
\text { Interval } \\
\text { (ft) }\end{array}$} & \multicolumn{2}{|c|}{ Burlington-Keokuk Limestone } & \multirow[b]{2}{*}{$\begin{array}{l}\text { Depth to Top } \\
\text { of Fern Glen } \\
\text { (ft) }\end{array}$} & \multirow[b]{2}{*}{ Units Monitored $^{\mathrm{a}}$} \\
\hline & & & & $\begin{array}{c}\text { Depth to Top } \\
\text { of Weathered } \\
\text { (ft) }\end{array}$ & $\begin{array}{c}\text { Depth to Top of } \\
\text { Unweathered } \\
\text { (ft) }\end{array}$ & & \\
\hline USGS-3 & Active & 585 & $66-80$ & 66 & NA & NA & UD B-K \\
\hline USGS-4 & Active & 601 & $30-107$ & 30 & $\mathrm{NA}$ & NA & UD B-K \\
\hline USGS-5 & Active & 580 & $23-87$ & 23 & $\mathrm{NA}$ & NA & UD B-K \\
\hline USGS-6 & Active & 590 & $70-107$ & 56 & 70 & NA & UW \\
\hline USGS-7 & Retrofitted & 570 & $32-107$ & 32 & $\mathrm{NA}$ & $\mathrm{NA}$ & UD B-K \\
\hline USGS-8 & Active & 625 & $60-107$ & 60 & $\mathrm{NA}$ & $\mathrm{NA}$ & UD B-K \\
\hline USGS-9 & Active & 590 & $24-90$ & 24 & $\mathrm{NA}$ & NA & UD B-K \\
\hline
\end{tabular}

a $\mathrm{BCH}=$ Bachelor Formation; $\mathrm{CH}=$ Chouteau Group; $\mathrm{DC}=$ Decorah Group; FG = Fern Glen Formation; KM = Kimmswick Limestonc; $\mathrm{OB}=$ overburden; $S S=$ Sulphur Springs Group; UD = undifferentiated; UW = unweathered Burlington-Keokuk Limestone; $W=$ weathered Burlington-Keokuk Limestone.

b $\mathrm{NA}=$ no data available.

c Units open to well based on MWD-02 stratigraphy.

d Units open to well based on MWD-05 stratigraphy.

e Depth to top of Chouteau Group - $116 \mathrm{ft}$; depth to top of Bachelor Formation - $138.6 \mathrm{ft}$; depth to top of Sulphur Springs Group-140.8 $\mathrm{ft}$.

i Unit open to well based on MWD-06 stratigraphy.

$g$ Units open based on MWD-18 stratigraphy.

h $\mathrm{NP}=$ not present

i Depth to top of Choutcau Group - $48.7 \mathrm{ft}$; depth to top of Bachelor Formation - $70 \mathrm{ft}$; depth to top of Sulphur Springs Group - $71.1 \mathrm{ft}$; depth to top of Kimmswick Limestone - $91.0 \mathrm{ft}$.

$\mathrm{j}$ Depth to top of Kimmswick Limestone - $44 \mathrm{ft}$.

k Units open to well based on MWD-25 stratigraphy.

1 Units open to well based on MWD-26 stratigraphy.

m Units open to well based on MWD-109 stratigraphy.

Sources: IT Corporation (1993); Mugel (1997). 
TABLE B.3 Physical Characteristics of the Overburden Units

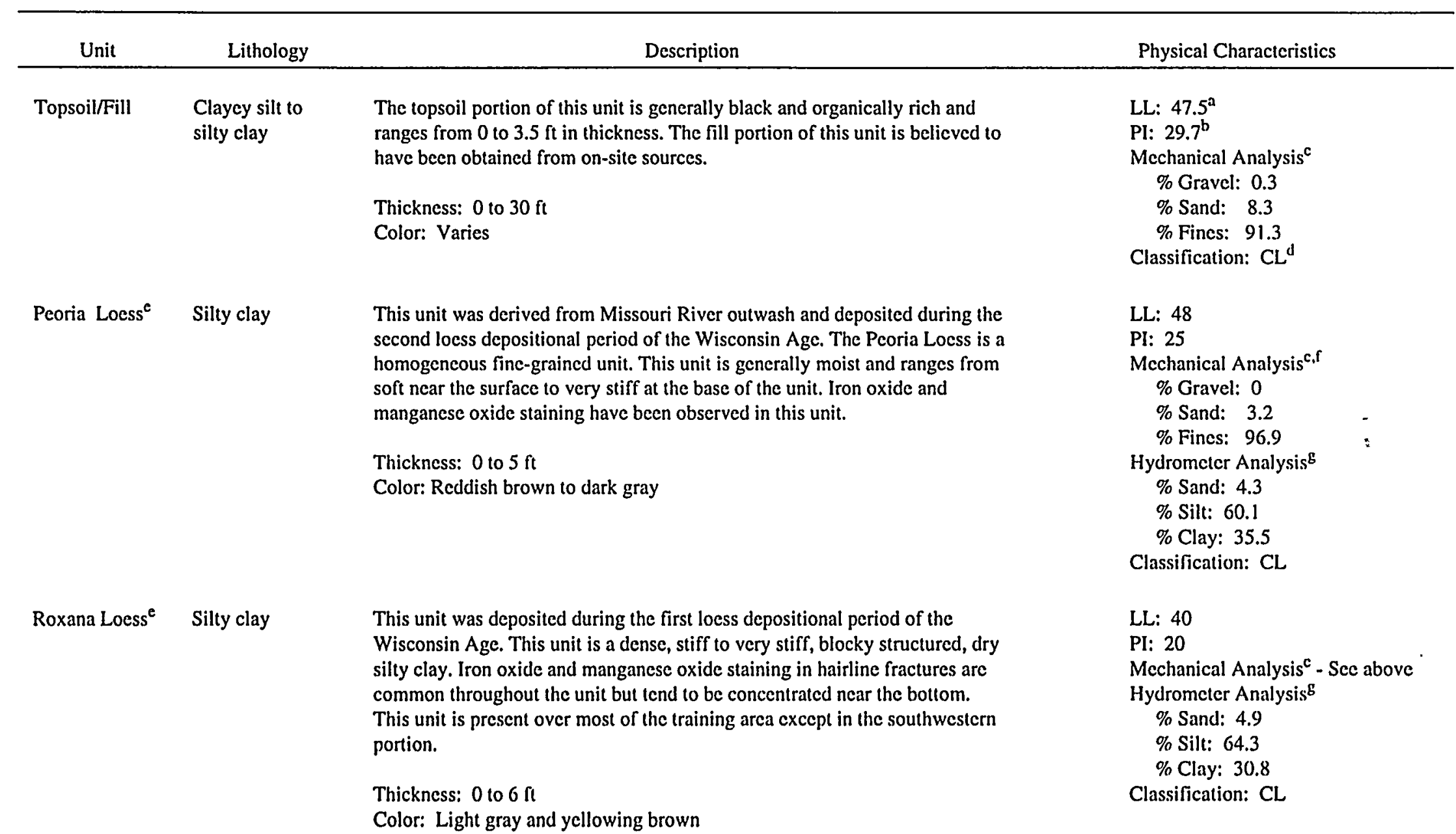


TABLE B.3 (Cont.)

\begin{tabular}{lll}
\hline Unit & Lithology & Description \\
\hline
\end{tabular}

$\begin{array}{ll}\text { Ferrelview } & \text { Clay and some } \\ \text { Formation } & \text { silty clay }\end{array}$

Sandy silty clay to clayey silt with minor gravel clay

Clay Tilli

Basal Till

Sandy, claycy, silty gravely, or gravelly silt
This unit is speculated to be a mid-Pleistocene glacial till plain sediment. The unit is very stiff and plastic. Iron oxide nodules and manganese oxide fracturc coatings are common. Fractures are frequently conchoidal and in many cases slickensided due to consolidation and compaction after deposition. This unit is present over most of the chemical plant area, the training area, and the northern portion of the ordnance works area.

Thickness: 0 to $22 \mathrm{ft}$

Color: gray and dark yellowish-orange (mottled)

This Pleistocene glacial till unit is the most areally extensive unit. This unit is massive, very stiff, and contains some sand and rounded pebbles, cobbles, and boulders of chert and igncous and metamorphic rock. Pyrolusite fracture coatings and iron oxide nodules are abundant.

\section{Outwash subunit}

Thickness: 0 to $30 \mathrm{ft}$

Color: yellowish-brown

This unit is the lower member of the Pleistocene glacial till sediments and underlies the clay till unit. At the chemical plant area, it has been found mainly on the western and north-central areas of the site. Deposition appears to be influenced by the bedrock topography since the unit is generally thin or absent in areas of higher bedrock clevations. This unit has been tentatively identified in several monitoring wells on the training area. This unit is a clayey, silty gravel or gravelly silt. The gravel fraction is usually angular chert, which is bound in the silty matrix.

Thickness: 0 to $11 \mathrm{ft}$

Color: yellowish-brown

\section{LL: 52.2 \\ Pl: 32.8}

Mechanical Analysis $\mathrm{c}$

$\%$ Gravel: 0.3

$\%$ Sand: 5.1

\% Fines: 94.6

Hydrometer Analysis ${ }^{g}$

\% Sand: 8.4

\% Silt: 44.0

\% Clay: 47.6

Classification: $\mathrm{CL}-\mathrm{CH}^{\mathrm{h}}$

LL: 48.8

PI: 32.9

Mechanical Analysis ${ }^{\mathrm{a}}$

\% Gravel: 0.9

\% Sand: 23.2

\% Fines: 75.9

Hydrometer Analysis ${ }^{\mathrm{e}, \mathrm{j}}$

\% Sand: 22.6

$\%$ Silt: 34.1

$\%$ Clay: 43.3

Classification: $\mathrm{CL}-\mathrm{CH}$

LL: 40.0

PI: 23.7

Mechanical Analysis ${ }^{c}$

\% Sand: 12.1

\% Silt: 21.8

$\%$ Clay: 66.1

Hydrometer Analysis $^{\text {d.f }}$ - See above

Classification: $\mathrm{CL}$ 
TABLE B.3 (Cont.)

\begin{tabular}{|c|c|c|c|}
\hline Unit & Lithology & Description & Physical Characteristics \\
\hline Residuum & $\begin{array}{l}\text { Gravelly clay and } \\
\text { clayey gravel }\end{array}$ & $\begin{array}{l}\text { This unit is the residual erosional material derived from the physical and } \\
\text { chemical weathering of the underlying and possibly overlying limestonc. } \\
\text { This unit is highly heterogeneous with a wide range of particle sizes (clay, } \\
\text { gravel, boulder, cobble). Relict chert beds were noted. } \\
\text { Thickness: } 0 \text { to } 34 \mathrm{ft} \\
\text { Color: reddish-brown }\end{array}$ & $\begin{array}{l}\text { LL: } 63.7 \\
\text { PI: } 44.3 \\
\text { Mechanical Analysis }{ }^{\mathfrak{a}} \\
\text { \% Sand: } 37.9 \\
\text { \% Silt: } 19.3 \\
\text { \% Clay: } 42.8 \\
\text { Hydromctcr Analysis } \\
\text { \% Sand: } 21.6 \\
\text { \% Silt: } 25.2 \\
\text { \% Clay: } 53.2 \\
\text { Classification: CL/GC }\end{array}$ \\
\hline
\end{tabular}

a $L L=$ liquid limit.

b PI = plasticity index.

c Source: MK-Environmental Services (1991).

d $\mathrm{CL}=$ low plastic clay.

e This unit is not differentiated in discussions regarding the chemical plant area.

$f$ Results of mechanical analysis for loess unit; the Roxana Silt and Peoria Loess are not differentiated.

g Source: Rueff (1992).

h $\mathrm{CH}=$ high plastic clay.

$i$ This unit is not differentiated in discussions regarding the ordnance works area.

j Results of hydrometer analysis for till unit; the Clay Till and Basal Till are not differentiated. 
TABLE B.4 Hydraulic Properties of the Overburden Units in the Vadose Zone as Determined from Laboratory Testing ${ }^{a}$

\begin{tabular}{lccc}
\hline & $\begin{array}{c}\text { In situ } \\
\text { Moisture } \\
\text { Content } \\
\text { Overburden Unit }\end{array}$ & $\begin{array}{c}\text { Porosity } \\
(\%)\end{array}$ & $\begin{array}{c}\text { Average Hydraulic } \\
\text { Conductivity } \\
(\mathrm{cm} / \mathrm{s})\end{array}$ \\
\hline Loess & $\mathrm{NA}^{\mathrm{b}}$ & $\mathrm{NA}$ & $6.2 \times 10^{-6}$ \\
Ferrelview Formation & 90 & 40.3 & $8.9 \times 10^{-8}$ \\
Clay Till & 93 & 37.8 & $2.6 \times 10^{-8}$ \\
Basal Till & 91 & 36.2 & $3.8 \times 10^{-8}$ \\
Residuum & 65 & 44.2 & $5.0 \times 10^{-8}$ \\
\hline
\end{tabular}

a Overburden samples were obtained from the chemical plant area.

b $\mathrm{NA}=$ data not available.

Sources: MK-Environmental Services (1991); MK-Ferguson Company and Jacobs Engineering Group, Inc. (1992); MK-Environmental Services (1993).

saturation because of the variability of composition (clay, gravel, and relict chert beds) of the residuum, which allows water to be released more readily. The moisture contents of the Ferrelview Formation and till units would suggest that the release of water is slow, which would result in steady recharge to the shallow aquifer.

Because of the fine textures of the materials in these units, the total porosity is relatively high, ranging from 36 to 44\% (MK-Environmental Services 1993). Effective porosity, or those void spaces in the soils that are interconnected, controls the hydraulic properties of each unit. On the basis of a bromide ion tracer test performed on six soils samples, the observed effective porosities ranged from 5 to $11.7 \%$. These values are consistent with soil moisture characteristic curve data from previous testing.

The soil moisture characteristic curves describe the relationship between the suction head and the moisture content for a soil and are used to develop a relationship between the unsaturated hydraulic conductivity and the moisture content as determined from the suction head. In general, the soil-water retention curves for the Ferrelview Formation and clay till units are very steep, which indicates a relatively minor moisture content decrease with increasing suction head. Also, the residual moisture content $\left(\Theta_{\mathrm{r}}\right)$ is not significantly different from the moisture content at saturation $\left(\Theta_{\mathrm{s}}\right)$, in most cases. The results of these tests indicated an effective porosity of $4.6 \%$ for the Ferrelview Formation and $5.3 \%$ for the clay till unit. These values agree with the lower range of effective porosity determined from previous tests. Table B.5 gives a statistical summary of soil- 
moisture curve fitting parameters. A narrow range between the saturated and residual moisture contents was determined for each unit and indicates the magnitude of the effective porosity. It can be assumed that the residual moisture content cannot be drained and, therefore, represents the dead pore space. The difference between the saturated and residual moisture contents is approximately the minimum value of the effective porosity.

Two-stage borehole tests (Boutwell tests) were conducted to determine saturated hydraulic conductivity of the overburden units (Ferrelview Formation and clay till) and to provide additional values for hydraulic properties of the soils underlying the disposal cell (MK-Environmental Services 1993). Hydraulic conductivity results of the in situ testing were $1.2 \times 10^{-9} \mathrm{~cm} / \mathrm{s}\left(3.9 \times 10^{-11} \mathrm{ft} /\right.$ day $)$ for the Ferrelview Formation and $3.25 \times 10^{-9} \mathrm{~cm} / \mathrm{s}\left(1.1 \times 10^{-10} \mathrm{ft} /\right.$ day $)$ for the clay till. Boutwell tests provide estimates of saturated hydraulic conductivity from the material in the immediate vicinity of the borehole. The saturated hydraulic conductivity values estimated from the tests appear to be representative of the matrix material.

For comparison, laboratory tests (flexible wall permeameter and submerged pressure outflow cell tests) were conducted on soil samples obtained from the same locations and depths tested in the field. The laboratory results were similar to those obtained from field testing. Average values obtained from triaxial permeability tests were $8.94 \times 10^{-9} \mathrm{~cm} / \mathrm{s}\left(2.9 \times 10^{-10} \mathrm{ft} / \mathrm{s}\right)$ for the Ferrelview Formation, $6.46 \times 10^{-8} \mathrm{~cm} / \mathrm{s}\left(2.1 \times 10^{-9} \mathrm{ft} / \mathrm{s}\right)$ for the clay till, $2.45 \times 10^{-7} \mathrm{~cm} / \mathrm{s}$ $\left(8.0 \times 10^{-9} \mathrm{ft} / \mathrm{s}\right)$ for the basal till, and $2.58 \times 10^{-7} \mathrm{~cm} / \mathrm{s}\left(8.5 \times 10^{-9} \mathrm{ft} / \mathrm{s}\right)$ for the residuum (MK-Environmental Services 1994). Because of the variable composition of the residuum, a range of values for this unit is possible and likely a function of secondary porosity (gravel, relic chert beds, etc.) within the unit as indicated from the slug tests results in Table B.6.

TABLE B.5 Soil-Moisture Characteristics of Overburden at the Chemical Plant Area ${ }^{a}$

\begin{tabular}{lccc}
\hline & \multicolumn{2}{c}{$\begin{array}{c}\text { Average Moisture } \\
\text { Content (\%) }\end{array}$} & \\
\cline { 2 - 3 } & & & $\begin{array}{c}\text { Average Effective } \\
\text { Porosity (\%) }\end{array}$ \\
\hline Overburden Unit & Residual & Saturated & Poros \\
Ferrelview Formation & 36.9 & 41.5 & 4.6 \\
Clay Till & 31.7 & 37.0 & 5.3 \\
\hline
\end{tabular}

a Samples were obtained from the chemical plant area.

Source: MK-Environmental Services (1993). 
TABLE B.6 Summary of Single Well Hydraulic Conductivity Testing Results in the Overburden Units

\begin{tabular}{|c|c|c|}
\hline Well ID & $\begin{array}{l}\text { Hydraulic } \\
\text { Conductivity } \\
(\mathrm{cm} / \mathrm{s})\end{array}$ & Unit \\
\hline
\end{tabular}

Chemical Plant Area

$\begin{array}{lll}\text { MW-3004 } & 1.4 \times 10^{-8} & \text { Clay Till } \\ \text { MW-3005 } & 9.4 \times 10^{-9} & \text { Ferrelview/Clay Till } \\ \text { MW-3011 } & 1.2 \times 10^{-8} & \text { Clay Till/Basal Till }\end{array}$

Ordnance Works Area

\begin{tabular}{lll} 
MWV-09 & $1.05 \times 10^{-7}$ & Till/Residuum \\
MWV-16 & $2.60 \times 10^{-7}$ & Residuum \\
MWV-22 & $\mathbf{2 . 3 7} \times \mathbf{1 0}^{-5}$ & Residuum \\
MWV-24R & $\mathbf{1 . 2 6 \times 1 0 ^ { - 5 }}$ & Residuum \\
\hline
\end{tabular}

a New data to support this RI are shown in bold.

Sources: IT Corporation (1992); Allan (1987).

\section{B.1.1.2 Saturated Overburden}

Saturated overburden materials occur in localized areas of the chemical plant area and the ordnance works area. In the northern and western parts of the chemical plant area, the residuum unit of the overburden is saturated in bedrock lows associated with paleochannels. In localized areas in the vicinity of Raffinate Pits 1,3 , and 4, the clay till unit is saturated where perched water occurs from seepage of the raffinate pits. In the northern portion of the ordnance works, the residuum and till units are likely saturated where the potentiometric surface extends into these units (Mugel 1997).

Eight monitoring wells were installed in the overburden adjacent to the raffinate pits (Figure B.1). A comparison between the water levels measured in each of these wells with the watertable surface and water levels measured in the weathered Burlington-Keokuk indicated that perched water exists. In the vicinity of the raffinate pits, the elevation of the water table ranges from about 181 to $187 \mathrm{~m}$ (594 to $614 \mathrm{ft}$ ) on the basis of wells open to the Burlington-Keokuk (see Section B.3.6). The static water levels in monitoring wells MW-3004, MW-3005, MW-3011, MW-3013, and MW-3015 have been consistently much higher than the elevation of the water-table surface (Table B.7). On the basis of the static water levels measured in MW-3016, MW-3017, and MW-3018 these wells monitor the shallow aquifer (Figure B.2, Table B.7). 


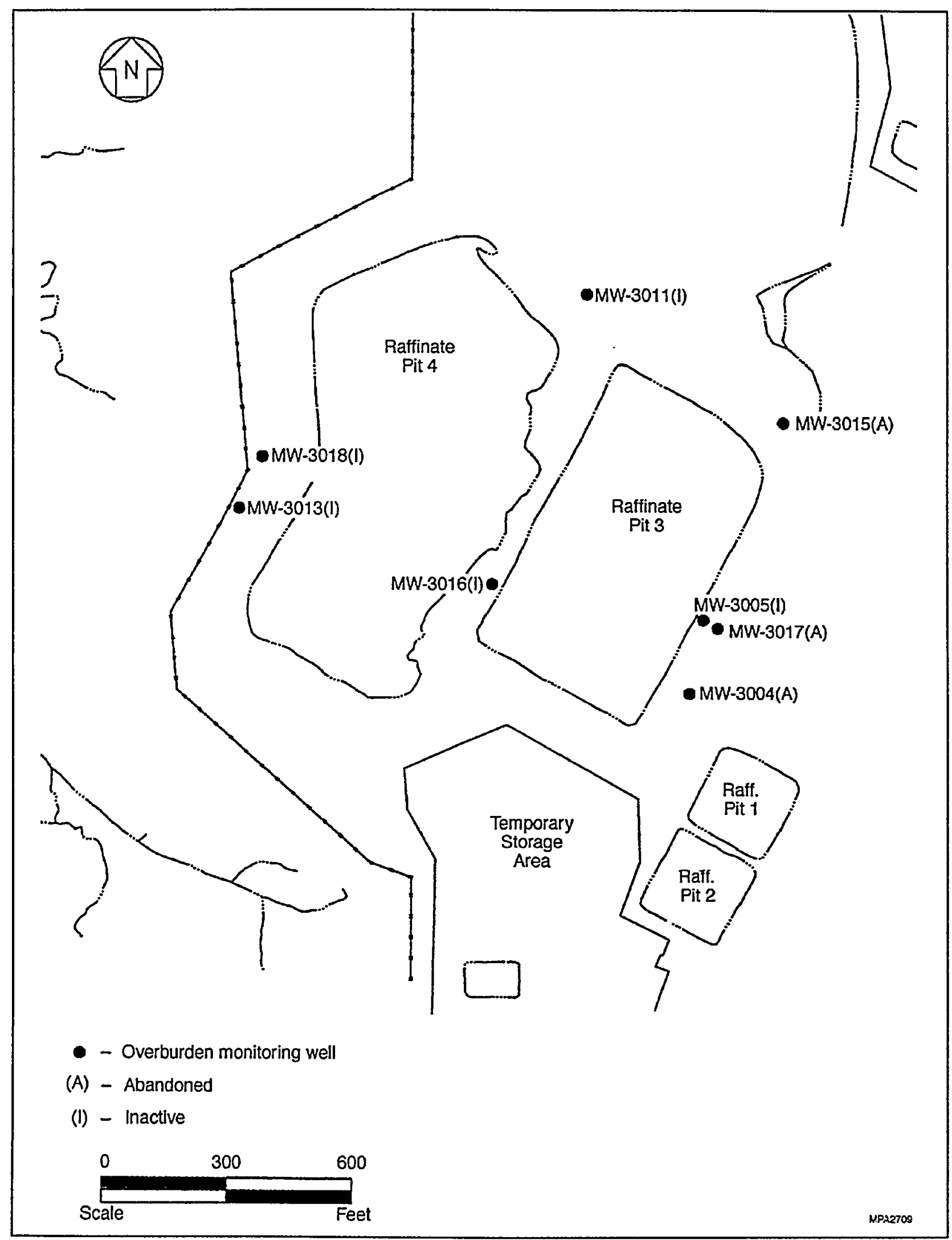

FIGURE B.1 Overburden Monitoring Locations - Chemical Plant Area 
TABLE B.7 Overburden Monitoring Well Construction and Water-Level Data at the Chemical Plant Area

\begin{tabular}{|c|c|c|c|c|c|c|c|}
\hline \multirow[b]{2}{*}{ Well ID } & \multirow[b]{2}{*}{$\begin{array}{l}\text { Ground } \\
\text { Elevation } \\
\text { (ft) }\end{array}$} & \multirow[b]{2}{*}{$\begin{array}{c}\text { Monitor } \\
\text { Interval } \\
\text { (ft) }\end{array}$} & \multirow[b]{2}{*}{$\begin{array}{l}\text { Total } \\
\text { Depth } \\
(\mathrm{ft})\end{array}$} & \multirow[b]{2}{*}{$\begin{array}{c}\text { Depth to } \\
\text { Bedrock } \\
\text { (ft) }\end{array}$} & \multicolumn{2}{|c|}{$\begin{array}{l}\text { Range Groundwater } \\
\text { Elevation ( } \mathrm{ft} \text { ) }\end{array}$} & \multirow[b]{2}{*}{$\begin{array}{l}\text { Monitor } \\
\text { Location }\end{array}$} \\
\hline & & & & & $\begin{array}{l}\text { Maximum } \\
(\mathrm{ft})\end{array}$ & $\begin{array}{l}\text { Minimum } \\
(\mathrm{ft})\end{array}$ & \\
\hline MW-3004 & 653.5 & $13.7-21.8$ & 21.8 & $\mathrm{ND}^{\mathrm{a}}$ & 641.08 & 633.86 & Perched \\
\hline MW-3005 & 663.4 & $24.3-37.0$ & 37.0 & ND & 651.14 & 634.03 & Perched \\
\hline $\mathrm{MW}-3011$ & 649.2 & $20.0-23.5$ & 23.5 & 23.5 & 630.41 & 626.68 & Perched \\
\hline$M W-3013$ & 641.5 & $N A^{b}-22.0$ & 22.0 & ND & 634.63 & 634.09 & Perched \\
\hline MW-3015 & 640.1 & NA-20.0 & 20.0 & ND & 627.36 & 627.28 & Perched \\
\hline MW-3016 & 664 & NA-51.0 & 51.0 & ND & 618.11 & 617.28 & Shallow aquifer \\
\hline MW-3017 & 649.8 & NA-35.0 & 35.0 & ND & 618.58 & 618.31 & Shallow aquifer \\
\hline MW-3018 & 631 & $18.8-29.6$ & 29.6 & 29.6 & 611.1 & 609.15 & Shallow aquifer \\
\hline
\end{tabular}

At the ordnance works area, 10 monitoring wells open to the overburden (vadose) unit. A comparison between the water levels measured in each of these wells with the water-table surface and water levels measured in the nearby wells open to the shallow aquifer indicate that perched water exists. The static water levels in MWV-08, MWV-17, and MWV-18 are either dry or are consistently higher than the water-table elevation or, in many cases, these wells are dry (Table B.8). It appears that these three wells monitor perched water, and the other overburden wells monitor the shallow aquifer.

A geophysical survey was performed (Bechtel National, Inc. 1984) in the raffinate pit area in an effort to delineate the saturated overburden area. The results were inconclusive but have provided information on possible areas of saturation that are generally supported by static waterlevel data from overburden monitoring wells. On the basis of the results of geophysical surveys, it was inferred that unsaturated overburden occurs beneath Raffinate Pit 4 and portions of Raffinate Pit 3 and generally outside these pits, especially along the western half of Raffinate Pit 4. Possible areas of saturation were outlined by seismic methods beneath the center of Raffinate Pit 3 . Thin, shallow layers were also outlined on the east side of Raffinate Pit 3 (between Raffinate Pit 3 and Raffinate Pits 1 and 2), on the south side of Raffinate Pit 3, and on the northern side of Raffinate Pit 1. Additional areas of possible saturation were identified at the northeastern corner of Raffinate Pit 3 and in the area south of Raffinate Pit 3, which is now the Temporary Storage Area, although the results were inconclusive. Table B.6 summarizes the results of the single well hydraulic conductivity testing in the overburden units. 


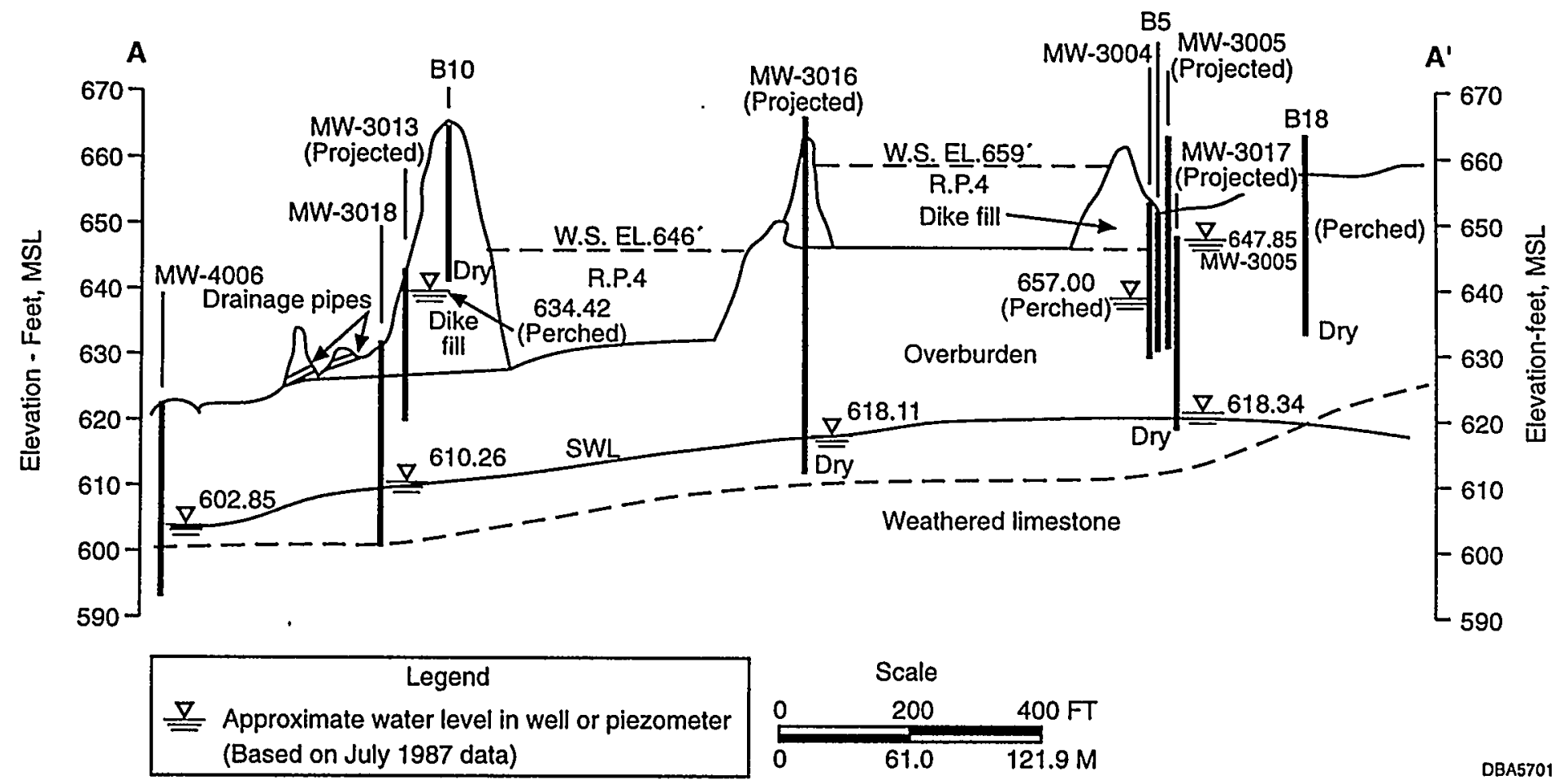

FIGURE B.2 Cross Section through Raffinate Pits 3 and 4 
TABLE B.8 Overburden Monitoring Well Construction and Water-Level Data at the Ordnance Works Area

\begin{tabular}{|c|c|c|c|c|c|c|c|}
\hline \multirow[b]{2}{*}{ Well ID } & \multirow[b]{2}{*}{$\begin{array}{l}\text { Ground } \\
\text { Elevation } \\
\text { (fi) }\end{array}$} & \multirow[b]{2}{*}{$\begin{array}{l}\text { Monitor } \\
\text { Interval } \\
\text { (ft) }\end{array}$} & \multirow[b]{2}{*}{$\begin{array}{l}\text { Total } \\
\text { Depth } \\
\text { (ft) }\end{array}$} & \multirow[b]{2}{*}{$\begin{array}{l}\text { Depth to } \\
\text { Bedrock } \\
\text { (ft) }\end{array}$} & \multicolumn{2}{|c|}{$\begin{array}{l}\text { Range Groundwater } \\
\text { Elevation (ft) }\end{array}$} & \multirow[b]{2}{*}{$\begin{array}{l}\text { Monitor } \\
\text { Location }\end{array}$} \\
\hline & & & & & $\begin{array}{l}\text { Maximum } \\
(\mathrm{ft})\end{array}$ & $\underset{(\mathrm{ft})}{\operatorname{Minimum}}$ & \\
\hline MWV-01 & 595.84 & $7.3-15.0$ & 15.0 & 15.0 & 586.94 & Dry & Shallow aquifer \\
\hline MWV-02 & 603.07 & $8.8-16.8$ & 17.0 & 17.0 & 589.41 & Dry & Shallow aquifer \\
\hline MWV-08 & 688.80 & $9.8-23.8$ & 23.8 & 23.8 & 666.25 & Dry & Perched \\
\hline MWV-09 & 634.49 & $10.4-25.4$ & 25.4 & 25.4 & 619.94 & 616.75 & Shallow aquifer \\
\hline MWV-13 & 690.18 & $27.0-41.5$ & 41.5 & 41.5 & 655.42 & 648.94 & Shallow aquifer \\
\hline MWV-16 & 649.48 & $25.0-39.0$ & 39.7 & 39.7 & 639.84 & 625.46 & Shallow aquifer \\
\hline MWV-17 & 658.53 & $4.0-17.0$ & 17.0 & 17.0 & 645.83 & Dry & Perched \\
\hline MWV-18 & 599.61 & $6.0-19.0$ & 19.6 & 19.6 & 581.21 & Dry & Perched \\
\hline MWV-22 & 661.9 & $25.0-37.6$ & 37.6 & 37.6 & 649.25 & 645.38 & Shallow aquifer \\
\hline MWV-24R & 640 & $26.7-41.0$ & 41.0 & 41.0 & 623.06 & 621.04 & Shallow aquifer \\
\hline
\end{tabular}

\section{B.1.2 Bedrock}

The following sections discuss the properties and flow dynamics of the shallow bedrock aquifer on the basis of data obtained from previous investigations and the remedial investigations for these GWOUs. The bedrock geology of the shallow aquifer system consists of BurlingtonKeokuk Limestone and the Fern Glen Formation. These units are composed of Osagean Mississippian limestones and dolomites. Emphasis has been placed on the Burlington- Keokuk Limestone, the uppermost rock unit over the majority of the chemical plant area and the ordnance works area. The underlying Fern Glen Formation is discussed, where necessary, to elaborate on the interaction of this formation with the Burlington-Keokuk Limestone.

Subsurface investigations have defined two units, weathered and unweathered, within the Burlington-Keokuk Limestone on the basis of lithology and the degree of weathering and fracturing. A third subunit that is strongly weathered has been identified in some borings and is not continuous across the chemical plant area and the ordnance works area. The contact between the weathered and unweathered units is not distinct, but rather gradual, since the degree of weathering gradually decreases with depth.

The weathered unit is an argillaceous, silty limestone that contains up to $60 \%$ chert. The unit is micritic to finely crystalline, thinly bedded, fossiliferous, closely fractured, and slightly to severely weathered with abundant iron and manganese oxide staining in the rock matrix and along fractures. Fracture spacing ranges from 3 to $30 \mathrm{~cm}(0.1$ to $1 \mathrm{ft})$. Angled borings indicate that 
horizontal bedding plane fractures occur more frequently than vertical fractures by approximately 20 to 1 . Horizontal fractures typically occur along shaley interbeds, bedding planes, and chert interbeds (DOE 1995b). The weathered unit is moderately to highly fractured with $73 \%$ of the rock quality designation (RQD) values in the poor to very poor category (MK-Ferguson Company and Jacobs Engineering Group, Inc. 1992).

On the basis of data gathered during geologic investigations at both sites, the weathered Burlington-Keokuk Limestone at the chemical plant area ranges in thickness from 3 to $17 \mathrm{~m}$ (10 to $55 \mathrm{ft}$ ) (MK-Ferguson Company and Jacobs Engineering Group, Inc. 1992) and ranges from 0 to $19.5 \mathrm{~m}(0$ to $64 \mathrm{ft}$ ) at the ordnance works area; however, at one well location (MWS-111), this unit is 34-m (113-ft) thick (Mugel 1997). Solution features are quite common in this unit and range from

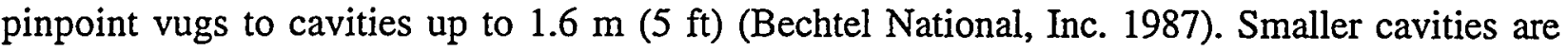
commonly lined with calcite and drusy to euhedral quartz. The larger cavities appear to be filled with clay or mixtures of silty clay and chert gravel. Solution features in this unit are typically oriented parallel to bedding planes (MK-Ferguson Company and Jacobs Engineering Group, Inc. 1992).

The strongly weathered subunit has been identified where weathering features are particularly abundant or intense (Mugel 1997). Poor RQDs and core recovery, which may be indicative of clay-filled voids, are typical of this subunit. A distinguishing characteristic of the strongly weathered unit is a vuggy, weakly cemented chert breccia that sometimes contains limestone. Core recovery from this breccia is typically poor. This unit usually occurs in the upper portions of the weathered unit but has been observed within lower sections of weathered BurlingtonKeokuk Limestone at the chemical plant.

Beneath the weathered unit is the unweathered unit of the Burlington-Keokuk Limestone. The unit is finely to coarsely crystalline, thin to massively bedded, locally argillaceous, fossiliferous, and slightly weathered to fresh with 20 to $40 \%$ chert, although zones or more intense weathering may occur (MK-Ferguson Company and Jacobs Engineering Group, Inc. 1992). Fresh pyrite is present on some of the fracture surfaces, although this portion of the unit lacks significant fracturing and iron staining. An estimated 79\% of the RQD values for this unit are in the fair to excellent category (MK-Ferguson Company and Jacobs Engineering Group, Inc. 1992). Large solution features are uncommon in this unit on the basis of logging of rock core obtained from the chemical plant area and the ordnance works area.

The unweathered unit makes up the remaining thickness of the Burlington-Keokuk Limestone, which overlies the Fern Glen Formation. On the basis of coring activities at both the chemical plant area and the ordnance works area, the unweathered portion of this formation ranges from 0 to greater than $34 \mathrm{~m}$ ( 0 to greater than $113 \mathrm{ft}$ ) (Mugel 1997).

The Fern Glen Formation is generally a finely crystalline dolomite and less commonly limestone with nodular and interbedded chert. Parts of the Fern Glen Formation are characterized 
by pinpoint porosity, some quartz- or calcite-lined or filled vugs (geodes) (Whitfield et al. 1989). The base of this unit typically becomes coarser and exhibits a lesser chert content. This unit ranges in thickness from 8.8 to $20.3 \mathrm{~m}$ ( 28.7 to $66.6 \mathrm{ft}$ ) on the basis of geologic information from the training area (Mugel 1997).

\section{B.2 SUMMARY OF FIELD INVESTIGATIONS}

Field investigations performed in support of this remedial investigation consisted of soil and rock core logging, monitoring well installation, packer testing, slug testing, and subsurface dye tracer testing. A summary of each of these activities and the methodology used is provided in the following sections.

\section{B.2.1 Soil and Rock Core Logging}

The soil and rock portions of the six new monitoring wells and three angled borings were logged to provide additional information on the overburden and bedrock units encountered at the chemical plant area and the ordnance works area. These materials were logged in accordance with the Sampling Plan (DOE 1995a), and emphasis during logging was placed on identification of fractures, solution features, and other discontinuities that could affect groundwater movement. These logs are provided in Hydrogeologic Field Characterization Data for the Chemical Plant Area and Ordnance Works Area Collected in the 1995 Joint Sampling Activities (MK-Ferguson Company and Jacobs Engineering Group, Inc. 1996).

\section{B.2.2 Monitoring Well Installation}

Six new groundwater monitoring wells were installed in support of this remedial investigation, and one existing open hole well was retrofitted to monitor a discrete bedrock interval. These wells were installed or retrofitted in accordance with state regulations 10 CSR 23-4 - Missouri Monitoring Well Construction Code. Variances for the construction or development were requested and approved by the state. The monitoring well details are provided in MK-Ferguson Company and Jacobs Engineering Group, Inc. (1996).

\section{B.2.3 In Situ Pressure (Packer) Test Methodology .}

The bedrock portion of the angled borings and the groundwater monitoring wells installed in support of this remedial investigation were pressure tested to determine the hydraulic conductivity of the bedrock. Intervals typically ranging from 3 to $6 \mathrm{~m}$ (10 to $20 \mathrm{ft}$ ) were tested to determine the 
variation of hydraulic conductivity within the bedrock units and to better determine the factors influencing groundwater movement in each unit. The results of these tests and of all the other in situ pressure packer tests are presented in Tables B.9, B.10, and B.11.

The data were analyzed by using a procedure outlined by the U.S. Department of Interior (U.S. Department of the Interior 1977) in the Sampling Plan (MK-Ferguson Company and Jacobs Engineering Group 1995). This method is consistent with previous hydraulic conductivity determinations from packer tests. An explanation of the calculations, parameters, and assumptions is provided in Figure B.3. Data sheets are provided in Hydrogeologic Field Characterization Data for the Chemical Plant Area and Ordnance Works Area Collected in the 1995 Joint Sampling Activities (MK-Ferguson Company and Jacobs Engineering Group, Inc. 1996).

\section{B.2.4 Single Well Hydraulic Conductivity (Slug) Test Methodology}

Existing monitoring wells were tested to determine the variation in hydraulic conductivity within the Burlington-Keokuk across the chemical plant area and the ordnance works area. These data were obtained to determine the heterogeneity and anisotropy of this limestone unit and to identify possible preferential flow zones.

Slug testing was performed in accordance with Environmental Safety and Health Procedure 4.3.2s., Single Well Hydraulic Conductivity Testing, or ASTM D-4044, Test Method for Instantaneous Change in Head for Determining Hydraulic Head Properties of Aquifers, as outlined in the Sampling Plan (MK-Ferguson Company and Jacobs Engineering Group 1995). Both rising and falling head tests were performed on each well. Standard pressure transducers and data loggers were used to obtain water-level measurements as recommended in ASTM D-4050, Test Method for Withdrawal and Injection Well Tests for Determining Hydraulic Properties of Aquifer Systems.

TABLE B.9 Summary of Packer Test Results from the Overburden/Bedrock Interface

\begin{tabular}{cccccc}
\hline $\begin{array}{c}\text { Well } \\
\text { ID }\end{array}$ & Location & $\begin{array}{c}\text { Hydraulic } \\
\text { Conductivity } \\
(\mathrm{cm} / \mathrm{s})\end{array}$ & $\begin{array}{c}\text { Well } \\
\text { ID }\end{array}$ & Location & $\begin{array}{c}\text { Hydraulic } \\
\text { Conductivity } \\
(\mathrm{cm} / \mathrm{s})\end{array}$ \\
\hline G8 & $\begin{array}{l}\text { East-central portion of } \\
\text { the chemical plant area }\end{array}$ & $4.7 \times 10^{-3}$ & $\mathrm{G} 16$ & $\begin{array}{l}\text { Southwest portion of } \\
\text { the chemical plant area }\end{array}$ & $1.5 \times 10^{-4}$ \\
G9 & $\begin{array}{l}\text { East-central portion of } \\
\text { the chemical plant area }\end{array}$ & $9.2 \times 10^{-2}$ & G19 & $\begin{array}{l}\text { Northwest portion of } \\
\text { the chemical plant area }\end{array}$ & $6.3 \times 10^{-2}$ \\
\hline
\end{tabular}

Source: MK-Ferguson Company and Jacobs Engineering Group, Inc. (1992). 
TABLE B.10 Summary of Packer Test Results at the Chemical Plant Area

\begin{tabular}{|c|c|c|c|c|}
\hline Location & $\begin{array}{c}\text { Interval }^{\mathrm{a}} \\
(\mathrm{ft})\end{array}$ & Unit & $\begin{array}{c}\text { Depth } \\
\text { to Rock } \\
\text { (ft) }\end{array}$ & $\mathrm{K}(\mathrm{cm} / \mathrm{s})^{\mathrm{b}}$ \\
\hline MW-2001 & $29.0-35.0$ & Weathered & 26.5 & $<9.5 \times 10^{-7}$ \\
\hline MW-2002 & $39.2-45.2$ & Weathered & 28.5 & $2.1 \times 10^{-4}$ \\
\hline MW-2002 & $53.8-59.8$ & Weathered & & $<6.8 \times 10^{-7}$ \\
\hline MW-2003 & $30.0-36.0$ & Weathered & 38.8 & $3.4 \times 10^{-4}$ \\
\hline MW-2003 & $44.0-50.0$ & Weathered & & $<8.0 \times 10^{-7}$ \\
\hline MW-2004 & $38.0-44.0$ & Weathered & 37 & $<9.3 \times 10^{-7}$ \\
\hline MW-2004 & $52.0-58.0$ & Weathered & & $<9.3 \times 10^{-7}$ \\
\hline MW-2004 & $53.6-72.0$ & Weathered & & $<3.9 \times 10^{-7}$ \\
\hline MW-2006 & $32.8-38.7$ & Weathered & 22.6 & $2.6 \times 10^{-6}$ \\
\hline MW-2006 & $41.8-47.7$ & Weathered & & $8.9 \times 10^{-5}$ \\
\hline MW-2007 & $62.0-68.0$ & Weathered & 59 & $8.2 \times 10^{-7}$ \\
\hline MW-2008 & $35.0-41.0$ & Weathered & 31.5 & $3.7 \times 10^{-5}$ \\
\hline MW-2008 & $47.9-53.9$ & $\begin{array}{l}\text { Weathered/ } \\
\text { unweathered }\end{array}$ & & $3.9 \times 10^{-5}$ \\
\hline MW-2009 & $22.0-28.0$ & Weathered & 20.5 & $3.6 \times 10^{-3}$ \\
\hline MW-2010 & $43.3-49.3$ & Weathered & 32.8 & $2.1 \times 10^{-3}$ \\
\hline MW-2012 & $52.0-58.0$ & Unweathered & 25 & $1.7 \times 10^{-5}$ \\
\hline MW-2013 & $40.0-46.0$ & Weathered & 27.5 & $5.9 \times 10^{-6}$ \\
\hline MW-2013 & $62.0-68.0$ & Unweathered & & $5.2 \times 10^{-6}$ \\
\hline MW-2014 & $43.0-49.0$ & Weathered & 33 & $2.8 \times 10^{-4}$ \\
\hline MW-2015 & $50.3-56.2$ & Weathered & 45.5 & $9.1 \times 10^{-3}$ \\
\hline MW-2015 & $62.3-68.7$ & Weathered & & $5.2 \times 10^{-5}$ \\
\hline MW-2017 & $25.7-31.7$ & Weathered & 23.6 & $4.7 \times 10^{-3}$ \\
\hline$M W-2018$ & $30.0-36.0$ & $\begin{array}{l}\text { Residuum/ } \\
\text { Weathered }\end{array}$ & 32.5 & $6.8 \times 10^{-6}$ \\
\hline MW-2018 & $42.0-48.0$ & Weathered & & $8.9 \times 10^{-5}$ \\
\hline MW-4024 & $27.0-37.6$ & Weathered $^{e}$ & 24.3 & $2.61 \times 10^{-3}$ \\
\hline MW-4024 & $37.0-49.0$ & Weathered & & $1.25 \times 10^{-3}$ \\
\hline MW-4024 & $48.5-59.0$ & Weathered & & $5.73 \times 10^{-5}$ \\
\hline MW-4025 & $32.0-43.7$ & Weathered & 27.5 & $4.17 \times 10^{-4}$ \\
\hline MW-4025 & $43.0-53.7$ & Weathered & & $6.88 \times 10^{-5}$ \\
\hline G1 & $54.0-64.7$ & Weathered & 39.7 & $1.0 \times 10^{-3}$ \\
\hline G1 & $69.6-90.6$ & $\begin{array}{l}\text { Weathered/ } \\
\text { unweathered }\end{array}$ & & $2.8 \times 10^{-4}$ \\
\hline
\end{tabular}


TABLE B.10 (Cont.)

\begin{tabular}{|c|c|c|c|c|}
\hline Location & $\begin{array}{c}\text { Interval }^{a} \\
(\mathrm{ft})\end{array}$ & Unit & $\begin{array}{c}\text { Depth } \\
\text { to Rock } \\
\text { (ft) }\end{array}$ & $\mathrm{K}(\mathrm{cm} / \mathrm{s})^{\mathrm{b}}$ \\
\hline G2A & $64.7-75.4$ & $\begin{array}{l}\text { Weathered/ } \\
\text { unweathered }\end{array}$ & & $3.5 \times 10^{-4}$ \\
\hline G2A & $75.2-85.9$ & Unweathered & 44.8 & $1.2 \times 10^{-4}$ \\
\hline G3 & $56.0-66.7$ & Weathered & 54.6 & $1.4 \times 10^{-3}$ \\
\hline G4 & $58.8-69.5$ & Weathered & 53 & $1.1 \times 10^{-3}$ \\
\hline G5 & $45.3-51.3$ & Weathered & 40 & $<6.4 \times 10^{-7}$ \\
\hline G5 & $50.0-56.0$ & Weathered & & $1.3 \times 10^{-6}$ \\
\hline G7 & $0-5.9$ & Weathered & 26.0 & $2.2 \times 10^{-3}$ \\
\hline G9 & $66.0-76.0$ & Unweathered & 37.5 & $3.6 \times 10^{-6}$ \\
\hline G13 & $30.1-36.0$ & Weathered & 28.5 & $5.0 \times 10^{-3}$ \\
\hline G14 & $64.0-76.4$ & Unweathered & 37.5 & $<3.5 \times 10^{-7}$ \\
\hline G15 & $53.0-59.3$ & Weathered & 41.0 & $2.4 \times 10^{-4}$ \\
\hline G16 & $45.5-50.8$ & Weathered & 34.0 & $6.1 \times 10^{-3}$ \\
\hline G18 & $41.6-47.6$ & Weathered & 30.0 & $8.5 \times 10^{-3}$ \\
\hline G19 & $41.5-49.5$ & Weathered & 41.5 & $8.0 \times 10^{-3}$ \\
\hline G19 & $51.0-570$ & $\begin{array}{l}\text { Weathered/ } \\
\text { unweathered }\end{array}$ & 41.5 & $<7.8 \times 10^{-7}$ \\
\hline G20 & $40.0-46.0$ & Weathered & 32.5 & $1.9 \times 10^{-3}$ \\
\hline $\mathrm{G} 20$ & $43.0-49.0$ & Weathered & $\mathrm{NA}$ & $6.9 \times 10^{-4}$ \\
\hline G21 & $38.7-54.7$ & Weathered & 34.2 & $2.1 \times 10^{-6}$ \\
\hline AH-2001 & $34.5-43.3$ & Weathered & 30.7 & $9.3 \times 10^{-4}$ \\
\hline AH-2001 & $43.1-52.0$ & Weathered & $\mathrm{NA}$ & $6.1 \times 10^{-4}$ \\
\hline AH-2001 & $51.3-60.2$ & Weathered & $\mathrm{NA}$ & Not determined \\
\hline AH-2001 & $59.9-77.5$ & $\begin{array}{l}\text { Weathered/ } \\
\text { unweathered }\end{array}$ & $\mathrm{NA}$ & $<1.16 \times 10^{-5}$ \\
\hline $\mathrm{AH}-2001$ & $77.4-94.8$ & Unweathered & $\mathrm{NA}$ & $<3.6 \times 10^{-7}$ \\
\hline AH-2001 & $94.7-112.1$ & Unweathered & NA & $8.4 \times 10^{-6}$ \\
\hline AH-2001 & $110.4-131.3$ & Unweathered & NA & $<6.60 \times 10^{-8}$ \\
\hline AH-2002 & $46.4-54.9$ & Weathered & 42.2 & $8.7 \times 10^{-4}$ \\
\hline AH-2002 & $53.7-63.6$ & Weathered & $\mathrm{NA}$ & $1.7 \times 10^{-4}$ \\
\hline AH-2002 & $63.2-72.2$ & Weathered & $\mathrm{NA}$ & $4.0 \times 10^{-7}$ \\
\hline $\mathrm{AH}-2002$ & $72.0-89.5$ & $\begin{array}{l}\text { Weathered/ } \\
\text { unweathered }\end{array}$ & $\mathrm{NA}$ & $<8.4 \times 10^{-6}$ \\
\hline AH-2002 & $89.4-106.9$ & Unweathered & $\mathrm{NA}$ & $<1.9 \times 10^{-6}$ \\
\hline AH-2002 & $106.7-124.2$ & Unweathered & NA & $1.0 \times 10^{-6}$ \\
\hline AH-2002 & $124.0-142.9$ & Unweathered & NA & $2.1 \times 10^{-5}$ \\
\hline
\end{tabular}


TABLE B.10 (Cont.)

\begin{tabular}{|c|c|c|c|c|}
\hline Location & $\begin{array}{c}\text { Interval }^{\mathrm{a}} \\
(\mathrm{ft})\end{array}$ & Unit & $\begin{array}{l}\text { Depth } \\
\text { to Rock } \\
\text { (ft) }\end{array}$ & $\mathrm{K}(\mathrm{cm} / \mathrm{s})^{\mathrm{b}}$ \\
\hline $\mathrm{AH}-2003$ & 40.9-50.0 & $\begin{array}{l}\text { Residuum/ } \\
\text { Weathered }\end{array}$ & 46.5 & $6.74 \times 10^{-4}$ \\
\hline AH-2003 & $50.1-58.6$ & Weathered & NA & $7.67 \times 10^{-6}$ \\
\hline AH-2003 & $58.0-67.3$ & Weathered & NA & $1.43 \times 10^{-5}$ \\
\hline AH-2003 & $66.7-75.9$ & $\begin{array}{l}\text { Weathered/ } \\
\text { unweathered }\end{array}$ & NA & $3.8 \times 10^{-4}$ \\
\hline AH-2004 & 29.9-38.1 & Weathered & 26.8 & $5.69 \times 10^{-4}$ \\
\hline AH-2004 & 46.7-53.7 & Weathered & NA & Not determined \\
\hline AH-2005 & $37.2-46.7$ & Weathered & 24.7 & Not determined \\
\hline AH-2005 & 45.9-55.0 & Weathered & NA & Not determined \\
\hline AH-2005 & $54.5-62.6$ & Weathered & NA & $8.61 \times 10^{-6}$ \\
\hline \multicolumn{5}{|c|}{ a Interval measured as depth below ground surface. } \\
\hline \multicolumn{5}{|c|}{$\mathrm{b}$ Convert $\mathrm{cm} / \mathrm{s}$ to $\mathrm{ft} / \mathrm{s}$ by dividing by 30.48} \\
\hline \multicolumn{5}{|c|}{ NA = data not available. } \\
\hline \multicolumn{5}{|c|}{$\begin{array}{l}\text { The formation did not take measurable quantities of water during the test } \\
\text { period. Hydraulic conductivity cannot be estimated for this interval; it is, } \\
\text { however, expected to be lower than the lowest estimate given in this table. }\end{array}$} \\
\hline \multicolumn{5}{|c|}{ e New data to support this RI are shown in bold. } \\
\hline \multicolumn{5}{|c|}{$\begin{array}{l}\text { Sources: Bechtel National, Inc. (1987); MK-Ferguson Company and Jacobs } \\
\text { Engineering Group, Inc. (1992). }\end{array}$} \\
\hline
\end{tabular}

Hydraulic conductivity values obtained from these tests were determined by the Bouwer and Rice (1976) method. Data sheets are provided in MK-Ferguson Company and Jacobs Engineering Group (1996). Tables B.12 and B.13 give the single well hydraulic conductivity (slug) test results for all the wells tested.

\section{B.2.5 Dye Tracer Tests}

Dye tracer tests were performed in conjunction with the angled boring drilling at the chemical plant area to obtain information on conduit flow connecting the chemical plant with Burgermeister Spring. These tests were performed with the assistance of the Missouri Department of Natural Resources - Division of Geology and Land Survey. All testing was performed in accordance with state regulations in Section 256.621 of the Water Well Drillers Act and as outlined in the Sampling Plan (MK-Ferguson Company and Jacobs Engineering Group 1995). Copies of the 
TABLE B.11 Summary of Packer Test Results at the Ordnance Works Area ${ }^{\mathrm{a}}$

\begin{tabular}{|c|c|c|c|c|}
\hline Location & $\begin{array}{c}\text { Interval } \\
(\mathrm{ft})^{\mathrm{b}}\end{array}$ & Unit & $\begin{array}{c}\text { Depth to } \\
\text { Rock } \\
\text { (ft) }\end{array}$ & $\mathrm{K}(\mathrm{cm} / \mathrm{s})^{\mathrm{c}}$ \\
\hline MWD-23 & $38.3-52.9$ & Weathered & 38.3 & $1.65 \times 10^{-6}$ \\
\hline MWD-23 & $60-70$ & Weathered & & $1.10 \times 10^{-4}$ \\
\hline MWD-23 & $70-85$ & Weathered & & $3.27 \times 10^{-4}$ \\
\hline MWD-23 & $85-125$ & $\begin{array}{l}\text { Weathered/ } \\
\text { unweathered }\end{array}$ & & $8.52 \times 10^{-6}$ \\
\hline MWD-23 & $105-125$ & Unweathered & & $6.92 \times 10^{-6}$ \\
\hline MWD-25 & $18-28$ & Residuum & 36.5 & $4.11 \times 10^{-5}$ \\
\hline MWD-25 & $44.5-54.5$ & Weathered & & $6.75 \times 10^{-4}$ \\
\hline MWD-25 & $54.5-64.5$ & Weathered & & $1.12 \times 10^{-6}$ \\
\hline MWD-25 & $64.5-74.5$ & Weathered & & $9.87 \times 10^{-6}$ \\
\hline MWD-25 & $74.5-84.5$ & Weathered & & $3.12 \times 10^{-6}$ \\
\hline MWD-25 & $84.5-94.5$ & Weathered & & $1.77 \times 10^{-6}$ \\
\hline MWD-25 & $94.5-114.5$ & $\begin{array}{l}\text { Weathered/ } \\
\text { unweathered }\end{array}$ & & $1.11 \times 10^{-5}$ \\
\hline MWS-26 & $39.0-44.5$ & $\begin{array}{l}\text { Residuum/ } \\
\text { weathered }\end{array}$ & 40.6 & $6.20 \times 10^{-4}$ \\
\hline MWS-26 & $44.5-55$ & Weathered & & $<1 \times 10^{-7}$ \\
\hline MWS-26 & $55-65$ & Weathered & & $<1.46 \times 10^{-6}$ \\
\hline MWD-107 & $44-54$ & $\begin{array}{l}\text { Residuum/ } \\
\text { weathered }\end{array}$ & 46.0 & $7.28 \times 10^{-4}$ \\
\hline MWD-107 & $54-64$ & Weathered & & $<1 \times 10^{-7}$ \\
\hline MWD-107 & $64-74$ & Weathered & & $<1 \times 10^{-7}$ \\
\hline MWD-107 & $74-84$ & $\begin{array}{l}\text { Weathered/ } \\
\text { unweathered }\end{array}$ & & $<3.32 \times 10^{-6}$ \\
\hline MWD-107 & $84-94$ & Unweathered & & $1.65 \times 10^{-6}$ \\
\hline MWD-107 & $94-114$ & Unweathered & & $3.77 \times 10^{-6}$ \\
\hline MWD-107 & $114-134$ & Unweathered & & $7.95 \times 10^{-6}$ \\
\hline MWS-112 & $28.5-38.5$ & Unweathered & 18.0 & $2.99 \times 10^{-6}$ \\
\hline MWS-112 & $38.5-48.5$ & Unweathered & & $5.77 \times 10^{-6}$ \\
\hline MWS-112 & $48.5-58.5$ & Unweathered & & $2.19 \times 10^{-6}$ \\
\hline
\end{tabular}

a All new data were obtained to support this RI.

b The test interval was measured as the depth below the ground surface.

c Convert $\mathrm{cm} / \mathrm{s}$ to $\mathrm{ft} / \mathrm{s}$ by dividing by 30.48 . 


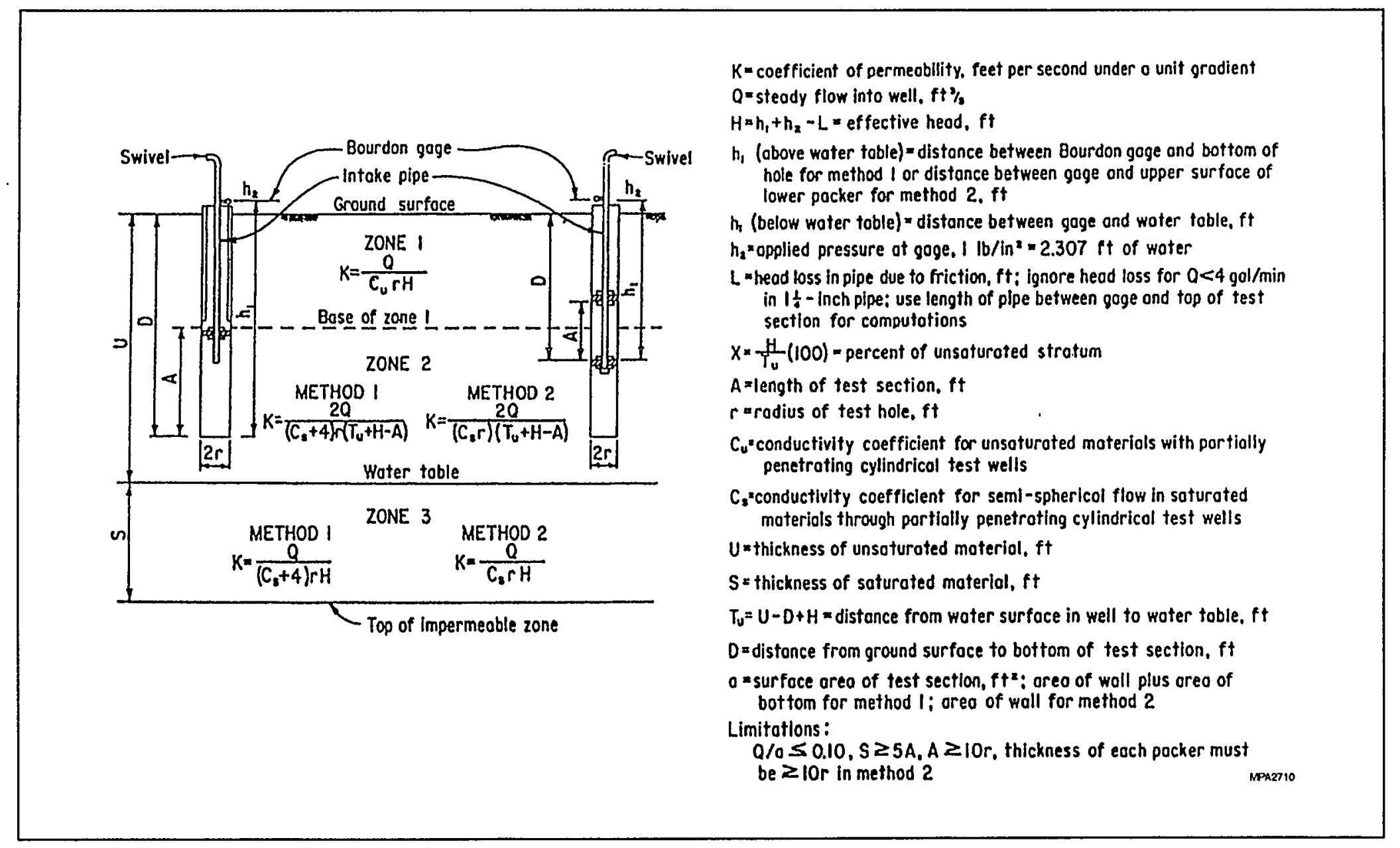

FIGURE B.3 Permeability Test Setup for Saturated and Unsaturated Bedrock 
TABLE B.12 Summary of Single Well Hydraulic Conductivity Slug Test Results at the Chemical Plant Area

\begin{tabular}{|c|c|c|c|c|c|}
\hline Well ID & Stratigraphic Unit & $\begin{array}{l}\text { Hydraulic } \\
\text { Conductivity } \\
(\mathrm{cm} / \mathrm{s})^{\mathrm{a}}\end{array}$ & Well ID & Stratigraphic Unit & $\begin{array}{l}\text { Hydraulic } \\
\text { Conductivity } \\
(\mathrm{cm} / \mathrm{s})^{\mathrm{a}}\end{array}$ \\
\hline MW-2001 & Weathered/unweathered ${ }^{b}$ & $3 \times 10^{-5}$ & MW-2044 & Weathered/unweathered & $1 \times 10^{-3}$ \\
\hline MW-2002 & Weathered/unweathered & $7.52 \times 10^{-5}$ & MW-3003 & Weathered/unweathered & $5.79 \times 10^{-6}$ \\
\hline MW-2003 & Weathered & $3 \times 10^{-5}$ & MW-3006 & Unweathered & $2.66 \times 10^{-4}$ \\
\hline MW-2005 & Weathered & $2.08 \times 10^{-5}$ & MW-3019 & Weathered/unweathered & $5.44 \times 10^{-5}$ \\
\hline MW-2006 & Weathered/unweathered & $6.83 \times 10^{-5}$ & MW-3023 & Weathered & $2 \times 10^{-5}$ \\
\hline MW-2007 & Weathered/unweathered & $6 \times 10^{-5}$ & MW-3024 & Unweathered & $3 \times 10^{-3}$ \\
\hline MW-2008 & Weathered/unweathered & $6.90 \times 10^{-5}$ & MW-3025 & Weathered & Not Determined \\
\hline MW-2010 & Weathered & $9 \times 10^{-3}$ & MW-3026 & Unweathered & Not Determined \\
\hline MW-2011 & Weathered/unweathered & $4 \times 10^{-3}$ & MW-3027 & Weathered & $9 \times 10^{-4}$ \\
\hline MW-2012 & Weathered/unweathered & $1 \times 10.3$ & MW-4001 & Weathered/unweathered & $4.98 \times 10^{-5}$ \\
\hline MW-2013 & Weathered/unweathered & $4.75 \times 10^{-5}$ & MW-4002 & Weathered/unweathered & $1 \times 10^{-3}$ \\
\hline MW-2014 & Weathered & $6 \times 10^{-3}$ & MW-4003 & Weathered & $6 \times 10^{-5}$ \\
\hline MW-2015 & Weathered/unweathered & $1.16 \times 10^{-4}$ & MW-4004 & Unweathered & $6.37 \times 10^{-6}$ \\
\hline MW-2017 & Weathered/unweathered & $7 \times 10^{-6}$ & MW-4005 & Weathered & $4.17 \times 10^{-6}$ \\
\hline MW-2018 & Weathered & $6.60 \times 10^{-5}$ & MW-4007 & Unweathered & $5 \times 10^{-6}$ \\
\hline MW-2019 & Unweathered & $1.97 \times 10^{-5}$ & MW-4008 & Unweathered & $1.03 \times 10^{-5}$ \\
\hline MW-2021 & Unweathered & $2.43 \times 10^{-5}$ & MW-4009 & Unweathered & $6.71 \times 10^{-6}$ \\
\hline MW-2022 & Unweathered & $4.05 \times 10^{-5}$ & MW-4010 & Weathered/unweathered & $4.98 \times 10^{-6}$ \\
\hline MW-2023 & Unweathered & $9.14 \times 10^{-6}$ & MW-4011 & Unwcathered & $1.74 \times 10^{-6}$ \\
\hline MW-2024 & Unweathered & $3.94 \times 10^{-5}$ & MW-4012 & Unweathered & $4.51 \times 10^{-6}$ \\
\hline MW-2025 & Unweathered & $3.94 \times 10^{-5}$ & MW-4013 & Weathered/unweathered & $5.67 \times 10^{-5}$ \\
\hline MW-2026 & Unweathered & $3.36 \times 10^{-5}$ & MW-4014 & Weathered/unweathered & $1.02 \times 10^{-3}$ \\
\hline MW-2027 & Unweathered & $1.39 \times 10^{-5}$ & MW-4015 & Weathered/unweathered & $2.89 \times 10^{-5}$ \\
\hline
\end{tabular}




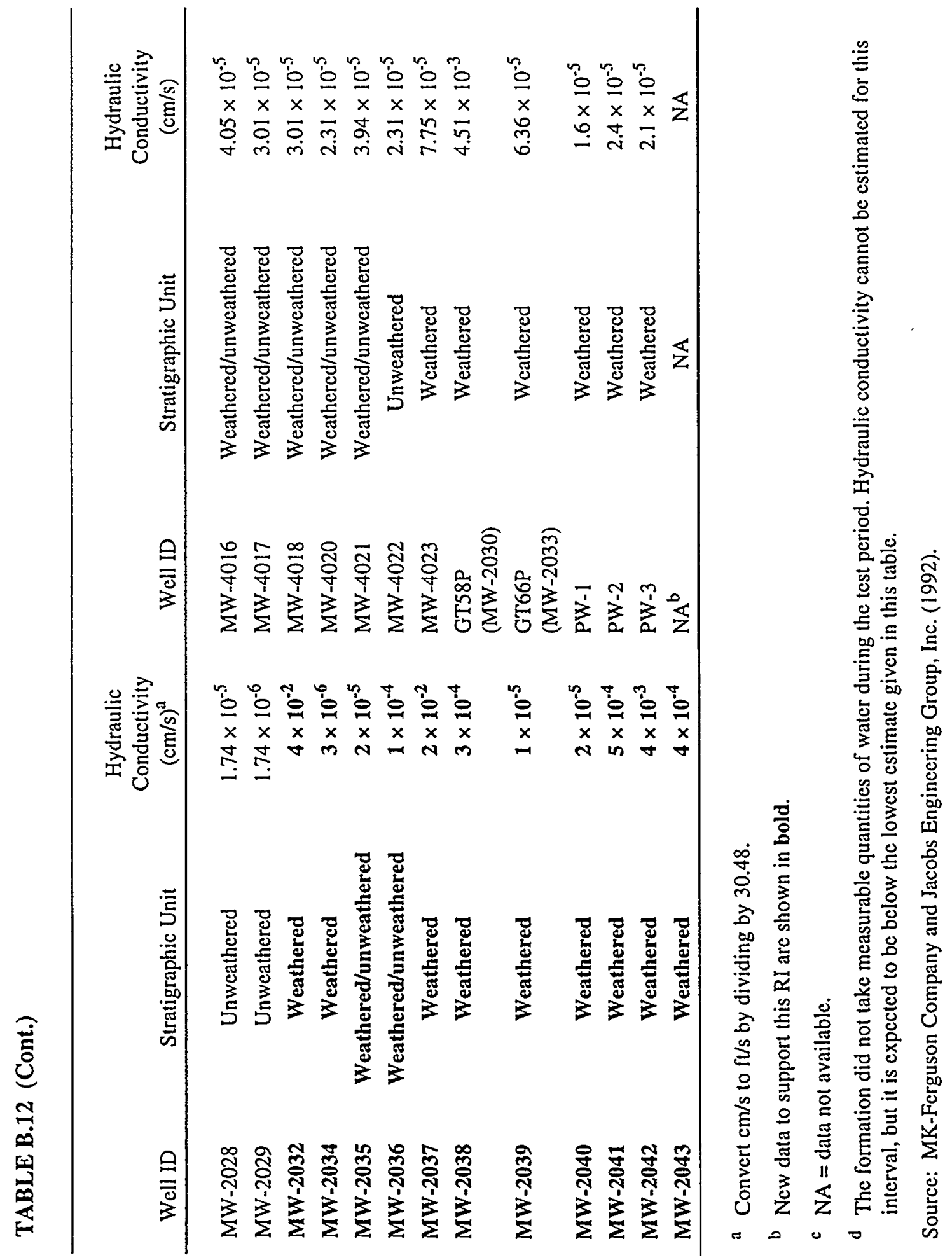


TABLE B.13 Summary of Single Well Hydraulic Conductivity Slug Test Results at the Ordnance Works Area

\begin{tabular}{|c|c|c|c|c|c|}
\hline Well ID & Stratigraphic Unit & $\begin{array}{c}\text { Hydraulic } \\
\text { Conductivity } \\
(\mathrm{cm} / \mathrm{s})^{\mathrm{a}}\end{array}$ & Well ID & Stratigraphic Unit & $\begin{array}{c}\text { Hydraulic } \\
\text { Conductivity } \\
(\mathrm{cm} / \mathrm{s})^{\mathrm{a}}\end{array}$ \\
\hline MWS-01 & Weathered/unweathered & $1.94 \times 10^{-7}$ & MWD-D18 & Kimmswick & $4.95 \times 10^{-6}$ \\
\hline MWS-02 & Weathered/unweathered & $1.31 \times 10^{-7}$ & MWS-19 & Weathered & $2.42 \times 10^{-7}$ \\
\hline MWD-02 & Unweathered & $9.13 \times 10^{-7}$ & MWS-20 & Weathered/unweathered & $2.84 \times 10^{-7}$ \\
\hline MWS-03 & Weathered/unweathered & $7.36 \times 10^{-8}$ & MWS-21 ${ }^{b}$ & Weathered & $3.61 \times 10^{-6}$ \\
\hline MWS-04 & Weathered & $1.58 \times 10^{-5}$ & MWS-22 & Weathered & $1.58 \times 10^{-4}$ \\
\hline MWS-05 & Unweathered/Fern Glen & $6.97 \times 10^{-7}$ & MWS-24 & Weathered & $7.44 \times 10^{-6}$ \\
\hline MWD-05 & Fern Glen/Chouteau & $2.51 \times 10^{-8}$ & MWS-101 & Kimmswick & $5.44 \times 10^{-7}$ \\
\hline MWS-06 & Unweathered & $1.94 \times 10^{-7}$ & MWS-102 & Decorah & $1.01 \times 10^{-8}$ \\
\hline MWD-06 & Unweathered & $8.97 \times 10^{-7}$ & MWS-103 & $\begin{array}{l}\text { Sulphur Springs/ } \\
\text { Kimmswick }\end{array}$ & $2.12 \times 10^{-8}$ \\
\hline MWS-07 & Weathered & $7.01 \times 10^{-6}$ & MWS-104 & Weathered/unweathered & $8.22 \times 10^{-8}$ \\
\hline MWS-09 & Weathered & $3.46 \times 10^{-7}$ & MWS-105 & Unweathered & $7.39 \times 10^{-8}$ \\
\hline MWD-09 & Unweathered & $1.93 \times 10^{-6}$ & MWD-105 & Unweathered/Fern Glen & $5.91 \times 10^{-7}$ \\
\hline MWS-10 & Weathered & $9.32 \times 10^{-7}$ & MWS-106 & Unweathered & $4.68 \times 10^{-8}$ \\
\hline MWS-11 & Weathered & $2.80 \times 10^{-5}$ & MWD-106 & Unweathered/Fern Glen & $7.26 \times 10^{-5}$ \\
\hline MWS-12 & Weathered & $1.43 \times 10^{-6}$ & MWS-107 & Weathered/unweathered & $2.24 \times 10^{-7}$ \\
\hline MWS-13 & Weathered & $5.15 \times 10^{-7}$ & MWS-108 & Unwcathered & $1.82 \times 10^{-7}$ \\
\hline MWS-15 & Weathered & $1.10 \times 10^{-6}$ & MWS-109 & Unweathered & $1.12 \times 10^{-7}$ \\
\hline MWD-15 & Weathered & $4.19 \times 10^{-7}$ & MWD-109 & Unweathered/Fern Glen & $2.18 \times 10^{-7}$ \\
\hline MWS-16 & Weathered & $2.35 \times 10^{-7}$ & MWS-110 & Weathered/unweathered & $4.28 \times 10^{-7}$ \\
\hline MWS-17 & Weathered/unweathered & $1.46 \times 10^{-7}$ & MWS-111 & Weathered & $8.66 \times 10^{-7}$ \\
\hline
\end{tabular}

${ }^{\mathfrak{a}}$ Convert $\mathrm{cm} / \mathrm{s}$ to $\mathrm{f} / \mathrm{s}$ by dividing by 30.48 .

b New data to support this RI are shown in bold.

Source: IT Corporation (1993). 
registration forms and data sheets are provided in MK-Ferguson Company and Jacobs Engineering Group (1996).

\section{B.2.6 Groundwater Elevation Measurements}

As part of the joint sampling effort, water-level elevations were measured from all active chemical plant area and ordnance works area monitoring wells in April and July 1995 to provide a regional representation of the water table surface. Table B.14 summarizes the static water-level measurements for these two months.

Table B.15 summarizes the elevation fluctuations at each monitoring well on the basis of the water-level data collected from 1987 through July 1995. 
TABLE B.14 Summary of Water-Level Measurements — April and July 1995

\begin{tabular}{|c|c|c|c|c|c|}
\hline \multirow[b]{2}{*}{ Well ID } & \multirow[b]{2}{*}{$\begin{array}{c}\text { Top of Casing } \\
\text { Elevation } \\
\text { (ft) }\end{array}$} & \multicolumn{2}{|c|}{ April 1995} & \multicolumn{2}{|c|}{ July 1995} \\
\hline & & $\begin{array}{l}\text { Depth to } \\
\text { Water } \\
\text { (ft) }\end{array}$ & $\begin{array}{l}\text { Groundwater } \\
\text { Elevation } \\
\text { (ft) }\end{array}$ & $\begin{array}{l}\text { Depth to } \\
\text { Water } \\
\text { (ft) }\end{array}$ & $\begin{array}{l}\text { Groundwater } \\
\text { Elevation } \\
\text { (ft) }\end{array}$ \\
\hline \multicolumn{6}{|c|}{ Chemical Plant Area } \\
\hline MW-2001 & 613.44 & 22.70 & 590.74 & 24.78 & 588.66 \\
\hline MW-2002 & 625.75 & 31.65 & 594.10 & 31.91 & 593.84 \\
\hline MW-2003 & 638.78 & 35.66 & 603.12 & 40.86 & 597.92 \\
\hline MW-2005 & 637.38 & 49.62 & 587.76 & 49.58 & 587.80 \\
\hline MW-2006 & 635.92 & 33.45 & 602.47 & 38.17 & 597.75 \\
\hline MW-2007 & 653.60 & 59.44 & 594.16 & 60.85 & 592.75 \\
\hline MW-2010 & 644.67 & 44.06 & 600.61 & 43.97 & 600.70 \\
\hline MW-2011 & 655.28 & 54.18 & 600.10 & 54.45 & 600.83 \\
\hline MW-2012 & 636.61 & 29.21 & 607.40 & 28.78 & 607.83 \\
\hline MW-2013 & 647.13 & 41.11 & 606.02 & 40.83 & 606.30 \\
\hline MW-2014 & 649.37 & 44.96 & 604.41 & 44.81 & 604.56 \\
\hline MW-2015 & 659.99 & 56.08 & 603.91 & 55.98 & 604.01 \\
\hline MW-2017 & 659.84 & 54.15 & 605.69 & 53.80 & 606.04 \\
\hline MW-2018 & 663.50 & 47.77 & 615.73 & 47.39 & 616.11 \\
\hline MW-2019 & 663.24 & 70.28 & 592.96 & 69.96 & 593.28 \\
\hline MW-2021 & 626.19 & 36.24 & 589.95 & 36.36 & 589.83 \\
\hline MW-2022 & 637.24 & 50.45 & 586.79 & 51.47 & 585.77 \\
\hline MW-2023 & 637.29 & 54.60 & 582.69 & 54.34 & 582.95 \\
\hline MW-2024 & 636.70 & 67.33 & 569.37 & 67.29 & 569.41 \\
\hline MW-2026 & 637.22 & 45.22 & 592.00 & 45.63 & 591.59 \\
\hline MW-2027 & 646.83 & 53.84 & 592.99 & 54.27 & 592.56 \\
\hline MW-2028 & 659.74 & 64.10 & 595.64 & 64.08 & 595.66 \\
\hline MW-2030 & 654.63 & 53.70 & 600.93 & 53.66 & 600.97 \\
\hline MW-2032 & 635.81 & 54.27 & 581.54 & 54.31 & 581.50 \\
\hline MW-2033 & 647.50 & 41.41 & 606.09 & 40.82 & 606.68 \\
\hline MW-2034 & 660.83 & 54.19 & 606.64 & 53.71 & 607.12 \\
\hline MW-2035 & 668.40 & 53.86 & 614.54 & 53.57 & 614.83 \\
\hline MW-2036 & 658.01 & 44.38 & 613.63 & 44.07 & 613.94 \\
\hline MW-2037 & 659.08 & 45.07 & 614.01 & 44.86 & 614.22 \\
\hline MW-2038 & 667.19 & 53.86 & 613.33 & 53.68 & 613.51 \\
\hline MW-2039 & 665.25 & 51.52 & 613.73 & 51.24 & 614.01 \\
\hline MW-2040 & 662.39 & 49.50 & 612.89 & 49.15 & 613.24 \\
\hline
\end{tabular}


TABLE B.14 (Cont.)

\begin{tabular}{|c|c|c|c|c|c|}
\hline \multirow[b]{2}{*}{ Well ID } & \multirow[b]{2}{*}{$\begin{array}{c}\text { Top of Casing } \\
\text { Elevation } \\
(\mathrm{ft})\end{array}$} & \multicolumn{2}{|c|}{ April 1995} & \multicolumn{2}{|c|}{ July 1995} \\
\hline & & $\begin{array}{l}\text { Depth to } \\
\text { Water } \\
(\mathrm{ft})\end{array}$ & $\begin{array}{c}\text { Groundwater } \\
\text { Elevation } \\
(\mathrm{ft})\end{array}$ & $\begin{array}{c}\text { Depth to } \\
\text { Water } \\
\text { (ft) }\end{array}$ & $\begin{array}{l}\text { Groundwater } \\
\text { Elevation } \\
(\mathrm{ft})\end{array}$ \\
\hline MW-2041 & 661.59 & 48.31 & 613.28 & 48.05 & 613.54 \\
\hline MW-2042 & 662.68 & 48.51 & 614.17 & 48.17 & 614.51 \\
\hline MW-2043 & 662.30 & 48.59 & 613.71 & 48.20 & 614.10 \\
\hline MW-2044 & 657.11 & 43.04 & 614.07 & 43.10 & 614.01 \\
\hline \multicolumn{6}{|c|}{ Raffinate Pits } \\
\hline MW-3003 & 646.96 & 46.94 & 600.02 & 46.92 & 600.04 \\
\hline MW-3006 & 647.13 & 53.05 & 594.08 & 53.42 & 593.71 \\
\hline MW-3019 & 662.03 & 54.56 & 607.47 & 53.98 & 608.05 \\
\hline MW-3023 & 648.07 & 45.27 & 602.80 & 45.23 & 602.84 \\
\hline MW-3024 & 647.90 & 35.45 & 612.45 & 34.47 & 612.43 \\
\hline MW-3025 & 648.58 & 37.57 & 611.01 & 37.21 & 611.37 \\
\hline MW-3026 & 647.07 & 36.68 & 610.39 & 36.25 & 610.82 \\
\hline MW-3027 & 647.41 & 33.99 & 613.42 & 33.89 & 613.52 \\
\hline \multicolumn{6}{|c|}{ Off-Site Wells } \\
\hline$M W-4001$ & $622: 83$ & 18.82 & 604.01 & 19.34 & 603.49 \\
\hline$M W-4002$ & 635.20 & 53.85 & 581.35 & 66.36 & 568.84 \\
\hline MW-4003 & 671.52 & 56.85 & 614.67 & 56.26 & 615.26 \\
\hline MW-4004 & 653.19 & 40.22 & 612.97 & 40.09 & 613.10 \\
\hline MW-4005 & 657.25 & 46.76 & 610.49 & 46.42 & 610.83 \\
\hline MW-4006 & 622.95 & 18.73 & 604.22 & 19.10 & 603.85 \\
\hline MW-4007 & 624.13 & 26.63 & 597.50 & 27.25 & 596.88 \\
\hline MW-4008 & 637.47 & 39.38 & 598.09 & 39.33 & 598.14 \\
\hline MW-4009 & 625.89 & 30.53 & 595.36 & 30.91 & 594.98 \\
\hline$M W-4010$ & 630.70 & 40.06 & 590.64 & 41.18 & 589.52 \\
\hline MW-4011 & 628.16 & 36.05 & 592.11 & 37.29 & 590.87 \\
\hline MW-4012 & 617.38 & 49.88 & 567.50 & 46.12 & 571.26 \\
\hline MW-4013 & 608.73 & 48.21 & 560.52 & 48.24 & 560.49 \\
\hline MW-4014 & 609.30 & 47.75 & 561.55 & 47.85 & 561.45 \\
\hline MW-4015 & 619.58 & 37.10 & 582.48 & 37.81 & 581.77 \\
\hline MW-4016 & 643.91 & 54.36 & 589.55 & 54.04 & 589.87 \\
\hline MW-4018 & 649.93 & 51.37 & 598.56 & 51.27 & 598.66 \\
\hline
\end{tabular}


TABLE B.14 (Cont.)

\begin{tabular}{|c|c|c|c|c|c|}
\hline \multirow[b]{2}{*}{ Well ID } & \multirow[b]{2}{*}{$\begin{array}{c}\text { Top of Casing } \\
\text { Elevation } \\
\text { (ft) }\end{array}$} & \multicolumn{2}{|c|}{ April 1995} & \multicolumn{2}{|c|}{ July 1995} \\
\hline & & $\begin{array}{c}\text { Depth to } \\
\text { Water } \\
(\mathrm{ft})\end{array}$ & $\begin{array}{c}\text { Groundwater } \\
\text { Elevation } \\
\text { (ft) }\end{array}$ & $\begin{array}{l}\text { Depth to } \\
\text { Water } \\
\text { (ft) }\end{array}$ & $\begin{array}{l}\text { Groundwater } \\
\text { Elevation } \\
(\mathrm{ft})\end{array}$ \\
\hline MW-4019 & 647.34 & 34.26 & 613.08 & 33.85 & 613.49 \\
\hline MW-4020 & 659.17 & 53.16 & 505.01 & 52.78 & 606.39 \\
\hline MW-4022 & 667.98 & 70.57 & 597.41 & 69.82 & 598.16 \\
\hline MW-4023 & 648.53 & 32.85 & 615.68 & 32.81 & 615.72 \\
\hline MW-4024 & 657.84 & Not installed & $\mathrm{NA}^{\mathrm{a}}$ & 51.06 & 606.48 \\
\hline MW-4025 & 648.46 & Not installed & $\mathrm{NA}$ & 42.63 & 605.83 \\
\hline \multicolumn{6}{|c|}{ Training Area } \\
\hline MWS-01 & 597.83 & 14.06 & 583.77 & 16.30 & 581.53 \\
\hline MWV-01 & 597.84 & 13.15 & 584.69 & Dry & NA \\
\hline MWD-02 & 605.88 & 19.62 & 586.26 & 21.90 & 583.98 \\
\hline MWS-02 & 605.25 & 19.69 & 585.56 & 22.62 & 582.63 \\
\hline MWV-02 & 604357 & 17.35 & 587.22 & 17.56 & 587.01 \\
\hline MWS-03 & 635.39 & 39.50 & 595.89 & 39.46 & 595.93 \\
\hline MWS-04 & 624.09 & 20.49 & 603.60 & 21.28 & 602.81 \\
\hline MWD-05 & 600.68 & 19.87 & 580.81 & 20.10 & 580.58 \\
\hline MWS-05 & 600.60 & 34.98 & 565.62 & 35.71 & 564.89 \\
\hline MWD-06 & 621.56 & 17.99 & 603.57 & 17.45 & 604.11 \\
\hline MWS-06 & 621.32 & 18.11 & 603.21 & 17.54 & 603.78 \\
\hline MWS-07 & 641.49 & 42.66 & 598.83 & 41.97 & 599.52 \\
\hline MWS-08 & 690.15 & 34.24 & 655.91 & 35.08 & 655.07 \\
\hline MWV-08 & 690.36 & 24.58 & 665.78 & 24.49 & 665.87 \\
\hline MWD-09 & 636.08 & 17.19 & 618.89 & 17.12 & 618.96 \\
\hline MWS-09 & 635.37 & 15.53 & 619.84 & 16.03 & 619.34 \\
\hline MWV-09 & 635.79 & 17.51 & 618.28 & 18.20 & 617.59 \\
\hline MWS-10 & 654.19 & 22.93 & 631.26 & 23.52 & 630.67 \\
\hline MWS-11 & 676.35 & 26.79 & 649.56 & 26.45 & 649.90 \\
\hline MWS-12 & 657.11 & 20.47 & 636.64 & 20.46 & 636.65 \\
\hline MWS-13 & 692.39 & 38.93 & 653.46 & 38.72 & 653.67 \\
\hline MWV-13 & 692.18 & 38.61 & 653.57 & 38.63 & 653.55 \\
\hline MWS-14 & 705.07 & 37.10 & 667.97 & 38.76 & 666.31 \\
\hline MWD-15 & 655.76 & 29.00 & 626.76 & 28.98 & 626.78 \\
\hline
\end{tabular}


TABLE B.14 (Cont.)

\begin{tabular}{|c|c|c|c|c|c|}
\hline \multirow[b]{2}{*}{ Well ID } & \multirow[b]{2}{*}{$\begin{array}{l}\text { Top of Casing } \\
\text { Elevation } \\
\text { (ft) }\end{array}$} & \multicolumn{2}{|c|}{ April 1995} & \multicolumn{2}{|c|}{ July 1995} \\
\hline & & $\begin{array}{l}\text { Depth to } \\
\text { Water } \\
\text { (ft) }\end{array}$ & $\begin{array}{l}\text { Groundwater } \\
\text { Elevation } \\
\text { (ft) }\end{array}$ & $\begin{array}{l}\text { Depth to } \\
\text { Water } \\
\text { (ft) }\end{array}$ & $\begin{array}{l}\text { Groundwater } \\
\text { Elevation } \\
\text { (ft) }\end{array}$ \\
\hline MWS-15 & 656.72 & 28.25 & 628.47 & 28.61 & 628.11 \\
\hline MWS-16 & 651.78 & 17.93 & 633.85 & 17.31 & 634.47 \\
\hline MWV-16 & 651.24 & 17.02 & 634.22 & 16.76 & 634.48 \\
\hline MWS-17 & 660.28 & 20.29 & 639.99 & 22.23 & 638.05 \\
\hline MWV-17 & 659.60 & 15.40 & 644.20 & 17.22 & 642.38 \\
\hline MWD-18 & 601.55 & 20.24 & 581.31 & 22.95 & 578.60 \\
\hline MWS-18 & 601.43 & 66.84 & 534.59 & 66.87 & 534.56 \\
\hline MWV-18 & 601.91 & 20.32 & 581.59 & Dry & NA \\
\hline MWS-19 & 648.66 & 20.46 & 528.20 & 22.96 & 625.70 \\
\hline MWS-20 & 668.48 & 35.41 & 633.07 & 34.59 & 633.89 \\
\hline MWS-21 & 642.28 & 28.12 & 614.16 & 27.91 & 614.37 \\
\hline MWS-22 & 664.14 & 15.26 & 648.88 & 15.31 & 648.83 \\
\hline MWV-22 & 663.82 & 14.87 & 648.95 & 14.81 & 649.01 \\
\hline MWD-23 & 710.80 & Not installed & NA & 57.94 & 652.86 \\
\hline MWS-23 & 710.32 & 54.48 & 655.84 & 56.40 & 653.92 \\
\hline MWS-24 & 657.23 & 22.52 & 634.71 & 22.50 & 634.73 \\
\hline$M W V-24 R$ & 642.19 & 21.25 & 620.94 & 21.81 & 620.38 \\
\hline MWD-25 & 683.84 & Not installed & NA & 59.32 & 624.52 \\
\hline MWS-25 & 683.46 & Not installed & NA & 51.51 & 631.95 \\
\hline MWS-26 & 675.19 & Not installed & NA & Dry & NA \\
\hline \multicolumn{6}{|c|}{ Ordnance Works Area } \\
\hline MWS-101 & 491.55 & Access flooded & $\mathrm{NA}$ & 11.28 & 480.27 \\
\hline MWS-102 & 481.13 & 17.66 & 463.47 & 15.11 & 466.02 \\
\hline MWS-103 & 529.67 & 14.25 & 515.42 & 24.65 & 505.02 \\
\hline MWS-104 & 566.85 & 9.55 & 557.30 & 10.81 & 556.04 \\
\hline MWD-105 & 575.48 & 19.98 & 555.50 & 19.83 & 555.65 \\
\hline MWS-105 & 575.45 & 19.49 & 555.96 & 20.49 & 554.96 \\
\hline MWD-106 & 532.03 & 0 & $532.03^{\mathrm{b}}$ & 0 & 532.03 \\
\hline MWS-106 & 532.93 & 1.44 & 531.49 & 3.42 & 529.51 \\
\hline MWD-107 & 609.96 & Not installed & NA & 25.62 & 584.34 \\
\hline MWS-107 & 608.99 & 25.30 & 583.69 & 23.82 & 585.17 \\
\hline MWS-108 & 606.56 & 19.62 & 586.94 & 19.81 & 586.75 \\
\hline
\end{tabular}




\begin{tabular}{|c|c|c|c|c|c|}
\hline \multirow[b]{2}{*}{ Well ID } & \multirow[b]{2}{*}{$\begin{array}{c}\text { Top of Casing } \\
\text { Elevation } \\
(\mathrm{ft})\end{array}$} & \multicolumn{2}{|c|}{ April 1995} & \multicolumn{2}{|c|}{ July 1995} \\
\hline & & $\begin{array}{l}\text { Depth to } \\
\text { Water } \\
\text { (ft) }\end{array}$ & $\begin{array}{c}\text { Groundwater } \\
\text { Elevation } \\
\text { (ft) }\end{array}$ & $\begin{array}{l}\text { Depth to } \\
\text { Water } \\
\text { (ft) }\end{array}$ & $\begin{array}{l}\text { Groundwater } \\
\text { Elevation } \\
\text { (ft) }\end{array}$ \\
\hline MWD-109 & 552.17 & 7.46 & 544.71 & 7.47 & 544.70 \\
\hline MWS-109 & 552.31 & 7.14 & 545.17 & 7.84 & 544.47 \\
\hline MWS-110 & 607.03 & 59.61 & 547.42 & 59.93 & 547.10 \\
\hline MWS-111 & 622.90 & 1.42 & 621.48 & 3.12 & 619.78 \\
\hline MWD-112 & 571.00 & 19.64 & 551.36 & 17.38 & 553.62 \\
\hline MWS-112 & 575.45 & 28.35 & 547.10 & 28.62 & 546.83 \\
\hline USGS-1 & 591.00 & 46.64 & 544.36 & 46.00 & 545.00 \\
\hline USGS-2A & 560.00 & 7.61 & 552.39 & 8.83 & 551.17 \\
\hline USGS-3 & 586.00 & 22.40 & 564.10 & 22.33 & 564.17 \\
\hline USGS-4 & 602.00 & 12.71 & 589.29 & 13.06 & 588.94 \\
\hline USGS-5 & 581.00 & 41.56 & 539.44 & 41.39 & 539.61 \\
\hline USGS-6 & 591.00 & 56.55 & 534.45 & 56.84 & 534.16 \\
\hline USGS-8 & 626.00 & 53.65 & 572.35 & 53.93 & 572.07 \\
\hline USGS-9 & 591.00 & 15.07 & 575.93 & 16.90 & 574.10 \\
\hline
\end{tabular}

a $\mathrm{NA}=$ data not available.

b The groundwater elevation in MWD-106 is given as the top of casing elevation because groundwater flows from this well. 
TABLE B.15 Summary of Maximum and Minimum Static Water-Level Fluctuations of the Shallow Aquifer - the Chemical Plant Area and the Ordnance Works Area

\begin{tabular}{|c|c|c|c|}
\hline \multirow[b]{2}{*}{ Well ID } & \multicolumn{2}{|c|}{ Groundwater Elevation } & \multirow{2}{*}{$\begin{array}{l}\text { Groundwater } \\
\text { Fluctuation } \\
\text { (ft) }\end{array}$} \\
\hline & $\begin{array}{l}\text { Maximum } \\
(\mathrm{ft})\end{array}$ & $\begin{array}{l}\text { Minimum } \\
(\mathrm{ft})\end{array}$ & \\
\hline \multicolumn{4}{|c|}{ Chemical Plant Area } \\
\hline MW-2001 & 590.74 & 587.64 & 3.10 \\
\hline MW-2002 & 595.41 & 591.49 & 3.92 \\
\hline MW-2003 & 603.12 & 597.12 & 6.00 \\
\hline MW-2005 & 588.27 & 587.19 & 1.08 \\
\hline MW-2006 & 602.74 & 598.94 & 3.80 \\
\hline MW-2007 & 594.16 & 592.30 & 1.86 \\
\hline MW-2010 & 601.57 & 599.60 & 1.97 \\
\hline MW-2011 & 601.10 & 600.48 & 0.62 \\
\hline MW-2012 & 610.20 & 603.37 & 6.83 \\
\hline MW-2013 & 608.66 & 602.29 & 6.37 \\
\hline MW-2014 & 605.15 & 602.97 & 2.18 \\
\hline MW-2015 & 604.94 & 601.36 & 3.58 \\
\hline MW-2017 & 607.41 & 604.10 & 3.31 \\
\hline MW-2018 & 616.84 & 613.30 & 3.54 \\
\hline MW-2030 & 613.15 & 612.54 & 0.61 \\
\hline MW-2032 & 583.28 & 583.09 & 0.19 \\
\hline MW-2033 & 608.68 & 605.26 & 3.42 \\
\hline MW-2034 & 607.68 & 604.92 & 2.76 \\
\hline MW-2035 & 616.84 & 614.54 & 2.30 \\
\hline MW-2036 & 614.06 & 613.45 & 0.61 \\
\hline MW-2037 & 614.48 & 613.59 & 0.89 \\
\hline MW-2038 & 613.64 & 613.00 & 0.64 \\
\hline MW-2039 & 614.27 & 613.55 & 0.72 \\
\hline MW-2040 & 613.30 & 612.71 & 0.59 \\
\hline MW-2041 & 614.39 & 613.12 & 1.27 \\
\hline MW-2042 & 619.08 & 613.70 & 5.38 \\
\hline MW-2043 & 614.48 & 613.59 & 0.89 \\
\hline MW-2044 & 614.21 & 614.00 & 0.21 \\
\hline \multicolumn{4}{|c|}{ Raffinate Pits } \\
\hline MW-3001 & 613.92 & 610.00 & 3.92 \\
\hline MW-3019 & 608.35 & 603.35 & 5.00 \\
\hline
\end{tabular}


TABLE B.15 (Cont.)

\begin{tabular}{|c|c|c|c|}
\hline \multirow[b]{2}{*}{ Well ID } & \multicolumn{2}{|c|}{ Groundwater Elevation } & \multirow{2}{*}{$\begin{array}{l}\text { Groundwates } \\
\text { Fluctuation } \\
\text { (ft) }\end{array}$} \\
\hline & $\underset{(\mathrm{ft})}{\operatorname{Maximum}}$ & $\underset{(\mathrm{ft})}{\operatorname{Minimum}}$ & \\
\hline MW-3023 & 602.91 & 593.86 & 9.05 \\
\hline MW-3025 & 611.40 & 610.93 & 0.47 \\
\hline MW-3027 & 613.96 & 612.72 & 1.24 \\
\hline \multicolumn{4}{|c|}{ off-Site Wells } \\
\hline MW-4002 & 588.43 & 568.68 & 19.75 \\
\hline MW-4003 & 616.35 & 608.96 & 7.39 \\
\hline MW-4005 & 612.78 & 607.45 & 5.33 \\
\hline MW-4006 & 607.44 & 600.85 & 6.59 \\
\hline MW-4010 & 592.10 & 588.17 & 3.93 \\
\hline MW-4013 & 563.25 & 560.34 & 2.91 \\
\hline MW-4014 & 561.89 & 561.31 & 0.58 \\
\hline MW-4015 & 583.40 & 579.93 & 3.47 \\
\hline MW-4016 & 589.91 & 588.52 & 1.39 \\
\hline MW-4017 & 597.21 & 592.66 & 4.55 \\
\hline MW-4018 & 599.37 & 596.18 & 3.19 \\
\hline MW-4019 & 614.07 & 609.14 & 4.93 \\
\hline MW-4020 & 608.17 & 603.78 & 4.39 \\
\hline MW-4021 & 610.04 & 607.26 & 2.78 \\
\hline$M W-4023$ & 618.60 & 611.27 & 7.33 \\
\hline \multicolumn{4}{|c|}{ Training Area } \\
\hline MWS-01 & 584.71 & 579.96 & 4.75 \\
\hline MWS-02 & 588.05 & 581.85 & 6.20 \\
\hline MWS-03 & 596.39 & 594.01 & 2.38 \\
\hline MWS-04 & 604.33 & 602.05 & 2.28 \\
\hline MWS-05 & 567.44 & 565.06 & 2.38 \\
\hline MWS-07 & 601.01 & 596.35 & 4.66 \\
\hline MWS-08 & 656.82 & 652.30 & 4.52 \\
\hline MWS-09 & 621.29 & 617.93 & 3.36 \\
\hline MWS-10 & 631.91 & 626.28 & 5.63 \\
\hline MWS-11 & 650.84 & 646.11 & 4.73 \\
\hline MWS-12 & 637.59 & 634.99 & 2.60 \\
\hline MWS-13 & 655.11 & 649.58 & 5.53 \\
\hline
\end{tabular}


TABLE B.15 (Cont.)

\begin{tabular}{|c|c|c|c|}
\hline \multirow[b]{2}{*}{ Well ID } & \multicolumn{2}{|c|}{ Groundwater Elevation } & \multirow{2}{*}{$\begin{array}{c}\text { Groundwater } \\
\text { Fluctuation } \\
\text { (ft) }\end{array}$} \\
\hline & $\begin{array}{l}\text { Maximum } \\
(\mathrm{ft})\end{array}$ & $\begin{array}{l}\text { Minimum } \\
(\mathrm{ft})\end{array}$ & \\
\hline MWS-14 & 668.51 & 666.17 & 2.34 \\
\hline MWS-15 & 630.66 & 621.59 & 8.47 \\
\hline MWS-16 & 638.44 & 624.75 & 13.69 \\
\hline MWS-17 & 641.51 & 635.15 & 6.36 \\
\hline MWS-19 & 630.72 & 621.40 & 9.32 \\
\hline MWS-20 & 635.34 & 629.26 & 6.08 \\
\hline MWS-21 & 614.81 & 613.56 & 1.25 \\
\hline MWS-22 & 649.98 & 645.37 & 4.61 \\
\hline MWS-23 & 655.84 & 649.45 & 6.39 \\
\hline MWS-24 & 635.31 & 632.73 & 2.58 \\
\hline \multicolumn{4}{|c|}{ Ordnance Works Area } \\
\hline MWS-104 & 560.14 & 552.52 & 7.62 \\
\hline MWS-105 & 560.41 & 552.52 & 7.89 \\
\hline MWS-107 & 587.06 & 580.98 & 6.08 \\
\hline MWS-110 & 555.15 & 545.65 & 9.50 \\
\hline MWS-111 & 622.90 & 613.24 & 9.66 \\
\hline USGS-1 & 547.60 & 542.19 & 5.41 \\
\hline USGS-2A & 556.24 & 547.54 & 8.70 \\
\hline USGS-3 & 564.65 & 563.06 & 1.59 \\
\hline USGS-4 & 591.40 & 573.95 & 17.45 \\
\hline USGS-5 & 540.93 & 534.38 & 6.55 \\
\hline USGS-6 & 536.30 & 532.60 & 3.70 \\
\hline USGS-7 & 545.20 & 544.35 & 0.85 \\
\hline USGS-8 & 572.77 & 570.85 & 1.92 \\
\hline USGS-9 & 577.45 & 572.08 & 5.37 \\
\hline
\end{tabular}

Sources: Field sheets and IT Corporation (1995). 


\section{B.3 APPENDIX B REFERENCES}

Allan, J.N., 1987, letter from Allan (Project Director, MK-Ferguson Company and Jacobs Engineering Group, Inc., St. Charles, Mo.) to R. Nelson (U.S. Department of Energy, Weldon Spring Site Remedial Action Project) re: Falling Head Permeability Tests, June 26.

Bechtel National, Inc., 1984, Geologic Report, Weldon Spring Raffinate Pits Site, Weldon Spring, Missouri, DOE/OR/20722-6, prepared for U.S. Department of Energy, Oak Ridge Operations, Oak Ridge, Tenn., Nov.

Bechtel National, Inc., 1987, Hydrological Characterization Report for Weldon Spring Chemical Plant, DOE/OR/20722-137, prepared for U.S. Department of Energy, Oak Ridge Operations Office, Oak Ridge, Tenn., July.

Bouwer, H., and R.C. Rice, 1976, "A Slug Test for Determining Hydraulic Conductivity of Unconfined Aquifers with Completely or Partially Penetrating Wells," Water Resources Research 12(3), June.

DOE: see U.S. Department of Energy.

International Technology Corporation, 1992, Final Remediation Investigation Report, Weldon Spring Ordnance Works, Weldon Spring, Missouri, Project No. 312071, prepared by International Technology Corporation, Itasca, Ill., for U.S. Department of the Army, Corps of Engineers, Kansas City District, Nov.

International Technology Corporation, 1993, Final Remedial Investigation Report, Weldon Spring Training Area, Weldon Spring, Missouri, Project No. 312188, prepared by International Technology Corporation, Itasca, Ill., for U.S. Department of the Army, Corps of Engineers, Kansas City District, March (Rounds 1-3 analytical data; March and Oct. 1989; June 1991).

International Technology Corporation, 1995, 1994: Fourth Quarterly Groundwater Monitoring Report Weldon Spring Ordnance Works, Project No. 312430, prepared by International Technology Corporation, Itasca, Ill., for U.S. Department of the Army, Corps of Engineers, Kansas City District, Jan. (Round 15 analytical data; Nov. 1994).

IT: see International Technology Corporation.

MK-Environmental Services, 1991, WSSRAP-Disposal Facility Geotechnical Characterization Report, Report No. 340R-7005-0, Rev. 0, prepared for MK-Ferguson Group, Boise, Idaho, Oct. 
MK-Environmental Services, 1993, WSSRAP-Disposal Facility Supporting Study 3A: Hydraulic Properties of Undisturbed Soils, Report No. 3840R-7137-A, Rev. B, prepared for MK-Ferguson Group, Boise, Idaho, Nov.

MK-Environmental Services, 1994, In Situ Materials Calculations, Morrison Knudson Corporation, WSSRAP Calculation No. DC-7002-00, Document No. 3840-D: GE-C-01-9021, prepared for MKFerguson Group, Boise, Idaho.

MK-Ferguson and Jacobs Engineering Group, Inc., 1992, Remedial Investigation for the Chemical Plant Area of the Weldon Spring Site, Rev. 0, 2 vols., DOE/OR/21548-074, prepared for U.S. Department of Energy, Oak Ridge Operations Office, Weldon Spring Site Remedial Action Project, Weldon Spring, Mo.

MK-Ferguson and Jacobs Engineering Group, Inc., 1995, Weldon Spring Site Report for Calendar Year 1994, DOE/OR/21548-436, prepared for U.S. Department of Energy, Oak Ridge Operations Office, Oak Ridge, Tenn.

MK-Ferguson and Jacobs Engineering Group, Inc., 1996, Hydrological Field Characterization Data for the Chemical Plant Area and Ordnance Works Area Collected in the 1995 Joint Sampling Activities, prepared for U.S. Department of Energy, Weldon Spring Site Remedial Action Project, Weldon Spring, Mo., and U.S. Department of the Army, Corps of Engineers, Kansas City District, Kansas City, Mo.

Mugel, D.N., 1997, Geohydrology of the Weldon Spring Ordnance Work, St. Charles County, Missouri, USGS Water-Resources Investigations Report 96-4171, (in press), prepared in cooperation with the U.S. Army Corps of Engineers, Rolla, Mo.

Rueff, M., 1992, Surficial Materials Investigation at the Weldon Spring Training Area, St. Charles County, Missouri, prepared for U.S. Department of the Army, Kansas City District, Corps of Engineers, Kansas City, Mo., by the Missouri Department of Natural Resources, Sept.

U.S. Department of Energy, 1995a, Sampling Plan for the Remedial Investigation/Feasibility Study for the Groundwater Operable Units at the Chemical Plant Area and at the Ordnance Works Area, Weldon Spring, Missouri (Appendix to the Work Plan), Rev. 1, DOE/OR/21548-445, U.S. Department of Energy, Oak Ridge Operations Office, St. Charles, Mo., July.

U.S. Department of Energy, 1995b, Work Plan for the Remedial Investigation/Feasibility Study for the Groundwater Operable Unit at the Chemical Plant Area and the Ordnance Works Area, Weldon Spring, Mo., prepared by Environmental Assessment and Information Sciences Division, Argonne National Laboratory, Argonne, Ill., for Weldon Spring Site Remedial Action Project, Weldon Spring, Mo. 
U.S. Department of the Interior, 1977, Groundwater Manual, A Water Resources Technical Publication, 1st ed.

Whitfield, J.W., et al., 1989, Geologic Map of the Weldon Spring 7.5 Minute Quadrangle, St. Charles Count, Mo., OFM-89-252-GI, Missouri Department of Natural Resources, Division of Geology and Land Survey, Rolla, Mo. 
$C-1$

\section{APPENDIX C:}

RESULTS OF THE 1995 JOINT GROUNDWATER

SAMPLING FOR WELLS AND SPRINGS 
C-2 


\section{APPENDIX C:}

\section{RESULTS OF THE 1995 JOINT GROUNDWATER SAMPLING FOR WELLS AND SPRINGS}

Appendix C presents the data from the May and August 1995 joint sampling of groundwater and springs. All nondetected values are expressed as less than $(<)$ the analytical detection limit. The values shown in parentheses are categorized as "uncensored" data, that is, data that are below the detection limit but reported as a measured value. "NA" indicates that sampling was not scheduled, whereas "NS" indicates that the location was not sampled as scheduled because of sampling problems such as low-flow or dry conditions. 
TABLE C.1 Nitroaromatic Results from Joint Sampling, May 1995

\begin{tabular}{|c|c|c|c|c|c|c|c|c|c|c|c|}
\hline Well No. & $\begin{array}{c}1,3,5-\mathrm{TNB} \\
(\mu \mathrm{g} / \mathrm{L})\end{array}$ & $\begin{array}{c}\text { 1,3-DNB } \\
(\mu \mathrm{g} / \mathrm{L})\end{array}$ & $\begin{array}{c}2.4,6-T N T \\
(\mu \mathrm{g} / \mathrm{L})\end{array}$ & $\begin{array}{c}\text { 2,4-DNT } \\
(\mu \mathrm{g} / \mathrm{L})\end{array}$ & $\begin{array}{c}\text { 2.6-DNT } \\
(\mu \mathrm{g} / \mathrm{L})\end{array}$ & $\begin{array}{c}\text { 2-Amino } \\
(\mu \mathrm{g} / \mathrm{L})\end{array}$ & $\begin{array}{c}\text { 4-Amino } \\
(\mu \mathrm{g} / L)\end{array}$ & $\begin{array}{c}\text { 2-Nitrotoluene } \\
(\mu \mathrm{g} / \mathrm{L})\end{array}$ & $\begin{array}{l}\text { 3-Nitrotoluene } \\
(\mu \mathrm{g} / \mathrm{L})\end{array}$ & $\begin{array}{l}\text { 4-Nitrololuene } \\
(\mu g L))\end{array}$ & $\begin{array}{c}\text { Nitrobenzene } \\
(\mu \mathrm{g} / \mathrm{L})\end{array}$ \\
\hline MW-2001 & 0.054 & $<0.09$ & $<0.03$ & 0.12 & 0.056 & 13 & 24 & $<0.03$ & $<0.03$ & $<0.03$ & $<0.04$ \\
\hline$M W-2002$ & $<0.03$ & $<0.09$ & $<0.03$ & 0.055 & 0.36 & 0.64 & 0.80 & $<0.03$ & $<0.03$ & $<0.03$ & $<0.04$ \\
\hline MW-2003 & $<0.03$ & $<0.09$ & $<0.03$ & 0.15 & 0.45 & 0.18 & 0.46 & 0.18 & $<0.03$ & $<0.03$ & $<0.04$ \\
\hline MW-2005 & 0.035 & $<0.09$ & $<0.03$ & 0.057 & 0.090 & 0.12 & 0.12 & $<0.03$ & $<0.03$ & $<0.03$ & $<0.04$ \\
\hline MW-2006 & 6.1 & $<0.09$ & $<0.03$ & 0.14 & 1.3 & 1.9 & 1.6 & $<0.03$ & $<0.03$ & $<0.03$ & $<0.04$ \\
\hline MW-2007 & $<0.03$ & $<0.09$ & $<0.03$ & $<0.03$ & $<0.01$ & $<0.02$ & $<0.02$ & 0.083 & $<0.03$ & $<0.03$ & $<0.04$ \\
\hline$M W-2010$ & 0.14 & $<0.09$ & 0.28 & 0.094 & 0.50 & 0.82 & 0.82 & 0.20 & $<0.03$ & $<0.03$ & $<0.04$ \\
\hline MW-2011 & 0.27 & $<0.09$ & $<0.03$ & 0.20 & 1.6 & 1.5 & 0.81 & $<0.06$ & $<0.03$ & $<0.03$ & $<0.04$ \\
\hline$M W-2012$ & 1.4 & $<0.09$ & 0.46 & 0.079 & 0.44 & 0.31 & 0.37 & 0.16 & $<0.03$ & $<0.03$ & $<0.04$ \\
\hline$M W-2013$ & 4.8 & $<0.09$ & 0.52 & 0.30 & 3.5 & 1.4 & 1.5 & 0.22 & 0.049 & $<0.03$ & $<0.04$ \\
\hline MW-2014 & 3.0 & $(0.86)$ & 0.039 & 0.16 & 0.56 & 0.55 & 0.78 & $<0.03$ & $<0.03$ & $<0.03$ & $<0.04$ \\
\hline MW-2015 & $<0.03$ & $<0.09$ & $<0.03$ & $<0.03$ & $<0.01$ & $<0.02$ & $<0.02$ & $<0.03$ & $<0.03$ & $<0.03$ & $<0.04$ \\
\hline MW-2017 & $<0.03$ & $<0.09$ & $<0.03$ & $<0.03$ & $<0.01$ & $<0.02$ & $<0.02$ & $<0.03$ & $<0.03$ & $<0.03$ & $<0.04$ \\
\hline MW-2018 & $<0.03$ & $<0.09$ & $<0.03$ & $<0.03$ & $<0.01$ & $<0.02$ & $<0.02$ & $<0.03$ & $<0.03$ & $<0.03$ & $<0.04$ \\
\hline$M W-2019$ & $<0.03$ & $<0.09$ & $<0.03$ & $<0.03$ & $<0.01$ & $<0.02$ & $<0.02$ & $<0.03$ & $<0.03$ & $<0.03$ & $<0.04$ \\
\hline$M W-2021$ & $<0.03$ & $<0.09$ & $<0.03$ & $<0.03$ & $<0.01$ & $<0.02$ & $<0.02$ & $<0.03$ & $<0.03$ & $<0.03$ & $<0.04$ \\
\hline$M W-2022$ & $<0.03$ & $<0.09$ & $<0.03$ & $<0.03$ & $<0.01$ & $<0.02$ & $<0.02$ & $<0.03$ & $<0.03$ & $<0.03$ & $<0.04$ \\
\hline$M W-2023$ & $<0.03$ & $<0.09$ & $<0.03$ & $<0.03$ & $<0.01$ & $<0.02$ & $<0.02$ & $<0.03$ & $<0.03$ & $<0.03$ & $<0.04$ \\
\hline MW-2024 & $<0.03$ & $<0.09$ & $<0.03$ & $<0.03$ & $<0.01$ & $<0.02$ & $<0.02$ & $<0.016$ & $<0.03$ & $<0.03$ & $<0.04$ \\
\hline MW-2026 & $<0.03$ & $<0.09$ & $<0.03$ & $<0.03$ & $<0.01$ & $<0.02$ & $<0.02$ & $<0.03$ & $<0.03$ & $<0.03$ & $<0.04$ \\
\hline MW-2027 & $<0.03$ & $<0.09$ & $<0.03$ & $<0.03$ & $<0.01$ & $<0.02$ & $<0.02$ & $<0.03$ & $<0.03$ & $<0.03$ & $<0.04$ \\
\hline$M W-2028$ & $<0.03$ & $<0.09$ & $<0.03$ & $<0.03$ & $<0.01$ & $<0.02$ & $<0.02$ & $<0.45$ & $<0.03$ & $<0.03$ & $<0.04$ \\
\hline$M W-20.30$ & 8.3 & $<0.18$ & 29 & 0.25 & 11 & 3.9 & 4.3 & 0.24 & 0.039 & $<0.0 .3$ & $<0.04$ \\
\hline$M W-2032$ & 4.9 & $<0.03$ & 6.7 & $<1.5$ & 2.9 & 2.6 & 2.0 & 0.47 & 0.080 & $<0.03$ & $<0.04$ \\
\hline$M W-2033$ & 3.8 & $<0.09$ & 1.2 & 0.44 & 3.7 & 2.7 & 2.7 & $<0.03$ & 0.032 & $0.07 !$ & $<0.04$ \\
\hline$M W-2034$ & $<0.03$ & $<0.03$ & $<0.03$ & $<1.5$ & $<0.01$ & $<0.02$ & $<0.02$ & $<0.03$ & $<0.03$ & $<0.03$ & $<0.04$ \\
\hline MW-2035 & $<0.03$ & $<0.09$ & $<0.03$ & $<0.03$ & $<0.01$ & $<0.02$ & $<0.02$ & $<0.03$ & $<0.03$ & $<0.03$ & $<0.04$ \\
\hline MW-2036 & $<0.03$ & $<0.09$ & $<0.03$ & $<0.03$ & $<0.01$ & $<0.02$ & $<0.02$ & $<0.17$ & $<0.03$ & $<0.03$ & $<0.04$ \\
\hline MW-2037 & 0.19 & $<0.09$ & $<0.03$ & 0.56 & 0.13 & 0.11 & 0.10 & $<0.24$ & $<0.06$ & $<0.03$ & $<0.04$ \\
\hline$M W-2038$ & 0.24 & $<0.09$ & $<0.03$ & 1.7 & 0.32 & 0.40 & 0.46 & $<0.03$ & $<0.06$ & $<0.06$ & 0.062 \\
\hline
\end{tabular}


TABLE C.1 (Cont.)

\begin{tabular}{|c|c|c|c|c|c|c|c|c|c|c|c|}
\hline Well No. & $\begin{array}{c}1,3,5-\mathrm{TNB} \\
(\mu \mathrm{g} / \mathrm{L})\end{array}$ & $\begin{array}{c}\text { 1,3-DNB } \\
(\mu \mathrm{g} / \mathrm{L})\end{array}$ & $\begin{array}{c}2,4,6-\mathrm{TNT} \\
(\mu \mathrm{g} / \mathrm{L})\end{array}$ & $\begin{array}{c}\text { 2,4-DNT } \\
(\mu \mathrm{g} / \mathrm{L})\end{array}$ & $\begin{array}{c}2,6-\mathrm{DNT} \\
(\mu \mathrm{g} / \mathrm{L})\end{array}$ & $\begin{array}{c}\text { 2-Amino } \\
(\mu \mathrm{g} / \mathrm{L})\end{array}$ & $\begin{array}{c}\text { 4-Amino } \\
(\mu \mathrm{g} / \mathrm{L})\end{array}$ & $\begin{array}{c}\text { 2-Nitrotoluene } \\
(\mu \mathrm{g} / \mathrm{L})\end{array}$ & $\begin{array}{c}\text { 3-Nitrotoluene } \\
(\mu \mathrm{g} / \mathrm{L})\end{array}$ & $\begin{array}{c}\text { 4-Nitrotoluene } \\
(\mu \mathrm{gL})\end{array}$ & $\begin{array}{c}\text { Nitrobenzene } \\
(\mu \mathrm{g} / \mathrm{L})\end{array}$ \\
\hline MW-2039 & $<0.03$ & $<0.09$ & $<0.03$ & $<0.03$ & $<0.01$ & $<0.02$ & $<0.02$ & $<0.03$ & $<0.03$ & $<0.03$ & $<0.04$ \\
\hline MW-2040 & $<0.03$ & $<0.09$ & $<0.03$ & $<0.03$ & $<0.01$ & $<0.02$ & $<0.02$ & $<0.03$ & $<0.03$ & $<0.03$ & $<0.04$ \\
\hline MW-2041 & $<0.03$ & $<0.09$ & $<0.03$ & $<0.03$ & $<0.01$ & $<0.02$ & $<0.02$ & $<0.03$ & $<0.03$ & $<0.03$ & $<0.04$ \\
\hline MW-2042 & $<0.03$ & $<0.09$ & $<0.03$ & $<0.03$ & $<0.01$ & $<0.02$ & $<0.02$ & $<0.03$ & $<0.03$ & $<0.03$ & $<0.04$ \\
\hline MW-2043 & $<0.03$ & $<0.09$ & $<0.03$ & 0.073 & $<0.01$ & $<0.02$ & $<0.02$ & $<0.03$ & $<0.03$ & $<0.03$ & $<0.04$ \\
\hline MW-2044 & $<0.03$ & $<0.09$ & $<0.03$ & $<0.03$ & $<0.01$ & 0.022 & 0.033 & 0.50 & $<0.03$ & $<0.03$ & $<0.04$ \\
\hline MW-3003 & $<0.03$ & $<0.03$ & $<0.03$ & $(0.048)$ & 0.085 & $<0.02$ & $<0.02$ & $<0.06$ & $<0.03$ & $<0.03$ & $<0.04$ \\
\hline MW-3006 & $<0.03$ & $<0.09$ & $<0.03$ & $<0.03$ & $<0.01$ & $<0.02$ & $<0.02$ & $<0.03$ & $<0.03$ & $<0.03$ & $<0.04$ \\
\hline MW-3019 & $<0.03$ & $<0.09$ & $<0.03$ & $<0.03$ & $<0.01$ & $<0.02$ & $<0.02$ & 54 & $<0.03$ & $<0.03$ & $<0.04$ \\
\hline$M W-3023$ & $<0.03$ & $<0.09$ & $<0.06$ & 5.0 & 5.0 & 0.17 & 0.32 & 0.29 & 4.3 & 0.70 & $<0.04$ \\
\hline MW-3024 & $<0.03$ & $<0.09$ & $<0.03$ & 0.12 & 0.44 & 0.032 & 0.057 & 0.18 & 0.041 & $<0.03$ & $<0.04$ \\
\hline MW-3025 & $<0.03$ & $<0.09$ & $<0.03$ & 0.063 & 0.22 & $<0.02$ & 0.020 & $<0.03$ & $<0.03$ & $<0.03$ & $<0.04$ \\
\hline$M W-3026$ & 0.068 & $<0.09$ & $<0.03$ & 0.072 & 0.040 & 0.30 & 0.37 & $<0.03$ & $<0.03$ & $<0.03$ & $<0.04$ \\
\hline MW-3027 & 0.074 & $<0.09$ & $<0.03$ & 0.058 & 0.040 & 0.19 & 0.18 & 0.83 & $<0.03$ & $<0.03$ & $<0.04$ \\
\hline MW-400I & 35 & $<0.09$ & 1.8 & 0.42 & 3.1 & 16 & 22 & $<0.03$ & $<0.06$ & $<0.03$ & $<0.04$ \\
\hline$M W-4002$ & 0.062 & $<0.09$ & 1.8 & 0.14 & 0.29 & 1.4 & 2.3 & $<0.03$ & $<0.03$ & $<0.03$ & $<0.04$ \\
\hline MW-4003 & $<0.03$ & $<0.09$ & $<0.03$ & $<0.03$ & $<0.01$ & $<0.02$ & $<0.03$ & $<0.03$ & $<0.03$ & $<0.03$ & $<0.04$ \\
\hline MW-4004 & $<0.03$ & $<0.09$ & $<0.03$ & $<0.03$ & $<0.01$ & $<0.02$ & $<0.02$ & $<0.03$ & $<0.03$ & $<0.03$ & $<0.04$ \\
\hline MW-4005 & $<0.03$ & $<0.09$ & $<0.03$ & $<0.03$ & $<0.01$ & $<0.02$ & $<0.02$ & 0.69 & $<0.03$ & $<0.03$ & $<0.04$ \\
\hline$M W-4006$ & 19 & $<0.09$ & $<0.0 .3$ & 0.16 & 3.1 & 1.8 & 2.5 & $<0.03$ & 0.032 & $<0.03$ & $<0.04$ \\
\hline$M W-4007$ & $<0.03$ & $<0.09$ & $<0.03$ & $<0.03$ & $<0.01$ & $<0.02$ & $<0.02$ & $<0.03$ & $<0.03$ & $<0.03$ & $<0.03$ \\
\hline MW-4008 & $<0.03$ & $<0.09$ & $<0.03$ & $<0.03$ & $<0.01$ & $<0.02$ & $<0.02$ & $<0.03$ & $<0.03$ & $<0.03$ & $<0.04$ \\
\hline$M W-4009$ & $<0.03$ & $<0.09$ & $<0.03$ & $<0.03$ & $<0.01$ & $<0.02$ & $<0.02$ & $<0.03$ & $<0.0 .3$ & $<0.0 .3$ & $<0.04$ \\
\hline$M W-4010$ & $<0.03$ & $<0.09$ & $<0.03$ & $<0.03$ & $<0.01$ & $<0.02$ & $<0.02$ & $<0.03$ & $<0.03$ & $<0.03$ & $<0.04$ \\
\hline$M W-4012$ & $<0.03$ & $<0.09$ & $<0.03$ & $<0.03$ & 0.062 & 0.77 & 1.8 & $<0.03$ & $<0.03$ & $<0.03$ & $<0.04$ \\
\hline$M W-4013$ & 27 & $<0.09$ & $<0.03$ & $<0.03$ & $<0.01$ & $<0.02$ & $<0.02$ & $<0.03$ & $<0.03$ & $<0.03$ & $<0.04$ \\
\hline$M W-4014$ & 0.11 & $<0.09$ & 0.039 & 0.059 & 0.66 & 1.7 & 1.3 & $<0.03$ & $<0.03$ & $<0.03$ & $<0.04$ \\
\hline MW-4015 & 1.8 & $<0.09$ & $<0.03$ & $(0.026)$ & 0.087 & 0.28 & 0.52 & 0.11 & $<0.03$ & $<0.03$ & $<0.04$ \\
\hline MW-4016 & $<0.03$ & $<0.09$ & $<0.03$ & 0.14 & 1.1 & 3.0 & $<0.02$ & $<0.03$ & $<0.03$ & $<0.03$ & $<0.04$ \\
\hline MW-4018 & $<0.03$ & $<0.09$ & $<0.03$ & $<0.03$ & $<0.01$ & $<0.03$ & $<0.02$ & $<0.03$ & $<0.03$ & $<0.03$ & $<0.04$ \\
\hline
\end{tabular}


TABLE C.1 (Cont.)

\begin{tabular}{|c|c|c|c|c|c|c|c|c|c|c|c|}
\hline Well No. & $\begin{array}{c}\text { 1,3,5-TNB } \\
(\mu \mathrm{g} / \mathrm{L})\end{array}$ & $\begin{array}{c}\text { 1,3-DNB } \\
(\mu \mathrm{g} / \mathrm{L})\end{array}$ & $\begin{array}{c}2,4,6-\mathrm{TNT} \\
(\mu \mathrm{g} / \mathrm{L})\end{array}$ & $\begin{array}{c}2,4-\mathrm{DNT} \\
(\mu \mathrm{g} / \mathrm{L})\end{array}$ & $\begin{array}{c}2,6-\mathrm{DNT} \\
(\mu \mathrm{g} / \mathrm{L})\end{array}$ & $\begin{array}{c}\text { 2-Amino } \\
(\mu \mathrm{g} / \mathrm{L})\end{array}$ & $\begin{array}{c}\text { 4-Amino } \\
(\mu \mathrm{g} / \mathrm{L})\end{array}$ & $\begin{array}{c}\text { 2-Nitrotoluene } \\
(\mu \mathrm{g} / \mathrm{L})\end{array}$ & $\begin{array}{c}\text { 3-Nitrotoluene } \\
(\mu \mathrm{g} / \mathrm{L})\end{array}$ & $\begin{array}{l}\text { 4-Nitrotoluene } \\
\quad(\mu \mathrm{gL} L)\end{array}$ & $\begin{array}{c}\text { Nitrobenzene } \\
(\mu \mathrm{g} / \mathrm{L})\end{array}$ \\
\hline$M W \cdot 4019$ & $<0.03$ & $<0.09$ & $<0.03$ & $<0.03$ & $<0.01$ & $<0.02$ & $<0.02$ & $<0.03$ & $<0.03$ & $<0.03$ & $<0.04$ \\
\hline$M W-4020$ & $<0.03$ & $<0.09$ & $<0.03$ & $<0.03$ & $<0.01$ & $<0.02$ & $<0.02$ & $<0.06$ & $<0.03$ & $<0.03$ & $<0.04$ \\
\hline$M W-4021$ & $<0.03$ & $<0.09$ & $<0.03$ & $<0.03$ & $<0.01$ & $<0.02$ & $<0.02$ & $<0.03$ & $<0.03$ & $<0.03$ & $<0.04$ \\
\hline MW-4022 & $<0.03$ & $<0.09$ & $<0.03$ & $<0.03$ & $<0.01$ & $<0.02$ & $<0.02$ & $<0.06$ & $<0.03$ & $<0.03$ & $<0.04$ \\
\hline MW-4023 & 0.088 & $<0.09$ & $<0.03$ & $<0.03$ & $<0.01$ & $<0.02$ & $<0.02$ & $<0.03$ & $<0.03$ & $<0.03$ & $<0.04$ \\
\hline$M W-4024^{n}$ & $<0.03$ & $<0.09$ & $<0.03$ & 0.065 & 0.023 & 0.038 & 0.050 & $<0.03$ & $<0.03$ & $<0.03$ & $<0.04$ \\
\hline MW-4025 & $<0.03$ & $<0.09$ & $<0.03$ & $<0.03$ & $<0.01$ & $<0.02$ & $<0.02$ & $<0.06$ & $<0.03$ & $<0.03$ & $<0.04$ \\
\hline MWD-2 & $<0.03$ & $<0.09$ & $<0.03$ & $<0.03$ & $<0.01$ & $<0.02$ & $<0.02$ & $<0.03$ & $<0.03$ & $<0.03$ & $<0.04$ \\
\hline MWD-5 & $<0.03$ & $<0.09$ & $<0.03$ & $<0.03$ & $<0.01$ & $<0.02$ & $<0.02$ & $<0.03$ & $<0.03$ & $<0.03$ & $<0.04$ \\
\hline MWD.6 & $<0.03$ & $<0.09$ & $<0.03$ & $<0.03$ & $<0.01$ & $<0.02$ & $<0.02$ & $<0.03$ & $<0.03$ & $<0.03$ & $<0.04$ \\
\hline MWD-9 & 0.065 & $<0.09$ & $<0.03$ & 0.042 & 0.16 & 0.095 & 0.50 & $<0.15$ & $<0.03$ & $<0.03$ & $<0.04$ \\
\hline MWD-15 & $<0.03$ & $<0.1$ & $<0.03$ & $<0.03$ & 0.64 & 0.71 & 1.7 & $<0.03$ & $<0.03$ & $<0.03$ & $<0.04$ \\
\hline MWD-18 & $<0.03$ & $<0.09$ & $<0.03$ & $<0.03$ & $<0.01$ & $<0.02$ & $<0.02$ & $<0.03$ & $<0.03$ & $<0.03$ & $<0.04$ \\
\hline MWD-23 & $<0.03$ & $<0.09$ & $<0.03$ & $<0.03$ & $<0.01$ & $<0.02$ & $<0.02$ & $<0.03$ & $<0.03$ & $<0.03$ & $<0.04$ \\
\hline MWD-25 & $<0.03$ & $<0.09$ & $<0.03$ & $<0.03$ & $<0.01$ & $<0.02$ & $<0.02$ & $<0.03$ & $<0.03$ & $<0.03$ & $<0.04$ \\
\hline MWD-105 & $<0.03$ & $<0.09$ & $<0.03$ & $<0.03$ & $<0.01$ & $<0.02$ & $<0.02$ & $<0.03$ & $<0.03$ & $<0.03$ & $<0.04$ \\
\hline MWD-106 & $<0.03$ & $<0.09$ & $<0.03$ & $<0.03$ & $<0.01$ & $<0.02$ & $<0.02$ & $<0.06$ & $<0.03$ & $<0.03$ & $<0.04$ \\
\hline MWD-107 & 0.047 & $<0.09$ & $<0.03$ & $(0.020)$ & 0.090 & 0.040 & 0.51 & $<0.08$ & $<0.03$ & $<0.03$ & $<0.04$ \\
\hline MWD-109 & $<0.03$ & $<0.09$ & $<0.03$ & $<0.03$ & $<0.01$ & $<0.02$ & $<0.02$ & $<0.03$ & $<0.03$ & $<0.03$ & $<0.04$ \\
\hline MWD-112 & $<0.03$ & $<0.09$ & $<0.03$ & $<0.03$ & $<0.01$ & $<0.02$ & $<0.02$ & $<0.03$ & $<0.03$ & $<0.03$ & $<0.04$ \\
\hline MWS-1 & $<0.03$ & $<0.09$ & $<0.03$ & $<0.03$ & 0.64 & $<0.02$ & 0.044 & $<0.03$ & $<0.03$ & $<0.03$ & $<0.04$ \\
\hline MWS-2 & $<0.03$ & $<0.09$ & $<0.03$ & $<0.03$ & $<0.01$ & $<0.02$ & $<0.02$ & $<0.03$ & $<0.03$ & $<0.03$ & $<0.04$ \\
\hline MWS-3 & $<0.03$ & $<0.09$ & $<0.03$ & $<0.03$ & $<0.01$ & $<0.02$ & $<0.02$ & 0.21 & $<0.03$ & $<0.03$ & $<0.04$ \\
\hline MWS-4 & 9.2 & $<0.09$ & 0.88 & 0.082 & 1.2 & 7.6 & 8.3 & $<0.03$ & $<0.03$ & $<0.03$ & $<0.04$ \\
\hline MWS-5 & $<0.03$ & $<0.09$ & $<0.03$ & $<0.03$ & $<0.01$ & $<0.02$ & $<0.02$ & $<0.03$ & $<0.03$ & $<0.03$ & $<0.04$ \\
\hline MWS-6 & $<0.03$ & $<0.09$ & $<0.03$ & $<0.03$ & $<0.01$ & $<0.02$ & $<0.02$ & $<0.07$ & $<0.03$ & $<0.03$ & $<0.04$ \\
\hline MWS-7 & 18 & $<0.09$ & 2.6 & 0.048 & 1.2 & 5.6 & 11 & $<0.03$ & $<0.03$ & $<0.03$ & $<0.04$ \\
\hline MWS-8 & $<0.03$ & $<0.09$ & $<0.03$ & $<0.03$ & $<0.01$ & $<0.02$ & $<0.02$ & $<0.03$ & $<0.03$ & $<0.03$ & $<0.04$ \\
\hline MWS-9 & $<0.03$ & $<0.09$ & $<0.03$ & $<0.03$ & $<0.01$ & $<0.02$ & $<0.02$ & 0.10 & $<0.03$ & $<0.03$ & $<0.04$ \\
\hline MWS-10 & 0.30 & $<0.09$ & $<0.03$ & 0.069 & 1.9 & 5.1 & 15 & $<0.06$ & $<0.03$ & $<0.03$ & $<0.04$ \\
\hline
\end{tabular}




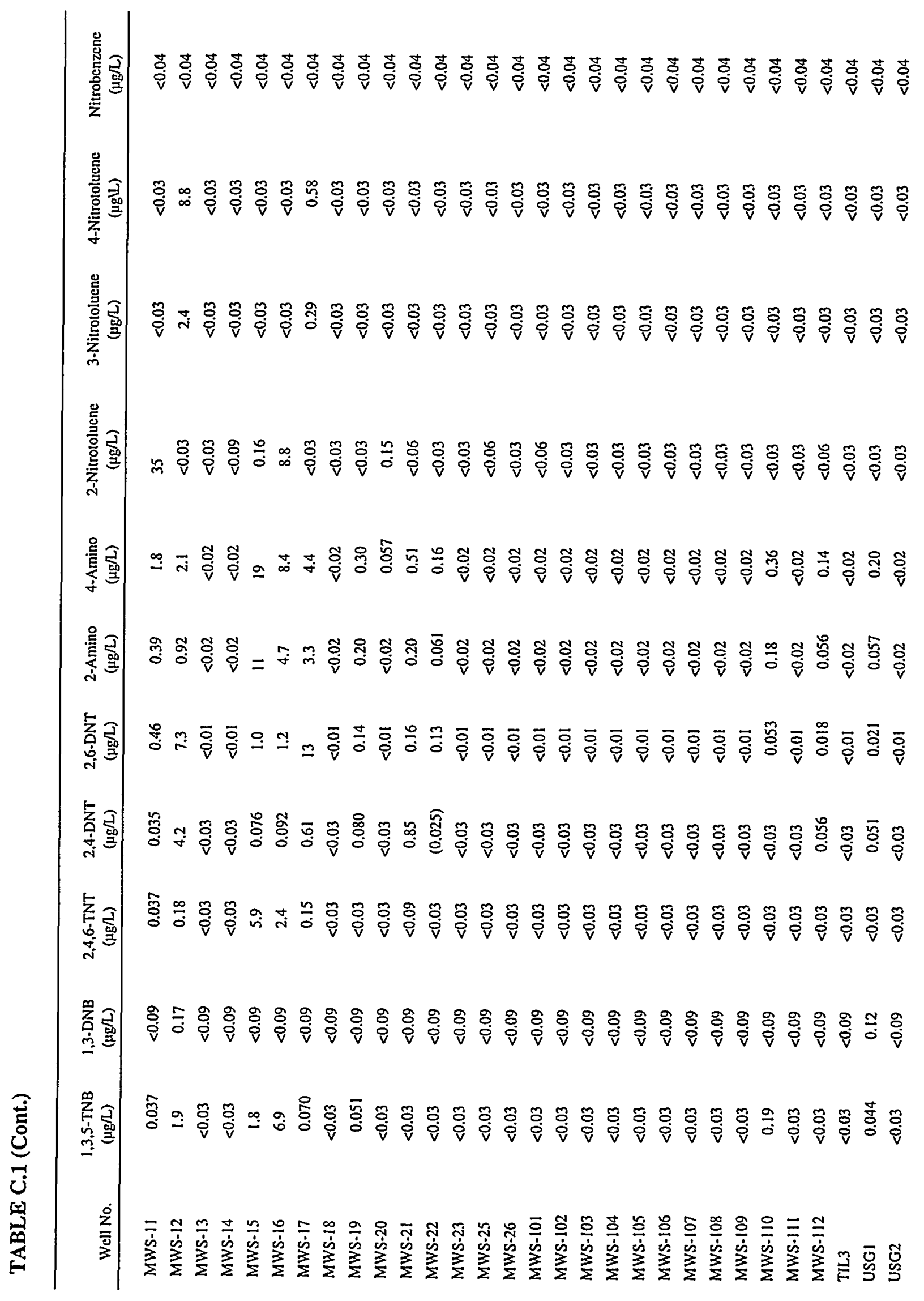


TABLE C.1 (Cont.)

\begin{tabular}{|c|c|c|c|c|c|c|c|c|c|c|c|}
\hline Well No. & $\begin{array}{c}\text { 1,3,5-TNB } \\
(\mu \mathrm{g} / \mathrm{L})\end{array}$ & $\begin{array}{c}\text { I,3-DNB } \\
(\mu \mathrm{g} / \mathrm{L})\end{array}$ & $\begin{array}{c}2,4,6 \cdot \mathrm{TNT} \\
(\mu \mathrm{g} / \mathrm{L})\end{array}$ & $\begin{array}{c}\text { 2,4-DNT } \\
(\mu \mathrm{g} / \mathrm{L})\end{array}$ & $\begin{array}{c}\text { 2,6-DNT } \\
(\mu \mathrm{g} / \mathrm{L})\end{array}$ & $\begin{array}{c}\text { 2-Atnino } \\
(\mu \mathrm{g} / \mathrm{L})\end{array}$ & $\begin{array}{c}\text { 4-Amino } \\
(\mu \mathrm{g} / \mathrm{L})\end{array}$ & $\begin{array}{c}\text { 2-Nitrotoluene } \\
(\mu \mathrm{g} / \mathrm{L})\end{array}$ & $\begin{array}{l}\text { 3-Nitrotoluene } \\
(\mu \mathrm{g} / \mathrm{L})\end{array}$ & $\begin{array}{l}\text { 4-Nitrotoluene } \\
\text { ( } \mu g L L)\end{array}$ & $\begin{array}{c}\text { Nitrobenzene } \\
(\mu \mathrm{g} / \mathrm{L})\end{array}$ \\
\hline USG3 & 0.058 & $<0.09$ & $<0.03$ & $<0.03$ & 0.19 & 0.023 & 0.25 & 1.0 & $<0.03$ & $<0.03$ & $<0.04$ \\
\hline USG4 & 1.3 & $<0.09$ & $<0.03$ & 1.5 & 2.1 & 1.5 & 1.8 & $<0.06$ & 0.11 & $<0.03$ & $<0.04$ \\
\hline USG.5 & $<0.03$ & $<0.09$ & $<0.03$ & $<0.03$ & $<0.01$ & $<0.02$ & $<0.02$ & $<0.12$ & $<0.03$ & $<0.03$ & $<0.04$ \\
\hline USG6 & $<0.03$ & $<0.09$ & $<0.03$ & $<0.03$ & $<0.01$ & $<0.02$ & $<0.02$ & $<0.03$ & $<0.03$ & $<0.03$ & $<0.04$ \\
\hline USG8 & $<0.03$ & $<0.09$ & $<0.03$ & $<0.03$ & $<0.01$ & $<0.02$ & $<0.02$ & 0.16 & $<0.03$ & $<0.03$ & $<0.04$ \\
\hline USG9 & $<0.03$ & $<0.09$ & $<0.03$ & 0.091 & 0.015 & 2.6 & 3.7 & $<0.03$ & $<0.03$ & $<0.03$ & $<0.04$ \\
\hline MWV-1 & 0.038 & $<0.09$ & 11 & 0.11 & 1.0 & 3.8 & 6.8 & $<0.03$ & $<0.03$ & $<0.03$ & $<0.04$ \\
\hline MWV-2 & $<0.03$ & $<0.09$ & 0.11 & 0.059 & 0.048 & 0.50 & 1.0 & $<0.03$ & $<0.03$ & $<0.03$ & $<0.04$ \\
\hline MWV.9 & 13 & 0.32 & 28 & 15 & 2.9 & 35 & 26 & $<0.03$ & 0.098 & 0.16 & $<0.04$ \\
\hline MWV-13 & $<0.03$ & $<0.09$ & $<0.03$ & $<0.03$ & $<0.01$ & $<0.02$ & $<0.02$ & $<0.03$ & $<0.03$ & $<0.03$ & $<0.04$ \\
\hline$M W V-16$ & 0.29 & $<0.09$ & 0.25 & $<0.03$ & 0.043 & 0.32 & 0.41 & 0.14 & $<0.03$ & $<0.03$ & $<0.04$ \\
\hline MWV-17 & $<0.03$ & $<0.09$ & $<0.03$ & $<0.03$ & $<0.01$ & $<0.02$ & $<0.03$ & $<0.03$ & $<0.03$ & $<0.0 .3$ & $<0.04$ \\
\hline$M W V-22$ & $<0.03$ & $<0.09$ & $<0.03$ & $<0.03$ & 0.13 & 0.050 & 0.18 & $<0.03$ & $<0.03$ & $<0.03$ & $<0.04$ \\
\hline MWV-24 & 2.0 & $<0.09$ & 0.67 & 0.062 & 1.2 & 0.47 & 1.0 & 0.14 & $<0.03$ & $<0.03$ & $<0.04$ \\
\hline
\end{tabular}

a Sample taken in July 1995. 
TABLE C.2 Anion and Radiological Results from Groundwater Locations Sampled in May $1995^{\mathrm{a}}$

\begin{tabular}{|c|c|c|}
\hline Well No. & $\begin{array}{l}\text { Nitrate } \\
(\mathrm{mg} / \mathrm{L})\end{array}$ & $\begin{array}{l}\text { Uranium } \\
\text { (pCi/L) }\end{array}$ \\
\hline MW-2001 & 43 & 1.8 \\
\hline MW-2002 & 100 & 1.4 \\
\hline MW-2003 & 280 & 1.8 \\
\hline MW-2005 & 66 & 0.73 \\
\hline MW-2006 & 4.7 & $(0.48)$ \\
\hline MW-2007 & 2.9 & 1.0 \\
\hline$M W-2010$ & 1.4 & 1.2 \\
\hline MW-2011 & 4.5 & 0.30 \\
\hline MW-2012 & 0.53 & 0.96 \\
\hline MW-2013 & 0.99 & 3.9 \\
\hline MW-2014 & 1.8 & 0.94 \\
\hline MW-2015 & $<0.1$ & 1.9 \\
\hline MW-2017 & 0.81 & 15 \\
\hline MW-2018 & 0.61 & 1.5 \\
\hline MW-2019 & $<0.1$ & 3.0 \\
\hline MW-2021 & $<0.1$ & 0.86 \\
\hline MW-2022 & $<0.1$ & 1.2 \\
\hline MW-2023 & $<0.1$ & 2.8 \\
\hline MW-2024 & $<0.1$ & $(0.11)$ \\
\hline MW-2026 & $<0.1$ & 0.81 \\
\hline MW-2027 & $<0.1$ & 0.99 \\
\hline MW-2028 & $<0.1$ & 1.3 \\
\hline MW-2030 & 1.3 & 11 \\
\hline MW-2032 & 56 & 4.5 \\
\hline MW-2033 & 1.1 & 0.84 \\
\hline MW-2034 & 4.8 & 2.7 \\
\hline MW-2035 & 0.42 & 0.39 \\
\hline MW-2036 & 2.9 & 0.72 \\
\hline MW-2037 & 34 & 1.2 \\
\hline MW-2038 & 900 & 1.4 \\
\hline MW-2039 & 52 & 3.1 \\
\hline MW-2040 & 230 & 3.0 \\
\hline MW-2041 & 300 & 3.3 \\
\hline MW-2042 & 5.6 & 2.6 \\
\hline MW-2043 & 5.8 & 1.8 \\
\hline MW-2044 & 1.2 & 2.3 \\
\hline
\end{tabular}




\section{C- 10}

TABLE C.2 (Cont.)

\begin{tabular}{|c|c|c|}
\hline Well No. & $\begin{array}{l}\text { Nitrate } \\
(\mathrm{mg} / \mathrm{L})\end{array}$ & $\begin{array}{l}\text { Uranium } \\
\text { (pCi/L) }\end{array}$ \\
\hline MW-3003 & 300 & 16.0 \\
\hline MW-3006 & $<0.1$ & 0.29 \\
\hline MW-3019 & 1.2 & 2.1 \\
\hline MW-3023 & 210 & 6.8 \\
\hline MW-3024 & 370 & 3.0 \\
\hline MW-3025 & 250 & 2.8 \\
\hline MW-3026 & 220 & 4.2 \\
\hline MW-3027 & 62 & 1.3 \\
\hline MW-4001 & 24 & 0.41 \\
\hline MW-4002 & 5.2 & 0.60 \\
\hline MW-4003 & 0.65 & 1.1 \\
\hline MW-4004 & 1.1 & 2.1 \\
\hline MW-4005 & 1.6 & 1.6 \\
\hline MW-4006 & 14 & 0.21 \\
\hline MW-4007 & $<0.1$ & 1.78 \\
\hline MW-4008 & $<0.1$ & 0.82 \\
\hline MW-4009 & 0.14 & 1.7 \\
\hline MW-4010 & $<0.1$ & 3.1 \\
\hline MW-4011 & 160 & 3.0 \\
\hline MW-4012 & $<0.1$ & 2.7 \\
\hline MW-4013 & 75 & 1.2 \\
\hline MW-4014 & 5.8 & 0.22 \\
\hline MW-4015 & 4.0 & 0.32 \\
\hline MW-4016 & $<0.1$ & 3.2 \\
\hline$M W-4018$ & 2.7 & 0.64 \\
\hline MW-4019 & 0.26 & 1.4 \\
\hline MW-4020 & $<0.1$ & 9.7 \\
\hline$M W-4021$ & $<0.1$ & 3.1 \\
\hline MW-4022 & 0.39 & 4.5 \\
\hline MW-4023 & 2.6 & 1.6 \\
\hline $\mathrm{MW}-4024^{\mathrm{b}}$ & 0.46 & 60.0 \\
\hline MW-4025 & 1.1 & 1.0 \\
\hline MWD-2 & $<0.1$ & 2.5 \\
\hline MWD-5 & 0.13 & 0.57 \\
\hline MWD-6 & $<0.1$ & 0.58 \\
\hline MWD-9 & 0.80 & 0.93 \\
\hline MWD-15 & 4.0 & 0.49 \\
\hline MWD-18 & $<0.1$ & 0.78 \\
\hline
\end{tabular}




\section{C-11}

TABLE C.2 (Cont.)

\begin{tabular}{|c|c|c|}
\hline Well No. & $\begin{array}{l}\text { Nitrate } \\
(\mathrm{mg} / \mathrm{L})\end{array}$ & $\begin{array}{l}\text { Uranium } \\
\text { (pCi/L) }\end{array}$ \\
\hline MWD-23 & $<0.1$ & 5.0 \\
\hline MWD-25 & 0.38 & 1.6 \\
\hline MWD-105 & $<0.1$ & 0.32 \\
\hline MWD-106 & $<0.1$ & $<0.16$ \\
\hline MWD-107 & $<0.1$ & 1.9 \\
\hline MWD-109 & $<0.1$ & 0.56 \\
\hline MWD-112 & $<0.1$ & 0.77 \\
\hline MWS-1 & 2.2 & 1.3 \\
\hline MWS-2 & 0.10 & 2.0 \\
\hline MWS-3 & $<0.1$ & 3.3 \\
\hline MWS-4 & 8.9 & 0.64 \\
\hline MWS-5 & $<0.1$ & 0.99 \\
\hline MWS-6 & $<0.1$ & 2.0 \\
\hline MWS-7 & 2.2 & 0.72 \\
\hline MWS-8 & 1.5 & 1.1 \\
\hline MWS-9 & $<0.1$ & 1.2 \\
\hline MWS-10 & 8.6 & $<0.17$ \\
\hline MWS-11 & 7.9 & 1.7 \\
\hline MWS-12 & 2.9 & $(0.700)$ \\
\hline MWS-13 & 1.2 & 0.54 \\
\hline MWS-14 & 0.18 & 2.7 \\
\hline MWS-15 & 0.90 & 0.56 \\
\hline MWS-16 & 7.7 & 0.65 \\
\hline MWS-17 & 1.6 & 0.80 \\
\hline MWS-18 & 0.30 & 1.5 \\
\hline MWS-19 & 0.13 & 1.3 \\
\hline MWS-20 & 5.5 & 0.56 \\
\hline MWS-21 & 520 & 3.0 \\
\hline MWS-22 & 3.0 & 1.2 \\
\hline MWS-23 & 0.20 & 0.94 \\
\hline MWS-25 & 0.15 & 0.92 \\
\hline MWS-26 & 0.52 & 3.9 \\
\hline MWS-101 & $<0.1$ & 0.53 \\
\hline MWS-102 & $<0.1$ & 2.6 \\
\hline MWS-103 & $<0.1$ & 0.76 \\
\hline MWS-104 & $<0.1$ & 1.3 \\
\hline MWS-105 & $<0.1$ & $(0.16)$ \\
\hline MWS-106 & $<0.1$ & 1.2 \\
\hline
\end{tabular}




\section{C- 12}

TABLE C.2 (Cont.)

\begin{tabular}{|c|c|c|}
\hline Well No. & $\begin{array}{l}\text { Nitrate } \\
(\mathrm{mg} / \mathrm{L})\end{array}$ & $\begin{array}{l}\text { Uranium } \\
(\mathrm{pCi} / \mathrm{L})\end{array}$ \\
\hline MWS-107 & 1.0 & 1.7 \\
\hline MWS-108 & $<0.1$ & $<0.14$ \\
\hline MWS-109 & $<0.1$ & 1.01 \\
\hline MWS- 110 & 0.80 & 0.49 \\
\hline MWS-111 & 0.24 & 0.41 \\
\hline MWS- 112 & 0.13 & 2.7 \\
\hline TIL3 & $<0.1$ & $(0.07)$ \\
\hline USGS1 & 0.77 & 1.05 \\
\hline USGS2 & $<0.1$ & $(0.001)$ \\
\hline USGS3 & 0.88 & 1.4 \\
\hline USGS4 & 1.3 & 0.24 \\
\hline USGS5 & $<0.1$ & 4.9 \\
\hline USGS6 & 0.55 & 1.7 \\
\hline USGS8 & 3.2 & 0.62 \\
\hline USGS9 & 3.2 & 0.34 \\
\hline MWV-1 & 0.68 & 0.92 \\
\hline MWV-2 & 0.33 & 3.04 \\
\hline MWV-9 & $<0.1$ & 0.72 \\
\hline MWV-13 & 1.5 & 1.4 \\
\hline MWV-16 & 1.1 & 0.59 \\
\hline MWV-17 & 0.18 & $<0.20$ \\
\hline MWV-22 & 3.3 & 0.88 \\
\hline MWV-24 & 0.21 & 0.60 \\
\hline
\end{tabular}

a Chloride, fluoride, and sulfate were not scheduled for sampling in May 1995.

b Sample taken in July 1995. 
TABLE C.3 Metals Data (filtered and unfiltered) from May 1995 Joint Sampling

\begin{tabular}{|c|c|c|c|c|c|c|c|c|c|c|}
\hline Well No. & $\begin{array}{c}\text { Aluminum } \\
(\mu \mathrm{g} / \mathrm{L})\end{array}$ & $\begin{array}{c}\text { Antimony } \\
(\mu \mathrm{g} / \mathrm{L})\end{array}$ & $\begin{array}{c}\text { Arsenic } \\
(\mu \mathrm{g} / \mathrm{L})\end{array}$ & $\begin{array}{c}\text { Barium } \\
(\mu \mathrm{g} / \mathrm{L})\end{array}$ & $\begin{array}{c}\text { Cadmium } \\
(\mu \mathrm{g} / \mathrm{L})\end{array}$ & $\begin{array}{c}\text { Chromium } \\
(\mu \mathrm{g} / \mathrm{L})\end{array}$ & $\begin{array}{c}\text { Copper } \\
(\mu \mathrm{g} / \mathrm{L})\end{array}$ & $\begin{array}{c}\text { Iron } \\
(\mu \mathrm{g} / \mathrm{L})\end{array}$ & $\begin{array}{c}\text { Lead } \\
(\mu \mathrm{g} / \mathrm{L})\end{array}$ & $\begin{array}{c}\text { Lithium } \\
(\mu \mathrm{g} / \mathrm{L})\end{array}$ \\
\hline MW-2001 & $<14.0$ & $<1.0$ & $<2.0$ & 282 & $<1.0$ & 4.4 & $<2.0$ & 40.0 & 4.0 & 2.6 \\
\hline$M W-2001-F^{a}$ & $<14.0$ & $<1.0$ & $<2.0$ & 279 & $<1.0$ & 4.5 & $<2.0$ & $<15.0$ & 1.9 & 2.5 \\
\hline MW-2002 & 90.2 & 1.7 & $<2.0$ & 113 & $<1.0$ & 5.9 & $<2.0$ & 114 & 3.0 & 269 \\
\hline$M W-2002-F$ & $<14.0$ & 1.4 & $<2.0$ & 111 & $<1.0$ & 3.5 & $<2.0$ & 28 & $<1.0$ & 251 \\
\hline MW-2003 & 1,040 & $<1.0$ & $<2.0$ & 303 & $<1.0$ & 5.7 & $<2.0$ & 862 & 4.7 & 428 \\
\hline$M W-2003-F$ & $<14.0$ & 2.0 & $<2.0$ & 266 & $<1.0$ & 4.3 & $<2.0$ & 68 & $<1.0$ & 497 \\
\hline MW-2005 & 19 & $<1.0$ & $<2.0$ & 165 & $<1.0$ & 1.6 & 3.0 & 65 & 6.1 & 81 \\
\hline MW-2005-F & $<14.0$ & 1.7 & $<2.0$ & 166 & $<1.0$ & 3.3 & $<2.0$ & 55.0 & 2.5 & 83 \\
\hline MW-2006 & 22 & $<1.0$ & $<2.0$ & 338 & $<1.0$ & 10.8 & $<2.0$ & 143 & 7.3 & 8.8 \\
\hline MW-2006-F & $<14.0$ & $<1.0$ & $<2.0$ & 322 & $<1.0$ & $<1.0$ & $<2.0$ & 115 & $<1.0$ & 9.1 \\
\hline MW-2007 & $<14.0$ & $<1.0$ & $<2.0$ & 148 & $<1.0$ & 3.1 & 2.2 & $<15.0$ & 11.7 & 3.4 \\
\hline MW-2007-F & $<14.0$ & $<1.0$ & $<2.0$ & 147 & $<1.0$ & 2.4 & 2.5 & $<15.0$ & $<1.0$ & 3.5 \\
\hline MW-2010 & 22 & $<1.0$ & $<2.0$ & 242 & $<1.0$ & 37.0 & $<2.0$ & 188 & 2.5 & 17.0 \\
\hline$M W-2010-F$ & 24 & 2.0 & $<2.0$ & 236 & $<1.0$ & 23 & $<2.0$ & 126 & $<1.0$ & 13 \\
\hline MW-2011 & 35 & $<1.0$ & $<2.0$ & 137 & $<1.0$ & 4.3 & 2.6 & 39 & 1.0 & 6.4 \\
\hline$M W-2011-F$ & 37 & $<1.0$ & $<2.0$ & 137 & $<1.0$ & 1.7 & $<2.0$ & $<15.0$ & $<1.0$ & 5.8 \\
\hline MW-2012 & $<14.0$ & $<1.0$ & $<2.0$ & 113 & $<1.0$ & 1.4 & $<2.0$ & 54 & $<1.0$ & $<2.0$ \\
\hline$M W-2012-F$ & 16 & $<1.0$ & $<2.0$ & 113 & $<1.0$ & 1.0 & $<2.0$ & 43 & $<1.0$ & $<2.0$ \\
\hline MW-2013 & $<14.0$ & $<1.0$ & $<2.0$ & 111 & $<1.0$ & 2.3 & $<2.0$ & 21 & 1.0 & 4.5 \\
\hline$M W-2013-F$ & $<14.0$ & $<1.0$ & $<2.0$ & 107 & $<1.0$ & 2.1 & 3.0 & $<15.0$ & $<1.0$ & 4.2 \\
\hline MW-2014 & 170 & $<1.0$ & $<2.0$ & 257 & $<1.0$ & 3.8 & 8.4 & 726 & 2.9 & 4.6 \\
\hline$M W-2014-F$ & $<14.0$ & 2.2 & $<2.0$ & 248 & $<1.0$ & 1.5 & $<2.0$ & 32 & $<1.0$ & 7.6 \\
\hline$M W-2015$ & $<14.0$ & $<1.0$ & $<2.0$ & 68 & $<1.0$ & 7.5 & 2.2 & 29 & 1.7 & 15 \\
\hline$M W-2015-F$ & $<14.0$ & $<1.0$ & $<2.0$ & 68 & $<1.0$ & 9.8 & $<2.0$ & 35 & 1.4 & 15 \\
\hline MW-2017 & 40.9 & $<1.0$ & $<2.0$ & 320 & $<1.0$ & 5.6 & 10.8 & 812 & 2.6 & 108 \\
\hline MW-2017-F & $<14.0$ & 2.7 & $<2.0$ & 36 & $<1.0$ & 8.9 & 3.3 & 59 & $<1.0$ & 69 \\
\hline
\end{tabular}


TABLE C.3 (Cont.)

\begin{tabular}{|c|c|c|c|c|c|c|c|c|c|c|}
\hline Well No. & $\begin{array}{c}\text { Aluminum } \\
(\mu \mathrm{g} / \mathrm{L})\end{array}$ & $\begin{array}{c}\text { Antimony } \\
(\mu \mathrm{g} / \mathrm{L})\end{array}$ & $\begin{array}{l}\text { Arsenic } \\
(\mu \mathrm{g} / \mathrm{L})\end{array}$ & $\begin{array}{l}\text { Barium } \\
(\mu g / L)\end{array}$ & $\begin{array}{c}\text { Cadmium } \\
(\mu \mathrm{g} / \mathrm{L})\end{array}$ & $\begin{array}{l}\text { Chromium } \\
(\mu \mathrm{g} / \mathrm{L})\end{array}$ & $\begin{array}{l}\text { Copper } \\
(\mu g / L)\end{array}$ & $\begin{array}{l}\text { Iron } \\
(\mu \mathrm{g} / \mathrm{L})\end{array}$ & $\begin{array}{l}\text { Lead } \\
(\mu \mathrm{g} / \mathrm{L})\end{array}$ & $\begin{array}{c}\text { Lithium } \\
(\mu \mathrm{g} / \mathrm{L})\end{array}$ \\
\hline MW-2018 & $<14.0$ & $<1.0$ & $<2.0$ & 404 & $<1.0$ & $<1.0$ & 3.4 & $<15.0$ & 1.7 & 17 \\
\hline MW-2018-F & $<14.0$ & $<1.0$ & $<2.0$ & 415 & $<1.0$ & $<1.0$ & $<2.0$ & $<30.0$ & $<1.0$ & 16 \\
\hline MW-2019 & $<14.0$ & $<1.0$ & $<2.0$ & 142 & $<1.0$ & 2.3 & 2.7 & $<15.0$ & $<1.0$ & 18 \\
\hline MW-2019-F & $<14.0$ & $<1.0$ & $<2.0$ & 140 & $<1.0$ & 1.9 & 2.3 & $<30.0$ & $<1.0$ & 19 \\
\hline$M W-2021$ & 452 & $<1.0$ & $<2.0$ & 225 & $<1.0$ & 21 & $<2.0$ & 255 & $<1.0$ & 3.8 \\
\hline MW-2021.F & 14 & $<1.0$ & $<2.0$ & 218 & $<1.0$ & 18 & $<2.0$ & 49 & $<1.0$ & 3.3 \\
\hline MW-2022 & 883 & $<1.0$ & $<2.0$ & 181 & $<1.0$ & $<1.0$ & $<2.0$ & $<15.0$ & 1.0 & 3.4 \\
\hline MW-2022-F & $<14.0$ & 2.1 & $<2.0$ & 178 & $<1.0$ & 1.7 & $<2.0$ & 18 & $<1.0$ & 3.6 \\
\hline MW-2023 & 100 & 1.1 & $<2.0$ & 97 & $<1.0$ & 5.7 & 6.5 & 204 & 16 & 3.2 \\
\hline$M W-2023-F$ & 49 & $<1.0$ & $<2.0$ & 93 & $<1.0$ & 2.9 & 2.1 & 34 & 1.1 & 3.3 \\
\hline MW-2024 & 23 & $<1.0$ & $<2.0$ & 83.0 & $<1.0$ & 3.8 & 2.4 & 157 & 5.1 & 3.9 \\
\hline MW-2024-F & 22 & $<1.0$ & $<2.0$ & 82 & $<1.0$ & 3.9 & 2.1 & 40 & $<1.0$ & 3.8 \\
\hline MW-2026 & 232 & $<1.0$ & $<2.0$ & 225 & $<1.0$ & 5.8 & 2.2 & 119 & 2.0 & 2.9 \\
\hline MW-2026-F & 23 & $<1.0$ & $<2.0$ & 216 & $<1.0$ & 2.4 & $<2.0$ & $<15.0$ & $<1.0$ & 2.8 \\
\hline MW-2027 & $<14.0$ & $<1.0$ & $<2.0$ & 271 & $<1.0$ & 2.0 & $<2.0$ & 216 & $<1.0$ & 4.1 \\
\hline MW-2027-F & 21 & $<1.0$ & $<2.0$ & 269 & $<1.0$ & 2.8 & $<2.0$ & 23 & $<1.0$ & 4.2 \\
\hline MW-2028 & 123 & $<1.0$ & $<2.0$ & 110 & $<1.0$ & 24 & 3.3 & 320 & 1.3 & 19 \\
\hline MW-2028-F & $<14.0$ & 1.5 & $<2.0$ & 107 & $<1.0$ & 11.0 & $<2.0$ & 57 & $<1.0$ & 17 \\
\hline MW-2030 & 8840 & $<1.0$ & $<2.0$ & 285 & $<1.0$ & 12.0 & 85 & 10400 & 13 & 6.4 \\
\hline MW-2030-F & 26 & $<1.0$ & $<2.0$ & 132 & $<1.0$ & 3.8 & 4.8 & 42 & $<1.0$ & 2.4 \\
\hline MW-2032 & 425 & $<1.0$ & $<2.0$ & 322 & $<1.0$ & 5.6 & 11 & 850 & 2.5 & 14 \\
\hline MW-2032-F & 27 & 6.8 & $<2.0$ & 298 & $<1.0$ & 4.6 & 5.0 & 136 & $<1.0$ & 13 \\
\hline MW-2033 & 1270 & $<1.0$ & $<2.0$ & 126 & $<1.0$ & 7.5 & 16 & 2770 & 12 & 3.5 \\
\hline MW-2033-F & $<14.0$ & $<1.0$ & $<2.0$ & 107 & $<1.0$ & 2.6 & 4.2 & 54 & $<1.0$ & 3.0 \\
\hline MW-2034 & 201 & $<1.0$ & $<2.0$ & 27 & $<1.0$ & 6.3 & 16 & 573 & 12 & 30.0 \\
\hline MW-2034-F & 18 & 2.6 & $<2.0$ & 19 & $<1.0$ & 5.2 & 5.8 & 71 & $<1.0$ & 28 \\
\hline
\end{tabular}


TABLE C.3 (Cont.)

\begin{tabular}{|c|c|c|c|c|c|c|c|c|c|c|}
\hline Well No. & $\begin{array}{c}\text { Aluminum } \\
(\mu \mathrm{g} / \mathrm{L})\end{array}$ & $\begin{array}{c}\text { Antimony } \\
(\mu \mathrm{g} / L)\end{array}$ & $\begin{array}{c}\text { Arsenic } \\
(\mu \mathrm{g} / \mathrm{L})\end{array}$ & $\begin{array}{c}\text { Barium } \\
(\mu \mathrm{g} / \mathrm{L})\end{array}$ & $\begin{array}{c}\text { Cadmium } \\
(\mu \mathrm{g} / \mathrm{L})\end{array}$ & $\begin{array}{c}\text { Chromium } \\
(\mu \mathrm{g} / \mathrm{L})\end{array}$ & $\begin{array}{l}\text { Copper } \\
(\mu \mathrm{g} / \mathrm{L})\end{array}$ & $\begin{array}{c}\text { Iron } \\
(\mu g / L)\end{array}$ & $\begin{array}{c}\text { Lead } \\
(\mu \mathrm{g} / \mathrm{L})\end{array}$ & $\begin{array}{c}\text { Lithium } \\
(\mu \mathrm{g} / \mathrm{L})\end{array}$ \\
\hline MW-2035 & 15 & $<1.0$ & $<2.0$ & 89.0 & $<1.0$ & 3.8 & 3.0 & 90 & $<1.0$ & $<2.0$ \\
\hline$M W-2035-F$ & 19 & $<1.0$ & $<2.0$ & 89.4 & $<1.0$ & 3.7 & 2.8 & $<15.0$ & $<1.0$ & 2.1 \\
\hline MW-2036 & 143 & $<1.0$ & $<2.0$ & 274 & $<1.0$ & 2.4 & $<2.0$ & $<15.0$ & $<1.0$ & 6.7 \\
\hline MW-2036-F & $<14.0$ & $<1.0$ & $<2.0$ & 280 & $<1.0$ & 1.7 & $<2.0$ & $<15.0$ & $<1.0$ & 7.0 \\
\hline MW-2037 & $<14.0$ & $<1.0$ & $<2.0$ & 82 & $<1.0$ & $<1.0$ & $<2.0$ & $<15.0$ & $<1.0$ & 411 \\
\hline MW-2037-F & $<14.0$ & 1.2 & $<2.0$ & 83 & $<1.0$ & 1.4 & $<2.0$ & $<15.0$ & $<1.0$ & 415 \\
\hline MW-2038 & 100 & $<1.0$ & $<2.0$ & 193 & $<1.0$ & 2.5 & $<2.0$ & 135 & $<1.0$ & 516 \\
\hline$M W-2038-F$ & 14 & $<1.0$ & $<2.0$ & 200 & $<1.0$ & 2.6 & $<2.0$ & 59 & $<1.0$ & 523 \\
\hline MW-2039 & 386 & $<1.0$ & $<2.0$ & 221 & $<1.0$ & 11 & 4.1 & 588 & 1.5 & 22 \\
\hline MW-2039-F & $<14.0$ & 1.8 & $<2.0$ & 203 & $<1.0$ & 5.8 & $<2.0$ & 36 & $<1.0$ & 21 \\
\hline MW-2040 & 1,100 & $<1.0$ & $<2.0$ & 784 & $<1.0$ & 12 & 4.9 & 1,410 & 1.1 & 33.0 \\
\hline $\mathrm{MW}-2040-\mathrm{F}$ & $<14.0$ & $<1.0$ & $<2.0$ & 766 & $<1.0$ & 5.3 & 3.3 & 47 & $<1.0$ & 32 \\
\hline MW-204l & 15 & $<1.0$ & $<2.0$ & 206 & $<1.0$ & 1.4 & 3.1 & 71 & $<1.0$ & 25 \\
\hline MW-2041-F & $<14.0$ & 1.7 & $<2.0$ & 200 & $<1.0$ & 1.3 & $<2.0$ & 24 & $<1.0$ & 26 \\
\hline MW-2042 & 42 & $<1.0$ & $<2.0$ & 498 & $<1.0$ & 3.8 & 2.3 & 139 & $<1.0$ & 20 \\
\hline MW-2042-F & $<14.0$ & $<1.0$ & $<2.0$ & 504 & $<1.0$ & 3.4 & $<2.0$ & 43 & $<1.0$ & 21 \\
\hline MW-2043 & 52 & $<1.0$ & $<2.0$ & 291 & $<1.0$ & 3.8 & 4.4 & 141 & $<1.0$ & 17.0 \\
\hline MW-2043-F & $<14.0$ & 2.1 & $<2.0$ & 293 & $<1.0$ & 3.5 & 3.9 & 20 & $<1.0$ & 17 \\
\hline MW-2044 & 65 & $<1.0$ & $<2.0$ & 48 & $<1.0$ & 2.5 & 2.2 & 55 & 1.1 & 29 \\
\hline MW-2044-F & 28 & 3.8 & $<2.0$ & 47 & $<1.0$ & 2.8 & 2.1 & 18 & $<1.0$ & 29 \\
\hline MW-3003 & 36.0 & $<1.0$ & $<2.0$ & 164 & $<1.0$ & 4.6 & 3.6 & 136 & 2.8 & 498 \\
\hline MW-3003-F & 21.0 & $<1.0$ & $<2.0$ & 164 & $<1.0$ & 3.8 & 3.2 & 78 & 1.3 & 500 \\
\hline MW-3006 & 2.5 & $<1.0$ & $<2.0$ & 157 & $<1.0$ & 3.6 & $<2.0$ & 329 & $<1.0$ & 12 \\
\hline MW-3006-F & 25 & $<1.0$ & 3.0 & 158 & $<1.0$ & 3.8 & $<2.0$ & 336 & $<1.0$ & 13 \\
\hline MW-3019 & 19 & $<1.0$ & $<2.0$ & 342 & $<1.0$ & 7.5 & $<2.0$ & 42 & 2.6 & 15 \\
\hline MW-3019-F & 19 & $<1.0$ & $<2.0$ & 346 & $<1.0$ & 5.0 & $<2.0$ & 19 & $<1.0$ & 11 \\
\hline
\end{tabular}


TABLE C.3 (Cont.)

\begin{tabular}{|c|c|c|c|c|c|c|c|c|c|c|}
\hline Well No. & $\begin{array}{c}\text { Aluminum } \\
(\mu \mathrm{g} / \mathrm{L})\end{array}$ & $\begin{array}{c}\text { Antimony } \\
(\mu \mathrm{g} / \mathrm{L})\end{array}$ & $\begin{array}{c}\text { Arsenic } \\
(\mu \mathrm{g} / \mathrm{L})\end{array}$ & $\begin{array}{l}\text { Barium } \\
(\mu \mathrm{g} / \mathrm{L})\end{array}$ & $\begin{array}{c}\text { Cadmium } \\
(\mu \mathrm{g} / \mathrm{L})\end{array}$ & $\begin{array}{c}\text { Chromium } \\
(\mu \mathrm{g} / \mathrm{L})\end{array}$ & $\begin{array}{l}\text { Copper } \\
(\mu g / L)\end{array}$ & $\begin{array}{c}\text { Iron } \\
(\mu \mathrm{g} / \mathrm{L})\end{array}$ & $\begin{array}{c}\text { Lead } \\
(\mu \mathrm{g} / \mathrm{L})\end{array}$ & $\begin{array}{c}\text { Lithium } \\
(\mu \mathrm{g} / \mathrm{L})\end{array}$ \\
\hline MW-3023 & 4,090 & $<1.0$ & 2.8 & 69 & $<1.0$ & 16.0 & 25 & 6,800 & 16 & 601 \\
\hline MW-3023-F & 17.0 & $<1.0$ & $<2.0$ & 42 & $<1.0$ & 3.7 & 7.5 & 79 & $<1.0$ & 611 \\
\hline MW-3024 & $<14.0$ & $<1.0$ & $<2.0$ & 170 & $<1.0$ & 1.7 & 3.3 & 33 & $<1.0$ & 202 \\
\hline MW-3024-F & $<14.0$ & 1.5 & $<2.0$ & 165 & $<1.0$ & 2.1 & 3.2 & $<15.0$ & $<1.0$ & 213 \\
\hline MW-3025 & 148 & $<1.0$ & $<2.0$ & 654 & $<1.0$ & 2.4 & 3.5 & 1,070 & 1.2 & 109 \\
\hline MW-3025-F & $<14.0$ & $<1.0$ & $<2.0$ & 610 & $<1.0$ & 2.7 & 3.0 & 30 & $<1.0$ & 135 \\
\hline MW-3026 & 2,520 & $<1.0$ & $<2.0$ & 1,660 & $<1.0$ & 2.1 & 9.4 & 1,230 & 8.2 & 34 \\
\hline$M W-3026-F$ & $<14.0$ & 1.6 & $<2.0$ & 1,360 & $<1.0$ & 1.6 & $<2.0$ & 105 & $<1.0$ & 34 \\
\hline MW-3027 & 825 & $<1.0$ & $<2.0$ & 900 & $<1.0$ & 2.9 & 7.6 & 1,120 & 2.3 & 18.0 \\
\hline MW-3027-F & $<14.0$ & $<1.0$ & $<2.0$ & 832 & $<1.0$ & 1.4 & $<2.0$ & 69.0 & $<1.0$ & 17 \\
\hline MW-4001 & 28 & $<1.0$ & $<2.0$ & 83 & $<1.0$ & 1.9 & $<2.0$ & 70 & 1.6 & 7.7 \\
\hline MW-4001-F & $<14.0$ & $<1.0$ & $<2.0$ & 80 & $<1.0$ & 1.8 & $<2.0$ & $<15.0$ & $<1.0$ & 6.7 \\
\hline$M W-4002$ & 128 & $<1.0$ & $<2.0$ & 109 & $<1.0$ & 1.6 & 3.4 & 643 & 3.2 & 2.4 \\
\hline $\mathrm{MW}-4002-\mathrm{F}$ & 32.0 & $<1.0$ & $<2.0$ & 92 & $<1.0$ & 1.6 & 2.1 & 26 & $<1.0$ & $<2.0$ \\
\hline MW-4003 & $<14.0$ & $<1.0$ & $<2.0$ & 162 & $<1.0$ & 2.3 & 3.3 & 42 & $<1.0$ & 3.0 \\
\hline MW-4003-F & $<14.0$ & 1.9 & $<2.0$ & 163 & $<1.0$ & 1.7 & $<2.0$ & $<15.0$ & $<1.0$ & 3.1 \\
\hline MW-4004 & 118 & $<1.0$ & $<2.0$ & 86 & $<1.0$ & 3.6 & $<2.0$ & 632 & 2.3 & 4.0 \\
\hline MW-4004-F & $<14.0$ & $<1.0$ & $<2.0$ & 81 & $<1.0$ & 3.6 & $<2.0$ & $<15.0$ & $<1.0$ & 4.2 \\
\hline MW-4005 & $<14.0$ & 1.0 & $<2.0$ & 93 & $<1.0$ & 13 & 2.4 & 123 & 31 & 6.7 \\
\hline MW-4005-F & $<14.0$ & 2.4 & $<2.0$ & 92 & $<1.0$ & 12.0 & $<2.0$ & 24 & 15 & 6.8 \\
\hline MW-4006 & 135 & $<1.0$ & $<2.0$ & 180 & $<1.0$ & 1.5 & $<2.0$ & 102 & 1.8 & $<2.0$ \\
\hline$M W-4006-F$ & $<14.0$ & 1.3 & 2.5 & 173 & $<1.0$ & 1.6 & $<2.0$ & $<15.0$ & $<1.0$ & $<2.0$ \\
\hline$M W-4007$ & 163 & $<1.0$ & 2.2 & 76 & $<1.0$ & 9.8 & 3.0 & 125 & 4.8 & 6.0 \\
\hline$M W-4007-F$ & $<14.0$ & 2.1 & $<2.0$ & 75.0 & $<1.0$ & 9.5 & $<2.0$ & $<15.0$ & $<1.0$ & 5.9 \\
\hline MW-4008 & 25 & $<1.0$ & $<2.0$ & 109 & $<1.0$ & 5.7 & $<2.0$ & 95 & 15 & 2.6 \\
\hline$M W-4008-F$ & $<14.0$ & $<1.0$ & $<2.0$ & 106 & $<1.0$ & 3.7 & $<2.0$ & $<15.0$ & $<1.0$ & 2.3 \\
\hline
\end{tabular}


TABLE C.3 (Cont.)

\begin{tabular}{|c|c|c|c|c|c|c|c|c|c|c|}
\hline Well No. & $\begin{array}{c}\text { Aluminum } \\
(\mu \mathrm{g} / L)\end{array}$ & $\begin{array}{c}\text { Antimony } \\
(\mu \mathrm{g} / \mathrm{L})\end{array}$ & $\begin{array}{c}\text { Arsenic } \\
(\mu \mathrm{g} / L)\end{array}$ & $\begin{array}{c}\text { Barium } \\
(\mu g / L)\end{array}$ & $\begin{array}{c}\text { Cadmium } \\
(\mu \mathrm{g} / \mathrm{L})\end{array}$ & $\begin{array}{c}\text { Chromium } \\
(\mu \mathrm{g} / L)\end{array}$ & $\begin{array}{l}\text { Copper } \\
(\mu \mathrm{g} / \mathrm{L})\end{array}$ & $\begin{array}{c}\text { Iron } \\
(\mu \mathrm{g} / \mathrm{L})\end{array}$ & $\begin{array}{c}\text { Lead } \\
(\mu \mathrm{g} / \mathrm{L})\end{array}$ & $\begin{array}{c}\text { Lithium } \\
(\mu \mathrm{g} / \mathrm{L})\end{array}$ \\
\hline MW-4009 & 19 & 2.1 & $<2.0$ & 31 & $<1.0$ & 27 & $<2.0$ & 18 & 4.3 & 90 \\
\hline MW-4009-F & 36 & 2.9 & $<2.0$ & 31 & $<1.0$ & 25 & $<2.0$ & $<15.0$ & $<1.0$ & 87.0 \\
\hline$M W-4010$ & 18 & 1.3 & $<2.0$ & 83.0 & $<1.0$ & 2.7 & 6.6 & 75 & 35 & 4.9 \\
\hline MW-4010-F & $<14.0$ & 1.2 & $<2.0$ & 78 & $<1.0$ & 4.7 & 39.0 & $<15.0$ & 14 & 4.7 \\
\hline MW-401I & 20 & $<1.0$ & $<2.0$ & 334 & $<1.0$ & 13 & 2.1 & $<15.0$ & 5.8 & 65.0 \\
\hline$M W-40 \mid I-F$ & 28 & 5.0 & $<2.0$ & 318 & $<1.0$ & 16 & 2.3 & $<15.0$ & 1.4 & 66 \\
\hline MW-4012 & 46 & $<1.0$ & 3.7 & 20 & $<1.0$ & 99 & 2.6 & 199 & 3.3 & 84 \\
\hline$M W-4012-F$ & $<14.0$ & 2.5 & 5.4 & 18.0 & $<1.0$ & 94 & $<2.0$ & 21 & $<1.0$ & $811^{\circ}$ \\
\hline MW-4013 & $<14.0$ & $<1.0$ & 6.3 & 152 & $<1.0$ & 3.5 & $<2.0$ & 63 & $<1.0$ & 68.0 \\
\hline$M W-4013-F$ & 16 & 1.6 & 5.4 & 158 & $<1.0$ & 3.8 & $<2.0$ & 80 & $<1.0$ & 72 \\
\hline MW-4014 & 50.0 & 2.1 & 4.1 & 122 & $<1.0$ & 4.8 & $<2.0$ & 437 & 1.5 & 2.8 \\
\hline$M W-4014-F$ & $<14.0$ & 1.3 & 5.4 & 125 & $<1.0$ & 4.9 & $<2.0$ & 72 & $<1.0$ & 2.9 \\
\hline$M W-4015$ & 40.0 & $<1.0$ & $<2.0$ & 235 & $<1.0$ & 2.7 & $<2.0$ & 325 & $<1.0$ & $<2.0$ \\
\hline MW-4015-F & 20 & 1.3 & $<2.0$ & 218 & $<1.0$ & 1.5 & $<2.0$ & 64 & $<1.0$ & $<2.0$ \\
\hline MW-4016 & 15 & $<1.0$ & $<2.0$ & 246 & $<1.0$ & 3.8 & $<2.0$ & 154 & 1.3 & 3.7 \\
\hline MW-4016-F & $<14.0$ & $<1.0$ & $<2.0$ & 244 & $<1.0$ & 4.2 & $<2.0$ & 68 & $<1.0$ & 3.7 \\
\hline MW-4018 & $<14.0$ & $<1.0$ & 3.6 & 214 & $<1.0$ & 5.2 & $<2.0$ & 35 & 10 & 4.1 \\
\hline$M W-4018-F$ & $<14.0$ & 1.4 & 3.7 & 216 & $<1.0$ & 4.4 & $<2.0$ & 32 & $<1.0$ & 3.3 \\
\hline MW-4019 & 322 & $<1.0$ & $<2.0$ & 189 & $<1.0$ & 6.1 & 5.4 & 411 & 46 & 10.0 \\
\hline MW-4019-F & 231 & $<1.0$ & 5.3 & 178 & $<1.0$ & 7.1 & 3.7 & 452 & 23 & 9.8 \\
\hline MW-4020 & $<14.0$ & $<1.0$ & 3.8 & 72 & $<1.0$ & 13 & $<2.0$ & 89 & 3.6 & 22 \\
\hline MW-4020-F & $<14.0$ & $<1.0$ & 4.0 & 71.0 & $<1.0$ & 13 & $<2.0$ & 93 & 1.4 & 21 \\
\hline$M W-4021$ & $<14.0$ & $<1.0$ & $<2.0$ & 35 & $<1.0$ & 5.8 & $<2.0$ & 70 & 3.4 & 23 \\
\hline$M W-4021-F$ & 20 & 2.9 & $<2.0$ & 36.0 & $<1.0$ & 4.5 & $<2.0$ & 53 & 1.7 & 20 \\
\hline MW-4022 & 33,200 & $<1.0$ & 18 & 635 & 1.9 & 180 & 67 & 56,800 & 206 & 28 \\
\hline$M W-4022-F$ & 29 & 1.2 & 4.1 & 85 & $<1.0$ & 9.2 & $<2.0$ & 71 & $<1.0$ & 7.0 \\
\hline
\end{tabular}


TABLE C.3 (Cont.)

\begin{tabular}{|c|c|c|c|c|c|c|c|c|c|c|}
\hline Well No. & $\begin{array}{c}\text { Aluminum } \\
(\mu \mathrm{g} / \mathrm{L})\end{array}$ & $\begin{array}{c}\text { Antimony } \\
(\mu \mathrm{g} / \mathrm{L})\end{array}$ & $\begin{array}{l}\text { Arsenic } \\
(\mu \mathrm{g} / \mathrm{L})\end{array}$ & $\begin{array}{l}\text { Barium } \\
(\mu \mathrm{g} / \mathrm{L})\end{array}$ & $\begin{array}{c}\text { Cadmium } \\
(\mu \mathrm{g} / \mathrm{L})\end{array}$ & $\begin{array}{c}\text { Chromium } \\
(\mu \mathrm{g} / \mathrm{L})\end{array}$ & $\begin{array}{l}\text { Copper } \\
(\mu \mathrm{g} / \mathrm{L})\end{array}$ & $\begin{array}{c}\text { Iron } \\
(\mu \mathrm{g} / \mathrm{L})\end{array}$ & $\begin{array}{l}\text { Lead } \\
(\mu g / L)\end{array}$ & $\begin{array}{c}\text { Lithium } \\
(\mu \mathrm{g} / \mathrm{L})\end{array}$ \\
\hline$M W-4023$ & $<14.0$ & $<1.0$ & $<2.0$ & 90 & $<1.0$ & 3.0 & 2.4 & 79 & 1.1 & 14 \\
\hline MW-4023-F & $<14.0$ & 1.4 & $<2.0$ & 92 & $<1.0$ & 2.0 & $<2.0$ & 29 & $<1.0$ & 15 \\
\hline$M W-4024^{b}$ & $26,800.0$ & $<25.0$ & $<4.0$ & 143.0 & $<3.0$ & 122.0 & 33.7 & $14,800.0$ & 7.0 & 81.8 \\
\hline$M W-4024-F^{h}$ & 40.4 & $<25.0$ & $<4.0$ & 21.2 & $<3.0$ & 7.6 & $<2.0$ & 7.6 & $<5.0$ & 24.8 \\
\hline MW-4025 & 2,370 & 2.3 & 6.1 & 183 & $<1.0$ & 35 & 15 & 4,480 & 6.9 & 12 \\
\hline MW-4025-F & $<14.0$ & $<1.0$ & 4.7 & 127 & $<1.0$ & 3.9 & 3.4 & 33 & $<1.0$ & 9.2 \\
\hline MWD-2 & 62,400 & 1.4 & 12 & 674 & $<1.0$ & 25 & 28.0 & 33,200 & 82 & 30 \\
\hline MWD-2-F & 569 & 3.4 & 3.1 & 108 & $<1.0$ & 3.1 & $<2.0$ & 272 & $<1.0$ & 4.7 \\
\hline MWD-5 & 234 & $<1.0$ & $<2.0$ & 103 & $<1.0$ & 3.5 & 2.0 & 194 & $<1.0$ & 20 \\
\hline MWD-5-F & $<14.0$ & 2.6 & $<2.0$ & 100 & $<1.0$ & 3.4 & $<2.0$ & $<15.0$ & $<1.0$ & 20 \\
\hline MWD-6 & $<14.0$ & $<1.0$ & $<2.0$ & 175 & $<1.0$ & 1.7 & $<2.0$ & $<15.0$ & $<1.0$ & 3.5 \\
\hline MWD-6-F & $<14.0$ & $<1.0$ & $<2.0$ & 181 & $<1.0$ & 2.4 & $<2.0$ & $<15.0$ & $<1.0$ & 3.6 \\
\hline MWD-9 & 20 & $<1.0$ & $<2.0$ & 145 & $<1.0$ & 1.1 & $<2.0$ & $<15.0$ & $<1.0$ & 5.4 \\
\hline MWD-9-F & $<14.0$ & $<1.0$ & $<2.0$ & 142 & $<1.0$ & 2.0 & $<2.0$ & 25 & $<1.0$ & 5.5 \\
\hline MWD-15 & 496 & $<1.0$ & $<2.0$ & 118 & $<1.0$ & 1.7 & $<2.0$ & 171 & $<1.0$ & $<2.0$ \\
\hline MWD-15-F & $<14.0$ & $<1.0$ & $<2.0$ & 118 & $<1.0$ & 2.2 & $<2.0$ & 20 & $<1.0$ & $<2.0$ \\
\hline MWD-18 & 46 & $<1.0$ & $<2.0$ & 129 & $<1.0$ & 1.7 & $<2.0$ & 179 & $<1.0$ & 6.7 \\
\hline MWD-18-F & $<14.0$ & $<1.0$ & $<2.0$ & 131 & $<1.0$ & 1.7 & $<2.0$ & $<15.0$ & $<1.0$ & 7.3 \\
\hline MWD-23 & 903 & $<1.0$ & 3.3 & 167 & $<1.0$ & 4.3 & 7.4 & 612 & 2.1 & 4.3 \\
\hline MWD-23-F & 74 & 2.1 & $<2.0$ & 155 & $<1.0$ & 2.0 & 2.4 & 90 & $<1.0$ & 3.8 \\
\hline MWD-25 & 21 & $<1.0$ & 2.9 & 121 & $<1.0$ & 4.4 & $<2.0$ & 181 & $<1.0$ & 2.4 \\
\hline MWD-25-F & 27 & $<1.0$ & 2.2 & 122 & $<1.0$ & 3.6 & $<2.0$ & 104 & $<1.0$ & 2.3 \\
\hline MWD-105 & 23 & $<1.0$ & $<2.0$ & 107 & $<1.0$ & 2.4 & $<2.0$ & $<15.0$ & $<1.0$ & 3.7 \\
\hline MWD-105-F & $<14.0$ & $<1.0$ & $<2.0$ & 110 & $<1.0$ & 1.8 & $<2.0$ & $<15.0$ & $<1.0$ & 3.8 \\
\hline MWD-106 & $<14.0$ & $<1.0$ & $<2.0$ & 133 & $<1.0$ & 2.1 & 2.3 & 157 & $<1.0$ & 3.6 \\
\hline MWD-106-F & $<14.0$ & $<1.0$ & $<2.0$ & 134 & $<1.0$ & 2.1 & $<2.0$ & 77 & $<1.0$ & 3.6 \\
\hline MWD-107 & 963 & $<1.0$ & 7.3 & 174 & $<1.0$ & 2.5 & 9.2 & 494 & 2.5 & 5.4 \\
\hline MWD-107-F & 36 & $<1.0$ & 4.4 & 153 & $<1.0$ & 2.8 & $<2.0$ & 33 & $<1.0$ & 5.0 \\
\hline
\end{tabular}


TABLE C.3 (Cont.)

\begin{tabular}{|c|c|c|c|c|c|c|c|c|c|c|}
\hline Well No. & $\begin{array}{c}\text { Aluminum } \\
(\mu \mathrm{g} / \mathrm{L})\end{array}$ & $\begin{array}{c}\text { Antimony } \\
(\mu \mathrm{g} / \mathrm{L})\end{array}$ & $\begin{array}{c}\text { Arsenic } \\
(\mu g / L)\end{array}$ & $\begin{array}{c}\text { Barium } \\
(\mu \mathrm{g} / L)\end{array}$ & $\begin{array}{c}\text { Cadmium } \\
(\mu \mathrm{g} / \mathrm{L})\end{array}$ & $\begin{array}{c}\text { Chromium } \\
(\mu \mathrm{g} / \mathrm{L})\end{array}$ & $\begin{array}{l}\text { Copper } \\
(\mu \mathrm{g} / \mathrm{L})\end{array}$ & $\begin{array}{c}\text { Iron } \\
(\mu \mathrm{g} / \mathrm{L})\end{array}$ & $\begin{array}{c}\text { Lead } \\
(\mu \mathrm{g} / \mathrm{L})\end{array}$ & $\begin{array}{c}\text { Lithium } \\
(\mu g / L)\end{array}$ \\
\hline MW-D109 & $<14.0$ & $<1.0$ & $<2.0$ & 150 & $<1.0$ & 1.3 & $<2.0$ & 22 & $<1.0$ & 3.9 \\
\hline MWD-109-F & $<14.0$ & $<1.0$ & $<2.0$ & 146 & $<1.0$ & $<1.0$ & $<2.0$ & $<15.0$ & $<1.0$ & 3.3 \\
\hline MWD-112 & $<14.0$ & $<1.0$ & 4.9 & 86 & $<1.0$ & 5.7 & $<2.0$ & 245 & $<1.0$ & 2.7 \\
\hline MWD-112-F & 14.0 & $<1.0$ & 5.6 & 85 & $<1.0$ & 5.8 & $<2.0$ & 270 & $<1.0$ & 2.7 \\
\hline MWS-1 & $<14.0$ & $<1.0$ & $<2.0$ & 98 & $<1.0$ & 2.9 & $<2.0$ & 41 & $<1.0$ & $<2.0$ \\
\hline MWS-1-F & $<14.0$ & $<1.0$ & $<2.0$ & 98 & $<1.0$ & 2.2 & $<2.0$ & $<15.0$ & $<1.0$ & $<2.0$ \\
\hline MWS-2 & $<14.0$ & $<1.0$ & $<2.0$ & 101 & $<1.0$ & 6.1 & $<2.0$ & 22 & $<1.0$ & 3.6 \\
\hline MWS-2-F & $<14.0$ & $<1.0$ & $<2.0$ & 99 & $<1.0$ & 4.4 & $<2.0$ & $<15.0$ & $<1.0$ & 3.8 \\
\hline MWS-3 & 58 & $<1.0$ & $<2.0$ & 90 & $<1.0$ & 9.4 & 2.4 & 43 & $<1.0$ & 5.1 \\
\hline MWS-3-F & $<14.0$ & $<1.0$ & $<2.0$ & 93 & $<1.0$ & 9.3 & $<2.0$ & $<15.0$ & $<1.0$ & 4.8 \\
\hline MWS-4 & 557 & $<1.0$ & $<2.0$ & 166 & $<1.0$ & 2.0 & 7.2 & 521 & 2.1 & 4.0 \\
\hline MWS-4-F & 69 & $<1.0$ & $<2.0$ & 158 & $<1.0$ & 1.7 & $<2.0$ & 48 & $<1.0$ & 3.6 \\
\hline MWS-5 & 62 & $<1.0$ & $<2.0$ & 107 & $<1.0$ & 3.2 & $<2.0$ & 74 & $<1.0$ & 3.0 \\
\hline MWS-5-F & $<14.0$ & $<1.0$ & $<2.0$ & 107 & $<1.0$ & 5.3 & 2.3 & 182 & $<1.0$ & 2.9 \\
\hline MWS-6 & $<14.0$ & $<1.0$ & $<2.0$ & 160 & $<1.0$ & 1.7 & $<2.0$ & 18 & $<1.0$ & 3.5 \\
\hline MWS-6-F & $<14.0$ & $<1.0$ & $<2.0$ & 161 & $<1.0$ & 1.6 & $<2.0$ & $<15.0$ & $<1.0$ & 3.6 \\
\hline MWS-7 & $<14.0$ & $<1.0$ & $<2.0$ & 138 & $<1.0$ & 1.2 & $<2.0$ & 16 & $<1.0$ & $<2.0$ \\
\hline MWS-7-F & $<14.0$ & $<1.0$ & $<2.0$ & 136 & $<1.0$ & 1.2 & $<2.0$ & $<15.0$ & $<1.0$ & $<2.0$ \\
\hline MWS-8 & 550 & $<1.0$ & $<2.0$ & 229 & $<1.0$ & 7.6 & 9.8 & 792 & 3.0 & 22.6 \\
\hline MWS-8-F & $<14.0$ & 1.8 & $<2.0$ & 221 & $<1.0$ & 3.4 & $<2.0$ & -26 & $<1.0$ & 22.0 \\
\hline MWS-9 & $<14.0$ & $<1.0$ & $<2.0$ & 134 & $<1.0$ & 2.5 & $<2.0$ & $<15.0$ & $<1.0$ & 6.5 \\
\hline MWS-9-F & $<14.0$ & $<1.0$ & $<2.0$ & 136 & $<1.0$ & 2.5 & $<2.0$ & 25 & $<1.0$ & 6.7 \\
\hline MWS-10 & $<14.0$ & $<1.0$ & $<2.0$ & 215 & $<1.0$ & 2.7 & $<2.0$ & 25.0 & $<1.0$ & 4.5 \\
\hline MWS-10-F & $<14.0$ & $<1.0$ & $<2.0$ & 214 & $<1.0$ & 3.2 & $<2.0$ & $<15.0$ & $<1.0$ & 4.4 \\
\hline MWS-11 & 89 & $(0.55)$ & $<2.0$ & 122 & $(0.12)$ & $<1.8$ & $(1.20)$ & $<80$ & $(0.04)$ & 2.4 \\
\hline MWS-11-F & $<14.0$ & 2.0 & $<2.0$ & 125 & $(0.09)$ & $<1.4$ & $(1.02)$ & (8.3) & $<1.0$ & 2.2 \\
\hline
\end{tabular}


TABLE C.3 (Cont.)

\begin{tabular}{|c|c|c|c|c|c|c|c|c|c|c|}
\hline Well No. & $\begin{array}{c}\text { Aluminum } \\
(\mu \mathrm{g} / \mathrm{L})\end{array}$ & $\begin{array}{c}\text { Antimony } \\
(\mu g / L)\end{array}$ & $\begin{array}{c}\text { Arscnic } \\
(\mu \mathrm{g} / \mathrm{L})\end{array}$ & $\begin{array}{l}\text { Barium } \\
(\mu \mathrm{g} / \mathrm{L})\end{array}$ & $\begin{array}{c}\text { Cadmium } \\
(\mu \mathrm{g} / \mathrm{L})\end{array}$ & $\begin{array}{c}\text { Chromium } \\
(\mu \mathrm{g} / \mathrm{L})\end{array}$ & $\begin{array}{l}\text { Copper } \\
(\mu \mathrm{g} / \mathrm{L})\end{array}$ & $\begin{array}{c}\text { Iron } \\
(\mu \mathrm{g} / \mathrm{L})\end{array}$ & $\begin{array}{c}\text { Lead } \\
(\mu \mathrm{g} / \mathrm{L})\end{array}$ & $\begin{array}{c}\text { Lithium } \\
(\mu \mathrm{g} / \mathrm{L})\end{array}$ \\
\hline MWS-12 & 601 & $<1.0$ & $<2.0$ & 77 & $<1.0$ & 3.9 & $<2.0$ & 33 & $<1.0$ & 3.1 \\
\hline MWS-12-F & $<14.0$ & $<1.0$ & $<2.0$ & 73 & $<1.0$ & 2.9 & $<2.0$ & 25 & $<1.0$ & 2.5 \\
\hline MW-13 & $(5.00)$ & $(0.49)$ & $<2.0$ & 26 & $(0.54)$ & $<1.6$ & 3.4 & $<47$ & $<1.0$ & 6.8 \\
\hline MWS-13-F & $(5.1)$ & 2.6 & $<2.0$ & 25 & $(0.53)$ & $<1.8$ & 3.4 & $<33$ & $<1.0$ & 6.7 \\
\hline MWS-14 & 179 & $<1.0$ & $<2.0$ & 604 & $<1.0$ & 3.9 & 7.2 & 798 & 2.4 & 25 \\
\hline MWS-14-F & $<14.0$ & 1.4 & 2.4 & 573 & $<1.0$ & 1.9 & 2.1 & 37 & $<1.0$ & 24.0 \\
\hline MWS-15 & $<14.0$ & $<1.0$ & $<2.0$ & 80 & $<1.0$ & 1.1 & $<2.0$ & 30.0 & $<1.0$ & $<2.0$ \\
\hline MWS-15-F & $<14.0$ & 1.1 & $<2.0$ & 79 & $<1.0$ & 2.1 & $<2.0$ & 38 & $<1.0$ & $<2.0$ \\
\hline MWS-16 & $<14.0$ & $<1.0$ & $<2.0$ & 139 & $<1.0$ & $<1.0$ & $<2.0$ & 21 & $<1.0$ & $<2.0$ \\
\hline MWS-16-F & $<14.0$ & $<1.0$ & $<2.0$ & 134 & $<1.0$ & 1.2 & $<2.0$ & 17 & $<1.0$ & $<2.0$ \\
\hline MWS-17 & 81.0 & $(0.23)$ & $<2.0$ & 79 & $<1.0$ & $<2.0$ & (1.3) & 127 & $(0.03)$ & $(2.0)$ \\
\hline MWS-17-F & $<14.0$ & $(0.43)$ & $(2.0)$ & 78 & $(0.11)$ & $<1.5$ & (1.2) & 27 & $(0.09)$ & 2.0 \\
\hline MWS-18 & 326 & 1.7 & 2.4 & 67 & $<1.0$ & 5.9 & 3.3 & 772 & 2.9 & 9.4 \\
\hline MWS-18-F & 37 & 3.2 & $<2.0$ & 58 & $<1.0$ & 2.4 & 2.3 & $<15.0$ & $<1.0$ & 9.6 \\
\hline MWS-19 & 1,140 & $<1.0$ & $<2.0$ & 116 & $<1.0$ & 3.4 & 2.9 & 660 & 2.7 & $<2.0$ \\
\hline MWS-19-F & $<14.0$ & 2.2 & $<2.0$ & 109 & $<1.0$ & 2.4 & $<2.0$ & 27 & $<1.0$ & $<2.0$ \\
\hline MWS-20 & $(3.9)$ & $(0.005)$ & $<2.0$ & 78 & $(0.06)$ & 7.9 & $(1.4)$ & $<63.0$ & $(0.01)$ & (1.4) \\
\hline MWS-20-F & $(2.4)$ & $<1.0$ & 2.2 & 78 & $(0.06)$ & $<7.1$ & $(1.5)$ & $<27$ & $(0.03)$ & (1.3) \\
\hline MWS-2I & 723 & $<1.0$ & $<2.0$ & 372 & $<1.0$ & 2.2 & 5.5 & 1220 & 3.8 & 356 \\
\hline MWS-21-F & $<14.0$ & $<1.0$ & $<2.0$ & 357 & $<1.0$ & 1.7 & 24 & 62 & $<1.0$ & 348 \\
\hline MWS-22 & 50 & $<1.0$ & $<2.0$ & 147 & $(0.08)$ & $<2.4$ & $(1.1)$ & $<111$ & $(0.13)$ & 2.9 \\
\hline MWS-22-F & $<14.0$ & $(0.68)$ & $(0.07)$ & 153 & $(0.11)$ & $(0.91)$ & $(0.69)$ & $<15.0$ & $<1.0$ & 2.9 \\
\hline MWS-23 & 15,900 & $<1.0$ & 7.8 & 21.5 & $<1.0$ & 19 & 33 & 21,200 & 15 & 10 \\
\hline MWS-23-F & $<14.0$ & 1.2 & $<2.0$ & 89 & $<1.0$ & 1.8 & 2.3 & 16 & $<1.0$ & $<2.0$ \\
\hline MWS-25 & 559 & $<1.0$ & 5.2 & 81 & $<1.0$ & 1.8 & 2.6 & 552 & $<1.0$ & $<2.0$ \\
\hline MWS-25-F & $<14.0$ & $<1.0$ & 3.6 & 77 & $<1.0$ & $<1.0$ & 2.5 & 52 & $<1.0$ & $<2.0$ \\
\hline
\end{tabular}


TABLE C.3 (Cont.)

\begin{tabular}{|c|c|c|c|c|c|c|c|c|c|c|}
\hline Well No. & $\begin{array}{c}\text { Aluminum } \\
(\mu \mathrm{g} / \mathrm{L})\end{array}$ & $\begin{array}{c}\text { Antimony } \\
(\mu \mathrm{g} / \mathrm{L})\end{array}$ & $\begin{array}{c}\text { Arsenic } \\
(\mu \mathrm{g} /)\end{array}$ & $\begin{array}{c}\text { Barium } \\
(\mu \mathrm{g} / \mathrm{L})\end{array}$ & $\begin{array}{c}\text { Cadmium } \\
(\mu g / L)\end{array}$ & $\begin{array}{c}\text { Chromium } \\
(\mu \mathrm{g} / \mathrm{L})\end{array}$ & $\begin{array}{l}\text { Copper } \\
(\mu \mathrm{g} / \mathrm{L})\end{array}$ & $\begin{array}{c}\text { Iron } \\
(\mu \mathrm{g} / \mathrm{L})\end{array}$ & $\begin{array}{c}\text { Lead } \\
(\mu \mathrm{g} / \mathrm{L})\end{array}$ & $\begin{array}{c}\text { Lithium } \\
(\mu \mathrm{g} / \mathrm{L})\end{array}$ \\
\hline MWS-26 & 16,400 & $(0.28)$ & $<7.2$ & 158 & $(0.74)$ & 23 & 25 & 31.500 & 19 & 15 \\
\hline MWS-26-F & 282 & $(0.24)$ & $(0.63)$ & 37 & $(0.08)$ & $<1.8$ & 6.4 & 514 & 1.3 & 5.8 \\
\hline MWS-101 & $<14.0$ & $<1.0$ & 11 & 449 & $<1.0$ & $<1.0$ & $<2.0$ & 5,650 & $<1.0$ & $<2.0$ \\
\hline MWS-101-F & 888 & $<1.0$ & 11 & 463 & $<1.0$ & 4.9 & 7.3 & 6,300 & 1.9 & $<2.0$ \\
\hline MWS-102 & 8,190 & $<1.0$ & 12 & 255 & $<1.0$ & 5.0 & 13.0 & 7,670 & 14 & 7.4 \\
\hline MWS-102-F & 56 & $<1.0$ & 14 & 216 & $<1.0$ & 1.0 & 5.3 & 2,850 & $<1.0$ & 3.1 \\
\hline MWS-103 & 3,620 & $<1.0$ & 56 & 210 & $<1.0$ & 4.6 & 19.0 & 15,800 & 11 & 4.2 \\
\hline MWS-103-F & $<14.0$ & 4.7 & 6.0 & 150 & $<1.0$ & $<1.0$ & $<2.0$ & 77.0 & $<1.0$ & $<2.0$ \\
\hline MWS-104 & 593 & $<1.0$ & $<2.0$ & 183 & $<1.0$ & 1.5 & $<2.0$ & 220 & $<1.0$ & $<2.0$ \\
\hline MWS-104-F & 33 & $<1.0$ & $<2.0$ & 183 & $<1.0$ & 1.6 & $<2.0$ & $<15.0$ & $<1.0$ & $<2.0$ \\
\hline MWS-105 & $<14.0$ & $<1.0$ & $<2.0$ & 137 & $<1.0$ & 2.3 & $<2.0$ & $<15.0$ & $<1.0$ & $<2.0$, \\
\hline MWS-105-F & $<14.0$ & $<1.0$ & 2.3 & 136 & $<1.0$ & 2.3 & $<2.0$ & $<15.0$ & $<1.0$ & $<2.0$ \\
\hline MWS-106 & 1,070 & $<1.0$ & $<2.0$ & 223 & $<1.0$ & 2.4 & 10 & 859 & 6.0 & 2.3 \\
\hline MWS-106-F & $<14.0$ & $<1.0$ & $<2.0$ & 203 & $<1.0$ & 2.4 & $<2.0$ & 54.0 & $<1.0$ & $<2.0$. \\
\hline MWS-107 & 599 & $<1.0$ & $<2.0$ & 142 & $<1.0$ & 4.1 & 7.7 & 713 & 1.7 & 4.3 \\
\hline MWS-107-F & $<14.0$ & $<1.0$ & 2.1 & 126 & $<1.0$ & 3.0 & $<2.0$ & 175 & $<1.0$ & 4.8 \\
\hline MWS-108 & $<14.0$ & 1.0 & 5.6 & 137 & $<1.0$ & 3.1 & 2.0 & 39 & $<1.0$ & 4.0 \\
\hline MWS-108-F & $<14.0$ & $<1.0$ & $<2.0$ & 126 & $<1.0$ & 2.5 & $<2.0$ & 148 & $<1.0$ & 4.7 \\
\hline MWS-109 & 109 & $<1.0$ & $<2.0$ & 223 & $<1.0$ & 1.0 & $<2.0$ & 242 & $<1.0$ & 2.2 \\
\hline MWS-109-F & $<14.0$ & 1.3 & $<2.0$ & 222 & $<1.0$ & 1.6 & $<2.0$ & $<15.0$ & $<1.0$ & 2.3 \\
\hline MWS-110 & 431 & $<1.0$ & $<2.0$ & 175 & $<1.0$ & 2.3 & $<2.0$ & 516 & $<1.0$ & 2.8 \\
\hline MWS-110-F & $<14.0$ & $<1.0$ & $<2.0$ & 167 & $<1.0$ & 1.4 & $<2.0$ & $<15.0$ & $<1.0$ & 2.5 \\
\hline MWS-111 & $<14.0$ & $<1.0$ & $<2.0$ & 377 & $<1.0$ & 2.9 & $<2.0$ & 20 & $<1.0$ & $<2.0$ \\
\hline MWS-111-F & $<14.0$ & $<1.0$ & $<2.0$ & 374 & $<1.0$ & 2.8 & $<2.0$ & $<15.0$ & $<1.0$ & $<2.0$ \\
\hline MWS-112 & 356 & 1.3 & 5.4 & 58 & $<1.0$ & 3.7 & 15 & 283 & 1.6 & 17.0 \\
\hline MWS-112-F & 209 & 2.5 & 4.5 & 52 & $<1.0$ & 2.3 & 13 & 193 & 1.2 & 21 \\
\hline
\end{tabular}


TABLE C.3 (Cont.)

\begin{tabular}{|c|c|c|c|c|c|c|c|c|c|c|}
\hline Well No. & $\begin{array}{c}\text { Aluminum } \\
(\mu \mathrm{g} / \mathrm{L})\end{array}$ & $\begin{array}{c}\text { Antimony } \\
(\mu \mathrm{g} / \mathrm{L})\end{array}$ & $\begin{array}{c}\text { Arsenic } \\
(\mu \mathrm{g} / \mathrm{L})\end{array}$ & $\begin{array}{c}\text { Barium } \\
(\mu \mathrm{g} / \mathrm{L})\end{array}$ & $\begin{array}{c}\text { Cadmium } \\
(\mu \mathrm{g} / \mathrm{L})\end{array}$ & $\begin{array}{c}\text { Chromium } \\
(\mu \mathrm{g} / \mathrm{L})\end{array}$ & $\begin{array}{l}\text { Copper } \\
(\mu \mathrm{g} / \mathrm{L})\end{array}$ & $\begin{array}{l}\text { Iron } \\
(\mu \mathrm{g} / \mathrm{L})\end{array}$ & $\begin{array}{c}\text { Lead } \\
(\mu \mathrm{g} / \mathrm{L})\end{array}$ & $\begin{array}{c}\text { Lithium } \\
(\mu \mathrm{g} / \mathrm{L})\end{array}$ \\
\hline TIL3 & 166 & $<1.0$ & $<2.0$ & 194 & $<1.0$ & 2.6 & 19 & 12,600 & 85 & 3.3 \\
\hline TIL3-F & $2 !$ & $<1.0$ & $<2.0$ & 191 & $<1.0$ & 2.1 & $<2.0$ & 2,340 & $<1.0$ & 3.3 \\
\hline USG1 & $<14.0$ & 1.5 & $<2.0$ & 205 & $<1.0$ & 1.4 & $<2.0$ & $<15.0$ & $<1.0$ & 3.8 \\
\hline USGI-F & 18 & $<1.0$ & $<2.0$ & 209 & $<1.0$ & 2.9 & $<2.0$ & $<15.0$ & $<1.0$ & 4.0 \\
\hline USG2 & 58 & 5.6 & $<2.0$ & 253 & $<1.0$ & 2.5 & $<2.0$ & 229 & $<1.0$ & $<2.0$ \\
\hline USG2-F & $<14.0$ & $<1.0$ & $<2.0$ & 252 & $<1.0$ & 1.8 & $<2.0$ & 51 & $<1.0$ & $<2.0$ \\
\hline USG3 & $<14.0$ & $<1.0$ & $<2.0$ & 216 & $<1.0$ & 2.4 & $<2.0$ & $<15.0$ & $<1.0$ & 3.7 \\
\hline USG3-F & 14.0 & $<1.0$ & $<2.0$ & 204 & $<1.0$ & 6.1 & $<2.0$ & 18 & $<1.0$ & 3.8 \\
\hline USG4 & $<14.0$ & $<1.0$ & $<2.0$ & 101 & $<1.0$ & 2.4 & $<2.0$ & $<15.0$ & $<1.0$ & 3.9 \\
\hline USG4-F & $<14.0$ & $<1.0$ & $<2.0$ & 102 & $<1.0$ & 2.9 & $<2.0$ & 25 & $<1.0$ & 3.5 \\
\hline USG5 & $<14.0$ & $<1.0$ & $<2.0$ & 178 & $<1.0$ & 1.5 & $<2.0$ & $<15.0$ & $<1.0$ & 3.5 \\
\hline USG5-F & $<14.0$ & $<1.0$ & $<2.0$ & 177 & $<1.0$ & 1.0 & $<2.0$ & $<15.0$ & $<1.0$ & 3.4 \\
\hline USG6 & $<14.0$ & $<1.0$ & $<2.0$ & 224 & $<1.0$ & 1.6 & $<2.0$ & 44 & $<1.0$ & $<2.0$ \\
\hline USG6-F & $<14.0$ & $<1.0$ & $<2.0$ & 224 & $<1.0$ & $<1.0$ & $<2.0$ & $<15.0$ & $<1.0$ & $<2.0$ \\
\hline USG8 & 34 & $<1.0$ & $<2.0$ & 122 & $<1.0$ & 2.3 & $<2.0$ & 883 & 2.8 & 10 \\
\hline USG8-F & $<14.0$ & $<1.0$ & $<2.0$ & 145 & $<1.0$ & 1.0 & $<2.0$ & $<15.0$ & $<1.0$ & 3.9 \\
\hline USG9 & $<14.0$ & $<1.0$ & $<2.0$ & 92 & $<1.0$ & 2.3 & $<2.0$ & $<15.0$ & $<1.0$ & 3.0 \\
\hline USG9-F & $<14.0$ & $<1.0$ & $<2.0$ & 88.0 & $<1.0$ & 2.7 & $<2.0$ & $<15.0$ & $<1.0$ & 2.9 \\
\hline MSV-I & 1,330 & $<1.0$ & $<2.0$ & 62.0 & $<1.0$ & 2.6 & 3.5 & 1,020 & $<1.0$ & $<2.0$ \\
\hline MSV-1-F & 132 & 1.4 & $<2.0$ & 53.0 & $<1.0$ & $<1.0$ & 2.1 & 122 & $<1.0$ & $<2.0$ \\
\hline MSV-2 & 1.380 & $<1.0$ & $<2.0$ & 63 & $<1.0$ & 3.7 & 8.6 & 1,350 & 1.6 & 2.4 \\
\hline MSV-2-F & $57 !$ & $<1.0$ & $<2.0$ & 54 & $<1.0$ & 1.1 & 2.4 & 382 & $<1.0$ & 2.0 \\
\hline MSV-9 & $<14.0$ & $<1.0$ & $<2.0$ & 104 & $<1.0$ & 1.8 & 2.8 & 92 & $<1.0$ & 7.0 \\
\hline MSV-9-F & $<14.0$ & $<1.0$ & $<2.0$ & 84 & $<1.0$ & 1.0 & $<2.0$ & 16 & $<1.0$ & 5.8 \\
\hline MSV-13 & 96 & $<1.0$ & $(0.40)$ & 37 & $(0.07)$ & $<5.4$ & 2.3 & 259 & $(0.41)$ & 3.2 \\
\hline MSV-13-F & $<14.0$ & 1.5 & $<2.0$ & 26 & $(0.15)$ & $<2.6$ & 2.5 & $<15.0$ & $<1.0$ & 3.1 \\
\hline
\end{tabular}


TABLE C.3 (Cont.)

\begin{tabular}{|c|c|c|c|c|c|c|c|c|c|c|}
\hline Well No. & $\begin{array}{c}\text { Aluminum } \\
(\mu \mathrm{g} / \mathrm{L})\end{array}$ & $\begin{array}{c}\text { Antimony } \\
(\mu \mathrm{g} / \mathrm{L})\end{array}$ & $\begin{array}{c}\text { Arsenic } \\
(\mu \mathrm{g} / \mathrm{L})\end{array}$ & $\begin{array}{c}\text { Barium } \\
(\mu \mathrm{g} / L)\end{array}$ & $\begin{array}{c}\text { Cadmium } \\
(\mu \mathrm{g} / \mathrm{L})\end{array}$ & $\begin{array}{c}\text { Chromium } \\
(\mu \mathrm{g} / \mathrm{L})\end{array}$ & $\begin{array}{l}\text { Copper } \\
(\mu \mathrm{g} / \mathrm{L})\end{array}$ & $\begin{array}{c}\text { Iron } \\
(\mu \mathrm{g} / \mathrm{L})\end{array}$ & $\begin{array}{l}\text { Lead } \\
(\mu \mathrm{g} / \mathrm{L})\end{array}$ & $\begin{array}{c}\text { Lithium } \\
(\mu \mathrm{g} / \mathrm{L})\end{array}$ \\
\hline MSV-16 & 362 & $<1.0$ & 3.8 & 75 & $<1.0$ & 4.3 & 7.9 & 515 & 1.7 & $<2.0$ \\
\hline MSV-16-F & 26 & $<1.0$ & 4.5 & 67 & $<1.0$ & 1.9 & $<2.0$ & 35 & $<1.0$ & $<2.0$ \\
\hline MSV-17 & 25 & $<1.0$ & $(0.26)$ & 94 & $(0.09)$ & $<1.3$ & $(0.90)$ & $<33$ & $(0.07)$ & $(0.26)$ \\
\hline MSV-17-F & $<14.0$ & 2.9 & $<2.0$ & 91 & $(0.06)$ & $<1.1$ & $(1.6)$ & $<20.0$ & $(0.55)$ & $(0.25)$ \\
\hline MSV-22 & 25 & $<1.0$ & $<2.0$ & 158 & $(0.10)$ & $<1.7$ & (1.1) & $<50$ & $<1.0$ & 2.3 \\
\hline MSV-22-F & $(0.25)$ & $(0.30)$ & $<2.0$ & 156 & $(0.04)$ & $<1.2$ & $(0.48)$ & $(0.9 \mathrm{~g})$ & $<1.0$ & 2.3 \\
\hline MSV-24 & $<14.0$ & $<1.0$ & $<2.0$ & 100 & $<1.0$ & $<1.0$ & $<2.0$ & 178 & $<1.0$ & 8.2 \\
\hline MSV-24-F & $<14.0$ & $<1.0$ & $<2.0$ & 98.8 & $<1.0$ & 1.0 & $<2.0$ & 33 & $<1.0$ & 7.9 \\
\hline
\end{tabular}


TABLE C.3 (Cont.)

\begin{tabular}{|c|c|c|c|c|c|c|c|}
\hline Well No. & $\begin{array}{c}\text { Manganese } \\
(\mu \mathrm{g} / \mathrm{L})\end{array}$ & $\begin{array}{l}\text { Mercury } \\
(\mu \mathrm{g} / \mathrm{L})\end{array}$ & $\begin{array}{l}\text { Molybdenum } \\
(\mu \mathrm{g} / \mathrm{L})\end{array}$ & $\begin{array}{l}\text { Nickel } \\
(\mu \mathrm{g} / \mathrm{L})\end{array}$ & $\begin{array}{c}\text { Sclenium } \\
(\mu \mathrm{g} / \mathrm{L})\end{array}$ & $\begin{array}{l}\text { Silver } \\
(\mu \mathrm{g} / \mathrm{L})\end{array}$ & $\begin{array}{c}\text { Thallium } \\
(\mu \mathrm{g} / \mathrm{L})\end{array}$ \\
\hline$M W-2001-F$ & $<1.0$ & $<0.2$ & $<1.0$ & 2.7 & $<3.0$ & $<1.0$ & $<1.0$ \\
\hline MW-2002 & 2.6 & $<0.2$ & 111 & 6.7 & 4.2 & $<1.0$ & $<1.0$ \\
\hline$M W-2002-F$ & $<1.0$ & $<0.2$ & 12 & 5.5 & 3.9 & $<1.0$ & $<1.0$ \\
\hline MW-2003 & 32 & $<0.2$ & 2.2 & 8.1 & 8.8 & 5.5 & $<1.0$ \\
\hline MW-2003-F & 2.5 & $<0.2$ & 2.1 & 7.1 & 8.3 & $<1.0$ & $<1.0$ \\
\hline MW-2005 & $<1.0$ & $<0.2$ & 1.4 & 2.1 & $<3.0$ & $<1.0$ & $<1.0$ \\
\hline$M W-2005-F$ & $<1.0$ & $<0.2$ & 1.1 & 2.3 & $<3.0$ & $<1.0$ & $<1.0$ \\
\hline MW-2006 & 24 & $<0.2$ & 2.4 & 65 & $<3.0$ & $<1.0$ & $<1.0$ \\
\hline MW-2006-F & 22 & $<0.2$ & 1.4 & 62 & $<3.0$ & $<1.0$ & $<1.0$ \\
\hline MW-2007 & 15 & $<0.2$ & 4.2 & 2.5 & $<3.0$ & $<1.0$ & $<1.0$ \\
\hline MW-2007-F & 4.0 & $<0.2$ & 4.4 & 1.9 & $<3.0$ & $<1.0$ & $<1.0$ \\
\hline MW-2010 & 74 & $<0.2$ & 11 & 72 & $<3.0$ & $<1.0$ & $<1.0$ \\
\hline MW-2010-F & 61 & $<0.2$ & 9.7 & 62.0 & $<3.0$ & $<1.0$ & $<1.0$ \\
\hline MW-2011 & $<1.0$ & $<0.2$ & $<1.0$ & 3.1 & $<3.0$ & $<1.0$ & $<1.0$ \\
\hline$M W-2011-F$ & $<1.0$ & $<0.2$ & $<1.0$ & 2.3 & $<3.0$ & $<1.0$ & $<1.0$ \\
\hline MW-2012 & $<1.0$ & $<0.2$ & $<1.0$ & 2.5 & $<3.0$ & $<1.0$ & $<1.0$ \\
\hline $\mathrm{MW}-2012-\mathrm{F}$ & $<1.0$ & $<0.2$ & $<1.0$ & 2.4 & $<3.0$ & $<1.0$ & $<1.0$ \\
\hline MW-2013 & $<1.0$ & $<0.2$ & $<1.0$ & 3.4 & $<3.0$ & $<1.0$ & $<1.0$ \\
\hline MW-2013-F & $<1.0$ & $<0.2$ & $<1.0$ & 3.0 & $<3.0$ & $<1.0$ & $<1.0$ \\
\hline MW-2014 & 20 & $<0.2$ & $<1.0$ & 4.3 & $<3.0$ & $<1.0$ & $<1.0$ \\
\hline$M W-2014-F$ & 1.1 & $<0.2$ & 1.0 & 2.1 & $<3.0$ & $<1.0$ & $<1.0$ \\
\hline MW-2015 & $<1.0$ & $<0.2$ & $<1.0$ & 2.3 & $<3.0$ & $<1.0$ & $<1.0$ \\
\hline MW-2015-F & $<1.0$ & $<0.2$ & $<1.0$ & 2.3 & $<3.0$ & $<1.0$ & $<1.0$ \\
\hline MW-2017 & 19 & $<0.2$ & 2.0 & 6.6 & $<3.0$ & $<1.0$ & $<1.0$ \\
\hline $\mathrm{MW}-2017-\mathrm{F}$ & 1.0 & $<0.2$ & 19 & 9.9 & 4.5 & $<1.0$ & $<1.0$ \\
\hline MW-2018 & 2.6 & $<0.2$ & 4.5 & 2.1 & $<3.0$ & $<1.0$ & $<1.0$ \\
\hline
\end{tabular}


TABLE C.3 (Cont.)

\begin{tabular}{|c|c|c|c|c|c|c|c|}
\hline Well No. & $\begin{array}{c}\text { Manganese } \\
(\mu \mathrm{g} / \mathrm{L})\end{array}$ & $\begin{array}{c}\text { Mercury } \\
(\mu \mathrm{g} / \mathrm{L})\end{array}$ & $\begin{array}{c}\text { Molybdenum } \\
(\mu \mathrm{g} / \mathrm{L})\end{array}$ & $\begin{array}{l}\text { Nickel } \\
(\mu \mathrm{g} / \mathrm{L})\end{array}$ & $\begin{array}{c}\begin{array}{c}\text { Selenium } \\
(\mu \mathrm{g} / \mathrm{L})\end{array} \\
\end{array}$ & $\begin{array}{l}\text { Silver } \\
(\mu \mathrm{g} / \mathrm{L})\end{array}$ & $\begin{array}{c}\text { Thallium } \\
(\mu \mathrm{g} / \mathrm{L})\end{array}$ \\
\hline MW-2018-F & $<1.0$ & $<0.2$ & 2.7 & 1.1 & $<3.0$ & $<1.0$ & $<1.0$ \\
\hline MW-2019 & 51 & $<0.2$ & 27 & 3.8 & $<3.0$ & $<1.0$ & $<1.0$ \\
\hline MW-2019-F & 48 & $<0.2$ & 27 & 3.7 & $<3.0$ & $<1.0$ & $<1.0$ \\
\hline MW-202I & 38 & $<0.2$ & 7.6 & 11.0 & $<3.0$ & $<1.0$ & $<1.0$ \\
\hline $\mathrm{MW}-2021 \cdot \mathrm{F}$ & 33.0 & $<0.2$ & 6.8 & 9.5 & $<3.0$ & $<1.0$ & $<1.0$ \\
\hline MW-2022 & 102 & $<0.2$ & 2.3 & 3.6 & $<3.0$ & $<1.0$ & $<1.0$ \\
\hline$M W-2022-F$ & 100 & $<0.2$ & 3.0 & 3.5 & $<3.0$ & $<1.0$ & $<1.0$ \\
\hline MW-2023 & 34 & $<0.2$ & 6.6 & 6.1 & $<3.0$ & $<1.0$ & $<1.0$ \\
\hline MW-2023-F & 6.0 & $<0.2$ & 6.5 & 3.4 & $<3.0$ & $<1.0$ & $<1.0$ \\
\hline MW-2024 & 77 & $<0.2$ & 2.0 & 3.6 & $<3.0$ & $<1.0$ & $<1.0$ \\
\hline MW-2024-F & 69 & $<0.2$ & 1.1 & 3.3 & $<3.0$ & $<1.0$ & $<1.0$ \\
\hline MW-2026 & 142 & $<0.2$ & 8.2 & 25 & $<3.0$ & $<1.0$ & $<1.0$ \\
\hline MW-2026-F & 118 & $<0.2$ & 7.2 & 18 & $<3.0$ & $<1.0$ & $<1.0$ \\
\hline MW-2027 & 432 & $<0.2$ & 3.2 & 2.1 & $<3.0$ & $<1.0$ & $<1.0$ \\
\hline MW-2027-F & 431 & $<0.2$ & 3.4 & 2.5 & $<3.0$ & $<1.0$ & $<1.0$ \\
\hline MW-2028 & 226 & $<0.2$ & 4.7 & 7.8 & $<3.0$ & $<1.0$ & $<1.0$ \\
\hline MW-2028-F & 197 & $<0.2$ & 4.9 & 5.7 & $<3.0$ & $<1.0$ & $<1.0$ \\
\hline MW-2030 & 310 & 0.20 & $<1.0$ & 15 & $<3.0$ & $<1.0$ & $<1.0$ \\
\hline MW-2030-F & 4.3 & $<0.2$ & $<1.0$ & 4.3 & $<3.0$ & $<1.0$ & $<1.0$ \\
\hline MW-2032 & 20 & $<0.2$ & 1.8 & 6.7 & 4.1 & $<1.0$ & $<1.0$ \\
\hline MW-2032-F & 1.5 & $<0.2$ & $<1.0$ & 4.2 & 3.3 & $<1.0$ & $<1.0$ \\
\hline MW-2033 & 148 & $<0.2$ & $<1.0$ & 9.4 & $<3.0$ & $<1.0$ & $<1.0$ \\
\hline MW-2033-F & 2.5 & $<0.2$ & $<1.0$ & 3.0 & $<3.0$ & $<1.0$ & $<1.0$ \\
\hline MW-2034 & 12 & $<0.2$ & $<1.0$ & 19 & 4.0 & $<1.0$ & $<1.0$ \\
\hline $\mathrm{MW}-2034-\mathrm{F}$ & 1.2 & $<0.2$ & $<1.0$ & 15.0 & 3.3 & $<1.0$ & $<1.0$ \\
\hline MW-2035 & 9.4 & $<0.2$ & 3.4 & 1.9 & $<3.0$ & $<1.0$ & $<1.0$ \\
\hline
\end{tabular}


TABLE C.3 (Cont.)

\begin{tabular}{|c|c|c|c|c|c|c|c|}
\hline Well No. & $\begin{array}{c}\text { Manganesc } \\
(\mu \mathrm{g} / \mathrm{L})\end{array}$ & $\begin{array}{c}\text { Mercury } \\
(\mu g / L)\end{array}$ & $\begin{array}{c}\text { Molybdenum } \\
(\mu \mathrm{g} / \mathrm{L})\end{array}$ & $\begin{array}{l}\text { Nickel } \\
(\mu \mathrm{g} / \mathrm{L})\end{array}$ & $\begin{array}{c}\text { Selenium } \\
(\mu \mathrm{g} / \mathrm{L})\end{array}$ & $\begin{array}{l}\text { Silver } \\
(\mu \mathrm{g} / \mathrm{L})\end{array}$ & $\begin{array}{c}\text { Thallium } \\
(\mu \mathrm{g} / \mathrm{L})\end{array}$ \\
\hline MW-2035-F & $<1.0$ & $<0.2$ & $<1.0$ & 1.9 & $<3.0$ & $<1.0$ & $<1.0$ \\
\hline MW-2036 & $<1.0$ & $<0.2$ & $<1.0$ & 2.0 & $<3.0$ & $<1.0$ & $<1.0$ \\
\hline MW-2036-F & $<1.0$ & $<0.2$ & $<1.0$ & 1.7 & $<3.0$ & $<1.0$ & $<1.0$ \\
\hline$M W-2037$ & 66.0 & 3.5 & $<1.0$ & 9.9 & $<3.0$ & $<1.0$ & $<1.0$ \\
\hline MW-2037-F & 68 & 1.4 & $<1.0$ & 9.9 & 4.1 & $<1.0$ & $<1.0$ \\
\hline MW-2038 & 26 & 4.5 & 1.4 & 18 & 9.3 & $<1.0$ & $<1.0$ \\
\hline $\mathrm{MW}-2038-\mathrm{F}$ & 22 & 3.8 & $<1.0$ & 18.0 & 11 & $<1.0$ & $<1.0$ \\
\hline MW-2039 & 49 & $<0.2$ & 4.3 & 7.5 & 5.7 & $<1.0$ & $<1.0$ \\
\hline MW-2039-F & $<1.0$ & $<0.2$ & 3.0 & 4.5 & 5.8 & $<1.0$ & $<1.0$ \\
\hline MW-2040 & 67 & $<0.2$ & 5.0 & 8.9 & $<3.0$ & $<1.0$ & $<1.0$ \\
\hline MW-2040-F & 4.4 & $<0.2$ & 5.2 & 6.1 & 3.6 & $<1.0$ & $<1.0$ \\
\hline MW-2041 & 27 & $<0.2$ & $<1.0$ & 5.2 & 12 & $<1.0$ & $<1.0$ \\
\hline MW-2041-F & 22 & $<0.2$ & $<1.0$ & 5.0 & 11 & $<1.0$ & $<1.0$ \\
\hline MW-2042 & 4.8 & $<0.2$ & $<1.0$ & 3.0 & $<3.0$ & $<1.0$ & $<1.0$ \\
\hline MW-2042-F & $<1.0$ & $<0.2$ & $<1.0$ & 2.4 & $<3.0$ & $<1.0$ & $<1.0$ \\
\hline MW-2043 & 9.9 & $<0.2$ & 1.5 & 2.9 & 3.1 & $<1.0$ & $<1.0$ \\
\hline$M W-2043-F$ & 1.3 & $<0.2$ & 1.4 & 2.4 & $<3.0$ & $<1.0$ & $<1.0$ \\
\hline MW-2044 & 2.3 & $<0.2$ & 1.8 & 3.3 & $<3.0$ & $<1.0$ & $<1.0$ \\
\hline MW-2044-F & 1.7 & $<0.2$ & 1.4 & 3.3 & $<3.0$ & $<1.0$ & $<1.0$ \\
\hline MW-3003 & 25 & $<0.2$ & 5.7 & 11 & 6.9 & $<1.0$ & $<1.0$ \\
\hline$M W-3003-F$ & 23 & $<0.2$ & 5.7 & 11 & 6.7 & $<1.0$ & $<1.0$ \\
\hline MW-3006 & 111 & $<0.2$ & 7.0 & 4.8 & $<3.0$ & $<1.0$ & $<1.0$ \\
\hline$M W-3006-F$ & 127 & $<0.2$ & 8.1 & 4.7 & $<3.0$ & $<1.0$ & $<1.0$ \\
\hline MW-3019 & 127 & $<0.2$ & $<1.0$ & 2.7 & $<3.0$ & $<1.0$ & $<1.0$ \\
\hline MW-3019-F & 129 & $<0.2$ & $<1.0$ & 1.8 & $<3.0$ & $<1.0$ & $<1.0$ \\
\hline MW-3023 & 102 & $<0.2$ & 252 & 19 & 8.1 & $<1.0$ & $<1.0$ \\
\hline
\end{tabular}


TABLE C.3 (Cont.)

\begin{tabular}{|c|c|c|c|c|c|c|c|}
\hline Well No. & $\begin{array}{c}\text { Manganese } \\
(\mu \mathrm{g} / \mathrm{L})\end{array}$ & $\begin{array}{c}\text { Mercury } \\
(\mu \mathrm{g} / \mathrm{L})\end{array}$ & $\begin{array}{c}\text { Molybdenum } \\
(\mu \mathrm{g} / \mathrm{L})\end{array}$ & $\begin{array}{l}\text { Nickel } \\
(\mu \mathrm{g} / \mathrm{L})\end{array}$ & $\begin{array}{c}\text { Selenium } \\
(\mu \mathrm{g} / \mathrm{L})\end{array}$ & $\begin{array}{l}\text { Silver } \\
(\mu \mathrm{g} / \mathrm{L})\end{array}$ & $\begin{array}{c}\text { Thallium } \\
(\mu \mathrm{g} / \mathrm{L})\end{array}$ \\
\hline MW-3023-F & 7.2 & $<0.2$ & 257 & 8.1 & 6.3 & $<1.0$ & $<1.0$ \\
\hline MW-3024 & $<1.0$ & 1.5 & $<1.0$ & 8.3 & 10 & $<1.0$ & $<1.0$ \\
\hline$M W-3024-F$ & $<1.0$ & 0.94 & $<1.0$ & 8.6 & 12 & $<1.0$ & $<1.0$ \\
\hline MW-3025 & 31 & 0.43 & $<1.0$ & 14 & 8.0 & $<1.0$ & $<1.0$ \\
\hline$M W-3025-F$ & 18 & 0.42 & $<1.0$ & 12 & 7.7 & $<1.0$ & $<1.0$ \\
\hline MW-3026 & 69 & $<0.2$ & 2.1 & 14 & $<3.0$ & $<1.0$ & $<1.0$ \\
\hline MW-3026-F & 1.1 & $<0.2$ & 2.0 & 11.0 & $<3.0$ & $<1.0$ & $<1.0$ \\
\hline MW-3027 & 25.0 & 0.46 & $<1.0$ & 6.7 & $<3.0$ & $<1.0$ & $<1.0$ \\
\hline MW-3027-F & 2.4 & 0.29 & $<1.0$ & 2.0 & $<3.0$ & $<1.0$ & $<1.0$ \\
\hline MW-4001 & 4.1 & $<0.2$ & 1.8 & 2.7 & $<3.0$ & $<1.0$ & $<1.0$ \\
\hline MW-4001-F & 1.6 & $<0.2$ & $<1.0$ & 3.1 & $<3.0$ & $<1.0$ & $<1.0$ \\
\hline$M W-4002$ & 22 & $<0.2$ & $<1.0$ & 2.8 & $<3.0$ & $<1.0$ & $<1.0$ \\
\hline$M W-4002-F$ & 1.7 & $<0.2$ & 1.2 & 1.8 & $<3.0$ & $<1.0$ & $<1.0$ \\
\hline MW-4003 & $<1.0$ & $<0.2$ & $<1.0$ & 1.1 & $<3.0$ & $<1.0$ & $<1.0$ \\
\hline$M W-4003-F$ & $<1.0$ & $<0.2$ & $<1.0$ & $<1.0$ & $<3.0$ & $<1.0$ & $<1.0$ \\
\hline MW-4004 & 75 & $<0.2$ & 4.7 & 2.8 & $<3.0$ & $<1.0$ & $<1.0$ \\
\hline MW-4004-F & $<1.0$ & $<0.2$ & 5.9 & $<1.0$ & 3.4 & $<1.0$ & $<1.0$ \\
\hline MW-4005 & 5.3 & $<0.2$ & 5.0 & 6.1 & $<3.0$ & $<1.0$ & $<1.0$ \\
\hline$M W-4005-F$ & $<1.0$ & $<0.2$ & 5.3 & 4.8 & $<3.0$ & $<1.0$ & $<1.0$ \\
\hline MW-4006 & 26.0 & $<0.2$ & $<1.0$ & 1.9 & $<3.0$ & $<1.0$ & $<1.0$ \\
\hline MW-4006-F & $<1.0$ & $<0.2$ & $<1.0$ & 1.9 & $<3.0$ & $<1.0$ & $<1.0$ \\
\hline$M W-4007$ & 43 & $<0.2$ & 5.8 & 5.0 & $<3.0$ & $<1.0$ & $<1.0$ \\
\hline$M W-4007-F$ & 1.2 & $<0.2$ & 5.9 & 2.3 & $<3.0$ & $<1.0$ & $<1.0$ \\
\hline$M W-4008$ & 32 & $<0.2$ & $<1.0$ & 3.8 & $<3.0$ & $<1.0$ & $<1.0$ \\
\hline $\mathrm{MW}-4008-\mathrm{F}$ & 8.1 & $<0.2$ & $<1.0$ & 1.7 & $<3.0$ & $<1.0$ & $<1.0$ \\
\hline$M W-4009$ & 3.7 & $<0.2$ & 8.3 & 1.3 & $<3.0$ & $<1.0$ & $<1.0$ \\
\hline
\end{tabular}


TABLE C.3 (Cont.)

\begin{tabular}{|c|c|c|c|c|c|c|c|}
\hline Well No. & $\begin{array}{c}\text { Manganese } \\
(\mu \mathrm{g} / \mathrm{L})\end{array}$ & $\begin{array}{c}\text { Mercury } \\
(\mu \mathrm{g} / \mathrm{L})\end{array}$ & $\begin{array}{c}\text { Molybdenum } \\
(\mu \mathrm{g} / \mathrm{L})\end{array}$ & $\begin{array}{l}\text { Nickcl } \\
(\mu \mathrm{g} / \mathrm{L})\end{array}$ & $\begin{array}{c}\text { Sclenium } \\
(\mu \mathrm{g} / \mathrm{L})\end{array}$ & $\begin{array}{l}\text { Silver } \\
(\mu \mathrm{g} / \mathrm{L})\end{array}$ & $\begin{array}{c}\text { Thallium } \\
(\mu \mathrm{g} / \mathrm{L})\end{array}$ \\
\hline MW-4009-F & $<1.0$ & $<0.2$ & 9.1 & 1.0 & $<3.0$ & $<1.0$ & $<1.0$ \\
\hline$M W-4010$ & 9.3 & $<0.2$ & 3.1 & 4.5 & $<3.0$ & $<1.0$ & $<1.0$ \\
\hline$M W-4010-F$ & 5.2 & $<0.2$ & 2.8 & 3.1 & $<3.0$ & $<1.0$ & $<1.0$ \\
\hline MW-4011 & 27 & $<0.2$ & 1.2 & 8.3 & 4.2 & $<1.0$ & $<1.0$ \\
\hline$M W-4011-F$ & $<1.0$ & $<0.2$ & 2.2 & 7.4 & 3.9 & $<1.0$ & $<1.0$ \\
\hline MW-4012 & 16 & $<0.2$ & 37.0 & 2.2 & $<3.0$ & $<1.0$ & $<1.0$ \\
\hline MW-4012-F & $<1.0$ & $<0.2$ & 37 & $<1.0$ & $<3.0$ & $<1.0$ & $<1.0$ \\
\hline$M W-4013$ & $<1.0$ & $<0.2$ & $<1.0$ & 3.3 & $<3.0$ & $<1.0$ & $<1.0$ \\
\hline MW-4013-F & $<1.0$ & $<0.2$ & $<1.0$ & 3.5 & $<3.0$ & $<1.0$ & $<1.0$ \\
\hline MW-4014 & 24 & $<0.2$ & $<1.0$ & 2.0 & $<3.0$ & $<1.0$ & $<1.0$ \\
\hline MW-4014-F & 16 & $<0.2$ & $<1.0$ & 2.4 & $<3.0$ & $<1.0$ & $<1.0$ \\
\hline MW-4015 & 14 & $<0.2$ & $<1.0$ & 2.1 & $<3.0$ & 1.8 & $<1.0$ \\
\hline MW-4015-F & $<1.0$ & $<0.2$ & $<1.0$ & 1.3 & $<3.0$ & $<1.0$ & $<1.0$ \\
\hline$M W-4016$ & 84 & $<0.2$ & 9.6 & 3.3 & $<3.0$ & $<1.0$ & $<1.0$ \\
\hline MW-4016-F & 41 & $<0.2$ & 10 & 2.0 & $<3.0$ & $<1.0$ & $<1.0$ \\
\hline MW-4018 & $<1.0$ & $<0.2$ & $<1.0$ & 3.0 & $<3.0$ & $<1.0$ & $<1.0$ \\
\hline $\mathrm{MW}-4018-\mathrm{F}$ & $<1.0$ & $<0.2$ & $<1.0$ & 2.6 & $<3.0$ & $<1.0$ & $<1.0$ \\
\hline MW-4019 & 33 & $<0.2$ & $<1.0$ & 3.1 & $<3.0$ & $<1.0$ & $<1.0$ \\
\hline MW-4019-F & 47 & $<0.2$ & $<1.0$ & 3.1 & $<3.0$ & $<1.0$ & $<1.0$ \\
\hline MW-4020 & 35 & $<0.2$ & 1.3 & 16 & $<3.0$ & $<1.0$ & $<1.0$ \\
\hline MW-4020-F & 21 & $<0.2$ & 1.1 & 16 & $<3.0$ & $<1.0$ & $<1.0$ \\
\hline MW-4021 & 50 & $<0.2$ & $<1.0$ & 8.9 & $<3.0$ & $<1.0$ & $<1.0$ \\
\hline $\mathrm{MW}-4021-\mathrm{F}$ & 32 & $<0.2$ & 1.7 & 7.6 & $<3.0$ & $<1.0$ & $<1.0$ \\
\hline MW-4022 & 2140 & $<0.2$ & 6.3 & 246 & $<3.0$ & 19.1 & $<1.0$ \\
\hline MW-4022-F & 286 & $<0.2$ & 4.0 & 12 & $<3.0$ & $<1.0$ & $<1.0$ \\
\hline$M W-4023$ & $<1.0$ & $<0.2$ & $<1.0$ & 2.6 & $<3.0$ & $<1.0$ & $<1.0$ \\
\hline
\end{tabular}


TABLE C.3 (Cont.)

\begin{tabular}{|c|c|c|c|c|c|c|c|}
\hline Well No. & $\begin{array}{c}\text { Manganesc } \\
(\mu \mathrm{g} / \mathrm{L})\end{array}$ & $\begin{array}{l}\text { Mercury } \\
(\mu \mathrm{g} / \mathrm{L})\end{array}$ & $\begin{array}{c}\text { Molybdenum } \\
(\mu \mathrm{g} / \mathrm{L})\end{array}$ & $\begin{array}{l}\text { Nickel } \\
(\mu \mathrm{g} / \mathrm{L})\end{array}$ & $\begin{array}{c}\text { Sclenium } \\
(\mu \mathrm{g} / \mathrm{L})\end{array}$ & $\begin{array}{l}\text { Silver } \\
(\mu \mathrm{g} / \mathrm{L})\end{array}$ & $\begin{array}{c}\text { Thallium } \\
(\mu \mathrm{g} / \mathrm{L})\end{array}$ \\
\hline MW-4023-F & $<1.0$ & $<0.2$ & $<1.0$ & 1.7 & $<3.0$ & $<1.0$ & $<1.0$ \\
\hline$M W-4024^{b}$ & 388.0 & $<0.8$ & 11.1 & 166.0 & $<4.0$ & 14.4 & $<2.0$ \\
\hline $\mathrm{MW}-4024-\mathrm{F}^{\mathrm{b}}$ & 105.0 & $<0.8$ & $<5.0$ & 49.8 & $<4.0$ & 3.2 & $<2.0$ \\
\hline MW-4025 & 177 & $<0.2$ & 4.2 & 32 & $<3.0$ & 1.8 & $<1.0$ \\
\hline MW-4025-F & 9.6 & $<0.2$ & $<1.0$ & 3.8 & $<3.0$ & $<1.0$ & $<1.0$ \\
\hline MWD-2 & 2130 & $<0.2$ & 8.0 & 27 & $<3.0$ & $<1.0$ & 1.1 \\
\hline MWD-2-F & 100 & $<0.2$ & 11 & 1.5 & $<3.0$ & $<1.0$ & $<1.0$ \\
\hline MWD-5 & 19 & $<0.2$ & 1.3 & 2.0 & $<3.0$ & $<1.0$ & $<1.0$ \\
\hline MWD-5-F & 1.4 & $<0.2$ & 1.1 & 1.4 & $<3.0$ & $<1.0$ & $<1.0$ \\
\hline MWD-6 & 73 & $<0.2$ & $<1.0$ & 2.4 & $<3.0$ & $<1.0$ & $<1.0$ \\
\hline MWD-6-F & 73 & $<0.2$ & $<1.0$ & 2.8 & $<3.0$ & $<1.0$ & $<1.0$ \\
\hline MWD-9 & $<1.0$ & $<0.2$ & $<1.0$ & 1.2 & $<3.0$ & $<1.0$ & $<1.0$ \\
\hline MWD-9-F & $<1.0$ & $<0.2$ & $<1.0$ & 1.2 & $<3.0$ & $<1.0$ & $<1.0$ \\
\hline MWD-15 & 11.0 & $<0.2$ & $<1.0$ & 1.1 & $<3.0$ & $<1.0$ & $<1.0$ \\
\hline MWD-15-F & 9.7 & $<0.2$ & $<1.0$ & 1.3 & $<3.0$ & $<1.0$ & $<1.0$ \\
\hline MWD-18 & 6.1 & $<0.2$ & $<1.0$ & 1.8 & $<3.0$ & $<1.0$ & $<1.0$ \\
\hline MWD-18-F & 2.8 & $<0.2$ & $<1.0$ & 1.1 & $<3.0$ & $<1.0$ & $<1.0$ \\
\hline MWD-23 & 357 & $<0.2$ & 24 & 94 & $<3.0$ & $<1.0$ & $<1.0$ \\
\hline MWD-23-F & 340 & $<0.2$ & 25 & 90 & $<3.0$ & $<1.0$ & $<1.0$ \\
\hline MWD-25 & 22 & $<0.2$ & $<1.0$ & 4.2 & $<3.0$ & $<1.0$ & $<1.0$ \\
\hline MWD-25-F & 18 & $<0.2$ & $<1.0$ & 3.7 & $<3.0$ & $<1.0$ & $<1.0$ \\
\hline MWD-105 & 6.8 & $<0.2$ & $<1.0$ & 1.5 & $<3.0$ & $<1.0$ & $<1.0$ \\
\hline MWD-105-F & 6.2 & $<0.2$ & $<1.0$ & 1.3 & $<3.0$ & $<1.0$ & $<1.0$ \\
\hline MWD-106 & 5.5 & $<0.2$ & $<1.0$ & 1.2 & $<3.0$ & $<1.0$ & $<1.0$ \\
\hline MWD-106-F & 5.3 & $<0.2$ & $<1.0$ & 1.1 & $<3.0$ & $<1.0$ & $<1.0$ \\
\hline MWD-107 & 36 & $<0.2$ & 2.1 & 28 & $<3.0$ & $<1.0$ & $<1.0$ \\
\hline MWD-107-F & 25 & $<0.2$ & 2.3 & 27 & $<3.0$ & $<1.0$ & $<1.0$ \\
\hline MWD-109 & 9.5 & $<0.2$ & 2.4 & 2.8 & $<3.0$ & $<1.0$ & $<1.0$ \\
\hline
\end{tabular}


TABLE C.3 (Cont.)

\begin{tabular}{|c|c|c|c|c|c|c|c|}
\hline Well No. & $\begin{array}{c}\text { Manganese } \\
(\mu \mathrm{g} / \mathrm{L})\end{array}$ & $\begin{array}{c}\text { Mercury } \\
(\mu \mathrm{g} / \mathrm{L})\end{array}$ & $\begin{array}{c}\text { Molybdenum } \\
(\mu \mathrm{g} / \mathrm{L})\end{array}$ & $\begin{array}{l}\text { Nickel } \\
(\mu \mathrm{g} / \mathrm{L})\end{array}$ & $\begin{array}{c}\text { Sclenium } \\
(\mu \mathrm{g} / \mathrm{L})\end{array}$ & $\begin{array}{l}\text { Silver } \\
(\mu \mathrm{g} / \mathrm{L})\end{array}$ & $\begin{array}{c}\text { Thallium } \\
(\mu \mathrm{g} / \mathrm{L})\end{array}$ \\
\hline MWD-109-F & 6.3 & $<0.2$ & $<1.0$ & 2.2 & $<3.0$ & $<1.0$ & $<1.0$ \\
\hline MWD-112 & 19.0 & $<0.2$ & 2.2 & 11.0 & $<3.0$ & $<1.0$ & $<1.0$ \\
\hline MWD-112-F & 20.2 & $<0.2$ & 2.9 & 11 & $<3.0$ & $<1.0$ & $<1.0$ \\
\hline MWS-1 & 2.3 & $<0.2$ & $<1.0$ & 1.5 & $<3.0$ & $<1.0$ & $<1.0$ \\
\hline MWS-1-F & $<1.0$ & $<0.2$ & $<1.0$ & $<1.0$ & $<3.0$ & $<1.0$ & $<1.0$ \\
\hline MWS-2 & 1.9 & $<0.2$ & 4.2 & 2.1 & $<3.0$ & $<1.0$ & $<1.0$ \\
\hline MWS-2-F & $<1.0$ & $<0.2$ & 3.8 & 2.0 & $<3.0$ & $<1.0$ & $<1.0$ \\
\hline MWS-3 & 2.4 & $<0.2$ & 3.4 & 2.8 & $<3.0$ & $<1.0$ & $<1.0$ \\
\hline MWS-3-F & $<1.0$ & $<0.2$ & 4.1 & 2.9 & $<3.0$ & $<1.0$ & $<1.0$ \\
\hline MWS-4 & 22 & $<0.2$ & $<1.0$ & 4.9 & $<3.0$ & $<1.0$ & $<1.0$ \\
\hline MWS-4-F & $<1.0$ & $<0.2$ & $<1.0$ & 2.6 & $<3.0$ & $<1.0$ & $<1.0$ \\
\hline MWS-5 & 9.2 & $<0.2$ & $<1.0$ & 3.4 & $<3.0$ & $<1.0$ & $<1.0$ \\
\hline MWS-5-F & 4.0 & $<0.2$ & $<1.0$ & 5.7 & $<3.0$ & $<1.0$ & $<1.0$ \\
\hline MWS-6 & 1.8 & $<0.2$ & $<1.0$ & 4.0 & $<3.0$ & $<1.0$ & $<1.0$ \\
\hline MWS-6-F & 1.6 & $<0.2$ & $<1.0$ & 4.3 & $<3.0$ & $<1.0$ & $<1.0$ \\
\hline MWS-7 & $<1.0$ & $<0.2$ & $<1.0$ & 1.6 & $<3.0$ & $<1.0$ & $<1.0$ \\
\hline MWS-7-F & $<1.0$ & $<0.2$ & $<1.0$ & 1.3 & $<3.0$ & $<1.0$ & $<1.0$ \\
\hline MWS-8 & 38 & $<0.2$ & $<1.0$ & 12 & $<3.0$ & $<1.0$ & $<1.0$ \\
\hline MWS-8-F & 1.0 & $<0.2$ & $<1.0$ & 4.5 & $<3.0$ & $<1.0$ & $<1.0$ \\
\hline MWS-9 & 4.2 & $<0.2$ & $<1.0$ & 2.4 & $<3.0$ & $<1.0$ & $<1.0$ \\
\hline MWS-9-F & 5.3 & $<0.2$ & $<1.0$ & 2.9 & $<3.0$ & $<1.0$ & $<1.0$ \\
\hline MWS-10 & $<1.0$ & $<0.2$ & $<1.0$ & 3.0 & $<3.0$ & $<1.0$ & $<1.0$ \\
\hline MWS-10-F & $<1.0$ & $<0.2$ & $<1.0$ & 3.1 & $<3.0$ & $<1.0$ & $<1.0$ \\
\hline MWS-11 & 7.1 & $<0.2$ & $<1.3$ & 2.4 & $(1.3)$ & $(0.03)$ & $(0.180)$ \\
\hline MWS-11-F & $(0.980)$ & $<0.2$ & $(0.880)$ & 2.3 & $(0.53)$ & $<1.0$ & $<1.0$ \\
\hline MWS- 12 & 6.9 & $<0.2$ & $<1.0$ & 2.4 & $<3.0$ & $<1.0$ & $<1.0$ \\
\hline
\end{tabular}


TABLE C.3 (Cont.)

\begin{tabular}{|c|c|c|c|c|c|c|c|}
\hline Well No. & $\begin{array}{c}\text { Manganese } \\
(\mu \mathrm{g} / \mathrm{L})\end{array}$ & $\begin{array}{l}\text { Mercury } \\
(\mu \mathrm{g} / \mathrm{L})\end{array}$ & $\begin{array}{c}\text { Molybdenum } \\
(\mu \mathrm{g} / \mathrm{L})\end{array}$ & $\begin{array}{l}\text { Nickel } \\
(\mu \mathrm{g} / \mathrm{L})\end{array}$ & $\begin{array}{l}\text { Selcnium } \\
(\mu \mathrm{g} / \mathrm{L})\end{array}$ & $\begin{array}{l}\text { Silver } \\
(\mu \mathrm{g} / \mathrm{L})\end{array}$ & $\begin{array}{c}\text { Thallium } \\
(\mu \mathrm{g} / \mathrm{L})\end{array}$ \\
\hline MWS-12-F & 5.5 & $<0.2$ & $<1.0$ & 1.7 & $<3.0$ & $<1.0$ & $<1.0$ \\
\hline MWS-13 & 12 & $<0.2$ & $(0.53)$ & 6.5 & $(0.27)$ & $(0.005)$ & $<1.0$ \\
\hline MWS-13-F & 10 & $<0.2$ & $(0.39)$ & 7.9 & $<3.0$ & $(0.010)$ & $<1.0$ \\
\hline MWS-14 & 26 & $<0.2$ & 1.6 & 7.9 & $<3.0$ & $<1.0$ & $<1.0$ \\
\hline MWS-14-F & $<1.0$ & $<0.2$ & 1.1 & 3.7 & $<3.0$ & $<1.0$ & $<1.0$ \\
\hline MWS-15 & 2.0 & $<0.2$ & $<1.0$ & 15 & $<3.0$ & $<1.0$ & $<1.0$ \\
\hline MWS-15-F & $<1.0$ & $<0.2$ & $<1.0$ & 23 & $<3.0$ & $<1.0$ & $<1.0$ \\
\hline MWS-16 & $<1.0$ & $<0.2$ & $<1.0$ & 2.8 & $<3.0$ & $<1.0$ & $<1.0$ \\
\hline MWS-16-F & $<1.0$ & $<0.2$ & $<1.0$ & 2.5 & $<3.0$ & $<1.0$ & $<1.0$ \\
\hline MWS-17 & 4.7 & $<0.2$ & $<1.1$ & 2.2 & $(1.8)$ & $(0.005)$ & $<1.0$ \\
\hline MWS-17-F & $(0.60)$ & $<0.2$ & $(0.80)$ & 2.0 & $(1.30)$ & $<1.0$ & $(0.18)$ \\
\hline MWS-18 & 81 & $<0.2$ & 7.1 & 8.6 & $<3.0$ & $<1.0$ & $<1.0$ \\
\hline MWS-18-F & 1.5 & $<0.2$ & 6.7 & 5.0 & $<3.0$ & $<1.0$ & $<1.0$ \\
\hline MWS-19 & 42 & $<0.2$ & $<1.0$ & 5.0 & $<3.0$ & $<1.0$ & $<1.0$ \\
\hline MWS-19-F & 32 & $<0.2$ & $<1.0$ & 3.7 & $<3.0$ & $<1.0$ & $<1.0$ \\
\hline MWS-20 & 1.4 & $<0.2$ & $<1.0$ & 1.8 & $(0.33)$ & $<1.0$ & $<1.0$ \\
\hline MWS-20-F & $(0.09)$ & $<0.2$ & $(0.49)$ & 1.7 & $(0.36)$ & $(0.007)$ & $<1.0$ \\
\hline MWS-21 & 149 & 0.35 & 4.9 & 101 & 6.5 & $<1.0$ & $<1.0$ \\
\hline MWS-21-F & 100 & $<0.2$ & 4.6 & 95 & 7.3 & $<1.0$ & $<1.0$ \\
\hline MWS-22 & 3.6 & $=0.2$ & $(0.13)$ & 3.2 & $<3.0$ & $(0.043)$ & $<1.0$ \\
\hline MWS-22-F & 1.8 & $<0.2$ & $(0.39)$ & 2.7 & $(0.88)$ & $(0.033)$ & $(0.083)$ \\
\hline MWS-23 & 739 & $<0.2$ & $<1.0$ & 38 & $<3.0$ & $<1.0$ & $<1.0$ \\
\hline MWS-23-F & 74 & $<0.2$ & $<1.0$ & 3.1 & $<3.0$ & $<1.0$ & $<1.0$ \\
\hline MWS-25 & 27 & $<0.2$ & $<1.0$ & 3.1 & $<3.0$ & $<1.0$ & $<1.0$ \\
\hline MWS-25-F & 4.7 & $<0.2$ & $<1.0$ & 1.9 & $<3.0$ & $<1.0$ & $<1.0$ \\
\hline MWS-26 & 1040 & $<0.2$ & 2.0 & 54 & $<3.0$ & $(0.031)$ & $(0.17)$ \\
\hline
\end{tabular}


TABLE C.3 (Cont.)

\begin{tabular}{|c|c|c|c|c|c|c|c|}
\hline Well No. & $\begin{array}{c}\text { Manganese } \\
(\mu \mathrm{g} / \mathrm{L})\end{array}$ & $\begin{array}{c}\text { Mercury } \\
(\mu g / L)\end{array}$ & $\begin{array}{c}\text { Molybdenum } \\
(\mu \mathrm{g} / \mathrm{L})\end{array}$ & $\begin{array}{l}\text { Nickel } \\
(\mu \mathrm{g} / \mathrm{L})\end{array}$ & $\begin{array}{c}\text { Selenium } \\
(\mu \mathrm{g} / \mathrm{L})\end{array}$ & $\begin{array}{l}\text { Silver } \\
(\mu \mathrm{g} / \mathrm{L})\end{array}$ & $\begin{array}{c}\text { Thallium } \\
(\mu \mathrm{g} / \mathrm{L})\end{array}$ \\
\hline MWS-26-F & 44 & $<0.2$ & $<2.2$ & 3.0 & $(0.045)$ & $<1.0$ & $<1.0$ \\
\hline MWS-101 & 842 & $<0.2$ & $<1.0$ & 1.6 & $<3.0$ & $<1.0$ & $<1.0$ \\
\hline MWS-101-F & 852 & $<0.2$ & $<1.0$ & 5.1 & $<3.0$ & $<1.0$ & $<1.0$ \\
\hline MWS-102 & 560 & $<0.2$ & 1.9 & 8.9 & $<3.0$ & $<1.0$ & $<1.0$ \\
\hline MWS-102-F & 508 & $<0.2$ & 3.5 & 4.2 & $<3.0$ & $<1.0$ & $<1.0$ \\
\hline MWS-103 & 356 & $<0.2$ & $<1.0$ & 13 & $<3.0$ & $<1.0$ & $<1.0$ \\
\hline MWS-103-F & 33 & $<0.2$ & $<1.0$ & 3.3 & $<3.0$ & $<1.0$ & $<1.0$ \\
\hline MWS-104 & 7.8 & $<0.2$ & 2.9 & 3.9 & $<3.0$ & $<1.0$ & $<1.0$ \\
\hline MWS-104-F & 2.5 & $<0.2$ & 3.5 & 3.0 & $<3.0$ & $<1.0$ & $<1.0$ \\
\hline MWS-10S & 19 & $<0.2$ & 1.6 & 3.7 & $<3.0$ & $<1.0$ & $<1.0$ \\
\hline MWS-105-F & 18 & $<0.2$ & 2.0 & 3.3 & $<3.0$ & $<1.0$ & $<1.0$ \\
\hline MWS-106 & 119 & $<0.2$ & 1.1 & 6.2 & $<3.0$ & $<1.0$ & $<1.0$ \\
\hline MWS-106-F & 93 & $<0.2$ & 1.9 & 1.6 & $<3.0$ & $<1.0$ & $<1.0$ \\
\hline MWS-107 & 28 & $<0.2$ & $<1.0$ & 3.5 & $<3.0$ & $<1.0$ & $<1.0$ \\
\hline MWS-107-F & 32 & $<0.2$ & $<1.0$ & 1.5 & $<3.0$ & $<1.0$ & $<1.0$ \\
\hline MWS-108 & 4.0 & $<0.2$ & 1.9 & 1.4 & $<3.0$ & $<1.0$ & $<1.0$ \\
\hline MWS-108-F & 30 & $<0.2$ & $<1.0$ & 1.3 & $<3.0$ & $<1.0$ & $<1.0$ \\
\hline MWS-109 & 111 & $<0.2$ & 1.2 & 4.4 & $<3.0$ & $<1.0$ & $<1.0$ \\
\hline MWS-109-F & 70 & $<0.2$ & 1.8 & 3.6 & $<3.0$ & $<1.0$ & $<1.0$ \\
\hline MWS-110 & 13 & $<0.2$ & $<1.0$ & 3.3 & $<3.0$ & $<1.0$ & $<1.0$ \\
\hline MWS-110-F & 1.3 & $<0.2$ & $<1.0$ & $<1.0$ & $<3.0$ & $<1.0$ & $<1.0$ \\
\hline MWS-111 & 4.9 & $<0.2$ & $<1.0$ & $<1.0$ & $<3.0$ & $<1.0$ & $<1.0$ \\
\hline MWS-111-F & $<1.0$ & $<0.2$ & $<1.0$ & $<1.0$ & $<3.0$ & $<1.0$ & $<1.0$ \\
\hline MWS-112 & 60 & $<0.2$ & 35 & 39 & $<3.0$ & $<1.0$ & $<1.0$ \\
\hline MWS-112-F & 61 & $<0.2$ & 46 & 55 & $<3.0$ & $<1.0$ & $<1.0$ \\
\hline TIL3 & 40 & $<0.2$ & 1.6 & 2.6 & $<3.0$ & $<1.0$ & $<1.0$ \\
\hline
\end{tabular}


TABLE C.3 (Cont.)

\begin{tabular}{|c|c|c|c|c|c|c|c|}
\hline Well No. & $\begin{array}{c}\text { Manganese } \\
(\mu \mathrm{g} / \mathrm{L})\end{array}$ & $\begin{array}{l}\text { Mercury } \\
(\mu \mathrm{g} / \mathrm{L})\end{array}$ & $\begin{array}{c}\text { Molybdenum } \\
(\mu \mathrm{g} / \mathrm{L})\end{array}$ & $\begin{array}{l}\text { Nickel } \\
(\mu \mathrm{g} / \mathrm{L})\end{array}$ & $\begin{array}{c}\begin{array}{c}\text { Sclenium } \\
(\mu \mathrm{g} / \mathrm{L})\end{array} \\
\end{array}$ & $\begin{array}{l}\text { Silver } \\
(\mu \mathrm{g} / \mathrm{L}) \\
\end{array}$ & $\begin{array}{c}\text { Thallium } \\
(\mu \mathrm{g} / \mathrm{L})\end{array}$ \\
\hline TIL3-F & 33 & $<0.2$ & 1.8 & 1.7 & $<3.0$ & $<1.0$ & $<1.0$ \\
\hline USGI & $<1.0$ & $<0.2$ & $<1.0$ & $<1.0$ & $<3.0$ & $<1.0$ & $<1.0$ \\
\hline USG 1-F & $<1.0$ & $<0.2$ & 1.3 & 1.4 & $<3.0$ & $<1.0$ & $<1.0$ \\
\hline USG2 & 5.1 & $<0.2$ & 1.8 & 2.9 & $<3.0$ & $<1.0$ & $<1.0$ \\
\hline USG2-F & 4.4 & $<0.2$ & 1.9 & 4.5 & $<3.0$ & $<1.0$ & $<1.0$ \\
\hline USG3 & $<1.0$ & $<0.2$ & $<1.0$ & 1.5 & $<3.0$ & $<1.0$ & $<1.0$ \\
\hline USG3-F & $<1.0$ & $<0.2$ & 2.4 & 1.8 & $<3.0$ & $<1.0$ & $<1.0$ \\
\hline USG4 & $<1.0$ & $<0.2$ & $<1.0$ & 1.9 & $<3.0$ & $<1.0$ & $<1.0$ \\
\hline USG4-F & $<1.0$ & $<0.2$ & $<1.0$ & 2.3 & $<3.0$ & $<1.0$ & $<1.0$ \\
\hline USG5 & 77 & $<0.2$ & 5.4 & 49 & $<3.0$ & $<1.0$ & $<1.0$ \\
\hline USG5-F & 64 & $<0.2$ & 4.9 & 49 & $<3.0$ & $<1.0$ & $<1.0$ \\
\hline USG6 & 14 & $<0.2$ & 1.8 & 2.3 & $<3.0$ & $<1.0$ & $<1.0$ \\
\hline USG6-F & $<1.0$ & $<0.2$ & 4.0 & 1.8 & $<3.0$ & $<1.0$ & $<1.0$ \\
\hline USG8 & 14 & $<0.2$ & 1.6 & 8.4 & $<3.0$ & $<1.0$ & $<1.0$ \\
\hline USG8-F & 6.8 & $<0.2$ & 2.5 & 2.3 & $<3.0$ & $<1.0$ & $<1.0$ \\
\hline USG9 & $<1.0$ & $<0.2$ & $<1.0$ & 2.7 & $<3.0$ & $<1.0$ & $<1.0$ \\
\hline USG9-F & $<1.0$ & $<0.2$ & $<1.0$ & 2.4 & $<3.0$ & $<1.0$ & $<1.0$ \\
\hline MWV-I & 10 & $<0.2$ & $<1.0$ & 2.9 & $<3.0$ & $<1.0$ & $<1.0$ \\
\hline MWV-1-F & 2.4 & $<0.2$ & $<1.0$ & 1.4 & $<3.0$ & $<1.0$ & $<1.0$ \\
\hline MWV-2 & 12.0 & $<0.2$ & 1.6 & 3.7 & $<3.0$ & $<1.0$ & $<1.0$ \\
\hline$M W V-2-F$ & 3.9 & $<0.2$ & 1.4 & 2.4 & $<3.0$ & $<1.0$ & $<1.0$ \\
\hline MWV-9 & 23 & $<0.2$ & $<1.0$ & 3.0 & $<3.0$ & $<1.0$ & $<1.0$ \\
\hline MWV-9-F & 6.7 & $<0.2$ & $<1.0$ & 2.0 & $<3.0$ & $<1.0$ & $<1.0$ \\
\hline MWV-13 & 16 & $<0.2$ & $<1.6$ & 3.5 & $(0.39)$ & $<1.0$ & $<1.0$ \\
\hline MWV-13-F & $(0.42)$ & $<0.2$ & $(0.80)$ & 2.4 & $(0.14)$ & $<1.0$ & $<1.0$ \\
\hline MWV-16 & 34 & $<0.2$ & $<1.0$ & 4.2 & $<3.0$ & $<1.0$ & $<1.0$ \\
\hline
\end{tabular}




\section{TABLE C.3 (Cont.)}

\begin{tabular}{lccccccc}
\hline Well No. & $\begin{array}{c}\text { Manganesc } \\
(\mu \mathrm{g} / \mathrm{L})\end{array}$ & $\begin{array}{c}\text { Mercury } \\
(\mu \mathrm{g} / \mathrm{L})\end{array}$ & $\begin{array}{c}\text { Molybicnum } \\
(\mu \mathrm{g} / \mathrm{L})\end{array}$ & $\begin{array}{c}\text { Nickel } \\
(\mu \mathrm{g} / \mathrm{L})\end{array}$ & $\begin{array}{c}\text { Selenium } \\
(\mu \mathrm{g} / \mathrm{L})\end{array}$ & $\begin{array}{c}\text { Silver } \\
(\mu \mathrm{g} / \mathrm{L})\end{array}$ & $\begin{array}{c}\text { Thallium } \\
(\mu \mathrm{g} / \mathrm{L})\end{array}$ \\
\hline MWV-16-F & 1.4 & $<0.2$ & $<1.0$ & 2.2 & $<3.0$ & $<1.0$ & $<1.0$ \\
MWV-17 & 43 & $<0.2$ & $<1.0$ & $(0.94)$ & $<3.0$ & $<1.0$ & $<1.0$ \\
MWV-17-F & 1.2 & $<0.2$ & $<1.0$ & $(0.64)$ & $<3.0$ & $<1.0$ & $<1.0$ \\
MWV-22 & 6.7 & $<0.2$ & $(0.49)$ & 51 & $<3.0$ & $<1.0$ & $<1.0$ \\
MWV-22-F & 2.4 & $<0.2$ & $(0.34)$ & 55 & $<3.0$ & $<1.0$ & $<1.0$ \\
MWV-24 & 38.0 & $<0.2$ & 1.1 & 4.3 & $<3.0$ & $<1.0$ & $<1.0$ \\
MWV-24-F & 19 & $<0.2$ & 1.2 & 4.0 & $<3.0$ & $<1.0$ & $<1.0$ \\
\hline
\end{tabular}

a $F=$ filtered data.

b Sample taken in July 1995. 
TABLE C.4 Nitroaromatic Results from Joint Sampling, August 1995

\begin{tabular}{|c|c|c|c|c|c|c|c|c|c|c|c|}
\hline Well No. & $\begin{array}{c}\text { 1,3,5-TNB } \\
(\mu \mathrm{g} / \mathrm{L})\end{array}$ & $\begin{array}{c}\text { 1,3-DNB } \\
(\mu \mathrm{g} / \mathrm{L})\end{array}$ & $\begin{array}{c}2,4,6-\mathrm{TNT} \\
(\mu \mathrm{g} / \mathrm{L})\end{array}$ & $\begin{array}{c}\text { 2,4-DNT } \\
(\mu \mathrm{g} / \mathrm{L})\end{array}$ & $\begin{array}{c}\text { 2.6-DNT } \\
(\mu \mathrm{g} / \mathrm{L})\end{array}$ & $\begin{array}{c}\text { 2-Amino } \\
(\mu \mathrm{g} / \mathrm{L})\end{array}$ & $\begin{array}{c}\text { 4-Amino } \\
(\mu \mathrm{g} / \mathrm{L})\end{array}$ & $\begin{array}{l}\text { 2-Nitrotoluene } \\
(\mu \mathrm{g} / \mathrm{L})\end{array}$ & $\begin{array}{c}\text { 3-Nitrotoluene } \\
(\mu \mathrm{g} / \mathrm{L})\end{array}$ & $\begin{array}{c}\text { 4-Nitrotoluene } \\
(\mu \mathrm{g} / \mathrm{L})\end{array}$ & $\begin{array}{c}\text { Nitrobenzene } \\
(\mu \mathrm{g} / \mathrm{L})\end{array}$ \\
\hline MW-200I & 0.052 & $<0.090$ & $<0.030$ & 0.13 & 0.054 & 13 & 24 & $<0.030$ & $<0.030$ & $<0.030$ & $<0.040$ \\
\hline$M W-2002$ & $<0.030$ & $<0.090$ & $<0.030$ & 0.070 & 0.41 & 0.83 & 0.93 & $<0.030$ & $<0.030$ & $<0.030$ & $<0.040$ \\
\hline MW-2003 & $<0.030$ & $<0.090$ & $<0.030$ & 0.13 & 0.40 & 0.14 & 0.32 & $<0.120$ & $<0.060$ & $<0.030$ & $<0.040$ \\
\hline MW-2005 & $<0.060$ & $<0.090$ & $<0.030$ & 0.061 & 0.084 & 0.099 & 0.095 & $<0.030$ & $<0.030$ & $<0.030$ & $<0.040$ \\
\hline MW-2006 & $<0.030$ & $<0.090$ & $<0.030$ & $<0.030$ & $(0.009)$ & $<0.020$ & $<0.020$ & $<0.030$ & $<0.030$ & $<0.030$ & $<0.040$ \\
\hline MW-2007 & $<0.030$ & $<0.090$ & $<0.030$ & $<0.030$ & $<0.010$ & $<0.020$ & $<0.020$ & $<0.030$ & $<0.030$ & $<0.030$ & $<0.040$ \\
\hline$M W-2010$ & 0.15 & $<0.090$ & 0.34 & 0.088 & 0.75 & 0.72 & 0.81 & $<0.060$ & $<0.030$ & $<0.030$ & $<0.040$ \\
\hline$M W-2011$ & 0.40 & $<0.090$ & $<0.030$ & 0.18 & 1.4 & 2.0 & 0.98 & 0.22 & $<0.030$ & $<0.030$ & $<0.040$ \\
\hline$M W-2012$ & 1.2 & $<0.090$ & 0.45 & 0.099 & 0.65 & 0.27 & 0.28 & $<0.060$ & $<0.030$ & 0.28 & $<0.040$ \\
\hline$M W \cdot 2013$ & 6.2 & $<0.090$ & 0.85 & 0.36 & 4.4 & 2.4 & 2.2 & 0.26 & 0.058 & $<0.030$ & $<0.040$ \\
\hline MW-2014 & 1.9 & $<0.090$ & 0.044 & 0.15 & 0.41 & 0.41 & 0.63 & 0.14 & $<0.030$ & $<0.030$ & $<0.040$ \\
\hline MW-2015 & $<0.030$ & $<0.090$ & $<0.030$ & $<0.030$ & $<0.010$ & $<0.020$ & $<0.020$ & $<0.030$ & $<0.030$ & $<0.030$ & $<0.040$ \\
\hline MW-2017 & $<0.030$ & $<0.090$ & $<0.030$ & $<0.030$ & $<0.010$ & $<0.020$ & $<0.020$ & $<0.030$ & $<0.030$ & $<0.030$ & $<0.040$ \\
\hline MW-2018 & $<0.030$ & $<0.090$ & $<0.030$ & $<0.030$ & $<0.010$ & $<0.020$ & $<0.020$ & $<0.060$ & $<0.030$ & $<0.030$ & $<0.040$ \\
\hline MW-2019 & $<0.030$ & $<0.090$ & $<0.030$ & $<0.030$ & $<0.010$ & $<0.020$ & $<0.020$ & $<0.070$ & $<0.030$ & $<0.030$ & $<0.040$ \\
\hline$M W-2021$ & $<0.030$ & $<0.090$ & $<0.030$ & $<0.030$ & $<0.010$ & $<0.020$ & $<0.020$ & $<0.030$ & $<0.030$ & $<0.030$ & $<0.040$ \\
\hline$M W-2022$ & $<0.030$ & $<0.090$ & $<0.030$ & $<0.030$ & $<0.010$ & $<0.020$ & $<0.020$ & $<0.030$ & $<0.030$ & $<0.030$ & $<0.040$ \\
\hline$M W-2023$ & $<0.030$ & $<0.090$ & $<0.030$ & $<0.030$ & $<0.010$ & $<0.020$ & $<0.020$ & $<0.030$ & $<0.030$ & $<0.030$ & $<0.040$ \\
\hline MW-2024 & $<0.030$ & $<0.090$ & $<0.030$ & $<0.030$ & $<0.010$ & $<0.020$ & $<0.020$ & $<0.030$ & $<0.030$ & $<0.030$ & $<0.040$ \\
\hline MW-2026 & $<0.030$ & $<0.090$ & $<0.030$ & $<0.030$ & $<0.010$ & $<0.020$ & $<0.020$ & $<0.030$ & $<0.030$ & $<0.030$ & $<0.040$ \\
\hline MW-2027 & $<0.030$ & $<0.090$ & $<0.030$ & $N S^{\sharp}$ & $<0.010$ & $<0.020$ & $<0.020$ & $<0.030$ & $<0.030$ & $<0.030$ & $<0.040$ \\
\hline$M W-2028$ & $<0.030$ & $<0.090$ & $<0.030$ & $N S^{4}$ & $<0.010$ & $<0.020$ & $<0.020$ & $<0.030$ & $<0.030$ & $<0.030$ & $<0.040$ \\
\hline$M W-2030$ & 7.2 & $<0.090$ & 19 & 0.16 & 7.7 & 5.5 & 4.4 & $<0.210$ & 0.060 & $<0.030$ & $<0.040$ \\
\hline$M W-2032$ & 2.3 & $<0.180$ & 6.2 & 0.14 & 4.4 & 3.6 & 2.8 & 0.21 & 0.043 & $<0.030$ & $<0.040$ \\
\hline MW-20.33 & 4.5 & $<0.090$ & 1.1 & 0.55 & 4.9 & 3.6 & 3.3 & 0.65 & 0.047 & 0.090 & $<0.040$ \\
\hline MW-2034 & $<0.030$ & $<0.090$ & $<0.030$ & $<0.030$ & $<0.010$ & $<0.020$ & $<0.020$ & $<0.030$ & $<0.030$ & $<0.030$ & $<0.040$ \\
\hline MW-2035 & $<0.030$ & $<0.090$ & $<0.030$ & $<0.030$ & $<0.010$ & $<0.020$ & $<0.020$ & $<0.030$ & $<0.030$ & $<0.030$ & $<0.030$ \\
\hline MW-2036 & $<0.030$ & $<0.090$ & $<0.030$ & $<0.030$ & $<0.010$ & $<0.020$ & $<0.020$ & $<0.030$ & $<0.030$ & $<0.030$ & $<0.030$ \\
\hline
\end{tabular}


TABLE C.4 (Cont.)

\begin{tabular}{|c|c|c|c|c|c|c|c|c|c|c|c|}
\hline Well No. & $\begin{array}{c}1,3,5-\mathrm{TNB} \\
(\mu \mathrm{g} / \mathrm{L})\end{array}$ & $\begin{array}{c}\text { 1,3-DNB } \\
(\mu \mathrm{g} / \mathrm{L})\end{array}$ & $\begin{array}{c}2,4,6-\mathrm{TNT} \\
(\mu \mathrm{g} / \mathrm{L})\end{array}$ & $\begin{array}{c}2,4-\mathrm{DNT} \\
(\mu \mathrm{g} / \mathrm{L})\end{array}$ & $\begin{array}{c}\text { 2,6-DNT } \\
(\mu \mathrm{g} / \mathrm{L})\end{array}$ & $\begin{array}{c}\text { 2-Amino } \\
(\mu \mathrm{g} / \mathrm{L})\end{array}$ & $\begin{array}{c}\text { 4-Amino } \\
(\mu \mathrm{g} / \mathrm{L})\end{array}$ & $\begin{array}{c}\text { 2-Nitrotoluene } \\
(\mu \mathrm{g} / \mathrm{L})\end{array}$ & $\begin{array}{c}\text { 3-Nitrotoluene } \\
(\mu \mathrm{g} / \mathrm{L})\end{array}$ & $\begin{array}{l}\text { 4-Nitrotoluene } \\
(\mu \mathrm{g} / \mathrm{L})\end{array}$ & $\begin{array}{c}\text { Nitrobenzene } \\
(\mu \mathrm{g} / \mathrm{L})\end{array}$ \\
\hline MW-2037 & 0.16 & $<0.090$ & $<0.030$ & 0.42 & 0.097 & 0.086 & 0.11 & $<0.140$ & $<0.030$ & $<0.030$ & $<0.060$ \\
\hline MW-2038 & $0.2 !$ & $<0.090$ & $<0.030$ & 1.6 & 0.30 & & & & & & $<0.040$ \\
\hline$M W-2039$ & 7.3 & $<0.090$ & $<0.030$ & 0.12 & 1.7 & 2.0 & 1.6 & 0.63 & $<0.030$ & $<0.030$ & 0.054 \\
\hline MW-2040 & $<0.030$ & $<0.090$ & $<0.030$ & $<0.030$ & $<0.010$ & $<0.020$ & $<0.020$ & $<0.030$ & $<0.030$ & $<0.030$ & $<0.040$ \\
\hline$M W-2041$ & $<0.030$ & $<0.090$ & $<0.030$ & $<0.030$ & $<0.010$ & $<0.020$ & $<0.020$ & $<0.030$ & $<0.030$ & $<0.030$ & $<0.040$ \\
\hline$M W-2042$ & $<0.030$ & $<0.090$ & $<0.030$ & $<0.030$ & $<0.010$ & $<0.020$ & $<0.020$ & $<0.030$ & $<0.030$ & $<0.030$ & $<0.040$ \\
\hline$M W-2043$ & $<0.030$ & $<0.090$ & $<0.030$ & 0.087 & $<0.010$ & $<0.020$ & $<0.020$ & $<0.030$ & $<0.030$ & $<0.030$ & $<0.040$ \\
\hline MW-2044 & $<0.030$ & $<0.090$ & $<0.030$ & $<0.030$ & $<0.010$ & $<0.020$ & $<0.020$ & $<0.030$ & $<0.030$ & $<0.030$ & $<0.040$ \\
\hline MW-3003 & $<0.030$ & $<0.090$ & $<0.030$ & 0.17 & 0.37 & $<0.020$ & 0.034 & $<0.030$ & 0.14 & 0.15 & $<0.040$ \\
\hline MW-3006 & $<0.030$ & $<0.090$ & $<0.030$ & $<0.030$ & $<0.010$ & $<0.020$ & $<0.020$ & 1.6 & $<0.030$ & $<0.030$ & $<0.040$ \\
\hline$M W-3019$ & $<0.030$ & $<0.090$ & $<0.030$ & $<0.030$ & $<0.010$ & $<0.020$ & $<0.020$ & $<0.030$ & $<0.030$ & $<0.030$ & $<0.040$ \\
\hline$M W-3023$ & $<0.030$ & $<0.090$ & $<0.030$ & 4.9 & 4.4 & 0.12 & 0.28 & 45 & 3.3 & 0.50 & $<0.040$ \\
\hline$M W-3024$ & $<0.030$ & $<0.090$ & $<0.030$ & 0.13 & 0.45 & 0.031 & 0.047 & 0.30 & $<0.110$ & $<0.060$ & $<0.040$ \\
\hline$M W-3025$ & $<0.030$ & $<0.090$ & $<0.030$ & 0.094 & 0.26 & $<0.020$ & 0.030 & 0.20 & $<0.030$ & $<0.030$ & $<0.040$ \\
\hline$M W-3026$ & 0.14 & $<0.090$ & $<0.030$ & 0.063 & 0.046 & 0.20 & 0.25 & $<0.030$ & $<0.030$ & $<0.030$ & $<0.0 .40$ \\
\hline$M W-3027$ & 0.051 & $<0.090$ & $<0.030$ & 0.052 & 0.026 & 0.13 & 0.13 & $<0.030$ & $<0.030$ & $<0.030$ & $<0.040$ \\
\hline MW-4001 & 39 & $<0.090$ & 1.6 & 1.3 & 3.0 & 14 & 20 & 0.7 & $<0.060$ & $<0.030$ & $<0.060$ \\
\hline MW-4002 & $<0.030$ & $<0.090$ & $<0.030$ & $<0.030$ & $(0.007 l)$ & 0.026 & 0.059 & $<0.030$ & $<0.030$ & $<0.030$ & $<0.040$ \\
\hline MW-4003 & $<0.030$ & $<0.090$ & $<0.030$ & $<0.030$ & $<0.010$ & $(0.016)$ & 0.028 & $<0.030$ & $<0.030$ & $<0.030$ & $<0.040$ \\
\hline$M W-4004$ & $<0.030$ & $<0.090$ & $<0.030$ & $<0.030$ & $<0.010$ & $<0.020$ & $<0.020$ & $<0.030$ & $<0.030$ & $<0.030$ & $<0.040$ \\
\hline MW-4005 & $<0.030$ & $<0.090$ & $<0.030$ & $<0.030$ & $<0.010$ & $<0.020$ & $<0.020$ & $<0.030$ & $<0.030$ & $<0.030$ & $<0.040$ \\
\hline MW-4006 & 10 & $<0.090$ & $<0.030$ & 0.11 & 2.4 & 1.5 & 2.1 & 0.32 & $<0.030$ & $<0.030$ & $<0.040$ \\
\hline$M W-4007$ & $<0.030$ & $<0.090$ & $<0.030$ & $<0.030$ & $<0.010$ & $<0.020$ & $(0.017)$ & $<0.030$ & $<0.030$ & $<0.030$ & $<0.040$ \\
\hline MW-4008 & $<0.030$ & $<0.090$ & $<0.030$ & $<0.030$ & $<0.010$ & $<0.020$ & $<0.020$ & $<0.030$ & $<0.030$ & $<0.030$ & $<0.040$ \\
\hline$M W-4009$ & $<0.030$ & $<0.090$ & $<0.030$ & $<0.030$ & $<0.010$ & $<0.020$ & $<0.020$ & $<0.030$ & $<0.030$ & $<0.030$ & $<0.040$ \\
\hline$M W-4010$ & $<0.030$ & $<0.090$ & $<0.030$ & $<0.030$ & $<0.010$ & $<0.020$ & $<0.020$ & $<0.030$ & $<0.030$ & $<0.030$ & $<0.040$ \\
\hline$M W-4011$ & $<0.030$ & $<0.090$ & $<0.030$ & $<0.030$ & 0.065 & 0.75 & 1.7 & $<0.030$ & $<0.030$ & $<0.030$ & $<0.040$ \\
\hline$M W-4012$ & $<0.030$ & $<0.090$ & $<0.030$ & $<0.030$ & $<0.010$ & $<0.020$ & $<0.020$ & $<0.030$ & $<0.030$ & $<0.030$ & $<0.040$ \\
\hline$M W-4013$ & 24 & $<0.090$ & 0.046 & 0.077 & 0.74 & 1.7 & 2.0 & $<0.030$ & $<0.030$ & $<0.030$ & $<0.040$ \\
\hline$M W-4014$ & $<0.030$ & $<0.090$ & $<0.030$ & $<0.030$ & $<0.010$ & $<0.020$ & $<0.020$ & $<0.030$ & $<0.030$ & $<0.030$ & $<0.040$ \\
\hline
\end{tabular}


TABLE C.4 (Cont.)

\begin{tabular}{|c|c|c|c|c|c|c|c|c|c|c|c|}
\hline Well No. & $\begin{array}{c}1,3,5-\text { TNB } \\
(\mu \mathrm{g} / \mathrm{L})\end{array}$ & $\begin{array}{c}\text { 1,3-DNB } \\
(\mu \mathrm{g} / \mathrm{L})\end{array}$ & $\begin{array}{c}2,4,6-\mathrm{TNT} \\
(\mu \mathrm{g} / \mathrm{L})\end{array}$ & $\begin{array}{c}\text { 2,4-DNT } \\
(\mu \mathrm{g} / \mathrm{L})\end{array}$ & $\begin{array}{c}2,6-\mathrm{DNT} \\
(\mu \mathrm{g} / \mathrm{L})\end{array}$ & $\begin{array}{c}\text { 2-Amino } \\
(\mu \mathrm{g} / \mathrm{L})\end{array}$ & $\begin{array}{c}\text { 4-Amino } \\
(\mu \mathrm{g} / \mathrm{L})\end{array}$ & $\begin{array}{c}\text { 2-Nitrotoluene } \\
(\mu \mathrm{g} / \mathrm{L})\end{array}$ & $\begin{array}{l}\text { 3-Nitrotoluene } \\
(\mu \mathrm{g} / \mathrm{L})\end{array}$ & $\begin{array}{l}\text { 4-Nitrotoluene } \\
(\mu \mathrm{g} / \mathrm{L})\end{array}$ & $\begin{array}{c}\text { Nitrobenzene } \\
(\mu \mathrm{g} / \mathrm{L})\end{array}$ \\
\hline MW-4015 & 1.5 & $<0.090$ & $<0.030$ & 0.19 & 0.84 & 3.2 & 4.1 & $<0.030$ & $<0.030$ & $<0.030$ & $<0.040$ \\
\hline MW-4016 & $<0.030$ & $<0.090$ & $<0.030$ & $<0.030$ & $<0.010$ & $<0.020$ & $<0.020$ & $<0.030$ & $<0.030$ & $<0.030$ & $<0.040$ \\
\hline$M W-4018$ & $<0.030$ & $<0.090$ & $<0.030$ & $<0.030$ & $<0.010$ & $<0.020$ & $<0.020$ & $<0.030$ & $<0.030$ & $<0.030$ & $<0.040$ \\
\hline$M W .4019$ & $<0.030$ & $<0.090$ & $<0.030$ & $<0.030$ & $<0.010$ & $<0.020$ & $<0.020$ & $<0.030$ & $<0.030$ & $<0.030$ & $<0.040$ \\
\hline MW-4020 & $<0.030$ & $<0.090$ & $<0.030$ & $<0.030$ & $<0.010$ & $<0.020$ & $<0.020$ & $<0.030$ & $<0.030$ & $<0.030$ & $<0.040$ \\
\hline MW-4021 & $<0.030$ & $<0.090$ & $<0.030$ & $<0.030$ & $<0.010$ & $<0.020$ & $<0.020$ & $<0.030$ & $<0.030$ & $<0.030$ & $<0.040$ \\
\hline$M W-4022$ & $<0.030$ & $<0.090$ & $<0.030$ & $<0.030$ & $<0.010$ & $<0.020$ & $<0.020$ & $<0.130$ & $<0.030$ & $<0.030$ & $<0.040$ \\
\hline$M W-4023$ & 0.082 & $<0.090$ & $<0.030$ & 0.067 & 0.021 & 0.034 & 0.041 & $<0.030$ & $<0.030$ & $<0.030$ & $<0.040$ \\
\hline$M W-4024$ & $<0.030$ & $<0.090$ & $<0.030$ & $<0.030$ & $<0.010$ & $<0.020$ & $<0.020$ & $<0.030$ & $<0.030$ & $<0.030$ & $<0.040$ \\
\hline MW-4025 & $<0.030$ & $<0.090$ & $<0.030$ & $<0.030$ & $<0.010$ & $<0.020$ & $<0.020$ & $<0.030$ & $<0.030$ & $<0.030$ & $<0.040$ \\
\hline MWD-2 & $<0.030$ & $<0.090$ & $<0.030$ & $<0.030$ & $<0.010$ & $<0.020$ & $<0.020$ & $<0.030$ & $<0.030$ & $<0.030$ & $<0.040$ \\
\hline MWD-5 & $<0.030$ & $<0.090$ & $<0.030$ & $<0.030$ & $<0.010$ & $<0.020$ & $<0.020$ & $<0.030$ & $<0.030$ & $<0.030$ & $<0.040$ \\
\hline MWD-6 & $<0.030$ & $<0.090$ & $<0.030$ & $<0.030$ & $<0.010$ & $<0.020$ & $<0.020$ & $<0.030$ & $<0.030$ & $<0.030$ & $<0.040$ \\
\hline MWD-9 & 0.055 & $<0.090$ & $<0.030$ & 0.036 & 0.13 & 0.071 & 0.42 & $<0.060$ & $<0.030$ & $<0.030$ & $<0.040$ \\
\hline MWD-15 & $<0.030$ & $<0.090$ & $<0.030$ & $<0.030$ & 0.076 & 0.66 & 1.4 & $<0.030$ & $<0.030$ & $<0.030$ & $<0.040$ \\
\hline MWD-18 & $<0.030$ & $<0.090$ & $<0.030$ & $<0.030$ & $<0.010$ & $<0.020$ & $<0.020$ & $<0.030$ & $<0.030$ & $<0.030$ & $<0.040$ \\
\hline MWD-23 & $<0.030$ & $<0.090$ & $<0.030$ & $<0.030$ & $<0.010$ & $<0.020$ & $<0.020$ & $<0.030$ & $<0.030$ & $<0.030$ & $<0.040$ \\
\hline MWD-25 & $<0.030$ & $<0.090$ & $<0.030$ & $<0.030$ & $<0.010$ & $<0.020$ & $<0.020$ & $<0.030$ & $<0.030$ & $<0.030$ & $<0.040$ \\
\hline MWD-105 & $<0.030$ & $<0.090$ & $<0.030$ & $<0.030$ & $<0.010$ & $<0.020$ & $<0.020$ & $<0.030$ & $<0.030$ & $<0.030$ & $<0.040$ \\
\hline MWD-106 & $<0.030$ & $<0.090$ & $<0.030$ & $<0.030$ & $<0.010$ & $<0.020$ & $<0.020$ & $<0.030$ & $<0.030$ & $<0.030$ & $<0.040$ \\
\hline MWD-107 & $<0.030$ & $<0.090$ & $<0.030$ & $<0.030$ & $<0.010$ & $<0.020$ & $<0.020$ & $<0.030$ & $<0.030$ & $<0.030$ & $<0.040$ \\
\hline MWD-109 & $<0.030$ & $<0.090$ & $<0.030$ & $<0.030$ & $<0.010$ & $<0.020$ & $<0.020$ & $<0.030$ & $<0.030$ & $<0.030$ & $<0.040$ \\
\hline MWD-112 & $<0.030$ & $<0.090$ & $<0.030$ & $<0.030$ & $<0.010$ & $<0.020$ & $<0.020$ & $<0.030$ & $<0.030$ & $<0.030$ & $<0.040$ \\
\hline MWS-1 & $<0.030$ & $<0.090$ & $<0.030$ & $<0.030$ & 0.43 & $<0.020$ & 0.028 & $<0.030$ & $<0.030$ & $<0.030$ & $<0.040$ \\
\hline MWS-2 & $<0.030$ & $<0.090$ & $<0.030$ & $<0.030$ & $<0.010$ & $<0.020$ & $<0.020$ & $<0.030$ & $<0.030$ & $<0.030$ & $<0.040$ \\
\hline MWS-3 & $<0.030$ & $<0.090$ & $<0.030$ & $<0.030$ & $<0.010$ & $<0.020$ & $<0.020$ & $<0.030$ & $<0.030$ & $<0.030$ & $<0.040$ \\
\hline MWS-4 & 11 & $<0.090$ & 1.2 & 0.10 & 0.96 & 6.3 & 6.9 & $<0.29$ & $<0.030$ & $<0.030$ & $<0.040$ \\
\hline MWS-5 & $<0.030$ & $<0.090$ & $<0.030$ & $<0.030$ & $<0.010$ & $<0.020$ & $<0.020$ & $<0.030$ & $<0.030$ & $<0.030$ & $<0.040$ \\
\hline MWS-6 & $<0.030$ & $<0.090$ & $<0.030$ & $<0.030$ & $<0.010$ & $<0.020$ & $<0.020$ & $<0.030$ & $<0.030$ & $<0.030$ & $<0.040$ \\
\hline MWS-7 & 11 & $<0.090$ & 1.0 & 0.049 & 0.49 & 4.1 & 8.4 & $<0.080$ & $<0.030$ & $<0.030$ & $<0.040$ \\
\hline
\end{tabular}


TABLE C.4 (Cont.)

\begin{tabular}{|c|c|c|c|c|c|c|c|c|c|c|c|}
\hline Well No. & $\begin{array}{c}1,3,5-\mathrm{TNB} \\
(\mu \mathrm{g} / \mathrm{L})\end{array}$ & $\begin{array}{c}\text { I,3-DNB } \\
(\mu \mathrm{g} / \mathrm{L})\end{array}$ & $\begin{array}{c}2,4,6-\mathrm{TNT} \\
(\mu \mathrm{g} / \mathrm{L})\end{array}$ & $\begin{array}{c}2,4-\mathrm{DNT} \\
(\mu \mathrm{g} / \mathrm{L})\end{array}$ & $\begin{array}{c}2,6-\mathrm{DNT} \\
(\mu \mathrm{g} / \mathrm{L}) \\
\end{array}$ & $\begin{array}{c}\text { 2-Amino } \\
(\mu \mathrm{g} / \mathrm{L})\end{array}$ & $\begin{array}{c}\text { 4-Amino } \\
(\mu \mathrm{g} / \mathrm{L})\end{array}$ & $\begin{array}{c}2 \cdot \text { Nitrotoluene } \\
(\mu \mathrm{g} / \mathrm{L})\end{array}$ & $\begin{array}{c}\text { 3-Nitrotoluene } \\
(\mu \mathrm{g} / \mathrm{L})\end{array}$ & $\begin{array}{c}\text { 4-Nitrotoluene } \\
(\mu \mathrm{g} / \mathrm{L})\end{array}$ & $\begin{array}{c}\text { Nitrobenzene } \\
(\mu \mathrm{g} / \mathrm{L})\end{array}$ \\
\hline MWS-8 & $<0.030$ & $<0.090$ & $<0.030$ & $<0.030$ & $<0.010$ & $<0.020$ & $<0.020$ & $<0.030$ & $<0.030$ & $<0.030$ & $<0.040$ \\
\hline MWS-9 & $<0.030$ & $<0.090$ & $<0.030$ & $<0.030$ & $<0.010$ & $<0.020$ & $<0.020$ & $<0.030$ & $<0.030$ & $<0.030$ & $<0.040$ \\
\hline MWS-10 & 0.21 & $<0.090$ & $(0.028)$ & 0.082 & 2.0 & 6.3 & 16 & $<0.090$ & $<0.030$ & $<0.030$ & $<0.040$ \\
\hline MWS-1! & $<0.060$ & $<0.090$ & 0.046 & 0.055 & 0.54 & 0.48 & 2.3 & $<0.070$ & $<0.030$ & $<0.030$ & $<0.040$ \\
\hline MWS-12 & 0.49 & 0.27 & 0.14 & 8.8 & 15 & 1.1 & 2.5 & 100 & 7.7 & 30 & $<0.040$ \\
\hline MWS-13 & $<0.030$ & $<0.090$ & $<0.030$ & $<0.030$ & $<0.010$ & $<0.020$ & $<0.020$ & $<0.030$ & $<0.030$ & $<0.030$ & $<0.040$ \\
\hline MWS-14 & $<0.030$ & $<0.090$ & $<0.030$ & $<0.030$ & $<0.010$ & $<0.020$ & $<0.020$ & $<0.030$ & $<0.030$ & $<0.030$ & $<0.040$ \\
\hline MWS- 15 & 1.1 & $<0.090$ & 5.6 & 0.081 & 1.0 & 11 & 20 & $<0.060$ & $<0.030$ & $<0.030$ & $<0.040$ \\
\hline MWS- 16 & 10 & $<0.090$ & 2.9 & 0.074 & 0.99 & 3.9 & 6.0 & 0.14 & $<0.030$ & $<0.030$ & $<0.040$ \\
\hline MWS. 17 & $<0.030$ & $<0.090$ & $<0.030$ & 1.1 & 1.8 & 3.9 & 4.6 & 7.2 & 0.31 & 0.93 & $<0.040$ \\
\hline MWS-18 & $<0.030$ & $<0.090$ & $<0.030$ & $<0.030$ & $<0.010$ & $<0.020$ & $<0.020$ & $<0.030$ & $<0.030$ & $<0.030$ & $<0.040$ \\
\hline MWS-19 & 0.042 & $<0.090$ & $<0.030$ & 0.079 & 0.10 & 0.27 & 0.39 & $<0.040$ & $<0.030$ & $<0.030$ & $<0.040$ \\
\hline MWS-20 & $<0.030$ & $<0.090$ & $<0.030$ & $<0.030$ & $<0.010$ & $<0.020$ & 0.040 & $<0.030$ & $<0.030$ & $<0.030$ & $<0.040$ \\
\hline MWS-21 & $<0.030$ & $<0.090$ & $<0.060$ & 0.94 & 0.17 & 0.23 & 0.41 & $<0.090$ & $<0.060$ & $<0.030$ & $<0.040$ \\
\hline MWS-22 & $<0.030$ & $<0.090$ & $<0.030$ & $<0.060$ & 0.12 & 0.073 & 0.19 & $<0.060$ & $<0.030$ & $<0.030$ & $<0.040$ \\
\hline MWS-23 & $<0.030$ & $<0.090$ & $<0.030$ & $<0.030$ & $<0.010$ & $<0.020$ & $<0.020$ & $<0.030$ & $<0.030$ & $<0.030$ & $<0.040$ \\
\hline MWS-25 & $<0.030$ & $<0.090$ & $<0.030$ & $<0.030$ & $<0.010$ & $<0.020$ & $<0.020$ & $<0.030$ & $<0.030$ & $<0.030$ & $<0.040$ \\
\hline MWS-26 & $<0.030$ & $<0.090$ & $<0.030$ & $<0.030$ & $<0.010$ & $<0.020$ & $<0.020$ & $<0.030$ & $<0.030$ & $<0.030$ & $<0.040$ \\
\hline MWS-101 & $<0.030$ & $<0.090$ & $<0.030$ & $<0.040$ & $<0.010$ & $<0.020$ & $<0.020$ & $<0.030$ & $<0.030$ & $<0.030$ & $<0.040$ \\
\hline MWS-102 & $<0.030$ & $<0.090$ & $<0.030$ & $<0.030$ & $<0.010$ & $<0.020$ & $<0.020$ & $<0.030$ & $<0.030$ & $<0.030$ & $<0.040$ \\
\hline MWS-103 & $<0.030$ & $<0.090$ & $<0.030$ & $<0.030$ & $<0.010$ & $<0.020$ & $<0.020$ & $<0.030$ & $<0.030$ & $<0.030$ & $<0.040$ \\
\hline MWS-104 & $<0.030$ & $<0.090$ & $<0.030$ & $<0.030$ & $<0.010$ & $<0.020$ & $<0.020$ & $<0.030$ & $<0.030$ & $<0.030$ & $<0.040$ \\
\hline MWS-105 & $<0.030$ & $<0.090$ & $<0.030$ & $<0.030$ & $<0.010$ & $<0.020$ & $<0.020$ & $<0.030$ & $<0.030$ & $<0.030$ & $<0.040$ \\
\hline MWS-106 & $<0.030$ & $<0.090$ & $<0.030$ & $<0.030$ & $<0.010$ & $<0.020$ & $<0.020$ & $<0.030$ & $<0.030$ & $<0.030$ & $<0.040$ \\
\hline MWS- 107 & 0.065 & $<0.090$ & $<0.030$ & 0.059 & 0.16 & 0.059 & 0.65 & $<0.030$ & $<0.030$ & $<0.030$ & $<0.040$ \\
\hline MWS- 108 & $<0.030$ & $<0.090$ & $<0.030$ & $<0.030$ & $<0.010$ & $<0.020$ & $<0.020$ & $<0.030$ & $<0.030$ & $<0.030$ & $<0.040$ \\
\hline MWS-109 & $<0.030$ & $<0.090$ & $<0.030$ & $<0.030$ & $<0.010$ & $<0.020$ & $<0.020$ & $<0.030$ & $<0.030$ & $<0.030$ & $<0.040$ \\
\hline MWS-110 & 0.072 & $<0.090$ & $<0.030$ & $<0.030$ & 0.054 & 0.17 & 0.37 & $<0.030$ & $<0.030$ & $<0.030$ & $<0.040$ \\
\hline MWS-111 & $<0.030$ & $<0.090$ & $<0.030$ & $<0.030$ & $<0.010$ & $<0.020$ & $<0.020$ & $<0.030$ & $<0.030$ & $<0.030$ & $<0.040$ \\
\hline MWS- 112 & $<0.030$ & $<0.090$ & $<0.030$ & $(0.027)$ & $<0.010$ & $<0.020$ & $<0.020$ & $<0.030$ & $<0.030$ & $<0.030$ & 0.062 \\
\hline
\end{tabular}


TABLE C.4 (Cont.)

\begin{tabular}{|c|c|c|c|c|c|c|c|c|c|c|c|}
\hline Well No. & $\begin{array}{c}1,3,5-\mathrm{TNB} \\
(\mu \mathrm{g} / \mathrm{L})\end{array}$ & $\begin{array}{c}\text { 1,3-DNB } \\
(\mu \mathrm{g} / \mathrm{L})\end{array}$ & $\begin{array}{c}2,4,6-\mathrm{TNT} \\
(\mu \mathrm{g} / \mathrm{L})\end{array}$ & $\begin{array}{c}2,4-\mathrm{DNT} \\
(\mu \mathrm{g} / \mathrm{L}) \\
\end{array}$ & $\begin{array}{c}2,6-\mathrm{DNT} \\
(\mu \mathrm{g} / \mathrm{L})\end{array}$ & $\begin{array}{c}\text { 2-Amino } \\
(\mu \mathrm{g} / \mathrm{L})\end{array}$ & $\begin{array}{c}\text { 4-Amino } \\
(\mu \mathrm{g} / \mathrm{L})\end{array}$ & $\begin{array}{c}\text { 2-Nitrotoluene } \\
(\mu \mathrm{g} / \mathrm{L})\end{array}$ & $\begin{array}{l}\text { 3-Nitrotoluene } \\
(\mu \mathrm{g} / \mathrm{L})\end{array}$ & $\begin{array}{l}\text { 4-Nitrotoluene } \\
(\mu \mathrm{g} / \mathrm{L})\end{array}$ & $\begin{array}{c}\text { Nitrobenzene } \\
(\mu \mathrm{g} / \mathrm{L})\end{array}$ \\
\hline TIL3 & $<0.030$ & $<0.090$ & $<0.030$ & $<0.060$ & $<0.010$ & $<0.020$ & $<0.020$ & $<0.030$ & $<0.030$ & $<0.030$ & $<0.040$ \\
\hline USGI & 0.063 & 0.14 & $<0.030$ & 0.046 & 0.022 & 0.057 & 0.17 & $<0.030$ & $<0.030$ & $<0.030$ & $<0.040$ \\
\hline USG2 & $<0.030$ & $<0.090$ & $<0.030$ & $<0.030$ & $<0.010$ & $<0.020$ & $<0.020$ & $<0.030$ & $<0.030$ & $<0.030$ & $<0.040$ \\
\hline USG3 & 0.10 & $<0.090$ & $<0.030$ & $(0.022)$ & 0.15 & 0.025 & 0.19 & $<0.030$ & $<0.030$ & $<0.030$ & $<0.040$ \\
\hline USG4 & 1.8 & $<0.090$ & $<0.030$ & 0.19 & 1.7 & 2.0 & 2.2 & 0.57 & 0.049 & $<0.030$ & $<0.040$ \\
\hline USG.5 & $<0.030$ & $<0.090$ & $<0.030$ & $<0.030$ & $<0.010$ & $<0.020$ & $<0.020$ & $<0.030$ & $<0.030$ & $<0.030$ & $<0.040$ \\
\hline USG6 & $<0.030$ & $<0.090$ & $<0.030$ & $<0.030$ & $<0.010$ & $<0.020$ & $<0.020$ & $<0.030$ & $<0.030$ & $<0.030$ & $<0.040$ \\
\hline USG8 & $<0.030$ & $<0.090$ & $<0.030$ & & $<0.010$ & $<0.020$ & $<0.020$ & $<0.030$ & $<0.070$ & $<0.030$ & $<0.040$ \\
\hline USG9 & $<0.030$ & $<0.090$ & $<0.030$ & 0.092 & $(0.0080)$ & 2.0 & 2.7 & $<0.030$ & $<0.030$ & $<0.030$ & $<0.040$ \\
\hline MWV-1 & $<0.030$ & $<0.090$ & 0.035 & 0.067 & 0.40 & 1.7 & 3.3 & 0.13 & $<0.030$ & $<0.030$ & $<0.040$ \\
\hline$M W V-2$ & $<0.030$ & $<0.090$ & $<0.030$ & $<0.030$ & 0.018 & 0.17 & 0.54 & $<0.030$ & $<0.030$ & $<0.030$ & $<0.040$ \\
\hline MWV-9 & 14 & 0.40 & 30 & 20 & 2.9 & 31 & 24 & $N S^{a}$ & 0.13 & 0.22 & $<0.040$ \\
\hline$M W V-13$ & $<0.030$ & $<0.090$ & $<0.030$ & $<0.030$ & $<0.010$ & $<0.020$ & $<0.020$ & $<0.030$ & $<0.030$ & $<0.030$ & $<0.040$ \\
\hline MWV-16 & 0.33 & $<0.090$ & 0.27 & $<0.030$ & 0.069 & 0.040 & 0.57 & $<0.030$ & $<0.030$ & $<0.030$ & $<0.040$ \\
\hline$M W V-17$ & $<0.030$ & $<0.090$ & $<0.030$ & $<0.030$ & $<0.010$ & $<0.020$ & $<0.020$ & $<0.030$ & $<0.030$ & $<0.030$ & $<0.040$ \\
\hline MWV-22 & $<0.030$ & $<0.090$ & $<0.030$ & $<0.030$ & 0.14 & 0.057 & 0.21 & $<0.060$ & $<0.030$ & $<0.030$ & $<0.040$ \\
\hline MWV-24 & 3.1 & $<0.090$ & 1.1 & 0.13 & 1.4 & 0.42 & 0.74 & 0.36 & $<0.030$ & 0.063 & $<0.040$ \\
\hline
\end{tabular}

a $N S=$ no sample. 
TABLE C.5 Anion and Radiological Results for Groundwater Samples from August 1995

\begin{tabular}{|c|c|c|c|c|c|}
\hline $\begin{array}{l}\text { Well } \\
\text { No. }\end{array}$ & $\begin{array}{l}\text { Chloride } \\
\text { (mg/L) }\end{array}$ & $\begin{array}{c}\text { Fluoride } \\
\text { (mg/L) }\end{array}$ & $\begin{array}{l}\text { Nitrate } \\
(\mathrm{mg} / \mathrm{L})\end{array}$ & $\begin{array}{l}\text { Sulfate } \\
(\mathrm{mg} / \mathrm{L})\end{array}$ & $\begin{array}{l}\text { Uranium } \\
(\mathrm{pCi} / \mathrm{L})\end{array}$ \\
\hline MW-2001 & 5.9 & $(0.066)$ & 49 & 12 & $(0.65)$ \\
\hline MW-2002 & 6.6 & $(0.055)$ & 130 & 120 & $(0.48)$ \\
\hline MW-2003 & 9.0 & $<0.1$ & 310 & 100 & 1.06 \\
\hline MW-2005 & 3.5 & $<0.1$ & 60 & 29 & $(0.45)$ \\
\hline MW-2006 & 3.7 & $<0.1$ & 4.9 & $(9.2)$ & $(0.310)$ \\
\hline MW-2007 & 1.2 & 0.12 & $<0.1$ & 15 & 0.95 \\
\hline MW-2010 & 47 & 0.10 & 1.1 & 41 & 1.11 \\
\hline MW-2011 & 4.2 & 0.11 & 4.8 & 13 & $(0.27)$ \\
\hline MW-2012 & 48 & $<0.1$ & 0.37 & 58 & $(0.33)$ \\
\hline MW-2013 & 5.3 & $<0.1$ & 1.0 & 27 & 0.66 \\
\hline MW-2014 & 26 & $<0.1$ & 1.7 & 38 & $(0.48)$ \\
\hline MW-2015 & 1.07 & 0.11 & 0.53 & 132 & 1.5 \\
\hline MW-2017 & 15 & 0.14 & 5.5 & 1120 & 12.0 \\
\hline MW-2018 & 7.9 & 0.23 & 0.67 & 11 & 1.5 \\
\hline MW-2019 & 1.0 & 0.26 & $<0.1$ & 22 & 2.2 \\
\hline MW-2021 & 1.10 & 0.110 & $(0.005)$ & 13.0 & 0.87 \\
\hline MW-2022 & 1.2 & 0.12 & $<0.1$ & 14 & 1.03 \\
\hline MW-2023 & 1.1 & 0.18 & $<0.1$ & 14 & 2.5 \\
\hline MW-2024 & 1.7 & 0.18 & $<0.1$ & 29 & $(0.11)$ \\
\hline MW-2026 & 1.4 & 0.18 & $<0.1$ & 13 & 0.63 \\
\hline MW-2027 & 1.1 & 0.21 & $<0.1$ & (5.3) & 0.81 \\
\hline MW-2028 & 1.3 & 0.12 & $<0.1$ & 125 & 0.73 \\
\hline MW-2030 & 24 & $<0.1$ & 1.3 & 50.0 & 13 \\
\hline MW-2032 & 17 & $(0.09)$ & 29 & 54 & 4.20 \\
\hline MW-2033 & 5.4 & $<0.1$ & 1.1 & 42 & 2.3 \\
\hline$M W-2034$ & 26 & 0.19 & $<0.1$ & 320 & 3.0 \\
\hline MW-2035 & $<1.0$ & 0.30 & 0.41 & $<10.0$ & $(0.36)$ \\
\hline MW-2036 & $<1.0$ & 0.24 & 3.2 & $<10.0$ & 0.77 \\
\hline MW-2037 & 32 & 0.10 & 290 & 130 & 0.93 \\
\hline MW-2038 & $<1.0$ & $<0.1$ & 780 & 110 & 1.1 \\
\hline MW-2039 & 49 & 0.27 & 36 & 33 & 2.80 \\
\hline MW-2040 & 3.0 & 0.17 & 197 & $(9.9)$ & 1.7 \\
\hline MW-2041 & 5.7 & 0.18 & 260 & 35 & 2.3 \\
\hline MW-2042 & 8.80 & 0.26 & 4.8 & 24 & 2.2 \\
\hline
\end{tabular}


TABLE C.5 (Cont.)

\begin{tabular}{|c|c|c|c|c|c|}
\hline $\begin{array}{l}\text { Well } \\
\text { No. }\end{array}$ & $\begin{array}{c}\text { Chloride } \\
\text { (mg/L) }\end{array}$ & $\begin{array}{c}\text { Fluoride } \\
(\mathrm{mg} / \mathrm{L})\end{array}$ & $\begin{array}{l}\text { Nitrate } \\
(\mathrm{mg} / \mathrm{L})\end{array}$ & $\begin{array}{l}\text { Sulfate } \\
(\mathrm{mg} / \mathrm{L})\end{array}$ & $\begin{array}{l}\text { Uranium } \\
(\mathrm{pCi} / \mathrm{L})\end{array}$ \\
\hline MW-2043 & 3.30 & 0.23 & 5.17 & 15.1 & 1.5 \\
\hline MW-2044 & 19 & 0.24 & 1.3 & 130 & 1.6 \\
\hline MW-3003 & 12 & 0.14 & 440 & 135 & 12.2 \\
\hline MW-3006 & 1.2 & 0.16 & $<1.0$ & 22 & 0.700 \\
\hline MW-3019 & $<1.0$ & 0.28 & $<0.1$ & $<10.0$ & 1.7 \\
\hline MW-3023 & 9.6 & 0.17 & 49 & 250 & 7.9 \\
\hline MW-3024 & 12 & 0.15 & 350 & 81 & 2.9 \\
\hline MW-3025 & 11 & 0.15 & 520 & 55 & 2.7 \\
\hline MW-3026 & 6.3 & $<0.1$ & 200 & 14 & 3.07 \\
\hline MW-3027 & 2.4 & 0.23 & 57 & $<10.0$ & 0.98 \\
\hline MW-4001 & 3.1 & $<0.1$ & 40 & 65 & $(0.25)$ \\
\hline MW-4002 & $(0.99)$ & 0.11 & 0.80 & 14 & 0.56 \\
\hline MW-4003 & 4.8 & 0.22 & 0.63 & 27 & 1.1 \\
\hline MW-4004 & 3.3 & 0.28 & 0.88 & 19 & 1.7 \\
\hline MW-4005 & 5.7 & 0.28 & 1.6 & 19 & 1.50 \\
\hline MW-4006 & 1.6 & 0.13 & 11 & 24 & $(0.26)$ \\
\hline MW-4007 & 2.3 & 0.23 & $<0.1$ & 62 & 1.4 \\
\hline MW-4008 & $<1.0$ & 0.26 & $<0.1$ & 14 & 0.64 \\
\hline MW-4009 & $<1.0$ & 0.23 & 0.11 & 13 & 1.2 \\
\hline MW-4010 & 1.1 & 0.17 & $<0.1$ & 23 & 2.8 \\
\hline MW-4011 & 11 & $(0.07)$ & 170 & 83 & 3.1 \\
\hline MW-4012 & 1.8 & 0.34 & $<0.1$ & 36 & 5.00 \\
\hline MW-4013 & 7.6 & $<0.1$ & 94 & 56 & $<0.67$ \\
\hline MW-4014 & 1.7 & 0.21 & 0.25 & 25 & $<0.67$ \\
\hline MW-4015 & 8.1 & $(0.083)$ & 4.2 & 27 & $(0.25)$ \\
\hline MW-4016 & $(0.81)$ & 0.17 & $(0.04)$ & 13.9 & 2.5 \\
\hline MW-4018 & 20 & $<0.1$ & 2.6 & $<10.0$ & 0.51 \\
\hline MW-4019 & $<1.0$ & 0.31 & 0.23 & $<10.0$ & 1.7 \\
\hline MW-4020 & 15 & 0.19 & $<0.1$ & 150 & 0.85 \\
\hline MW-4021 & 1.2 & 0.11 & $<0.1$ & 260 & 1.8 \\
\hline MW-4022 & 2.6 & 0.22 & 0.26 & 23 & 5.2 \\
\hline MW-4023 & 12 & 0.19 & 2.3 & 93 & 0.47 \\
\hline MW-4024 & 7.5 & 0.16 & 1.4 & 680 & 16.6 \\
\hline MW-4025 & 8.7 & 0.13 & 0.86 & 26 & 0.98 \\
\hline MWD-2 & 1.1 & 0.20 & $<0.1$ & 16 & 1.1 \\
\hline MWD-5 & 1.9 & 1.2 & 0.12 & 26 & $(0.26)$ \\
\hline MWD-6 & $<1.0$ & 0.16 & $<0.1$ & 20 & 0.49 \\
\hline
\end{tabular}


TABLE C.5 (Cont.)

\begin{tabular}{|c|c|c|c|c|c|}
\hline $\begin{array}{l}\text { Well } \\
\text { No. }\end{array}$ & $\begin{array}{c}\text { Chloride } \\
(\mathrm{mg} / \mathrm{L})\end{array}$ & $\begin{array}{c}\text { Fluoride } \\
\text { (mg/L) }\end{array}$ & $\begin{array}{l}\text { Nitrate } \\
(\mathrm{mg} / \mathrm{L})\end{array}$ & $\begin{array}{l}\text { Sulfate } \\
(\mathrm{mg} / \mathrm{L})\end{array}$ & $\begin{array}{l}\text { Uranium } \\
(\mathrm{pCi} / \mathrm{L})\end{array}$ \\
\hline MWD-9 & 1.2 & 0.16 & $<0.1$ & 12 & 0.54 \\
\hline MWD-15 & 1.4 & 0.12 & 4.3 & $<10.0$ & $(0.34)$ \\
\hline MWD-18 & 1.8 & 0.63 & $<0.1$ & 15 & $(0.08)$ \\
\hline MWD-23 & 3.1 & 0.26 & $<0.1$ & 20 & 3.6 \\
\hline MWD-25 & 11 & 0.18 & 0.33 & 45 & 1.8 \\
\hline MWD-105 & 1.7 & 0.59 & $<0.1$ & 29 & $(0.28)$ \\
\hline MWD-106 & 1.8 & 0.99 & $<0.1$ & 16 & $<0.67$ \\
\hline MWD-107 & 3.1 & 0.16 & $<0.1$ & 25 & 2.03 \\
\hline MWD-109 & 1.1 & 0.19 & $<0.1$ & 14 & $(0.51)$ \\
\hline MWD-112 & 1.3 & 0.34 & $<0.1$ & 19 & $(0.40)$ \\
\hline MWS-1 & 2.3 & $<0.1$ & 2.5 & $<10.0$ & 0.68 \\
\hline MWS-2 & 1.0 & 0.18 & $<0.1$ & 15 & 1.4 \\
\hline MWS-3 & 1.3 & 0.26 & $<0.1$ & 23 & 3.0 \\
\hline MWS-4 & 2.2 & $<0.1$ & 7.9 & 35 & 10 \\
\hline MWS-5 & $<1.0$ & 0.20 & $<0.1$ & 19 & 0.83 \\
\hline MWS-6 & 1.0 & 0.17 & $<0.1$ & 19 & 2.8 \\
\hline MWS-7 & 1.9 & 0.14 & 2.3 & 39 & 0.71 \\
\hline MWS-8 & 3.9 & 0.14 & 1.9 & 33 & 0.98 \\
\hline MWS-9 & $(0.96)$ & 0.24 & $<0.1$ & 12 & 1.00 \\
\hline MWS-10 & 2.1 & 0.16 & 7.2 & 64 & $(0.13)$ \\
\hline MWS-11 & 3.2 & 0.21 & 8.8 & 43 & 1.4 \\
\hline MWS-12 & 1.9 & 0.16 & 2.8 & $<10.0$ & 1.0 \\
\hline MWS-13 & 6.6 & $<0.1$ & 1.2 & 600 & $(0.5)$ \\
\hline MWS-14 & 11 & 0.17 & 0.14 & 24 & 1.50 \\
\hline MWS-15 & 1.8 & $<0.1$ & 0.91 & 33 & 0.45 \\
\hline MWS-16 & 9.0 & $<0.1$ & 6.6 & 23 & 0.55 \\
\hline MWS-17 & 4.3 & $<0.1$ & 3.1 & 45 & 1.2 \\
\hline MWS-18 & 2.9 & 0.88 & 0.33 & 100 & 1.2 \\
\hline MWS-19 & 1.4 & $<0.1$ & 0.15 & 20 & 0.64 \\
\hline MWS-20 & 2.4 & 0.11 & 5.6 & 17 & 0.69 \\
\hline MWS-21 & 26 & 0.18 & 420 & 95 & 2.9 \\
\hline MWS-22 & 4.3 & 0.22 & 3.0 & 18 & 0.72 \\
\hline MWS-23 & $<1.0$ & $<0.1$ & $<0.1$ & $<10.0$ & $(0.44)$ \\
\hline MWS-25 & 6.8 & 0.17 & 0.60 & 37 & 1.6 \\
\hline MWS-26 & ns & ns & ns & ns & ns \\
\hline MWS-101 & 9.1 & 0.11 & $<0.1$ & $(8.4)$ & $(0.07)$ \\
\hline MWS-102 & 4.2 & 0.21 & $<0.1$ & 15 & $<4.2$ \\
\hline MWS-103 & 3.2 & $(0.09)$ & $<0.1$ & 49 & $<0.84$ \\
\hline
\end{tabular}




$$
\text { C-43 }
$$

TABLE C.5 (Cont.)

\begin{tabular}{lccccc}
\hline Well & $\begin{array}{c}\text { Chloride } \\
\text { No. }\end{array}$ & $\begin{array}{c}\text { Fluoride } \\
(\mathrm{mg} / \mathrm{L})\end{array}$ & $\begin{array}{c}\text { Nitrate } \\
(\mathrm{mg} / \mathrm{L})\end{array}$ & $\begin{array}{c}\text { Sulfate } \\
(\mathrm{mg} / \mathrm{L})\end{array}$ & $\begin{array}{c}\text { Uranium } \\
(\mathrm{pCi} / \mathrm{L})\end{array}$ \\
\hline MWS-104 & $<1.0$ & 0.13 & $<0.1$ & 11 & 1.30 \\
MWS-105 & 1.3 & 0.25 & $<0.1$ & 11 & $(0.12)$ \\
MWS-106 & 1.6 & 0.47 & $<0.1$ & 11 & $(0.42)$ \\
MWS-107 & 3.9 & 0.14 & 1.6 & 16 & 1.81 \\
MWS-108 & 1.1 & 0.25 & $<0.1$ & 14 & $<0.57$ \\
MWS-109 & 1.0 & 0.14 & $<0.1$ & 12 & 0.73 \\
MWS-110 & 1.6 & 0.14 & 0.68 & 20 & $(0.62)$ \\
MWS-111 & 1.2 & 0.17 & 0.25 & $(0.42)$ & $(0.75)$ \\
MWS-112 & 3.1 & 0.29 & $<0.1$ & 20 & 1.1 \\
TIL3 & 2.3 & 1.5 & $<0.1$ & 11 & $(0.11)$ \\
USG1 & 3.7 & 0.19 & 0.79 & 15 & 0.85 \\
USG2 & 1.2 & 0.25 & $<0.1$ & 10 & $<0.67$ \\
USG3 & 2.2 & 0.23 & 0.85 & 17 & 1.1 \\
USG4 & 2.8 & $(0.09)$ & 1.5 & 25 & $(0.54)$ \\
USG5 & 1.2 & 0.14 & 0.23 & $(8.1)$ & $<0.84$ \\
USG6 & 1.8 & 0.50 & 0.51 & 15 & 3.9 \\
USG8 & 2.9 & 0.10 & 3.0 & 13 & $(0.41)$ \\
USG9 & 5.1 & $<0.1$ & 3.2 & 19 & $(0.13)$ \\
MWV-1 & $<1.0$ & 0.14 & 1.5 & 14 & 4.1 \\
MWV-2 & 1.8 & 0.13 & 2.7 & 25 & 3.4 \\
MWV-9 & 2.3 & 0.19 & 0.79 & 56 & 0.43 \\
MWV-13 & 6.6 & 0.11 & 1.1 & 360 & 1.2 \\
MWV-16 & 3.0 & 0.19 & 0.82 & 25 & 1.2 \\
MWV-17 & $<1.0$ & $<0.1$ & 2.1 & 15 & $(0.06)$ \\
MWV-22 & 4.0 & 0.23 & 3.4 & 14 & 0.74 \\
MWV-24 & 1.1 & 0.26 & 0.35 & 31 & 1.5 \\
\hline
\end{tabular}


TABLE C.6 Metals Results (filtered and unfiltered) for August 1995 Joint Sampling

\begin{tabular}{|c|c|c|c|c|c|c|c|c|c|c|}
\hline Well No. & $\begin{array}{c}\text { Aluminum } \\
(\mu \mathrm{g} / \mathrm{L})\end{array}$ & $\begin{array}{c}\text { Antimony } \\
(\mu \mathrm{g} / \mathrm{L})\end{array}$ & $\begin{array}{c}\text { Arsenic } \\
(\mu \mathrm{g} / \mathrm{L})\end{array}$ & $\begin{array}{l}\text { Barium } \\
(\mu \mathrm{g} / \mathrm{L})\end{array}$ & $\begin{array}{c}\text { Cadmium } \\
(\mu \mathrm{g} / \mathrm{L})\end{array}$ & $\begin{array}{c}\text { Chromium } \\
(\mu \mathrm{g} / \mathrm{L})\end{array}$ & $\begin{array}{l}\text { Copper } \\
(\mu g / L)\end{array}$ & $\begin{array}{c}\text { Iron } \\
(\mu \mathrm{g} / \mathrm{L})\end{array}$ & $\begin{array}{l}\text { Lead } \\
(\mu g / L)\end{array}$ & $\begin{array}{c}\text { Lithium } \\
(\mu \mathrm{g} / \mathrm{L})\end{array}$ \\
\hline MW-2001 & $<480$ & $<1.0$ & $<2.0$ & 272 & $<1.0$ & $<2.3$ & $<35$ & $<89.0$ & $<3.3$ & $<3.0$ \\
\hline$M W-2001-F^{a}$ & $<473$ & $<1.0$ & $<2.0$ & 279 & $<1.0$ & $<3.4$ & $<35$ & $<92$ & $<3.0$ & $<3.0$ \\
\hline$M W-2002$ & $<469$ & $<1.0$ & $<2.0$ & 123 & $<1.0$ & $<2.2$ & $<34$ & $<105$ & $<3.1$ & 256 \\
\hline$M W-2002-F$ & $<573$ & 1.5 & $<2.0$ & 119 & $<1.0$ & $<2.4$ & $<37$ & $<101$ & $<2.5$ & 243 \\
\hline MW-2003 & $<1,040$ & $<1.0$ & $<2.0$ & 259 & $<1.0$ & $<1.6$ & $<35.0$ & 774 & $<3.2$ & 378 \\
\hline$M W-2003-F$ & $<484$ & $<1.0$ & $<2.0$ & 253 & $<1.0$ & $<1.40$ & $<34$ & $<114$ & $<1.6$ & 405 \\
\hline$M W-2005$ & $<14.0$ & $<1.0$ & $<2.0$ & 166 & $<1.0$ & 3.7 & $<2.0$ & 118 & 7.3 & 97 \\
\hline $\mathrm{MW}-2005-\mathrm{F}$ & $<14.0$ & 1.2 & $<2.0$ & 169 & $<1.0$ & 3.0 & 2.6 & 86 & 3.0 & 101 \\
\hline MW-2006 & 41 & 1.1 & 2.8 & 292 & $<1.0$ & 12 & 3.3 & 179 & 4.4 & 16 \\
\hline MW-2006-F & 39 & 3.4 & 3.5 & 272 & $<1.0$ & 7.1 & $<2.0$ & 103 & 1.1 & 17 \\
\hline MW-2007 & $<14.0$ & $<1.0$ & $<2.0$ & 157 & $<1.0$ & 3.6 & $<2.0$ & 88 & 10.6 & 4.0 \\
\hline$M W-2007-F$ & $<14.0$ & 2.5 & $<2.0$ & 150 & $<1.0$ & 1.9 & $<2.0$ & 49 & $<1.0$ & 3.9 \\
\hline MW-2010 & 38 & $<1.0$ & $<2.0$ & 262 & $<1.0$ & 22 & 2.1 & 323 & 2.3 & 6.7 \\
\hline MW-2010-F & 51 & 6.0 & 8.0 & 245 & $<1.0$ & 10 & 2.2 & 183 & $<1.0$ & 7.4 \\
\hline MW-2011 & $<28$ & $<1.0$ & 5.3 & 136 & $<1.0$ & $<2.7$ & $<2.0$ & 41 & $<1.0$ & 4.5 \\
\hline$M W-2011-F$ & $<19$ & $<1.0$ & 4.8 & 140 & $<1.0$ & $<5.4$ & $<2.0$ & 140 & $<1.0$ & 4.3 \\
\hline$M W-2012$ & 50 & 1.9 & 2.3 & 110 & $<1.0$ & $<1.0$ & 2.6 & 250 & 1.7 & 1.8 \\
\hline$M W-2012-F$ & 23 & $<1.0$ & $<2.0$ & 114 & $<1.0$ & $<1.0$ & $<2.0$ & 94 & $<1.0$ & 1.9 \\
\hline$M W-2013$ & (26) & $<1.0$ & $<2.0$ & 110 & $<1.0$ & $<1.0$ & 2.7 & $<32.0$ & 1.8 & 6.1 \\
\hline$M W-2013-F$ & $(16)$ & 3.1 & $<2.0$ & 112 & $<1.0$ & $<1.0$ & 2.2 & $<32.0$ & 1.1 & 6.0 \\
\hline MW-2014 & $<14.0$ & $<1.0$ & $<2.0$ & 270 & $<1.0$ & 1.6 & $<2.0$ & 293 & $<1.0$ & 20 \\
\hline MW-2014-F & $<14.0$ & 2.2 & $<2.0$ & 260 & $<1.0$ & 2.0 & $<2.0$ & 262 & $<1.0$ & 40 \\
\hline$M W-2015$ & $<19$ & $<1.0$ & 4.6 & 66 & $<1.0$ & $<5.7$ & $<2.0$ & 42 & 1.4 & 13 \\
\hline MW-2015-F & $<14$ & $<1.6$ & 6.3 & 67 & $<1.0$ & $<5.8$ & $<2.0$ & 34.0 & $<1.0$ & 13 \\
\hline$M W-2017$ & 813 & $<2.0$ & $<3.0$ & 65 & $<1.0$ & 4.0 & $<2.0$ & 566 & $<7.70$ & 86 \\
\hline MW-2017-F & $<98$ & 6.5 & 3.3 & 38.0 & $<1.0$ & 1.8 & $<2.0$ & $<34.0$ & $<4.20$ & 170 \\
\hline
\end{tabular}


TABLE C.6 (Cont.)

\begin{tabular}{|c|c|c|c|c|c|c|c|c|c|c|}
\hline Well No. & $\begin{array}{l}\text { Aluminum } \\
(\mu \mathrm{g} / \mathrm{L})\end{array}$ & $\begin{array}{c}\text { Antimony } \\
(\mu \mathrm{g} / \mathrm{L})\end{array}$ & $\begin{array}{l}\text { Arsenic } \\
(\mu \mathrm{g} / \mathrm{L})\end{array}$ & $\begin{array}{c}\text { Barium } \\
(\mu \mathrm{g} / \mathrm{L})\end{array}$ & $\begin{array}{c}\text { Cadmium } \\
(\mu \mathrm{g} / \mathrm{L})\end{array}$ & $\begin{array}{c}\text { Chromium } \\
(\mu \mathrm{g} / \mathrm{L})\end{array}$ & $\begin{array}{l}\text { Copper } \\
(\mu \mathrm{g} / \mathrm{L})\end{array}$ & $\begin{array}{c}\text { Iron } \\
(\mu \mathrm{g} / \mathrm{L})\end{array}$ & $\begin{array}{c}\text { Lead } \\
(\mu \mathrm{g} / \mathrm{L})\end{array}$ & $\begin{array}{c}\text { Lithium } \\
(\mu \mathrm{g} / \mathrm{L})\end{array}$ \\
\hline MW-2018 & 17.0 & $<1.0$ & $<2.0$ & 439 & $<1.0$ & 1.5 & $<2.0$ & 54 & 1.7 & 20.0 \\
\hline $\mathrm{MW}-2018-\mathrm{F}$ & $<14.0$ & 3.6 & $<2.0$ & 438 & $<1.0$ & 1.0 & $<2.0$ & 102 & 1.4 & 20 \\
\hline MW-2019 & $<14.0$ & $<1.0$ & $<2.0$ & 168 & $<1.0$ & 2.9 & 3.1 & 160 & $<1.0$ & 21.0 \\
\hline MW-2019-F & 32 & 2.9 & $<2.0$ & 167 & $<1.0$ & 2.1 & $<2.0$ & 128 & $<1.0$ & 21 \\
\hline MW-2021 & $<768$ & $<1.0$ & $<2.0$ & 224 & $<1.0$ & 15 & $<35$ & $<278$ & $<2.1$ & $(0.90)$ \\
\hline MW-2021-F & $<471$ & 1.3 & $<2.0$ & 214 & $<1.0$ & 16 & $<34$ & $<80$ & $<1.4$ & $(0.30)$ \\
\hline MW-2022 & 28 & $<1.0$ & $<2.0$ & 183 & $<1.0$ & 2.7 & 2.2 & 124 & 1.1 & 3.7 \\
\hline MW-2022-F & $<14.0$ & 1.6 & $<2.0$ & 184 & $<1.0$ & 2.8 & 4.2 & 91 & $<1.0$ & 3.7 \\
\hline$M W-2023$ & 74 & 1.7 & $<2.0$ & 100 & $<1.0$ & 4.8 & 8.0 & 261 & 6.7 & 3.6 \\
\hline MW-2023-F & $<14.0$ & 3.1 & $<2.0$ & 89 & $<1.0$ & 2.3 & $<2.0$ & 49 & $<1.0$ & 3.0 \\
\hline MW-2024 & 27 & $<1.0$ & $<2.0$ & 86 & $<1.0$ & 1.6 & $<2.0$ & 241 & $<1.0$ & 5.3 \\
\hline MW-2024-F & $<14.0$ & 2.1 & $<2.0$ & 83 & $<1.0$ & 2.1 & $<2.0$ & 251 & $<1.0$ & 5.2 \\
\hline MW-2026 & 232 & $<1.0$ & 7.4 & 214 & $<1.0$ & 11.0 & 4.3 & 315 & 5.0 & 2.7 \\
\hline MW-2026-F & 76.0 & 1.7 & 9.2 & 202 & $<1.0$ & 3.3 & $<2.0$ & 86 & $<1.0$ & 2.7 \\
\hline MW-2027 & $(20)$ & $<1.0$ & $<2.0$ & 264 & $<1.0$ & 1.6 & $<2.0$ & 198 & $<1.0$ & 3.7 \\
\hline MW-2027-F & (23) & 1.6 & $<2.0$ & 274 & $<1.0$ & 1.5 & $<2.0$ & 211 & $<1.0$ & 3.9 \\
\hline MW-2028 & $<30$ & $<1.0$ & 6.9 & 122 & $<1.0$ & $<3.7$ & 2.9 & 605 & $<1.0$ & 15 \\
\hline MW-2028-F & $<23$ & $<2.3$ & $<2.0$ & 116 & $<1.0$ & $<2.6$ & $<2.0$ & $\cdot 87$ & $<1.0$ & 15 \\
\hline MW-2030 & 1,960 & $<1.0$ & $<2.0$ & 228 & $<1.0$ & $<5.0$ & 32 & 2,840 & 7.2 & 3.4 \\
\hline $\mathrm{MW}-2030-\mathrm{F}$ & $<19$ & $<1.0$ & $<2.0$ & 192 & $<1.0$ & $<1.7$ & 3.5 & 149 & $<1.0$ & 2.5 \\
\hline MW-2032 & 2,190 & $<1.0$ & 3.1 & 343 & $<1.0$ & 6.5 & 16 & 3,160 & 9.7 & 14 \\
\hline MW-2032-F & 74 & 1.6 & $<2.0$ & 314 & $<1.0$ & 2.9 & 6.8 & 82 & 1.5 & 13 \\
\hline MW-2033 & 881 & $<1.0$ & $<2.0$ & 128 & $<1.0$ & 3.8 & 13 & 1,450 & 7.1 & 3.7 \\
\hline MW-2033-F & $(20)$ & 2.6 & $<2.0$ & 110 & $<1.0$ & $<1.0$ & 2.8 & $<32.0$ & $<1.0$ & 3.3 \\
\hline MW-2034 & $<168$ & $<2.0$ & $<3.0$ & 27.0 & $<1.0$ & 1.2 & $<2.0$ & 44.0 & $<5.90$ & 32 \\
\hline MW-2034-F & $<85$ & 2.4 & $<3.0$ & 26 & $<1.0$ & $<1.0$ & $<2.00$ & $<34.0$ & $<2.50$ & 32 \\
\hline
\end{tabular}


TABLE C.6 (Cont.)

\begin{tabular}{|c|c|c|c|c|c|c|c|c|c|c|}
\hline Well No. & $\begin{array}{c}\text { Aluminum } \\
(\mu \mathrm{g} / \mathrm{L})\end{array}$ & $\begin{array}{c}\text { Antimony } \\
(\mu \mathrm{g} / \mathrm{L})\end{array}$ & $\begin{array}{c}\text { Arsenic } \\
(\mu \mathrm{g} / \mathrm{L})\end{array}$ & $\begin{array}{l}\text { Barium } \\
(\mu \mathrm{g} / \mathrm{L})\end{array}$ & $\begin{array}{c}\text { Cadmium } \\
(\mu \mathrm{g} / \mathrm{L})\end{array}$ & $\begin{array}{c}\text { Chromium } \\
(\mu \mathrm{g} / \mathrm{L})\end{array}$ & $\begin{array}{l}\text { Copper } \\
(\mu \mathrm{g} / \mathrm{L})\end{array}$ & $\begin{array}{c}\text { Iron } \\
(\mu \mathrm{g} / \mathrm{L})\end{array}$ & $\begin{array}{c}\text { Lead } \\
(\mu \mathrm{g} / \mathrm{L})\end{array}$ & $\begin{array}{c}\text { Lithium } \\
(\mu \mathrm{g} / \mathrm{L})\end{array}$ \\
\hline MW-2035 & 21.0 & $<1.0$ & $<2.0$ & 88 & $<1.0$ & $<1.0$ & 2.0 & 120 & 1.1 & 2.7 \\
\hline MW-2035-F & 27 & 2.2 & $<2.0$ & 87 & $<1.0$ & 1.0 & $<2.0$ & 122 & 1.3 & 2.7 \\
\hline MW-2036 & $<14.0$ & $<1.0$ & $<2.0$ & 284 & $<1.0$ & $<1.0$ & $<2.0$ & $<32.0$ & $<1.0$ & 6.8 \\
\hline$M W-2036-F$ & 43 & 1.0 & $<2.0$ & 279 & $<1.0$ & 1.3 & 34 & 152 & $<1.0$ & 6.7 \\
\hline MW-2037 & 19 & $<1.0$ & $<2.0$ & 79 & $<1.0$ & $<1.0$ & $<2.0$ & 130 & 1.5 & 395 \\
\hline MW-2037-F & 17 & 1.3 & $<2.0$ & 75 & $<1.0$ & $<1.0$ & $<2.0$ & 56.0 & $<1.0$ & 380 \\
\hline MW-2038 & 299 & $<1.0$ & $<2.0$ & 178 & $<1.0$ & 1.7 & 3.6 & 472 & $<1.0$ & 496 \\
\hline MW-2038-F & 19 & $<1.0$ & $<2.0$ & 172 & $<1.0$ & $<1.0$ & 2.4 & 100 & $<1.0$ & 449 \\
\hline MW-2039 & 1,320 & $<1.0$ & 6.2 & 214 & $<1.0$ & 10 & 6.4 & 1,490 & 3.0 & 22 \\
\hline MW-2039-F & 50 & 2.7 & $<2.0$ & 212 & $<1.0$ & 6.1 & 3.1 & 33 & $<1.0$ & 21 \\
\hline$M W-2040$ & 1,310 & $<1.0$ & $<2.0$ & 562 & $<1.0$ & 25 & 52 & 4,930 & 12.0 & 23 \\
\hline MW-2040-F & $<14.0$ & $<1.0$ & $<2.0$ & 606 & $<1.0$ & 14 & 11 & 89 & $<1.0$ & 24 \\
\hline MW-2041 & 125 & $<1.0$ & $<2.0$ & 223 & $<1.0$ & 2.4 & $<2.0$ & 231 & 1.1 & 24 \\
\hline MW-2041-F & (17) & 2.0 & $<2.0$ & 228 & $<1.0$ & 4.3 & $<2.0$ & 44 & $<1.0$ & 23 \\
\hline MW-2042 & 261 & $<1.0$ & $<2.0$ & 472 & $<1.0$ & $<3.8$ & 3.7 & 328 & $<1.0$ & 18.0 \\
\hline MW-2042-F & $<14.0$ & 2.1 & $<2.0$ & 446 & $<1.0$ & $<2.4$ & $<2.0$ & 53 & $<1.0$ & 16 \\
\hline MW-2043 & 171 & $<1.0$ & $<2.0$ & 254 & $<1.0$ & $<4.6$ & 5.2 & 238 & $<1.0$ & 13 \\
\hline MW-2043-F & $<14.0$ & $<1.0$ & $<2.0$ & 253 & $<1.0$ & $<5.3$ & 4.9 & 38 & $<1.0$ & 14 \\
\hline MW-2044 & 517 & $<1.0$ & $<2.0$ & 46 & $<1.0$ & 3.8 & 6.8 & 315 & 4.9 & 28 \\
\hline MW-2044-F & (23) & 3.1 & 2.5 & 43 & $<1.0$ & 4.5 & $<2.0$ & 61 & $<1.0$ & 28 \\
\hline MW-3003 & 42 & 1.1 & $<2.0$ & 180 & $<1.0$ & 2.2 & $<2.0$ & 87 & 1.9 & 648 \\
\hline MW-3003-F & 54 & 3.2 & $<2.0$ & 175 & $<1.0$ & 2.1 & $<2.0$ & 47 & $<1.0$ & 676 \\
\hline MW-3006 & (25) & $<1.0$ & $<2.0$ & 149 & $<1.0$ & 2.4 & $<2.0$ & 299 & $<1.0$ & 12 \\
\hline MW-3006-F & $(17)$ & 2.1 & $<2.0$ & 148 & $<1.0$ & 1.8 & $<2.0$ & 300 & $<1.0$ & 12.0 \\
\hline MW-3019 & $<14.0$ & 1.8 & $<2.0$ & 342 & $<1.0$ & 1.5 & $<2.0$ & 54 & 2.2 & 11.0 \\
\hline MW-3019-F & $<14.0$ & $<1.0$ & 2.1 & 333 & $<1.0$ & 1.8 & 2.1 & 159 & $<1.0$ & 12.0 \\
\hline
\end{tabular}


TABLE C.6 (Cont.)

\begin{tabular}{|c|c|c|c|c|c|c|c|c|c|c|}
\hline Well No. & $\begin{array}{c}\text { Aluminum } \\
(\mu \mathrm{g} / \mathrm{L})\end{array}$ & $\begin{array}{c}\text { Antimony } \\
(\mu \mathrm{g} / \mathrm{L})\end{array}$ & $\begin{array}{c}\text { Arsenic } \\
(\mu \mathrm{g} / \mathrm{L})\end{array}$ & $\begin{array}{c}\text { Barium } \\
(\mu \mathrm{g} / \mathrm{L})\end{array}$ & $\begin{array}{c}\text { Cadmium } \\
(\mu \mathrm{g} / \mathrm{L})\end{array}$ & $\begin{array}{c}\text { Chromium } \\
(\mu \mathrm{g} / \mathrm{L})\end{array}$ & $\begin{array}{l}\text { Copper } \\
(\mu \mathrm{g} / \mathrm{L})\end{array}$ & $\begin{array}{c}\text { Iron } \\
(\mu \mathrm{g} / \mathrm{L})\end{array}$ & $\begin{array}{l}\text { Lead } \\
(\mu \mathrm{g} / \mathrm{L})\end{array}$ & $\begin{array}{c}\text { Lithium } \\
(\mu \mathrm{g} / \mathrm{L})\end{array}$ \\
\hline MW-3023 & 1,680 & $<1.0$ & $<2.0$ & 48 & $<1.0$ & 6.8 & 7.5 & 2,430 & 4.0 & 644 \\
\hline MW-3023-F & $(16)$ & 2.1 & $<2.0$ & 35 & $<1.0$ & 1.2 & $<2.0$ & $<32.0$ & $<1.0$ & 603 \\
\hline MW-3024 & $<14.0$ & $<1.0$ & $<2.0$ & 164 & $<1.0$ & 2.0 & 2.0 & 160 & $<1.0$ & 201 \\
\hline MW-3024-F & $<14.0$ & 2.5 & $<2.0$ & 162 & $<1.0$ & 1.6 & $<2.0$ & 144 & $<1.0$ & 212 \\
\hline$M W-3025$ & 897 & 1.6 & $<2.0$ & 490 & $<1.0$ & 3.7 & 3.8 & 2,490 & 2.4 & 159 \\
\hline MW-3025-F & $<14.0$ & 1.5 & $<2.0$ & 470 & $<1.0$ & 2.7 & $<2.0$ & 130 & $<1.0$ & 151 \\
\hline MW-3026 & 8,650 & $<1.0$ & $<2.0$ & 2,600 & $<1.0$ & 2.7 & 20 & 3,580 & 25 & 35 \\
\hline $\mathrm{MW}-3026-\mathrm{F}$ & 19 & 4.1 & $<2.0$ & 1,310 & $<1.0$ & 1.2 & 2.1 & 73 & $<1.0$ & 31 \\
\hline MW-3027 & 924 & $<1.0$ & $<2.0$ & 772 & $<1.0$ & 2.7 & 2.3 & 1,880 & 2.1 & 16 \\
\hline $\mathrm{MW}-3027-\mathrm{F}$ & 26 & 2.9 & $<2.0$ & 766 & $<1.0$ & $<1.0$ & $<2.0$ & 55 & $<1.0$ & 15.0 \\
\hline$M W-4001$ & 34 & $<1.0$ & $<2.0$ & 76 & $<1.0$ & $<1.0$ & $<2.0$ & 91 & $<1.0$ & 6.5 \\
\hline $\mathrm{MW}-4001-\mathrm{F}$ & $<14.0$ & 2.4 & $<2.0$ & 75 & $<1.0$ & $<1.0$ & $<2.0$ & 59 & $<1.0$ & 7.6 \\
\hline$M W-4002$ & 1,210 & $(0.86)$ & $<2.0$ & 129 & $(0.13)$ & $<8.0$ & 8.2 & 2,240 & 6.1 & 3.9 \\
\hline MW-4002-F & $<20$ & 1.8 & $<2.0$ & 119 & $(0.10)$ & $<1.10$ & 6.4 & 614 & $(0.68)$ & 1.8 \\
\hline MW-4003 & 32 & $<1.0$ & $<2.0$ & 164 & $<1.0$ & $<1.0$ & 2.0 & 117 & 25 & 2.7 \\
\hline$M W-4003-F$ & 20 & 1.7 & $<2.0$ & 154 & $<1.0$ & $<1.0$ & 2.1 & $<32.0$ & $<1.0$ & 2.7 \\
\hline MW-4004 & 34 & $<1.0$ & $<2.0$ & 128 & $<1.0$ & $<1.0$ & $<2.0$ & 55 & 6.9 & 3.6 \\
\hline MW-4004-F & $<14.0$ & 1.7 & $<2.0$ & 124 & $<1.0$ & $<1.0$ & $<2.0$ & $<32.0$ & 2.7 & 3.6 \\
\hline MW-4005 & 40.0 & $<1.0$ & $<2.0$ & 87 & $<1.0$ & 4.5 & $<2.0$ & $<32.0$ & 18 & 5.1 \\
\hline MW-4005-F & 15 & 1.6 & $<2.0$ & 90 & $<1.0$ & 4.8 & $<2.0$ & $<32.0$ & 12 & 5.1 \\
\hline MW-4006 & 753 & $<1.0$ & $<2.0$ & 173 & $<1.0$ & 2.3 & $<2.0$ & 663 & 2.7 & 3.0 \\
\hline MW-4006-F & 31 & 1.2 & $<2.0$ & 176 & $<1.0$ & $<1.0$ & $<2.0$ & 51 & $<1.0$ & 2.3 \\
\hline MW-4007 & 137 & $<1.0$ & $<2.0$ & 77 & $<1.0$ & 5.4 & 2.7 & 136 & 3.3 & 5.5 \\
\hline MW-4007-F & $<14.0$ & 4.0 & $<2.0$ & 76 & $<1.0$ & 5.3 & 2.5 & 34 & $<1.0$ & 5.9 \\
\hline MW-4008 & 40 & 1.5 & $<2.0$ & 111 & $<1.0$ & 8.1 & 5.4 & 259 & 71 & 2.3 \\
\hline MW-4008-F & 17 & 2.7 & $<2.0$ & 105 & $<1.0$ & 1.9 & $<2.0$ & 56 & $<1.0$ & 2.3 \\
\hline
\end{tabular}


TABLE C.6 (Cont.)

\begin{tabular}{|c|c|c|c|c|c|c|c|c|c|c|}
\hline Well No. & $\begin{array}{c}\text { Aluminum } \\
(\mu \mathrm{g} / \mathrm{L})\end{array}$ & $\begin{array}{c}\text { Antimony } \\
(\mu \mathrm{g} / \mathrm{L})\end{array}$ & $\begin{array}{c}\text { Arsenic } \\
(\mu \mathrm{g} / \mathrm{L})\end{array}$ & $\begin{array}{l}\text { Barium } \\
(\mu g / L)\end{array}$ & $\begin{array}{l}\text { Cadmium } \\
(\mu \mathrm{g} / \mathrm{L})\end{array}$ & $\begin{array}{l}\text { Chromium } \\
(\mu \mathrm{g} / \mathrm{L})\end{array}$ & $\begin{array}{l}\text { Copper } \\
(\mu \mathrm{g} / \mathrm{L})\end{array}$ & $\begin{array}{c}\text { Iron } \\
(\mu g / L)\end{array}$ & $\begin{array}{c}\text { Lead } \\
(\mu \mathrm{g} / \mathrm{L})\end{array}$ & $\begin{array}{c}\text { Lithium } \\
(\mu \mathrm{g} / \mathrm{L})\end{array}$ \\
\hline MW-4009 & $<14.0$ & 4.4 & $<2.0$ & 42 & $<1.0$ & 21 & $<2.0$ & 38 & 3.2 & 67 \\
\hline MW-4009-F & 14 & 2.1 & $<2.0$ & 38.0 & $<1.0$ & 21 & $<2.0$ & $<32.0$ & $<1.0$ & 67 \\
\hline MW-4010 & $<20$ & 1.6 & $(0.12)$ & 83 & $(0.17)$ & $<2.10$ & 5.4 & 462 & 18 & 5.8 \\
\hline$M W-4010-F$ & $<28$ & 2.3 & $<2.0$ & 85 & $(0.15)$ & $<2.10$ & 5.1 & 422 & 15 & 5.7 \\
\hline$M W-4011$ & $<35$ & $(0.23)$ & $<2.0$ & 298 & $(0.03)$ & $<2.90$ & 5.9 & 1,560 & 2.1 & 59 \\
\hline$M W-4011-F$ & (13) & 2.5 & $<2.0$ & 303 & $<1.0$ & $<1.90$ & 5.7 & 1,530 & 1.0 & 58 \\
\hline MW-4012 & 209 & $<1.0$ & $<2.0$ & 78.0 & 1.9 & 29 & $<2.0$ & 1,490 & 6.1 & 25 \\
\hline $\mathrm{MW}-4012-\mathrm{F}$ & $<14.0$ & 2.7 & $<2.0$ & 71 & $<1.0$ & 12 & $<2.0$ & 81 & $<1.0$ & 22 \\
\hline$M W-4013$ & $<14.0$ & $<1.0$ & $<2.0$ & 178 & $<1.0$ & 1.2 & $<2.0$ & 280 & 1.1 & 58 \\
\hline $\mathrm{MW}-4013-\mathrm{F}$ & $<14.0$ & 2.3 & $<2.0$ & 184 & $<1.0$ & 1.0 & $<2.0$ & 250 & $<1.0$ & 67 \\
\hline MW-4014 & 120 & $<1.0$ & $<2.0$ & 109 & $<1.0$ & 1.9 & $<2.0$ & 887 & 3.1 & 3.5 \\
\hline MW-4014-F & $<14.0$ & 2.7 & $<2.0$ & 103 & $<1.0$ & 1.8 & $<2.0$ & 107 & $<1.0$ & 3.1 \\
\hline MW-4015 & $<57$ & $(0.18)$ & $<2.0$ & 200 & $(0.10)$ & $<2.40$ & 6.3 & 907 & 1.2 & 1.9 \\
\hline MW-4015-F & $<36.0$ & 1.5 & $(0.73)$ & 198 & $<1.0$ & $<1.70$ & 3.8 & 513 & $(0.67)$ & 1.9 \\
\hline MW-4016 & $<14.0$ & $<1.0$ & $<2.0$ & 224 & $<1.0$ & $<5.2$ & $<2.0$ & 163 & $<1.0$ & 2.7 \\
\hline$M W-4016-F$ & $<14.0$ & 1.6 & $<2.0$ & 221 & $<1.0$ & $<4.8$ & $<2.0$ & 32 & $<1.0$ & 2.6 \\
\hline$M W-4018$ & 74 & $<1.0$ & $<2.0$ & 198 & $<1.0$ & $<1.0$ & $<2.0$ & 34 & 8.8 & 3.9 \\
\hline $\mathrm{MW}-4018-\mathrm{F}$ & 61 & 1.6 & $<2.0$ & 191 & $<1.0$ & $<1.0$ & $<2.0$ & 34 & 1.9 & 4.6 \\
\hline MW-4019 & 873 & 1.7 & $<2.0$ & 190 & $<1.0$ & 2.6 & 5.0 & 1,510 & 11.0 & 9.8 \\
\hline MW-4019-F & 19 & $<1.0$ & $<2.0$ & 180 & $<1.0$ & $<1.0$ & $<2.0$ & 123 & $<1.0$ & 8.7 \\
\hline MW-4020 & 16.0 & $<1.0$ & $<2.0$ & 69 & $<1.0$ & $<1.0$ & $<2.0$ & $<32.0$ & 9.1 & 17 \\
\hline$M W-4020-F$ & 34 & 1.9 & $<2.0$ & 69 & $<1.0$ & 2.6 & $<2.0$ & 65 & 1.7 & 18 \\
\hline MW-4021 & 26 & 1.1 & $<2.0$ & 33 & $<1.0$ & $<1.0$ & $<2.0$ & 51.0 & 4.7 & 19 \\
\hline$M W-4021-F$ & 34 & 1.7 & $<2.0$ & 33 & $<1.0$ & $<1.0$ & $<2.0$ & 45 & $<1.0$ & 19 \\
\hline MW-4022 & 47,600 & 1.4 & 12 & 855 & 3.0 & 161 & 56 & 57,000 & 371 & 34 \\
\hline$M W-4022-F$ & $<14.0$ & 4.5 & $<2.0$ & 152 & $<1.0$ & $<1.0$ & $<2.0$ & 35 & $<1.0$ & 7.0 \\
\hline
\end{tabular}


TABLE C.6 (Cont.)

\begin{tabular}{|c|c|c|c|c|c|c|c|c|c|c|}
\hline Well No. & $\begin{array}{c}\text { Aluminum } \\
(\mu \mathrm{g} / \mathrm{L})\end{array}$ & $\begin{array}{c}\text { Antimony } \\
(\mu \mathrm{g} / \mathrm{L})\end{array}$ & $\begin{array}{l}\text { Arsenic } \\
(\mu \mathrm{g} / \mathrm{L})\end{array}$ & $\begin{array}{l}\text { Barium } \\
(\mu \mathrm{g} / \mathrm{L})\end{array}$ & $\begin{array}{c}\text { Cadmium } \\
(\mu \mathrm{g} / \mathrm{L})\end{array}$ & $\begin{array}{c}\text { Chromium } \\
(\mu \mathrm{g} / \mathrm{L})\end{array}$ & $\begin{array}{c}\text { Copper } \\
(\mu g / L)\end{array}$ & $\begin{array}{l}\text { Iron } \\
(\mu \mathrm{g} / \mathrm{L})\end{array}$ & $\begin{array}{c}\text { Lead } \\
(\mu g / L)\end{array}$ & $\begin{array}{c}\text { Lithium } \\
(\mu \mathrm{g} / \mathrm{L})\end{array}$ \\
\hline MW-4023 & 39.0 & $<1.0$ & $<2.0$ & 84 & $<1.0$ & $<1.0$ & $<2.0$ & $<32.0$ & $<1.0$ & 15.0 \\
\hline $\mathrm{MW}-4023-\mathrm{F}$ & 58 & 1.3 & $<2.0$ & 84 & $<1.0$ & $<1.0$ & $<2.0$ & $<32.0$ & $<1.0$ & 15 \\
\hline MW-4024 & 5,430 & $<2.0$ & 5.8 & 88 & $<1.0$ & 37 & 15 & 7,410 & 16 & 36 \\
\hline MW-4024-F & $<105$ & 2.4 & $<3.0$ & 34 & $<1.0$ & $<1.0$ & $<2.0$ & $<34.0$ & $<2.10$ & 31 \\
\hline MW-4025 & 1,200 & $<2.0$ & $<3.0$ & 174 & $<1.0$ & 14 & $<2.0$ & 2,390 & $<6.70$ & 9.4 \\
\hline$M W-4025-F$ & $<94$ & $<2.0$ & $<3.0$ & 152 & $<1.0$ & $<1.0$ & $<2.0$ & $<34.0$ & $<2.30$ & $<8.30$ \\
\hline MWD-2 & 2,010 & $<1.0$ & $<2.0$ & 196 & $<1.0$ & 2.3 & $<2.0$ & 1,440 & 3.7 & 3.9 \\
\hline MWD-2-F & 38 & 4.2 & $<2.0$ & 167 & $<1.0$ & 1.6 & $<2.0$ & 157 & $<1.0$ & 2.8 \\
\hline MWD-5 & 32 & 1.6 & $<2.0$ & 99.0 & $<1.0$ & $<1.0$ & 2.8 & 33 & $<1.0$ & 17 \\
\hline MWD-5-F & $<14.0$ & $<1.0$ & $<2.0$ & 98 & $<1.0$ & $<1.0$ & $<2.0$ & 34 & $<1.0$ & 17.0 \\
\hline MWD-6 & 15 & $<1.0$ & $<2.0$ & 155 & $<1.0$ & $<1.0$ & $<2.0$ & $<32.0$ & $<1.0$ & 4.1 \\
\hline MWD-6-F & 55 & $<1.0$ & $<2.0$ & 156 & $<1.0$ & $<1.0$ & 6.1 & $<32.0$ & $<1.0$ & 4.6 \\
\hline MWD-9 & $<38.0$ & $<1.0$ & $<2.0$ & 129 & $<1.0$ & 1.2 & $<2.0$ & $<32.0$ & $<1.0$ & 4.1 \\
\hline MWD-9-F & $<38.0$ & 1.5 & $<2.0$ & 126 & $<1.0$ & 2.1 & $<2.0$ & 58 & $<1.0$ & 4.2 \\
\hline MWD-15 & 15 & $<1.0$ & $<2.0$ & 93.0 & $<1.0$ & 3.7 & 15 & 43 & $<1.0$ & 1.2 \\
\hline MWD-15-F & $<14.0$ & 1.7 & $<2.0$ & 95 & $<1.0$ & 4.2 & 2.2 & $<32.0$ & $<1.0$ & 1.2 \\
\hline MWD-18 & 19 & $<1.0$ & $<2.0$ & 127 & $<1.0$ & $<1.0$ & 3.8 & 493 & $<1.0$ & 5.7 \\
\hline MWD-18-F & $<14.0$ & 1.3 & $<2.0$ & 130 & $<1.0$ & $<1.0$ & $<2.0$ & 127 & $<1.0$ & 5.9 \\
\hline MWD-23 & 102 & $<1.0$ & 4.3 & 150 & $<1.0$ & 1.5 & 2.6 & 349 & $<1.0$ & 3.6 \\
\hline MWD-23-F & $<29.0$ & 1.1 & $<2.0$ & 148 & $<1.0$ & 1.6 & $<2.0$ & 206 & $<1.0$ & 3.7 \\
\hline MWD-25 & 62 & $<1.0$ & $<2.0$ & 119 & $<1.0$ & 1.8 & 2.7 & 227 & $<1.0$ & 2.1 \\
\hline MWD-25-F & 22 & $<1.0$ & $<2.0$ & 117 & $<1.0$ & 1.0 & $<2.0$ & 83 & $<1.0$ & 1.4 \\
\hline MWD-105 & 80 & $<1.0$ & 3.3 & 110 & $<1.0$ & 1.8 & 2.2 & 57 & $<1.0$ & 3.6 \\
\hline MWD-105-F & 169 & $<1.0$ & 4.7 & 108 & $<1.0$ & 1.6 & $<2.0$ & $<32.0$ & $<1.0$ & 3.6 \\
\hline MWD-106 & $<49.0$ & $<1.0$ & $<2.0$ & 139 & $<1.0$ & 2.8 & 216 & 1,390 & $<1.0$ & 3.1 \\
\hline MWD-106-F & $<49.0$ & $<1.0$ & $<2.0$ & 130 & $<1.0$ & 3.7 & $<2.0$ & 70 & $<1.0$ & 3.0 \\
\hline
\end{tabular}


TABLE C.6 (Cont.)

\begin{tabular}{|c|c|c|c|c|c|c|c|c|c|c|}
\hline Well No. & $\begin{array}{c}\text { Aluminum } \\
(\mu \mathrm{g} / \mathrm{L})\end{array}$ & $\begin{array}{c}\text { Antimony } \\
(\mu \mathrm{g} / \mathrm{L})\end{array}$ & $\begin{array}{l}\text { Arsenic } \\
(\mu \mathrm{g} / \mathrm{L})\end{array}$ & $\begin{array}{l}\text { Barium } \\
(\mu \mathrm{g} / \mathrm{L})\end{array}$ & $\begin{array}{l}\text { Cadmium } \\
(\mu g / L)\end{array}$ & $\begin{array}{c}\text { Chromium } \\
(\mu \mathrm{g} / \mathrm{L})\end{array}$ & $\begin{array}{l}\text { Copper } \\
(\mu \mathrm{g} / \mathrm{L})\end{array}$ & $\begin{array}{l}\text { Iron } \\
(\mu \mathrm{g} / \mathrm{L})\end{array}$ & $\begin{array}{l}\text { Lead } \\
(\mu \mathrm{g} / \mathrm{L})\end{array}$ & $\begin{array}{c}\text { Lithium } \\
(\mu \mathrm{g} / \mathrm{L})\end{array}$ \\
\hline MWD-107 & $<29.0$ & $<1.0$ & 15 & 143 & $<1.0$ & 1.7 & $<2.0$ & 176 & $<1.0$ & 4.2 \\
\hline MWD-107-F & 33.0 & $<1.0$ & 15 & 136 & $<1.0$ & 1.3 & $<2.0$ & 189 & $<1.0$ & 4.0 \\
\hline MWD-109 & 35 & $<1.0$ & $<2.0$ & 137 & $<1.0$ & 1.0 & $<2.0$ & 76 & $<1.0$ & 3.4 \\
\hline MWD-109-F & 16.0 & $<1.0$ & $<2.0$ & 144 & $<1.0$ & 1.0 & $<2.0$ & $<32.0$ & $<1.0$ & 3.5 \\
\hline MWD-112 & 34 & $<1.0$ & $<2.0$ & 85 & $<1.0$ & 1.8 & $<2.0$ & 248 & $<1.0$ & 2.2 \\
\hline MWD-112-F & 24 & $<1.0$ & $<2.0$ & 85.0 & $<1.0$ & 1.8 & $<2.0$ & 196 & $<1.0$ & 2.3 \\
\hline MWS-1 & 26 & $<1.0$ & $<2.0$ & 116 & $<1.0$ & 3.4 & $<2.0$ & 59 & $<1.0$ & 1.9 \\
\hline MWS-1-F & 67 & $<1.0$ & $<2.0$ & 116 & $<1.0$ & 3.2 & $<2.0$ & 71 & $<1.0$ & 1.8 \\
\hline MWS-2 & 286 & $<1.0$ & $<2.0$ & 120 & $<1.0$ & 5.0 & $<2.0$ & 361 & $<1.0$ & 3.4 \\
\hline MWS-2-F & 22 & 1.0 & $<2.0$ & 116 & $<1.0$ & 4.9 & $<2.0$ & 123 & $<1.0$ & 3.4 \\
\hline MWS-3 & 49 & $<1.0$ & $<2.0$ & 98 & $<1.0$ & 4.6 & $<2.0$ & 176 & $<1.0$ & 4.1 \\
\hline MWS-3-F & $<14.0$ & $<1.0$ & $<2.0$ & 137 & $<1.0$ & 2.1 & $<2.0$ & 79 & $<1.0$ & $<1.0$ \\
\hline MWS-4 & 915 & $<1.0$ & $<2.0$ & 149 & $<1.0$ & $<1.0$ & 3.0 & 452 & 2.1 & 3.9 \\
\hline MWS-4-F & $<14.0$ & $<1.0$ & $<2.0$ & 149 & $<1.0$ & $<1.0$ & $<2.0$ & $<32.0$ & $<1.0$ & 3.5 \\
\hline MWS-5 & 22 & $<1.0$ & $<2.0$ & 109 & $<1.0$ & $<1.0$ & $<2.0$ & 67 & $<1.0$ & 2.6 \\
\hline MWS-5-F & $<14.0$ & $<1.0$ & $<2.0$ & 109 & $<1.0$ & $<1.0$ & $<2.0$ & $<32.0$ & $<1.0$ & 3.0 \\
\hline MWS-6 & $<14.0$ & $<1.0$ & $<2.0$ & 150 & $<1.0$ & $<1.0$ & $<2.0$ & $<32.0$ & $<1.0$ & 4.3 \\
\hline MWS-6-F & 33 & 6.9 & $<2.0$ & 146 & $<1.0$ & $<1.0$ & $<2.0$ & $<32.0$ & $<1.0$ & 4.2 \\
\hline MWS-7 & 49.0 & $<1.0$ & $<2.0$ & 137 & $<1.0$ & 2.3 & 2.1 & 81 & $<1.0$ & $<1.0$ \\
\hline MWS-7-F & $<14.0$ & $<1.0$ & $<2.0$ & 133 & $<1.0$ & 1.8 & $<2.0$ & $<32.0$ & $<1.0$ & $<1.0$ \\
\hline MWS-8 & 1,300 & 2.4 & $<2.0$ & 223 & $<1.0$ & 3.3 & 5.9 & 607 & 2.2 & 22 \\
\hline MWS-8-F & $<14.0$ & 1.0 & $<2.0$ & 216 & $<1.0$ & $<1.0$ & $<2.0$ & 72 & $<1.0$ & 19 \\
\hline MWS-9 & $<38.0$ & $<1.0$ & $<2.0$ & 138 & $<1.0$ & 4.4 & $<2.0$ & 37 & $<1.0$ & 6.6 \\
\hline MWS-9-F & $<38.0$ & $<1.0$ & $<2.0$ & 128 & $<1.0$ & 4.4 & $<2.0$ & $<32.0$ & $<1.0$ & 6.8 \\
\hline MWS-10 & 31 & $<1.0$ & $<2.0$ & 227 & $<1.0$ & 4.5 & $<2.0$ & 160 & $<1.0$ & 3.2 \\
\hline MWS-10-F & $<14.0$ & $<1.0$ & $<2.0$ & 222 & $<1.0$ & 4.4 & $<2.0$ & 110 & $<1.0$ & 3.0 \\
\hline
\end{tabular}


TABLE C.6 (Cont.)

\begin{tabular}{|c|c|c|c|c|c|c|c|c|c|c|}
\hline Well No. & $\begin{array}{c}\text { Aluminum } \\
(\mu \mathrm{g} / \mathrm{L})\end{array}$ & $\begin{array}{c}\text { Antimony } \\
(\mu \mathrm{g} / \mathrm{L})\end{array}$ & $\begin{array}{l}\text { Arsenic } \\
(\mu g / L)\end{array}$ & $\begin{array}{l}\text { Barium } \\
(\mu \mathrm{g} / \mathrm{L})\end{array}$ & $\begin{array}{c}\text { Cadmium } \\
(\mu g / L)\end{array}$ & $\begin{array}{c}\text { Chromium } \\
(\mu g / L)\end{array}$ & $\begin{array}{l}\text { Copper } \\
(\mu \mathrm{g} / \mathrm{L})\end{array}$ & $\begin{array}{c}\text { Iron } \\
(\mu \mathrm{g} / \mathrm{L})\end{array}$ & $\begin{array}{c}\text { Lcad } \\
(\mu \mathrm{g} / \mathrm{L})\end{array}$ & $\begin{array}{c}\text { Lithium } \\
(\mu \mathrm{g} / \mathrm{L})\end{array}$ \\
\hline MWS-11 & 316 & $<1.0$ & $<2.0$ & 158 & $<1.0$ & $<1.0$ & $<2.0$ & 283 & $<1.0$ & 2.0 \\
\hline MWS-11-F & $<14.0$ & $<1.0$ & 2.0 & 150 & $<1.0$ & $<1.0$ & $<2.0$ & 89 & $<1.0$ & 1.8 \\
\hline MWS-12 & 121 & $<1.0$ & $<2.0$ & 90 & $<1.0$ & $<1.0$ & $<2.0$ & 231 & $<1.0$ & 2.5 \\
\hline MWS-12-F & 75 & $<1.0$ & $<2.0$ & 78 & $<1.0$ & $<1.0$ & $<2.0$ & 138 & $<1.0$ & 2.5 \\
\hline MWS-13 & $<14.0$ & $<1.0$ & $<2.0$ & 28 & $<1.0$ & $<1.0$ & $<2.0$ & 308 & $<1.0$ & 6.4 \\
\hline MWS-13-F & $<14.0$ & $<1.0$ & $<2.0$ & 29 & $<1.0$ & $<1.0$ & $<2.0$ & 256 & $<1.0$ & 6.4 \\
\hline MWS-14 & 220 & $<1.0$ & 2.2 & 585 & $<1.0$ & $<1.0$ & 6.7 & 495 & 1.6 & 22 \\
\hline MWS-14-F & 15 & $<1.0$ & $<2.0$ & 596 & $<1.0$ & $<1.0$ & 7.2 & 49 & 1.0 & 22 \\
\hline MWS-15 & 55 & $<1.0$ & $<2.0$ & 73 & $<1.0$ & $<1.0$ & 3.0 & 130 & $<1.0$ & 1.3 \\
\hline MWS-15-F & $<14.0$ & $<1.0$ & $<2.0$ & 73.0 & $<1.0$ & $<1.0$ & $<2.0$ & 57 & $<1.0$ & 1.2 \\
\hline MWS-16 & $<14.0$ & $<1.0$ & $<2.0$ & 114 & $<1.0$ & $<1.0$ & 3.0 & 443 & $<1.0$ & $<1.0$ \\
\hline MWS-16-F & $<14.0$ & $<1.0$ & $<2.0$ & 117 & $<1.0$ & $<1.0$ & $<2.0$ & 98.0 & $<1.0$ & $<1.0$ \\
\hline MWS-17 & 1,250 & 1.8 & $<2.0$ & 88 & $<1.0$ & 1.1 & 3.0 & 907 & 1.7 & 2.6 \\
\hline MWS-17-F & $<14.0$ & $<1.0$ & $<2.0$ & 82 & $<1.0$ & 1.8 & $<2.0$ & 86 & $<1.0$ & 2.2 \\
\hline MWS-18 & 236 & 1.1 & 3.0 & 60 & $<1.0$ & $<1.0$ & 2.5 & 103 & 1.5 & 8.2 \\
\hline MWS-18-F & 16 & 1.8 & 2.9 & 50 & $<1.0$ & $<1.0$ & 2.3 & 56 & $<1.0$ & 7.9 \\
\hline MWS-19 & 1,090 & $<1.0$ & $<2.0$ & 111 & $<1.0$ & $<1.0$ & $<2.0$ & $57 !$ & 1.3 & 1.2 \\
\hline MWS-19-F & 23 & $<1.0$ & 2.0 & 105 & $<1.0$ & $<1.0$ & $<2.0$ & 54 & $<1.0$ & $<1.0$ \\
\hline MWS-20 & $<14.0$ & $<1.0$ & $<2.0$ & 74 & $<1.0$ & 5.2 & $<2.0$ & $<32.0$ & $<1.0$ & 1.4 \\
\hline MWS-20-F & 19 & $<1.0$ & $<2.0$ & 74 & $<1.0$ & 4.2 & $<2.0$ & $<32.0$ & $<1.0$ & 1.4 \\
\hline MWS-21 & 329 & $<1.0$ & $<2.0$ & 212 & $<1.0$ & 1.2 & 49 & 653 & $<1.0$ & 274 \\
\hline MWS-21-F & $<14.0$ & $<1.0$ & $<2.0$ & 213 & $<1.0$ & 1.1 & 42 & 545 & $<1.0$ & 260 \\
\hline MWS-22 & 52 & $<1.0$ & 14 & 154 & $<1.0$ & 2.4 & 3.6 & 101 & $<1.0$ & 3.0 \\
\hline MWS-22-F & 64 & $<1.0$ & 2.5 & 155 & $<1.0$ & 1.8 & 2.1 & $<32.0$ & $<1.0$ & 3.0 \\
\hline MWS-23 & 15,300 & $<1.0$ & 8.8 & 167 & $<1.0$ & 22 & 29 & 17,600 & 14 & 10 \\
\hline MWS-23-F & 3,860 & $<1.0$ & $<2.0$ & 89 & $<1.0$ & 5.6 & 12 & 3,170 & 3.4 & 3.6 \\
\hline
\end{tabular}


TABLE C.6 (Cont.)

\begin{tabular}{|c|c|c|c|c|c|c|c|c|c|c|}
\hline Well No. & $\begin{array}{c}\text { Aluminum } \\
(\mu \mathrm{g} / \mathrm{L})\end{array}$ & $\begin{array}{c}\text { Antimony } \\
(\mu \mathrm{g} / \mathrm{L})\end{array}$ & $\begin{array}{c}\text { Arsenic } \\
(\mu \mathrm{g} / \mathrm{L})\end{array}$ & $\begin{array}{l}\text { Barium } \\
(\mu \mathrm{g} / \mathrm{L})\end{array}$ & $\begin{array}{c}\text { Cadmium } \\
(\mu \mathrm{g} / \mathrm{L})\end{array}$ & $\begin{array}{c}\text { Chromium } \\
(\mu \mathrm{g} / \mathrm{L})\end{array}$ & $\begin{array}{c}\text { Copper } \\
(\mu g / L)\end{array}$ & $\begin{array}{c}\text { Iron } \\
(\mu \mathrm{g} / \mathrm{L})\end{array}$ & $\begin{array}{c}\text { Lead } \\
(\mu \mathrm{g} / \mathrm{L})\end{array}$ & $\begin{array}{c}\text { Lithium } \\
(\mu \mathrm{g} / \mathrm{L})\end{array}$ \\
\hline MWS-25 & 947 & $<1.0$ & 2.5 & 150 & $<1.0$ & 9.9 & 14 & 4,170 & 4.4 & $<1.0$ \\
\hline MWS-25-F & $<14.0$ & 2.5 & $<2.0$ & 107 & $<1.0$ & 1.8 & 2.1 & 417 & $<1.0$ & $<1.0$ \\
\hline MWS-10I & 244 & $<1.0$ & 4.8 & 426 & $<1.0$ & 1.2 & $<2.0$ & 5,600 & $<1.0$ & 1.1 \\
\hline MWS-101-F & $<38.0$ & $<1.0$ & 5.4 & 425 & $<1.0$ & $<1.0$ & $<2.0$ & 5,560 & $<1.0$ & $<1.0$ \\
\hline MWS-102 & 679 & $<1.0$ & 10 & 217 & $<1.0$ & 1.5 & 10 & 2,320 & 2.6 & 4.9 \\
\hline MWS-102-F & $<14.0$ & $<1.0$ & 8.7 & 198 & $<1.0$ & 1.1 & $<2.0$ & 1,590 & $<1.0$ & 5.3 \\
\hline MWS-103 & 1,750 & $<1.0$ & 43 & 180 & $<1.0$ & 2.4 & 11 & 12,400 & 8.7 & 2.0 \\
\hline MWS-103-F & 40 & $<1.0$ & $<2.0$ & 143 & $<1.0$ & $<1.0$ & $<2.0$ & 152 & $<1.0$ & 1.0 \\
\hline MWS-104 & 414 & $<1.0$ & $<2.0$ & 201 & $<1.0$ & $<1.0$ & 2.8 & 254 & 1.2 & 1.7 \\
\hline MWS-104-F & $<14.0$ & $<1.0$ & $<2.0$ & 195 & $<1.0$ & $<1.0$ & $<2.0$ & $<32.0$ & $<1.0$ & 1.6 \\
\hline MWS-105 & 22.0 & $<1.0$ & 6.0 & 141 & $<1.0$ & 2.1 & $<2.0$ & 72 & $<1.0$ & 2.0 \\
\hline MWS-105-F & $<21$ & 2.6 & 6.9 & 141 & $<1.0$ & 2.1 & $<2.0$ & 94 & $<1.0$ & 2.1 \\
\hline MWS-106 & 939 & 1.7 & $<2.0$ & 224 & $<1.0$ & 2.1 & $<2.0$ & 629 & 2.1 & 1.6 \\
\hline MWS-106-F & $<49.0$ & $<1.0$ & $<2.0$ & 214 & $<1.0$ & 1.6 & 3.4 & 63.0 & $<1.0$ & 1.2 \\
\hline MWS-107 & 716 & $<1.0$ & $<2.0$ & 197 & $<1.0$ & 1.7 & 5.7 & 613 & 2.0 & 5.0 \\
\hline MWS-107-F & $<29.0$ & $<1.0$ & $<2.0$ & 201 & $<1.0$ & $<1.0$ & $<2.0$ & $<32.0$ & $<1.0$ & 4.3 \\
\hline MWS-108 & 83 & $<1.0$ & 9.7 & 130 & $<1.0$ & 1.6 & 3,4 & 368 & $<1.0$ & 4.5 \\
\hline MWS-108-F & 48 & $<1.0$ & 3.3 & 131 & $<1.0$ & 1.5 & 2.2 & 138 & $<1.0$ & 4.6 \\
\hline MWS-109 & 69 & $<1.0$ & $<2.0$ & 214 & $<1.0$ & 1.5 & $<2.0$ & 147 & $<1.0$ & 2.2 \\
\hline MWS-109-F & 19 & $<1.0$ & $<2.0$ & 217 & $<1.0$ & 1.2 & $<2.0$ & $<32.0$ & $<1.0$ & 2.3 \\
\hline MWS-110 & 1,230 & $<1.0$ & $<2.0$ & 186 & $<1.0$ & 3.1 & 7.9 & 1,530 & 3.0 & 3.3 \\
\hline MWS-110-F & $<14.0$ & $<1.0$ & $<2.0$ & 171 & $<1.0$ & 2.2 & $<2.0$ & 314 & $<1.0$ & 2.4 \\
\hline MWS-111 & 110 & $<1.0$ & $<2.0$ & 420 & $<1.0$ & 4.0 & 7.6 & 983 & 2.4 & 2.0 \\
\hline MWS-111-F & $<14.0$ & 1.1 & $<2.0$ & 405 & $<1.0$ & 1.6 & $<2.0$ & 41 & $<1.0$ & 2.0 \\
\hline MWS-112 & 2,520 & 1.6 & $<2.0$ & 148 & $<1.0$ & 26 & 63 & 4,150 & 11 & 10 \\
\hline MWS-112-F & 16.0 & 2.0 & $<2.0$ & 113 & $<1.0$ & 1.3 & $<2.0$ & 48 & $<1.0$ & 13 \\
\hline
\end{tabular}


TABLE C.6 (Cont.)

\begin{tabular}{|c|c|c|c|c|c|c|c|c|c|c|}
\hline Well No. & $\begin{array}{c}\text { Aluminum } \\
(\mu \mathrm{g} / \mathrm{L})\end{array}$ & $\begin{array}{c}\text { Antimony } \\
(\mu \mathrm{g} / \mathrm{L})\end{array}$ & $\begin{array}{c}\text { Arsenic } \\
(\mu \mathrm{g} / \mathrm{L})\end{array}$ & $\begin{array}{l}\text { Barium } \\
(\mu \mathrm{g} / \mathrm{L})\end{array}$ & $\begin{array}{c}\text { Cadmium } \\
(\mu \mathrm{g} / \mathrm{L})\end{array}$ & $\begin{array}{c}\text { Chromium } \\
(\mu \mathrm{g} / \mathrm{L})\end{array}$ & $\begin{array}{l}\text { Copper } \\
(\mu \mathrm{g} / \mathrm{L})\end{array}$ & $\begin{array}{c}\text { Iron } \\
(\mu \mathrm{g} / \mathrm{L})\end{array}$ & $\begin{array}{c}\text { Lead } \\
(\mu \mathrm{g} / \mathrm{L})\end{array}$ & $\begin{array}{c}\text { Lithium } \\
(\mu \mathrm{g} / \mathrm{L})\end{array}$ \\
\hline TIL3 & 207 & $<1.0$ & 16.0 & 292 & 1.6 & 2.9 & 33 & 18,100 & 184 & 3.7 \\
\hline TIL3-F & 83 & 1.8 & $<2.0$ & 293 & $<1.0$ & 1.5 & $<2.0$ & 5,640 & $<1.0$ & 3.6 \\
\hline USG 1 & 62 & $<1.0$ & $<2.0$ & 202 & $<1.0$ & $<1.0$ & $<2.0$ & 105 & $<1.0$ & 3.0 \\
\hline USG1-F & $<49.0$ & $<1.0$ & $<2.0$ & 203 & $<1.0$ & $<1.0$ & $<2.0$ & 34.0 & $<1.0$ & 3.0 \\
\hline USG2 & $<49.0$ & 3.1 & $<2.0$ & 243 & $<1.0$ & 1.9 & $<2.0$ & 241 & $<1.0$ & $<1.0$ \\
\hline USG2-F & $<49.0$ & $<1.0$ & $<2.0$ & 241 & $<1.0$ & 1.7 & $<2.0$ & 80 & $<1.0$ & $<1.0$ \\
\hline USG3 & $<14.0$ & $<1.0$ & $<2.0$ & 209 & $<1.0$ & 1.8 & $<2.0$ & 58 & $<1.0$ & $\ldots \quad 4.8$ \\
\hline USG3-F & $<14.0$ & 1.9 & $<2.0$ & 217 & $<1.0$ & 1.6 & $<2.0$ & 55 & $<1.0$ & 5.0 \\
\hline USG4 & $<14.0$ & $<1.0$ & $<2.0$ & 98 & $<1.0$ & 2.1 & $<2.0$ & 56 & $<1.0$ & 3.7 \\
\hline USG4-F & $<14.0$ & $<1.0$ & $<2.0$ & 97 & $<1.0$ & 2.4 & $<2.0$ & 75 & $<1.0$ & 3.8 \\
\hline USG5 & $<14.0$ & $<1.0$ & $<2.0$ & 177 & $<1.0$ & 1.2 & $<2.0$ & 54 & $<1.0$ & 3.0 \\
\hline USG5-F & $<14.0$ & 1.0 & $<2.0$ & 181 & $<1.0$ & 1.6 & $<2.0$ & 59.0 & $<1.0$ & 3.0 \\
\hline USG6 & $<14.0$ & $<1.0$ & $<2.0$ & 227 & $<1.0$ & 2.2 & $<2.0$ & 69 & $<1.0$ & 1.8 \\
\hline USG6-F & $<14.0$ & $<1.0$ & $<2.0$ & 225 & $<1.0$ & 2.5 & $<2.0$ & 86 & $<1.0$ & 1.7 \\
\hline USG8 & 32.0 & 1.1 & 3.6 & 124 & $<1.0$ & 2.5 & $<2.0$ & 344 & 1.6 & 1.8 \\
\hline USG8-F & 27 & 2.2 & 2.6 & 124 & $<1.0$ & 2.0 & $<2.0$ & 105 & $<1.0$ & 1.7 \\
\hline USG9 & $<21$ & $<1.0$ & 2.5 & 88 & $<1.0$ & 3.0 & $<2.0$ & 32 & $<1.0$ & 2.0 \\
\hline USG9-F & $<21$ & $<1.0$ & 3.2 & 90 & $<1.0$ & 3.1 & $<2.0$ & 111 & $<1.0$ & 1.9 \\
\hline MWV-1 & 332 & $<1.0$ & $<2.0$ & 105 & $<1.0$ & 1.2 & 3.3 & 335 & $<1.0$ & 2.3 \\
\hline MWV-1-F & 39 & 2.3 & $<2.0$ & 102 & $<1.0$ & $<1.0$ & 2.6 & 54 & $<1.0$ & 2.2 \\
\hline MWV-2 & 449 & $<1.0$ & $<2.0$ & 115 & $<1.0$ & 4.6 & $<2.0$ & 670 & 1.9 & 3.0 \\
\hline MWV-2-F & 23 & 4.0 & $<2.0$ & 106 & $<1.0$ & $<1.0$ & 2.0 & 176 & $<1.0$ & 2.6 \\
\hline MWV-9 & $<38.0$ & $<1.0$ & $<2.0$ & 109 & $<1.0$ & $<1.0$ & $<2.0$ & 41 & $<1.0$ & 6.6 \\
\hline MWV-9-F & $<38.0$ & $<1.0$ & $<2.0$ & 91 & $<1.0$ & 2.5 & $<2.0$ & $<32.0$ & $<1.0$ & 6.0 \\
\hline MWV-13 & 133 & $<1.0$ & $<2.0$ & 39 & $<1.0$ & 3.3 & $<2.0$ & 498 & $<1.0$ & 3.0 \\
\hline MWV-13-F & $<14.0$ & 1.9 & $<2.0$ & 31 & $<1.0$ & 2.3 & $<2.0$ & 205 & $<1.0$ & 3.2 \\
\hline
\end{tabular}


TABLE C.6 (Cont.)

\begin{tabular}{|c|c|c|c|c|c|c|c|c|c|c|}
\hline Well No. & $\begin{array}{c}\text { Aluminum } \\
(\mu \mathrm{g} / \mathrm{L})\end{array}$ & $\begin{array}{c}\text { Antimony } \\
(\mu \mathrm{g} / \mathrm{L})\end{array}$ & $\begin{array}{c}\text { Arsenic } \\
(\mu g / L)\end{array}$ & $\begin{array}{c}\text { Barium } \\
(\mu g / L)\end{array}$ & $\begin{array}{c}\text { Cadmium } \\
(\mu g / L)\end{array}$ & $\begin{array}{c}\text { Chromium } \\
(\mu \mathrm{g} / \mathrm{L})\end{array}$ & $\begin{array}{c}\text { Copper } \\
(\mu \mathrm{g} / \mathrm{L})\end{array}$ & $\begin{array}{c}\text { Iron } \\
(\mu \mathrm{g} / \mathrm{L})\end{array}$ & $\begin{array}{c}\text { Lcad } \\
(\mu \mathrm{g} / \mathrm{L})\end{array}$ & $\begin{array}{c}\text { Lithium } \\
(\mu \mathrm{g} / \mathrm{L})\end{array}$ \\
\hline MWV-16 & 93 & $<1.0$ & $<2.0$ & 90 & $<1.0$ & $<1.0$ & 2.9 & 186 & $<1.0$ & 1.2 \\
\hline MWV-16-F & $<14.0$ & $<1.0$ & $<2.0$ & 83 & $<1.0$ & $<1.0$ & 2.3 & 169 & $<1.0$ & 1.1 \\
\hline$M W V-17$ & 248 & 1.7 & $<2.0$ & 116 & 1.2 & 11 & 7.5 & 298 & 19 & $<1.0$ \\
\hline MWV-17-F & 36 & 7.0 & $<2.0$ & 105 & $<1.0$ & 6.6 & 3.8 & 41 & $<1.0$ & $<1.0$ \\
\hline MWV-22 & 91.0 & $<1.0$ & 7.6 & 148 & $<1.0$ & 2.2 & $<2.0$ & 102 & $<1.0$ & 2.3 \\
\hline$M W V-22-F$ & 63.0 & $<1.0$ & $<2.0$ & 145 & $<1.0$ & 2.3 & $<2.0$ & 53 & $<1.0$ & 2.2 \\
\hline MWV-24 & 27 & $<1.0$ & $<2.0$ & 98 & $<1.0$ & $<1.0$ & $<2.0$ & 277 & $<1.0$ & 7.4 \\
\hline MWV-24-F & 35 & 1.4 & $<2.0$ & 98 & $<1.0$ & $<1.0$ & $<2.0$ & 167 & $<1.0$ & 7.4 \\
\hline
\end{tabular}


TABLE C.6 (Cont.)

\begin{tabular}{|c|c|c|c|c|c|c|c|}
\hline Well No. & $\begin{array}{c}\text { Mangancse } \\
(\mu \mathrm{g} / \mathrm{L})\end{array}$ & $\begin{array}{c}\text { Mercury } \\
(\mu \mathrm{g} / \mathrm{L})\end{array}$ & $\begin{array}{l}\text { Molybdenum } \\
(\mu / L)\end{array}$ & $\begin{array}{l}\text { Nickel } \\
(\mu \mathrm{g} / \mathrm{L})\end{array}$ & $\begin{array}{l}\text { Selenium } \\
(\mu \mathrm{g} / \mathrm{L})\end{array}$ & $\begin{array}{l}\text { Silver } \\
(\mu \mathrm{g} / \mathrm{L})\end{array}$ & $\begin{array}{c}\text { Thallium } \\
(\mu \mathrm{g} / \mathrm{L})\end{array}$ \\
\hline MWD-2001 & $<2.2$ & $<0.2$ & $<5.9$ & $(0.01)$ & $<3.0$ & $<1.0$ & $<3.6$ \\
\hline MWD-2001-F & $<2.0$ & $<0.2$ & $<5.4$ & $(0.1)$ & $<3.0$ & $<1.0$ & $<3.4$ \\
\hline MWD-2002 & $<2.8$ & $<0.2$ & $<13$ & 1.6 & $<3.0$ & $<1.0$ & $<3.2$ \\
\hline MWD-2002-F & $<2.9$ & $<0.2$ & $<13$ & 1.7 & $<3.0$ & $<1.0$ & $<3.1$ \\
\hline MWD-2003 & 26.7 & $<0.2$ & $<6.2$ & 4.5 & $(1.5)$ & 7.0 & $<3.2$ \\
\hline MWD-2003-F & $<3.4$ & $<0.2$ & $<6.2$ & 3.6 & 3.2 & $<1.0$ & $<3.2$ \\
\hline MWD-2005 & 1.3 & 0.48 & $<1.0$ & 3.6 & 3.7 & $<1.0$ & $<1.0$ \\
\hline MWD-2005-F & $<1.0$ & $<0.2$ & $<1.0$ & 3.1 & 4.1 & $<1.0$ & $<1.0$ \\
\hline MWD-2006 & 25 & $<0.2$ & 1.6 & 67 & $<3.0$ & $<1.0$ & $<1.0$ \\
\hline MWD-2006-F & 26 & $<0.2$ & 1.2 & 58 & $<3.0$ & $<1.0$ & $<1.0$ \\
\hline MWD-2007 & 12 & $<0.2$ & $<1.0$ & 3.3 & $<3.0$ & $<1.0$ & $<1.0$ \\
\hline MWD-2007-F & 4.7 & $<0.2$ & $<1.0$ & 1.6 & $<3.0$ & $<1.0$ & $<1.0$ \\
\hline MWD-2010 & 97 & $<0.2$ & 2.8 & 85 & $<3.0$ & $<1.0$ & $<1.0$ \\
\hline MWD-2010-F & 94 & $<0.2$ & 2.7 & 90 & $<3.0$ & $<1.0$ & $<1.0$ \\
\hline MWD-2011 & $<1.0$ & $<0.2$ & $<1.0$ & 2.4 & $<3.0$ & $<1.0$ & $<1.0$ \\
\hline MWD-2011-F & $<1.0$ & $<0.2$ & $<1.0$ & 4.2 & $<3.0$ & $<1.0$ & $<1.0$ \\
\hline MWD-2012 & 1.8 & $<0.2$ & $<1.0$ & 1.6 & $<3.0$ & $<1.0$ & $<1.0$ \\
\hline MWD-2012-F & $<1.0$ & $<0.2$ & $<1.0$ & 1.5 & $<3.0$ & $<1.0$ & $<1.0$ \\
\hline MWD-2013 & $<1.0$ & $<0.2$ & $<1.0$ & 3.3 & $<3.0$ & $<1.0$ & $<1.0$ \\
\hline MWD-2013-F & $<1.0$ & $<0.2$ & $<1.0$ & 3.5 & $<3.0$ & $<1.0$ & $<1.0$ \\
\hline MWD-2014 & 1.2 & $<0.2$ & $<1.0$ & 2.5 & $<3.0$ & $<1.0$ & $<1.0$ \\
\hline MWD-2014-F & $<1.0$ & $<0.2$ & $<1.0$ & 2.7 & $<3.0$ & $<1.0$ & $<1.0$ \\
\hline MWD-2015 & $<1.0$ & $<0.2$ & $<1.0$ & 2.1 & 3.5 & $<1.0$ & $<1.0$ \\
\hline MWD-2015-F & $<1.0$ & $<0.2$ & $<1.0$ & 1.9 & 4.0 & $<1.0$ & $<1.0$ \\
\hline MWD-2017 & 26 & $<0.2$ & 16 & 8.9 & $<5.00$ & $<1.0$ & $<12$ \\
\hline MWD-2017-F & $<1.0$ & $<0.2$ & 16 & 4.8 & $<5.0$ & $<1.0$ & $<12$ \\
\hline MWD-2018 & 2.5 & $<0.2$ & $<1.0$ & $<1.0$ & $<3.0$ & $<1.0$ & $<1.0$ \\
\hline
\end{tabular}


TABLE C.6 (Cont.)

\begin{tabular}{|c|c|c|c|c|c|c|c|}
\hline Well No. & $\begin{array}{c}\text { Manganese } \\
(\mu \mathrm{g} / \mathrm{L})\end{array}$ & $\begin{array}{c}\text { Mercury } \\
(\mu \mathrm{g} / \mathrm{L})\end{array}$ & $\begin{array}{c}\text { Molybdenum } \\
(\mu / L)\end{array}$ & $\begin{array}{l}\text { Nickel } \\
(\mu \mathrm{g} / \mathrm{L})\end{array}$ & $\begin{array}{c}\text { Selenium } \\
(\mu \mathrm{g} / \mathrm{L})\end{array}$ & $\begin{array}{l}\text { Silver } \\
(\mu \mathrm{g} / \mathrm{L})\end{array}$ & $\begin{array}{c}\text { Thallium } \\
(\mu \mathrm{g} / \mathrm{L})\end{array}$ \\
\hline$M W-2018-F$ & $<1.0$ & $<0.2$ & $<1.0$ & $<1.0$ & $<3.0$ & $<1.0$ & $<1.0$ \\
\hline MW-2019 & 41 & $<0.2$ & 16 & 4.0 & $<3.0$ & $<1.0$ & $<1.0$ \\
\hline MW-2019-F & 50 & $<0.2$ & 15 & 4.2 & $<3.0$ & $<1.0$ & $<1.0$ \\
\hline MW-2021 & 56 & $<0.2$ & $<9.7$ & 6.1 & $<3.0$ & $<1.0$ & $<3.1$ \\
\hline MW-2021-F & 35 & $<0.2$ & $<9.7$ & 5.5 & $<3.0$ & $<1.0$ & $<3.0$ \\
\hline MW-2022 & 124 & $<0.2$ & 2.1 & 4.1 & $<3.0$ & $<1.0$ & $<1.0$ \\
\hline $\mathrm{MW}-2022-\mathrm{F}$ & 125 & $<0.2$ & 2.1 & 4.0 & $<3.0$ & $<1.0$ & $<1.0$ \\
\hline MW-2023 & 13 & $<0.2$ & 6.2 & 10 & $<3.0$ & $<1.0$ & $<1.0$ \\
\hline MW-2023-F & 5.5 & $<0.2$ & 5.3 & 2.8 & $<3.0$ & $<1.0$ & $<1.0$ \\
\hline MW-2024 & 56 & $<0.2$ & $<1.0$ & 3.0 & $<3.0$ & $<1.0$ & $<1.0$ \\
\hline$M W-2024-F$ & 52 & $<0.2$ & $<1.0$ & 2.8 & $<3.0$ & $<1.0$ & $<1.0$ \\
\hline MW-2026 & 98 & $<0.2$ & 5.8 & 12 & $<3.0$ & $<1.0$ & $<1.0$ \\
\hline$M W-2026-F$ & 69 & $<0.2$ & 5.6 & 11 & $<3.0$ & $<1.0$ & $<1.0$ \\
\hline MW-2027 & 376 & $<0.2$ & 2.9 & 2.4 & $<3.0$ & $<1.0$ & $<1.0$ \\
\hline MW-2027-F & 388 & $<0.2$ & 3.1 & 2.2 & $<3.0$ & $<1.0$ & $<1.0$ \\
\hline MW-2028 & 436 & $<0.2$ & 1.6 & 13 & $<3.0$ & $<1.0$ & $<1.0$ \\
\hline$M W-2028-F$ & 419 & $<0.2$ & 1.7 & 12 & $<3.0$ & $<1.0$ & $<1.0$ \\
\hline$M W-2030$ & 123 & $<0.2$ & $<1.0$ & 9.4 & 3.5 & $<1.0$ & $<1.0$ \\
\hline MW-2030-F & 6.1 & $<0.2$ & $<1.0$ & 4.3 & $<3.0$ & $<1.0$ & $<1.0$ \\
\hline MW-2032 & 189 & $<0.2$ & $<1.0$ & 14 & 4.8 & 2.9 & $<1.0$ \\
\hline$M W-2032-F$ & 9.1 & $<0.2$ & $<1.0$ & 6.3 & 4.6 & $<1.0$ & $<1.0$ \\
\hline MW-2033 & 86 & 0.35 & $<1.0$ & 9.6 & $<3.0$ & $<1.0$ & $<1.0$ \\
\hline MW-2033-F & 2.2 & $<0.2$ & $<1.0$ & 3.4 & $<3.0$ & $<1.0$ & $<1.0$ \\
\hline MW-2034 & $<1.0$ & $<0.2$ & $<1.0$ & 9.9 & $<5.00$ & $<1.0$ & $<11.8$ \\
\hline$M W-2034-F$ & $<1.0$ & $<0.2$ & $<1.0$ & 9.0 & $<5.0$ & $<1.0$ & $<11.8$ \\
\hline MW-2035 & $<1.0$ & $<0.2$ & $<1.0$ & 2.2 & $<3.0$ & $<1.0$ & $<1.0$ \\
\hline MW-2035-F & $<1.0$ & $<0.2$ & $<1.0$ & $<1.0$ & $<3.0$ & $<1.0$ & $<1.0$ \\
\hline
\end{tabular}


TABLE C.6 (Cont.)

\begin{tabular}{|c|c|c|c|c|c|c|c|}
\hline Well No. & $\begin{array}{c}\text { Manganese } \\
(\mu \mathrm{g} / \mathrm{L})\end{array}$ & $\begin{array}{l}\text { Mercury } \\
(\mu \mathrm{g} / \mathrm{L})\end{array}$ & $\begin{array}{l}\text { Molybdenum } \\
(\mu / \mathrm{L})\end{array}$ & $\begin{array}{l}\text { Nickel } \\
(\mu g / L)\end{array}$ & $\begin{array}{l}\text { Selenium } \\
(\mu \mathrm{g} / \mathrm{L})\end{array}$ & $\begin{array}{l}\text { Silver } \\
(\mu g / L)\end{array}$ & $\begin{array}{c}\text { Thallium } \\
(\mu \mathrm{g} / \mathrm{L})\end{array}$ \\
\hline MW-2036 & $<1.0$ & $<0.2$ & $<1.0$ & $<1.0$ & $<3.0$ & $<1.0$ & $<1.0$ \\
\hline$M W-2036-F$ & $<1.0$ & $<0.2$ & $<1.0$ & $<1.0$ & $<3.0$ & $<1.0$ & $<1.0$ \\
\hline MW-2037 & 65 & 3.6 & $<1.0$ & 7.4 & 5.6 & $<1.0$ & $<1.0$ \\
\hline MW-2038 & 25 & 3.5 & $<1.0$ & 15 & 12.0 & $<1.0$ & $<1.0$ \\
\hline$M W-2038-F$ & 22 & 2.8 & $<1.0$ & 13 & 13 & $<1.0$ & $<1.0$ \\
\hline MW-2039 & 95 & $<0.2$ & 4.4 & 9.6 & 7.5 & $<1.0$ & $<1.0$ \\
\hline MW-2039-F & 1.7 & $<0.2$ & 3.8 & 5.4 & 8.0 & $<1.0$ & $<1.0$ \\
\hline MW-2040 & 274 & $<0.2$ & 6.6 & 32.0 & 5.5 & 7.1 & $<1.0$ \\
\hline MW-2042 & 11 & $<0.2$ & $<1.0$ & $<6.9$ & $<3.0$ & $<1.0$ & $<1.0$ \\
\hline MW-2042-F & $<1.0$ & $<0.2$ & $<1.0$ & $<5.7$ & 3.4 & $<1.0$ & $<1.0$ \\
\hline MW-2043 & 18 & $<0.2$ & $<1.0$ & $<6.2$ & 4.1 & $<1.0$ & $<1.0$ \\
\hline MW-2043-F & $<1.0$ & $<0.2$ & 1.2 & $<5.6$ & 4.9 & $<1.0$ & $<1.0$ \\
\hline MW-2044 & 6.5 & $<0.2$ & $<1.0$ & 5.1 & 3.7 & $<1.0$ & $<1.0$ \\
\hline MW-2044-F & 1.2 & $<0.2$ & 1.4 & 3.2 & 3.5 & $<1.0$ & $<1.0$ \\
\hline MW-3003 & 23 & $<0.2$ & 4.9 & 8.1 & 8.2 & $<1.0$ & $<1.0$ \\
\hline MW-3003-F & 21 & $<0.2$ & 5.2 & 7.8 & 8.0 & $<1.0$ & $<1.0$ \\
\hline MW-3006 & 120 & $<0.2$ & 14 & 4.7 & $<3.0$ & $<1.0$ & $<1.0$ \\
\hline
\end{tabular}


TABLE C.6 (Cont.)

\begin{tabular}{|c|c|c|c|c|c|c|c|}
\hline Well No. & $\begin{array}{c}\text { Manganese } \\
(\mu \mathrm{g} / \mathrm{L})\end{array}$ & $\begin{array}{l}\text { Mercury } \\
(\mu \mathrm{g} / \mathrm{L})\end{array}$ & $\begin{array}{l}\text { Molybdenum } \\
(\mu / \mathrm{L})\end{array}$ & $\begin{array}{l}\text { Nickel } \\
(\mu g / L)\end{array}$ & $\begin{array}{l}\text { Selenium } \\
(\mu \mathrm{g} / \mathrm{L})\end{array}$ & $\begin{array}{l}\text { Silver } \\
(\mu g / L)\end{array}$ & $\begin{array}{c}\text { Thallium } \\
(\mu \mathrm{g} / \mathrm{L})\end{array}$ \\
\hline MW-3025 & 46 & 0.53 & $<1.0$ & 16.0 & 12 & $<1.0$ & $<1.0$ \\
\hline MW-3025-F & 20 & 0.31 & $<1.0$ & 15 & 11 & $<1.0$ & $<1.0$ \\
\hline $\mathrm{MW}-3026-\mathrm{F}$ & 2.7 & $<0.2$ & 1.1 & 9.2 & 3.4 & $<1.0$ & $<1.0$ \\
\hline MW-3027 & 44 & 0.38 & $<1.0$ & 7.4 & $<3.0$ & $<1.0$ & $<1.0$ \\
\hline$M W-3027-F$ & 2.0 & 0.22 & $<1.0$ & 2.8 & $<3.0$ & $<1.0$ & $<1.0$ \\
\hline$M W-4001$ & 17 & $<0.2$ & $<1.0$ & 8.5 & $<3.0$ & $<1.0$ & $<1.0$ \\
\hline$M W-4001-F$ & 2.0 & $<0.2$ & $<1.0$ & 6.8 & $<3.0$ & $<1.0$ & $<1.0$ \\
\hline$M W-4003-F$ & $<1.0$ & $<0.2$ & $<1.0$ & 1.8 & $<3.0$ & $<1.0$ & $<1.0$ \\
\hline MW-4004 & 2.6 & $<0.2$ & 2.3 & 1.2 & $<3.0$ & $<1.0$ & $<1.0$ \\
\hline MW-4004-F & $<1.0$ & $<0.2$ & 2.3 & 2.1 & $<3.0$ & $<1.0$ & $<1.0$ \\
\hline MW-4005 & 3.0 & $<0.2$ & 3.8 & 4.4 & $<3.0$ & $<1.0$ & $<1.0$ \\
\hline MW-4005-F & $<1.0$ & $<0.2$ & 3.7 & 4.2 & $<3.0$ & $<1.0$ & $<1.0$ \\
\hline MW-4006 & 97 & $<0.2$ & 1.1 & 7.0 & 3.1 & $<1.0$ & $<1.0$ \\
\hline MW-4006-F & $<1.0$ & $<0.2$ & $<1.0$ & 3.9 & $<3.0$ & $<1.0$ & $<1.0$ \\
\hline$M W-4007$ & 26 & $<0.2$ & 5.1 & 5.9 & $<3.0$ & $<1.0$ & $<1.0$ \\
\hline$M W-4007-F$ & 1.4 & $<0.2$ & 5.5 & 5.0 & $<3.0$ & $<1.0$ & $<1.0$ \\
\hline MW-4010-F & 1.4 & $<0.2$ & 3.7 & 5.7 & $(1.1)$ & $(0.005)$ & $<1.0$ \\
\hline
\end{tabular}


TABLE C.6 (Cont.)

\begin{tabular}{|c|c|c|c|c|c|c|c|}
\hline Well No. & $\begin{array}{c}\text { Manganese } \\
(\mu \mathrm{g} / \mathrm{L})\end{array}$ & $\begin{array}{c}\text { Mercury } \\
(\mu \mathrm{g} / \mathrm{L})\end{array}$ & $\begin{array}{c}\text { Molybdenum } \\
(\mu / \mathrm{L})\end{array}$ & $\begin{array}{l}\text { Nickel } \\
(\mu g / L)\end{array}$ & $\begin{array}{c}\text { Selenium } \\
(\mu \mathrm{g} / \mathrm{L})\end{array}$ & $\begin{array}{l}\text { Silver } \\
(\mu \mathrm{g} / \mathrm{L})\end{array}$ & $\begin{array}{c}\text { Thallium } \\
(\mu \mathrm{g} / \mathrm{L})\end{array}$ \\
\hline MW-4011 & 12 & $<0.2$ & 3.2 & 11 & 5.3 & $(0.01)$ & $<1.0$ \\
\hline MW-4011-F & 1.2 & $<0.2$ & 3.3 & 11 & 6.1 & $<1.0$ & $<1.0$ \\
\hline MW-4012 & 129 & $<0.2$ & 30 & 9.6 & $<3.0$ & 1.4 & $<1.0$ \\
\hline $\mathrm{MW}-4012-\mathrm{F}$ & 5.3 & $<0.2$ & 31 & 1.3 & $<3.0$ & $<1.0$ & $<1.0$ \\
\hline MW-4013 & 2.6 & $<0.2$ & $<1.0$ & 2.5 & $<3.0$ & $<1.0$ & $<1.0$ \\
\hline$M W-4013-F$ & 2.4 & $<0.2$ & $<1.0$ & 2.5 & $<3.0$ & $<1.0$ & $<1.0$ \\
\hline MW-4014 & 66 & $<0.2$ & $<1.0$ & 2.3 & $<3.0$ & $<1.0$ & $<1.0$ \\
\hline MW-4014-F & 30 & $<0.2$ & $<1.0$ & 1.3 & $<3.0$ & $<1.0$ & $<1.0$ \\
\hline MW-4015 & 9.8 & $<0.2$ & $(0.25)$ & 5.0 & (1.9) & $(0.16)$ & $<1.0$ \\
\hline$M W-4015-F$ & 1.5 & $<0.2$ & $(0.17)$ & 4.4 & $(1.6)$ & $(0.01)$ & $<1.0$ \\
\hline$M W-4016$ & 44 & $<0.2$ & 8.1 & $<5.1$ & $<3.0$ & $<1.0$ & $<1.0$ \\
\hline MW-4016-F & 29.0 & $<0.2$ & 7.8 & $<4.3$ & $<3.0$ & $<1.0$ & $<1.0$ \\
\hline MW-4018 & 4.6 & $<0.2$ & $<1,0$ & 4.0 & $<3.0$ & $<1.0$ & $<1.0$ \\
\hline MW-4018-F & $<1.0$ & $<0.2$ & $<1.0$ & 3.9 & $<3.0$ & $<1.0$ & $<1.0$ \\
\hline MW-4019 & 146 & $<0.2$ & $<1.0$ & 4.7 & $<3.0$ & $<1.0$ & $<1.0$ \\
\hline MW-4019-F & $<1.0$ & $<0.2$ & $<1.0$ & $<1.0$ & $<3.0$ & $<1.0$ & $<1.0$ \\
\hline MW-4020 & 48 & $<0.2$ & 1.4 & 16 & $<3.0$ & $<1.0$ & $<1.0$ \\
\hline MW-4020-F & 27 & $<0.2$ & 1.6 & 14 & $<3.0$ & $<1.0$ & $<1.0$ \\
\hline MW-4021 & 38 & $<0.2$ & $<1.0$ & 8.6 & $<3.0$ & $<1.0$ & $<1.0$ \\
\hline MW-4021-F & 28 & $<0.2$ & $<1.0$ & 10 & $<3.0$ & $<1.0$ & $<1.0$ \\
\hline MW-4022 & 4,870 & 0.21 & 6.6 & 293 & 5.8 & 22 & $<1.0$ \\
\hline MW-4022-F & 329 & $<0.2$ & 4.3 & 16 & $<3.0$ & $<1.0$ & $<1.0$ \\
\hline MW-4023 & 1.5 & $<0.2$ & $<1.0$ & 2.6 & $<3.0$ & $<1.0$ & $<1.0$ \\
\hline MW-4023-F & $<1.0$ & $<0.2$ & $<1.0$ & 2.2 & $<3.0$ & $<1.0$ & $<1.0$ \\
\hline MW-4024 & 239 & $<0.2$ & 6.2 & 67.0 & $<5.0$ & 1.1 & $<13$ \\
\hline MW-4024-F & 122 & $<0.2$ & $<2.40$ & 17 & $<5.0$ & $<1.0$ & $<13$ \\
\hline MW-4025 & 118 & $<0.2$ & $<2.60$ & 15 & $<5.0$ & $<1.0$ & $<12.0$ \\
\hline
\end{tabular}


TABLE C.6 (Cont.)

\begin{tabular}{|c|c|c|c|c|c|c|c|}
\hline Well No. & $\begin{array}{c}\text { Manganese } \\
(\mu \mathrm{g} / \mathrm{L})\end{array}$ & $\begin{array}{c}\text { Mercury } \\
(\mu \mathrm{g} / \mathrm{L})\end{array}$ & $\begin{array}{l}\text { Molybdenum } \\
(\mu / L)\end{array}$ & $\begin{array}{l}\text { Nickel } \\
(\mu \mathrm{g} / \mathrm{L})\end{array}$ & $\begin{array}{c}\text { Selenium } \\
(\mu \mathrm{g} / \mathrm{L})\end{array}$ & $\begin{array}{l}\text { Silver } \\
(\mu \mathrm{g} / \mathrm{L})\end{array}$ & $\begin{array}{c}\text { Thallium } \\
(\mu \mathrm{g} / \mathrm{L})\end{array}$ \\
\hline MW-4025-F & $<1.0$ & $<0.2$ & $<1.0$ & $<1.0$ & $<5.0$ & $<1.0$ & $<12$ \\
\hline MWD-2 & 205 & $<0.2$ & 5.3 & 4.3 & $<3.0$ & $<1.0$ & $<1.0$ \\
\hline MWD-2-F & 81 & $<0.2$ & 5.2 & 2.3 & $<3.0$ & $<1.0$ & $<1.0$ \\
\hline MWD-5 & 11 & $<0.2$ & $<1.0$ & $<1.0$ & $<3.0$ & $<1.0$ & $<1.0$ \\
\hline MWD-5-F & $<1.0$ & $<0.2$ & $<1.0$ & $<1.0$ & $<3.0$ & $<1.0$ & $<1.0$ \\
\hline MWD-6 & 33 & $<0.2$ & $<1.0$ & 3.7 & $<3.0$ & $<1.0$ & $<1.0$ \\
\hline MWD-6-F & 31 & $<0.2$ & $<1.0$ & 6.3 & $<3.0$ & $<1.0$ & $<1.0$ \\
\hline MWD-9 & $<1.0$ & $<0.2$ & $<1.0$ & 1.3 & $<3.0$ & $<1.0$ & $<1.0$ \\
\hline MWD-9-F & 1.2 & $<0.2$ & $<1.0$ & 2.8 & $<3.0$ & $<1.0$ & $<1.0$ \\
\hline MWD-15 & 1.4 & $<0.2$ & $<1.0$ & 3.2 & $<3.0$ & $<1.0$ & $<1.0$ \\
\hline MWD-15-F & $<1.0$ & $<0.2$ & $<1.0$ & 3.3 & $<3.0$ & $<1.0$ & $<1.0$ \\
\hline MWD-18 & 12 & $<0.2$ & $<1.0$ & $<1.0$ & $<3.0$ & $<1.0$ & $<1.0$ \\
\hline MWD-18-F & 8.7 & $<0.2$ & $<1.0$ & 1.2 & $<3.0$ & $<1.0$ & $<1.0$ \\
\hline MWD-23 & 358 & $<0.2$ & 22 & 58 & $<3.0$ & $<1.0$ & $<1.0$ \\
\hline MWD-23-F & 270 & $<0.2$ & 21 & 59.0 & $<3.0$ & $<1.0$ & $<1.0$ \\
\hline MWD-25 & 22 & $<0.2$ & 1.9 & 6.7 & $<3.0$ & $<1.0$ & 1.9 \\
\hline MWD-25-F & 16.0 & $<0.2$ & 1.7 & 3.7 & $<3.0$ & $<1.0$ & 2.2 \\
\hline MWD-105 & 9.9 & $<0.2$ & $<1.0$ & 1.9 & $<3.0$ & $<1.0$ & $<1.0$ \\
\hline MWD-105-F & 1.7 & $<0.2$ & $<1.0$ & 1.4 & $<3.0$ & $<1.0$ & $<1.0$ \\
\hline MWD-106 & 8.8 & $<0.2$ & $<1.0$ & 1.4 & $<3.0$ & $<1.0$ & $<1.0$ \\
\hline MWD-106-F & 8.6 & $<0.2$ & $<1.0$ & 1.4 & $<3.0$ & $<1.0$ & $<1.0$ \\
\hline MWD-107 & 47 & $<0.2$ & 4.6 & 11 & $<3.0$ & $<1.0$ & $<1.0$ \\
\hline MWD-107-F & 50.0 & $<0.2$ & 4.7 & 11 & $<3.0$ & $<1.0$ & $<1.0$ \\
\hline MWD-109 & 18 & $<0.2$ & 1.3 & 4.8 & $<3.0$ & $<1.0$ & $<1.0$ \\
\hline MWD-109-F & 6.4 & $<0.2$ & 1.3 & 2.1 & $<3.0$ & $<1.0$ & $<1.0$ \\
\hline MWD-112 & 16 & $<0.2$ & 1.6 & 4.1 & $<3.0$ & $<1.0$ & $<1.0$ \\
\hline MWD-112-F & 14 & $<0.2$ & 1.6 & 3.3 & $<3.0$ & $<1.0$ & $<1.0$ \\
\hline
\end{tabular}


TABLE C.6 (Cont.)

\begin{tabular}{|c|c|c|c|c|c|c|c|}
\hline Well No. & $\begin{array}{c}\text { Manganese } \\
(\mu \mathrm{g} / \mathrm{L})\end{array}$ & $\begin{array}{l}\text { Mercury } \\
(\mu \mathrm{g} / \mathrm{L})\end{array}$ & $\begin{array}{l}\text { Molybdenum } \\
(\mu / L)\end{array}$ & $\begin{array}{l}\text { Nickel } \\
(\mu \mathrm{g} / \mathrm{L})\end{array}$ & $\begin{array}{c}\text { Selenium } \\
(\mu \mathrm{g} / \mathrm{L})\end{array}$ & $\begin{array}{l}\text { Silver } \\
(\mu g / L)\end{array}$ & $\begin{array}{c}\text { Thallium } \\
(\mu \mathrm{g} / \mathrm{L})\end{array}$ \\
\hline MWS-1 & $<1.0$ & $<0.2$ & $<1.0$ & 5.2 & $<3.0$ & $<1.0$ & $<1.0$ \\
\hline MWS-1-F & $<1.0$ & $<0.2$ & 1.0 & 4.6 & $<3.0$ & $<1.0$ & $<1.0$ \\
\hline MWS-2 & 2.5 & $<0.2$ & 3.2 & 3.8 & $<3.0$ & $<1.0$ & $<1.0$ \\
\hline MWS-3 & 9.2 & $<0.2$ & 3.3 & 3.7 & $<3.0$ & $<1.0$ & 1.1 \\
\hline MWS-3-F & 1.2 & $<0.2$ & $<1.0$ & 2.1 & $<3.0$ & $<1.0$ & 1.9 \\
\hline MWS-4 & 21 & 0.20 & $<1.0$ & 4.4 & $<3.0$ & $<1.0$ & $<1.0$ \\
\hline MWS-4-F & $<1.0$ & $<0.2$ & $<1.0$ & 4.1 & $<3.0$ & $<1.0$ & $<1.0$ \\
\hline MWS-6-F & 17 & $<0.2$ & $<1.0$ & 6.0 & $<3.0$ & $<1.0$ & $<1.0$ \\
\hline MWS-7 & 1.2 & $<0.2$ & $<1.0$ & 2.0 & $<3.0$ & $<1.0$ & $<1.0$ \\
\hline MWS-7-F & $<1.0$ & $<0.2$ & $<1.0$ & $<1.0$ & $<3.0$ & $<1.0$ & $<1.0$ \\
\hline MWS-8 & 37 & $<0.2$ & $<1.0$ & 7.1 & $<3.0$ & $<1.0$ & $<1.0$ \\
\hline MWS-8-F & $<1.0$ & $<0.2$ & $<1.0$ & 2.6 & $<3.0$ & $<1.0$ & $<1.0$ \\
\hline MWS-9 & 3.5 & $<0.2$ & $<1.0$ & 2.5 & $<3.0$ & $<1.0$ & $<1.0$ \\
\hline MWS-9-F & 2.5 & $<0.2$ & $<1.0$ & 2.5 & $<3.0$ & $<1.0$ & $<1.0$ \\
\hline MWS-10 & $<1.0$ & $<0.2$ & 1.7 & 2.8 & $<3.0$ & $<1.0$ & $<1.0$ \\
\hline MWS-10-F & $<1.0$ & $<0.2$ & $<1.0$ & 2.3 & $<3.0$ & $<1.0$ & $<1.0$ \\
\hline MWS-14 & 16 & $<0.2$ & $<1.0$ & 4.4 & $<3.0$ & $<1.0$ & $<1.0$ \\
\hline
\end{tabular}


TABLE C.6 (Cont.)

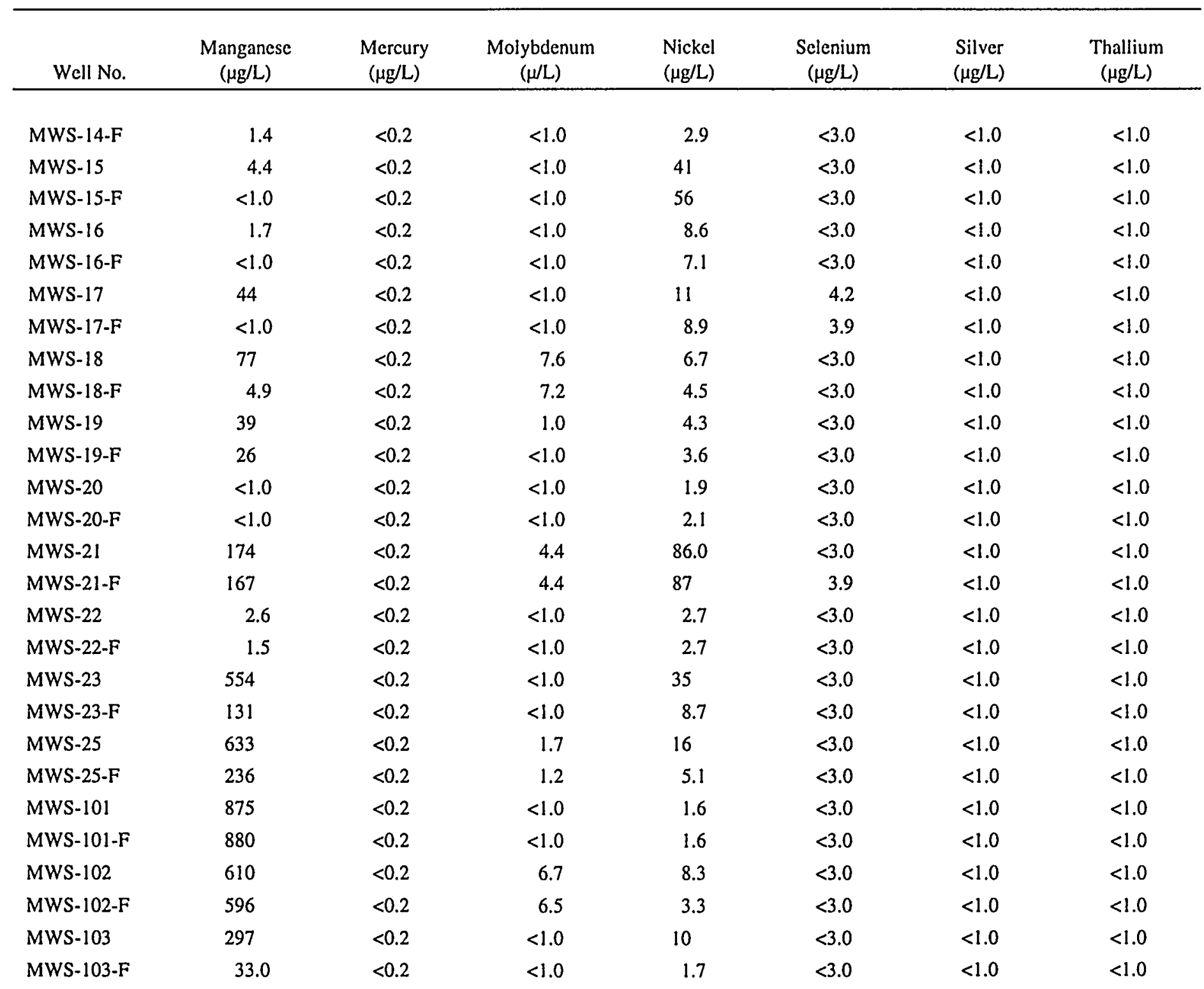


TABLE C.6 (Cont.)

\begin{tabular}{|c|c|c|c|c|c|c|c|}
\hline Well No. & $\begin{array}{c}\text { Manganese } \\
(\mu \mathrm{g} / \mathrm{L})\end{array}$ & $\begin{array}{c}\text { Mercury } \\
(\mu \mathrm{g} / \mathrm{L})\end{array}$ & $\begin{array}{l}\text { Molybdenum } \\
(\mu / L)\end{array}$ & $\begin{array}{l}\text { Nickel } \\
(\mu g / L)\end{array}$ & $\begin{array}{c}\text { Selenium } \\
(\mu \mathrm{g} / \mathrm{L})\end{array}$ & $\begin{array}{l}\text { Silver } \\
(\mu g / L)\end{array}$ & $\begin{array}{c}\text { Thallium } \\
(\mu \mathrm{g} / \mathrm{L})\end{array}$ \\
\hline MWS-104 & 22 & $<0.2$ & 4.4 & 2.3 & $<3.0$ & $<1.0$ & $<1.0$ \\
\hline MWS-104-F & 15 & $<0.2$ & 4.2 & 3.1 & $<3.0$ & $<1.0$ & $<1.0$ \\
\hline MWS-105 & 13 & $<0.2$ & 4.4 & 4.8 & $<3.0$ & $<1.0$ & $<1.0$ \\
\hline MWS-105-F & 11 & $<0.2$ & 4.5 & 4.8 & $<3.0$ & $<1.0$ & $<1.0$ \\
\hline MWS-106 & 66 & $<0.2$ & 2.3 & 3.3 & $<3.0$ & $<1.0$ & $<1.0$ \\
\hline MWS-106-F & 60 & $<0.2$ & 2.1 & 1.7 & $<3.0$ & $<1.0$ & $<1.0$ \\
\hline MWS-107 & 25 & $<0.2$ & 1.0 & 3.9 & $<3.0$ & $<1.0$ & $<1.0$ \\
\hline MWS-107-F & 2.0 & $<0.2$ & $<1.0$ & 1.7 & $<3.0$ & $<1.0$ & $<1.0$ \\
\hline MWS-108 & 39 & $<0.2$ & $<1.0$ & $<1.0$ & $<3.0$ & $<1.0$ & $<1.0$ \\
\hline MWS-108-F & 39 & $<0.2$ & $<1.0$ & $<1.0$ & $<3.0$ & $<1.0$ & $<1.0$ \\
\hline MWS-109 & 106 & $<0.2$ & 1.9 & 4.9 & $<3.0$ & $<1.0$ & $<1.0$ \\
\hline MWS-109-F & 76 & $<0.2$ & 2.3 & 3.5 & $<3.0$ & $<1.0$ & $<1.0$ \\
\hline MWS-110 & 48 & $<0.2$ & $<1.0$ & 18 & $<3.0$ & $<1.0$ & $<1.0$ \\
\hline MWS-110-F & 5.5 & $<0.2$ & $<1.0$ & 2.3 & $<3.0$ & $<1.0$ & $<1.0$ \\
\hline MWS-111 & 98 & $<0.2$ & $<1.0$ & 12 & $<3.0$ & $<1.0$ & $<1.0$ \\
\hline MWS-111-F & $<1.0$ & $<0.2$ & $<1.0$ & 1.8 & $<3.0$ & $<1.0$ & $<1.0$ \\
\hline MWS-112 & 190 & $<0.2$ & 8.8 & 135 & 3.9 & $<1.0$ & $<1.0$ \\
\hline MWS-112-F & 145 & $<0.2$ & 11 & 23 & $<3.0$ & $<1.0$ & $<1.0$ \\
\hline TIL3 & 47 & $<0.2$ & 2.5 & 1.6 & $<3.0$ & $<1.0$ & $<1.0$ \\
\hline TIL3-F & 36 & $<0.2$ & 2.5 & $<1.0$ & $<3.0$ & $<1.0$ & $<1.0$ \\
\hline USGI & 1.6 & $<0.2$ & $<1.0$ & 2.0 & $<3.0$ & $<1.0$ & $<1.0$ \\
\hline USGI-F & $<1.0$ & $<0.2$ & $<1.0$ & 2.0 & $<3.0$ & $<1.0$ & $<1.0$ \\
\hline USG2 & 6.2 & $<0.2$ & 1.8 & 3.4 & $<3.0$ & $<1.0$ & $<1.0$ \\
\hline USG2-F & 5.0 & $<0.2$ & 1.7 & 3.2 & $<3.0$ & $<1.0$ & $<1.0$ \\
\hline USG3 & $<1.0$ & $<0.2$ & 1.6 & 2.6 & $<3.0$ & $<1.0$ & $<1.0$ \\
\hline USG3-F & $<1.0$ & $<0.2$ & 1.4 & 2.7 & $<3.0$ & $<1.0$ & $<1.0$ \\
\hline USG4 & 1.3 & $<0.2$ & 1.2 & 8.7 & $<3.0$ & $<1.0$ & $<1.0$ \\
\hline
\end{tabular}


TABLE C.6 (Cont.)

\begin{tabular}{|c|c|c|c|c|c|c|c|}
\hline Well No. & $\begin{array}{c}\text { Manganese } \\
(\mu \mathrm{g} / \mathrm{L})\end{array}$ & $\begin{array}{c}\text { Mercury } \\
(\mu g / L)\end{array}$ & $\begin{array}{c}\text { Molybdenum } \\
\qquad(\mu / L)\end{array}$ & $\begin{array}{l}\text { Nickel } \\
(\mu \mathrm{g} / \mathrm{L})\end{array}$ & $\begin{array}{l}\text { Selenium } \\
(\mu \mathrm{g} / \mathrm{L})\end{array}$ & $\begin{array}{l}\text { Silver } \\
(\mu \mathrm{g} / \mathrm{L})\end{array}$ & $\begin{array}{c}\text { Thallium } \\
(\mu \mathrm{g} / \mathrm{L})\end{array}$ \\
\hline USG4-F & 1.1 & $<0.2$ & 1.3 & 9.2 & $<3.0$ & $<1.0$ & $<1.0$ \\
\hline USG5 & 1.6 & $<0.2$ & 2.0 & 9.0 & $<3.0$ & $<1.0$ & $<1.0$ \\
\hline USG5-F & $<1.0$ & $<0.2$ & 1.9 & 8.9 & $<3.0$ & $<1.0$ & $<1.0$ \\
\hline USG6 & 1.4 & $<0.2$ & 3.2 & 2.3 & $<3.0$ & $<1.0$ & $<1.0$ \\
\hline USG6-F & $<1.0$ & $<0.2$ & 3.1 & 2.7 & $<3.0$ & $<1.0$ & $<1.0$ \\
\hline USG8 & 11 & $<0.2$ & $<1.0$ & 7.2 & 3.2 & $<1.0$ & $<1.0$ \\
\hline USG8-F & 5.9 & $<0.2$ & $<1.0$ & 4.8 & 3.1 & $<1.0$ & $<1.0$ \\
\hline USG9 & $<1.0$ & $<0.2$ & $<1.0$ & 2.2 & $<3.0$ & $<1.0$ & $<1.0$ \\
\hline USG9-F & $<1.0$ & $<0.2$ & $<1.0$ & 2.0 & $<3.0$ & $<1.0$ & $<1.0$ \\
\hline MWV-1 & 8.1 & $<0.2$ & $<1.0$ & 5.1 & $<3.0$ & $<1.0$ & $<1.0$ \\
\hline MWV-1-F & 2.1 & $<0.2$ & $<1.0$ & 4.7 & $<3.0$ & $<1.0$ & $<1.0$ \\
\hline MWV-2 & 15 & $<0.2$ & $<1.0$ & 5.8 & $<3.0$ & $<1.0$ & $<1.0$ \\
\hline MWV-2-F & 3.8 & $<0.2$ & $<1.0$ & 2.7 & $<3.0$ & $<1.0$ & $<1.0$ \\
\hline MWV-9 & 33 & $<0.2$ & $<1.0$ & 2.2 & $<3.0$ & $<1.0$ & $<1.0$ \\
\hline MWV-9-F & 14 & $<0.2$ & $<1.0$ & 2.7 & $<3.0$ & $<1.0$ & $<1.0$ \\
\hline MWV-13 & 15 & $<0.2$ & $<1.0$ & 3.6 & $<3.0$ & $<1.0$ & $<1.0$ \\
\hline MWV-13-F & $<1.0$ & $<0.2$ & $<1.0$ & 1.8 & $<3.0$ & $<1.0$ & $<1.0$ \\
\hline MWV-16 & 10 & $<0.2$ & 1.1 & 6.4 & $<3.0$ & $<1.0$ & $<1.0$ \\
\hline MWV-16-F & 1.0 & $<0.2$ & $<1.0$ & 6.3 & $<3.0$ & $<1.0$ & $<1.0$ \\
\hline MWV-17 & 144 & $<0.2$ & $<1.0$ & 8.9 & $<3.0$ & $<1.0$ & $<1.0$ \\
\hline MWV-17-F & 6.7 & $<0.2$ & $<1.0$ & 5.1 & $<3.0$ & $<1.0$ & $<1.0$ \\
\hline MWV-22 & 2.4 & $<0.2$ & $<1.0$ & 19 & $<3.0$ & $<1.0$ & $<1.0$ \\
\hline MWV-22-F & $<1.0$ & $<0.2$ & $<1.0$ & 21 & $<3.0$ & $<1.0$ & $<1.0$ \\
\hline MWV-24 & 63 & $<0.2$ & $<1.0$ & 5.4 & $<3.0$ & $<1.0$ & $<1.0$ \\
\hline MWV-24-F & 53 & $<0.2$ & 1.0 & 5.3 & $<3.0$ & $<1.0$ & $<1.0$ \\
\hline
\end{tabular}

${ }^{a} \mathrm{~F}=$ filtered sample. 
TABLE C.7 Results of 1995 Joint Spring Sampling

\begin{tabular}{|c|c|c|c|c|c|c|c|c|c|c|c|c|}
\hline \multirow[b]{2}{*}{ Parameter } & \multicolumn{2}{|c|}{5101} & \multicolumn{2}{|c|}{5201} & \multicolumn{2}{|c|}{5303} & \multicolumn{2}{|c|}{5402} & \multicolumn{2}{|c|}{5501} & \multicolumn{2}{|c|}{5504} \\
\hline & May & Aug. & May & Aug. & May & Aug. & May & Aug. & May & Aug. & May & Aug. \\
\hline \multicolumn{13}{|l|}{ Ions $(m g / L)$} \\
\hline Nitrate & $N S^{a}$ & 2.5 & $<0.1$ & 0.17 & 0.72 & 2.1 & 0.42 & 0.14 & 0.11 & 0.41 & $<0.1$ & $<0.1$ \\
\hline Sulfate & NS & 48 & NS & 36 & NS & 51 & NS & 23 & NS & 39 & NS & 30 \\
\hline Chloride & NS & 35 & NS & 13 & NS & 21 & NS & 22 & NS & 5.4 & NS & 2.7 \\
\hline Fluoride & NS & 0.19 & NS & 0.14 & NS & 0.35 & NS & 0.14 & NS & 0.13 & NS & $<0.1$ \\
\hline \multicolumn{13}{|c|}{ Filtered Metals $(\mu \mathrm{g} / L)$} \\
\hline Aluminum & NS & $<14$ & 35 & $<14$ & $<14$ & $<14$ & $<14$ & $<14$ & 25 & 45 & $<14$ & 25 \\
\hline Antimony & NS & 2.7 & $<1$ & 2.4 & $<1$ & 3.2 & 1.9 & 1.8 & 2.6 & 2.2 & $<1$ & 1.6 \\
\hline Arsenic & NS & $<2$ & $<2$ & $<2$ & $<2$ & $<2$ & $<2$ & $<2$ & $<2$ & $<2$ & $<2$ & $<2$ \\
\hline Barium & NS & 153 & 84 & 121 & 90 & 113 & 108 & 180 & 101 & 112 & 93 & 117 \\
\hline Cadmium & NS & $<1$ & $<1$ & $<1$ & $<1$ & $<1$ & $<1$ & $<1$ & $<1$ & $<1$ & $<1$ & $<1$ \\
\hline Chromium & NS & $<1.2$ & $<1$ & $<1$ & $<1$ & 1.6 & $<1$ & 2.3 & $<1$ & $<1$ & $<1$ & $<1$ \\
\hline Copper & NS & 3.9 & 2.3 & $<2$ & $<2$ & $<2$ & $<2$ & $<2$ & 4.1 & $<2$ & 4.3 & 6.1 \\
\hline Iron & NS & 82 & 48 & 64 & 33 & 74 & 24.0 & 106 & 60 & $<32$ & 42 & 90 \\
\hline Lead & NS & $<1$ & $<1$ & $<1$ & $<1$ & $<1$ & $<1$ & $<1$ & $<1$ & $<1$ & $<1$ & $<1$ \\
\hline Lithium & NS & 2.5 & $<2$ & $<1$ & 3.1 & 8.8 & $<2$ & $<1$ & $<2$ & 2.2 & $<2$ & $<1$ \\
\hline Manganese & NS & 14 & $<1$ & 3.4 & 6.9 & 4.1 & 1.7 & 4.7 & 16 & 21 & 1.7 & 3.9 \\
\hline Mercury & NS & $<0.2$ & $<0.2$ & $<0.2$ & $<0.2$ & $<0.2$ & $<0.2$ & $<0.2$ & $<0.2$ & $<0.2$ & $<0.2$ & $<0.2$ \\
\hline Molybdenum & NS & $<1$ & $<1$ & $<1$ & 6.7 & 14 & $<1$ & $<1$ & $<1$ & $<1$ & $<1$ & $<1$ \\
\hline Nickel & NS & 4.9 & 3.2 & 21 & 3.3 & 2.8 & 1.7 & 4.5 & 2.1 & 2.8 & 4.6 & 7.7 \\
\hline Sclenium & NS & $<3$ & $<3$ & $<3$ & $<3$ & $<3$ & $<3$ & $<3$ & $<3$ & $<3$ & $<3$ & $<3$ \\
\hline Silver & NS & $<1$ & $<1$ & $<1$ & $<1$ & $<1$ & $<1$ & $<1$ & $<1$ & $<1$ & $<1.7$ & $<1$ \\
\hline Thallium & NS & $<1$ & $<1$ & $<1$ & $<1$ & $<1$ & $<1$ & $<1$ & $<1$ & $<1$ & $<1$ & $<1$ \\
\hline
\end{tabular}


TABLE C.7 (Cont.)

\begin{tabular}{|c|c|c|c|c|c|c|c|c|c|c|c|c|}
\hline \multirow[b]{2}{*}{ Parameter } & \multicolumn{2}{|c|}{5101} & \multicolumn{2}{|c|}{5201} & \multicolumn{2}{|c|}{5303} & \multicolumn{2}{|c|}{5402} & \multicolumn{2}{|c|}{.5501} & \multicolumn{2}{|c|}{5504} \\
\hline & May & Aug. & May & Aug. & May & Aug. & May & Aug. & May & Aug. & May & Aug. \\
\hline \multicolumn{13}{|c|}{ Unfiltered Metals (mg/L) } \\
\hline Aluminum & NS & 97 & 83 & $<14$ & 153 & 115 & 133 & 80 & 180 & 210 & 33 & 136 \\
\hline Antimony & NS & $<1$ & $<1$ & $<1$ & $<!$ & $<1$ & 1.7 & $<1$ & $<1$ & 1.2 & $<1$ & $<1$ \\
\hline Arsenic & NS & $<2$ & $<2$ & $<2$ & $<2$ & $<2$ & $<2$ & $<2$ & $<2$ & $<2$ & $<2$ & $<2$ \\
\hline Barium & NS & 165 & 85 & 119 & 92.0 & 119 & 107 & 183 & 102 & 113 & 103 & 115 \\
\hline Cadmium & NS & $<1$ & $<1$ & $<1$ & $<1$ & $<1$ & $<1$ & $<1$ & $<1$ & $<1$ & $<1$ & $<1$ \\
\hline Chromium & NS & $<1$ & $<1$ & 2.90 & $<1$ & 1.2 & $<1$ & 1.6 & 1.5 & $<1$ & $<1$ & $<1$ \\
\hline Copper & NS & 6.1 & 2.1 & $<2$ & $<2.9$ & $<2$ & $<2$ & $<2$ & $<2$ & $<2$ & $<2$ & $<2$ \\
\hline Iron & NS & 792 & 130 & 173 & 223 & 1,440 & 261 & 859 & 280 & 219 & 96 & 135 \\
\hline Lead & NS & $<1$ & $<1$ & $<1$ & 2.0 & 1.3 & $<2$ & $<1$ & $<1$ & $<1$ & $<1$ & $<1$ \\
\hline Lithium & NS & 2.60 & $<2$ & $<1$ & 3.1 & 6.6 & $<2$ & $<1$ & $<2$ & 2.3 & $<2$ & $<1$ \\
\hline Manganese & NS & 55 & 2.0 & 5.5 & 11 & 44 & 4.4 & 13 & 21 & 31 & 1.7 & 6.1 \\
\hline Mercury & NS & $<0.2$ & $<0.2$ & $<0.2$ & 1.1 & $<0.2$ & $<0.2$ & $<0.2$ & $<0.2$ & $<0.2$ & $<0.2$ & $<0.2$ \\
\hline Molybdenum & NS & $<1$ & $<1$ & $<1$ & 6.9 & 10 & $<1$ & $<1$ & $<1$ & $<1$ & $<1$ & $<1$ \\
\hline Nickel & NS & 4.7 & 3.9 & 5.1 & 3.8 & 3.0 & 1.6 & 1.8 & 1.7 & 2.3 & 4.1 & 6.0 \\
\hline Selenium & NS & $<3$ & $<3$ & $<3$ & $<3$ & $<3$ & $<3$ & $<3$ & $<3$ & $<3$ & $<3$ & $<3$ \\
\hline Silver & NS & $<1$ & $<1$ & $<1$ & $<2$ & $<1$ & $<2$ & $<1$ & $<1$ & $<1$ & $<1$ & $<1$ \\
\hline Thallium & NS & $<1$ & $<1$ & $<1$ & $<1$ & $<1$ & $<1$ & $<1$ & $<1$ & $<1$ & $<1$ & $<1$ \\
\hline \multicolumn{13}{|c|}{ Radiological (pCi/L) } \\
\hline Uranium, Total & NS & 0.384 & 0.59 & 0.87 & 95 & 123 & 0.6 & 0.95 & 0.37 & 0.74 & 0.39 & 0.50 \\
\hline \multicolumn{13}{|c|}{ Nitroaromatics $(m g / L)$} \\
\hline 1,3,5-TNB & NS & $<0.03$ & 3.6 & 6.0 & 0.08 & 0.41 & $<0.03$ & $<0.03$ & $<0.03$ & $<0.03$ & $<0.03$ & $<0.03$ \\
\hline 1,3-DNB & NS & $<0.09$ & $<0.09$ & $<0.09$ & $<0.09$ & b & $<0.09$ & $<0.09$ & $<0.09$ & $<0.09$ & $<0.09$ & $<0.09$ \\
\hline $2,4,6-\mathrm{TNT}$ & NS & $<0.03$ & 40 & 110 & 17 & 120 & $<0.03$ & $<0.03$ & $<0.03$ & $<0.03$ & $<0.03$ & $<0.03$ \\
\hline 2,4-DNT & NS & $<0.03$ & 0.08 & 0.07 & 0.05 & 0.21 & $<0.03$ & $<0.03$ & $<0.03$ & 0.05 & $<0.03$ & $<0.03$ \\
\hline
\end{tabular}


TABLE C.7 (Cont.)

\begin{tabular}{|c|c|c|c|c|c|c|c|c|c|c|c|c|}
\hline \multirow[b]{2}{*}{ Parameter } & \multicolumn{2}{|c|}{5101} & \multicolumn{2}{|c|}{5201} & \multicolumn{2}{|c|}{5303} & \multicolumn{2}{|c|}{5402} & \multicolumn{2}{|c|}{5501} & \multicolumn{2}{|c|}{5504} \\
\hline & May & Aug. & May & Aug. & May & Aug. & May & Aug. & May & Aug. & May & Aug. \\
\hline \multicolumn{7}{|c|}{ Nitroaromatics (mg/L) (Cont.) } & \multicolumn{6}{|c|}{ - } \\
\hline 2,6-DNT & NS & $<0.01$ & 0.51 & 1.8 & 0.09 & 0.41 & $<0.01$ & $<0.01$ & $<0.01$ & 0.08 & $<0.01$ & $<0.01$ \\
\hline 2-Amino-4,6-DNT & NS & $<0.02$ & 7.4 & 19 & 2.6 & 9.2 & $<0.02$ & $<0.02$ & $<0.02$ & 0.22 & $<0.02$ & $<0.02$ \\
\hline 4-Amino-2,6-DNT & NS & $<0.02$ & 8.1 & 20 & 3.9 & 15 & $<0.02$ & $<0.02$ & $<0.02$ & 0.37 & $<0.02$ & $<0.02$ \\
\hline 2-Nitrotoluene & NS & $<0.03$ & $<0.03$ & $<0.03$ & 0.003 & 0.06 & $<0.03$ & $<0.03$ & $<0.03$ & $<0.03$ & $<0.03$ & $<0.03$ \\
\hline 3-Nitrotoluene & NS & $<0.03$ & $<0.03$ & $<0.03$ & $<0.03$ & $<0.03$ & $<0.03$ & $<0.03$ & $<0.03$ & $<0.03$ & $<0.03$ & $<0.03$ \\
\hline 4-Nitrotoluene & NS & $<0.03$ & $<0.03$ & $<0.03$ & $<0.03$ & $<0.03$ & $<0.03$ & $<0.03$ & $<0.03$ & $<0.03$ & $<0.03$ & $<0.03$ \\
\hline Nitrobenzene & NS & $<0.04$ & $<0.04$ & $<0.04$ & $<0.04$ & $<0.04$ & $<0.04$ & $<0.04$ & $<0.04$ & $<0.04$ & $<0.04$ & $<0.04$ \\
\hline
\end{tabular}


TABLE C.7 (Cont.)

\begin{tabular}{|c|c|c|c|c|c|c|c|c|c|c|}
\hline \multirow[b]{2}{*}{ Parameter } & \multicolumn{2}{|c|}{5601} & \multicolumn{2}{|c|}{5602} & \multicolumn{2}{|c|}{5605} & \multicolumn{2}{|c|}{5612} & \multicolumn{2}{|c|}{6301} \\
\hline & May & Aug. & May & Aug. & May & Aug. & May & Aug. & May & Aug. \\
\hline \multicolumn{11}{|l|}{ Ions (mg/L) } \\
\hline Nitrate & $<0.1$ & $<0.1$ & 0.11 & 0.46 & NS & 0.14 & NS & $<0.1$ & 5.1 & 17 \\
\hline Sulfate & NS & 18 & NS & 14 & NS & 21 & NS & 23 & NS & 43 \\
\hline Chloride & NS & 2.1 & NS & 1.1 & NS & 2.6 & NS & 2.2 & NS & 10 \\
\hline Fluoride & NS & $<0.1$ & NS & $<0.1$ & NS & $<0.1$ & NS & $<0.1$ & NS & 0.15 \\
\hline \multicolumn{11}{|c|}{ Filtered Metals $(\mu \mathrm{g} / L)$} \\
\hline Aluminum & $<14$ & 199 & 28 & 52 & NS & 431 & NS & 51 & $<14$ & $<14$ \\
\hline Antimony & 2.0 & $<1$ & 3.5 & $<1$ & NS & $<1$ & NS & 13.0 & 2.1 & 1.5 \\
\hline Arsenic & $<2$ & $<2$ & $<2$ & $<2$ & NS & $<2$ & NS & $<2$ & 3.5 & $<2$ \\
\hline Barium & 71 & 9.8 & 76 & 95 & NS & 116 & NS & 111 & 84 & 121 \\
\hline Cadmium & $<1$ & $<1$ & $<1$ & $<1$ & NS & $<1$ & NS & $<1$ & $<1$ & $<1$ \\
\hline Chromium & $<1$ & $<1$ & 1.1 & $<1$ & NS & $<1$ & NS & $<1$ & $<1$ & 1.1 \\
\hline Copper & $<2$ & 2.7 & $<20$ & $<2$ & NS & 2.1 & NS & $<2$ & 2.2 & $<2$ \\
\hline Iron & 19 & 1,220 & 829 & 89 & NS & 358 & NS & 86 & 31.0 & 53 \\
\hline Lead & $<1$ & $<1$ & $<1$ & $<1$ & NS & $<1$ & NS & $<1$ & $<1$ & $<1$ \\
\hline Lithium & $<2$ & $<1$ & $<2$ & $<1$ & NS & $<1$ & NS & $<1$ & 5.3 & 18 \\
\hline Manganese & 1.3 & 261 & 53 & 2.4 & NS & 32 & NS & 9.6 & $<1$ & $<1$ \\
\hline Mercury & $<0.2$ & $<0.2$ & $<0.2$ & $<0.2$ & NS & $<0.2$ & NS & $<0.2$ & $<0.2$ & $<0.2$ \\
\hline Molybdenum & $<1$ & $<1$ & $<1$ & $<1$ & NS & $<1$ & NS & $<1$ & $<1$ & $<1$ \\
\hline Nickel & 1.3 & 6.8 & 2.8 & 5.9 & NS & 6.6 & NS & 6.8 & 1.1 & 1.7 \\
\hline Selenium & $<3$ & $<3$ & $<3$ & $<3$ & NS & $<3$ & NS & $<3$ & $<3$ & $<3$ \\
\hline Silver & $<1$ & $<1$ & $<1$ & $<1$ & NS & $<1$ & NS & $<1$ & $<1$ & $<1$ \\
\hline Thallium & $<1$ & $<1$ & $<1$ & $<1$ & NS & $<1$ & NS & $<1$ & $<1$ & $<1$ \\
\hline
\end{tabular}


TABLE C.7 (Cont.)

\begin{tabular}{|c|c|c|c|c|c|c|c|c|c|c|}
\hline \multirow[b]{2}{*}{ Parameter } & \multicolumn{2}{|c|}{5601} & \multicolumn{2}{|c|}{5602} & \multicolumn{2}{|c|}{5605} & \multicolumn{2}{|c|}{5612} & \multicolumn{2}{|c|}{6301} \\
\hline & May & Aug. & May & Aug. & May & Aug. & May & Aug. & May & Aug. \\
\hline \multicolumn{11}{|c|}{ Unfiltered Metals $(\mu g / L)$} \\
\hline Aluminum & 47 & 99 & 301 & 30 & NS & 15 & NS & 49 & 626 & 320 \\
\hline Antimony & 3.6 & $<1$ & $<1$ & 9.2 & NS & 2.7 & NS & 13.0 & $<1$ & $<1$ \\
\hline Arsenic & 2.10 & $<2$ & $<2$ & $<2$ & NS & $<2$ & NS & $<2$ & 4.3 & $<2$ \\
\hline Barium & 72 & 83 & 77 & 67 & NS & 95 & NS & 110 & 89 & 123 \\
\hline Cadmium & $<1$ & $<1$ & $<1$ & $<1$ & NS & $<1$ & NS & $<1$ & $<1$ & $<1$ \\
\hline Chromium & $<1$ & $<1$ & $<1$ & $<1$ & NS & $<1$ & NS & $<1$ & 1.5 & 1.1 \\
\hline Copper & 2.5 & $<2$ & 2.4 & 2.8 & NS & 2.1 & NS & $<2$ & 2.1 & $<2$ \\
\hline Iron & 86 & 139 & 562 & 205 & NS & 57.0 & NS & 86 & 428 & 316 \\
\hline Lead & $<1$ & $<1$ & $<1$ & $<1$ & NS & $<1$ & NS & $<1$ & $<1$ & $<1$ \\
\hline Lithium & $<2$ & $<1$ & $<2$ & $<1$ & NS & $<1$ & NS & 9.5 & 6.1 & 18 \\
\hline Manganese & 4.0 & 5.1 & 56 & 242 & NS & 4.0 & NS & $<0.2$ & 8.5 & 4.6 \\
\hline Mercury & $<0.2$ & $<0.2$ & $<0.2$ & $<0.2$ & NS & $<0.2$ & NS & $<1.0$ & $<0.2$ & $<0.2$ \\
\hline Molybdenum & $<1$ & $<1$ & $<1$ & $<1$ & NS & $<1$ & NS & $<1.0$ & $<1.0$ & $<1.0$ \\
\hline Nickel & 1.5 & 4.8 & 2.7 & 6.6 & NS & 5.3 & NS & $<3$ & $<3$ & 2.0 \\
\hline Selenium & $<3$ & $<3$ & $<3$ & $<3$ & NS & $<3$ & NS & $<1$ & $<1$ & $<3$ \\
\hline Silver & $<1$ & $<1$ & $<1$ & $<1$ & NS & $<1$ & NS & $<1$ & $<1$ & $<1$ \\
\hline Thallium & $<1$ & $<1$ & $<1$ & $<1$ & NS & $<1$ & NS & $<1$ & $<1$ & $<1$ \\
\hline \multicolumn{11}{|c|}{ Radiological (pCi/L) } \\
\hline Uranium, Total & 0.45 & $(0.27)$ & 0.33 & $(0.14)$ & NS & 0.06 & NS & 0.52 & 48 & 69 \\
\hline \multicolumn{11}{|c|}{ Nitroaromatics $(\mu \mathrm{g} / L)$} \\
\hline 1,3,5-TNB & $<0.03$ & $<0.03$ & 0.25 & $<0.03$ & NS & 0.10 & NS & $<0.3$ & $<0.03$ & 0.03 \\
\hline 1,3-DNB & $<0.09$ & $<0.09$ & $<0.09$ & $<0.09$ & NS & $<0.09$ & NS & $<0.09$ & $<0.09$ & $<0.09$ \\
\hline $2,4,6-\mathrm{TNT}$ & $<0.03$ & $<0.03$ & 1.0 & $<0.03$ & NS & 4.8 & NS & 0.07 & 0.09 & 0.42 \\
\hline 2,4-DNT & $<0.03$ & 0.04 & 0.01 & 0.04 & NS & 0.15 & NS & $<0.03$ & 0.05 & 0.09 \\
\hline
\end{tabular}


TABLE C.7 (Cont.)

\begin{tabular}{|c|c|c|c|c|c|c|c|c|c|c|}
\hline \multirow[b]{2}{*}{ Parameter } & \multicolumn{2}{|c|}{5601} & \multicolumn{2}{|c|}{5602} & \multicolumn{2}{|c|}{5605} & \multicolumn{2}{|c|}{5612} & \multicolumn{2}{|c|}{6301} \\
\hline & May & Aug. & May & Aug. & May & Aug. & May & Aug. & May & Aug. \\
\hline \multicolumn{11}{|c|}{ Nitroaromatics $(\mu \mathrm{g} / L)($ Cont.) } \\
\hline 2,6-DNT & 0.05 & 0.04 & 2.0 & 0.88 & NS & 0.27 & NS & $<0.01$ & 0.15 & 0.31 \\
\hline 2-Amino-4,6-DNT & 0.02 & 0.02 & 0.01 & 0.05 & NS & 1.6 & NS & 0.46 & 0.58 & 0.84 \\
\hline 4-Amino-2,6-DNT & 0.36 & 0.37 & 1.3 & 1.0 & NS & 2.8 & NS & 0.58 & 1.0 & 1.5 \\
\hline 2-Nitrotoluene & $<0.03$ & $<0.03$ & c & $<0.06$ & NS & $<0.03$ & NS & $<0.03$ & $<0.03$ & $<0.07$ \\
\hline 3-Nitrotoluene & $<0.03$ & $<0.03$ & $<0.03$ & $<0.03$ & NS & $<0.03$ & NS & $<0.03$ & $<0.03$ & $<0.03$ \\
\hline 4-Nitrotoluene & $<0.03$ & $<0.03$ & $<0.03$ & $<0.03$ & NS & $<0.03$ & NS & $<0.03$ & $<0.03$ & $<0.03$ \\
\hline Nitrobenzene & $<0.04$ & $<0.04$ & $<0.04$ & $<0.04$ & NS & $<0.04$ & NS & $<0.04$ & $<0.04$ & $<0.04$ \\
\hline
\end{tabular}


TABLE C.7 (Cont.)

\begin{tabular}{|c|c|c|c|c|c|c|c|c|}
\hline \multirow[b]{2}{*}{ Parameter } & \multicolumn{2}{|c|}{6303} & \multicolumn{2}{|c|}{6306} & \multicolumn{2}{|c|}{6501} & \multicolumn{2}{|c|}{6601} \\
\hline & May & Aug. & May & Aug. & May & Aug. & May & Aug. \\
\hline \multicolumn{9}{|l|}{ Ions $(m g / L)$} \\
\hline Nitrate & 2.0 & 12 & $<0.1$ & $<0.1$ & 0.49 & 0.42 & 0.43 & 0.76 \\
\hline Sulfate & NS & 25 & NS & $<10$ & NS & 15 & NS & 14 \\
\hline Chloride & NS & 3.3 & NS & 7.5 & NS & 2.4 & NS & 2.1 \\
\hline Fluoride & NS & 0.12 & NS & 0.26 & NS & 0.12 & NS & 0.10 \\
\hline \multicolumn{9}{|c|}{ Filtered Metals $(\mu \mathrm{g} / L)$} \\
\hline Aluminum & $<14$ & $<14$ & $<14$ & $<14$ & 534 & 17 & $<14$ & 29 \\
\hline Antimony & 1.9 & 5.8 & 2.4 & 1.6 & $<1$ & 1.4 & 2.4 & 1.1 \\
\hline Arsenic & $<2$ & $<2$ & 2.9 & $<2$ & $<2$ & $<2$ & $<2$ & $<2$ \\
\hline Barium & 70 & 128 & 308 & 399 & 79 & 90 & 76 & 104 \\
\hline Cadmium & $<1$ & $<1$ & $<1$ & $<1$ & $<1$ & $<1$ & $<1$ & $<1$ \\
\hline Chromium & 2.1 & 1.7 & $<1$ & 1.5 & 1.0 & $<1$ & $<1$ & $<1.0$ \\
\hline Copper & $<2$ & $<2$ & $<2$ & $<2$ & $<2$ & $<2$ & $<2$ & $<2$ \\
\hline Iron & 24 & 66 & 2,830 & 1,300 & 644 & $<32$ & 28 & 65 \\
\hline Lead & $<1$ & $<1$ & $<1$ & $<1$ & $<1$ & $<1$ & $<1$ & $<\mathrm{I}$ \\
\hline Lithium & $<2$ & 3.5 & $<2$ & $<1$ & $<2$ & $<1$ & $<2$ & $<1$ \\
\hline Manganese & 7.4 & 51 & 6,240 & 360 & 14 & 4.4 & 12 & 42 \\
\hline Mercury & $<0.2$ & $<0.2$ & $<0.2$ & $<0.2$ & $<0.2$ & $<0.2$ & $<0.2$ & $<0.2$ \\
\hline Molybdenum & $<1$ & $<1$ & 2.5 & 4.6 & $<1$ & $<1$ & $<1$ & $<1$ \\
\hline Nickel & 1.3 & 2.0 & 2.8 & 3.3 & 2.1 & 4.4 & 1.4 & 5.4 \\
\hline Selenium & $<3$ & $<3$ & $<3$ & $<3$ & $<3$ & $<3$ & $<3$ & $<3$ \\
\hline Silver & $<1$ & $<1$ & $<1$ & $<1$ & $<1$ & $<1$ & $<1$ & $<1$ \\
\hline Thallium & $<1$ & $<1$ & $<1$ & $<1$ & $<1$ & $<1$ & $<1$ & $<1$ \\
\hline
\end{tabular}


TABLE C.7 (Cont.)

\begin{tabular}{|c|c|c|c|c|c|c|c|c|}
\hline \multirow[b]{2}{*}{ Parameter } & \multicolumn{2}{|c|}{6303} & \multicolumn{2}{|c|}{6306} & \multicolumn{2}{|c|}{6501} & \multicolumn{2}{|c|}{6601} \\
\hline & May & Aug. & May & Aug. & May & Aug. & May & Aug. \\
\hline \multicolumn{9}{|c|}{ Unfiltered Metals $(\mu \mathrm{g} / \mathrm{L})$} \\
\hline Aluminum & 412 & 144 & 93 & 17 & $<26$ & 857 & 229 & 55 \\
\hline Antimony & 3.1 & $<1$ & $<1$ & $<1$ & $<2$ & $<1$ & $<1$ & 5.3 \\
\hline Arsenic & $<2$ & $<2$ & 4.7 & 15 & $<4$ & $<2$ & $<2$ & $<2$ \\
\hline Barium & 77 & 134 & 374 & 450 & 72 & 97 & 80 & 102 \\
\hline Cadmium & $<1$ & $<1$ & $<1$ & $<1$ & $<1$ & $<1$ & $<1$ & $<1$ \\
\hline Chromium & 2.6 & 2.2 & $<1$ & 1.8 & $<1$ & $<1$ & $<1$ & $<1$ \\
\hline Copper & 6 & $<2$ & $<2$ & $<2$ & $<2$ & 2.1 & $<2$ & $<2$ \\
\hline Iron & 546 & 1,040 & 5,930 & 727 & $<55$ & 647 & 378 & 147 \\
\hline Lead & $<1$ & $<1$ & $<1$ & $<1$ & $<1$ & $<1$ & $<1$ & $<1$ \\
\hline Lithium & $<2$ & 3.6 & $<2$ & $<1$ & $<2$ & $<1$ & $<1$ & $<1$ \\
\hline Manganese & 23.0 & 52 & 7,350 & 8,590 & 7.9 & 32 & 20 & 45 \\
\hline Mercury & $<0.2$ & $<0.2$ & $<0.2$ & $<0.2$ & $<0.2$ & $<0.2$ & $<0.2$ & $<0.2$ \\
\hline Molybdenum & $<1.0$ & $<1.0$ & 3.2 & 4.7 & $<1.0$ & $<1.0$ & $<1.0$ & $<1.0$ \\
\hline Nickel & 2.1 & 2.3 & 2.8 & 3.4 & 2.0 & 5.2 & 1.8 & 4.7 \\
\hline Selenium & $<3$ & $<3$ & $<3$ & $<3$ & $<3$ & $<3$ & $<3$ & $<3$ \\
\hline Silver & $<1$ & $<1$ & $<1$ & $<1$ & $<1$ & $<1$ & $<1$ & $<1$ \\
\hline Thallium & $<1$ & $<1$ & $<1$ & $<1$ & $<1$ & $<1$ & $<1$ & $<1$ \\
\hline \multicolumn{9}{|l|}{ Radiological (pCi/L) } \\
\hline Uranium, Total & 0.63 & 1.3 & 0.69 & 0.44 & $<0.19$ & $(0.21)$ & 0.30 & 0.38 \\
\hline \multicolumn{9}{|c|}{ Nitroaromatics $(\mu g / L)$} \\
\hline 1,3,5-TNB & 0.06 & 0.09 & $<0.03$ & $<0.03$ & $<0.03$ & $<0.03$ & $<0.03$ & $<0.03$ \\
\hline 1,3-DNB & $<0.09$ & $<0.09$ & $<0.09$ & $<0.09$ & $<0.09$ & $<0.09$ & $<0.09$ & $<0.09$ \\
\hline $2,4,6-\mathrm{TNT}$ & 1.5 & 0.64 & $<0.03$ & $<0.03$ & $<0.03$ & $<0.03$ & $<0.03$ & 0.02 \\
\hline 2,4-DNT & 0.15 & 0.14 & $<0.03$ & $<0.03$ & $<0.03$ & $<0.03$ & $<0.03$ & $<0.03$ \\
\hline
\end{tabular}


TABLE C.7 (Cont.)

\begin{tabular}{|c|c|c|c|c|c|c|c|c|}
\hline \multirow[b]{2}{*}{ Parameter } & \multicolumn{2}{|c|}{6303} & \multicolumn{2}{|c|}{6306} & \multicolumn{2}{|c|}{6501} & \multicolumn{2}{|c|}{6601} \\
\hline & May & Aug. & May & Aug. & May & Aug. & May & Aug. \\
\hline \multicolumn{9}{|c|}{ Nitroaromatics $(\mu g / L)$ (Cont.) } \\
\hline 2,6-DNT & 0.24 & 0.40 & $<0.01$ & $<0.01$ & $<0.01$ & $<0.01$ & $(0.007)$ & 0.05 \\
\hline 4-Amino-2,6-DNT & 1.3 & 2.1 & $<0.02$ & $<0.02$ & 0.04 & $<0.02$ & 0.12 & 0.59 \\
\hline 2-Nitrotoluene & $<0.03$ & $<0.03$ & $<0.26$ & $<0.03$ & $<0.03$ & $<0.03$ & $<0.03$ & $<0.03$ \\
\hline 3-Nitrololuene & $<0.03$ & $<0.03$ & $<0.03$ & $<0.03$ & $<0.03$ & $<0.03$ & $<0.03$ & $<0.03$ \\
\hline 4-Nitrotoluene & $<0.03$ & $<0.03$ & $<0.03$ & $<0.03$ & $<0.03$ & $<0.03$ & $<0.03$ & $<0.03$ \\
\hline Nitrobenzene & $<0.04$ & $<0.04$ & $<0.04$ & $<0.04$ & $<0.04$ & $<0.04$ & $<0.04$ & $<0.04$ \\
\hline
\end{tabular}

Note: Data in parentheses are uncensored data; i.e., those data reported below the detection limit.

a $N S=$ not sampled.

b Indicates rejected datapoint.

c Value not quantified by laboratory. 
APPENDIX D:

CONTAMINANT FATE AND TRANSPORT TABLES 


$$
\text { D-2 }
$$


TABLE D.1 Estimated Distribution Coefficient $\left(K_{d}\right)$ Values for Contaminants in Site Soil ${ }^{\mathrm{a}}$

\begin{tabular}{|c|c|c|}
\hline Contaminant & $\begin{array}{c}\mathrm{K}_{\mathrm{d}} \\
(\mathrm{mL} / \mathrm{g})\end{array}$ & Source \\
\hline \multicolumn{3}{|l|}{ Radionuclides } \\
\hline Uranium & 330 & Schumacher and Stollenwerk (1991) \\
\hline \multicolumn{3}{|l|}{ Metals } \\
\hline Antimony & 150 & Sheppard et al. (1984) \\
\hline Arsenic & 10 & Baes and Sharp $(1983)^{c}$ \\
\hline Cadmium & 27 & Baes and Sharp (1983) \\
\hline Lead & 150 & Schumacher and Stollenwerk (1991) \\
\hline Lithium & 9 & $\begin{array}{l}\text { Baes et al. (1984); Schumacher and } \\
\text { Stollenwerk (1991) }\end{array}$ \\
\hline Manganese & 150 & Baes and Sharp (1983) \\
\hline Mercury & 100 & Nuclear Safety Associates (1980) \\
\hline Molybdenum & 30 & $\begin{array}{l}\text { Sheppard and Thibault (1990); } \\
\text { Baes et al. (1984) }\end{array}$ \\
\hline Selenium & 110 & Sheppard and Thibault (1990) \\
\hline Silver & 120 & Sheppard and Thibault (1990) \\
\hline \multicolumn{3}{|l|}{ Inorganic anions } \\
\hline Nitrate & 0.5 & Baes et al. (1984) \\
\hline \multicolumn{3}{|c|}{ Nitroaromatic compounds } \\
\hline DNB & 0.22 & Verschueren $(1983)^{\mathrm{h}}$ \\
\hline 2,4-DNT & 0.63 & Mabey et al. (1982) $)^{i}$ \\
\hline 2,6-DNT & 1.29 & Mabey et al. (1982) \\
\hline NB & 0.5 & Mabey et al. (1982) ${ }^{\mathbf{i}}$ \\
\hline TNB & 0.15 & Mabey et al. $(1982)^{i}$ \\
\hline TNT & 0.28 & McKone $(1990)^{j}$ \\
\hline
\end{tabular}

a Estimated from literature data in combination with site-specific information, including soil type and $\mathrm{pH}$. Because the range of literature values is highly variable, screeninglevel leaching calculations were performed for the metals with local soil and groundwater data to provide a limited consistency check for this assessment. Additional site-specific data that will be collected to support the groundwater operable unit will be used to refine these preliminary estimates within the next several years.

b Determined from site-specific data for solution in equilibrium with the Ferrelview clay at neutral $\mathrm{pH}$ (fixed).

Footnotes continue on next page 
c Midrange for pentavalent arsenic in agricultural soil and clay (2 to $18 \mathrm{~mL} / \mathrm{g}$ ), as supported by a screening-level calibration estimate with data for local soil and groundwater.

$\downarrow$ Determined from site-specific data for solution in equilibrium with the clay till at neutral $\mathrm{pH}$ (unadjusted).

- Modified from the value of $300 \mathrm{~mL} / \mathrm{g}$ in Baes et al. (1984) and estimates of 1 to $2 \mathrm{~mL} / \mathrm{g}$ from Schumacher and Stollenwerk (1991) by a screening-level calibration estimate with data for local soil and groundwater.

r Modified from the median values of 125 and $90 \mathrm{~mL} / \mathrm{g}$ for loam and clay in Sheppard and Thibault (1990), combined with the value of $20 \mathrm{~mL} / \mathrm{g}$ in Baes et al. (1984) and a screening-level calibration estimate with data for local soil and groundwater.

8 Modified from the median value of $115 \mathrm{~mL} / \mathrm{g}$ for clay by a screening-level calibration estimate with data for local soil and groundwater.

h Calculated by multiplying the octanol-water partition coefficient $\left(\mathrm{K}_{\mathrm{ow}}\right)$ value given in Verschueren (1983) by a site-specific estimate of $1.4 \%$ for the fraction of organic carbon in soil.

i Calculated by multiplying the $\mathrm{K}_{\mathrm{ow}}$ value given in Mabey et al. (1982) by a site-specific estimate of $1.4 \%$ for the fraction of organic carbon in soil.

i Calculated by multiplying the $\mathrm{K}_{\mathrm{ow}}$ value given in McKone (1990) by a site-specific estimate of $1.4 \%$ for the fraction of organic carbon in soil. 
TABLE D.2 Results of Equilibrium-Speciation Calculations on Samples from Selected Contaminated Monitoring Wells at the Weldon Spring Chemical Plant Site and Vicinity Property

\begin{tabular}{|c|c|c|c|c|c|}
\hline \multirow[b]{2}{*}{$\begin{array}{l}\text { Property or } \\
\text { Constituent }\end{array}$} & \multicolumn{5}{|c|}{ Monitoring Well } \\
\hline & $\begin{array}{c}\text { GT64-P } \\
(6 / 14 / 90) \\
\end{array}$ & $\begin{array}{c}M W-2002 \\
(8 / 02 / 89) \\
\end{array}$ & $\begin{array}{c}M W-2003 \\
(6 / 06 / 89) \\
\end{array}$ & $\begin{array}{c}M W-2005 \\
6 / 06 / 89 \\
\end{array}$ & $\begin{array}{c}M W-3003 \\
(5 / 10 / 89) \\
\end{array}$ \\
\hline $\mathrm{pH}$ & 7.0 & 7.2 & 6.2 & 6.9 & 6.8 \\
\hline Temperature $\left({ }^{\circ} \mathrm{C}\right)$ & 16.0 & 15.0 & 14.5 & 14.2 & 14.0 \\
\hline$p E^{a}$ & 3.8 & 3.3 & 4.3 & 4.7 & 4.6 \\
\hline Cadmium (mg/L) & 450 & 260 & 530 & 86 & 320 \\
\hline Magnesium (mg/L) & 100 & 85 & 190 & 45 & 140 \\
\hline Sodium (mg/L) & 270 & 110 & 240 & 71 & 230 \\
\hline Potassium $(\mathrm{mg} / \mathrm{L})$ & 4.8 & 2.0 & 12 & 1.8 & 10 \\
\hline Hydrogen carbonate (mg/L) & 305 & 350 & 300 & 360 & 340 \\
\hline Sulfate $(\mathrm{mg} / \mathrm{L})$ & 130 & 100 & 220 & 7.0 & 200 \\
\hline Chlorine $(\mathrm{mg} / \mathrm{L})$ & 18 & 11 & 21 & 2.5 & 13 \\
\hline Fluorine (mg/L) & 0.10 & 0.10 & 0.10 & 0.10 & 0.20 \\
\hline Silica $(\mathrm{mg} / \mathrm{L})$ & 12 & 15 & 11 & 9.4 & 10 \\
\hline Nitrate $(\mathrm{mg} / \mathrm{L})$ & 1,810 & 974 & 3,010 & 160 & 1,950 \\
\hline Phosphate $(\mathrm{mg} / \mathrm{L})$ & 0.09 & 0.12 & 0.06 & 0.12 & 0.09 \\
\hline Aluminum $(\mu \mathrm{g} / \mathrm{L})$ & $<10$ & $<10$ & $<10$ & $<10$ & $<10$ \\
\hline Barium $(\mu \mathrm{g} / \mathrm{L})$ & $<100$ & 300 & 300 & 170 & 300 \\
\hline Copper $(\mu \mathrm{g} / \mathrm{L})$ & 30 & 30 & 40 & 5.0 & 20 \\
\hline Lithium $(\mu \mathrm{g} / \mathrm{L})$ & 1,100 & 450 & 1,000 & 39 & 740 \\
\hline Manganese $(\mu \mathrm{g} / \mathrm{L})$ & 30 & $<10$ & 20 & $<6$ & $<1$ \\
\hline Strontium $(\mu \mathrm{g} / \mathrm{L})$ & 950 & 360 & 1,100 & 120 & 830 \\
\hline Vanadium $(\mu \mathrm{g} / \mathrm{L})$ & 1.0 & 1 & $<1$ & $<6$ & $<1$ \\
\hline Uranium $(\mu \mathrm{g} / \mathrm{L})$ & 6.7 & 1.8 & 3.0 & 1.0 & 17 \\
\hline Uranium, maximum ${ }^{b}(\mu g / L)$ & $>1,000$ & $>1,000$ & $>1,000$ & $>1,000$ & $>1,000$ \\
\hline \multicolumn{6}{|c|}{ Calculated Predominant Aqueous Species } \\
\hline $\begin{array}{l}\text { Nitrogen } \\
\text { Uranium }\end{array}$ & $\begin{array}{c}\mathrm{NH}_{4}^{-} \\
\mathrm{NO}_{3}\left(\mathrm{CO}_{3}\right)^{2-}\end{array}$ & $\mathrm{UO}_{2}\left(\mathrm{CO}_{3}^{-}\right)_{3}^{4-}$ & $\begin{array}{c}\mathrm{NH}_{4}^{-} \\
\mathrm{NO}_{2}\left(\mathrm{CO}_{3}\right)_{2}{ }^{2-}\end{array}$ & $\frac{\mathrm{NH}_{4}^{-}}{\mathrm{UO}_{2}\left(\mathrm{HPO}_{4}\right)_{2}{ }^{2-}}$ & $\begin{array}{c}\mathrm{NH}_{4}^{-} \\
\mathrm{UO}_{2}\left(\mathrm{CO}_{3}\right)_{2}{ }^{2-} \\
\mathrm{UO}_{2}\left(\mathrm{HPO}_{4}\right)_{2}^{2-}\end{array}$ \\
\hline
\end{tabular}


TABLE D.2 (Cont.)

\begin{tabular}{|c|c|c|c|c|c|}
\hline \multirow[b]{2}{*}{$\begin{array}{l}\text { Property or } \\
\text { Constituent }\end{array}$} & \multirow[b]{2}{*}{$\begin{array}{c}\text { GT64-P } \\
(6 / 14 / 90)\end{array}$} & \multicolumn{3}{|c|}{ Monitoring Well } & \multirow[b]{2}{*}{$\begin{array}{c}M W-3003 \\
(5 / 10 / 89)\end{array}$} \\
\hline & & $\begin{array}{c}\text { MW-2002 } \\
(8 / 02 / 89)\end{array}$ & $\begin{array}{c}\text { MW-2003 } \\
(6 / 06 / 89)\end{array}$ & $\begin{array}{c}\text { MW-2005 } \\
6 / 06 / 89\end{array}$ & \\
\hline \multicolumn{6}{|c|}{ Saturation Indexes (Unitless) } \\
\hline Calcite & 0.33 & 0.40 & 0.15 & -0.22 & 0.01 \\
\hline Dolomite & 0.23 & 0.49 & 0.04 & -0.53 & -0.14 \\
\hline Siderite & -1.66 & -1.39 & -1.80 & -2.37 & -2.02 \\
\hline Strontianite & -1.85 & -1.96 & -2.04 & -2.57 & -2.06 \\
\hline Gypsum & -1.09 & -1.31 & -0.86 & -2.71 & -1.02 \\
\hline Celestite & -2.06 & $N A^{c}$ & NA & $\mathrm{NA}$ & NA \\
\hline Barite & 0.24 & 0.75 & 0.87 & -0.38 & 0.96 \\
\hline $\mathrm{SiO}_{2}$ (amorphous) & -0.91 & -0.80 & -0.93 & -0.99 & -0.97 \\
\hline Quartz & 0.42 & 0.53 & 0.41 & 0.35 & 0.38 \\
\hline $\mathrm{Fe}(\mathrm{OH})_{3}$ (amorphous) & 0.00 & 0.00 & 0.02 & 0.00 & 0.00 \\
\hline Rhodonchrosite & -1.39 & -1.61 & -1.82 & -2.44 & -0.78 \\
\hline Uraninite & -6.81 & -8.90 & -7.00 & -9.59 & -7.67 \\
\hline Uraninite (amorphous) & -12.0 & -14.0 & -12.8 & -14.6 & -12.7 \\
\hline Coffinite & -7.34 & -9.92 & -8.19 & -10.2 & -8.25 \\
\hline Camotite & -7.92 & -9.91 & -7.44 & -8.81 & -6.23 \\
\hline Shoepite & -5.11 & -5.86 & -5.45 & -6.20 & -4.85 \\
\hline Autunite & -9.99 & $\mathrm{NA}$ & NA & NA & $\mathrm{NA}$ \\
\hline Sodium autunite & -8.39 & $\mathrm{NA}$ & NA & $\mathrm{NA}$ & $\mathrm{NA}$ \\
\hline Tyuyamunite & -5.78 & -7.29 & -6.09 & -6.57 & -4.98 \\
\hline
\end{tabular}




\begin{tabular}{|c|c|c|c|c|c|}
\hline \multirow[b]{2}{*}{$\begin{array}{l}\text { Property or } \\
\text { Constituent }\end{array}$} & \multicolumn{5}{|c|}{ Monitoring Well } \\
\hline & $\begin{array}{c}M W-3006 \\
(6 / 12 / 90)\end{array}$ & $\begin{array}{c}M W-3007 \\
(6 / 18 / 86)\end{array}$ & $\begin{array}{c}M W-3008 \\
(6 / 06 / 89) \\
\end{array}$ & $\begin{array}{c}\text { MW-3009 } \\
(6 / 06 / 89)\end{array}$ & $\begin{array}{c}M W-4013 \\
(6 / 01 / 90) \\
\end{array}$ \\
\hline $\mathrm{pH}$ & 7.2 & 7.0 & 6.2 & 7.5 & 7.0 \\
\hline Temperature $\left({ }^{\circ} \mathrm{C}\right)$ & 14.5 & 15.5 & 15.0 & 15.0 & 13.5 \\
\hline $\mathrm{pE}^{\mathrm{a}}$ & 2.6 & 3.6 & 4.6 & 3.3 & -- \\
\hline Cadmium (mg/L) & 64 & 820 & 900 & 57 & 120 \\
\hline Magnesium $(\mathrm{mg} / \mathrm{L})$ & 52 & 280 & 240 & 39 & 52 \\
\hline Sodium $(\mathrm{mg} / \mathrm{L})$ & 19 & 340 & 260 & 10 & 29 \\
\hline Potassium $(\mathrm{mg} / \mathrm{L})$ & 1.3 & 13 & 2.6 & 0.5 & 5.7 \\
\hline Hydrogen carbonate $(\mathrm{mg} / \mathrm{L})$ & 493 & 270 & 300 & 200 & 387 \\
\hline Sulfate $(\mathrm{mg} / \mathrm{L})$ & 23 & 320 & 43 & 65 & 40 \\
\hline Chlorine $(\mathrm{mg} / \mathrm{L})$ & 4.6 & 22 & 20 & 1.8 & 9.9 \\
\hline Fluorine $(\mathrm{mg} / \mathrm{L})$ & 0.20 & 0.20 & 0.10 & 0.20 & 0.20 \\
\hline Silica (mg/L) & 12 & 10 & 12 & 8.4 & 8.3 \\
\hline Nitrate $(\mathrm{mg} / \mathrm{L})$ & 62 & 4,120 & 4,870 & 106 & 288 \\
\hline Phosphate (mg/L) & 0.15 & 0.24 & 0.03 & 0.03 & 1.8 \\
\hline Aluminum $(\mu \mathrm{g} / \mathrm{L})$ & $<10$ & $\mathrm{NA}$ & $<10$ & $<10$ & $<10$ \\
\hline Barium $(\mu \mathrm{g} / \mathrm{L})$ & 170 & $\mathrm{NA}$ & 500 & 450 & 150 \\
\hline Copper $(\mu \mathrm{g} / \mathrm{L})$ & 110 & $\mathrm{NA}$ & 40 & $<3$ & 3.0 \\
\hline Lithium $(\mu \mathrm{g} / \mathrm{L})$ & 18 & 1,700 & 170 & 8 & 52 \\
\hline Manganese $(\mu \mathrm{g} / \mathrm{L})$ & 200 & $\mathrm{NA}$ & $<20$ & 8 & 3.0 \\
\hline Strontium $(\mu \mathrm{g} / \mathrm{L})$ & 230 & 1,500 & 2,900 & 110 & 140 \\
\hline Vanadium $(\mu \mathrm{g} / \mathrm{L})$ & $<6$ & 1.0 & $<1$ & $<6$ & 1.0 \\
\hline Uranium $(\mu \mathrm{g} / \mathrm{L})$ & 0.90 & 6.0 & 7.0 & 110 & 2.1 \\
\hline Uranium, maximum $^{\mathrm{b}}(\mu \mathrm{g} / \mathrm{L})$ & $>1,000$ & $>1,000$ & $>1,000$ & $>1,000$ & $>1,000$ \\
\hline \multicolumn{6}{|c|}{ Calculated Predominant Aqueous Species } \\
\hline $\begin{array}{l}\text { Nitrogen } \\
\text { Uranium }\end{array}$ & $\begin{array}{c}\mathrm{NH}_{4}^{-} \\
\mathrm{UO}_{2}\left(\mathrm{CO}_{3}\right)_{2}{ }^{2-} \\
\mathrm{UO}_{2}\left(\mathrm{CO}_{3}\right)_{3}^{4-}\end{array}$ & $\mathrm{UO}_{2}\left(\mathrm{CO}_{3}\right)_{3}{ }^{4-}$ & $\begin{array}{c}\mathrm{NH}_{4}^{-} \\
\mathrm{UO}_{2}\left(\mathrm{CO}_{3}\right)_{2}^{2-}\end{array}$ & $\begin{array}{c}\mathrm{NH}_{4}^{-} \\
\mathrm{UO}_{2}\left(\mathrm{CO}_{3}\right)_{2}{ }^{2-}\end{array}$ & $\begin{array}{c}\mathrm{NH}_{4}^{-} \\
\mathrm{UO}_{2}\left(\mathrm{HPO}_{4}\right)_{2}{ }^{2-}\end{array}$ \\
\hline
\end{tabular}


TABLE D.2 (Cont.)

Monitoring Well

\begin{tabular}{|c|c|c|c|c|c|}
\hline $\begin{array}{l}\text { Property or } \\
\text { Constituent }\end{array}$ & $\begin{array}{c}\text { MW-3006 } \\
(6 / 12 / 90)\end{array}$ & $\begin{array}{c}M W-3007 \\
(6 / 18 / 86) \\
\end{array}$ & $\begin{array}{c}\text { MW-3008 } \\
(6 / 06 / 89) \\
\end{array}$ & $\begin{array}{c}\text { MW-3009 } \\
(6 / 06 / 89)\end{array}$ & $\begin{array}{c}\text { MW-4013 } \\
(6 / 01 / 90)\end{array}$ \\
\hline \multicolumn{6}{|c|}{ Saturation Indexes (Unitless) } \\
\hline Calcite & 0.05 & 0.41 & 0.22 & -0.09 & -0.01 \\
\hline Dolomite & 0.24 & 0.56 & 0.08 & -0.14 & -0.21 \\
\hline Siderite & -0.60 & -1.60 & -1.94 & -2.25 & -2.55 \\
\hline Strontianite & -1.89 & -1.82 & -1.76 & -2.30 & -2.43 \\
\hline Gypsum & -2.34 & -0.66 & -1.47 & -1.88 & -1.87 \\
\hline Celestite & $\mathrm{NA}$ & -1.69 & -2.27 & -2.90 & -3.10 \\
\hline Barite & 0.09 & $\mathrm{NA}$ & 0.28 & 1.01 & 0.27 \\
\hline $\mathrm{SiO}_{2}$ (amorphous) & -0.91 & -0.98 & -0.89 & -1.06 & -1.04 \\
\hline Quartz & 0.42 & 0.36 & 0.44 & 0.29 & 0.30 \\
\hline $\mathrm{Fe}(\mathrm{OH})_{3}$ (amorphous) & 0.00 & 0.00 & 0.00 & 0.00 & 0.00 \\
\hline Rhodonchrosite & -0.10 & NA & -1.95 & -1.52 & -2.20 \\
\hline Uraninite & -6.07 & -6.70 & -7.77 & -5.01 & -2.20 \\
\hline Uraninite (amorphous) & -11.2 & -11.8 & -12.9 & -10.1 & -16.5 \\
\hline Coffinite & -6.61 & -7.30 & -8.28 & -5.69 & -12.1 \\
\hline Camotite & -11.5 & -7.56 & -8.13 & -6.24 & -12.5 \\
\hline Shoepite & -6.37 & -5.37 & -5.06 & -3.39 & -7.83 \\
\hline Autunite & $\mathrm{NA}$ & -9.81 & -10.5 & -8.50 & -12.9 \\
\hline Sodium autunite & $\mathrm{NA}$ & -8.22 & -9.20 & -8.89 & -12.6 \\
\hline Tyuyamunite & -9.03 & -6.08 & -5.22 & -3.03 & -11.2 \\
\hline
\end{tabular}

${ }^{a} \mathrm{pE}$ determined by assuming dissolved iron is ferrous and in equilibrium with ferrihydrite.

${ }^{b}$ The maximum uranium concentration in solution assuming mineral equilibrium controls.

${ }^{c} \mathrm{NA}=$ data not available.

Source: Schumacher et al. (1993). 
TABLE D.3 Selected Physical Properties and Environmental Parameters for Nitroaromatic Compounds

\begin{tabular}{|c|c|c|c|c|c|}
\hline Property or Parameter & TNT & 2,4-DNT & 2,6-DNT & $1,3,5$-TNB & 1,3-DNB \\
\hline CAS number & $118-96-7$ & $121-14-2$ & $606-20-2$ & $99-35-4$ & $99-65-0$ \\
\hline Molecular weight ( $\mathrm{g} / \mathrm{mol})$ & 227.13 & 182.14 & 182.14 & 213.11 & 168.11 \\
\hline Density $\left(\mathrm{g} / \mathrm{cm}^{3}\right)$ & $1.654-1.663$ & $1.521\left(4^{\circ} \mathrm{C}\right)$ & $1.538\left(4^{\circ} \mathrm{C}\right)$ & $1.654-1.688$ & $1.574\left(18^{\circ} \mathrm{C}\right)$ \\
\hline Melting point $\left({ }^{\circ} \mathrm{C}\right)$ & $80.1-80.65$ & $-71^{\circ} \mathrm{C}$ & $\sim 65$ & $122.0-122.5$ & $89-90$ \\
\hline Dipole moment & $1.37 \mathrm{D}$ & $3.78-4.33^{\mathrm{a}}$ & $2.81-2.98^{\mathrm{a}}$ & $\sim 0$ & $N A^{b}$ \\
\hline Henry's Law constant, $K_{H}\left(a t m-m^{3} / m o l\right)$ & $1.1 \mathrm{E}-8$ & $1.86 \mathrm{E}-7$ & $4.86-\mathrm{E}-07$ & $2.21 \mathrm{E}-09$ & $8.07 \mathrm{E}-07$ \\
\hline $\begin{array}{l}\text { Vapor pressure, solid (torr) } \\
20^{\circ} \mathrm{C} \\
25^{\circ} \mathrm{C}\end{array}$ & $\begin{array}{l}1.28 \mathrm{E}-06 \\
5.51 \mathrm{E}-06\end{array}$ & $\begin{array}{l}1.3 \mathrm{E}-04 \\
2.17 \mathrm{E}-04\end{array}$ & $\begin{array}{l}1.35 \mathrm{E}-04 \\
5.67 \mathrm{E}-04\end{array}$ & $\begin{array}{c}\mathrm{NA} \\
3.03 \mathrm{E}-06\end{array}$ & $\begin{array}{c}\text { NA } \\
1.93 \mathrm{E}-04\end{array}$ \\
\hline $\begin{array}{l}\text { Water solubility }(\mathrm{mg} / \mathrm{L}) \\
0^{\circ} \mathrm{C} \\
10^{\circ} \mathrm{C} \\
15^{\circ} \mathrm{C} \\
20^{\circ} \mathrm{C} \\
25^{\circ} \mathrm{C}\end{array}$ & $\begin{array}{l}100 \\
110 \\
120 \\
130 \\
150\end{array}$ & $\begin{array}{c}\text { NA } \\
\text { NA } \\
\text { NA } \\
270\left(22^{\circ} \mathrm{C}\right) \\
280 \text { (est) }\end{array}$ & $\begin{array}{l}\text { NA } \\
\text { NA } \\
\text { NA } \\
\text { NA } \\
208\end{array}$ & $\begin{array}{c}\text { NA } \\
\text { NA } \\
\text { NA } \\
\text { NA } \\
350-385\end{array}$ & $\begin{array}{c}-- \\
-- \\
469 \\
180-200 \\
533\end{array}$ \\
\hline U.S. EPA Drinking Water Equivalent Level (mg/L) & 0.02 & NA & NA & NA & -- \\
\hline $\begin{array}{l}\text { Partitioning coefficients ( } \mathrm{K}_{\mathrm{d}} \text { values in } \mathrm{mL} / \mathrm{kg} \text { ) } \\
\log \mathrm{K}_{\mathrm{ow}} \\
\log \mathrm{K}_{\mathrm{oc}} \\
\mathrm{K}_{\mathrm{d}} \text { (WSTA, top soils; Fink [1992]) } \\
\mathrm{K}_{\mathrm{d}} \text { (WSTA, Ferrelview Fm-clay till; Fink 1992) } \\
\mathrm{K}_{\mathrm{d}} \text { (WSTA, near surface clay till; USGS unpublished } \\
\mathrm{K}_{\mathrm{d}} \text { (WSTA, residuum; USGS unpublished) }\end{array}$ & $\begin{array}{l}1.86-2.06 \\
2.72 \\
2-56 \\
\text { NA } \\
2.9-3.5 \\
4.7 \\
0.6\end{array}$ & $\begin{array}{l}1.98 \\
1.79 \text { (est)-2.40 } \\
\text { NA } \\
1.8-3.9 \\
2.0-2.3 \\
1.9-4.4 \\
0.2\end{array}$ & $\begin{array}{c}1.89-2.02 \\
1.79 \text { (est)-1.89(est) } \\
\text { NA } \\
0.6-2.9 \\
0.53-0.99 \\
1.6 \\
0.2\end{array}$ & $\begin{array}{l}1.18 \\
1.30 \\
\text { NA } \\
\text { NA } \\
\text { NA } \\
\text { NA } \\
\text { NA }\end{array}$ & $\begin{array}{l}1.49 \\
1.56(\mathrm{est}) \\
\mathrm{NA} \\
\mathrm{NA} \\
\mathrm{NA} \\
\mathrm{NA} \\
\mathrm{NA}\end{array}$ \\
\hline Diffusion $\left(\mathrm{cm}^{2} / \mathrm{s}\right.$ at $\left.25^{\circ} \mathrm{C}\right)$ & $\begin{array}{l}6.71 \mathrm{E}-06 \\
\text { (water) } \\
0.64 \text { (air) }\end{array}$ & $\begin{array}{c}7.31 \mathrm{E}-06 \text { (water) } \\
0.67 \text { (air) }\end{array}$ & $\begin{array}{c}7.31 \text { E-06 (water) } \\
0.67 \text { (air) }\end{array}$ & $\begin{array}{c}7.20 \mathrm{E}-06 \\
\text { (water) } \\
0.068 \text { (air) }\end{array}$ & $\begin{array}{c}7.94 \mathrm{E}-04 \\
\text { (water) } \\
0.073 \text { (air) }\end{array}$ \\
\hline Photolysis (estimated half-life) & Significant & $\begin{array}{l}\text { 23-72 hours } \\
\text { (water) }\end{array}$ & NA & photostable & $\begin{array}{l}0.029-0.043 \\
\text { per day } \\
\text { (rate constant) }\end{array}$ \\
\hline
\end{tabular}

a Data from Fink (1992). 


\section{REFERENCES FOR APPENDIX D}

Baes, C.F., and R.D. Sharp, 1983, "A Proposal for Estimation of Soil Leaching Constants for Use in Assessment Models," Journal of Environmental Quality 12(1):17-28.

Baes, C.F., et al., 1984, A Review and Analysis of Parameters for Assessing Transport of Environmentally Released Radionuclides through Agriculture, ORNL-5786, prepared by Oak Ridge National Laboratory, Oak Ridge, Tenn., for U.S. Department of Energy, Oak Ridge Operations, Oak Ridge, Tenn.

Fink, S.A., 1992, "Uptake of Nitroaromatic Compounds by Weldon Spring Soils," master's thesis, University of Missouri-Rolla, Rolla, Mo.

Mabey, W.R., et al., 1982, Aquatic Fate Process Data for Organic Priority Pollutants, EPA 440/481-014, U.S. Environmental Protection Agency, Washington, D.C.

McKone, N.B., 1990, "Dermal Uptake of Organic Chemicals from a Soil Matrix," Risk Analysis 10(3):407-419.

Nuclear Safety Associates, Inc., 1980, Comparison of Waste at the Western New York Nuclear Service Center, Nuclear Safety Associates, Inc., Bethesda, Md.

Schumacher, J.G., and K.G. Stollenwerk, 1991, "Geochemical Controls on Migration of Molybdenum, Uranium, and Other Constituents at the Weldon Spring Chemical Plant Site," in Proceedings of the Geosciences Workshop, DOE/OR/21548-197, published by MK-Ferguson Company and Jacobs Engineering Group, St. Charles, Mo., for U.S. Department of Energy, Oak Ridge Operations, Weldon Spring Site Remedial Action Project, St. Charles, Mo., pp. 87-140.

Schumacher, J.G., et al., 1993, Geochemistry and Migration of Contaminants at the Weldon Spring Chemical Plant Site, St. Charles County, Missouri - 1989-91, U.S. Geological Survey Open-File Report 93-433, prepared in cooperation with U.S. Department of Energy, Rolla, Mo.

Sheppard, M.I., and D.H. Thibault, 1990, "Default Soil Solid/Liquid Partition Coefficients, $\mathrm{K}_{\mathrm{d}}$ s, for Four Major Soil Types: A Compendium," Health Physics 59:471-482.

Sheppard, M.I., et al., 1984, Soil Nuclide Distribution Coefficients and Their Statistical Distributions, AECL-8364, prepared by Atomic Energy of Canada Limited, Whiteshell Nuclear Research Establishment, Pinawa, Manitoba.

Verschueren, K., 1983, Handbook of Environmental Data on Organic Chemicals, 2nd Ed., Van Nostrand Reinhold, New York, N.Y. 